\begin{abstract}
UNIVERSIDADE DE SÃO PAULO
FACULDADE DE EDUCAÇÃO

PROGRAMA DE PÓS-GRADUAÇÃO EM EDUCAÇÃO
\end{abstract}

Adriana Aparecida Dragone Silveira

O DIREITO À EDUCAÇÃO DE CRIANÇAS E ADOLESCENTES: ANÁLISE DA ATUAÇÃO DO TRIBUNAL DE JUSTIÇA DE SÃO PAULO (1991-2008) 
Adriana Aparecida Dragone Silveira

\section{O DIREITO À EDUCAÇÃO DE CRIANÇAS E ADOLESCENTES: ANÁLISE DA ATUAÇÃO DO TRIBUNAL DE JUSTIÇA DE SÃO PAULO (1991-2008)}

Tese apresentada ao Programa de PósGraduação da Faculdade de Educação da Universidade de São Paulo para a obtenção do título de Doutor em Educação.

Área de concentração: Estado, Sociedade e Educação

Orientador: Prof. Dr. Romualdo Portela de Oliveira

\section{São Paulo}


Autorizo a reprodução e divulgação total ou parcial deste trabalho, por qualquer meio convencional ou eletrônico, para fins de estudo e pesquisa, desde que citada a fonte.

Catalogação na Publicação

Serviço de Biblioteca e Documentação

Faculdade de Educação da Universidade de São Paulo

379.61 Silveira, Adriana Aparecida Dragone

S587t O direito à educação de crianças e adolescentes: análise da atuação do Tribunal de Justiça de São Paulo (1991-2008) / Adriana Aparecida Dragone Silveira; orientação Romualdo Portela de Oliveira. São Paulo: s.n., 2010. 303p. : il., grafs. tabs.

Tese (Doutorado - Programa de Pós-Graduação em Educação. Área de Concentração: Estado, Sociedade e Educação ) - Faculdade de Educação da Universidade de São Paulo.

1. Direito à educação 2. Políticas públicas educacionais 3. Poder Judiciário 4. Tribunal de Justiça 5. Estatuto da Criança e do Adolescente 6. Financiamento da educação I. Oliveira, Romualdo Portela de, orient. 


\section{FOLHA DE APROVAÇÃO}

Adriana Aparecida Dragone Silveira

O direito à educação de crianças e adolescentes: análise da atuação do Tribunal de Justiça de São Paulo (1991-2008)

Tese apresentada ao Programa de PósGraduação da Faculdade de Educação da Universidade de São Paulo para a obtenção do título de Doutor em Educação.

Área de concentração: Estado, Sociedade e Educação

Aprovada em:

\section{Banca Examinadora}

Prof. Dr.

Instituição: Assinatura:

Prof. Dr.

Instituição: Assinatura:

Prof. Dr.

Instituição:

Assinatura:

Prof. Dr.

Instituição:

Assinatura:

Prof. Dr.

Instituição: Assinatura: 


\section{AGRADECIMENTOS}

À Fapesp pelo apoio financeiro, com a concessão da bolsa de doutorado, fundamental para o desenvolvimento desta pesquisa.

Ao Professor Romualdo Portela de Oliveira, meu orientador, pelas observações e sugestões para a definição e aprimoramento da tese. Também, pelo estímulo ao estudo do direito à educação.

À Professora Clarice Seixas Duarte e ao professor Carlos Roberto Jamil Cury agradeço o privilégio de suas participações na banca de qualificação e, em outros momentos, aprimorando este trabalho com sugestões e valiosas contribuições.

À Professora Rosângela Gavioli Prieto pelas importantes sugestões e generosidade dedicada nos momentos em que recorri ao seu auxílio.

À Professora Nina Beatriz Stocco Ranieri pelo acolhimento nos seminários na Faculdade de Direito, que enriqueceram a análise de muitas questões que permeiam este trabalho.

Aos colegas de orientação, Carlos, Isaac, Luciane, Marcelo, Natália, Patrícia e Vanda, que contribuíram com sugestões e comentários em diversas fases deste trabalho. E, principalmente, por dividirmos nossas experiências e angústias ao longo desse período.

Aos pesquisadores do Greppe pelo convite à participação nos grupos de estudos e nas pesquisas, imprescindíveis para o aprimoramento da minha formação e para a definição deste estudo.

Ao Salomão Ximenes, por auxiliar-me gentilmente na discussão sobre alguns procedimentos jurídicos.

À Maria José Silveira e Luzia Silveira Ogawa sou especialmente grata pelas diferentes formas de auxílio, gerando condições para a realização deste trabalho.

À amiga e eterna orientadora, Professora Theresa Adrião, meu especial agradecimento, por acreditar em mim, pelo incentivo a trilhar o caminho da pós-graduação e pelas discussões e sugestões, nas diferentes etapas, fundamentais para a realização desta tese.

Aos meus pais, João e Lurdes, que me ensinaram por meio de seus gestos e atitudes o valor da educação e de nunca perder a fé naquilo em que se acredita.

Finalmente, ao Paulo de Tarso, que soube aceitar os momentos de ausência para a realização do doutorado e, mesmo assim, colaborar para a concretização dos meus sonhos. 


\section{RESUMO}

SILVEIRA, Adriana Aparecida Dragone. O direito à educação de crianças e adolescentes: análise da atuação do Tribunal de Justiça de São Paulo (1991-2008). 2010. 303 p. Tese (Doutorado). Faculdade de Educação, Universidade de São Paulo, 2010.

Na Constituição Federal de 1988 (CF/88) o direito à educação é declarado como um direito fundamental, de caráter social, configurando-se um direito de todos e dever do Estado. Todavia, há um longo caminho a ser percorrido para que todos, sem distinção, tenham acesso à educação, e que esta seja de qualidade. Recorrer ao Poder Judiciário pode ser uma das possibilidades de efetivá-lo. Esta tese analisa como os desembargadores têm apreciado e julgado as demandas envolvendo os direitos de crianças e adolescentes à educação, no âmbito do Tribunal de Justiça de São Paulo (TJ-SP), instância de recurso do Poder Judiciário, no período após a implantação do Estatuto da Criança e do Adolescente. Objetivou-se identificar em quais litígios consolidou-se uma jurisprudência favorável à exigibilidade judicial, e localizar os possíveis entraves quanto à interpretação do direito à educação, procurando compreender se a intervenção judicial possibilita uma ampliação da efetivação dos direitos educacionais e, consequentemente, o fortalecimento da democracia. Nas referências teóricas buscou-se discutir a efetividade e a interpretação das normas relacionadas ao direito à educação, como um direito social, no contexto do Estado democrático de direito adotado pela $\mathrm{CF} / 88$, o processo de expansão do Poder Judiciário para a proteção dos direitos sociais e as características institucionais do Judiciário brasileiro e do TJ-SP. Tendo em vista os objetivos, realizou-se uma pesquisa documental, com a coleta de 483 decisões proferidas pelo TJ-SP, no período de 1991 a 2008. Esses documentos, com base nas principais demandas e questionamentos discutidos nos processos, foram organizados e analisados em amplas categorias: acesso à educação básica; permanência; responsabilidade estatal; poder de regulação estatal; decisões administrativas e políticas; gestão dos recursos públicos e deveres dos pais. A partir da análise geral das decisões, denota-se que os principais obstáculos para a exigibilidade judicial do direito à educação estão relacionados, sobretudo, às questões sobre o orçamento público, aos limites da discricionariedade do administrador e do campo decisório do Judiciário e ao atendimento às demandas difusas e coletivas envolvendo a formulação e a implementação de políticas públicas. Observa-se que há uma tendência majoritária entre os membros do TJ-SP a aceitar com mais facilidade as demandas que requisitavam, individualmente ou para um número definido de interessados, o acesso à educação, consolidando uma jurisprudência favorável ao longo dos anos, principalmente com relação à educação infantil e à educação especial. Todavia, os desembargadores foram mais resistentes em acatar os pedidos relacionados às questões técnicas ou políticas, considerando o argumento da separação dos poderes. Por fim, constata-se que o Judiciário constitui importante instrumento para a consolidação da democracia ao possibilitar reivindicar a efetivação do direito à educação, no entanto torna-se fundamental a mudança de concepção de parcela dos seus membros, no que se refere à interferência desta instituição no controle da ação da administração pública, quando esta deixa de cumprir com os direitos declarados.

Palavras-chave: Direito à educação básica; Tribunal de Justiça de São Paulo; Políticas públicas educacionais; Estatuto da Criança e do Adolescente; financiamento da educação; 


\begin{abstract}
SILVEIRA, Adriana Aparecida Dragone. The right to education of the childrens and adolescents: analysis of São Paulo Justice Court performance (1991-2008). 2010. 303 p. Thesis (Doctoral). Faculdade de Educação, Universidade de São Paulo, 2010.
\end{abstract}

In the Federal Constitution of $1988(\mathrm{CF} / 88)$ the right to education is declared as a fundamental right, social character, configuring a everyone right and duty of the State. However, there is a long way to be crawled so that everyone, without distinction, has access to education, and that this is quality. Recourse to the Judiciary can be one of the possibilities to make permanent. This thesis examines how the magistrates have esteemed and judged demands involving the rights of children and adolescents to education, in the context of the São Paulo Justice Court (TJ-SP), the judiciary' instance appeal, in the period after the implantation of the Children and Adolescents' Statute. The target is identify in which litigations consolidated a favorable jurisprudence to judicial enforceability and find potential barriers as to the interpretation of the right to education, trying to understand if judicial intervention enables extension of effective educational rights and consequently, the strengthening of the democracy. In the theoretical references attempted discuss the effectiveness and interpretation of standards related to the right to education, as a social law, in the Democratic State context adopted by $\mathrm{CF} / 88$, the process of Judiciary expansion to the protection of social rights and institutional characteristics of the Brazilian Judiciary, and judicial and the São Paulo Justice Court (TJ-SP). According the objectives, achieved the research with 483 decisions given by the TJ-SP, during the period 1991 to 2008. These documents, on the basis of the main demands and questions discussed in the processes, were organized and analyzed in wide categories: access to basic education; permanence; State responsibility; State regulatory power; policies and administrative decisions; management of public resources and parents obligations. From the general analysis of the decisions, denotes that the main obstacles to judicial enforceability of the right to education are related, primarily, to questions about the public budget, to the administrator discretionary limits and the Judiciary decisive area, and the attendance to the diffuse and collective demands involving the formulation and implementation of public policies. Noted that there is a tendency majority among of the TJ-SP members to accept more easily demands that required, individually or to a defined number of interested parties, the access to education, consolidating a favorable jurisprudence over the years, mainly with respect to early childhood education and special education. However, the magistrates were more resistant to accept requests related to policy or technical issues, whereas the argument of the separation of powers. Finally, the Judiciary constitutes an important instrument for consolidating to democracy, enabled identifiable claim the right to education, however it, becomes crucial to changing the conception of its members, regarding the interference of this institution in control of the action of public administration, when this not comply with the rights declared.

Keywords: Right to basic education; São Paulo Justice Court; Educational public policies; Children and Adolescents Statute; education financial support. 


\section{LISTA DE ILUSTRAÇÕES}

\section{FIGURAS}

Figura 1 - Estrutura do Poder Judiciário brasileiro

Figura 2 - Estrutura do TJ-SP

\section{GRÁFICOS}

Gráfico 1 - Números de decisões do TJ-SP envolvendo acesso à educação básica 106

Gráfico 2 - Decisões do TJ-SP objetivando o direito à vaga em EI (1999-2008) 108

Gráfico 3 - Demandas por acesso ao EF 120

Gráfico 4 - Distribuição anual das decisões sobre acesso ao ensino profissionalizante 131

Gráfico 5 - Distribuição anual das decisões envolvendo crianças e adolescentes com necessidades educacionais especiais 139

Gráfico 6 - Distribuição anual das decisões envolvendo mensalidades escolares 163

Gráfico 7 - Distribuição anual das decisões versando sobre financiamento da educação

\section{QUADROS}

Quadro 1 - Organização das decisões por categorias e temas 32

Quadro 2 - Os Tribunais como instrumentos estratégicos 79

Quadro 3 - Presidência do TJ-SP entre os anos de 1991 a 2008 90

Quadro 4 - Composição Câmara Especial do TJ-SP (1991-2008) 91

Quadro 5 - Dados biográficos dos desembargadores do TJ-SP. 94

Quadro 6 - Síntese dos principais consensos para a afirmativa e negativa da exigibilidade das demandas educacionais julgadas pelo TJ-SP 


\section{LISTA DE TABELAS}

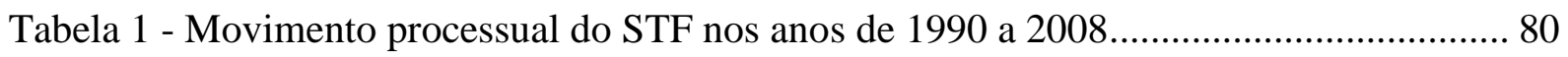

Tabela 2 - Distribuição anual das decisões organizadas em categorias ................................ 102

Tabela 3 - Decisões agrupadas por temas envolvendo "Acesso à educação básica" ............ 103

Tabela 4 - Decisões agrupadas por temas envolvendo "Permanência" .................................. 103

Tabela 5 - Decisões agrupadas por temas envolvendo "Responsabilidade estatal" ................ 104

Tabela 6 - Decisões envolvendo "Poder de regulação estatal" agrupadas por temas ........... 104

Tabela 7 - Decisões agrupadas por temas envolvendo "Decisões administrativas e políticas" 105

Tabela 8 - Decisões agrupadas por tema envolvendo "Gestão dos recursos públicos” "......... 105

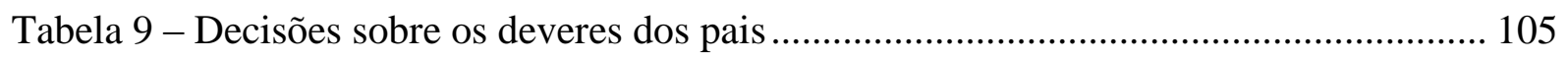

Tabela 10 - Matrículas em creches e pré-escolas no estado de São Paulo (1998-2010)........ 108

Tabela 11 - Resultados das votações do TJ-SP: decisões unânimes e por maioria ................ 111

Tabela 12 - Decisões sobre acesso Educação Infantil envolvendo demandas individuais,

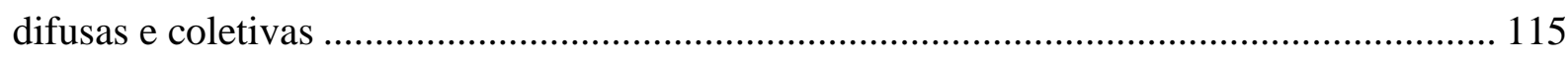

Tabela 13 - Decisões do TJ-SP versando sobre mensalidades escolares .............................. 163 


\section{LISTA DE ABREVIATURAS E SIGLAS}

ABMP - Associação Brasileira de Magistrados e Promotores de Justiça da Infância e Juventude

Adcon - Ação Declaratória de Constitucionalidade

Adin - Ação Direta de Inconstitucionalidade

Apeoesp - Sindicato dos Professores do Ensino Oficial do Estado de São Paulo

Art. - Artigo

CAO - Centro de Apoio Operacional

CEE - Conselho Estadual de Educação

CEETEPS - Centro Estadual de Educação Tecnológica "Paula Souza"

Cefam - Centro Específico de Formação e Aperfeiçoamento de Magistério

CEL - Centro de Estudos de Línguas

CF/88 - Constituição Federal de 1988

CFE - Conselho Federal de Educação

CNE - Conselho Nacional de Educação

CEB - Câmara de Educação Básica

DCA - Defesa das Crianças e Adolescentes

Des. - Desembargador (a)

EC - Emenda Constitucional

ECA - Estatuto da Criança e do Adolescente

EI - Educação Infantil

EJA - Educação de Jovens e Adultos

EM - Ensino Médio

ETE - Escolas Técnicas Estaduais

Fatec - Faculdades de Tecnologia

Feusp - Faculdade de Educação da Universidade de São Paulo

Fundeb - Fundo de Manutenção e Desenvolvimento da Educação Básica e de Valorização dos Profissionais da Educação

Fundef - Fundo de Manutenção e Desenvolvimento do Ensino Fundamental e de Valorização do Magistério

Ideb - Índice de Desenvolvimento da Educação Básica 
Inep - Instituto Nacional Instituto Nacional de Estudos e Pesquisas Educacionais Anísio Teixeira

JTJ - Jurisprudência do Tribunal de Justiça

LDB/96 - Lei de Diretrizes e Bases da Educação Nacional de 1996

MDE - Manutenção e Desenvolvimento do Ensino

MP - Ministério Público

NEE - Necessidades Educacionais Especiais

ONU - Organizações das Nações Unidas

PIDESC - Pacto Internacional sobre Direitos Econômicos, Sociais e Culturais

RJTJESP - Revista de Jurisprudência do Tribunal de Justiça do Estado de São Paulo

SEE - Secretaria da Educação do Estado de São Paulo

Senac - Serviço Nacional de Aprendizagem Comercial

Sesi - Serviço Social da Indústria

SP - São Paulo

STF - Supremo Tribunal Federal

STJ - Superior Tribunal de Justiça

TJSP - Tribunal de Justiça de São Paulo

TAC - Termo de Ajustamento de Conduta

USP - Universidade de São Paulo 


\section{SUMÁRIO}

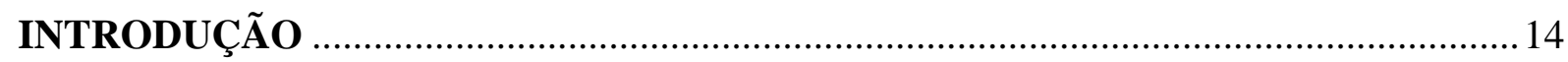

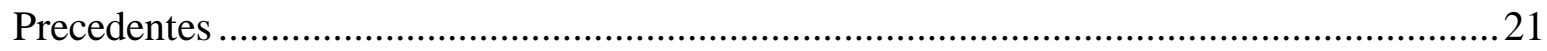

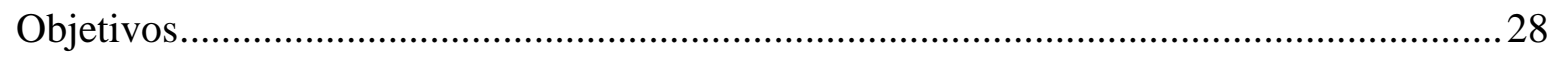

Procedimento de coleta e análise das decisões do TJ-SP .................................................2 29

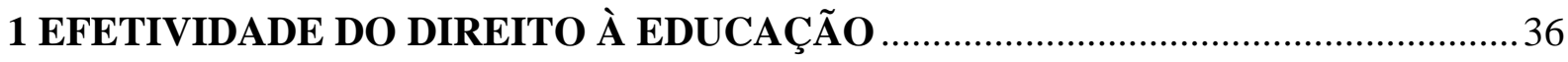

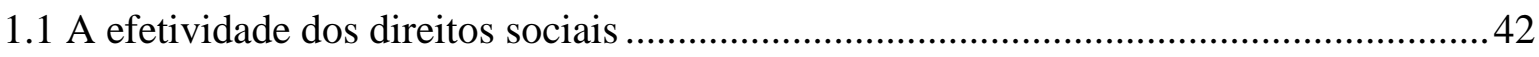

1.2 Estrutura das normas constitucionais: princípios e regras ....................................... 46

1.3 As políticas públicas como objeto dos direitos sociais...............................................54

2 EXPANSÃO DO PODER JUDICIÁRIO: HISTÓRICO E ATUAIS DEBATES ..........59

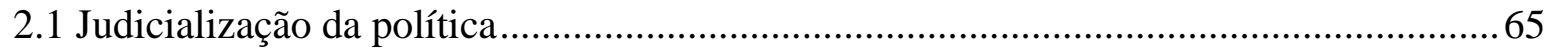

2.2 Intervencionismo político dos Tribunais: principais debates ....................................69

2.3 Desenho institucional do Poder Judiciário brasileiro ............................................ 75

2.3.1 Crise das instituições judiciárias ................................................................... 80

3. TRIBUNAL DE JUSTIÇA DE SÃO PAULO: ASPECTOS INSTITUCIONAIS........ 86

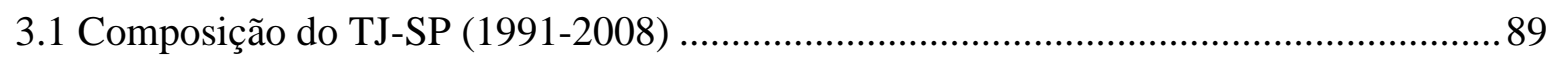

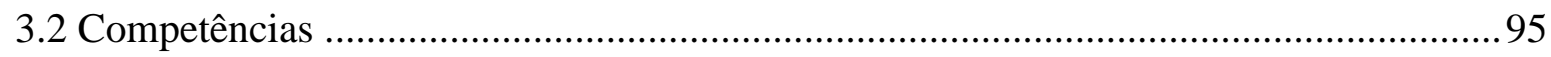

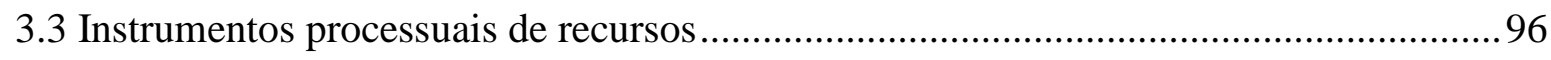

3.4 Indicadores da justiça estadual paulista............................................................. 99

4 DECISÕES EDUCACIONAIS DO TRIBUNAL DE JUSTIÇA DE SÃO PAULO .... 102

4.1 Acesso às diferentes etapas e modalidades da educação básica ....................................106

4.1.1 Demandas por vaga em instituições de Educação Infantil .................................... 107

4.1.2 Demandas por acesso ao Ensino Fundamental ............................................... 120

4.1.2.1. Restrição à matrícula de crianças com sete anos incompletos ......................120

4.1.2.2 Direito de frequentar escola mais próxima de sua residência e escolha da

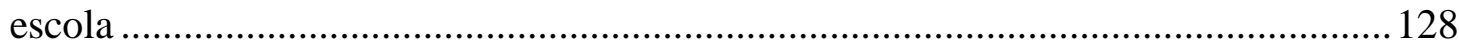


4.1.4. Educação de Jovens e Adultos: idade mínima para ingresso e gratuidade dos exames

4.1.5 Acessibilidade e atendimento especializado às crianças e aos adolescentes com

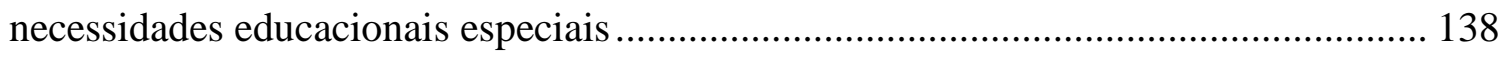

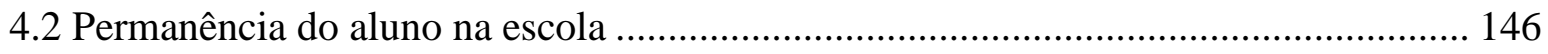

4.2.1 Penalidades por violação às normas escolares ................................................... 147

4.2.2 Indeferimento de matrícula em cursos de língua estrangeira............................... 149

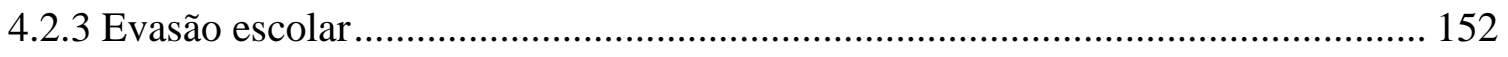



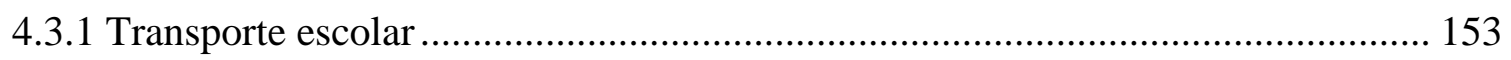

4.3.2 Reparação de danos morais e/ou materiais .................................................... 158

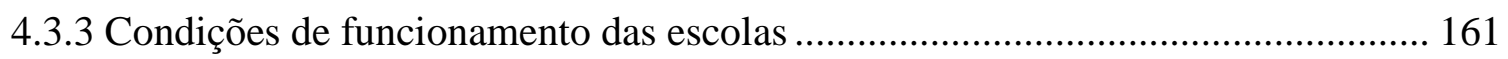

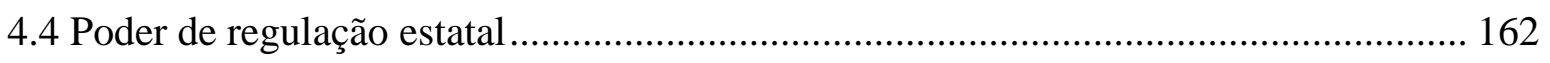

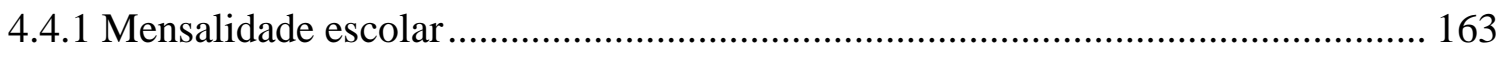

4.4.2 Autorização e credenciamento de instituições privadas ...................................... 168

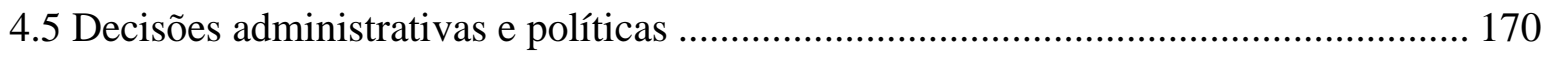

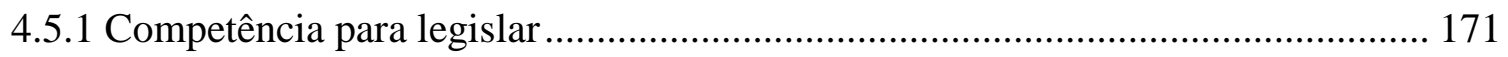

4.5.2 Reorganização das escolas estaduais ........................................................... 173

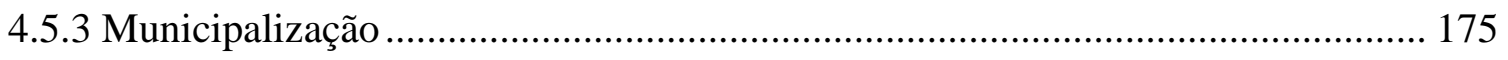

4.5.4 Fechamento de creche em período de férias escolares ...................................... 177

4.5.5 Outras decisões referentes às decisões administrativas e políticas ....................... 178

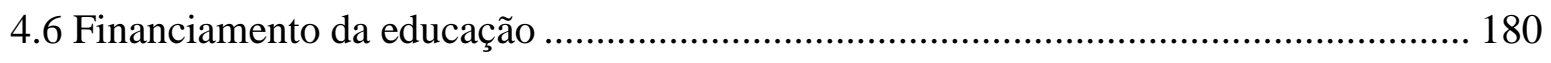

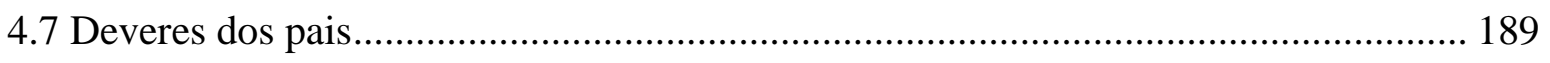

4.8 Considerações sobre os litígios julgados pelo TJ-SP: lições aprendidas ..................... 190

5 CONSENSOS E CONFLITOS NA EXIGIBILIDADE JUDICIAL DO DIREITO À

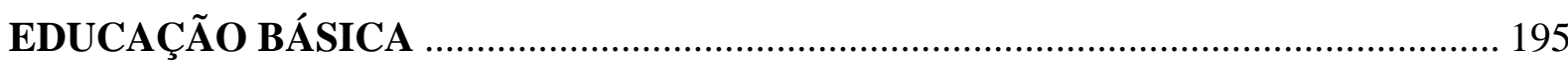


5.1 Capacidade econômico-financeira do Estado para a implementação dos direitos educacionais

5.2 Interferência do Judiciário no poder discricionário do Executivo: princípio da separação de poderes

5.3 Tutela dos direitos educacionais por meio de demandas individuais e coletivas .208

CONSIDERAÇÕES FINAIS .212

REFERÊNCIAS 226

APÊNDICE - Organização das decisões proferidas pelo TJ-SP sobre direito à educação (1991-2008) 


\section{INTRODUÇÃO}

Segundo Norberto Bobbio (2004), os direitos dos homens são uma construção histórica em função do aprimoramento das necessidades da convivência coletiva e "emergem gradualmente das lutas que o homem trava por sua própria emancipação e das transformações das condições de vida que essas lutas produzem" (p.51), portanto, são suscetíveis à mudança e ampliação. O seu desenvolvimento contemplou três etapas distintas. Inicialmente, com a declaração dos direitos de liberdade; posteriormente, dos políticos, e, na terceira fase, dos direitos sociais. $\mathrm{Na}$ atualidade, a inovação tecnológica e o progresso científico colocam desafios inéditos ao conjunto dos direitos humanos, fazendo com que uma quarta geração se estabeleça, no tocante às diferentes problemáticas deste novo século, como o direito ao meio ambiente, direito à intimidade e à privacidade, integridade do patrimônio genético dos seres humanos e dilemas da bioética ${ }^{1}$.

Como processo histórico, de acordo com Bobbio, os direitos humanos nascem quando o aumento de poder do homem sobre outro ameaça a liberdade deste, com a finalidade de impedir danos que podem ser impingidos pelo exercício do poder sobre os demais. Ainda, nascem para possibilitar a criação de novos remédios para as indigências da humanidade, exigindo que o poder intervenha para a proteção, obtendo, então, benefícios para a cobertura de riscos variados, tanto na vida individual como coletiva.

Nas últimas décadas, além do processo de conversão dos direitos humanos em direito positivo, de sua generalização e de sua internacionalização, há uma nova tendência, que Bobbio chama de "especificação", com a determinação dos sujeitos titulares. Essa especificação ocorreu, segundo o autor, com relação ao gênero, as fases da vida e aos estados excepcionais na vida humana. Estando esses, principalmente, no âmbito dos direitos sociais.

\footnotetext{
${ }^{1}$ Segundo Paulo Bonavides (2009a), o precursor na formulação da tese da geração de direitos é Karel Vasak, na aula inaugural de 1979, dos Cursos do Instituto Internacional dos Direitos do Homem, em Estrasburgo, tendo como inspiração o lema da Revolução Francesa liberdade, igualdade e fraternidade. Segundo esta concepção, os direitos civis e políticos correspondem aos direitos de liberdade, os da primeira geração. Os direitos de segunda geração são os direitos sociais, cuja base é a igualdade. A terceira geração, fundada no princípio da solidariedade, seria a dos direitos ao desenvolvimento, à paz, ao meio ambiente, à comunicação e ao patrimônio comum da humanidade e o direito à comunicação. Bonavides (2009a) acresce novas gerações a essa tríade. Na quarta geração, o direito à democracia, o direito à informação e o direito ao pluralismo. Na quinta geração, o direito à paz. Para afastar a ideia de sucessão cronológica, Bonavides sugere o verbete "dimensão". Apesar das distinções adotadas por diversos autores, entre as classificações dos direitos em cada geração, e das críticas à divisão, sua distinção deve ser considerada do ponto de vista histórico, sendo o termo gerações, como destaca Maria Victoria de Mesquita Benevides Soares (1998), utilizado no sentido da evolução histórica, pois os direitos não são superados com a chegada de uma nova geração, mas incorporados à nova geração. Também, por sua historicidade, se alteram ao longo do tempo e seu reconhecimento é diferente em distintos países.
} 
Essa especificação pode ser percebida com a aprovação de diferentes documentos pelos organismos internacionais, como: "Convenção sobre a eliminação de todas as formas de discriminação contra a Mulher” (1979), "Convenção sobre a eliminação de todas as formas de discriminação racial” (1965), "Convenção dos direitos da criança" (1989), "Convenção internacional sobre a proteção dos direitos de todos os trabalhadores migrantes e seus familiares" (1990). No âmbito do Sistema Interamericano de Direitos Humanos a "Convenção Interamericana para prevenir, punir e erradicar a violência contra a mulher" (1994) e a "Convenção Interamericana para a eliminação de todas as formas de discriminação contra as pessoas portadoras de deficiência" de 1999 (PIOVESAN, 2008).

Esse processo também pode ser percebido na legislação educacional brasileira. Segundo Carlos Roberto Jamil Cury (2008), a declaração do conceito de educação básica ${ }^{2}$, na Lei de Diretrizes de Bases da Educação Nacional, de 1996 (LDB/96), como direito do cidadão e dever do Estado, ampliou o espectro da cidadania em nosso país. Processo esse já iniciado na Constituição Federal de 1988 (CF/88) que declarara, no âmbito dos direitos educacionais, os deveres do Estado para com a Educação Infantil e a progressiva extensão da obrigatoriedade do ensino médio, e com a aprovação do Estatuto da Criança e do Adolescente (ECA), em 1990, adotando uma doutrina de proteção integral à infância.

A incorporação de novos direitos na Lei Maior brasileira, principalmente com relação à educação infantil, é a manifestação formal de um processo de sensibilização e de esclarecimento social da importância do atendimento educacional à primeira infância (CURY, 1998).

Os procedimentos relativos ao reconhecimento formal dos direitos, à sua ampliação e especificação, fazem com que se torne cada vez mais difícil sua satisfação, dado que a proteção aos direitos sociais requer uma atuação positiva do Estado, com obrigações para a sua promoção, ao contrário dos direitos individuais tradicionais, que precisam mais da abstenção de determinados comportamentos.

É supérfluo acrescentar que o reconhecimento dos direitos sociais suscita, além do
problema da proliferação dos direitos do homem, problemas bem mais difíceis de
resolver no que concerne àquela "prática" de que falei no início: é que a proteção
destes últimos requer uma intervenção ativa do Estado, que não é requerida pela
proteção dos direitos de liberdade, produzindo aquela organização dos serviços
públicos de onde nasceu até mesmo uma nova forma de Estado, o Estado social.
Enquanto os direitos de liberdade nascem contra o superpoder do Estado - e,
portanto, com o objetivo de limitar o poder -, os direitos sociais exigem, para sua
realização prática, ou seja, para a passagem da declaração puramente verbal à sua

\footnotetext{
${ }^{2}$ A educação básica é formada pela educação infantil, Ensino Fundamental e Ensino Médio (BRASIL, 1996, art.21, inciso I).
} 
proteção efetiva, precisamente o contrário, isto é, a ampliação dos poderes do Estado. (BOBBIO, 2004, p. 86-7).

Alguns autores, como Stephen Holmes e Cass R. Sunstein (1999) argumentam que todos os direitos são positivos e demandam algum tipo de prestação pública para a sua efetivação, pois, mesmo a proteção dos direitos de liberdade e os direitos políticos dependem da ação de agentes governamentais e de estrutura pública, por exemplo, a manutenção da Justiça e da segurança pública, sendo esses mantidos pelo erário público.

Víctor Abramovich e Christian Courtis (2002) explanam sobre a distinção que considera que os direitos de primeira geração provocam exclusivamente obrigações negativas ou de abstenção, e os direitos econômicos, sociais e culturais, obrigações positivas. Essa distinção está baseada em uma posição de Estado mínimo, tendo como função deste Estado garantir a justiça, a segurança e a defesa.

Assim, a diferença entre os direitos seria de grau. A faceta mais visível dos direitos econômicos, sociais e culturais refere-se às obrigações de fazer, por isso, às vezes são denominados por direitos de prestação (ABRAMOVICH; COURTIS, 2002).

Abramovich (2005), de acordo com a proposta de von Hoof, propõe quatro "níveis" de obrigações estatais que caracterizam cada direito: obrigações de respeitar, de proteger, de garantir, de promover o direito:

\begin{abstract}
As obrigações de respeitar se definem pelo dever do Estado de não interferir nem obstaculizar ou impedir o acesso ao desfrute dos bens que constituem o objeto do direito. As obrigações de proteger consistem em evitar que terceiros interfiram, obstaculizem ou impeçam o acesso a esses bens. As obrigações de garantir pressupõem assegurar que o titular do direito tenha acesso ao bem quando não puder fazê-lo por si mesmo. As obrigações de promover se caracterizam pelo dever de criar condições para que os titulares do direito tenham acesso ao bem. (ABRAMOVICH, 2005, p. 194-5, grifos nossos).
\end{abstract}

Tais níveis de obrigações são aplicáveis tanto aos direitos civis e políticos, como aos direitos econômicos, sociais e culturais.

Para a garantia do direito à educação são necessários os quatro níveis de obrigações estatais. As obrigações de promover são, efetivamente, as mais onerosas, pois se referem à prestação de um serviço, construindo e mantendo diferentes unidades de ensino.

Neste sentido, Katarina Tomasevski (2001), primeira relatora da ONU para o Direito à Educação, no período de 1998 a 2004, destaca que as obrigações governamentais com relação à educação podem ser estruturadas no esquema de quatro "A's": "availability, accessibility, acceptability, adaptability”, a fim de tornar a educação disponível, acessível, aceitável e adaptável a todos. 
A disponibilidade incorpora obrigações governamentais em dois sentidos. O direito à educação como direito civil e político exige que o Poder Público permita o estabelecimento de instituições privadas; enquanto direito social, exige o seu financiamento como meio de garantir que a educação esteja disponível, fornecendo prédios seguros, material, transporte apropriado e professores capacitados.

A acessibilidade é definida como obrigação de garantir educação para todas as crianças do ensino obrigatório, com a sua gratuidade e sem discriminação.

A aceitabilidade está relacionada à regulação e supervisão, para assegurar que a educação esteja disponível, acessível e de boa qualidade, garantindo normas mínimas, respeito à diversidade $\mathrm{e}$ aos direitos dos educandos.

A adaptabilidade refere-se à demanda para que as escolas se adequem às necessidades dos alunos, principalmente àqueles com necessidades especiais, trabalhadores, refugiados e privados de liberdade.

Fica patente que os direitos sociais necessitam de financiamento para a sua realização, e são "caros". "O direito da criança, para que tenha a devida instrução, necessita de proteção com eficácia e com financiamento. Deve-se ter este realismo, pois, caso contrário, o Direito embora proclamado, fica inócuo." (CURY, 1998, p.10).

Portanto, como destaca Bobbio (2004), os direitos sociais obtêm com relativa facilidade a sua declaração, contudo, no momento de executá-los iniciam-se as reservas e oposições. Não se trata de um problema filosófico, mas político, não se busca justificá-los, mas sim protegê-los, pois “à medida que as pretensões aumentam, a satisfação delas torna-se cada vez mais difícil” (p. 80).

Se os direitos sociais requerem também uma ampliação dos poderes do Estado para a sua plena efetivação, quais ações deste Estado devem garantir a viabilização desses direitos?

Segundo José Reinaldo de Lima Lopes (2002), os direitos sociais ${ }^{3}$ diferem também dos direitos individuais pelo "remédio" ou pela ação para a sua proteção, pois as situações precisam ser criadas. Ou seja, não consistem, como é o caso dos direitos individuais, apenas na "exclusão de outrem (Estado ou particular) numa esfera de interesses já consolidados e protegidos de alguém (indivíduo ou grupo)” (p. 126-7). Para exemplificar essa dificuldade o autor utiliza-se do direito à educação:

\footnotetext{
${ }^{3}$ A CF/88, artigo 6, enumerou como direitos sociais: "a educação, a saúde, a alimentação, o trabalho, a moradia, o lazer, a segurança, a previdência social, a proteção à maternidade e à infância, a assistência aos desamparados, na forma desta Constituição".
} 
[...] é mais do que direito de não ser excluído de uma escola; é de fato, o interesse de conseguir uma vaga e as condições para estudar (ou seja, tempo livre, material escolar, etc.). Ora, se a vaga não existe, se não existe o tempo livre, se não há material escolar a baixo custo, como garantir juridicamente tal direito? Como transformá-lo de um direito à não interferência (permissão, dever de abstenção) em um direito à prestação (dever de fazer, obrigação) de alguém? (LOPES, 2002, p. 127).

Para a sua exigibilidade, Lopes (2002) destaca algumas questões jurídicas que precisam ser enfrentadas. Inicialmente, é preciso "saber se os cidadãos em geral têm ou não o direito de exigir, judicialmente, a execução concreta de políticas públicas e a prestação de serviços públicos", e, depois, "se e como o Judiciário pode provocar a execução de tais políticas.” (p.130).

Do ponto de vista da declaração, dos direitos educacionais, o Brasil pode ser considerado um dos mais avançados, no entanto há um caminho longo a se percorrer para a plena satisfação desses direitos (CURY, 1998).

Aceitando-se que a concretização dos direitos sociais se dá por meio da ampliação da ação do Estado, através da implementação de políticas públicas, o grande desafio, segundo Clarice Seixas Duarte (2004), "tem sido o de estabelecer mecanismos para garantir a exigibilidade e o controle judicial do seu cumprimento, em caso de ausência ou insuficiência das políticas adotadas" (p. 114). Recorrer ao Poder Judiciário é uma das possibilidades de fazer valer este direito, conforme o que determina a própria $\mathrm{CF} / 88$ : "A lei não excluirá da apreciação do Poder Judiciário lesão ou ameaça a direito" (BRASIL, 1988, art. 5 inciso XXXV).

No entanto, Duarte (2006) aponta alguns obstáculos, quando se trata da efetivação do direito à educação e da possibilidade de exigibilidade perante o Poder Judiciário: 1) “dificuldade em delinear o regime jurídico aplicável aos direitos humanos de natureza social à luz do sistema internacional de proteção dos direitos humanos e do ordenamento jurídico interno"; 2) “Trata-se de verdadeiros direitos, ou de meros princípios, objetivos ou padrões de conduta gerais que devem guiar a atuação dos poderes públicos sem, contudo, gerar direitos subjetivos, exigíveis perante o Poder Judiciário, em caso de violação?”; $3^{\circ}$ ) “o Judiciário, diante de uma situação de inércia do Legislativo na elaboração e do administrador na concretização das referidas políticas, não poderia exercer o controle sobre tais violações, sob pena de invadir a esfera de competência dos demais poderes"; 4) "forma de proteção diferenciada conferida às diversas etapas e modalidades educacionais, à luz do ordenamento jurídico" (p. 128). 
No ordenamento jurídico brasileiro os direitos educacionais receberam proteção jurídica diferenciada, com especificação do seu conteúdo e formas de exigibilidade ao considerar o ensino obrigatório como direito público subjetivo.

De acordo com Duarte (2004, p. 113) a norma jurídica do direito público subjetivo, na definição clássica de Jellinek, "confere ao indivíduo a possibilidade de transformar a norma geral e abstrata contida num ordenamento jurídico em algo que possua como próprio. A maneira de fazê-lo é acionando as normas jurídicas (direito objetivo) e transformando-as em seu direito (direito subjetivo)."

Todavia, algumas questões se colocam. Quem são os titulares desse direito? É possível exigi-lo individual ou coletivamente? A exigibilidade judicial destina-se para a determinação de vagas ou a criação de políticas públicas? Quais mecanismos podem ser acionados em caso de sua oferta irregular ou insuficiente? (DUARTE, 2006, 2007).

Segundo Duarte (2004), a possibilidade de reconhecer ao indivíduo a probabilidade de “interferir nas decisões sobre alocação de recursos, realização de programas sociais, definição de prioridades de ação governamental, sobretudo pela via judicial, é uma hipótese vista com grande resistência por boa parte da doutrina e da Jurisprudência” (2004, p. 115). Entende-se que o Judiciário acabaria tendo que julgar questões cuja apreciação é da esfera da Administração Pública.

Para esta autora, o Judiciário, quando demandado à exigibilidade de políticas públicas, dificilmente reconhece que o Executivo e o Legislativo estão agindo com omissão. Nesse sentido, acaba prevalecendo a "falsa idéia de que a intervenção do Judiciário em questões políticas representaria uma extrapolação de seu papel, uma intervenção indevida em assuntos orçamentários, alçada daqueles que foram eleitos para isso.” (DUARTE, 2003, p. 45).

Sobre os conflitos inerentes ao Poder Judiciário, quando se lhe exige que julgue sobre a implementação de políticas públicas para a efetivação dos direitos sociais, Duarte (2004) destaca a "alegada 'preservação da separação dos poderes', há, ainda, o ideal de 'neutralidade axiológica' nas teorias e de 'isenção política' nas práticas jurídicas” (p. 117).

Em um Estado Democrático de Direito, como define a própria Constituição brasileira, o Poder Judiciário precisa repensar estas ideias. Nos últimos anos, a própria jurisprudência dos Tribunais brasileiros, bem como a literatura específica, têm se posicionado favoravelmente à intervenção desta instituição não implicando em ofensa ao princípio da separação dos poderes ou em interferência na discricionariedade administrativa. 
Considerando que os direitos sociais dependem da atuação ativa do Estado para a sua realização, e a sua concretização demanda impactos orçamentários, como o Poder Judiciário pode provocar a execução dessas políticas, para garantir que os direitos declarados sejam cumpridos pelos demais Poderes?

E, no caso da educação, a normatização detalhada no próprio texto constitucional e nas leis infraconstitucionais, com a enumeração de princípios, deveres do Estado para a sua efetivação, definição de responsabilidades dos entes federados e vinculação de recursos financeiros, favorece a exigibilidade judicial? Ou seja, há maior aceitação dessas demandas pelo Judiciário? Em quais litígios é possível consolidar uma jurisprudência favorável, com “a delimitação de seu conteúdo e determinação das responsabilidades das autoridades competentes" (DUARTE, 2006, p. 139)?

O reconhecimento do direito à educação pelo Poder Judiciário ultrapassa a dimensão de proteção de interesses individuais, vai além da determinação para a garantia de vagas nas escolas, mas seria válido para a definição e implementação de políticas públicas, com a criação de ações concretas por parte do Poder Público, aqui entendido como Poder Executivo e Legislativo?

Diante dessas indagações e considerações apresentam-se como questões de pesquisa: Em quais assuntos estabeleceu-se uma jurisprudência favorável para a exigibilidade do direito à educação por meio do Poder Judiciário? Quais as principais dificuldades quanto à interpretação deste direito? A estratégia de utilização do Judiciário para reivindicar e questionar os direitos educacionais possibilita uma ampliação dos mesmos, constituindo-se em um espaço para a consolidação da cidadania e da democracia?

A complexidade dos problemas sociais contemporâneos coloca novos desafios aos direitos sociais, surgimento de demandas inéditas por direitos, por uma efetividade das políticas públicas, implicando em custos elevados para a sua implantação. Porém, tais demandas surgem num contexto de contenção da capacidade econômico-financeira do Estado e de retração das políticas sociais. O processo se torna mais complexo na realidade brasileira, pois a $\mathrm{CF} / 88$ desencadeia a tentativa de construção de Estado de bem-estar, justamente no momento histórico marcado por uma crise mundial relativa a este modelo de Estado. Isto é, no contexto de difusão da agenda neoliberal, que defende o controle dos gastos públicos e a retração das estruturas do Estado.

Em razão dessas argumentações e questionamentos, este trabalho se propõe a analisar a atuação de um Tribunal de Justiça estadual com relação aos litígios envolvendo a educação, 
sejam eles por ação ou omissão do Poder Público, contribuindo para que este direito seja ofertado a todos os cidadãos, sem exceção e com qualidade, pois a educação contribui para o desenvolvimento pessoal e social, favorecendo o processo de consolidação da cidadania e da democracia brasileira.

O interesse da pesquisadora por este tema adveio da dissertação de mestrado, que evidenciou diferentes "entendimentos" sobre a declaração dos direitos educacionais entre os operadores do direito (promotores e procuradores de justiça, juízes e procuradores dos municípios), instigando-a averiguar o modo como o Poder Judiciário tem discutido o direito à educação. As divergências de entendimento e de concepções sobre a compreensão da declaração do mesmo foram vislumbradas na análise de ações judiciais ingressadas pelos Promotores de Justiça dos municípios investigados.

O interesse de uma pedagoga pela área do direito à educação consolidou-se, gradualmente, ao ter contato com a literatura e pesquisas sobre o tema e à medida que percebia que o estudo da interrelação entre as duas áreas se faz necessário, pois o conhecimento da legislação educacional e de sua aplicação pelo Sistema de Justiça pode colaborar para uma intervenção com mais sucesso na realidade brasileira, contribuindo para que todos os cidadãos brasileiros tenham um ensino público de qualidade.

\section{Precedentes}

A discussão judicial de direitos educacionais tem como referência a decisão da Suprema Corte norte-americana no caso Brown versus Board of Education of Topeka, de 1954, que condenou a política de segregação racial das escolas, obrigando o sistema escolar a integrar na mesma instituição alunos negros e brancos.

No Brasil, os estudos sobre a jurisprudência educacional não são, tradicionalmente, objetos de pesquisa. Situação diferente daquela dos Estados Unidos da América, país que disponibiliza trabalhos que reúnem e analisam as decisões da Suprema Corte, além de publicar revistas acadêmicas especializadas no tema, como o trabalho de David Fellman (1961), Arval Morris (1999). 
Como exemplo dos estudos recentes, o Teachers College da Universidade de Columbia, Nova York, tem uma página na internet ${ }^{4}$, oferecendo informações sobre ações judiciais que questionam o financiamento escolar nos estados norte-americanos e sobre estudos de Michael A. Rebell sobre recursos judiciais envolvendo a educação.

Nos últimos anos, o assunto está se tornando objeto de interesse de pesquisadores da área do Direito e da Educação, no Brasil. Têm surgido pesquisas voltadas à análise dos mecanismos de exigibilidade judicial do direito à educação e ao papel das diferentes instituições de Justiça nesse processo, como evidencia estudo anterior (SILVEIRA, 2008).

Nesse cenário, destacam-se os seguintes trabalhos de pesquisa: a tese em Educação "Educação e cidadania: O direito à educação na Constituição de 1988 da República Federativa do Brasil" de Romualdo Portela de Oliveira (1995), que analisa a declaração do direito à educação na $\mathrm{CF} / 88$, os mecanismos introduzidos para sua efetivação e a intervenção do Sistema de Justiça; a dissertação em Educação de Edson Machado (2003) "A educação e o Poder Judiciário: A jurisprudência educacional do Supremo Tribunal Federal, na vigência da Constituição de 1988 da República Federativa do Brasil”, sobre o conteúdo das decisões judiciais relacionadas às questões educacionais demandadas ao Supremo Tribunal Federal (STF); a publicação de César Pereira da Silva Machado Júnior (2003), “O direito à educação na realidade brasileira", resultado de mestrado em Educação, em que o autor analisa algumas decisões judiciais de tribunais brasileiros, verificando o significado da educação para o Judiciário; a tese em Direito de Irene Rodrigues (2005) sobre "O direito à escolarização da criança e do adolescente", que procura examinar, dentre outros objetivos, o papel do Ministério Público para a educação, recorrendo à legislação, doutrina e jurisprudência; a dissertação em Direito de Divan Alves Tavares (2006) "Efetividade do direito ao ensino fundamental: uma questão de justiça”, a qual destaca que o Poder Judiciário deverá se posicionar, em última instância, para determinar a formulação e a implementação das políticas públicas para a implementação do direito à educação; a tese em Direito de Eduardo Martines Júnior (2006), intitulada "Educação, Cidadania e Ministério Público: o artigo 205 da Constituição e sua abrangência", que discute como o Ministério Público pode atuar para garantir este direito; a dissertação em Educação de Denise Gisele de Britto Damasco (2008), intitulada "O direito à educação: a atuação das Promotorias de Justiça e de defesa da educação do Ministério Público do Distrito Federal e Territórios, entre 2001 e 2007”, que analisa o

\footnotetext{
${ }^{4}$ Informações disponíveis em: http://www.schoolfunding.info/litigation/litigation.php3. Acesso em: 1 set. 2010.
} 
direito à educação e sua garantia por meio das Recomendações públicas expedidas pelas Promotorias de Justiça de Defesa da Educação do Ministério Público.

Também, observa-se a publicação de artigos sobre essa temática, como o de Mariângela Graciano, Carolina Marinho e Fernanda Fernandes (2006), intitulado "As demandas judiciais por educação na cidade de São Paulo", que aporta informações sobre o comportamento do Poder Judiciário diante das demandas por educação básica. Flávia Piovesan (2007), em seu artigo "Justiciabilidade dos direitos sociais e econômicos: desafios e perspectivas", examina a proteção dos direitos sociais e econômicos na CF/88 e a partir do estudo de casos relativos à saúde e à educação avalia o grau de justiciabilidade desses direitos nas Cortes brasileiras. Sobre os casos educacionais, discute as decisões do STF sobre o dever do Estado de garantir creche e pré-escola para as crianças de 0 a 6 anos e os casos relativos à matrícula em instituições de ensino superior e à cobrança de mensalidade.

O artigo intitulado "Os Estados e o direito à educação na Constituição de 1988: comentários acerca da jurisprudência do Supremo Tribunal Federal”, de Nina Beatriz Stocco Ranieri (2009), aponta os avanços na garantia do direito à educação com análise de cinco casos sobre as competências concorrentes dos Estados-membros no STF.

A jurisprudência do STF do direito à educação, após a CF/88 também foi objeto de levantamento no artigo "O Poder Judiciário e o Direito à Educação", de Eduardo Pannunzio (2009), juntamente com os principais órgãos do Sistema Global e Interamericano de Proteção dos Direitos Humanos, constatando que a jurisprudência interna - ao menos do STF - é escassa, e a internacional relacionada ao Brasil é menor ainda.

O artigo de Carlos Roberto Jamil Cury e Luiz Antonio Miguel Ferreira (2009) discute o fenômeno da "judicialização da educação", que ocorre, segundo os autores, "quando os aspectos relacionados ao direito à educação passam a ser objeto de análise e julgamento pelo Poder Judiciário" (p.35). O texto traz, também, exemplos de decisões que envolvem o Poder Judiciário e a educação para além do acesso. Algumas ações citadas no artigo serão analisadas neste trabalho.

Sobre a relação entre judiciário e política na democracia brasileira destacam-se as pesquisas da área da Ciência Política como a dissertação de Vanessa Elias de Oliveira (2002) intitulada "O Poder Judiciário brasileiro após a Constituição de 1988: existe uma judicialização da política? Uma análise do processo de privatizações”, a qual verificou em que medida o Judiciário influencia as decisões políticas, assumindo funções que deveriam ser exercidas pelos Poderes Executivo e Legislativo; a tese de doutorado de Cristina Carvalho 
Pacheco (2006) “O Supremo Tribunal Federal e a Reforma do Estado: uma análise das Ações Diretas de Inconstitucionalidade julgadas no primeiro mandato de Fernando Henrique Cardoso (1995-1998)", analisando a atuação política do STF, em um período em que foi acionado inúmeras vezes, ao longo do processo político de reformas, por agentes que tinham em vista barrar ou alterar os projetos governamentais por meio da alteração da Constituição.

Destaca-se, ainda, a pesquisa de José Ricardo Cunha (2005), "Direitos humanos e justiciabilidade: pesquisa no Tribunal de Justiça do Rio de Janeiro", que procurou averiguar a maneira pela qual os juízes do Tribunal de Justiça deste estado concebem e aplicam as normas de direitos humanos, especialmente sobre os direitos econômico-sociais.

Os trabalhos envolvendo a jurisprudência educacional centram-se, em sua maioria, nas decisões do STF, sendo escassas as pesquisas, como evidenciado anteriormente, que analisam as instâncias inferiores do Poder Judiciário. Desse modo, este trabalho busca analisar como o Tribunal de Justiça de São Paulo (TJ-SP) julgou as demandas educacionais de crianças e adolescentes após a implantação do Estatuto da Criança e do Adolescente (ECA).

Em pesquisa no banco de teses da Coordenação de Aperfeiçoamento de Pessoal de Nível Superior (Capes) ${ }^{5}$ e na página do sítio eletrônico da Scientific electronic library online (Scielo) foram localizados alguns artigos e pesquisas de mestrado e doutorado sobre o Tribunal de Justiça paulista. O artigo de Maria da Gloria Bonelli (2001) "Os Desembargadores do Tribunal de Justiça do Estado de São Paulo e a Construção deste Profissionalismo, 1873-1997”, analisa a construção do profissionalismo entre os membros do Tribunal, focalizando o perfil social e padrões de carreira com a análise de conteúdos dos discursos publicados em periódicos. A tese na área de História, de Marília Helena Paulos Leal Schmeider (2001), intitulada “A magistratura paulista de 1889 a 1930: história e representações. O tribunal de justiça de São Paulo na Primeira República" analisa a estrutura do Poder Judiciário no estado durante este período.

Também, foram localizados estudos sobre decisões proferidas pelo TJ-SP acerca dos direitos sociais. A dissertação em Arquitetura e Urbanismo, de Mônica de Azevedo Costa Nogara (2008), versa sobre o direito à moradia e ao meio ambiente em assentamentos irregulares; o mestrado em Medicina Preventiva de Mario Cesar Scheffer (2006), aborda planos de saúde; o artigo de Silvia Badim Marques e Sueli Gandolfi Dallari (2007) focaliza a condenação do Estado no fornecimento de medicamentos; o mestrado em Serviço Social e política social, de Carmem Silvia Righetti (2006), investiga os processos judiciais que

\footnotetext{
${ }^{5}$ Disponível em: < http://servicos.capes.gov.br/capesdw/Teses.do> Acesso em 25 jan. 10.
} 
envolvem direitos sociais na área da Infância e da Juventude, analisando os casos que denotaram dificuldades de relacionamento com a rede de serviço social.

Destaca-se, também, o artigo de José Reinaldo de Lima Lopes (2006), sobre o levantamento de casos envolvendo a defesa coletiva dos direitos sociais à saúde e à educação, com base nas decisões de dois Tribunais brasileiros: o Superior Tribunal de Justiça (STJ) e o TJ-SP, em dois períodos: 1989 a 1996 e de 1996 a 2003. Destas ações analisadas, cinco do primeiro período, e 23, no segundo, versavam sobre decisões do TJ-SP envolvendo educação.

Considerando que a declaração do ECA foi um importante ordenador jurídico para a defesa dos direitos da infância e juventude, especialmente com inovações no campo de atuação do MP para a garantia do direito da criança e do adolescente, e incluindo nesse conjunto o direito à educação, define-se como período de análise das decisões a partir de sua implantação (1991). Outro fator que fundamenta a escolha por esse período é a afirmação de Oliveira (2007, p. 28), também confirmada pela pesquisa no mestrado (SILVEIRA, 2006), de que o Estatuto "tem servido de fundamento legal para boa parte das ações judiciais que visam garantir o direito à educação".

O ECA, Lei 8.069, de 13 de julho de 1990, substitui o antigo Código de Menores, Lei 6.697, de 10 de outubro de 1979, herança de um período autoritário. Esta nova lei, contemplando os direitos da criança e do adolescente ${ }^{6}$, regulamenta o artigo 227 da CF/88 e expressa resoluções da Convenção Internacional dos Direitos da Criança de 1989, proclamando uma doutrina de proteção integral.

É dever da família, da sociedade e do Estado assegurar à criança e ao adolescente,
com absoluta prioridade, o direito à vida, à saúde, à alimentação, à educação, ao
lazer, à profissionalização, à cultura, à dignidade, ao respeito, à liberdade e à
convivência familiar e comunitária, além de colocá-los a salvo de toda forma de
negligência, discriminação, exploração, violência, crueldade e opressão (BRASIL,
1988, art. 227, grifo nosso).

Segundo Wilson Donizete Liberati (2004), por “absoluta prioridade” entende-se que a criança e o adolescente "deverão estar em primeiro lugar na escala de preocupação dos governantes", e, desta forma:

[...] na área administrativa, enquanto não existirem creches, escolas, postos de saúde, atendimento preventivo e emergencial às gestantes, dignas moradias e trabalho, não se deveriam asfaltar ruas, construir praças, sambódromos, monumentos artísticos, etc., porque a vida, a saúde, o lar, a prevenção de doenças são mais importantes que as obras de concreto que ficam para demonstrar o poder do governante. (LIBERATI, 2004, p. 18-9).

\footnotetext{
${ }^{6} \mathrm{O}$ ECA distingue crianças os menores de zero a 12 anos e adolescente os de 12 a 18 anos.
} 
Há que se lembrar, também, que a expressão "absoluta prioridade" não é utilizada em nenhum outro dispositivo constitucional.

O ECA prevê, ainda, que a criança e o adolescente devem ter preferência na formulação e na execução das políticas sociais (BRASIL, 1990, art. 4º alínea b).

De acordo com Cátia Aida Silva (2003), o Estatuto teve como ponto de partida o documento "Normas gerais de proteção à infância", elaborado por procuradores de justiça do Ministério Público (MP) de São Paulo que atuavam na área da infância (Jurandir Marçura, Munir Cury e Paulo Afonso Garrido de Paula) e apresentado ao Fórum Nacional de Entidades Não-Governamentais de Defesa das Crianças e Adolescentes (Fórum DCA).

Os representantes do Fórum, apesar de divergências em alguns pontos, apresentaram o documento ao Congresso Nacional para agilizar a aprovação da nova lei. A comissão de redação da nova lei, composta por membros do Ministério Público paulista, por um membro do Poder Judiciário e por representantes do Unicef, da Fundação Nacional de Bem-Estar do Menor (Funabem), do Movimento Nacional dos Meninos e Meninas de Rua (MNMMR), da Pastoral do Menor e do Fórum DCA, discutiu a proposta com diferentes movimentos sociais.

O ECA foi aprovado por todos os líderes dos partidos políticos da Câmara e do Senado e sancionado sem nenhum veto pelo então presidente Fernando Collor de Mello. Segundo Silva (2003), baseando-se em depoimento do procurador de Justiça do MP, Paulo Afonso Garrido de Paula, essa aprovação é fruto da ampla articulação popular, que recebeu apoio dos segmentos engajados com a causa da criança, e da inexistência de lobbies contra o Estatuto. Apoio este que não se obteve na aprovação de outras leis referentes aos interesses difusos e coletivos, como o Código de Defesa do Consumidor.

O Código Brasileiro de Defesa do Consumidor (art. 81) explicita, no ordenamento jurídico brasileiro, os conceitos de interesses ou direitos difusos e coletivos ao definir que a defesa dos consumidores e das vítimas poderá também ser exercida de maneira coletiva. Entendem-se como interesses ou direitos difusos os transindividuais, de natureza indivisível, de que sejam titulares pessoas indeterminadas e ligadas por circunstâncias de fato. Os interesses ou direitos coletivos são aqueles de natureza indivisível de que seja titular grupo, categoria ou classe de pessoas ligadas entre si ou com a parte contrária por uma relação jurídica. O Código também define os interesses ou direitos individuais homogêneos como os decorrentes de origem comum, cujos titulares são pessoas determinadas.

Portanto, o ECA representa uma significativa contribuição para a ampliação e efetivação do direito à educação. 
A partir desses pressupostos, essa pesquisa tem como recorte temporal as decisões do TJ-SP de 1991-2008, versando sobre os direitos educacionais que envolvem crianças e adolescentes, completando um ciclo de análise dos dezoito anos de implantação desta nova legislação que modificou a visão do atendimento a este grupo da população brasileira.

Sobre a importância de verificar a interpretação da lei pelos Tribunais, Marcus Cláudio Acquaviva (1995) destaca que, embora a lei permaneça inalterada, a jurisprudência ${ }^{7}$ evolui, por isso não basta ao profissional conhecer somente a lei, mas "também o seu espírito", revelado pelos Tribunais: "As leis envelhecem rapidamente, à medida que deixam de existir suas circunstâncias motivadoras, mas quase sempre são rejuvenescidas pela interpretação jurisprudencial" (ACQUAVIVA, 1995, p. 860).

Infere-se, então, que a interpretação da legislação sobre a educação pelos Tribunais é parte inseparável da análise e compreensão do direito à educação:

Demandas e litígios são solucionados caso por caso. À medida que os casos
concretos se repetem, é natural que sentenças e acórdãos passem a consolidar uma
orientação uniforme, de tal forma que se pode depreender, antecipadamente, e com
segurança quase total, como decidirão os tribunais a respeito de casos que, a eles
submetidos, encontram precedentes nas decisões anteriores. Esta uniformidade de
decisões a respeito de um caso determinado se chama jurisprudência [...]
(ACQUAVIVA, 1995, p. 859).

Optou-se pela análise de decisões educacionais de um Tribunal de Justiça estadual, pois, segundo o Código de Processo Civil (art. 475), os processos versando sobre os interesses da União, do Estado, do Município e da Fazenda Pública devem, quando a sentença for contrária a esses interesses, seguir em recurso, havendo ou não apelação da parte vencida. Sendo assim, ao exigir o cumprimento do direito à educação a sentença judicial somente terá efeito depois de confirmada pelo Tribunal de Justiça, ou seja, após recurso à instância superior. O princípio do duplo grau de jurisdição ${ }^{8}$ visa evitar a possibilidade de haver abuso de poder e erro por parte do magistrado, possibilitando à parte vencida reclamar a decisão a outro órgão judiciário hierarquicamente superior para reexame. Esse fato aliou-se à constatação já apresentada, referente à escassez de pesquisas focadas neste órgão de Justiça e à educação.

Segundo Pacheco (2006), é preciso considerar o processo de tomada de decisão judicial em conjunto com os processos políticos mais gerais. Dessa forma, para a análise das

\footnotetext{
${ }^{7}$ As decisões judiciais reiteradas em determinado sentido constituem a jurisprudência, influenciando decisões posteriores.

8 "Princípio de organização judiciária que estabelece a existência de duas instâncias, inferior e superior. A primeira instância é constituída no juízo em que se inicia a demanda [...]. A segunda instância é aquela em que o tribunal toma conhecimento da causa já em grau de recurso [...]” (ACQUAVIVA, 1995, p. 580-1).
} 
decisões do TJ-SP devem ser acrescidas análises sobre o contexto educacional e das políticas públicas desenvolvidas no estado de São Paulo (SP) e no país, no período.

\section{Objetivos}

Com este trabalho pretende-se analisar, no âmbito do TJ-SP, como o Poder Judiciário tem decidido sobre as questões educacionais, a partir do comportamento e das argumentações dos operadores do direito, identificando em quais litígios se consolidou uma jurisprudência para a exigibilidade judicial, e localizar os possíveis entraves quanto à interpretação do direito à educação, tendo como objetivos específicos:

- Inventariar e caracterizar os litígios educacionais requeridos ao TJ-SP, a partir da aprovação do ECA, no período de 1991 a 2008;

- Descrever e analisar o conteúdo dos processos judiciais, procurando identificar a posição das diferentes partes envolvidas para a exigibilidade do direito à educação;

- Construir um quadro interpretativo, tendo em vista os resultados dos julgamentos, identificando os fundamentos para a negativa e afirmativa do direito requerido.

O trabalho não tem como preocupação fazer um estudo sobre a doutrina jurídica, mas analisar como o direito à educação está sendo apreciado pelo Poder Judiciário, mais especificamente pelo TJ-SP, procurando verificar se as decisões judiciais interferiram na definição e concretização de políticas públicas, ampliando a efetivação do direito social à educação.

A pesquisa tem como pressuposto depreender como os operadores do Sistema de Justiça traduzem o direito à educação, e, a partir desse conhecimento, contribuir para o aprimoramento de sua declaração e fortalecer os movimentos para implementação de uma política educacional que garanta a todos os cidadãos brasileiros acesso com qualidade aos direitos já consagrados em nossa legislação. 


\section{Procedimento de coleta e análise das decisões do TJ-SP}

A apreensão da realidade foi realizada por meio da pesquisa documental, ou seja, dos processos judiciais, em especial as decisões do TJ-SP, a partir da implantação do ECA.

Assim como o estudo de Lopes (2006) sobre os tribunais e os direitos sociais no Brasil, com análise de casos na saúde e educação, este estudo restringe-se às decisões judiciárias, entretanto, se faz relevante destacar:

[...] que uma boa parte dos casos não atinge os tribunais. É que eles se tornam objeto de acordos, transações e compromissos durante o inquérito civil, aquela parte do processo em que se preparam as provas e se faz uma instrução inquisitorial da ação. De outro lado é muito difícil constatar, à moda das ciências naturais, a 'validade social' das normas apenas pela contagem de casos. A partir dos casos judiciais podese ter uma idéia do que é a interpretação mais corrente de certa esfera da cultura. (LOPES, 2006, p. 223).

No projeto inicial de pesquisa, o período de análise das decisões do TJ-SP cobria o período entre 1991 e 2006, porém, durante o processo de coleta de dados julgou-se pertinente expandir o período para completar o ciclo de 18 anos da implantação do ECA.

A coleta de dados iniciou-se pela publicação "Interpretação Jurisprudencial" produzido pela Procuradoria Geral de Justiça de São Paulo, por meio do Centro de Apoio Operacional (CAO) das Promotorias de Justiça da Infância e Juventude do Ministério Público (SÃO PAULO, 2002). Nessa publicação estavam indicadas 40 decisões do TJ-SP, com as ementas 9 das decisões versando sobre "educação" e "evasão escolar", compreendendo o período de 1998 e 2002.

No sítio eletrônico da Biblioteca do $\mathrm{TJ}^{-\mathrm{SP}^{10}}$ e no banco de dados "Consulta de Jurisprudência" do $\mathrm{TJ}^{-\mathrm{SP}^{11}}$ realizou-se a busca pelas decisões, utilizando os seguintes descritores: "infância e juventude"; "educação"; "direito e educação", "evasão escolar"; "qualidade", “oferta irregular"; “creche”, “pré-escola”, “ensino”. Foram selecionados os registros que versavam sobre o direito de crianças e adolescentes à educação, totalizando 65 ementas. Alguns registros foram excluídos por tratarem de processos com data anterior a

\footnotetext{
${ }^{9}$ A ementa designa o resumo de um acórdão proferido pelo tribunal. Na maioria das ementas coletadas consta uma sinopse da decisão, além do número, o nome do desembargador relator, a data do julgamento e se a decisão foi unânime ou maioria dos votos.

${ }^{10}$ Dados disponíveis em: http://www.biblioteca.tj.sp.gov.br/acervo/principal.nsf. Acesso inicial em 17 de abril de 2008 e posterior busca em 28 de abril 2009.

${ }^{11}$ Dados disponíveis em: http://cjo.tj.sp.gov.br/esaj/jurisprudencia/consultaCompleta. Acesso inicial em $17 \mathrm{de}$ abril de 2008 e posterior busca em 02 de maio de 2009.
} 
1990; outros, por não conterem o número do processo, não se referirem à educação, terem registro duplicado e, ainda, por não infringirem direito relativo à infância e à juventude.

No portal eletrônico do TJ-SP, após leitura das ementas e/ou dos acórdãos ${ }^{12}$, foram selecionadas 271 ementas, que versavam propriamente sobre o tema da pesquisa. Com as palavras: educação, qualidade ou educação, oferta irregular não foram localizados processos pertinentes ao objeto da pesquisa.

No sítio eletrônico da Associação Brasileira de Magistrados e Promotores de Justiça da Infância e Juventude (ABMP) ${ }^{13}$ foram localizadas seis ementas versando sobre o objeto desta pesquisa.

Na revista "Jurisprudência do Tribunal de Justiça de São Paulo"14 (JTJ) foi realizada uma busca pelas decisões, por meio da leitura das ementas no volume "Índice Alfabético Geral $^{15}$, que organiza todas as ementas dos processos julgados pelo TJ-SP durante o ano. Buscou-se as decisões a partir dos seguintes tópicos elencados no índice: "Ensino"; "Ação civil pública"; "Mandado de segurança", "Ministério Público"; "Estabelecimento oficial de ensino"; "Inconstitucionalidade"; "Pátrio Poder"; "Prefeito"; "Resolução SE”; “Transportes"; e nos artigos referentes à educação na Constituição Federal de 1988, no Estatuto da Criança e do Adolescente e nas leis referentes à educação (Lei 5692/71; Lei 9394/96; Lei 9424/96). É importante enfatizar que estas palavras não constam com regularidade em todas as publicações. Na revista foram selecionados 134 acórdãos com suas respectivas ementas.

Alguns acórdãos de decisões foram acessados integralmente no sítio eletrônico do TJSP, no portal "Consulta", "Processo", "2a Instância", "Seção de direito público", utilizando os números das decisões, disponíveis nas ementas. Outros foram localizados acessando o portal de busca de jurisprudência do TJ-SP, utilizando o link "Consulta simples", número do recurso. Muitos não foram disponibilizados pela internet por estarem em segredo de justiça ${ }^{16}$ (68 decisões). Neste portal eletrônico foi possível localizar as decisões referentes ao período

\footnotetext{
${ }^{12} \mathrm{O}$ acórdão é o texto da decisão de um julgamento proferido pelos tribunais superiores (ACQUAVIVA, 1995).

${ }^{13}$ Dados disponíveis em: http://www.abmp.org.br/acervo.php?a=julgados\&\&j=24\&sj=39\&tp=5. Acesso: 17 de abril de 2008, posterior busca em 02 de maio de 2009.

${ }^{14}$ A biblioteca da Faculdade de Direito da Universidade de São Paulo possui o acervo completo desta Revista, disponibilizando as Ementas e os acórdãos. Até 1992, a "Revista de Jurisprudência do Tribunal de Justiça" (JTJ) era nomeada "Revista de Jurisprudência do Tribunal de Justiça do Estado de São Paulo" (RJTJESP) e após esse período é publicada mensalmente, disponibilizando um número maior de acórdãos

${ }^{15}$ No volume Índice Geral consta a organização do TJ-SP referente àquele ano.

${ }^{16}$ Destaca-se que nos processos cíveis que tenham corrido ou estejam a correr em segredo de Justiça (art. 155 do Código de Processo Civil) o direito de consultar os autos e de pedir certidões é restrito às partes e aos seus procuradores. O Regimento Interno do TJ-SP indica que terceiro que evidenciar interesse jurídico pode requerer ao juiz certidão do dispositivo da sentença e do acórdão. Não foi solicitado acesso aos processos, considerando as informações já disponibilizadas pela ementa.
} 
de 1997 a 2008. Outros foram acessados integralmente no sítio do Centro de Apoio Operacional (CAO) da Infância e Juventude do MP de São Paulo, no link "Jurisprudência", "Acórdãos", "Educação ${ }^{17 ", ~}$

Para as decisões que não foram acessadas, por estarem em segredo de justiça, foram registradas as ementas.

De acordo com informações fornecidas pela editoria da Revista JTJ, os acórdãos publicados neste periódico são selecionados pelos editores a partir de critérios subjetivos, portanto se infere que não é publicada a totalidade de julgados do TJ-SP.

Ainda, considerando as decisões coletadas no sítio eletrônico do TJ-SP, na publicação do MP e na Revista JTJ percebe-se que um número reduzido de decisões é encontrado simultaneamente nas diferentes fontes consultadas para esta pesquisa, denotando que apenas uma parcela das decisões julgadas pelo TJ-SP é divulgada.

Do conjunto de decisões selecionadas foram excluídas as que se referiam ao ensino superior, as que envolviam as questões trabalhistas dos profissionais da educação e as reivindicações dos funcionários do Poder Judiciário por auxílio-creche tendo em vista que o objeto desta pesquisa é o direito das crianças e adolescentes à educação, com o recorte temporal e legal do ECA.

Os acórdãos das decisões localizadas na Revista JTJ foram fotocopiados (134 documentos) e os que estavam disponíveis nos sítios eletrônicos das diferentes instituições pesquisadas foram impressos e salvos em arquivo digital, totalizando 276 decisões, o que poderá possibilitar novos trabalhos de pesquisa e divulgação deste material.

A partir dessas constatações é importante destacar que as decisões coletadas no âmbito desta pesquisa constituem-se de um conjunto ilustrativo, não podendo ser considerado uma amostra do que foi julgado pelo Tribunal de Justiça paulista referente ao direito de crianças e adolescentes à educação. Além desta premissa, é relevante enfatizar que um mesmo processo pode ser computado duplamente, pois com as diferentes possibilidades de recursos pode haver várias decisões no âmbito de um único processo, sendo inviável detectar pela forma de coleta dos dados se diferentes recursos referem-se a um mesmo processo. Assim, totalizam 483 decisões, entre o período de 1991 a 2008, que foram utilizadas para a análise da atuação do Tribunal de Justiça paulista sobre o direito à educação.

\footnotetext{
${ }^{17}$ Disponível em: http://www.mp.sp.gov.br/portal/page/portal/cao_infancia_juventude/jurisprudencia/juris_acordaos/juris_acordao _educacao. Acesso em: 05 maio 08.
} 
Após leitura preliminar das decisões coletadas, organizou-se o material em categorias, tendo como objetivo fornecer uma representação condensada da informação para armazenagem e consulta. Optou-se por classificar as decisões com base nas principais demandas e questionamentos discutidos nos processos.

Aceitando os limites da identificação proposta, a organização final contempla sete amplas categorias: acesso à educação básica; permanência, responsabilidade estatal, poder de regulação estatal, decisões administrativas e políticas, gestão dos recursos públicos deveres dos pais (QUADRO 1).

\begin{tabular}{|c|c|}
\hline CATEGORIAS & TEMAS \\
\hline \multirow{6}{*}{ ACESSO À EDUCAÇÃO BÁSICA } & Acesso educação infantil \\
\hline & Acesso ensino médio \\
\hline & Acesso ensino médio \\
\hline & Acesso EJA \\
\hline & Acesso Educação Especial \\
\hline & Acesso Pessoas com NEE \\
\hline \multirow{3}{*}{ PERMANÊNCIA } & Violação às normas escolares \\
\hline & $\begin{array}{l}\text { Cancelamento de matrícula em curso de língua } \\
\text { estrangeira }\end{array}$ \\
\hline & Evasão escolar \\
\hline \multirow{3}{*}{ RESPONSABILIDADE ESTATAL } & Transporte \\
\hline & Ações de reparação de danos \\
\hline & Condições de funcionamento das escolas \\
\hline \multirow{2}{*}{ PODER DE REGULAÇÃO ESTATAL } & Mensalidade Escolar \\
\hline & Autorização / credenciamento \\
\hline \multirow{4}{*}{ DECISÕES ADMINISTRATIVAS E POLÍTICAS } & Competência para legislar \\
\hline & Reorganização das escolas estaduais \\
\hline & Municipalização \\
\hline & Fechamento de creche no período de férias \\
\hline \multirow[t]{4}{*}{ GESTÃO DOS RECURSOS PÚBLICOS } & Aplicação mínima de recursos \\
\hline & Fundef \\
\hline & Contratos \\
\hline & Repasse de recursos públicos às instituições privadas \\
\hline DEVERES DOS PAIS & Responsabilidade dos pais e responsáveis \\
\hline
\end{tabular}

Quadro 1 - Organização das decisões por categorias e temas

Fonte: a autora com base na coleta de decisões proferidas pelo TJ-SP.

$\mathrm{Na}$ categoria "acesso à educação básica" foram agrupadas as decisões que requisitaram a matrícula, definição de políticas públicas visando a garantir condições para o ingresso de crianças e adolescentes às diferentes etapas e modalidades de ensino na educação básica: educação infantil, ensino fundamental, ensino médio, educação de jovens e adultos (EJA), educação profissional e estudantes com necessidades educacionais especiais (NEE).

Em "permanência”, os processos que questionavam o direito de continuidade de matrícula em curso de língua estrangeira, medidas que impediam a permanência do aluno na 
escola por infringir as normas disciplinares, como transferência compulsória e suspensão dos alunos das aulas e evasão.

A discussão sobre a obrigatoriedade do Estado em oferecer transporte escolar, as condições de funcionamento da escola e ações de reparações de danos, tanto morais como materiais, exigem indenizações do Estado aos alunos e/ou às suas famílias, questionando a responsabilidade objetiva do Estado em acidentes, mortes e outros fatos ocorridos nas escolas pelas condições do prédio e/ou pela negligência de atendimento dos funcionários aos alunos foram agrupadas na categoria "responsabilidade estatal".

A categoria "poder de regulação estatal" agrega as decisões judiciais relativas ao serviço educacional, enquanto atividade não-exclusiva do Estado, prestada pela iniciativa privada, envolvendo: mensalidades escolares; autorização e credenciamento das instituições; subsídios públicos às instituições privadas.

No tema mensalidade estão agrupadas as decisões que discutiram as relações contratuais, englobando reajuste e cobrança de mensalidades, redução dos valores pelo número de irmãos consanguíneos matriculados em um mesmo estabelecimento, restituição do valor da matrícula para o aluno desistente, retenção de documentos dos alunos inadimplentes. Em autorização e credenciamento das escolas privadas estão os feitos envolvendo, principalmente, a regularização dos diplomas e a autorização e credenciamento das instituições privadas de ensino.

$\mathrm{Na}$ categoria “decisões administrativas e políticas" foram alocados os processos abrangendo as Ações Diretas de Inconstitucionalidade (Adin), questionando a competência de diferentes atores para legislar sobre educação, as decisões sobre as políticas educacionais realizadas no período, como a reorganização das escolas estaduais paulistas e a municipalização do ensino fundamental.

A categoria "gestão dos recursos públicos" reúne as decisões judiciais focadas na vinculação mínima de recursos para a educação e os questionamentos sobre sua aplicação nas despesas em Manutenção e Desenvolvimento do Ensino (MDE), recursos do Fundo de Manutenção e Desenvolvimento do Ensino Fundamental (Fundef), contratos entre a Administração Pública e o setor privado e os processos que discutiam convênio entre o município e sociedade sem fins lucrativos, para oferta de atendimento educacional foram organizados na

Em deveres dos pais, os processos que exigiam destes a matrícula e a frequência de seus filhos às escolas. 
As decisões coletadas foram organizadas em um banco de dados, considerando os seguintes tópicos (APÊNDICE ${ }^{18}$ ):

- Número do processo;

- Natureza do recurso: Apelação Cível, Adin, Agravo de instrumento, Agravo Regimental, Embargos de Declaração, Embargos Infringentes, Mandado de Segurança, Recurso Ex Officio;

- Data do julgamento;

- Categorias: acesso à educação básica; permanência, responsabilidade estatal, poder de regulação estatal, decisões administrativas e políticas, gestão dos recursos públicos, deveres dos pais;

- Temas;

- Origem: Comarca originária do processo;

- Apelante/Recorrente: os nomes dos autores que recorreram da decisão anterior, quando menores de idade apresentou-se apenas as siglas;

- Apelados/Recorridos: os nomes dos autores que foram apelados ou recorridos para a solução do litígio;

- Câmara: Sessão onde ocorreu o julgamento;

- Votação: se unânime ou maioria dos votos;

- Resultado: se o recurso foi provido, não provido, parcialmente provido, recurso extinto;

- Relator: nome do desembargador relator da decisão;

- Localização da ementa e do acórdão: indicando a origem do acesso do material.

As diversas classificações realizadas para o agrupamento das decisões foram utilizadas para a sua análise, considerando também os objetivos elencados para a pesquisa. Essas informações serão apresentadas no capítulo quatro deste trabalho. A priori, julga-se necessário compreender as possibilidades e limitações da atuação do Poder Judiciário em um governo democrático para proteção dos direitos consagrados na legislação.

Para analisar com mais profundidade o debate sobre a exigibilidade judicial do direito à educação faz-se necessário apresentar as características desse modelo de Estado que reconhece a educação no conjunto dos direitos sociais. Para tanto, no primeiro capítulo analisa-se a estrutura das normas declaradas nos textos legais, buscando compreender os problemas referentes à sua interpretação.

\footnotetext{
${ }^{18}$ No quadro encontram-se os principais elementos para a referência das decisões analisadas neste trabalho.
} 
O segundo capítulo discute o processo de expansão do Poder Judiciário a partir do desenvolvimento do Estado social e de sua crise e os condicionantes institucionais de favorecimento do acesso à Justiça para a proteção dos direitos sociais. Este capítulo também aborda o processo de judicialização da política e as principais críticas à intervenção política dos integrantes do Poder Judiciário. As características do desenho institucional do Judiciário brasileiro são abordadas em conjunto com os debates sobre a crise dessa instituição e as reformas aprovadas na legislação.

No terceiro capítulo apresentam-se as características organizacionais do Tribunal de Justiça paulista, sua composição e os instrumentos de recurso utilizados nas ações envolvendo os direitos educacionais.

As análises das decisões do TJ-SP, concernentes ao direito à educação de crianças e adolescentes, serão abordadas no quarto capítulo. Nesta etapa, procura-se apresentar as decisões, englobando o processo de origem da demanda, os questionamentos do Poder Público para a negativa do pedido e as posições dos desembargadores, a fim de compreender em quais litígios se consolidou uma jurisprudência favorável para a ampliação da efetivação dos direitos educacionais.

No último capítulo discutem-se os principais consensos e os conflitos para a exigibilidade judicial do direito à educação, a partir de três obstáculos mais frequentemente, suscitados pela análise das decisões proferidas pelo TJ-SP: desafios de natureza orçamentária; limites da discricionariedade do administrador e do campo decisório do Judiciário e a natureza das demandas - direitos individuais versus direitos coletivos.

Nas considerações finais assinalam-se as principais contribuições do TJ-SP para a efetivação do direito à educação, a partir da interpretação dos operadores do direito sobre a educação, bem como os limites do recurso da arena judicial para ampliar a proteção estatal relacionada à educação. 


\section{EFETIVIDADE DO DIREITO À EDUCAÇÃO}

A primeira noção do Estado de Direito, nasce, segundo Paulo Bonavides (2009b ${ }^{19}$ ), da oposição histórica e secular, na Idade Moderna, entre a liberdade do indivíduo e o absolutismo do monarca. O primeiro Estado jurídico, como guardião das liberdades individuais, tem sua experimentação histórica com a Revolução Francesa.

No entanto, a burguesia, no momento em que se apodera do controle político da sociedade, não mantém na prática a universalidade dos princípios por ela proclamados na revolução. "Só de maneira formal os sustenta, uma vez que no plano de aplicação política eles se conservaram, de fato, princípios constitutivos de uma ideologia de classe" (BONAVIDES, 2009b, p. 42).

De acordo com Fábio Konder Comparato (1998), no modelo de constitucionalismo liberal a principal tarefa estatal consiste em propiciar a segurança física e jurídica à vida individual, não competindo ao Estado guiar a sociedade para a realização de fins comuns. Assim, os direitos humanos são concebidos para proteção da liberdade de expressão, de voto de consciência, como instrumentos de defesa do indivíduo contra o arbítrio e as interferências abusivas do poder estatal em sua esfera de liberdade (DUARTE, 2006).

A lei, no Estado de Direito de inspiração liberal, serve como limite de racionalidade ao poder, sendo importante "impedir a ingerência indevida do Estado no âmbito da liberdade civil e da sociedade" (DUARTE, 2006, p.20).

O princípio democrático deste Estado de Direito funda-se como necessidade de legitimação do poder do Estado. Da liberdade do homem perante o Estado avança-se para a ideia da presença do elemento popular na formação da vontade estatal (BONAVIDES, 2009b).

Todavia, a igualdade anunciada pelo liberalismo é apenas formal, encobrindo, na realidade, as desigualdades de fato: econômicas, sociais, políticas e pessoais (BONAVIDES, 2009b).

Com o advento da sociedade de massas e das transformações geradas pelo processo de industrialização, especialmente, pela ação dos movimentos trabalhistas do final do século XIX e início do século XX, passou-se a exigir do Estado a ampliação de sua interferência na ordem social, culminando na reivindicação de novas categorias de direitos:

19 O estudo de Bonavides (2009b) "Do Estado Liberal ao Estado Social” comemorou, em 2008, seu cinquentenário de publicação. 
O reconhecimento dos direitos sociais contribuiu para que se operasse uma profunda alteração no discurso vigente sobre a natureza dos direitos humanos, que acentuava o seu caráter meramente individual. Diferentemente do que até então se afirmava a respeito da proteção das liberdades, os direitos sociais não se realizam meramente por meio da adoção de uma postura basicamente negativa, ou, ainda pela oferta de prestações, bens ou ações individuais. Demandam, sim, via de regra, a realização de condutas positivas por parte do Estado, que deve implementar medidas concretas e colocá-las à disposição dos indivíduos e grupos. Trata-se de direitos de crédito diante do Estado que demandam o direcionamento dos governos para o cumprimento de necessidades sociais através do desenvolvimento de políticas públicas. (DUARTE, 2006, p. 130).

Bonavides (2009b), com base no sociólogo alemão Vierkandt, afirma que a Primeira Guerra Mundial abriu os olhos de muitos pensadores da escola liberal para a triste verdade da contradição existente entre a liberdade do liberalismo e a escravidão social dos trabalhadores.

Estes morriam de fome e de opressão, ao passo que os mais respeitáveis tribunais do Ocidente assentavam as bases de toda sua jurisprudência constitucional na inocência e no lirismo daqueles formosos postulados de que 'todos os homens são iguais perante a lei' [...]. (BONAVIDES, 2009b, p. 61).

A reação, nas palavras de Bonavides (2009b), foi uma "socialização branda", temperando o liberalismo com ingredientes da socialização moderna. Dessa forma, o Estado social, também conhecido como Estado de bem-estar-social ou Estado providência, é uma transformação do Estado liberal, fórmula de sobrevivência deste Estado. "Daí compadecer-se o Estado social no capitalismo com os mais variados sistemas de organização política, cujo programa não importe modificações fundamentais de certos postulados econômicos e sociais" (p. 184). São exemplos dessas contradições:

A Alemanha nazista, a Itália fascista, a Espanha franquista, o Portugal salazarista foram 'Estados sociais'. Da mesma forma, Estado social foi a Inglaterra de Churchill e Attlee; os Estados Unidos, em parte, desde Roosevelt; a França, com a Quarta República, principalmente; e o Brasil, desde a Revolução de 1930.

Estado social foi, por último, na órbita ocidental, a República Federal Alemã, que assim se confessava e proclamava textualmente em sua Constituição, adotada em Bonn, antes da unificação. (BONAVIDES, 2009b, p. 184).

Visando superar a contradição entre a igualdade política e a desigualdade social, o Estado social buscava reconhecimento de direitos ao proletariado. De acordo com Bonavides (2009b) a denominação de Estado social seria justa quando o Estado:

[...] coagido pela pressão das massas, pelas reivindicações que a impaciência do quarto estado faz ao poder político, confere, no Estado constitucional ou fora deste, os direitos do trabalho, da previdência, da educação, intervém na economia como distribuidor, dita o salário, manipula a moeda, regula os preços, combate o desemprego, protege os enfermos, dá ao trabalhador e ao burocrata a casa própria, controla as profissões, compra a produção, financia as exportações, concede crédito, institui comissões de abastecimento, provê necessidades individuais, enfrenta crises econômicas, coloca na sociedade todas as classes na mais estreita dependência de seu poderio econômico, político e social, em suma, estende sua influência a quase todos os domínios que dantes pertenciam, em grande parte, à área de iniciativa individual [...]. (BONAVIDES, 2009b, p. 186). 
Mas, como o próprio autor destaca, "a técnica de implantá-lo sem distúrbios mostrase, todavia, rodeada de problemas e dificuldades. Basta comparar a sua caracterização constitucional, a palavra dos textos, com a pobreza dos resultados obtidos na realidade" (BONAVIDES, 2009b, p. 187).

No Estado de Direito Liberal os valores fundamentais da vida, liberdade e propriedade gravitavam no centro da ordem jurídica e da legalidade; com o advento do Estado social os novos valores produzidos pela sociedade industrial abrangem o pleno emprego, a segurança existencial e a conservação da força de trabalho (BONAVIDES, 2009b).

Segundo o autor supracitado, a Constituição no Estado Liberal do século XIX disciplinava somente o poder estatal e os direitos individuais (direitos civis e direitos políticos) e o Estado Social do século XX regula uma esfera mais ampla, que inclui o poder estatal, a sociedade e o indivíduo.

No entanto, o Estado social não anula os princípios do modelo liberal, vem apenas complementá-los, como uma maneira de buscar a sobrevivência do liberalismo.

O Estado liberal está assentado em dois princípios fundamentais: liberdade e separação de poderes. E liberdade, no liberalismo clássico, entendida como ausente da interferência do Estado. No Estado burguês a divisão de poderes constitui-se como mecanismo de garantia dos direitos de liberdade, princípio com contribuição de Locke e Montesquieu. Como uma "forma de garantir o indivíduo, de rodeá-lo de proteção contra o Estado, implicitamente seu maior inimigo na teoria liberal, o negativum de que emanam as piores ameaças ao vasto círculo dos direitos individuais" (BONAVIDES, 2009b, p. 68).

Bonavides também explica que este princípio "visceralmente antagônico à concentração do poder, foi, portanto, princípio fecundo de que se serviu para a proteção da liberdade o constitucionalismo moderno, ao fundar, com o Estado jurídico, o governo da lei, e não o governo dos homens". No entanto o princípio da divisão de poderes gerou a ideia peculiar no liberalismo “de limitação máxima dos fins do Estado”. (2009b, p.72).

Porém, com o Estado social este princípio passou a ter interesse secundário, portanto:

[...] não segue a rota do individualismo tradicional, favorecido e amparado pela separação clássica, mas envereda pelos caminhos do social, visando não apenas a afiançar ao Homem os seus direitos fundamentais perante o Estado (princípio liberal), mas, sobretudo, a resguardar a participação daqueles na formação da vontade deste (princípio democrático), de modo a conduzir o aparelho estatal para uma democracia efetiva, onde os poderes públicos estejam capacitados a proporcionar ao indivíduo soma cada vez mais ampla de favores concretos. (BONAVIDES, 2009b, p. 65-6). 
De acordo com Bonavides (2009b), a inclusão do princípio da separação de poderes nas Constituições presidencialistas "não fez nosso homem mais livre" e seu repúdio refere-se ao "espírito de sua aplicação pelo liberalismo". Sendo que, no Brasil, formalmente quase todas as Constituições desde o Império até a República o consagraram, e o "presidencialismo, acobertado pela Constituição, dele se serve para cultivar, de fato, a hipertrofia do Executivo" (p.88).

E a nossa $\mathrm{CF} / 88$, é uma Constituição do Estado social? O que isto representa para a exigibilidade do direito à educação, considerado como um direito social?

A CF/88 apresenta, em seu art. 1º a República Federativa do Brasil como "Estado Democrático de Direito". Estabelecendo em seu parágrafo único que "todo poder emana do povo, que o exerce por meio de representantes eleitos diretamente, nos termos desta Constituição".

A noção de Estado de Direito, conceito de inspiração liberal, segundo José Afonso da Silva (2001), tem como características básicas a submissão do poder Estatal à lei, a separação de poderes e a enunciação e a garantia dos direitos individuais. O Estado Democrático fundase no princípio da soberania popular, não se exaurindo na formação das instituições representativas, mas visa à realização do princípio democrático como garantia dos direitos fundamentais da pessoa humana (SILVA, 2001).

A caracterização do Estado Democrático de Direito não significa, de acordo com Silva (2001), a união formal dos conceitos de Estado Democrático e Estado de Direito, mas de submissão da ordem jurídica em relação aos valores democráticos e aos interesses coletivos para a transformação do status quo. A expressão utilizada pela $\mathrm{CF} / 88$ é a expressão mais adequada, “em que o 'democrático' qualifica o Estado, o que irradia os valores da democracia sobre todos os elementos constitutivos do Estado e, pois, também sobre a ordem jurídica" (p.123).

Como fundamento do Estado, a CF/88 definiu a soberania, a cidadania, a dignidade da pessoa humana, os valores sociais do trabalho e da livre iniciativa, e o pluralismo político. E, como objetivos fundamentais que constituem a República:

\footnotetext{
I - construir uma sociedade livre, justa e solidária;

II - garantir o desenvolvimento nacional;

III - erradicar a pobreza e a marginalização e reduzir as desigualdades sociais e regionais;

IV - promover o bem de todos, sem preconceitos de origem, raça, sexo, cor, idade e quaisquer outras formas de discriminação. (BRASIL, 1988, art. $3^{\circ}$ ).
} 
$\mathrm{Na}$ atual Constituição brasileira os direitos e garantias individuais receberam proteção máxima, não sendo permitidas emendas ao texto constitucional que possam alterá-los; da mesma forma, com relação ao dispositivo da separação de poderes, da forma federativa de Estado e do voto secreto, universal e periódico (BRASIL, 1988, art. 60).

Com relação aos direitos sociais, a CF/88 enuncia-os em capítulo próprio, abrangendo a educação, a saúde, a alimentação, o trabalho, a moradia, o lazer, a segurança, a previdência social, a proteção à maternidade e à infância, a assistência aos desamparados ${ }^{20}$ (BRASIL, 1988 , art. $\left.6^{\circ}\right)$.

De acordo com Bonavides (2009a), os direitos sociais formam a "espinha dorsal do Estado social brasileiro". Mas, o autor indaga se esses direitos têm "caráter absoluto ou relativo?" Seriam eles da mesma natureza e grau dos demais direitos fundamentais, como os chamados direitos de liberdade, ou comporiam uma categoria "distinta, inconfundível para efeitos de reconhecimento ou execução pelo Estado?” (p. 374).

Desse modo, segundo Bonavides (2009a), se a CF/88 é, em muitas de suas dimensões essenciais, uma Constituição do Estado social, os problemas constitucionais têm que ser resolvidos à luz dos conceitos derivados desta modalidade de ordenamento. "Uma coisa é a Constituição do Estado liberal, outra a Constituição do Estado social. A primeira é uma Constituição antigoverno e anti-Estado; a segunda uma Constituição de valores refratários ao individualismo no Direito e ao absolutismo no Poder" (p. 371).

Para Duarte,

A adoção dos princípios, objetivos e fundamentos do Estado social e democrático de direito fez com que a Constituição Federal de 1988 não se limitasse à fixação dos contornos do poder frente à liberdade do indivíduo, nem à organização das formas de participação popular na esfera das decisões políticas. No âmbito desse Estado, de caráter prestacional, a positivação jurídica de valores sociais passou a servir de base não apenas à interpretação de toda a Constituição, mas à criação, direção e regulação de situações concretas. (DUARTE, 2007, p. 694).

Como afirma Bonavides, o verdadeiro problema do direito constitucional está em “como juridicizar o Estado social, como estabelecer e inaugurar novas técnicas ou institutos processuais para garantir os direitos sociais básicos, a fim de fazê-los efetivos" (2009a, p.373).

No Brasil, o movimento de direitos humanos, em geral, não tem reivindicado positivação de situações novas, mas pede o cumprimento de leis que já existem, explorando as contradições do próprio direito positivo (LOPES, 2006).

Posição também argumentada por Bonavides:

\footnotetext{
${ }^{20} \mathrm{O}$ direito social à moradia foi incluído pela $\mathrm{EC} \mathrm{n}^{\circ}$ 26/2000 e a alimentação pela EC nº 64/2010.
} 
Cumprida toda uma trajetória de avanços sociais, das Constituições já não se reclamam direitos, mas garantias. Os direitos existem de sobra, com tamanha abundância na esfera programática que formalmente o texto constitucional resolveu com o voto do constituinte todos os problemas básicos de educação, saúde, trabalho, previdência, lazer e, de último, até mesmo a qualidade de vida, consagrando um capítulo à ecologia ou, com mais propriedade, ao meio ambiente. (BONAVIDES, 2009a, p. 382).

Inquieta-nos a distância da declaração da norma e a sua aplicabilidade aos comportamentos. E este é um dos principais problemas da nossa legislação, com amplo reconhecimento dos direitos sociais, mas ineficaz cumprimento.

\footnotetext{
A ineficácia leva à manutenção de privilégios, de situações mantidas apenas por motivos pessoais, que não se estendem a qualquer um. Um Estado capaz de impor a lei de forma uniforme e universal é uma condição necessária para que se forme a noção moderna de direito. Na falta disso, compreende-se que a idéia de direitos se confunde com a noção de privilégio. (LOPES, 2006, p. 95).
}

Segundo Lopes (2006), nas últimas décadas a ineficácia das leis tem sido contestada por grupos sociais que resolveram exigir o cumprimento dos textos constitucionais e legais por meio do Judiciário.

O restabelecimento do "Estado de Direito", a partir da década de 80, com a supressão da censura política à imprensa, reorganização dos partidos políticos, realização de eleições parlamentares e de governadores, "não foram capazes de alterar as condições materiais impostas pelo modelo de capitalismo adotado no país". E é nesta conjuntura que o ataque à proteção dos direitos humanos cresce (LOPES, 2006, p. 42).

Ressalta-se, também, que os direitos sociais são invenção de um período marcado pelo capitalismo e pela economia industrial. E essas políticas não podem ser entendidas à parte do contexto político, econômico e social, tendo em vista que são criadas em resposta aos problemas e oportunidades que emergiram da construção e democratização do Estado capitalista.

Para a análise da emergência e o desenvolvimento do Estado social, que diferem de um país para outro, diversos fatores devem ser arrolados, como a formação do Estado nacional, com suas capacidades estatais e grau de autonomia; o contexto institucional, sendo que a natureza e forma das instituições estatais estabelecem limites e possibilidades para a ação política; e a influência das políticas sociais estabelecidas anteriormente. Todavia, a discussão desses aspectos não se conforma ao objeto proposto para este trabalho, que tem como enfoque os empecilhos atrelados à interpretação das normas positivadas.

Ademais, é preciso considerar que a maior dificuldade à concretização dos direitos sociais está relacionada à conjuntura neoliberal do capitalismo globalizado, que cada vez mais 
difunde uma agenda de controle dos gastos públicos e de retração das estruturas do Estado. Justamente neste contexto a Constituição de 1988 foi promulgada, consolidando um marco na construção de Estado de bem-estar em um momento mundial de crise deste modelo de Estado.

\subsection{A efetividade dos direitos sociais}

Ponderando-se que há um enorme descompasso da Constituição em relação à realidade, e o quanto é difícil fazer valer o que foi escrito, positivado, como aplicar essa Constituição que consagra o Estado social? Afinal, em que consiste a problemática da falta de efetivação? Para alguns juristas, a dificuldade residiria na qualidade das normas constitucionais existentes.

De acordo com Ingo Wolfgang Sarlet e Mariana Filchtiner Figueredo (2008), há uma controvérsia se os direitos sociais, econômicos, culturais e ambientais (DESCA) seriam "autênticos" direitos fundamentais e, em caso positivo, se estariam sujeitos a um regime jurídico equivalente.

Utiliza-se neste trabalho a definição proposta por Sarlet para a distinção entre direitos humanos e direitos fundamentais. Sendo os primeiros aqueles no plano internacional, assegurados a qualquer pessoa independentemente de seu vínculo com determinado Estado. Já os direitos fundamentais são os direitos humanos consagrados no plano do direito constitucional de cada Estado, configurando-se como direitos reconhecidos e assegurados por uma determinada Constituição (SARLET, FIGUEREDO, 2008).

Para Ana Paula de Barcellos (2007) a implementação dos direitos sociais positivados, em documentos constitucionais, precisa superar algumas dificuldades, que se destacam: problema dos custos para a realização dos direitos sociais e a imprecisão dos enunciados desses direitos.

Sobre os custos:

A doutrina registra, em geral, que os direitos sociais, diferentemente dos individuais e políticos (embora este ponto seja altamente discutível), dependem de prestações positivas do Estado para sua implementação, enfrentando o problema da escassez dos recursos públicos, sempre menores que as necessidades. Como consequência disso, afirma-se, grosso modo, que as normas que prevêem tais direitos não têm a capacidade de torná-los exigíveis diante do Estado, pois o Judiciário não teria competência para dispor a respeito do orçamento público. Em suma: tais "direitos" não seriam direitos subjetivos; não haveria um dever do Estado de prestá-los. (BARCELLOS, 2007, p. 102-3). 
No que se refere à formulação desses direitos:

Isso porque os chamados direitos sociais transitam pelas duas categorias de normas atualmente trabalhadas pela ciência jurídica - os princípios (como o da valorização do trabalho humano, o que assegura direito à saúde etc.) e as regras -, carregando, em consequência, as limitações do estado atual da dogmática quanto à normatividade de cada uma delas, especialmente no que diz respeito aos princípios. (BARCELLOS, 2007, p. 103-4).

Segundo Luzia Cristina Fonseca Frischeisen (2000, p. 38), as normas constitucionais referentes à ordem social têm sido questionadas pelo seguinte dilema: "teriam as mesmas força vinculante ou seriam meramente indicativas ou programáticas?”

Na definição de José Afonso da Silva (2009), normas programáticas são

[...] normas constitucionais através das quais o constituinte, em vez de regular, direta e imediatamente, determinados interesses, limitou-se a traçar-lhes os princípios para serem cumpridos pelos seus órgãos (legislativos, executivos, jurisdicionais e administrativos), como programas das respectivas atividades, visando à realização dos fins sociais do Estado. (SILVA, 2009, p. 138)

Alguns juristas negam efetividade às normas programáticas, enquanto outros restringem a sua eficácia à legislação futura.

De acordo com Frischeisen (2000), "felizmente, a dogmática constitucional tem caminhado no sentido de dotar de eficácia jurídica as chamadas normas programáticas, pois, sendo a Constituição o ápice da estrutura jurídica de um Estado, não poderia ela mesma conter dispositivos despidos de vigência, eficácia e aplicabilidade" (p.39).

No Brasil, Silva (2009) traz uma importante contribuição para a classificação das normas constitucionais, a partir dos aspectos da eficácia e da aplicabilidade: normas constitucionais de eficácia plena e aplicabilidade imediata, normas constitucionais de eficácia contida e aplicabilidade imediata, porém sujeitas a restrições, e normas constitucionais de eficácia limitada ou reduzida, que podem ser divididas em duas categorias: as definidoras de princípio institutivo ou organizacionais e as declaratórias de princípio programático.

As normas de eficácia plena são aquelas que não dependem de atuação legislativa posterior para a sua regulamentação. Segundo o autor, desta classificação constam as normas que:

a) contenham vedações ou proibições; b) confiram isenções, imunidades e prerrogativas; c) não designe órgãos ou autoridades especiais a que incumbam especificamente sua execução; d) não indiquem processos especiais de sua execução; e) não exijam a elaboração de novas normas legislativas que lhes completem o alcance e o sentido, ou lhes fixem o conteúdo, porque já se apresentaram suficientemente explícitas na definição dos interesses nelas regulados. (SILVA, 2009, p. 101).

Já as normas constitucionais de eficácia contida são: 
[...] aquelas em que o legislador constituinte regulou suficientemente os interesses relativos a determinada matéria, mas deixou margem à atuação restritiva por parte da competência discricionária do Poder Público, nos termos que a lei estabelecer ou nos termos de conceitos gerais nelas enunciados. (SILVA, 2009, p. 116).

As de eficácia limitada precisam de atuação legislativa posterior para que possam gerar plenamente todos os seus efeitos. Na subdivisão deste último grupo, as normas constitucionais de princípio institutivo são aquelas pelas quais o legislador constituinte traça esquemas gerais de estruturação e atribuições de órgãos e entidades para que o legislador ordinário os estruture em definitivo por meio de leis. Já as normas de princípio programático definem finalidades para a consecução dos fins sociais, ou seja, as normas que estabelecem programas. Nesta categoria, o autor indica como um dos exemplos o art. $211, \S 1^{\circ}$ da $\mathrm{CF} / 88$ : “A União [...] exercerá, em matéria educacional, função redistributiva e supletiva, de forma a garantir equalização de oportunidades educacionais e padrão mínimo de qualidade do ensino mediante assistência técnica e financeira aos Estados, ao Distrito Federal e aos Municípios”.

Silva (2009) ainda salienta que o direito à saúde (art. 196) e o direito à educação (art. 205) não são incluídos nos exemplos de normas programáticas dirigidas à ordem econômicosocial, porque nesses casos a norma "institui um dever correlato de um sujeito determinado: o Estado - que, por isso, tem a obrigação de satisfazer aquele direito. Se esta não é satisfeita, não se trata de programaticidade, mas de desrespeito ao direito, de descumprimento da norma". (2009, p. 150).

No mesmo sentido Bonavides argumenta que "as normas programáticas já não devem ser consideradas ineficazes ou providas apenas de valor meramente diretivo, servindo unicamente de guia e orientação ao intérprete", reduzindo, assim, o conteúdo programático das Constituições "a um devaneio teórico de boas intenções ou uma simples página de retórica política e literária.” (2009a, p. 250).

\footnotetext{
Em resumo, a programaticidade das Constituições será contudo um mal se não servir também ao Direito, se não for para o Poder um instrumento de racionalização e eficácia governativa, se não vier embebida de juridicidade, se não representar aquele espaço onde o espírito da Constituição elege o seu domicílio e se aloja, mas, ao contrário, venha a transformar-se nos Estados de constitucionalismo débil e apagada tradição jurídica em cômodo asilo das mais rudes transgressões constitucionais. A programaticidade sem juridicidade poderá enfim converter-se formal e materialmente no obstáculo dos obstáculos à edificação constitucional de um verdadeiro Estado de direito. (BONAVIDES, 2009a, p. 251).
}

Para afastar as dificuldades e equívocos na compreensão das normas constitucionais, os conceitos de norma programática e de norma de eficácia deferida precisam ser demarcados com toda a clareza possível (BONAVIDES, 2009a). 
Em seu posicionamento, as normas de eficácia deferida “já trazem definida, intacta e regulada pela Constituição a matéria que lhe serve de objeto, a qual depois será efetivada na prática mediante atos legislativos de aplicação". Não são "promessas cujo conteúdo há de ser ministrado ou estabelecido a posteriori pela autoridade legislativa interposta, como ocorre com as normas programáticas stricto sensu". (BONAVIDES, 2009a, p. 252, grifo do autor).

Bobbio (2004), ao afirmar que a defasagem entre as normas e sua efetiva aplicação é mais intensa no campo dos direitos sociais discute características das normas programáticas, assim chamadas as que se referem aos direitos sociais na Itália:

\begin{abstract}
Será que já nos perguntamos alguma vez que gênero são essas que não ordenam, proíbem ou permitem hic et nunc, mas ordenam, proíbem e permitem num futuro indefinido e sem um prazo de carência claramente delimitado? E, sobretudo, já nos perguntamos alguma vez que gênero de direitos são esses que tais normas definem? Um direito cujo reconhecimento e cuja efetiva proteção são adiados sine die, além de confiados à vontade de sujeitos cuja obrigação de executar o "programa" é apenas uma obrigação moral ou, no máximo, política, pode ainda ser chamado corretamente de "direito"? (BOBBIO, 2004, p. 90-1).
\end{abstract}

De acordo com Maria Paula Dallari Bucci (2006, p.7), “a introdução dos direitos sociais representa uma tormentosa questão no panorama do sistema jurídico". A enunciação contida no Pacto Internacional sobre Direitos Econômicos, Sociais e Culturais (PIDESC), de 1966, é, segundo a autora, ilustrativa da peculiaridade dessa categoria de direitos. Sendo que a "realização progressiva ${ }^{21 "}$ " que se refere o Pacto sugere "direitos enfraquecidos, na medida em que apenas enunciados, sem condição assegurada de exercício”.

Sob alegações de enunciações formuladas em termos genéricos e abstratos, isto é, sob normas programáticas, o descumprimento da vontade constitucional é justificado. Para Frischeisen (2000), muitas das normas que eram consideradas meramente programáticas geraram eficácia, integradas na sua maior parte por legislação infraconstitucional.

Refletindo sobre a eficácia do direito à educação, indaga-se se as normas enunciadas na Constituição seriam consideradas normas programáticas, definindo então apenas diretrizes, finalidades e programas de ação futura. Desta forma, compreender as características da norma jurídica se faz relevante na discussão acerca da exigibilidade judicial para sua efetivação. Ao analisar as decisões do TJ-SP, procurar-se-á, neste trabalho, verificar qual o sentido fixado pelo Judiciário ao julgar as demandas envolvendo a eficácia dessas normas.

\footnotetext{
${ }^{21}$ Cada Estado-parte do presente Pacto compromete-se a adotar medidas, tanto por esforço próprio como pela assistência e cooperação internacionais, principalmente nos planos econômicos e técnico, até o máximo de seus recursos disponíveis, que visem a assegurar, progressivamente, por todos os meios apropriados, o pleno exercício dos direitos reconhecidos no presente Pacto, incluindo, em particular, a adoção de medidas legislativas. (PACTO ..., 1966, art. $2^{\circ}$ ).
} 


\subsection{Estrutura das normas constitucionais: princípios e regras}

De acordo com Bonavides (2009a), mestres do Direito Público contemporâneo têm se preocupado em estabelecer os limites de eficácia dos princípios constitucionais, cujo excesso de generalidade os insere numa categoria especial, não invalidando a sua normatividade, posto que as normas compreendem os princípios e as regras.

Segundo Luís Roberto Barroso (2009) e Barcellos (2007), os problemas referentes à formulação de direitos seriam menores quando o direito social é veiculado por meio de uma regra definidora de direito, sendo possível identificar com precisão o dever exigível da outra parte.

Com relação à educação, a enunciação dos deveres do Estado no art. 208, a divisão de competências entre os entes federados (art. 211), destinação de recursos (art. 212) são regras que definem claramente os deveres do Poder Público para com a educação.

Já os enunciados que abordam os direitos sociais, sob a forma de princípios, "não expressam de forma clara e precisa o efeito que pretendem produzir ou as condutas que se pode exigir de seu destinatário" (BARCELLOS, 2007, p. 105). Na educação, o princípio constitucional da qualidade do ensino (art. 206, inciso VII), por exemplo, necessita de um conjunto de indicadores para que sejam passíveis de exigência judicial (OLIVEIRA, ARAUJO, 2005).

De acordo com Robert Alexy ${ }^{22}$ (2008), influente filósofo do direito alemão, para a análise da estrutura dos direitos fundamentais se faz importante a distinção entre regras e princípios, pois "com sua ajuda, problemas como os efeitos dos direitos fundamentais perante terceiros e a repartição de competências entre tribunal constitucional e parlamento podem ser mais bem esclarecidos" (p.85).

Ronald Dworkin $(2007)^{23}$, jurista de Havard, proclama o tratamento dos princípios como direito, abandonando a doutrina positivista, reconhecendo que tanto os princípios como as regras, positivamente estabelecidas, podem impor obrigação legal. No mesmo sentido, para Alexy (2008), tanto regras quanto princípios são normas, porque ambos prescrevem o que deve ser.

\footnotetext{
${ }^{22}$ A obra de Alexy é publicada originalmente em 1986.

${ }^{23}$ A obra de Dworkin é publicada originalmente em 1977.
} 
A distinção entre regras e princípios reside, segundo Alexy (2008), na generalidade. Segundo este critério, princípios são normas com grau de generalidade relativamente alto, enquanto o grau de generalidade das regras é relativamente baixo.

Alexy (2008) destaca como um ponto decisivo no critério de distinção: a satisfação. Sendo que os princípios caracterizam-se por mandamentos de otimização:

[...] princípios são normas que ordenam que algo seja realizado na maior medida possível dentro das possibilidades jurídicas e fáticas existentes. Princípios são, por conseguinte, mandamentos de otimização, que são caracterizados por poderem ser satisfeitos em graus variados e pelo fato de que a medida devida de sua satisfação não depende somente das possibilidades fáticas, mas também das possibilidades jurídicas. O âmbito das possibilidades jurídicas é determinado pelos princípios e regras colidentes. (ALEXY, 2008, p.90, grifo do autor).

Já as regras "são normas que são, sempre, ou satisfeitas ou não satisfeitas. Se uma regra vale, então, deve-se fazer exatamente aquilo que ela exige; nem mais, nem menos. Regras contêm, portanto, determinações no âmbito daquilo que é fática e juridicamente possível." (ALEXY, 2008, p.91, grifo do autor).

Para este autor, quando há conflitos entre regras e a solução não residiria com a introdução de uma cláusula de exceção, pelo menos uma das regras deveria ser considerada inválida, observando o critério do cronológico, da especialidade, ou, ainda, de acordo com a importância de cada regra em conflito.

No mesmo sentido, para Dworkin (2007), se duas regras entram em conflito, uma delas não pode ser válida. Para isto, deve-se recorrer a considerações que estão além das regras:

\footnotetext{
Um sistema jurídico pode regular esses conflitos através de outras regras, que dão preferência à regra promulgada pela autoridade de grau superior, à regra promulgada mais recentemente, à regra mais específica ou outra coisa desse gênero. Um sistema jurídico também pode preferir a regra que é sustentada pelos princípios mais importantes. (DWORKIN, 2007, p.43).
}

Já os princípios "exigem que algo seja realizado na maior medida possível dentro das possibilidades jurídicas e fáticas existentes. Nesse sentido, eles não contêm um mandamento definitivo, mas apenas prima facie” (ALEXY, 2008, p. 103-4).

Para a solução da colisão entre princípios, Alexy afirma que um dos princípios terá que ceder. "Isso não significa, contudo, nem que o princípio cedente deva ser declarado inválido, nem que nele deverá ser introduzida uma cláusula de exceção. Na verdade, o que ocorre é que um dos princípios tem precedência em face do outro sob determinadas condições" (2008, p.94). 
Já os "conflitos entre regras ocorrem na dimensão da validade, enquanto as colisões entre princípios - visto que só princípios válidos podem colidir - ocorrem, para além dessa dimensão, na dimensão do peso." (ALEXY, 2008, p.94). E o juízo de “ponderação" se realiza na observação e análise do caso concreto, pois sob outras circunstâncias é possível que a questão da precedência seja resolvida de forma contrária.

Portanto, a questão decisiva reside em saber sobre quais condições qual princípio deve prevalecer e qual deve ceder. Um dos fundamentos da teoria dos princípios defendida por Alexy refere-se à "lei da colisão", ou seja, "as condições sob as quais um princípio tem precedência em face de outro constituem o suporte fático de uma regra que expressa a conseqüência jurídica do princípio que tem precedência”. (p.99).

Segundo Dworkin, os positivistas sustentam que quando uma regra não está clara para a solução do conflito, os juízes devem exercer seu poder discricionário, decidindo com a criação de um novo item de legislação. O autor apresenta a seguinte analogia para o poder discricionário: "Tal como o espaço vazio no centro de uma rosca, o poder discricionário não existe a não ser como um espaço vazio, circundado por uma faixa de restrições. Trata-se, portanto, de um conceito relativo" (p.50-1).

Para os positivistas, um juiz não tem poder discricionário quando uma regra clara e estabelecida está disponível. No entanto, quando e de que maneira o juiz poderia mudar uma regra de direito em vigor? Dworkin (2007) apresenta duas maneiras distintas.

Na primeira é necessário,

[...] embora não suficiente que o juiz considere que a mudança favorecerá algum princípio; dessa maneira o princípio justifica a modificação [...].

Porém, não é qualquer princípio que pode ser invocado para justificar a mudança; caso contrário, nenhuma regra estaria a salvo. É preciso que existam alguns princípios com importância e outros sem importância e é preciso que existam alguns princípios mais importantes que outros. Esse princípio não pode depender das preferências pessoais do juiz, selecionadas em meio a um mar de padrões extrajurídicos respeitáveis, cada um deles podendo ser, em princípio, elegível. (DWORKIN, 2007, p.59-60).

$\mathrm{Na}$ segunda maneira de considerar o problema, o juiz deve levar em consideração alguns "padrões importantes que se opõem ao abandono da doutrina estabelecida, esses padrões são, na maior parte, princípios". No entanto, os juízes não têm "liberdade para escolher entre os princípios e as políticas que constituem essas doutrinas - também nesse caso, se eles fossem livres, nenhuma regra poderia ser considerada obrigatória" (DWORKIN, 2007, p.60).

Para o positivismo jurídico, "quando uma ação judicial específica não pode ser submetida a uma regra de direito clara, estabelecida de antemão por alguma instituição, o juiz 
tem, segundo tal teoria, o 'poder discricionário' para decidir o caso de uma maneira ou de outra”. Segundo Dworkin (2007), essa teoria é inadequada, pois o “juiz continua tendo o dever, mesmo nos casos difíceis, de descobrir quais são os direitos das partes, e não de inventar novos direitos retroativamente" (p. 127).

Segundo a posição de Alexy, já exposta, os conflitos entre princípios ocorrem na dimensão do peso e o critério para a solução residiria na ponderação dos interesses envolvidos no caso concreto, procurando qual interessante é mais relevante do que o outro. Sobre esta questão, é importante deter-se com mais detalhes à formulação do autor, essencialmente no que se refere aos direitos sociais mínimos, ou seja, direitos a um mínimo existencial que deveriam ser preponderantes em uma colisão de princípios.

Alexy (2008) destaca que o principal argumento a favor dos direitos fundamentais sociais é um argumento baseado na liberdade, e tem seu ponto de partida em duas teses.

A primeira sustenta "que a liberdade jurídica, isto é, a permissão jurídica de se fazer ou deixar de fazer algo, não tem valor sem uma liberdade fática (real), isto é a possibilidade fática de escolher entre as alternativas permitidas" (p.503). A segunda defende que "sob as condições da moderna sociedade industrial, a liberdade fática de um grande número de titulares de direitos fundamentais não encontra seu substrato material em um espaço vital por eles controlado, ela depende, sobretudo, de atividades estatais." (p.504).

Alexy (2008) concorda com essas teses, mas afirma que elas são apenas um ponto de partida para a defesa dos direitos fundamentais sociais. Para "justificar a atribuição de direitos fundamentais sociais com o auxílio de um argumento baseado na liberdade é necessário também fundamentar por que a liberdade garantida pelos direitos fundamentais inclui a liberdade fática” (p.505). Aqui, se relatam dois principais argumentos.

O primeiro argumento está baseado, segundo Alexy, na importância da liberdade fática para o indivíduo, pois é de “importância vital para o indivíduo não viver abaixo do mínimo existencial, não estar condenado a um desemprego de longo prazo e não estar excluído da vida cultural de seu tempo". O segundo está diretamente relacionado ao primeiro, pois a "liberdade fática é constitucionalmente importante não apenas sob o aspecto formal da garantia de coisas especialmente importantes, mas também sob o aspecto substancial" (p 505$6)$.

Por outro lado, as objeções aos direitos fundamentais sociais podem ser agrupadas em dois: um formal e um substancial.

No argumento formal encontra-se um dilema: 
[...] se os direitos fundamentais sociais forem vinculantes, eles deslocam a política social da competência parlamentar para a competência do tribunal constitucional; se eles não forem vinculantes, eles implicam uma violação da cláusula de vinculação do art. $1^{\circ}, \S 3^{\circ}$, da Constituição alemã. O ponto de partida desse argumento é a tese de que os direitos fundamentais, sociais ou não, são justiciáveis ou o são apenas em pequena medida. (ALEXY, 2008, p. 507).

Esse argumento baseado na competência ganha peso especial ao se considerar os efeitos financeiros dos direitos sociais. "Por causa dos grandes custos financeiros associados à sua realização, a existência de direitos fundamentais sociais abrangentes e exigíveis judicialmente conduziria a uma determinação jurídico-constitucional de grande parte da política orçamentária" (ALEXY, 2008, p. 508).

Mas, isso significaria que, segundo os princípios da separação de poderes e da democracia, a decisão sobre o conteúdo dos direitos fundamentais sociais estaria inserida não na competência dos tribunais, mas na do "legislador diretamente legitimado pelo povo". A partir dessa ideia, no âmbito dos direitos fundamentais sociais os tribunais poderiam decidir somente após o legislador já haver decidido e essas normas seriam compreendidas como normas não-vinculantes, não sujeitas ao controle do Tribunal (ALEXY, 2008, p.507-8).

$\mathrm{O}$ argumento substancial contra os direitos fundamentais sociais sustenta:

[...] que eles são incompatíveis - ou, ao menos, colidem - com normas constitucionais materiais. Na medida em que essas normas constitucionais materiais garantam direitos de liberdade, o argumento substancial é um argumento vinculado à liberdade contra os direitos fundamentais sociais sustentados em um argumento vinculado à liberdade. (ALEXY, 2008, p.509).

Para Alexy (2008), a solução para a argumentação dos direitos fundamentais sociais deveria levar em consideração os dois tipos de argumentos (contrários e favoráveis). Seu modelo, "ideia-guia":

[...] direitos fundamentais são posições que são tão importantes que a decisão sobre garanti-las ou não garanti-las não pode ser simplesmente deixada para a maioria parlamentar simples. Essa definição está sujeita a uma série de refinamentos. Um deles deve ser feito de imediato: aqui se trata dos direitos fundamentais da Constituição alemã, ou seja, de posição que, do ponto de vista do direito constitucional, são tão importantes que a decisão sobre garanti-las ou não garanti-las não pode ser simplesmente deixada para a maioria parlamentar simples. (ALEXY, p.446)

De acordo com essa ideia, saber quais direitos fundamentais sociais o indivíduo tem é uma "questão de sopesamento de princípios":

De um lado está, sobretudo, o princípio da liberdade fática. Do outro lado estão os princípios formais da competência decisória do legislador democraticamente legitimado e o princípio da separação de poderes, além de princípios materiais, que dizem respeito sobretudo à liberdade jurídica de terceiros, mas também a outros direitos fundamentais sociais e a interesses coletivos. (ALEXY, 2008, p. 512). 
O modelo não determina quais direitos sociais definitivos o indivíduo tem, dada sua flexibilidade em tempos de crise, sendo a resposta uma "tarefa da dogmática de cada um dos direitos fundamentais sociais" (p.512). Alexy propõe uma resposta geral:

\begin{abstract}
Uma posição no âmbito dos direitos a prestações tem que ser vista como definitivamente garantida se (1) o princípio da liberdade fática a exigir de forma premente e se (2) o princípio da separação de poderes e o princípio democrático (que inclui a competência orçamentária do parlamento) bem como (3) os princípios materiais colidentes (especialmente aqueles que dizem respeito à liberdade jurídica de outrem) forem afetados em uma medida relativamente pequena pela garantia constitucional que a levarem em consideração. Essas condições são necessariamente satisfeitas no caso dos direitos fundamentais sociais mínimos, ou seja, por exemplo, pelos direitos a um mínimo existencial, a uma moradia simples, à educação fundamental e média, à educação profissionalizante a um patamar mínimo de assistência médica (ALEXY, 2008, p. 512).
\end{abstract}

Segundo Alexy (2008), a Constituição alemã estabelece pelo menos um direito absoluto, inviolável: a dignidade humana. Assim, a norma da dignidade humana será tratada em parte como regra e em parte como princípio. Cabe destacar que na Lei Fundamental da Alemanha, de 1949, não existem, de um modo geral, direitos sociais expressamente positivados, excepcionando-se a previsão da proteção da maternidade e dos filhos e atuação positiva do Estado no campo da compensação de desigualdades relacionadas à discriminação de mulheres e às pessoas com necessidades especiais (SARLET, FIGUEIREDO, 2008, p.19).

Pressupõe-se que a $\mathrm{CF} / 88$, ao enumerar a dignidade humana como um dos fundamentos da República (art. $1^{\circ}$, inciso III), define que esse princípio também tem prioridade no ordenamento jurídico brasileiro. Piovesan (2008, p. 349) destaca que "o valor da dignidade humana impõe-se como núcleo básico e informador do ordenamento jurídico brasileiro, como critério e parâmetro de valoração a orientar a interpretação e compreensão do sistema constitucional instaurado em 1988".

De acordo com Barcellos (2007), ponderados os princípios e escolhido o da dignidade da pessoa humana como preponderante, "resta optar, dentre as medidas que o realizam, qual a que sacrifica em menor extensão os demais princípios envolvidos. É neste ponto que surge a garantia do mínimo existencial como regra, e não mais como princípio” (p.131).

Configurando-se o mínimo existencial um:

[...] conjunto de circunstâncias materiais mínimas a que todo o homem tem direito; é o núcleo irredutível da dignidade da pessoa humana. É, portanto, a redução máxima que se pode fazer em atenção aos demais princípios (menor interferência possível na competência de legislativo e executivo e menor custo possível para a sociedade) (BARCELLOS, 2007, p.131).

No confronto do princípio da dignidade da pessoa humana por um lado e, de outro, os da separação dos poderes, competência do legislador democrático e dos direitos de terceiros, 
Barcellos (2007), salienta e justifica a preponderância do princípio da dignidade da pessoa humana:

Primeiramente, é importante lembrar que o princípio da separação de poderes, bem como a competência para manipulação orçamentária, não são nem absolutos, pois sofrem exceções previstas na própria Constituição, nem fins em si mesmos, mas meios para o controle do poder estatal e a garantia dos direitos individuais. Não haveria, portanto, racionalidade em fazer prevalecer o meio em detrimento do fim que é a própria dignidade da pessoa humana e os direitos básicos do homem. (BARCELLOS, 2007, p.130).

Com base nessas reflexões, questionam-se quais direitos previstos na Constituição, seriam obrigatórios e sindicáveis pelo Poder Judiciário, podendo resultar na coerção estatal para o mínimo existencial no que se refere à educação.

No tocante ao direito social à educação, a Constituição brasileira estabelece que a educação é um "direito de todos e dever do Estado e da família, será promovida e incentivada com a colaboração da sociedade, visando ao pleno desenvolvimento da pessoa, seu preparo para o exercício da cidadania e sua qualificação para o trabalho" (art. 205).

No art. 208, os deveres do Estado para com a educação são enumerados:

I - educação básica obrigatória e gratuita dos 4 (quatro) aos 17 (dezessete) anos de idade, assegurada inclusive sua oferta gratuita para todos os que a ela não tiveram acesso na idade própria; (Redação dada pela Emenda Constitucional $n^{\circ} 59$, de $2009)^{24}$

II - progressiva universalização do ensino médio gratuito; (Redação dada pela Emenda Constitucional ${ }^{\circ} 14$, de 1996)

III - atendimento educacional especializado aos portadores de deficiência, preferencialmente na rede regular de ensino;

IV - educação infantil, em creche e pré-escola, às crianças até 5 (cinco) anos de idade; (Redação dada pela Emenda Constitucional n ${ }^{\circ} 53$, de 2006)

V - acesso aos níveis mais elevados do ensino, da pesquisa e da criação artística, segundo a capacidade de cada um;

VI - oferta de ensino noturno regular, adequado às condições do educando;

VII - atendimento ao educando, em todas as etapas da educação básica, por meio de programas suplementares de material didático escolar, transporte, alimentação e assistência à saúde. (Redação dada pela Emenda Constitucional no 59, de 2009)

$\S 1^{\circ}$ - O acesso ao ensino obrigatório e gratuito é direito público subjetivo.

$\S 2^{\circ}$ - O não-oferecimento do ensino obrigatório pelo Poder Público, ou sua oferta irregular, importa responsabilidade da autoridade competente.

$\S 3^{\circ}$ - Compete ao Poder Público recensear os educandos no ensino fundamental, fazer-lhes a chamada e zelar, junto aos pais ou responsáveis, pela frequiência à escola. (BRASIL, 1988, art. 208).

Como se constata, o legislador constituinte dispensou tratamento diferenciado ao ensino obrigatório, considerando-o também como direito público subjetivo. Nesse contexto, seria o ensino obrigatório, até EC no 59/2009, somente o Ensino Fundamental, considerado

\footnotetext{
${ }^{24} \mathrm{O}$ art. 208 foi alterado por três emendas constitucionais; na versão original, de 1988, o ensino obrigatório constituía somente o Ensino Fundamental e a Educação Infantil para o atendimento das crianças dos zero aos seis anos. A definição da faixa etária alterada para a educação infantil, com o início do Ensino Fundamental aos seis anos, pela EC n ${ }^{\circ} 53 / 2006$.
} 
como requisito essencial para a dignidade da pessoa humana, como mínimo existencial do direito social à educação? E a Educação Infantil e o Ensino Médio poderiam ser considerados como uma enunciação de uma norma programática, um princípio?

O ECA, seguindo o princípio da proteção integral da infância e da adolescência dispõe em seu art. $3^{\circ}$ :

A criança e o adolescente gozam de todos os direitos fundamentais inerentes à pessoa humana, sem prejuízo da proteção integral de que trata esta Lei, assegurandose-lhes, por lei ou por outros meios, todas as oportunidades e facilidades, a fim de lhes facultar o desenvolvimento físico, mental, moral, espiritual e social, em condições de liberdade e de dignidade. (BRASIL, 1990).

A LDB/96 reforça a possibilidade da exigibilidade do ensino obrigatório:

$\mathrm{O}$ acesso ao ensino fundamental é direito público subjetivo, podendo qualquer cidadão, grupo de cidadãos, associação comunitária, organização sindical, entidade de classe ou outra legalmente constituída, e, ainda, o Ministério Público, acionar o Poder Público para exigi-lo. (BRASIL, 1996, art. $5^{\circ}$ ).

Para Liberati (2004, p. 211), o status do direito público subjetivo não deveria ter sido articulado ao ensino obrigatório, mas a todo o sistema educacional, neste sentido o legislador constituinte "pensou grande e decidiu pouco".

O ECA enumera, de forma expressa, os direitos assegurados à criança e ao adolescente que, não oferecidos ou ofertados de maneira irregular, ensejam proteção judicial, com ações de responsabilidade:

I - do ensino obrigatório;

II - de atendimento educacional especializado aos portadores de deficiência;

III - de atendimento em creche e pré-escola às crianças de zero a seis anos de idade;

IV - de ensino noturno regular, adequado às condições do educando;

$\mathrm{V}$ - de programas suplementares de oferta de material didático-escolar, transporte $\mathrm{e}$ assistência à saúde do educando do ensino fundamental;

VI - de serviço de assistência social visando à proteção à família, à maternidade, à infância e à adolescência, bem como ao amparo às crianças e adolescentes que dele necessitem;

VII - de acesso às ações de serviço de saúde;

VIII - de escolarização e profissionalização dos adolescentes privados de liberdade.

Parágrafo único. As hipóteses previstas neste artigo não excluem da proteção judicial outros interesses individuais, difusos ou coletivos, próprios da infância e da adolescência, protegidos pela Constituição e pela lei.” (BRASIL, 1990, art. 208).

Infere-se, então, a exigibilidade do direito à educação não se restringe ao conceito abarcado pelo direito público subjetivo, ou seja, o período declarado como obrigatório. $\mathrm{O}$ ECA reconheceu que outros direitos assegurados à criança e ao adolescente, para além do atendimento ao ensino obrigatório, podem ser objeto de acionamento judicial, principalmente, considerando os deveres jurídicos do Estado (art. 208 da CF/88). Assim, como ressalta Emerson Garcia: 
Enquanto o Constituinte optou por indicar o mínimo existencial com a utilização do designativo direito subjetivo, o legislador infraconstitucional chegou a resultado similar por meio diverso. Como veremos, somente é possível falar em direito em havendo o correspondente dever jurídico, e somente poderemos falar em dever caso seja detectada a existência de um poder de coerção apto a alcançar o resultado almejado em não sendo ele espontaneamente observado. Assim, ao prever a exigibilidade desses direitos prestacionais e assegurar a imediata sindicabilidade judicial dos direitos mencionados no art. 208, o legislador infraconstitucional reconheceu, implicitamente, a sua essencialidade para um desenvolvimento digno das crianças e dos adolescentes. (GARCIA, 2004, p. 13 - grifos do autor)

Cumpre lembrar que os interesses juridicamente protegidos com relação à educação não se restringem ao acesso ao ensino obrigatório, pois o legislador constitucional e infraconstitucional brasileiro enumeram as normas que definem deveres para o Estado e também as possibilidades de sua exigibilidade. De acordo com Alexy (2008, p.188), "só é possível falar em um direito subjetivo se existir uma capacidade jurídica para exigi-lo.”, e no ECA essa capacidade é explícita.

Esta discussão será aprofundada nos capítulos seguintes, tendo em vista que o objetivo central deste trabalho é analisar como a jurisprudência, como parte integrante do direito, interpreta as normas, verificando se o direito à educação, em seus diferentes níveis e modalidades, é tratado como uma regra ou como princípio, um objetivo que deve conduzir a atuação do Poder Público.

\subsection{As políticas públicas como objeto dos direitos sociais}

Assim como afirma Andreas Krell (2002), os direitos sociais não são direitos contra o Estado, mas direitos através do Estado, exigindo, portanto, prestações materiais do poder público.

De acordo com Lopes (2006, p.159), "quando se diz que todo cidadão tem direito a ..., o que se está dizendo não é mais que há um dever de humanidade para com ele, mas um dever jurídico que se pode exigir de qualquer outro cidadão ou residente, assim como do próprio Estado". Nesse caso, o "remédio ou a ação para proteger tais direitos não consiste na exclusão de outrem (Estado ou particular) numa esfera de interesses já consolidados e protegidos de alguém (indivíduo ou grupo). Trata-se de situações que precisam ser criadas”. (2002, p. 1267). 
Os direitos sociais representam uma mudança de paradigma no fenômeno do direito, modificando a postura abstencionista do Estado para um enfoque prestacional.

A exigibilidade dos direitos civis e políticos difere dos sociais pela intervenção do Estado:

\begin{abstract}
Tradicionalmente, no modelo do Estado Liberal clássico, a exigibilidade individual de direitos civis e políticos sempre esteve calcada no reconhecimento de uma posição jurídica que confere aos seus titulares a possibilidade de barrarem qualquer intervenção estatal indevida em sua esfera própria de liberdade. De acordo com esta concepção, o que se pretende é uma omissão (conduta negativa) dos Poderes Públicos: não agir de forma arbitrária, ou seja, desrespeitando os parâmetros legais previamente estabelecidos. Entretanto, a busca por um patamar mínimo de igualdade, não apenas jurídica mas também material e efetiva - grande bandeira dos direitos sociais -, exige uma posição ativa do Estado no que se refere à proteção de direitos, pois o que se pretende é criar, por parte dos Poderes Públicos, condições concretas de vida digna. (DUARTE, 2004, p. 114).
\end{abstract}

Para os direitos sociais a ação Estatal deve estar voltada "para o cumprimento de programas de ação governamentais constitucionalmente delineados", implementando sistemas públicos para o atendimento a esses direitos. (DUARTE, 2004, p. 114).

Os direitos sociais são direitos-meio, "direitos cuja principal função é assegurar que toda pessoa tenha condições de gozar os direitos individuais de primeira geração". (BUCCI, 2006, p. 3).

O que equivale a dizer que os direitos sociais têm por objeto as políticas públicas, pois "representam a eficácia social do direito do cidadão a obter prestações positivas do Estado" (FRISCHEISEN, 2000, p. 76).

Segundo Bucci (2006, p.11), as políticas públicas têm distintos suportes legais, expressando-se em "disposições constitucionais, ou em leis, ou ainda em normas infralegais, como decretos e portarias e até mesmo em instrumentos jurídicos de outra natureza, como contratos de concessão de serviço público, por exemplo”.

De acordo com Lopes (2002), a educação, ao ser reconhecida no artigo $6^{\circ}$ da $\mathrm{CF} / 88$ como um direito fundamental, de natureza social, assume uma dimensão que ultrapassa a proteção de interesses individuais, pois os direitos sociais têm outro caráter, pois o direito à educação:

[...] é mais do que direito de não ser excluído de uma escola; é de fato, o interesse de conseguir uma vaga e as condições para estudar (ou seja, tempo livre, material escolar, etc.). Ora, se a vaga não existe, se não existe o tempo livre, se não há material escolar a baixo custo, como garantir juridicamente tal direito? Como transformá-lo de um direito à não interferência (permissão, dever de abstenção) em um direito à prestação (dever de fazer, obrigação) de alguém? (LOPES, 2002, p. 127). 
Duarte (2004, p. 115), questiona se a CF/88, ao reconhecer o Ensino Fundamental como direito público subjetivo, refere-se ao reconhecimento do "direito a uma pretensão individual (uma vaga na escola), ou à realização de políticas públicas?”.

O reconhecimento expresso do direito ao ensino obrigatório e gratuito como direito público subjetivo autoriza a possibilidade de, constatada a ocorrência de uma lesão, o mesmo ser exigido contra o Poder Público de imediato e individualmente. Quanto a este aspecto, parece não haver muita polêmica. Ocorre que, como estamos diante de um direito social, o seu objeto não é, simplesmente, uma prestação individualizada, mas sim a realização de políticas públicas, sendo que sua titularidade se estende aos grupos vulneráveis. [...] (DUARTE, 2004, p. 115).

E as demais etapas da educação básica (a Educação Infantil e Ensino Médio)? É possível assegurar a sua exigibilidade? De acordo com Duarte,

[...] A previsão expressa de um direito público subjetivo confere, apenas, uma diferença de grau à pretensão. Assim, mesmo para aqueles casos em que o direito público subjetivo não está previsto de forma expressa, o indivíduo tem o direito de exigir uma prestação individual; apenas a pretensão primária é pública (podendo ser exercida pelo Ministério Público, por exemplo) e está voltada, prioritariamente, à exigibilidade de políticas públicas. (DUARTE, 2004, p. 117).

Para Duarte, a figura do direito público subjetivo, no contexto de um Estado Social de Direito, "quando aplicada a um direito social, deve ser interpretada de forma ampliada em relação ao momento de seu surgimento, sob a égide do Estado Liberal, a fim de assegurar a exigibilidade coletiva e não apenas individual, do bem jurídico protegido" (2004, p.116). Isso implica em que o direito público subjetivo deveria incluir as políticas públicas.

No mesmo sentido, Lopes (2002) destaca que os direitos sociais exigem remédios distintos, pois permitem a discussão da justiça geral e da justiça distributiva.

Cabe, ainda, salientar que a formulação das políticas pública é reservada, em regra, ao Poder Executivo, sendo imprópria a atuação judicial na conformação das políticas públicas. Todavia, a possibilidade de submeter uma política pública a controle jurisdicional é, segundo Bucci (2006), inquestionável, considerando a garantia contida na $\mathrm{CF} / 88$, art. 5, XXXV: “A lei não excluirá da apreciação do Poder Judiciário lesão ou ameaça a direito". E “Judiciário tutela as políticas públicas na medida em que elas expressam direitos.” (BUCCI, 2006, p. 31).

No que se refere ao conceito de política pública, Bucci (2006) apresenta:

Política pública é o programa de ação governamental que resulta de um processo ou conjunto de processos juridicamente regulados - processo eleitoral, processo de planejamento, processo de governo, processo orçamentário, processo legislativo, processo administrativo, processo judicial - visando coordenar os meios à disposição do Estado e as atividades privadas, para a realização de objetivos socialmente relevantes e politicamente determinados.

Como tipo ideal, a política pública deve visar à realização de objetivos definidos, expressando a seleção de prioridades, a reserva dos meios necessários à sua consecução e o intervalo de tempo em que se espera o atingimento dos resultados. (BUCCI, 2006, p. 39). 
Segundo Dworkin (2007), as normas que se referem a interesses coletivos são denominadas de "políticas", sendo esta "um tipo de padrão que estabelece um objetivo a ser alcançado, em geral uma melhoria em algum aspecto econômico, político ou social da comunidade (ainda que certos objetivos sejam negativos pelo fato de estipularem que algum estado atual deve ser protegido contra mudanças adversas).” (p.36).

Para ele, política é contraposta à noção de princípios, e estes tendem a estabelecer um direito individual, enquanto as argumentações políticas concernem a interesses coletivos, são destinados a estabelecer um objetivo coletivo.

De acordo com Ana Paula de Barcellos (2008), o controle das políticas públicas dirigidas aos direitos fundamentais é uma decorrência de três elementos: disposições constitucionais são dotadas de normatividade; centralidade dos direitos fundamentais; Poder Público submetido à Constituição.

Aceitando-se que as políticas públicas são indispensáveis para a garantia dos direitos fundamentais sociais, e a ação estatal para a sua implementação envolve recursos financeiros públicos, e como os recursos são ilimitados, as escolhas são inevitáveis, mas essa escolha, segundo Barcellos (2008), é feita tomando como referência a Constituição.

Ainda que discutível, para Barcellos as políticas públicas a serem implementadas, considerando as normas da CF/88 sobre a educação, seriam o Ensino Fundamental e Médio, estando os poderes públicos obrigados a incluir em suas previsões orçamentárias rubricas capazes de atender essa necessidade.

No que diz respeito aos objetos que podem ser alvo de controle jurisdicional, quando se trata de políticas públicas em matéria de direitos fundamentais, Barcellos (2008) aponta: fixação de metas e prioridades; resultado final esperado; quantidade de recursos a ser investida; atendimento ou não das metas fixadas pelo próprio Poder Público; eficiência mínima na aplicação dos recursos públicos.

Observe-se, portanto, que as metas do Plano Nacional de Educação, assim como as do orçamento público, deveriam ser alvo de controle jurisdicional.

A inexistência das políticas públicas poderá ser objeto de controle do Poder Judiciário, pois o que qualifica a existência de um direito social como direito pleno não é simplesmente a conduta cumprida pelo Estado, mas a existência de algum poder jurídico para que o titular do direito possa, em caso de descumprimento da obrigação devida, exigir a sua autuação (ABRAMOVICH, COURTIS, 2002). 
Homes e Sunstein (1999) defendem que os direitos reconhecidos por um ordenamento jurídico "têm dentes"; já os meramente morais não possuem. Essa metáfora corresponde à possibilidade de acionar o Poder Público para que garanta os direitos reconhecidos pelos documentos legais. Da mesma forma, sustentam Abramovich e Courtis (2002), se de verdade temos direitos, devemos ter uma ação.

A partir dessas reflexões, o próximo capítulo discute como o Poder Judiciário, no desenvolvimento do Estado Social, pode contribuir para a proteção dos direitos sociais. 


\section{EXPANSÃO DO PODER JUDICIÁRIO: HISTÓRICO E ATUAIS DEBATES}

Segundo Rogério Bastos Arantes (2007), ao longo do século XX o Judiciário passou por um processo de expansão, tanto na função de controle de constitucionalidade das leis e dos atos normativos, como na prestação da justiça comum. O princípio da revisão judicial das leis foi gradativamente adotado por vários países. Na segunda metade do século XX, houve uma expansão marcante do Judiciário, em diferentes países, tornando-se uma instância de implementação de direitos sociais e coletivos.

Essa expansão, de acordo com Arantes (2007), é abordada, pelo menos, segundo duas perspectivas de análise. A primeira, de caráter mais sociológico, tem como principal representante Boaventura de Sousa Santos, relaciona a expansão do Judiciário e suas dificuldades atuais ao desenvolvimento e crise do Estado de Bem-Estar Social. A segunda utiliza uma explicação institucional, com apoio dos diagnósticos sociológicos da primeira, enfatiza os aspectos jurídicos e institucionais associados à ampliação do acesso à justiça aos atores coletivos da sociedade.

De acordo com Sousa Santos $(2007)^{25}$, a afirmação de um protagonismo dos Tribunais de Justiça pode ser encontrada, no século passado, nas decisões do Supremo Tribunal da Alemanha, na República de Weimar. Nos anos de 1930, destaca-se o Supremo Tribunal de Justiça dos Estados Unidos, pela maneira como dificultou a reforma do presidente Roosevelt, conhecida por New Deal. Nestes casos, para o autor, o protagonismo assumido pelos Tribunais apresentou um caráter conservador, "invocando concepções de direito civil e de propriedade estritamente individualistas, não permitiam fazer avançar as reformas" (p.13-4).

Nos Estados Unidos, relativo ao sistema judicial, o chamado Warren Court, com o Supremo Tribunal presidido pelo Chief Justice, Earl Warren, de 1953 a 1969, caracteriza-se como um período mais progressista. As decisões deste Tribunal, com forte impacto na ampliação dos direitos civis, acontecem a partir de 1950. Destaca-se, nessa fase, o julgamento que condenou a política de segregação racial das escolas, no caso Brown versus Junta de Educação de Topeka.

Sousa Santos et al. (1996) argumenta que o desenvolvimento do Estado-providência, no período posterior à Segunda Guerra Mundial, gerou mudanças no mundo do Direito e da

\footnotetext{
${ }^{25}$ Para as citações diretas de Sousa Santos (1996) e (2007) será mantida a ortografia dos textos originais.
} 
Justiça, com a consagração constitucional dos direitos sociais e econômicos: ao trabalho, à segurança no emprego, à saúde, à educação, à habitação, à segurança social, entre outros. Com essas transformações, o Judiciário passa a ser acionado para efetivar a nova legislação social.

Com a crise do Estado-providência, a partir dos finais da década de 70 e princípios da década de 80, as reformas orientadas pela lógica neoliberal, conduzindo a desresponsabilização do Estado de seu papel provedor e o agravamento das desigualdades sociais há aumento da exigibilidade do direito em um contexto de especificação dos mesmos, pelos documentos internacionais e legislações nacionais.

Sousa Santos (2007), apesar de considerar as diferenças entre experiências e trajetórias dos tribunais nos países centrais, semiperiféricos e periféricos ${ }^{26}$, afirma que o protagonismo emerge pela mudança política, em dois sentidos ${ }^{27}$. Por um lado:

[...] o novo modelo de desenvolvimento assenta nas regras de mercado e nos contratos privados e, para que estes sejam cumpridos e os negócios tenham estabilidade, é necessário um judiciário eficaz, rápido e independente; por outro lado, a precarização dos direitos económicos e sociais passa a ser um motivo de procura do judiciário. Muita da litigação que hoje chega aos tribunais deve-se ao desmantelamento do Estado social (direito laboral, previdência social, educação, saúde, etc.). (SOUSA SANTOS, 2007, p. 17).

Para a perspectiva sociológica, outros fenômenos também influenciam a atividade judicial:

[....] a crise dos meios tradicionais de representação política e a revalorização da sociedade civil, até mesmo como espaço de produção de bens coletivos não mais realizados pelo Estado; a globalização e seus efeitos sobre a produção e implementação do Direito em suas diversas áreas; o agravamento de problemas que colocam em risco as instituições e a esfera pública de um modo geral, tais como a corrupção e o crime organizado. Além disso, o Judiciário se vê desafiado também por novos movimentos sociais, muitas vezes articulados em defesa de direitos de minorias ou de causas novas como as ambientais e dos consumidores (ARANTES, 2007, p. 100).

De acordo com Sousa Santos (2007), o recurso ao Poder Judiciário está relacionado às “culturas jurídicas e políticas, mas tem a ver, também, com um nível de efectividade da aplicação dos direitos e com a existência de estruturas administrativas que sustentam essa aplicação" (p. 17).

No que se refere especificamente ao crescimento da exigibilidade do direito à educação, este pode estar relacionado com a baixa efetividade dos direitos declarados e com a

\footnotetext{
${ }^{26}$ Segundo Sousa Santos, os países centrais seriam os países capitalistas avançados, os periféricos os países do chamado terceiro mundo e semiperiféricos os que estão entre ambos.

27 "E é também diferente consoante as diferentes culturas jurídicas que existem nesses países e os processos históricos que levaram à construção do Estado.” (SOUSA SANTOS, 2007, p. 15).
} 
existência de remédios jurídicos e instituições do Sistema de Justiça que facilitam esse acionamento.

Considerados como uns dos principais estudiosos da perspectiva analítica institucional, Mauro Cappelletti e Bryant $\operatorname{Garth}^{28}$ (1988) discutem que o modelo de direito liberal, com o reconhecimento da titularidade de direitos apenas aos sujeitos individuais, foi ampliado com o acesso à Justiça dos chamados direitos difusos e coletivos.

O reconhecimento da dimensão difusa e coletiva de alguns direitos gerou mudanças nas formas processuais de acesso à Justiça, com a abertura da possibilidade de ações judiciais, além de inovações na estrutura judiciária, como os tribunais de pequenas causas (ARANTES, 2007).

Segundo Arantes (2007), no Brasil a expansão do Judiciário guarda relação com os mesmos motivos apresentados, tanto pela perspectiva sociológica, quanto pela análise institucional, embora se deva considerar as singularidades do sistema judiciário brasileiro.

No Brasil, segundo Arantes (2007), a expansão do Judiciário ainda pode ser relacionada ao desenvolvimento e crise do Estado-providência, e, também, à ampliação do acesso à Justiça dos atores coletivos da sociedade.

Todavia, é preciso considerar que embora não tenha se construído no Brasil um Estado social semelhante ao dos países europeus, aceita-se que a CF/88 seja uma tentativa de construção de um Estado de Bem-Estar Social, no sentido que reconhece os direitos sociais. No entanto, foi aprovada em um momento histórico mundial de crise deste modelo de Estado. Em outro contexto, as Emendas Constitucionais dos anos 90 retratam um processo de reforma do Estado brasileiro.

De acordo com Sousa Santos (2007), a Constituição brasileira de 1988 foi responsável pela ampliação de direitos civis, políticos, econômicos, sociais, culturais, e os de terceira geração: direitos do consumidor, meio ambiente, qualidade de vida, além de ampliar as "estratégias e instituições das quais se pode lançar mão para invocar os tribunais". Devido a esse fato, a redemocratização e o novo marco constitucional tendem "a aumentar as expectativas dos cidadãos de verem cumpridos os direitos e as garantias consignadas na Constituição, de tal forma que, a execução deficiente ou inexistente de muitas políticas sociais pode transformar-se num motivo de recurso aos tribunais" (SOUSA SANTOS, 2007, p. 18).

\footnotetext{
${ }^{28}$ Em trabalho publicado originalmente em 1978, apresentam um balanço sobre os limites e possibilidades de acesso à Justiça.
} 
Alguns trabalhos empíricos, como o de Luiz Werneck Vianna et al. (1999) e Cristina Carvalho Pacheco (2006) confirmam o processo de expansão do Poder Judiciário no Brasil pelo aumento expressivo das ações judiciais.

Para Arantes (2007), a criação da ação civil pública ${ }^{29}$, em 1985, é um marco fundamental na transformação do ordenamento jurídico brasileiro, com o reconhecimento da existência de direitos difusos e coletivos e com um processo judicial para a representação desses direitos. O processo de expansão da Justiça para a proteção dos direitos transindividuais se consolida na $\mathrm{CF} / 88$, que define o reconhecimento de vários outros direitos específicos, e, também, com a confirmação da função do Ministério Público (MP) na defesa desses direitos.

O MP, pela $\mathrm{CF} / 88$, tem como incumbência "a defesa da ordem jurídica, do regime democrático e dos interesses sociais e individuais indisponíveis" (BRASIL, 1988, art. 127).

A partir da $\mathrm{CF} / 88$ novas leis foram promulgadas com o objetivo de proteção coletiva de diversos direitos. Leis, essas, que reforçam o papel do MP, por exemplo: Lei 7853/89, para a proteção das pessoas portadoras de deficiência; Lei 7913/89, para proteção dos investidores do mercado de valores imobiliários; Lei 8069/90, criando o Estatuto da Criança e do Adolescente; Lei 8078/90, que criou o Código de Defesa do Consumidor; e, mais recentemente, a Lei 10.741/2003, que dispõe sobre o Estatuto do Idoso. Segundo Arantes (2007), esses ordenamentos infraconstitucionais possibilitaram que a Justiça brasileira se convertesse em "um palco importante de conflitos coletivos" e de protagonismo do MP (p. 106).

Para Sousa Santos (2007), as "pessoas que têm consciência de seus direitos, ao verem colocadas em causa as políticas sociais ou de desenvolvimento do Estado, recorrem aos tribunais para as protegerem ou exigirem a sua efectiva execução" (p. 19). Como nos casos das pessoas que recorrem ao Judiciário brasileiro para ter acesso a medicamentos ${ }^{30}$.

\footnotetext{
${ }^{29}$ A ação civil pública, criada pela Lei no 7.347 de 1985, elevou-se para nível constitucional com o art. 129, inc. III da $\mathrm{CF} / 88$, e visa à reparação de danos causados ao meio ambiente, ao consumidor, a bens e direitos de valor artístico, estético, histórico, turístico e paisagístico. Esse instrumento pode ser interposto pelo Ministério Público, pela União, pelos Estados, municípios, autarquias, empresas públicas, fundações, sociedades de economia mista ou por associações que estejam constituídas há, pelo menos, um ano, ou que incluam, entre suas finalidades, a proteção ao meio ambiente, ao consumidor, ao patrimônio artístico, estético, histórico, turístico e paisagístico. E, pelo ECA, compete ao Ministério Público promovê-la para a proteção dos interesses individuais, difusos e coletivos relativos à infância e à adolescência.

${ }^{30}$ De acordo com o secretário de Ciência e Tecnologia do Ministério da Saúde, Reinaldo Guimarães, no ano de 2007, as decisões judiciais obrigaram o Ministério custear medicamentos no valor de R $\$ 26$ milhões, e nos Estados, em média, R \$ 500 milhões por ano. Em uma ação no STF, a ministra Ellen Gracie, entendeu que não se deve confundir direito à saúde com direito a remédio, justificando que a CF/88 no artigo 196, ao assegurar o direito à saúde refere-se, em princípio, à efetivação de políticas públicas que alcancem a população como um todo, assegurando o acesso universal e igualitário. (REVISTA CONSULTOR JURÍDICO).
} 
Contudo, como afirma o autor supracitado, os litígios são "relações sociais que emergem e se transformam segundo dinâmicas sociologicamente identificáveis", sendo a transformação de um conflito em demanda judicial uma "alternativa entre outras", podendo variar de país para país e entre grupo social e área de interação. Ainda, os fatores que produzem o conflito podem não ser percebidos pelo lesado, ou este não saber que é possível reagir contra o dano ou o causador. "Por essa razão, níveis baixos de litigiosidade não significam necessariamente baixa incidência de comportamentos injustamente lesivos." (SOUSA SANTOS et al., 1996, p.45).

Alguns grupos sociais "têm uma capacidade muito maior que outros para identificar os danos, avaliar a sua injustiça e reagir contra ela". Já os grupos mais vulneráveis socialmente tendem a ter menor capacidade para transformar a experiência da lesão em litígio. (SOUSA SANTOS et al., 1996, p. 45).

Para esses autores, depois de reconhecida a existência do dano e seu causador, o litígio só emerge se o lesado acreditar que ele pode ser reparado, reclamando com o responsável e, ainda, que "saiba fazê-lo de maneira inteligível e credível". Portanto, está implícito que os grupos sociais que têm menores capacidades de perceber o dano também apresentam dificuldade de reagir judicialmente. Assim, "elevada consciência de direitos tende a ampliar o âmbito da lesão e, correspondentemente, os objetivos da sua reparação” (p. 46).

O recurso ao Judiciário para a resolução de um litígio decorre de várias alternativas, e quando esta escolha ocorre, ela é de tal modo um processo já em recurso, pois tentativas de mecanismos informais mais acessíveis foram utilizados na resolução inicial do conflito.

\begin{abstract}
A título de ilustração, a inacessibilidade dos tribunais, o seu magro desempenho ou a sua irrelevância na sociedade podem dever-se, em parte, à existência abundante de mecanismos informais, acessíveis e eficazes nessa sociedade em resultado da dominância de uma cultura jurídica de fuga à litigação judicial. Mas, por outro lado, a existência de tais mecanismos alternativos, longe de resultar de uma preferência cultural, pode apenas ser fruto de uma solução de recurso em função da inacessibilidade dos tribunais (SOUSA SANTOS et al., 1996, p. 45).
\end{abstract}

No entanto, a procura pelo judiciário é apenas a "ponta do iceberg", pois há uma grande "procura suprimida". "É a procura daqueles cidadãos que têm consciência dos seus direitos, mas que se sentem totalmente impotentes para os reivindicar quando são violados". (SOUSA SANTOS, 2007, p. 31). Nesta "procura suprimida", além dos que têm consciência de seus direitos é necessário considerar os que estão alijados do conhecimento de seus direitos.

Cabe ressaltar que, de acordo com Thomas Humphrey Marshall (1967), os Tribunais de Justiça são as instituições mais diretamente associadas aos direitos relacionados ao 
elemento civil da cidadania ${ }^{31}$ : liberdade de ir e vir, liberdade de imprensa, pensamento e fé, o direito à propriedade e de concluir contratos válidos e o direito à justiça.

Maria Tereza Sadek (2004) destaca que as dificuldades de acesso ao Judiciário são um fator inibidor da realização da cidadania plena.

Segundo esta autora (2004), no Brasil o sistema judicial estimula um "paradoxo demandas de menos e demandas de mais":

[...] de um lado, expressivos setores da população acham-se marginalizados dos serviços judiciais, utilizando-se, cada vez mais, da justiça paralela, governada pela lei do mais forte, certamente menos justa e com altíssima potencialidade de desfazer todo o tecido social. De outro, há os que usufruem em excesso da justiça oficial, gozando das vantagens de uma máquina lenta, atravancada e burocratizada. (SADEK, 2004, p. 86).

De acordo com Sousa Santos (2007), são necessárias profundas transformações no Sistema Judiciário para que ele satisfaça a procura "suprimida". Aponta como principais mecanismos dessa transformação:

- Profundas reformas processuais;

- Novos mecanismos e novos protagonismos no acesso ao direito e à justiça;

- Nova organização e gestão judiciárias;

- Revolução na formação de magistrados desde as Faculdades de Direito até a formação permanente;

- Novas concepções de independência judicial;

- Uma relação do poder judicial mais transparente com o poder político e a media, em mais densa com os movimentos e organizações sociais;

- Uma cultura jurídica democrática e não corporativa. (SOUSA SANTOS, 2007, p. 33).

O Poder Judiciário, nesse processo de expansão, assume funções relevantes na resolução de litígio; contudo, como destaca Sousa Santos (1996, 2007), nem todos os cidadãos procuram essa alternativa, principalmente os que não têm consciência de seus direitos e da possibilidade de acessar as estruturas do Poder Judiciário para exigir a sua concretização.

O Poder Judiciário brasileiro, além de sua atribuição da prestação jurisdicional na resolução de conflitos e garantia de direitos, também apresenta uma face, como afirma Sadek (2004), de poder de Estado, ao possibilitar aos seus integrantes a capacidade de agirem politicamente, questionando ou paralisando políticas.

\footnotetext{
${ }^{31} \mathrm{O}$ autor analisa o conceito de cidadania, subdividindo-o em três "partes ou elementos": civil, política e social. O elemento político é entendido como o direito de participar no exercício do poder político, tendo como instituições correspondentes o Parlamento e os Conselhos do governo local. O elemento social se refere a "tudo o que vai desde o direito a um mínimo de bem-estar econômico e segurança ao direito de participar, por completo, na herança social e levar a vida de um ser civilizado de acordo com os padrões que prevalecem na sociedade. As instituições mais intimamente ligadas com ele são o sistema educacional e os serviços sociais" (MARSHALL, 1967, p. 63-4).
} 


\subsection{Judicialização da política}

O fenômeno da expansão da judicialização da política é uma expressão utilizada pela ciência social e pelo direito, a partir do trabalho de C. Neal Tate e Torbjörn Vallinder (1995), que abordam esse processo em diversos países do mundo. Para os autores, algumas condições facilitam a judicialização, como: a democracia; a separação de poderes; o reconhecimento formal de direitos; a consciência dos meios judiciais pelos grupos de interesses e pelos partidos de oposição na realização de seus objetivos; inefetividade das instituições majoritárias; a incapacidade das instituições em dar provimento às demandas sociais, delegando às cortes a tomada de decisão em determinadas áreas da política.

Os direitos humanos também tiveram um papel fundamental neste processo, com o surgimento dos tribunais constitucionais ao fim da II Guerra Mundial.

Para Julio Rios-Figueroa e Matthew M. Taylor (2006), a judicialização da política está relacionada ao deslocamento crescente dos conflitos políticos das arenas tradicionais (Legislativo e Executivo) para o Judiciário, configurando-se a estrutura institucional um dos principais determinantes para o padrão/modelo de judicialização de política, sendo que as características institucionais do sistema jurídico, como a independência e a revisão judicial, influenciam no padrão de contestação de políticas.

Segundo Débora Alves Maciel e Andrei Koerner (2002), a judicialização da política ${ }^{32}$ pode ocorrer em dois contextos. No primeiro, há uma "ampliação das áreas de atuação dos tribunais pela via do poder de revisão judicial de ações legislativas e executivas, baseado na constitucionalização de direitos e dos mecanismos de checks and balances $^{33}$ ". Já o segundo contexto, seria “constituído pela introdução ou expansão de staff judicial ou de procedimentos

\footnotetext{
${ }^{32}$ A expressão "judicialização da política”, segundo Maciel e Koerner (2002), tem uso e sentido que às vezes são contraditórios. Para os juristas, o termo refere-se à "obrigação legal de que um determinado tema seja apreciado judicialmente" (p.115). Em sentido normativo, a judicialização é o "ingresso em juízo de determinada causa, que indicaria certa preferência do autor por esse tipo de via" (p. 115). "A expressão recebe um sentido de processo social e político, quando é usada para se referir à expansão do âmbito qualitativo de atuação do sistema judicial, do caráter dos procedimentos de que dispõem e, ainda aumento do número de processos nos tribunais" (p.115-6). Em sentido constitucional, a judicialização refere-se "ao novo estatuto dos direitos fundamentais e à superação do modelo da separação dos poderes do Estado, que levaria à ampliação dos poderes de intervenção dos tribunais na política”. (p. 117). Dada a proliferação de seus sentidos no Brasil, os autores afirmam que as relações entre o Judiciário e a políticas sejam tratadas sem a utilização do recurso a este conceito pouco preciso.

${ }^{33} \mathrm{O}$ sistema de freios e contrapesos (checks and balances), pensado por Montesquieu (1689-1755), na obra " $\mathrm{O}$ Espírito das leis" (1982), para a separação dos poderes, refere-se à necessidade de equilíbrio entre os três órgãos do Poder Estatal, com base na ideia de que cada poder deve ser autônomo e exercer determinada função, mas sendo controlado pelo próprio poder.
} 
judiciais no Executivo (como nos casos de tribunais e/ou juízes administrativos) e no Legislativo (como é o caso das Comissões Parlamentares de Inquérito)” (p. 114).

Para Luís Roberto Barroso (2009, p. 331), a judicialização significa que "algumas questões de larga repercussão política ou social estão sendo decididas por órgãos do Poder Judiciário, e não pelas instâncias tracionais”.

Barroso (2009) apresenta três causas da judicialização no Brasil: a redemocratização do país, que fortaleceu e expandiu o Poder Judiciário e também aumentou a demanda por justiça; a constitucionalização abrangente "que trouxe para a Constituição inúmeras matérias que antes eram deixadas para o processo majoritário e para a legislação ordinária”; e o sistema brasileiro de constitucionalidade ${ }^{34}$ (p. 333).

De acordo com Ernani Rodrigues de Carvalho (2004), as alterações nas estruturas institucionais possibilitaram ao Judiciário a participação nos processos decisórios, tendo um "lugar estratégico no controle" dos demais poderes, principalmente do Executivo. Justamente, a expansão do poder judicial, sobretudo no cenário político, implicou em alterações no “cálculo para a implementação de políticas públicas” (p 115).

Carvalho (2004), baseando-se na análise de Tate (1995) que procurou descobrir nas condições políticas de alguns países os motivos desse fenômeno, verifica se a judicialização é uma realidade no Brasil. Para tanto, analisa as seguintes classificações: democracia, separação dos poderes, direitos políticos, o uso dos tribunais pelos grupos de interesse e de oposição e inefetividade das instituições majoritárias.

A democracia é condição necessária, porém não suficiente, para o surgimento do fenômeno da judicialização. O estudo de Tate (1995) consolida a tese de que não é possível compatibilizar governos autoritários e expansão do Poder Judiciário. No Brasil, a separação dos poderes é um princípio constitucional e, após a $\mathrm{CF} / 88$, "as competências dos três ramos de poder parecem estar mais cristalizadas do que antes" (CARVALHO, 2004, p. 118).

Alguns cientistas sociais destacam que o reconhecimento formal de direitos na Constituição não é condição suficiente para a judicialização, entretanto "desde a reforma constitucional de 1988, pode-se detectar um nível aceitável de obediência à lei por parte da alta hierarquia governamental, pelo menos no que diz respeito aos direitos individuais". (CARVALHO, 2004, p. 118).

Analisando as Ações Diretas de Inconstitucionalidade (Adins) requeridas por entidades de classe ou confederações sindicais, entre 1988 a 2003, Carvalho (2004) destaca

\footnotetext{
${ }^{34}$ A próxima seção deste capítulo abordará especificamente esta característica do Poder Judiciário brasileiro.
} 
que há "uma participação efetiva dos grupos de interesse na utilização das Adins como instrumento de defesa de seus interesses". (p. 119).

Segundo Vianna et al. (1999), o processo de judicialização política no Brasil tem sido resultado de uma progressiva apropriação das inovações da Constituição de 88 por parte da sociedade e de agentes institucionais. Na nova arena política brasileira, dois atores exercem papel relevante nesse processo: os governadores e os procuradores; pois são responsáveis por 49\% das Adins propostas entre 1988 e 1998, mas com declínio relativo nos últimos anos do período analisado.

Os tribunais também são utilizados pelos partidos de oposição para barrar alterações realizadas pela maioria. Os dados dos trabalhos de Verneck Vianna et al. (1999) e Pacheco (2006) evidenciam o uso dos Tribunais pelos partidos de oposição no Brasil.

Para Vianna et al. (1999), o processo de judicialização no Brasil tem um caráter dúplice. De um lado, uma característica comum como a descrita pela bibliografia sobre o assunto, as minorias parlamentares demandam a intervenção do Judiciário contra a vontade da maioria; por outro lado, se afasta dessa característica com a ação dos Executivos estaduais e da Procuradoria da República contra a representação parlamentar, em sua maioria de âmbito estadual, indicando que a sociedade e a federação se encontram desajustadas da vontade do soberano e têm reclamado a presença de um terceiro na resolução dos problemas.

A ineficiência das instituições majoritárias relaciona-se à incapacidade dessas instituições em dar provimento às demandas sociais. "Alguns tribunais, diante da inércia dos políticos e da impossibilidade de negarem uma decisão, são obrigados a pôr um fim em conflitos que deveriam ser resolvidos no âmbito político." No entanto, destaca que "toda demanda social que não envolva interesse suficiente ou agregue alto custo certamente encontrará dificuldade para ser efetivada. (CARVALHO, 2004, p. 120). Essa posição de cautela é verificada no Brasil, segundo o autor, em momentos de crise; como exemplo cita a crise de governabilidade do final da década de 1980 e início da de 1990, com uma opção clara do STF pela não-interferência.

As condições políticas em torno do fenômeno da expansão do poder judicial, descritas anteriormente, estão quase todas presentes no Brasil. Entretanto, o aumento do número de processos pode não implicar em intervenção efetiva do Judiciário. Como indaga Carvalho, "até que ponto os juízes modificam as leis ou atos dos demais poderes? Ou "até que ponto essas decisões interferem na aplicação de políticas públicas?” (2004, p. 121).

A judicialização da política requer que os 
[...] operadores da lei prefiram participar da policy-making a deixá-la ao critério de políticos e administradores e, em sua dinâmica, ela própria implicaria papel político mais positivo da decisão judicial do que aquele envolvido em uma não decisão. Daí que a idéia de judicialização envolve tanto a dimensão procedimental quanto substantiva do exercício das funções judiciais. (MACIEL, KOERNER, 2002, p. 114).

Carvalho (2004), considerando o percentual de Adins julgadas em seu mérito, afirma que este não pode ser um argumento no diagnóstico da judicialização da política no Brasil. O mesmo questionamento é realizado por Pacheco (2006), em pesquisa que analisa as Adins julgadas no STF, no primeiro governo de Fernando Henrique Cardoso (1995-1998), um período marcado por programas de Reforma do Estado. As mudanças constitucionais promovidas pelo Executivo federal, com o apoio do legislativo, poderiam ser questionadas no Judiciário, representando o STF "um potencial ponto de veto para que a aliança majoritária fosse bem sucedida no seu programa de reformas." (p. 18-9).

Entretanto, Pacheco (2006) enfatiza que, apesar dos questionamentos das Emendas Constitucionais, o veto do STF foi utilizado apenas na cobrança dos inativos e pensionistas. E, na Emenda sobre a reeleição presidencial, a atuação do Supremo contribuiu para a sua aprovação. Em sua análise, a Corte julga "o mérito de questões de pequena relevância nacional" e utiliza-se de "argumentos formais para o não julgamento de questões de grande relevância para o país.” (p. 240).

Para Pacheco (2006) é preciso analisar as decisões, considerando a totalidade do ciclo de tomada de decisão do STF, incluindo as decisões por forma, e relacionar o impacto das mesmas em termos territoriais e de generalidade, contextualizando o conteúdo da norma declarada inconstitucional.

Diante dessas análises, pode-se afirmar que o fenômeno da judicialização da política não deve ser considerado apenas com os índices de acionamento do Judiciário, mas é preciso analisar as respostas dadas pelo Judiciário aos questionamentos, ou seja, os resultados políticos produzidos a partir do acionamento da via judicial.

De acordo com Barroso (2009) é preciso esclarecer a diferença entre judicialização e ativismo judicial, que são "primos", mas não tem a mesma origem.

A judicialização, no contexto brasileiro, "é uma circunstância que decorre do modelo constitucional que se adotou, e não um exercício deliberado de vontade política", pois "se uma norma constitucional permite que dela se deduza uma pretensão, subjetiva ou objetiva, ao juiz cabe dela conhecer, decidindo a matéria (BARROSO, 2009, p. 335).

Já o ativismo judicial é: 
[...] uma atitude, uma escolha de um modo específico e proativo de interpretar a Constituição, expandindo o seu sentido e alcance. Normalmente ele se instala em situações de retração do Poder Legislativo, de um certo deslocamento entre a classe política e a sociedade civil, impedindo que as demandas sociais sejam atendidas de maneira efetiva". (BARROSO, 2009, p. 335).

Uma atitude oposta ao ativismo é a "autocontenção judicial", quando o Judiciário procura reduzir sua interferência nas ações dos outros Poderes. Nesta linha, juízes e tribunais:

(i) evitam aplicar diretamente a Constituição a situações que não estejam no seu âmbito de incidência expressa, aguardando o pronunciamento do legislador ordinário; (ii) utilizam critérios rígidos e conservadores para a declaração de inconstitucionalidade de leis e atos normativos; (iii) abstêm-se de interferir na definição das políticas públicas. (BARROSO, 2009, p. 336).

A intervenção dos Tribunais nos processos decisórios de problemas eminentemente políticos não é consenso, sendo os integrantes dessas instituições constantemente questionados, principalmente no caráter democrático desta intervenção.

\subsection{Intervencionismo político dos Tribunais: principais debates}

Nos últimos anos, o Poder Judiciário brasileiro, principalmente, o STF, tem julgado ações de grande repercussão política e social. Dentre elas, destaca-se uma decisão desta Corte, que de maneira inédita decidiu limitar o número de vereadores das Câmaras Municipais, a partir de um critério de proporcionalidade, legislando sobre uma questão em aberto na CF/88. O julgamento, em 200, foi provocado por ação do MP contra um município paulista que aumentou o número de vereadores ${ }^{35}$.

Outra ação de grande visibilidade social, julgada pelo STF em 2008, foi sobre o artigo $5^{\circ}$ da Lei de Biossegurança, permitindo a utilização de células-tronco embrionárias em pesquisas científicas.

Tais julgamentos evidenciam o deslocamento de questões políticas do âmbito do Executivo e Legislativo para o Judiciário, colocando em destaque o papel político dos integrantes desta Corte.

O poder político do Judiciário, nos tempos modernos, decorre, segundo Arantes (2007), da "sua capacidade de controlar os atos normativos dos demais poderes,

\footnotetext{
${ }^{35}$ Recurso Extraordinário (RE 197917).
} 
especialmente as leis produzidas pelo parlamento" (p. 84). Essa função é conhecida como judicial review ou controle de constitucionalidade das leis.

\begin{abstract}
Nos países em que o Judiciário ou um tribunal especial pode ser acionado para verificar o respeito das leis e dos atos normativos à Constituição, pode-se dizer que existe um terceiro poder político de Estado, ao lado do Executivo e do Legislativo. Nos países em que essa função inexiste, o Judiciário assemelha-se a um órgão público ordinário, responsável pela importante tarefa de prestar justiça nos conflitos particulares, mas incapaz de desempenhar papel político no processo decisório normativo. (ARANTES, 2007, p. 84)
\end{abstract}

De acordo com Sousa Santos et al (1996), o fenômeno da judicialização dos conflitos políticos não é novo; apenas, ocorre na atualidade de modo diferente e por razões diversas. Nesse processo, três questões assumem maior significância: legitimidade, capacidade e independência.

Para os autores, a legitimidade é uma questão relevante nos regimes democráticos, pois na maioria dos casos os magistrados não são eleitos ${ }^{36}$, e, ao interferirem com o Poder Legislativo e Executivo, questiona-se o "conteúdo democrático do intervencionismo judiciário" (p. 20).

A capacidade dos tribunais está relacionada aos recursos disponíveis e é questionada em dois sentidos:

Por um lado, num quadro processual fixo e com recursos humanos e infra-estruturais relativamente inelásticos, qualquer acréscimo 'exagerado' da procura da intervenção judiciária pode significar o bloqueio da oferta e, em última instância, redundar em denegação da justiça. Por outro lado, os tribunais não dispõem de meios próprios para fazer executar as suas decisões sempre que estas, para produzir efeitos úteis, pressupõem uma prestação ativa de qualquer sector da administração pública (SOUSA SANTOS et al, 1996, p. 20).

Já a questão da independência dos tribunais surge em dois contextos. Com a legitimidade, quando o Legislativo ou o Executivo adotam medidas que o "Poder Judiciário entende serem mitigadoras da sua independência". E relacionada à sua capacidade, quando o Poder Judiciário "carecendo de autonomia financeira e administrativa, se vê dependente dos outros poderes para se apetrechar dos recursos que considera adequados para o bom desempenho das suas funções" (p. 21).

Para Sousa Santos et al. (1996), nos países semiperiféricos e periféricos os Tribunais estão assumindo, de maneira lenta e fragmentada, uma co-responsabilidade política na atuação do Estado providência. "A distância entre a Constituição e o direito ordinário é, nesses países, enorme, e os tribunais têm sido, em geral, tíbios em tentar encurtá-la”. Dentre

\footnotetext{
${ }^{36}$ No Brasil, o ingresso na carreira do Poder Judiciário ocorre por concurso público de provas e títulos para bacharéis em Direito, sendo o cargo inicial juiz substituto e a promoção se dá por critérios de antiguidade e merecimento.
} 
os fatores para essa atuação destaca: o conservadorismo dos magistrados, formados em faculdades de Direito dominadas "por concepções retrógradas da relação entre direito e sociedade"; desempenho rotinizado, "politicamente hostil à justiça distributiva e tecnicamente despreparado para ela"; “cultura jurídica 'cínica' que não leva a sério a garantia dos direitos”, considerando os direitos constitucionalmente consagrados como declarações programáticas; organização judiciária deficiente em recursos técnicos e humanos; "um Poder Judicial tutelado por um Poder Executivo, hostil à garantia dos direitos ou sem meios orçamentais para levar a cabo; a ausência de opinião pública forte e de movimentos sociais organizados para a defesa dos direitos; um direito processual hostil e antiquado" (p. 38-9).

O Judiciário ao assumir uma atitude mais ativa torna-se "mais controverso, mais visível e vulnerável politicamente" (SOUSA SANTOS, 2007, p. 23). Em alguns países, subsiste uma transferência de legitimidade do Poder Executivo e Legislativo para o Judiciário. Esse "movimento leva a que se criem expectativas positivas elevadas a respeito do sistema judiciário, esperando-se que resolva os problemas que o sistema político não consegue resolver" (SOUSA SANTOS, 2007, p.21). E o Judiciário, em grande medida, não consegue corresponder à expectativa.

Posição esta, também confirmada por José Eduardo Faria (2004). Para este autor, com a redemocratização do país, no início dos anos de 1980, o agravamento da crise econômica, a partir da segunda metade dessa década, a explosão da crise social, nos anos 1990, e o aumento das demandas sociais, o Judiciário brasileiro vem exercendo um papel decisivo, uma vez que é demandado a julgar conflitos inéditos na história dos Tribunais. No entanto, nesse processo de expansão o Judiciário brasileiro assumiu amplas tarefas que, muitas vezes, contrastam com sua capacidade de dar respostas efetivas às expectativas da sociedade.

Segundo Sadek (2004), o modelo institucional adotado pela CF/88 ampliou a possibilidade da atuação política ao Judiciário dada a "extensão e a complexidade dos direitos sociais garantidos" e a capacidade do Judiciário de exercer o controle da constitucionalidade das leis e atos normativos (p. 81).

Neste mesmo sentido, Faria (2004) afirma que a CF/88 contribui para a ampliação da discricionariedade do Sistema de Justiça, pois ela resulta de um processo Constituinte, marcado pela ausência de bancadas hegemônicas, e que utilizou a estratégia de recorrer ao recurso das normas programáticas e de cláusulas indeterminadas, com posterior regulamentação, para a aprovação final do texto. 
Para Faria (2004), o protagonismo judicial é exercido quando da interpretação da legislação em casos concretos:

[...] Como a ordem jurídica assim produzida não oferece aos operadores do direitos as condições para que possam extrair de suas normas critérios constantes e precisos de interpretação, ela exige um trabalho interpretativo contínuo. E como seu sentido definitivo só pode ser estabelecido quando de sua aplicação num caso concreto, na prática os juízes são obrigados a assumir um poder legislativo. Ou seja, ao aplicar as leis a casos concretos, eles terminam sendo seus co-autores. Por isso, a tradicional divisão do trabalho jurídico no Estado de Direito é rompida pela incapacidade do Executivo e do Legislativo de formular leis claras e sem lacunas, de respeitar os princípios gerais do direito e de incorporar as inovações legais exigidas pela crescente integração dos mercados. Isso propicia o aumento das possibilidades de escolha, decisão e controle oferecidas à promotoria e à magistratura, levando assim ao protagonismo judicial na política e da economia. E, na medida em que o 'sistema de Justiça' tem de decidir questões legais de curto prazo e com enormes implicações socioeconômicas, ele se converte numa instituição "legislativamente" ativa. (FARIA, 2004, p. 109).

Contudo, para este autor, o Sistema de Justiça encontra-se numa encruzilhada nas decisões que envolvem recursos materiais e investimentos do setor público para a implementação das sentenças e pareceres. De um lado, ao atuar obrigando o Executivo a oferecer serviços em um contexto de lei de responsabilidade fiscal e de cortes orçamentários o Poder Judiciário e o MP são “acusados de abandonar o 'princípio da neutralidade' e de "fazer política”, exorbitando suas funções e invadindo áreas que não são de sua alçada". Sendo, então, "ameaçados de retaliações e são objeto de críticas desqualificadoras, por não compreender a racionalidade sistêmica da economia" (p. 107). Por outro lado, "para neutralizar o risco de retaliações", atua pragmaticamente, não confrontando o Executivo, aceitando as justificativas dos ditames da responsabilidade fiscal e da estabilidade monetária para "legislar para situações pretéritas, revogar atos juridicamente perfeitos e interferir em direitos adquiridos" (FARIA, 2004, p. 107).

De acordo com Barroso, “o Judiciário é o guardião da Constituição e deve fazê-la valer, em nome dos direitos fundamentais e dos valores e procedimentos democráticos, inclusive em face dos outros Poderes. Eventual atuação contramajoritária, nessas hipóteses, se dará a favor, e não contra a democracia”. (BARROSO, 2009, p. 346).

Todavia, o próprio autor destaca que o ativismo judicial não é a solução para o problema brasileiro:

Mas ele é um antibiótico poderoso, cujo uso deve ser eventual e controlado. Em dose excessiva, há risco de se morrer da cura. A expansão do Judiciário não deve desviar a atenção da real disfunção que aflige a democracia brasileira: a crise de representatividade, legitimidade e funcionalidade do Poder Legislativo. Precisamos de reforma política. E esta não pode ser feita por juízes. (BARROSO, 2009, p. 346). 
Sobre o papel do Judiciário, e sua relação de independência dos demais poderes, destaca-se como relevante a discussão feita por Sousa Santos (2007):

É evidente que o sistema judicial não pode resolver todos os problemas causados pelas múltiplas injustiças. Mas, tem que assumir a sua quota-parte de responsabilidade na resolução. O sistema judicial está, hoje, colocado perante o seguinte dilema. Se não assumir a quota-parte da sua responsabilidade, continuará a ser independente de um ponto de vista corporativo, mas será cada vez mais irrelevante tanto social como politicamente. (SOUSA SANTOS, 2007, p. 34).

Concordo com o autor, pois em uma sociedade democrática o Judiciário tem o dever de assumir o seu papel de controlar a implementação dos direitos consagrados na legislação, exigindo dos demais poderes a sua realização. Nesse contexto, os Tribunais são utilizados, nas palavras de Sousa Santos, como uma "arma":

Não está na agenda política a revolução. Tão pouco parece estar na agenda política o socialismo. Em face disto, parece que o que resta é levar o direito e os direitos a sério. [...] E é aí que os movimentos começam a utilizar o direito e os tribunais como uma arma. (SOUSA SANTOS, 2007, p. 30-1).

Segundo Arantes (2007), as diferentes posições sobre o papel do Judiciário como órgão de justiça e como poder político, com a sua capacidade de controlar atos dos demais poderes, é fruto de dois distintos modelos constitucionais influenciados pelo pensamento liberal: texto constitucional americano, de 1787, e Revolução Francesa, iniciada em 1789 (ARANTES, 2007).

A experiência francesa, "mais republicana do que liberal, modernizou a função de justiça comum do Judiciário mas não lhe conferiu poder político" (ARANTES, 2007, p.82). Naquele momento histórico, o fortalecimento do Legislativo contrapondo-se à limitação do Executivo teve como pressuposto combater a monarquia absolutista. Já os Estados Unidos da América, por sua tradição mais liberal que republicana, "não só atribuiu à magistratura a importante função de prestação de justiça nos conflitos particulares, como elevou o Judiciário à condição de poder político". (p.82). E, no caso americano, na tentativa de prevenir a tirania de um governo autoritário, seja ele também eleito pela maioria, limitaram o poder político do parlamento, ao contrário dos franceses.

Também há diferença entre o modelo francês e americano concernente ao princípio da separação de poderes e a sua condição de poder político. A fórmula da separação de poderes, consagrada por Montesquieu (1689-1775), difundiu-se no final do século XVIII, segundo Arantes (2007), como necessária à limitação do poder político do Estado e à defesa das 
liberdades individuais, seguindo o princípio de que pela disposição das coisas o poder freie o poder.

Para o Judiciário, a tese de Montesquieu resultou em definições distintas quanto ao princípio da separação de poderes e a sua condição de poder político. Arantes (2007) analisa esse princípio no caso francês e americano:

[...] Na França, a idéia de supremacia do Legislativo, bem como a profunda desconfiança dos revolucionários em relação à magistratura do Antigo Regime, não poderiam ter levado a uma valorização do Judiciário como poder de Estado. Nos Estados Unidos, a preocupação com o direito à propriedade frente à voracidade legislativa de governos populares acabou elevando o Judiciário à condição de poder político, capaz de se colocar entre o governo e o cidadão, na defesa dos direitos individuais deste último (principalmente o direito à propriedade). (ARANTES, 2007, p. 83-4).

Ao analisar os modelos distintos de Judiciário americano e francês, ambos aplicáveis em um contexto democrático, Arantes (2007) explana que nos países que seguiram os Estados Unidos da América o Judiciário cumpre

[...] a importante função liberal de conter a vontade política majoritária, mas a condição não republicana da magistratura enfrentará de tempos em tempos tentativas de redução de sua independência quase aristocrática, especialmente nas situações em que o Judiciário assumir posição mais agressiva no controle dos atos normativos das maiorias políticas representativas. (ARANTES, 2007, p. 89).

Já nos países que tomam como exemplo a experiência francesa, o Judiciário "restringe-se a prestar justiça nos conflitos particulares" e

[...] não encontramos essa nova aristocracia no seio da república, mas ouvimos em contrapartida queixas recorrentes sobre a ausência de um guardião independente da Constituição e sobre a sujeição completa da sociedade à vontade política da maioria governante. (ARANTES, 2007, p. 89).

Esses distintos modelos vão influenciar o Judiciário brasileiro, ao longo de sua história. Analisar como se configura o Poder Judiciário brasileiro é o objetivo da próxima seção deste capítulo, procurando depreender como as características institucionais e a $\mathrm{CF} / 88$ favorecem a utilização do Judiciário enquanto instância para reivindicar a aplicação de direitos e de revisão da constitucionalidade das leis. 


\subsection{Desenho institucional do Poder Judiciário brasileiro}

Para compreender algumas de suas possibilidades e limites, no que se refere à utilização do Poder Judiciário brasileiro para a proteção dos direitos sociais, são descritas, a seguir, algumas considerações sobre seus aspectos institucionais.

De acordo com a CF/88, são órgãos do Poder Judiciário brasileiro: o Supremo Tribunal Federal (STF); o Superior Tribunal de Justiça (STJ); os Tribunais Regionais Federais e Juízes Federais; os Tribunais e Juízes do Trabalho; os Tribunais e Juízes Eleitorais; os Tribunais e Juízes Militares; os Tribunais e Juízes dos Estados e do Distrito Federal (FIGURA 1).

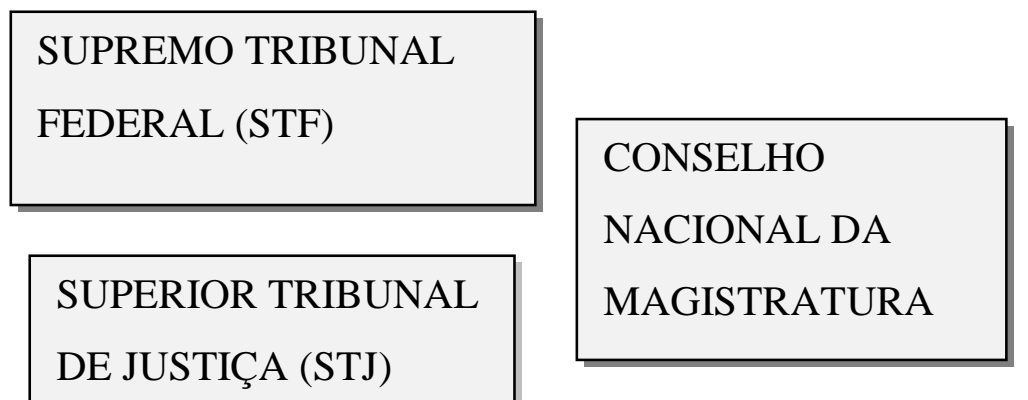

JUSTIÇA ESPECIAL

\begin{tabular}{|l|l|l|}
\hline JUSTIÇA & $\begin{array}{l}\text { JUSTIÇA DO } \\
\text { ELEITORAL }\end{array}$ & $\begin{array}{l}\text { JUSTIÇA } \\
\text { TRABALHO }\end{array}$ \\
\hline
\end{tabular}

Figura 1 - Estrutura do Poder Judiciário brasileiro

\section{JUSTIÇA COMUM}
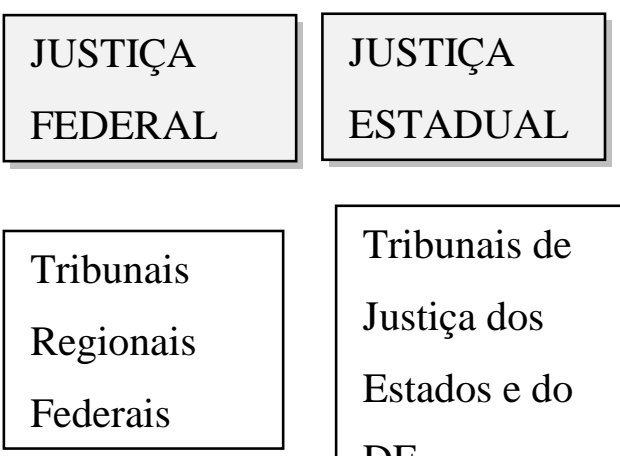

Tribunais de Justiça dos Estados e do DF

\section{Juízes}

Federais
Juízes

Estaduais

A Justiça pode ser comum ou especial, esta em razão de matéria especializada, de primeiro e segundo grau de jurisdição, federal ou estadual. À Justiça Federal competem as causas em que a União, entidade autárquica ou empresa pública federal forem interessadas e à 
Justiça Estadual competem as causas não reservadas à Justiça Federal. O Tribunal de Justiça, composto por desembargadores, é órgão superior do Poder Judiciário do Estado. A justiça dos Estados é formada por órgãos de primeiro e segundo grau de jurisdição. De acordo com a $\mathrm{CF} / 88$, a organização da justiça estadual compete às Constituições Estaduais.

A primeira instância no Sistema Judiciário brasileiro é composta por juízes e é responsável pelo julgamento de processos envolvendo matérias cíveis, de família, do consumidor, de sucessões, de falências e concordatas, da infância e juventude e matérias criminais. Nesta instância, utiliza-se o termo juízo ou vara.

Vara é uma expressão que designa a circunscrição, civil ou criminal, em que o juiz exerce sua jurisdição. A palavra é originária da antiga Roma, onde os magistrados se distinguiam por andar pelas vilas com varas, sendo um símbolo de autoridade. O costume passou para Portugal e, deste país, para a sua colônia (ACQUAVIVA, 1995).

O princípio de organização judiciária adotado pelo direito brasileiro estabelece a existência de duas instâncias, inferior e superior. A primeira instância constitui o juízo em que se iniciou a demanda, com a citação inicial até a sentença. A segunda instância é aquela em que a causa, em grau de recurso, chega a um Tribunal. (ACQUAVIVA, 1995).

O Superior Tribunal de Justiça (STJ) é a última instância da Justiça brasileira para as questões infraconstitucionais. O órgão de cúpula do Poder Judiciário é o Supremo Tribunal Federal (STF), com competência de uma Suprema Corte e Tribunal Constitucional, tem como função principal a guarda da CF/88. A sede do STF e dos Tribunais Superiores é na Capital Federal e sua jurisdição em todo o território nacional.

As regras para a escolha dos Ministros do STF e do STJ são definidas pela $\mathrm{CF} / 88$ : escolhidos dentre cidadãos com mais de 35 anos e menos de 75 anos, de notável saber jurídico e reputação ilibada, sendo nomeados pelo presidente da república após aprovação da escolha pela maioria absoluta do Senado Federal. Para o STJ, um terço dos Ministros são nomeados dentre juízes dos Tribunais Regionais Federais; um terço dentre desembargadores dos Tribunais de Justiça estaduais e um terço dentre advogados e membros do MP Federal, Estadual e do Distrito Federal, sempre indicados em lista tríplice. Observa-se, então, que os órgãos de cúpula do Poder Judiciário estão vinculados ao Poder Executivo.

A CF/88 adotou o princípio da independência e harmonia entre os Poderes Legislativo, Executivo e Judiciário (art. $2^{\circ}$ ).

A independência do Poder Judiciário brasileiro é estabelecida em dois sentidos: por não submeter-se aos demais Poderes do Estado e por não haver subordinação hierárquica 
entre seus magistrados. Segundo Comparato (2004), a independência funcional da magistratura é uma garantia institucional do regime democrático.

Pela CF/88 (art. 99) a autonomia do Poder Judiciário é assegurada de forma financeira e administrativa.

A autonomia financeira pode ser exercida com dificuldade, já que a proposta orçamentária elaborada pelo Judiciário deve ser enviada ao Executivo para compor o orçamento anual.

No que se refere às competências do Poder Judiciário, a primeira Constituição republicana brasileira, de 1891, copiou o modelo americano. As mudanças nas Constituições posteriores foram inspiradas nas experiências européias e tornaram o nosso sistema, segundo a literatura, singular no direito comparado. O Poder Judiciário brasileiro combina o modelo difuso e o concentrado (ARANTES, 2007).

No modelo difuso, os conflitos com a lei não são resolvidos diretamente pela Suprema Corte, antes, são julgados por ela via recursos, por meio das instâncias inferiores do Judiciário, não detendo o monopólio da interpretação constitucional das leis, dividindo esta competência com as diversas instâncias do Judiciário, tal como no modelo do Judiciário dos Estados Unidos. Já no modelo concentrado, a Corte Constitucional ${ }^{37}$, provocada por ação direta, tem competência para julgar sobre a constitucionalidade da lei, não sendo possível a outros órgãos realizarem o controle constitucional de maneira descentralizada; a principal referência desse modelo é o Judiciário austríaco. (ARANTES, 2007).

No Brasil, além da característica difusa, que possibilita aos juízes e tribunais inferiores de todo país julgar a aplicação de uma lei em casos concretos, o Supremo Tribunal Federal (STF) acionado pelo mecanismo da Ação Direta de Inconstitucionalidade (Adin) e pela Ação Declaratória de Constitucionalidade (Adcon), pode anular ou ratificar uma lei, funcionando como uma corte constitucional.

A Adcon, como novo instrumento concentrado de constitucionalidade, foi criada pela EC n 3 de 1993.

De acordo com a $\mathrm{CF} / 88$ e suas alterações posteriores, os seguintes atores políticos são legitimados para acionarem o STF para questionar a constitucionalidade de uma lei ou ato normativo.

A Constituição ampliou o número de atores políticos legitimados para acionarem o STF para questionar a constitucionalidade de uma lei, por meio da Adin e da Adcon:

\footnotetext{
${ }^{37}$ Cabe destacar que as Cortes Constitucionais são órgãos separados do Poder Judiciário, sendo reconhecidos como órgãos políticos.
} 
I - o Presidente da República;

II - a Mesa do Senado Federal;

III - a Mesa da Câmara dos Deputados;

IV - a Mesa da Assembléia Legislativa ou Câmara Legislativa do Distrito Federal;

V - o Governador de Estado ou do Distrito Federal;

VI - o Procurador-Geral da República;

VII - O Conselho Federal da Ordem dos Advogados do Brasil;

VIII - partido político com representação no Congresso Nacional;

IX - confederação sindical ou entidade de classe de âmbito nacional; (BRASIL, 1988, art. 103).

Segundo Matthew Taylor (2006), a Adin é um mecanismo privilegiado de acesso ao sistema judicial, podendo capacitar atores políticos específicos que, de outra forma, talvez tivessem pouca voz no processo político.

De acordo com Arantes (2007), nos últimos anos há um crescimento do número de Recursos Extraordinários ${ }^{38}$ e Adins no STF. Os Recursos Extraordinários passaram de cerca de 15 mil recursos, em 1997, para mais de 45 mil, em 2003. As Adins, em 1997, representavam mais de 200 ações; em 2005, ultrapassavam 250 (ARANTES, 2007). A partir desses dados é possível depreender o crescente uso do Judiciário para resolver não somente conflitos em último recurso, mas como um mecanismo de questionamentos de leis e atos normativos dos Poderes Executivos e Legislativo, permitindo "às minorias políticas exercer poder de veto, invocando a Constituição contra leis e atos normativos dos Poderes Legislativo e Executivo" (ARANTES, 2007, p. 98).

Taylor (2006), analisando o desenho institucional do Judiciário brasileiro, afirma que este pode agir como uma série de pontos de veto em política, sendo um local institucional para que outros atores políticos exerçam poder de veto no sistema político; aponta que esta é uma característica relevante no processo político brasileiro. "A estrutura dos tribunais pode oferecer um caminho que é especialmente vantajoso para específicos atores políticos que tentam bloquear políticas que alteram o status quo" (2006, p. 337).

Para este autor, o Judiciário federal brasileiro é uma forte instituição em diferentes perspectivas: melhor financiamento do sistema federal de cortes do hemisfério; altamente independente dos demais ramos do governo; suas decisões são aderidas pelos Executivo e Legislativo; membros são altamente qualificados e selecionados entre a elite profissional do direito.

O Judiciário brasileiro tem a "capacidade de influenciar a discussão das políticas públicas antes de elas serem aprovadas, sinalizando suas preferências e as fronteiras que as

\footnotetext{
${ }^{38}$ Por meio dos Recursos Extraordinários são julgados pelos STF os casos concretos envolvendo questões constitucionais decididas em instâncias inferiores do Judiciário.
} 
mudanças provocadas por essas políticas podem atingir" (sem utilizar de seus poderes formais), pois é comum supor que o Judiciário "somente atuará nas políticas públicas depois de elas serem aprovadas pelo Legislativo" (TAYLOR, 2007, p. 240).

Alguns instrumentos são mais "robustos" do que outros no impacto das políticas públicas, como as Adins. "No entanto, mesmo no caso da Adin, existe uma grande margem para mudar o timing do impacto judicial na implementação, seja acelerando uma decisão através de liminar, seja protelando o processo por meio de pedidos de vista". (TAYLOR, 2007, p. 242).

Observando as instâncias inferiores, Taylor afirma que o controle de seus juízes é menos decisivo, pois seus pareceres são passíveis de recursos. Mas, destaca:

[...] a elaboração de teses convincentes e o consenso entre juízes de instâncias inferiores podem ter uma influência importante, bloqueando ex post a implementação de políticas públicas ou tirando certas alternativas do leque de opções consideradas como plausíveis ex ante pelos formadores de políticas públicas. (TAYLOR, 2007, p. 242-3).

No quadro abaixo, elaborado por Taylor (2007), é possível depreender o grau de influência dos questionamentos das políticas nas diferentes instâncias do Poder Judiciário brasileiro, seja como um ponto de veto para as minorias, ou funcionando como um mecanismo de protelação, atrasando a sua implementação quando ameaçam seus interesses ou objetivos políticos.

\begin{tabular}{|l|c|c|}
\hline & $\begin{array}{l}\text { Potencial Ponto de Veto para } \\
\text { Minorias Afetadas }\end{array}$ & Mecanismo de Protelação \\
\hline STF / STJ & Alto & Baixo \\
\hline $\begin{array}{l}\text { Tribunais federais de } 1^{\text {a }} \text { instância / } \\
\text { TRFs }\end{array}$ & Baixo & Alto \\
\hline Tribunais estaduais & Baixo & Alto \\
\hline
\end{tabular}

Quadro 2 - Os Tribunais como instrumentos estratégicos

Fonte: Taylor, 2007, p. 245.

Para Taylor (2007), o Judiciário pode influenciar os resultados das políticas no processo de deliberação e também de implementação, por meio de variadas estratégias:

[...] sinalizando as fronteiras permitidas para a alteração da política pública, sustentando-a e legitimando-a diante da possível oposição, atrasando uma decisão sobre uma determinada política e, assim, controlando a agenda de deliberação da política pública ou, até mesmo, alterando ou rejeitando a proposta após sua implementação. (TAYLOR, 2007, p. 243).

Taylor aborda a contestação das políticas públicas, mas cabe salientar a importância da investigação de como o Judiciário atua na ausência de políticas, quando da não efetivação dos direitos proclamados na legislação em políticas públicas. 
As discussões acerca do Judiciário, apresentadas pela bibliografia analisada, revelam a forte ênfase sobre os Tribunais superiores. Porém, várias dessas referências contribuem para uma análise dos litígios educacionais no âmbito estadual. Isso ocorre, pois essas demandas, segundo o princípio do duplo grau de jurisdição e tendo como uma das partes o Poder Público, devem ser questionadas em recurso.

\subsubsection{Crise das instituições judiciárias}

Nos últimos tempos, algumas críticas ao Poder Judiciário permeiam o debate na sociedade brasileira, como: moroso e inepto como prestador de serviço, portanto incapaz de responder à crescente demanda e que sua instituição é refratária às modificações.

Segundo Sadek (2004), a crise no Judiciário não é uma problemática destas últimas décadas; ao contrário, é possível localizar em textos especializados, crônicas e debates parlamentares ao longo dos últimos quatro séculos. Entretanto, a situação recente difere dos períodos anteriores em pelo menos dois aspectos: 1) amplos setores da sociedade, políticos e os próprios operadores do direito percebem o problema, tendo o Judiciário na agenda de reformas; 2) diminuição do "grau de tolerância com a baixa eficiência do sistema judicial e, simultaneamente, aumentado a corrosão no prestígio do Judiciário” (p. 84).

Os dados a seguir (Tabela 1) apresentam o crescente movimento processual do STF nos últimos anos. Nota-se que, dos processos protocolados, um número menor é distribuído, com exceção de 1995 e 2003. Os processos julgados, nos anos de 1990, 1994-1999, 2001, 2004-2008 foram superiores aos distribuídos, conseguindo reduzir os números de processos existentes nesta Corte. Também, é muito reduzido o número de acórdãos publicados em relação aos julgados.

Tabela 1 - Movimento processual do STF nos anos de 1990 a 2008

\begin{tabular}{c|c|c|c|c|c|c|c|c|c|c}
\hline Movimentação STF & $\mathbf{1 9 9 0}$ & $\mathbf{1 9 9 1}$ & $\mathbf{1 9 9 2}$ & $\mathbf{1 9 9 3}$ & $\mathbf{1 9 9 4}$ & $\mathbf{1 9 9 5}$ & $\mathbf{1 9 9 6}$ & $\mathbf{1 9 9 7}$ & $\mathbf{1 9 9 8}$ & $\mathbf{1 9 9 9}$ \\
\hline Proc. Protocolados & 18.564 & 18.438 & 27.447 & 24.377 & 24.295 & 27.743 & 28.134 & 36.490 & 52.636 & 68.369 \\
\hline Proc. Distribuídos & 16.226 & 17.567 & 26.325 & 23.525 & 25.868 & 25.385 & 23.883 & 34.289 & 50.273 & 54.437 \\
\hline Julgamentos & 16.449 & 14.366 & 18.236 & 21.737 & 28.221 & 34.125 & 30.829 & 39.944 & 51.307 & 56.307 \\
\hline Acórdãos publicados & 1.067 & 1.514 & 2.482 & 4.538 & 7.800 & 19.507 & 9.811 & 14.661 & 13.954 & 16.117 \\
\hline
\end{tabular}




\begin{tabular}{c|c|c|c|c|c|c|c|c|c}
\hline $\begin{array}{c}\text { Movimentação } \\
\text { STF }\end{array}$ & $\mathbf{2 0 0 0}$ & $\mathbf{2 0 0 1}$ & $\mathbf{2 0 0 2}$ & $\mathbf{2 0 0 3}$ & $\mathbf{2 0 0 4}$ & $\mathbf{2 0 0 5}$ & $\mathbf{2 0 0 6}$ & $\mathbf{2 0 0 7}$ & $\mathbf{2 0 0 8}$ \\
\hline $\begin{array}{c}\text { Proc. } \\
\text { Protocolados }\end{array}$ & 105.307 & 110.771 & 160.453 & 87.186 & 83.667 & 95.212 & 127.535 & 119.324 & 100.781 \\
\hline $\begin{array}{c}\text { Proc. } \\
\text { Distribuídos }\end{array}$ & 90.839 & 89.574 & 87.313 & 109.965 & 69.171 & 79.577 & 116.216 & 112.938 & 66.873 \\
\hline Julgamentos & 86.138 & 109.692 & 83.097 & 107.867 & 101.690 & 103.700 & 110.284 & 159.522 & 130.747 \\
\hline $\begin{array}{c}\text { Acórdãos } \\
\text { publicados }\end{array}$ & 10.770 & 11.407 & 11.685 & 10.840 & 10.674 & 14.173 & 11.421 & 22.257 & 19.377 \\
\hline
\end{tabular}

Fonte: Estatísticas do STF.

Disponível em http://www.stf.jus.br/portal/cms/verTexto.asp?pagina=movimentoProcessual\&servico=estatistica. Acesso em 3 mar. 2009.

Obs.: No item 'julgamentos' incluem-se as decisões monocráticas e as decisões colegiadas.

A crescente demanda ao Poder Judiciário implica somente uma parte dos conflitos que poderiam ser resolvidos judicialmente, conforme discussão fundamentada em Sousa Santos, já apresentada (2007).

De acordo com Sadek (2004), o Poder Judiciário é um serviço público com extraordinária procura, no entanto são julgados, em média, $72 \%$ dos processos ingressados. "Calcula-se que, caso cessassem de ingressar novos casos, seriam necessários de cinco a oito anos, dependendo do ramo do Judiciário e da unidade da federação para que fossem colocados em dia todos os processos existentes" (p. 88).

Quando comparada a situação brasileira com outros países, os estudos evidenciam que não há correlação significativa entre número de juízes, eficiência e confiança da população (SADEK, 2004).

Alguns fatores são utilizados para explicar a falta de agilidade da prestação jurisdicional, como a "escassez de recursos materiais e/ou deficiências na infra-estrutura; o conjunto de problemas relacionado à esfera legislativa propriamente dita e aos ritos processuais" (SADEK, 2004, p. 89).

Ainda, para esta autora, a ampla possibilidade de recursos no Brasil, "mais do que contribuir para a garantia de defesa de direitos tem propiciado a litigância de má fé, o adiamento de decisões" por anos (p. 90).

Faria (2004) destaca, também, que os tribunais superiores ao prenderem-se a “minúcias processuais na avaliação dos julgamentos das instâncias inferiores, retardam as decisões terminativas e/ou deslocam o foco do julgamento das questões essenciais para questões meramente procedimentais" (p. 105).

Das críticas à prestação jurisdicional cabe salientar, ainda, as dificuldades de acesso ao Judiciário, que é um “fator inibidor da realização plena da cidadania” (SADEK, 2004, p. 86). 
A Emenda Constitucional (EC) $n^{\circ} 45$, relativa ao Judiciário, foi aprovada em 30 de novembro de 2004, após mais de uma década de tramitação no Congresso Nacional.

Uma primeira alteração que se destaca é a inclusão no art. $5^{\circ}$ da $\mathrm{CF} / 88$, no Título que trata dos direitos e garantias fundamentais: "LXXVIII - a todos, no âmbito judicial e administrativo, são assegurados a razoável duração do processo e os meios que garantam a celeridade de sua tramitação."

É de fundamental importância que esta norma constitucional, que assegura aos processos judiciais prazo razoável e celeridade, seja garantida, pois a cada ano se acumulam mais ações nas diferentes instâncias judiciais. Todavia, um questionamento se coloca: o que seria considerado um prazo razoável?

Para atender a esta demanda são necessárias mudanças na estrutura burocrática da Justiça brasileira, pois os numerosos recursos possíveis da lei processual e a ampliação dos prazos para o Estado contribuem para adiamento da resolução dos conflitos. E, o Estado brasileiro tem responsabilidade na criação de meios eficazes que assegurem a justa prestação jurisdicional a todos, respeitando o direito à ampla defesa.

No âmbito da $\mathrm{EC} \mathrm{n}$ o 45/04 o art. 93, inciso XIII, acrescentou que "o número de juízes na unidade jurisdicional será proporcional à efetiva demanda judicial e à respectiva população" e o inciso XV, estabeleceu que "a distribuição de processos será imediata em todos os graus de jurisdição". Essas medidas podem colaborar para a celeridade dos processos, em conjunto com outras ações.

No art. $5^{\circ}$ destaca-se a inclusão do parágrafo $3^{\circ}$, prevendo que "Os tratados e convenções internacionais sobre direitos humanos que forem aprovados, em cada Casa do Congresso Nacional, em dois turnos, por três quintos dos votos dos respectivos membros, serão equivalentes às emendas constitucionais”. Com esta inclusão os tratados e convenções sobre direitos humanos passam a ter status de norma constitucional. Antes da EC nº45/04 essas regras vigiam por meio de Decreto Legislativo como leis ordinárias.

No âmbito da reforma (EC nº45/04) foi criado o Conselho Nacional de Justiça, como um dos órgãos do Poder Judiciário (art. 92, inc. I-A). Essa criação foi um dos pontos mais polêmicos, por considerar o Conselho como um órgão de controle externo do Judiciário. $\mathrm{O}$ Conselho Nacional de Justiça compõe-se de quinze membros com mais de trinta e cinco anos e menos de sessenta e seis anos de idade, com mandato de dois anos, admitida uma recondução. Os membros do Conselho serão nomeados pelo Presidente da República, depois 
de aprovada a escolha pela maioria absoluta do Senado Federal, o que pode denotar controle do Poder Executivo sobre o mesmo.

Compete ao Conselho o controle sobre a atuação administrativa e financeira do Poder Judiciário e do cumprimento dos deveres funcionais dos juízes. Os incisos de I a VII definem suas atribuições, e outras podem ser conferidas pelo Estatuto da Magistratura.

Também foi criado pela EC nº45/94 o Conselho Nacional do MP (art. 130-A), composto de 14 membros, nomeados pelo Presidente da República.

A criação dos Conselhos Nacionais de Justiça e do MP recebeu muitas manifestações contrárias por membros de suas instituições, pois gera um "controle externo" das atividades administrativas e financeiras, interferindo em sua autonomia. No entanto, seus adeptos "sustentam que, dos três poderes, o Judiciário é o mais estável e o que tem menos mecanismos de controle e fiscalização, seja por parte da sociedade, seja de outros poderes”. (SADEK, 2004, p. 93).

Dentre os novos dispositivos criados pela EC n45/94, no âmbito da Reforma do Judiciário, a súmula vinculante pode colaborar para tornar o Poder Judiciário mais célere.

\begin{abstract}
Art. 103-A. O Supremo Tribunal Federal poderá, de ofício ou por provocação, mediante decisão de dois terços dos seus membros, após reiteradas decisões sobre matéria constitucional, aprovar súmula que, a partir de sua publicação na imprensa oficial, terá efeito vinculante em relação aos demais órgãos do Poder Judiciário e à administração pública direta e indireta, nas esferas federal, estadual e municipal, bem como proceder à sua revisão ou cancelamento, na forma estabelecida em lei. $\S 1^{\circ}$ A súmula terá por objetivo a validade, a interpretação e a eficácia de normas determinadas, acerca das quais haja controvérsia atual entre órgãos judiciários ou entre esses e a administração pública que acarrete grave insegurança jurídica e relevante multiplicação de processos sobre questão idêntica.

$\S 2^{\circ}$ Sem prejuízo do que vier a ser estabelecido em lei, a aprovação, revisão ou cancelamento de súmula poderá ser provocada por aqueles que podem propor a ação direta de inconstitucionalidade.

$\S 3^{\circ}$ Do ato administrativo ou decisão judicial que contrariar a súmula aplicável ou que indevidamente a aplicar, caberá reclamação ao Supremo Tribunal Federal que, julgando-a procedente, anulará o ato administrativo ou cassará a decisão judicial reclamada, e determinará que outra seja proferida com ou sem a aplicação da súmula, conforme o caso. (BRASIL, 1988, art.103-A).
\end{abstract}

A Lei $\mathrm{n}^{\mathrm{o}}$ 11.417, de 19 de dezembro de 2006, disciplina a edição, a revisão e o cancelamento de enunciado de súmula vinculante pelo STF e dá outras providências. Para a aprovação, revisão ou cancelamento de uma súmula vinculante é necessário o voto de dois terços dos membros do Supremo. Os atores legitimados para propor Adin também podem sugerir a edição, revisão ou cancelamento de súmula.

Os defensores da súmula vinculante afirmam que este instrumento contribuirá para garantir a segurança jurídica e evitar a multiplicação desnecessária de processos em várias instâncias, pois as decisões dos juízes das instâncias inferiores seriam proferidas seguindo o 
entendimento majoritário do STF, impedindo que parte dos processos seguisse em recurso, diminuindo os números de ações com o mesmo conteúdo. Porém, para os opositores a súmula vinculante "engessaria o Judiciário, impedindo a inovação e transformando os julgamentos de primeiro grau em meras cópias de decisões já tomadas (SADEK, 2004, p. 92).

De acordo com Barroso (2009), na prática a súmula vinculante se prestará a veicular o entendimento do Tribunal sobre uma questão constitucional, porque "estabelecida uma interpretação vinculante para determinado enunciado normativo, a consequência será a invalidade de qualquer ato ou comportamento que lhe seja contrário, oriundo do Poder Público ou mesmo de particulares" (p.82).

Barroso (2009, p. 87) também adverte sobre o dever de aplicação automática das súmulas, pois "a realidade pode apresentar inúmeras variáveis, e cabe ao aplicador verificar se a situação concreta submetida a julgamento enquadra-se efetivamente na situação-tipo que a súmula pretendeu capturar".

Até 2009, o STF aprovou 16 súmulas vinculantes ${ }^{39}$. Diretamente relacionada à educação, foi aprovada, em 22 de agosto de 2008, a súmula de $\mathrm{n}^{\circ} 12$, que trata da violação do art. 206 da CF/88, na cobrança de taxa de matrícula nas universidades públicas ${ }^{40}$.

No conjunto da Reforma do Judiciário foram também aprovadas outras medidas legais; entre elas, a Lei 11.277, de 7 de fevereiro de 2006, que acrescenta um artigo à Lei $\mathrm{n}^{\mathrm{o}}$ 5.869, de 11 de janeiro de 1973, que instituiu o Código de Processo Civil ${ }^{41}$. Esse acréscimo trata dos processos repetitivos, visando à redução do o número de processos na Justiça que versam sobre matérias idênticas. Neste caso, segundo Píerpaolo Cruz Bottini (2007), quando

\footnotetext{
${ }^{39}$ Informação disponível em:

http://www.stf.jus.br/portal/cms/verTexto.asp?servico=jurisprudenciaSumulaVinculante. Acesso em 29 set. 2009.

${ }^{40}$ Redação da súmula vinculante $\mathrm{n}^{\circ}$ 12: "A cobrança de taxa de matrícula nas Universidades Públicas viola o disposto no artigo 206 , inciso IV , da Constituição Federal". Um dos precedentes para a edição desta súmula é o Recurso Extraordinário da Universidade Federal de Goiás (UFG) contra decisão do Tribunal Regional Federal da $1^{a}$ Região, favorável a sete candidatos que passaram no vestibular daquela instituição de ensino superior. Para o TRF-1, a cobrança da contribuição para efetivação da matrícula dos estudantes seria inconstitucional por violar a $\mathrm{CF} / 88$. Isso porque, para eles, as instituições de ensino oficiais têm a obrigação de prestar ensino gratuito. Entre outros fundamentos, a universidade sustenta que "não se trata de taxa, como espécie de tributo, mas de preço público". Segundo a instituição, a taxa de matrícula não é cobrada a título de contraprestação pelo ensino público de nível superior, mas sim para tornar efetivo o dispositivo constitucional (art. 206, I) que impõe à sociedade o compromisso de garantir igualdade de acesso e permanência a todos, também, ao ensino superior. Com isso, a instituição vem garantindo a permanência de alunos carentes, com o pagamento de despesas com bolsa, transporte, alimentação, moradia.

41"Art. 285-A. Quando a matéria controvertida for unicamente de direito e no juízo já houver sido proferida sentença de total improcedência em outros casos idênticos, poderá ser dispensada a citação e proferida sentença, reproduzindo-se o teor da anteriormente prolatada.

$\S 1^{\underline{0}}$ Se o autor apelar, é facultado ao juiz decidir, no prazo de 5 (cinco) dias, não manter a sentença e determinar o prosseguimento da ação.

$\S 2^{\underline{0}}$ Caso seja mantida a sentença, será ordenada a citação do réu para responder ao recurso. (Lei n ${ }^{\circ}$ 5.869/73).
} 
um "juiz decidir sobre uma questão de direito reiteradas vezes, e, em todas elas, optar pela rejeição da pretensão inicial do autor, ele poderá, nos próximos pedidos idênticos, expedir antecipadamente sua decisão, sem necessidade de citar o réu e aguardar a contestação", reduzindo "o trabalho do magistrado, que manterá sua sentença anterior em todos os casos idênticos e repetidos, e o trabalho do réu, sem prejuízo algum para o autor, que teve o pleno direito de ajuizar sua demanda e tê-la submetida a um membro do Poder Judiciário”. (p. 967).

A Lei 11.276, de 7 de fevereiro de 2006, dispõe sobre a súmula impeditiva de recursos pelo STF ou STJ ${ }^{42}$, para orientação e indicação das posições destes Tribunais a respeito de determinadas matérias. Por esta lei é mantida a liberdade dos juízes "de seguir a orientação dos tribunais (STF e STJ) ou rechaçá-las, mas, caso opte por acatar o teor da súmula e aplicála ao caso concreto, ficará vedada a utilização de recursos, uma vez que já há posição consolidada nos tribunais a respeito" (BOTTINI, 2007, p. 97).

Essas alterações poderão contribuir na redução dos recursos, desafogando os Tribunais, ao mesmo tempo em que também valorizam a decisão do juiz de primeira instância.

\footnotetext{
${ }^{42}$ A Lei no 11.276/06 altera, dentre outros, o artigo 518 do Código de Processo Civil (Lei no 5.869/73). Pela nova redação: "§ $10 \mathrm{O}$ juiz não receberá o recurso de apelação quando a sentença estiver em conformidade com súmula do Superior Tribunal de Justiça ou do Supremo Tribunal Federal".
} 


\section{TRIBUNAL DE JUSTIÇA DE SÃO PAULO: ASPECTOS INSTITUCIONAIS}

O Tribunal de Justiça paulista foi criado pelo Decreto $\mathrm{n}^{\circ}$ 2.342, 6 de agosto de 1873, com o nome de "Tribunal de Relação da Província de São Paulo de Piratininga", com jurisdição também na Província do Paraná. Foi instalado solenemente em 3 de fevereiro de 1874, sendo seu primeiro Presidente, durante três meses, o Conselheiro Tristão de Alencar Araripe, deputado pelo Ceará. Essas informações sobre o histórico do TJ-SP estão baseadas em publicação de João Gualberto de Oliveira (1975) sobre o Centenário do Tribunal.

Em 1891, por um Decreto do Poder Executivo paulista, foi criado o primeiro “Tribunal de Justiça”. Porém, essa criação durou apenas nove dias, devido ao movimento que depôs Jorge Tibiriçá Piratininga, então nomeado governador do Estado de São Paulo, retornando à denominação anterior de "Tribunal de Relação".

Com o restabelecimento da ordem política no estado, o "Tribunal de Justiça do Estado de São Paulo" (TJ-SP) instalou-se definitivamente em 13 de setembro de 1892, sob a presidência do Desembargador João Augusto de Pádua Fleury.

Com a Constituição Federal de 1934, os Tribunais de segunda instância passaram a denominar-se "Corte de Apelação", e seus magistrados receberam a designação de Desembargador. Em 1937, os Tribunais tiveram modificada sua denominação para "Tribunal de Apelação". Com a Constituição de 1946, os Tribunais dos Estados passaram a chamar-se como atualmente "Tribunal de Justiça".

Em 1974, ano do seu centenário, o TJ-SP funcionava com 36 desembargadores e 40 substitutos. O Tribunal estava dividido em duas Sessões: Civil e Criminal. A sessão Civil dividia-se em seis Câmaras Civis e a Criminal em três Câmaras Criminais.

De acordo com a Constituição do Estado de São Paulo (1989), são órgãos do Poder Judiciário do Estado:

I - o Tribunal de Justiça;

II - o Tribunal de Justiça Militar;

III - os Tribunais do Júri;

IV - as Turmas de Recursos;

V - os Juízes de Direito;

VI - as Auditorias Militares;

VII - os Juizados Especiais; 
VIII - os Juizados de Pequenas Causas. (SÃO PAULO, 1989, art. 54 - Redação dada

pelo art. $1^{\circ}$ da Emenda Constitucional no 8, de 20 de maio de 1999).

De acordo com a Constituição paulista compete ao TJ-SP processar e julgar originariamente:

I - nas infrações penais comuns, o Vice-Governador, os Secretários de Estado, os Deputados Estaduais, o Procurador-Geral de Justiça, o Procurador-Geral do Estado, o Defensor Público Geral e os Prefeitos Municipais;

II - nas infrações penais comuns e nos crimes de responsabilidade, os juízes do Tribunal de Justiça Militar, os juízes de Direito e os juízes de Direito do juízo militar, os membros do Ministério Público, exceto o Procurador-Geral de Justiça, o Delegado Geral da Polícia Civil e o Comandante-Geral da Polícia Militar;

III - os mandados de segurança e os "habeas data" contra atos do Governador, da Mesa e da Presidência da Assembléia, do próprio Tribunal ou de algum de seus membros, dos Presidentes dos Tribunais de Contas do Estado e do Município de São Paulo, do Procurador-Geral de Justiça, do Prefeito e do Presidente da Câmara Municipal da Capital;

IV - os "habeas corpus", nos processos cujos recursos forem de sua competência ou quando o coator ou paciente for autoridade diretamente sujeita a sua jurisdição, ressalvada a competência do Tribunal de Justiça Militar, nos processos cujos recursos forem de sua competência;

V - os mandados de injunção, quando a inexistência de norma regulamentadora estadual ou municipal, de qualquer dos Poderes, inclusive da Administração indireta, torne inviável o exercício de direitos assegurados nesta Constituição;

VI - a representação de inconstitucionalidade de lei ou ato normativo estadual ou municipal, contestados em face desta Constituição, o pedido de intervenção em Município e ação de inconstitucionalidade por omissão, em face de preceito desta Constituição;

VII - as ações rescisórias de seus julgados e as revisões criminais nos processos de sua competência;

VIII - os conflitos de competência entre os Tribunais de Alçada ou as dúvidas de competência entre estes e o Tribunal de Justiça;

IX - os conflitos de atribuição entre as autoridades administrativas e judiciárias do Estado;

$\mathrm{X}$ - a reclamação para garantia da autoridade de suas decisões;

XI - a representação de inconstitucionalidade de lei ou ato normativo municipal, contestados em face da Constituição. (SÃO PAULO, 1989, art. $74^{43}$ ).

Também compete ao Tribunal "provocar a intervenção da União no Estado para garantir o livre exercício do Poder Judiciário" e "requisitar a intervenção do Estado em Município, nas hipóteses previstas em lei.” (SÃO PAULO, 1989, art. 75).

Em grau de recurso, processar e julgar as causas que não são reservadas à competência privativa de demais Tribunais de Segundo Grau ou dos órgãos recursais dos Juizados Especiais.

O TJ-SP é composto por juízes promovidos a desembargadores, por critérios alternados de merecimento e por antiguidade, sendo que um quinto dos lugares é composto de advogados e de membros do MP, de notório saber jurídico e reputação ilibada, indicados em lista sêxtupla, pela Seção Estadual da Ordem dos Advogados do Brasil ou pelo MP (SÃO

\footnotetext{
${ }^{43}$ Os incisos II e VIII têm redação alterada pela EC n ${ }^{\circ} 21$, de 14 de fevereiro de 2006.
} 
PAULO, 1989, art. 54 - Redação dada pelo art. $1^{\circ}$ da Emenda Constitucional no 25 , de 13 de maio de 2008).

Os Tribunais de Alçada foram criados por meio da Constituição Federal de 1946, objetivando a descentralização da justiça. A esse Tribunal, de $2^{\mathrm{a}}$ instância, mas inferior ao Tribunal de Justiça, competia julgar as ações em recursos. Foi extinto pela Emenda Constitucional (EC) nº 45/04 e seus membros passaram a integrar o Tribunal de Justiça.

O funcionamento do TJ-SP organiza-se nas seguintes sessões: Órgão Especial, Conselho Superior da Magistratura, Seção Criminal, Turmas Especiais de Uniformização da Jurisprudência, Grupos de Câmaras, Câmara Especial, Câmaras Civis ou Criminais Isoladas e Câmaras de Férias (SÃO PAULO, 1992, art. $5^{\circ}$ ).
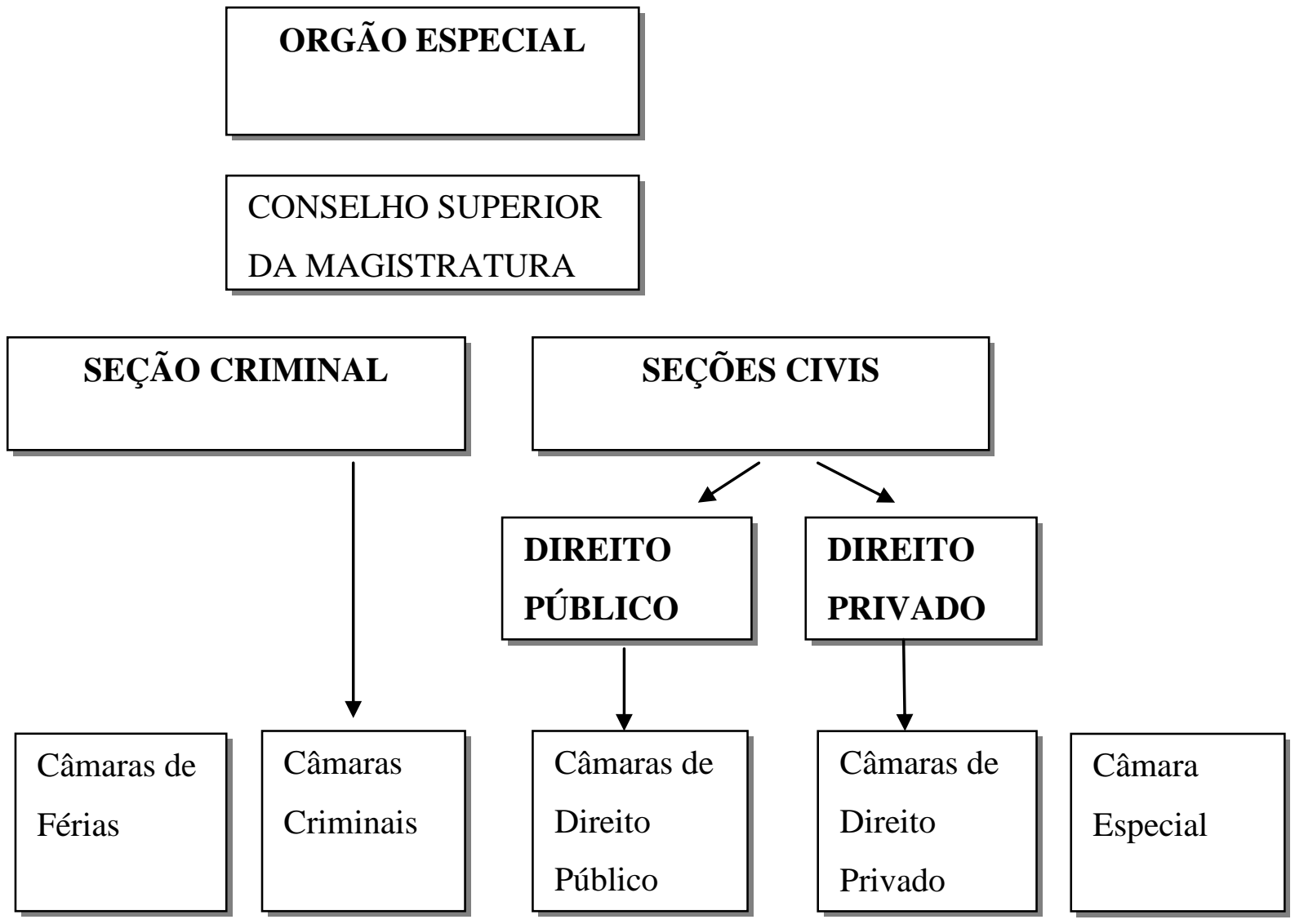

Figura 2 - Estrutura do TJ-SP

O TJ-SP, por decisão do Egrégio Conselho Superior da Magistratura, criou a Coordenadoria da Infância e da Juventude, que, formalmente, passou a existir a partir de $1^{\circ}$ de 
abril de 2007, com a função de oferecer assessoria na prestação jurisdicional e articulações necessárias para o bom desempenho das funções dos magistrados ${ }^{44}$.

\subsection{Composição do TJ-SP (1991-2008)}

Considerado o maior tribunal do país (ANUÁRIO DA JUSTIÇA PAULISTA, 2008), o TJ-SP é composto de 132 desembargadores, sendo o número alterado se o total de processos distribuídos e julgados no ano anterior for superior ao índice de trezentos feitos por juiz (SÃO PAULO, 1992, art. $4^{\circ}$ ). Para efeito desse cálculo não são computados os membros do Tribunal que estejam no exercício de cargos de direção, de Vice-Presidência ou de Decano ${ }^{45}$.

Segundo dados do Anuário da Justiça Paulista (2008), no ano de 2007 integravam o TJ-SP 348 desembargadores, auxiliados por mais 78 juízes substitutos. Destes, somente 5\% eram mulheres e $41 \%$ formaram-se na USP, $48 \%$ são professores e $34 \%$ escreveram pelo menos um livro. Os servidores (33.100) são responsáveis pela burocracia e administração do sistema judicial. Integram a folha de pagamento do Tribunal 11.223 aposentados.

Para os cargos de direção do Tribunal (presidente, vice-presidente e corregedor geral da justiça) podem concorrer à eleição os desembargadores integrantes do Órgão Especial. Três outros desembargadores exercem os cargos de segundo, terceiro e quarto vice-presidentes (SÃO PAULO, 1992).

O quadro abaixo apresenta a composição da presidência do TJ-SP entre os anos de 1991 a 2008:

\begin{tabular}{|l|l|}
\hline ANO & \multicolumn{1}{|c|}{ Presidência } \\
\hline 1991 & Aniceto Aliende \\
\hline 1992 & Odyr Porto \\
\hline 1993 & Odyr Porto \\
\hline 1994 & Weiss de Andrade \\
\hline 1995 & Weiss de Andrade \\
\hline 1996 & Yussef Cahali \\
\hline 1997 & Yussef Cahali \\
\hline 1998 & Dirceu de Mello \\
\hline
\end{tabular}

\footnotetext{
${ }^{44}$ Informação disponível em: http://www.tj.sp.gov.br/CoordenadoriaInfanciaJuventude/Default.aspx. Acesso em: 19 de agosto de 2010 .

${ }^{45} \mathrm{O}$ desembargador mais antigo do Tribunal, ou o seguinte, sucessivamente, na ordem de antiguidade, no caso de não ocupar cargo de direção ou de vice-presidência, exerce funções regimentais próprias com a denominação de Decano (SÃO PAULO, 1992, art. 25).
} 


\begin{tabular}{|l|l|}
\hline 1999 & Márcio Bonilha \\
\hline 2000 & Márcio Bonilha \\
\hline 2001 & Márcio Bonilha \\
\hline 2002 & Nigro Conceição \\
\hline 2003 & Nigro Conceição \\
\hline 2004 & Luiz Tâmbara \\
\hline 2005 & Luiz Tâmbara \\
\hline 2006 & Celso Limongi \\
\hline 2007 & Celso Limongi \\
\hline 2008 & Roberto Vallim Bellochi \\
\hline
\end{tabular}

Quadro 3 - Presidência do TJ-SP entre os anos de 1991 a 2008

Fonte: a autora com base nas informações da Revista JTJ.

O Tribunal de Justiça é composto de uma Seção Criminal e de duas Seções Civis, sendo uma especializada em Direito Privado e outra em Direito Público. Cada Câmara das Seções é composta por cinco desembargadores. A Seção Criminal é presidida pelo segundo vice-presidente. A presidência da Seção de Direito Privado é competência do terceiro vicepresidente do Tribunal e a de Direito Público pelo quarto Vice-Presidente. Cada grupo é presidido pelo desembargador mais antigo, dentre seus integrantes (SÃO PAULO, 1992).

Segundo as normas do Regimento Interno, as Câmaras de Férias são constituídas de cinco Juízes, com a presidência do desembargador mais antigo.

As decisões envolvendo os direitos educacionais foram julgadas, em sua maioria, pelo Órgão Especial, Câmara Especial e pelas Câmaras de Direito Público.

Participam do Órgão Especial, ou Plenário, o presidente, 12 desembargadores mais antigos, com mandato vitalício, e 12 eleitos para mandato de dois anos.

A presidência da Câmara Especial é responsabilidade do Primeiro Vice-Presidente do Tribunal e é composta pelos demais vice-presidentes e pelo Decano.

Considerando que os processos da jurisdição da Infância e da Juventude são exclusivos de sua competência para julgamento, apresenta-se a seguir a composição da Câmara Especial entre os anos de 1991 a 2008:

\begin{tabular}{|l|l|l|l|l|l|}
\hline ANO & $\begin{array}{l}\mathbf{1}^{\mathbf{0}} \text { vice- } \\
\text { presidente }\end{array}$ & $\begin{array}{l}\mathbf{2}^{\mathbf{0}} \text { vice- } \\
\text { presidente }\end{array}$ & $\begin{array}{l}\mathbf{3}^{\mathbf{0}} \text { vice- } \\
\text { presidente }\end{array}$ & $\begin{array}{l}\mathbf{4}^{\mathbf{0}} \text { vice- } \\
\text { presidente }\end{array}$ & Decano \\
\hline $\mathbf{1 9 9 1}$ & Odyr Porto & Marino Falcão & Garrigós Vinhaes & $\begin{array}{l}\text { Torres de } \\
\text { Carvalho }\end{array}$ & $\begin{array}{l}\text { Sylvio do } \\
\text { Amaral }\end{array}$ \\
\hline $\mathbf{1 9 9 2}$ & Lair Loureiro & Cunha Camargo & Yussef Cahali & Sabino Neto & $\begin{array}{l}\text { Cesar de } \\
\text { Moraes }\end{array}$ \\
\hline $\mathbf{1 9 9 3}$ & Lair Loureiro & Cunha Camargo & Yussef Cahali & Sabino Neto & $\begin{array}{l}\text { Cesar de } \\
\text { Moraes }\end{array}$ \\
\hline $\mathbf{1 9 9 4}$ & Yussef Cahali & Dirceu de Mello & Ney Almada & Nigro Conceição & Sabino Neto \\
\hline
\end{tabular}




\begin{tabular}{|c|c|c|c|c|c|}
\hline 1995 & Yussef Cahali & Dirceu de Mello & Ney Almada & Nigro Conceição & Sabino Neto \\
\hline 1996 & Dirceu de Mello & Cunha Bueno & Luís de Macedo & Carlos Ortiz & Lair Loureiro \\
\hline ANO & $\begin{array}{l}1^{\circ} \text { vice- } \\
\text { presidente }\end{array}$ & $\begin{array}{l}2^{\mathbf{0}} \text { vice- } \\
\text { presidente }\end{array}$ & $\begin{array}{l}3^{\circ} \text { vice- } \\
\text { presidente }\end{array}$ & $\begin{array}{l}4^{0} \text { vice- } \\
\text { presidente }\end{array}$ & Decano \\
\hline 1997 & Dirceu de Mello & Cunha Bueno & Luís de Macedo & Carlos Ortiz & Alves Braga \\
\hline 1998 & Cunha Bueno & Djalma Lofrano & Álvaro Lazzarini & Oetterer Guedes & Alves Braga \\
\hline 1999 & Álvaro Lazzarini & Djalma Lofrano & Fonseca Tavares & Oetterer Guedes & Yussef Cahali \\
\hline 2000 & Álvaro Lazzarini & Gentil Leite & Fonseca Tavares & Hermes Pinotti & $\begin{array}{l}\text { Nigro } \\
\text { Conceição }\end{array}$ \\
\hline 2001 & Álvaro Lazzarini & Gentil Leite & $\begin{array}{l}\text { Mohamed } \\
\text { Amaro }\end{array}$ & Luiz Tâmbara & $\begin{array}{l}\text { Nigro } \\
\text { Conceição }\end{array}$ \\
\hline 2002 & Luís de Macedo & Denser de Sá & $\begin{array}{l}\text { Mohamed } \\
\text { Amaro }\end{array}$ & Vallim Bellocchi & Gentil Leite \\
\hline 2003 & Luís de Macedo & Denser de Sá & $\begin{array}{l}\text { Mohamed } \\
\text { Amaro }\end{array}$ & Vallim Bellocchi & Viseu Júnior \\
\hline 2004 & $\begin{array}{l}\text { Mohamed } \\
\text { Amaro }\end{array}$ & Denser de Sá & Viseu Júnior & Vallim Bellocchi & $\begin{array}{l}\text { Nigro } \\
\text { Conceição }\end{array}$ \\
\hline 2005 & $\begin{array}{l}\text { Mohamed } \\
\text { Amaro }\end{array}$ & Jarbas Mazzoni & Ruy Camilo & Vallim Bellocchi & Gentil Leite \\
\hline 2006 & $\begin{array}{l}\text { Canguçu de } \\
\text { Almeida }\end{array}$ & Ademir Benedito & Sidnei Beneti & $\begin{array}{l}\text { Ribeiro dos } \\
\text { Santos }\end{array}$ & José Cardinale \\
\hline 2007 & $\begin{array}{l}\text { Canguçu de } \\
\text { Almeida }\end{array}$ & Ademir Benedito & Sidnei Beneti & $\begin{array}{l}\text { Ribeiro dos } \\
\text { Santos }\end{array}$ & Denser de Sá \\
\hline 2008 & Munhoz Soares & $\begin{array}{l}\text { Rodrigues da } \\
\text { Silva }\end{array}$ & Viana Santos & Eduardo Pereira & Luiz Tâmbara \\
\hline
\end{tabular}

Quadro 4 - Composição Câmara Especial do TJ-SP (1991-2008)

Fonte: Organizado pela autora com base nas informações da Revista JTJ.

Obs.: Em 2006 também constam da composição: Mohamed Amaro, Luiz Tâmbara, Jarbas Coimbra, Eduardo Cortez de Freitas Gouvêa*. Em 2007: Mohamed Amaro, Luiz Tâmbara, Jarbas Mazzoni, Eduardo Cortez de Freitas Gouvêa *, Maria Olívia Pinto Esteves Alves *. Em 2008: Eduardo Cortez de Freitas Gouvêa*, Maria Olívia Pinto Esteves Alves*, Edison da Silva Martins Pinto*, Jeferson Moreira de Carvalho*.

* Juiz de Direito Substituto em $2^{\circ}$ Grau.

Apresenta-se, a seguir, uma breve biografia de desembargadores que foram relatores dos principais acórdãos, versando sobre os litígios educacionais discutidos neste trabalho, sendo selecionados os magistrados que atuaram como relatores ou com apresentação de voto em pelo menos quatro acórdãos. Não foi possível localizar informações biográficas ${ }^{46}$ referentes a alguns desses desembargadores, portanto, são recopilados dados sobre 15 membros do TJ-SP (QUADRO 5).

A maior parte dos desembargadores atua no TJ-SP desde a década de 80; um, desde 1995; quatro foram promovidos depois de 2005. Tal composição evidencia a experiência dos membros do Tribunal paulista.

\footnotetext{
${ }^{46}$ Para os seguintes desembargadores não foram localizadas informações, nas fontes consultadas descritas no texto, sobre sua biografia: Borelli Machado, Djalma Lofrano, Eduardo Gouvêa, Fonseca Tavares, Gentil Leite, Hermes Pinotti, Maria Olívia Alves, Oetterer Guedes.
} 
A maioria dos desembargadores é paulista; sete formaram-se em bacharéis em Direito na Universidade de São Paulo (USP) e seis pela Pontifícia Universidade Católica (PUC).

Além da magistratura, oito desembargadores exercem a atividade docente, na sua maioria, em instituições privadas. Quatro são mestres, dois doutorandos e um doutor em Direito. Quatro desembargadores, Álvaro Lazzarini; Mohamed Amaro, Roberto Vallim Bellochi e Viana Santos escreveram livros sobre áreas do Direito em que se especializaram na pós-graduação ou em que atuavam como docentes.

Vale destacar, também, a atuação na Vara da Infância e Juventude do Desembargador Ademir Benedito e da juíza substituta no TJ-SP, Maria Olívia Alves.

Desde 2007, o desembargador Sidnei Beneti atua como ministro do Superior Tribunal de Justiça. 


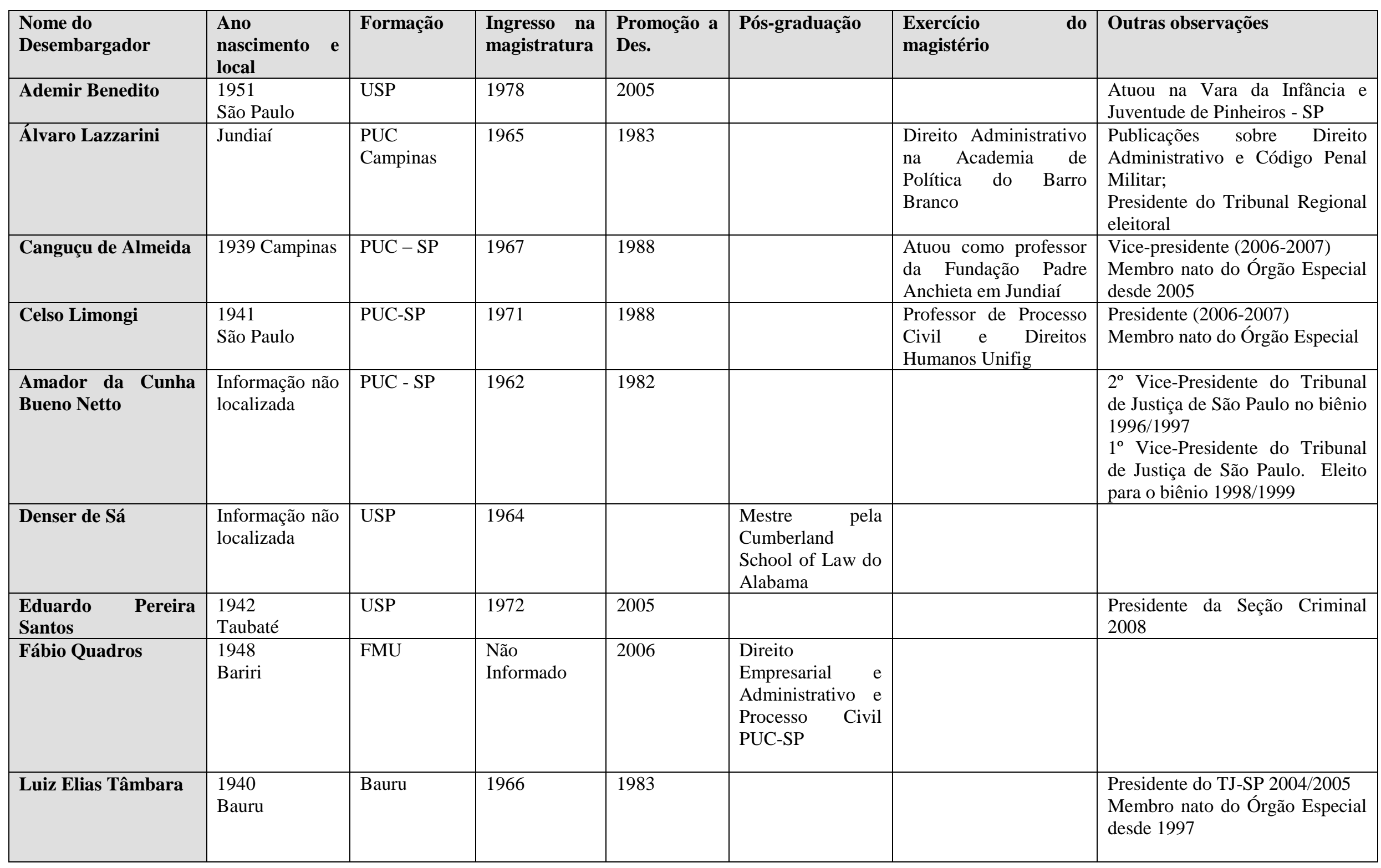




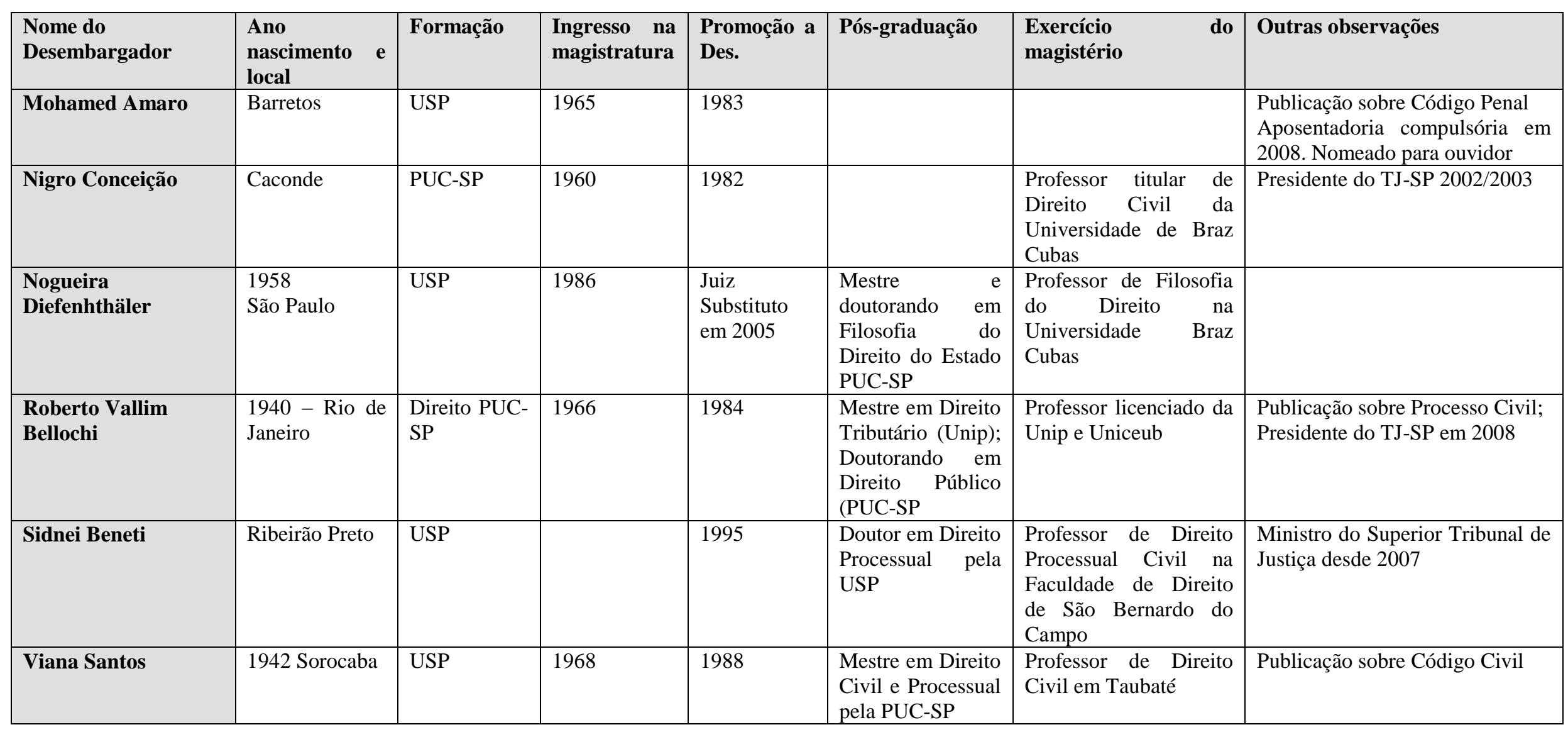

Quadro 5 - Dados biográficos dos desembargadores do TJ-SP

Fonte: A autora com base em Anuário da Justiça Paulista (2008) e sítios eletrônicos ${ }^{47}$.

\footnotetext{
${ }^{47}$ Sítios eletrônicos pesquisados: http://www.tribunadodireito.com.br/2003/novembro/Lazzarini.htm; http://www.tjsp.jus.br/museu/museu/expresidentes.aspx; http://www.tribunadodireito.com.br/2004/janeiro/janeiro_28.html; http://www.direito2.com.br/tjsp/2008/jan/8/conselho-superior-da-magistratura-realiza-primeira-reuniao; http://www.direito2.com.br/stj/2007/dez/12/sidnei-beneti-e-jorge-mussi-sao-empossados-como-ministros. Acesso às informações: 21 jan. 2010.
} 


\subsection{Competências}

Ao Órgão Especial, principal colegiado jurisdicional e administrativo do TJ-SP, compete processar e julgar, originariamente, dentre outras atribuições a "representação de inconstitucionalidade de lei ou ato normativo estadual ou municipal, contestados em face da Constituição do Estado; o pedido de intervenção em município e a ação direta de inconstitucionalidade por omissão, em face de preceito da Constituição Estadual' (SÃO PAULO, 1992, art. 177, inciso VI).

O julgamento nas infrações penais comuns de autoridades, como governador, vicegovernador, secretários de Estado, deputados estaduais é também de competência do Órgão Especial. Assim como processar e julgar nas infrações penais comuns e nos crimes de responsabilidade os juízes, membros do MP, Delegado Geral da Polícia Civil e Comandante Geral da Polícia Militar.

Aos órgãos da Seção de Direito Privado cabe processar e julgar as ações regidas pelo Direito Privado, destacando-se as relativas às seguintes matérias: "V - obrigações de Direito Privado em geral, ainda que oriundas de contrato do qual o Estado participe, ou de prestação de serviços que haja autorizado, delegado, permitido, ou concedido"; "VI - responsabilidade civil, contratual ou extracontratual, salvo a do Estado" (SÃO PAULO, 1992, art. 183).

Os processos regidos pelo Direito Público são de competência dos órgãos da Seção de Direito Público, compreendendo, dentre outras mencionadas no Regimento Interno, art. 184: controle e cumprimento de atos administrativos; licitações e contratos administrativos; ensino; ação popular ${ }^{48}$.

Os mandados de segurança, habeas corpus e recursos de qualquer natureza, em matéria da jurisdição da Infância e da Juventude, competem privativamente à Câmara Especial, tendo esses processos preferência na distribuição (SÃO PAULO, 1992, art. 405).

\footnotetext{
${ }^{48}$ Garantia constitucional prevista no art. $5^{\circ}$, inciso LXXIII, visa a anular atos lesivos ao patrimônio público ou de entidade de que o Estado participe, à moralidade administrativa, ao meio ambiente e ao patrimônio histórico e cultural. Qualquer cidadão é parte legítima para propor a ação popular, ficando o autor, salvo comprovada má-fé, isento de custas judiciais e do ônus da sucumbência, ou seja, os honorários do advogado da parte vencedora caso seja considerado parte perdedora.
} 


\subsection{Instrumentos processuais de recursos}

No Código de Processo Civil (art. 496) são cabíveis os seguintes recursos: Apelação; Agravo; Embargos Infringentes; Embargos de Declaração; Recurso Ordinário; Recurso Especial; Recurso Extraordinário; Embargos de Divergência em Recurso Especial e em Recurso Extraordinário.

Serão apresentados, em seguida, os principais instrumentos de recursos utilizados para a discussão dos litígios educacionais no âmbito do TJ-SP.

A Apelação Cível, no processo civil, é um recurso interposto junto ao próprio juiz da causa, visando a uma nova decisão. Na petição devem-se especificar os pontos da sentença que devem ser anulados ou reformados pelo Tribunal. Das 483 decisões coletadas para análise deste trabalho, 311 são apelações.

Quanto ao Agravo de instrumento, trata-se de um recurso cabível para as decisões que concedem ou não pedido de antecipação de tutela ${ }^{49}$. A expressão "de instrumento" foi suprimida pela Lei 8.950, de 13 de dezembro de 1994.

São características do Agravo: a) recurso contra ato pelo qual o Juiz, no curso do processo resolve questão incidental, ou seja, uma controvérsia que incide no curso do processo devendo a mesma ser decidida antes da questão principal; b) não se opõe ao andamento do processo e não interfere na eficácia da decisão agravada; c) deve sempre subir ao Tribunal de instância superior; d) "não esgota o ofício do juiz quanto à decisão agravada, uma vez que lhe será dado proferir novo ato decisório, para manter ou reformar a interlocutória que provocou o recurso" (ACQUAVIVA, 1995, p. 131).

O Agravo Regimental é disciplinado pelo próprio regimento do tribunal. Para o TJ-SP caberá esse recurso contra "decisão que causar prejuízo ao direito da parte, proferida pelo presidente, pelos vice-presidentes, pelo corregedor geral da justiça ou pelos relatores dos feitos". (SÃO PAULO, 1992, art. 858).

No processo civil, os Embargos de Declaração consistem em pedido de esclarecimentos de obscuridades, contradições e omissões, que se faz ao próprio juiz ou Tribunal que emitiu a sentença (ACQUAVIVA, 1995)

São cabíveis, no processo civil, os Embargos Infringentes, quando não for unânime o julgamento proferido em apelação ou em ação rescisória. A divergência pode ter sido

\footnotetext{
${ }^{49}$ A tutela antecipada consiste em ato do juiz que visa assegurar a satisfação antecipada total ou parcial do direito pretendido pela ação, enquanto o mérito da ação será discutido ao longo do processo.
} 
apresentada por apenas um julgador em relação aos demais. Aceitando-se o recurso, será sorteado novo relator, recaindo, quando possível, em juiz que não participou do julgamento da apelação (ACQUAVIVA, 1995).

A Ação Direta de Inconstitucionalidade (Adin) de lei ou ato normativo estadual ou municipal, contestado em face da Constituição estadual, pode ser proposta no âmbito de seu interesse pelas seguintes partes:

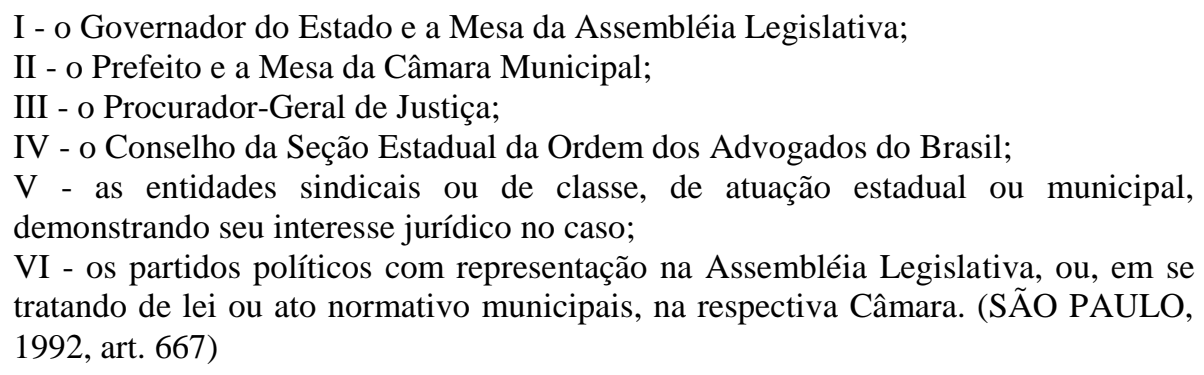

Algumas sentenças cíveis estão sujeitas ao reexame necessário, ou seja, ao duplo grau de jurisdição:
I - que anular o casamento;
II - proferida contra a União, o Estado e o Município;
III - que julgar improcedente a execução da dívida ativa da Fazenda Pública e de suas autarquias;
IV - que concluir pela improcedência ou pela carência da ação popular; V - proferida em ação de desapropriação e que condenar a Fazenda Pública em quantia superior ao dobro da oferecida;
VI - que conceder mandado de segurança ${ }^{50}$;
VII - que desacolher ação anulatória de registro ou matrícula de imóvel rural;
VIII- que julgar a liquidação por arbitramento ou artigos nas execuções movidas contra o Estado. (SÃO PAULO, 1992, art. 838).

Nesses casos os autos serão remetidos ao Tribunal, havendo ou não recurso voluntário.

De acordo com o Código de Processo Civil, art. 475, o duplo grau de jurisdição não é aplicável quando a sentença estiver fundada em jurisprudência do plenário do Supremo Tribunal Federal ou em súmula deste Tribunal ou do tribunal superior competente.

A Lei n 11.276, de 2006, também inclui no Código de Processo Civil, que, referente às sentenças que estiverem em conformidade com súmula do STJ ou STF, não caberá recurso de apelação. (CÓDIGO DE PROCESSO CIVIL, art. 518).

No conjunto das decisões do TJ-SP analisadas neste trabalho, 308, como já mencionado, são recursos de Apelação; 58 são do tipo Agravo Regimental; 46, Agravo de Instrumento; 22, Ação de Inconstitucionalidade de Lei ou ato normativo municipal ou

\footnotetext{
${ }^{50} \mathrm{O}$ mandado de segurança é previsto nos incisos LXIX e LXX do art. $5^{\circ}$ da CF/88 para a proteção de direito líquido e certo, não amparado por habeas-corpus ou hábeas-data, quando o responsável pela ilegalidade ou abuso de poder for autoridade pública ou agente de pessoa jurídica no exercício de atribuições do Poder Público.
} 
estadual; 20 se caracterizam como Embargos Infringentes; 13, como Embargos de Declaração e 13 são recursos ex officio, que seguem a obrigatoriedade de reexame.

Optou-se por analisar todas as decisões do TJ-SP que envolveram conflitos educacionais relativos a crianças e adolescentes. Portanto, focalizando, além das de mérito, as decisões dos recursos que são proferidas ao longo do processo, como nos Agravos, e os Embargos que discutem as próprias decisões do Tribunal. Justifica-se essa opção pelo fato de que, neste conjunto de julgados foi possível perceber as discordâncias de posições entre os desembargadores, como será enfatizado no próximo capítulo.

A seguir, apresenta-se o percurso de uma ação judicial, pela via difusa, exemplificando como um litígio pode ser analisado pelas diversas instâncias do Judiciário brasileiro.

A fase inicial de um processo se dá com o exame de sua admissibilidade, seguindo-se do conhecimento dos fatos e das provas pelo juiz de primeira instância. A ação pode ser proposta pelo MP, por um órgão do estado ou um particular, assistido pela defensoria pública ou por advogado privado. As ações coletivas, como as ações civis públicas, também poderão ser propostas por associações civis legalmente constituídas, sendo vedadas aos particulares.

Nesta fase, poderá ser solicitada a antecipação dos efeitos da tutela, que enseja ao juiz antecipar, total ou parcialmente, os efeitos da tutela pretendida no processo, desde que haja prova sobre receio de dano irreparável ou de difícil reparação, ou se ficar caracterizado o abuso de direito de defesa ou o manifesto propósito protelatório do réu (CÓDIGO DE PROCESSO CIVIL, art. 273). A tutela antecipada poderá ser concedida, revogada ou modificada a qualquer tempo.

As decisões que concedem ou não liminares, antecipando a tutela, podem ser questionadas por meio do recurso do Agravo, sendo julgado pelo Tribunal de Justiça.

Conforme o pedido, a ação é distribuída à Vara competente. Nas comarcas em que há varas especializadas, o processo que discute direitos de crianças e adolescentes será julgado pela Vara da Infância e Juventude.

O juiz, ao receber a ação, citará a parte contrária para que faça a sua contestação e, após analisar as provas e as argumentações das partes, proferirá a sentença, acolhendo ou rejeitando, no todo ou em parte, o pedido formulado pelo autor.

Da sentença do juiz, dentro do prazo, cabe às partes recurso. Conforme já mencionado, as decisões proferidas contra a União, o Estado, o Distrito Federal e o Município devem seguir o duplo grau de jurisdição, devendo a sentença ser confirmada pelo Tribunal. Ou seja, 
mesmo que nenhuma das partes recorra o processo subirá "de ofício" para revisão do Tribunal.

O recurso de apelação, interposto junto ao juiz da causa, será julgado pelo Tribunal de Justiça estadual. Os recursos, envolvendo matéria de Infância e Juventude, são distribuídos à Câmara Especial do TJ-SP.

Das decisões do Tribunal de Justiça, cabem os recursos anteriormente explicitados "Agravo Regimental", "Embargos de Declaração" e "Embargos Infringentes".

Dos julgados do Tribunal de Justiça estadual comporta recurso ao STJ e ao STF.

Ao STF, compete julgar, mediante recurso extraordinário, quando a decisão recorrida contrariar dispositivo da Constituição, declarar a inconstitucionalidade de tratado ou lei federal, julgar válida lei ou ato de governo local contestado em face da Constituição (BRASIL, 1988, art. 102). Nesse caso, é necessário que o fundamento constitucional tenha servido de base para a decisão em primeira ou segunda instância.

A competência do STJ para julgar recurso especial se dá quando a decisão recorrida contrariar tratado ou lei federal, ou negar-lhes vigência; julgar válido ato de governo local contestado em face de lei federal; der à lei federal interpretação divergente da que lhe haja atribuído outro tribunal (BRASIL, 1988, art. 105).

O STF e o STJ somente poderão decidir sobre as questões de direito alegadas nos recursos, não lhes cabendo reexaminar os fatos e provas alegados no processo.

\subsection{Indicadores da justiça estadual paulista}

A seguir apresentam-se alguns indicadores da justiça estadual paulista sobre despesas, litigiosidade, acesso à justiça e perfil das demandas, elaborados pelo Conselho Nacional de Justiça (2007), tendo como ano-base 2006.

Considerando o número de magistrados por habitante, São Paulo tem 2.363 magistrados, com a proporção de 5,9 magistrados por cem mil habitantes, sendo sua posição $17^{\mathrm{a}}$ se comparada aos outros estados.

A despesa total da Justiça estadual paulista corresponde a 0,48\% do PIB do Estado, ficando à frente apenas do estado do Paraná; ou seja, tem uma das mais baixas taxas de despesas dos estados brasileiros. Considerando a despesa total da Justiça estadual em relação 
à despesa pública, o percentual paulista corresponde a $4,36 \%$, estando na $19^{\mathrm{a}}$ posição entre os estados. Em relação à despesa total da justiça paulista (4.186.660.203), 90\% são aplicados em despesas com pessoal (3.768.660.795) e 10\% em bens e serviços (417.999.408).

Por habitante, a Justiça estadual paulista despende $\mathrm{R} \$ 105,12$, sendo o $11^{\circ}$ estado brasileiro neste item. Da despesa total da Justiça, 3,5\% são gastos com informática, com percentual abaixo do aplicado pelos estados de Alagoas e Rio de Janeiro.

Com relação à litigiosidade, em 2006 ingressaram 490.294 novos casos em segunda instância, 1.231 novos casos para cem mil habitantes (398), sendo o $4^{\circ}$ estado brasileiro, após os estados de Rio Grande do Sul, Mato Grosso do Sul e Santa Catarina. Cada magistrado em segunda instância recebeu 1.362 novos casos.

Considerando os casos novos, mais os casos pendentes na segunda instância (581.808) e o número de magistrados que atuam nessa instância (360), a relação da carga de trabalho é de 2.978 processos. Na primeira instância essa relação é de 9.663 .

A taxa de congestionamento é de $54 \%$, considerando que 492.881 foram julgados, 490.294 processos ingressaram, mais os casos pendentes de 581.808. Comparado a outros estados, São Paulo é o $5^{\circ}$ na classificação, após Ceará, Pernambuco, Bahia e Amazonas. Na primeira instância, a taxa de congestionamento paulista é muito alta $(84,3 \%)$, sendo o $9^{\circ}$ do ranking entre os estados.

O percentual de recursos à Instância $\operatorname{Superior}^{51}$ (119.152) é de $31 \%$ em relação aos acórdãos publicados no $2^{\circ} \mathrm{Grau}^{52}$ (384.704), sendo o $8^{\circ}$ estado. Na primeira instância, os dados revelam que $15 \%$ dos processos julgados foram a recurso; comparado aos demais estados, neste item São Paulo é o segundo, atrás somente do Rio Grande do Sul.

De acordo com dados do Anuário da Justiça Paulista (2008), um recurso, para chegar a julgamento, espera em média, cinco anos. Contudo, algumas Câmaras não estão com processos parados, estando livres para julgar os casos novos. Este cenário é marcado por diversidades: "em algumas câmaras, prevalece o pragmatismo. O colegiado empenha-se em limpar a pauta. Outras não abrem mão do aperfeiçoamento da doutrina. Investem tempo na reformulação de entendimentos calcificados e que não correspondem aos dias atuais", e há também os que acreditam que "só existe Justiça nos estritos termos dos códigos processuais e

\footnotetext{
${ }^{51}$ Nestes dados estão inclusos todas as modalidades de impugnação a decisões judiciais de Tribunais de $2^{\circ}$ Grau e endereçadas aos Tribunais Superiores, incluindo as de natureza recursais ordinárias e extraordinárias, bem como, mandado de segurança, suspensão de segurança, habeas corpus e reclamação. (CONSELHO NACIONAL DE JUSTIÇA, 2007).

52 Todos os acórdãos publicados em 2006 passíveis de recurso para o STJ e o STF, excluídos os acórdãos referentes a embargos de declaração.
} 
na literalidade da lei”, sendo os técnicos (p. 14). Esta heterogeneidade também se reflete nas diferentes posições sobre os litígios educacionais, como será apresentado no próximo capítulo.

O número de pessoas que ingressaram com alguma ação judicial na Justiça Estadual, em 2006, foi de 6.968.511, considerando como partes demandantes (autores) pessoas físicas e pessoas jurídicas de direito privado não governamental, sendo o primeiro estado brasileiro neste item e o segundo o Rio Grande do Sul.

A participação governamental na demanda da justiça estadual, ou seja, tendo o poder público como demandante (União, Estados, Municípios, INSS, CEF, Banco do Brasil e outros entes da administração pública indireta), foi de 1.973 .435 ações, mantendo a mesma classificação para as ações de pessoas físicas e jurídicas de direito privado, ou seja, o primeiro na classificação entre os estados.

Já a Participação Governamental na Demanda da Justiça Estadual - Poder Público como demandado, o número total de ações propostas contra a União, Estados, Municípios, INSS, CEF, Banco do Brasil e outros entes da Administração Pública indireta foi de 319.190 ações, mantendo a primeira posição no ranking dos estados.

São Paulo e o Rio Grande do Sul são os dois estados brasileiros que mais recebem processos anualmente, e têm mais processos parados. Em São Paulo, o número de processos novos não acompanha o ritmo de processos encerrados. De cada dez ações, apenas duas são julgadas no ano. Esses dados retrataram a morosidade do sistema, principalmente em primeira instância, não atendendo satisfatoriamente os demandantes. Aliado a isso, está o fato de que cada vez mais os conflitos são levados a litígio judicial, ampliando-se a carga de trabalho dos magistrados.

A partir dessas informações torna-se possível depreender as condições de funcionamento do Tribunal, com o excesso de processos ainda não julgados que refletem a lenteza para a conclusão de uma ação, podendo constituir-se em obstáculo para a eficácia de se recorrer ao Judiciário para a implementação dos direitos sociais. 


\section{DECISÕES EDUCACIONAIS DO TRIBUNAL DE JUSTIÇA DE SÃO PAULO}

Neste capítulo, apresenta-se a análise das decisões do TJ-SP proferidas sobre o direito de crianças e adolescentes à educação, após a implantação do ECA, ou seja, de 1991 a 2008. Optou-se por desenvolver essa análise a partir da organização das decisões em categorias e temas dos litígios, apresentada na introdução deste trabalho.

O uso do Tribunal de Justiça para a resolução de questões relativas à educação é evidenciado na tabela abaixo, sendo possível perceber um crescimento das demandas a partir da aprovação da Lei de Diretrizes e Bases da Educação Nacional em 1996 (LDB/96). Até 1995, as demandas são mais esparsas, destacando-se as decisões acerca do controle de mensalidades escolares no setor privado. Aceitando-se que as decisões analisadas não correspondem ao total de julgados, como explicitado anteriormente, ainda assim denota-se um acentuado número nos anos de 1998, 2006, 2007 e 2008, pois, como se verá posteriormente, alguns litígios são discutidos em períodos específicos, a partir de atos do Poder Público, sejam eles por omissão ou por ação, que impedem que o direito à educação seja garantido.

Tabela 2 - Distribuição anual das decisões organizadas em categorias

\begin{tabular}{|c|c|c|c|c|c|c|c|c|c|c|c|c|c|c|c|c|c|c|c|}
\hline $\begin{array}{c}\text { CATEGORIAS/ } \\
\text { ANO } \\
\end{array}$ & 91 & 92 & 93 & 94 & 95 & 96 & 97 & 98 & 99 & 00 & 01 & 02 & 03 & 04 & 05 & 06 & 07 & 08 & Total \\
\hline $\begin{array}{l}\text { Acesso à } \\
\text { educação básica }\end{array}$ & & & & & & 3 & 8 & 40 & 15 & 14 & 15 & 34 & 13 & 3 & 10 & 46 & 48 & 35 & 284 \\
\hline Permanência & & 2 & & & & 1 & 1 & 1 & 3 & 6 & 1 & 2 & & & & 5 & 9 & 5 & 36 \\
\hline $\begin{array}{l}\text { Responsabilidade } \\
\text { estatal }\end{array}$ & & & & & 1 & & 2 & 2 & 4 & 5 & 2 & 1 & & 2 & 2 & 5 & 5 & 4 & 35 \\
\hline $\begin{array}{l}\text { Poder de } \\
\text { regulação estatal }\end{array}$ & 4 & 10 & 4 & 2 & 1 & 12 & 6 & 2 & 2 & 3 & 3 & & 0 & 1 & 1 & 2 & 12 & 2 & 67 \\
\hline $\begin{array}{l}\text { Decisões } \\
\text { administrativas e } \\
\text { políticas }\end{array}$ & 1 & & 1 & 2 & & & 1 & 1 & 1 & 2 & & 2 & 7 & 6 & 1 & 2 & 4 & 5 & 36 \\
\hline $\begin{array}{l}\text { Gestão dos } \\
\text { recursos públicos }\end{array}$ & & & & 1 & & & 1 & 1 & & & & & 2 & & & 1 & 1 & 7 & 14 \\
\hline Deveres dos pais & & & & & & 1 & & & & & 3 & 1 & & 3 & & 1 & 2 & & 11 \\
\hline TOTAL & 5 & 12 & 5 & 5 & 2 & 17 & 19 & 47 & 25 & 30 & 24 & 40 & 22 & 15 & 14 & 62 & 81 & 58 & 483 \\
\hline
\end{tabular}

Fonte: a autora com base na coleta de decisões julgadas pelo TJ-SP.

As ações solicitando o acesso à educação básica representam 58,6\% do total das decisões analisadas no âmbito deste trabalho, e apontam para o uso do Poder Judiciário com a finalidade de requisitar o direito a uma vaga nas diferentes etapas e modalidades da educação básica. Neste grupo, destacam-se as dezenas de requisições na Educação Infantil (Tabela 3), 
representando $36 \%$ do total. Por outro lado, com relação ao ensino médio, considerado na LDB/96 como tendo a obrigatoriedade progressivamente estendida, foi localizada apenas uma decisão.

Tabela 3 - Decisões agrupadas por temas envolvendo "Acesso à educação básica"

\begin{tabular}{|c|c|c|c|c|c|c|c|c|c|c|c|c|c|c|c|c|c|c|c|}
\hline TEMAS/ANOS & 91 & 92 & 93 & 94 & 95 & 96 & 97 & 98 & 99 & 00 & 01 & 02 & 03 & 04 & 05 & 06 & 07 & 08 & Total \\
\hline Acesso educação infantil & & & & & & & & & 2 & 4 & 7 & 32 & 10 & 1 & 9 & 43 & 36 & 31 & 175 \\
\hline Acesso ensino fundamental & & & & & & 1 & 8 & 39 & 8 & 9 & 4 & 2 & & & & & 1 & 1 & 73 \\
\hline Acesso ensino médio & & & & & & & & & 1 & & & & & & & & & & 1 \\
\hline Acesso EJA & & & & & & & & & 2 & & 3 & & & & & & 1 & & 6 \\
\hline Acesso Ed. Profissional & & & & & & 2 & & 1 & 1 & 1 & 1 & & & & & 1 & 3 & & 10 \\
\hline Acesso Ed. Especial & & & & & & & & & 1 & & & & 3 & 2 & 1 & 2 & 6 & 2 & 17 \\
\hline $\begin{array}{l}\text { Acesso (não define } \\
\text { etapa/modalidade) }\end{array}$ & & & & & & & & & & & & & & & & & 1 & 1 & \\
\hline TOTAL & 0 & 0 & 0 & 0 & 0 & 3 & 8 & 40 & 15 & 14 & 15 & 34 & 13 & 3 & 10 & 46 & 48 & 35 & 284 \\
\hline
\end{tabular}

Fonte: a autora com base na coleta de decisões julgadas pelo TJ-SP.

A categoria "permanência" (TABELA 4) totaliza apenas 7\% das decisões analisadas, ressaltam-se as ações que contestam medidas impeditivas de frequência do aluno à escola, impostas como penalidade por desrespeito às normas escolares $(3 \%)$. Os processos que reivindicaram a manutenção da matrícula nos cursos de língua estrangeira, oferecidos pela rede estadual paulista, estão concentrados nos anos de 1996 a 1999, devido à normatização neste período, como será especificado posteriormente (2,3\%). As decisões versando sobre evasão também são escassas $(0,8 \%)$ e localizadas em momento específico.

Tabela 4 - Decisões agrupadas por temas envolvendo "Permanência"

\begin{tabular}{l|r|r|r|r|r|r|r|r|r|r|r|r|r|r|r|r|r|r|r}
\hline \multicolumn{1}{|c|}{ PERMANÊNCIA } & $\mathbf{9 1}$ & $\mathbf{9 2}$ & $\mathbf{9 3}$ & $\mathbf{9 4}$ & $\mathbf{9 5}$ & $\mathbf{9 6}$ & $\mathbf{9 7}$ & $\mathbf{9 8}$ & $\mathbf{9 9}$ & $\mathbf{0 0}$ & $\mathbf{0 1}$ & $\mathbf{0 2}$ & $\mathbf{0 3}$ & $\mathbf{0 4}$ & $\mathbf{0 5}$ & $\mathbf{0 6}$ & $\mathbf{0 7}$ & $\mathbf{0 8}$ & Total \\
\hline $\begin{array}{l}\text { Violação às normas } \\
\text { escolares }\end{array}$ & & & & & & & & & & & & & & & & & & & \\
\hline $\begin{array}{l}\text { Cancelamento de } \\
\text { matrícula em curso de } \\
\text { língua estrangeira }\end{array}$ & & & & & & & & & & & & & & & & & & & \\
\hline Evasão escolar & & & & & & & & & & 3 & 1 & & & & & & & & \\
\hline Outras & & 2 & & & & & & & 1 & & & 1 & & & & & 1 & 1 & 6 \\
\hline TOTAL & & $\mathbf{2}$ & & & & $\mathbf{4}$ & $\mathbf{6}$ & $\mathbf{4}$ & $\mathbf{3}$ & $\mathbf{6}$ & $\mathbf{1}$ & $\mathbf{2}$ & & & & $\mathbf{2}$ & $\mathbf{4}$ & $\mathbf{2}$ & $\mathbf{3 6}$ \\
\hline
\end{tabular}

Fonte: a autora com base na coleta de decisões julgadas pelo TJSP.

As decisões focadas nas responsabilidades do Estado quanto ao oferecimento de transporte escolar são julgadas a partir de 1999, e representam 2,8\% do total analisado. Já os processos requerendo reparação de danos, tanto morais como materiais, representam 3,7\%, 
sendo localizadas entre os anos de 1995 a 2008. As ações sobre as condições de funcionamento da escola, discutindo a construção de instalações educacionais adequadas e o número máximo de alunos por sala de aula também são pouco significativas no conjunto $(0,6 \%)$. (TABELA 5).

Tabela 5 - Decisões agrupadas por temas envolvendo "Responsabilidade estatal"

\begin{tabular}{l|l|l|l|l|l|l|l|l|l|l|l|l|l|l|l|l|r|r|r}
\hline Responsabilidade estatal & $\mathbf{9 1}$ & $\mathbf{9 2}$ & $\mathbf{9 3}$ & $\mathbf{9 4}$ & $\mathbf{9 5}$ & $\mathbf{9 6}$ & $\mathbf{9 7}$ & $\mathbf{9 8}$ & $\mathbf{9 9}$ & $\mathbf{1 0}$ & $\mathbf{0 1}$ & $\mathbf{0 2}$ & $\mathbf{0 3}$ & $\mathbf{0 4}$ & $\mathbf{0 5}$ & $\mathbf{0 6}$ & $\mathbf{0 7}$ & $\mathbf{0 8}$ & Total \\
\hline Transporte & & & & & & & & & 2 & 4 & 1 & & & 2 & & 2 & 1 & 2 & 14 \\
\hline $\begin{array}{l}\text { Ação de reparação de danos } \\
\begin{array}{l}\text { Condições de funcionamento } \\
\text { das escolas }\end{array}\end{array}$ & & & & 1 & & 1 & 1 & 2 & 1 & & 1 & & & 2 & 3 & 4 & 2 & 18 \\
\hline TOTAL & & & & & & & & & & & & & & & & & & 3 \\
\hline
\end{tabular}

Fonte: a autora com base na coleta de decisões julgadas pelo TJ-SP.

As ações que discutiram o Poder do Estado na regulação das instituições privadas que exercem atividade educacional compõem o segundo maior grupo de análise deste trabalho, com 14\% do total analisado (TABELA 6). Neste grupo, destacam-se as decisões concentradas nas mensalidades escolares das instituições privadas $(9,7 \%)$, que permearam o debate do TJSP sobre a educação na década de 90, assinalando menor incidência nos últimos anos do período analisado. Os processos que questionaram o poder de regulação do Estado, para autorização e credenciamento das instituições privadas, representam 4,3\%.

Tabela 6 - Decisões envolvendo "Poder de regulação estatal" agrupadas por temas

\begin{tabular}{l|r|r|r|r|r|r|r|r|r|r|r|r|r|r|r|r|r|r|r}
\hline TEMAS/ANOS & $\mathbf{9 1}$ & $\mathbf{9 2}$ & $\mathbf{9 3}$ & $\mathbf{9 4}$ & $\mathbf{9 5}$ & $\mathbf{9 6}$ & $\mathbf{9 7}$ & $\mathbf{9 8}$ & $\mathbf{9 9}$ & $\mathbf{0 0}$ & $\mathbf{0 1}$ & $\mathbf{0 2}$ & $\mathbf{0 3}$ & $\mathbf{0 4}$ & $\mathbf{0 5}$ & $\mathbf{0 6}$ & $\mathbf{0 7}$ & $\mathbf{0 8}$ & Total \\
\hline Mensalidade escolar & 4 & 10 & 4 & 2 & 1 & 10 & 5 & 2 & & & & & & & 1 & 1 & 4 & 2 & $\mathbf{4 6}$ \\
\hline $\begin{array}{l}\text { Autorização/ } \\
\text { credenciamento }\end{array}$ & & & & & & & & & & & & & & & & & & & \\
\hline TOTAL & $\mathbf{4}$ & $\mathbf{1 0}$ & $\mathbf{4}$ & $\mathbf{2}$ & $\mathbf{1}$ & $\mathbf{1 2}$ & $\mathbf{6}$ & $\mathbf{2}$ & $\mathbf{2}$ & $\mathbf{3}$ & $\mathbf{3}$ & $\mathbf{0}$ & $\mathbf{0}$ & $\mathbf{1}$ & $\mathbf{1}$ & $\mathbf{2}$ & $\mathbf{1 2}$ & $\mathbf{2}$ & $\mathbf{7 0}$ \\
\hline
\end{tabular}

Fonte: a autora com base na coleta de decisões julgadas pelo TJ-SP.

Dentre as decisões versando sobre deliberações administrativas e políticas (TABELA 7) são enfatizadas as ações propostas pelo Poder Executivo que colocam em questão a competência do Poder Legislativo para legislar sobre determinados assuntos (4,7\%). Houve menor incidência de ações contestando a municipalização, reorganização das escolas estaduais e fechamento das creches no período de férias. 
Tabela 7 - Decisões agrupadas por temas envolvendo "Decisões administrativas e políticas"

\begin{tabular}{|c|c|c|c|c|c|c|c|c|c|c|c|c|c|c|c|c|c|c|c|}
\hline TEMAS/ANOS & 91 & 92 & 93 & 94 & 95 & 96 & 97 & 98 & 99 & 00 & 01 & 02 & 03 & 04 & 05 & 06 & 07 & 08 & Total \\
\hline $\begin{array}{l}\text { Competência para } \\
\text { legislar }\end{array}$ & 1 & & 1 & 2 & & & & & 1 & & & & 6 & 6 & 1 & 1 & 1 & 3 & 23 \\
\hline Municipalização & & & & & & & & & & & & & & & & & 3 & & 3 \\
\hline $\begin{array}{l}\text { Reorganização das } \\
\text { escolas estaduais }\end{array}$ & & & & & & & 1 & & 1 & & & & & & & & & & 2 \\
\hline $\begin{array}{l}\text { Fechamento de creche } \\
\text { no período de férias }\end{array}$ & & & & & & & & & & & & & 1 & & & & & 1 & 2 \\
\hline Outros & & & & & & & & 1 & & 1 & & 2 & & & & 1 & 0 & 1 & 6 \\
\hline TOTAL & 1 & $\mathbf{0}$ & 1 & 2 & $\mathbf{0}$ & $\mathbf{0}$ & 1 & 1 & 1 & 2 & $\mathbf{0}$ & 2 & 7 & 6 & 1 & 2 & 4 & 5 & 36 \\
\hline
\end{tabular}

Fonte: a autora com base na coleta de decisões julgadas pelo TJ-SP.

Os questionamentos sobre a gestão dos recursos públicos correspondem a um pequeno percentual das decisões coletadas $(2,8 \%)$, sendo mais presente os que discutem a forma de aplicação dos recursos vinculados à educação (TABELA 8).

Tabela 8 - Decisões agrupadas por tema envolvendo "Gestão dos recursos públicos"

\begin{tabular}{l|c|c|c|c|c|c|c|c|c|c|c|c|c|c|c|c|c|r|r}
\hline ANOS/ TEMAS & 91 & 92 & 93 & 94 & 95 & 96 & 97 & 98 & 99 & 00 & 01 & 02 & 03 & 04 & 05 & 06 & 07 & 08 & Total \\
\hline $\begin{array}{l}\text { Aplicação dos recursos } \\
\text { MDE }\end{array}$ & & & & 1 & & & & & & & & & & & & & & & \\
\hline Fundef & & & & & & & & & & & & & & & & & & 1 & \\
\hline $\begin{array}{l}\text { Contratos } \\
\begin{array}{l}\text { Repasse de recursos } \\
\text { públicos às instituições } \\
\text { privadas }\end{array}\end{array}$ & & & & & & & & & & & & & & & & & & & \\
\hline TOTAL & & & & & & & & & & & & & & & & & 1 & \\
\hline
\end{tabular}

Fonte: a autora com base na coleta de decisões julgadas pelo TJ-SP.

Do conjunto de decisões investigadas neste trabalho, 2,3\% estão focadas nos deveres dos pais e responsáveis quanto à sua obrigação de matricular e garantir a frequência de seus filhos na escola (TABELA 9).

Tabela 9 - Decisões sobre os deveres dos pais

\begin{tabular}{c|c}
\hline ANO & Quantidade de decisões \\
\hline 1996 & 1 \\
\hline 2001 & 3 \\
\hline 2002 & 1 \\
\hline 2004 & 3 \\
\hline 2006 & 1 \\
\hline 2007 & 2 \\
\hline TOTAL & $\mathbf{1 1}$ \\
\hline
\end{tabular}

Fonte: a autora com base na coleta de decisões julgadas pelo TJ-SP.

A seguir, apresenta-se uma análise das decisões do TJ-SP. O que se visa é, a partir dos objetivos elencados para essa pesquisa, compreender as circunstâncias motivadoras para o 
ingresso da ação judicial, apresentar as posições das diferentes partes envolvidas, identificar os fundamentos para a negativa e a concessão do direito requerido ou questionado, enfatizando, também, a legislação aplicada.

\subsection{Acesso às diferentes etapas e modalidades da educação básica}

Das demandas que abrangem o acesso à educação básica, em suas diferentes etapas e modalidades, os litígios acerca da negação do direito à Educação Infantil (EI) são os mais presentes nos julgados do TJ-SP no período de análise, seguido das demandas por acesso ao Ensino Fundamental (EF).

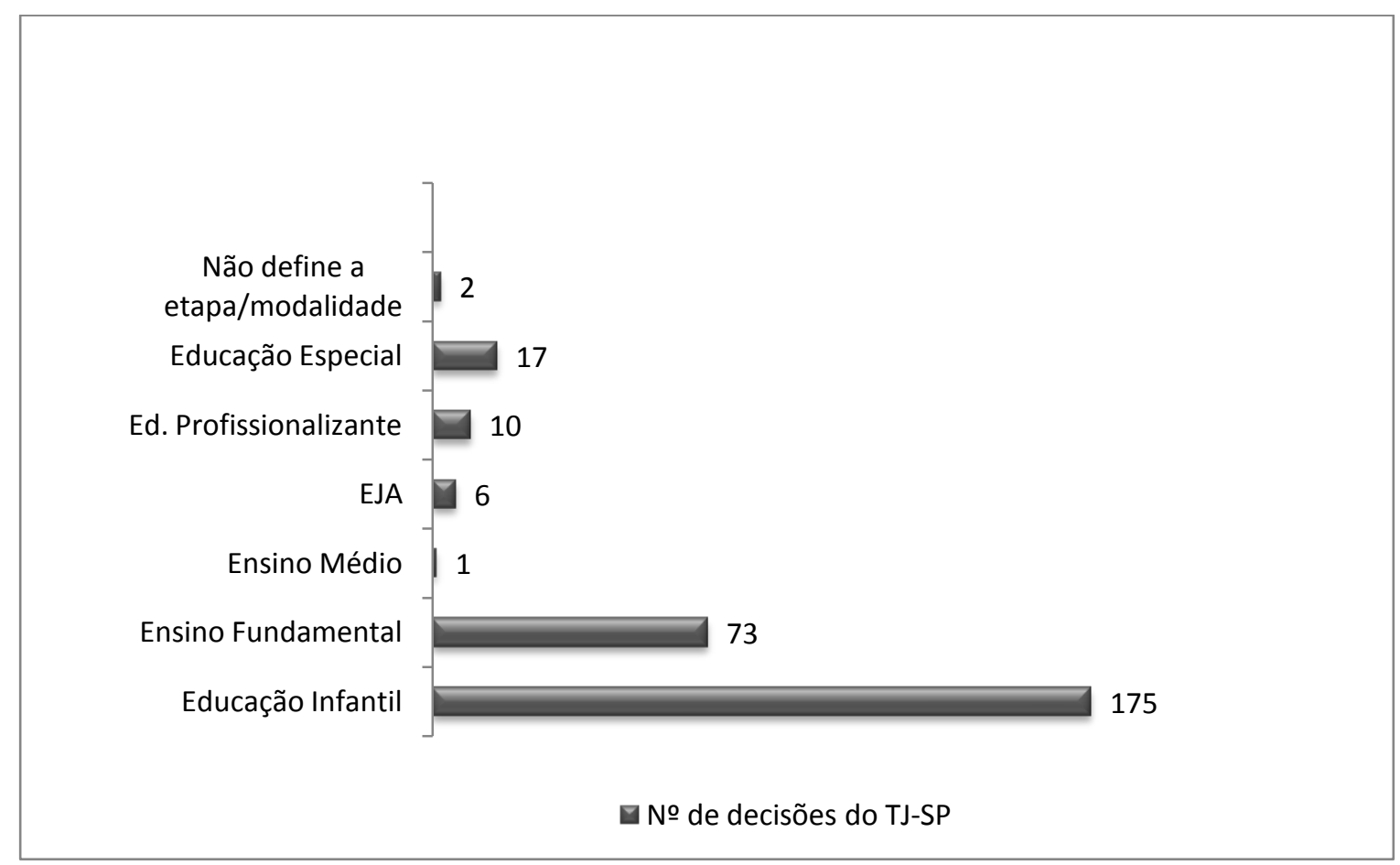

Gráfico 1 - Números de decisões do TJ-SP envolvendo acesso à educação básica Fonte: a autora com base na coleta de decisões julgadas pelo TJ-SP.

O gráfico acima permite observar a pouca incidência de julgados com foco no Ensino Médio (EM). A única decisão localizada ${ }^{53}$ discute o ato da Secretaria da Educação do Estado de São Paulo (SEE), que, sob alegação de adequação ao coeficiente de alunos por sala de aula, transferiu um aluno que iria iniciar o EM para o período noturno. A decisão em primeira

\footnotetext{
${ }^{53}$ Apelação Cível no 50.447-0/0-00, 1999.
} 
instância, como a do TJ-SP, julgou improcedente a medida adotada pela escola, pois fere as normas constitucionais e do ECA sobre o dever do Estado em assegurar ao adolescente o EM.

Essa ação foi julgada em março de 1999, porém, a restrição à matrícula acontecera no ano letivo de 1997. A demora no julgamento do recurso pelo TJ-SP poderia ter contribuído para a violação do direito, se a ação julgada em primeira instância não fosse concedida ao adolescente. Portanto, as ações com pedido liminar de tutela antecipada, para assegurar o direito enquanto o mérito da ação será discutido no decorrer do processo, bem como sua concessão em primeira instância, são fatores importantes para a efetivação do direito, como patenteiam as análises das demais decisões.

\subsubsection{Demandas por vaga em instituições de Educação Infantil ${ }^{54}$}

Conforme estabelecido pela $\mathrm{CF} / 88$, o reconhecimento do direito à EI é um dever do Estado, e reflete um processo de esclarecimento e reconhecimento da importância desse atendimento educacional à primeira infância (CURY, 1998) e, também, pelo aumento das reivindicações de movimentos sociais por instituições educacionais para atendimento dos filhos de mães trabalhadoras (KUHLMANN JR, 2000).

Incorporado como um direito fundamental da criança, e não mais da assistência ou do amparo social, compete prioritariamente aos municípios a sua oferta. Do ponto de vista legal, o direito à EI está contemplado, mas seu atendimento precisa ser ampliado, observando-se que, segundo o último Censo Populacional, apenas $11,6 \%$ das crianças de zero a três anos tinham acesso à creche e 52,1\% das crianças de quatro a seis anos frequentavam pré-escolas, estando muito aquém das metas estabelecidas pelo Plano Nacional de Educação de 2001 (INEP, 2004).

Os dados sobre o atendimento à EI no Estado de São Paulo estão disponíveis no Sistema de Estatísticas Educacionais, do Instituto Nacional de Estudos e Pesquisas Educacionais Anísio Teixeira (Inep), a partir de 1998, contudo, para a vertente creche a informação de 1998 está ausente.

\footnotetext{
${ }^{54}$ Parte desta seção foi apresentada no XXIV Simpósio Brasileiro III Congresso Interamericano de Política e Administração da Educação, realizado pela Anpae, em 2009. Neste trabalho, analisou-se a jurisprudência do TJSP e do Supremo Tribunal Federal sobre a exigibilidade do direito à Educação Infantil (SILVEIRA, 2009 a).
} 
A tabela abaixo possibilita evidenciar a distância entre o atendimento em creche e préescola. Nota-se, também, um crescimento expressivo nas matrículas em creche nos anos de 2003 e 2004, e acentuada queda em 2006, ano em que a pré-escola também tem um decréscimo em suas matrículas, fato que pode ser explicado, no caso da última etapa da EI, pela inserção dos alunos de seis anos no $\mathrm{EF}$, mas não para a creche. $\mathrm{O}$ atendimento em creche retoma a sua expansão a partir de 2008.

Tabela 10 - Matrículas em creches e pré-escolas no estado de São Paulo (1998-2010)

\begin{tabular}{c|c|c|c}
\hline ANO & CRECHE & PRÉ-ESCOLA & TOTAL \\
\hline $\mathbf{1 9 9 8}$ & Informação ausente & 1.054 .578 & 1.142 .316 \\
\hline $\mathbf{1 9 9 9}$ & 236.257 & 1.089 .632 & 1.325 .889 \\
\hline $\mathbf{2 0 0 0}$ & 258.949 & 1.130 .293 & 1.389 .242 \\
\hline $\mathbf{2 0 0 1}$ & 276.316 & 1.206 .641 & 1.482 .957 \\
\hline $\mathbf{2 0 0 2}$ & 298.520 & 1.276 .434 & 1.574 .954 \\
\hline $\mathbf{2 0 0 3}$ & 349.549 & 1.325 .507 & 1.675 .056 \\
\hline $\mathbf{2 0 0 4}$ & 394.857 & 1.391 .238 & 1.786 .095 \\
\hline $\mathbf{2 0 0 5}$ & 407.646 & 1.420 .385 & 1.828 .031 \\
\hline $\mathbf{2 0 0 6}$ & 366.986 & 1.375 .043 & 1.742 .029 \\
\hline $\mathbf{2 0 0 7}$ & 408.328 & 1.233 .016 & 1.641 .344 \\
\hline $\mathbf{2 0 0 8}$ & 485.099 & 1.229 .047 & 1.714 .146 \\
\hline $\mathbf{2 0 0 9}$ & 554.115 & 1.092 .183 & 1.688 .298 \\
\hline $\mathbf{2 0 1 0}$ & 634.975 & 1.054 .021 & \\
\hline
\end{tabular}

Fonte: Inep/ Sistema de Estatísticas Educacionais e Censo Escolar

A creche apresentou um crescimento de $62 \%$ no número de matrículas, entre 1999 e 2010; a pré-escola manteve um crescimento de 23\%, entre os anos de 1999 a 2005, excluindose o período final pela redução ocasionada com a alteração de idade para o ingresso no EF (GRÁFICO 2)

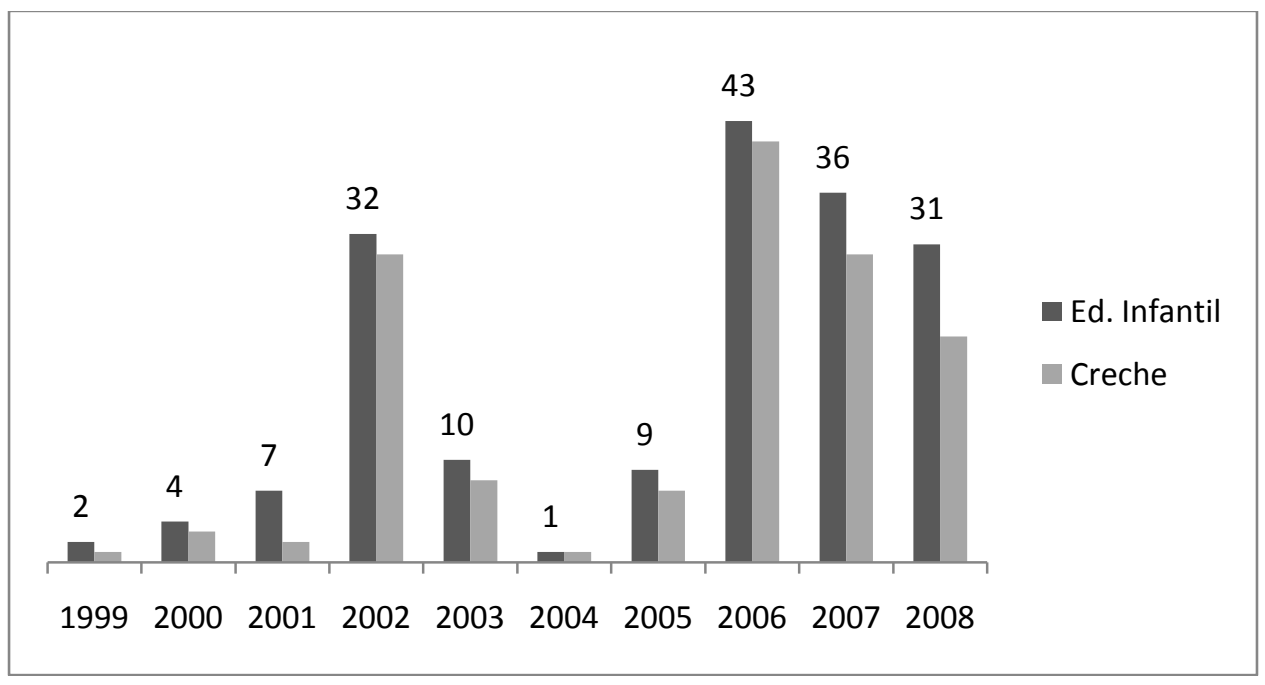

Gráfico 2 - Decisões do TJ-SP objetivando o direito à vaga em EI (1999-2008)

Fonte: a autora com base na coleta de decisões julgadas pelo TJ-SP. 
As decisões do TJ-SP, versando sobre EI, apresentam crescimento nos anos de 2002, 2006-2008. Do total das requisições, 83\% versavam sobre creche.

Nos recursos, os municípios apresentam, de maneira geral, as seguintes alegações para a negativa da concessão da vaga pretendida:

a) Falta de disponibilidade de vagas em suas creches e pré-escolas, não apresentando, portanto, estrutura para atender outras crianças;

b) Inexistência de obrigatoriedade legal no oferecimento de vagas na EI, mas previsão constitucional de organização do ensino;

c) A EI não pode ser considerada como direito público subjetivo, como ocorre com o EF;

d) Não imposição constitucional de universalização da EI, o que foi reforçado pela EC14/96 que vinculou recursos ao EF;

e) As demandas judiciais, visando ao atendimento individual, atentam contra o princípio da isonomia;

f) Continuas decisões judiciais, obrigando o atendimento em instituições de EI, acarretam a superlotação dos estabelecimentos e afetam a qualidade do serviço prestado;

g) Problema orçamentário para ampliação do atendimento em EI;

h) Necessidade de respeitar a existência de dotações orçamentárias prévias e os limites impostos pela Lei de Responsabilidade Fiscal (LRF);

i) Ausência de novos mecanismos de financiamento da EI;

j) EI como norma programática, sendo seu atendimento destinado à "reserva do possível";

k) Indevida ingerência do Judiciário no poder discricionário do Executivo, ao obrigar as matrículas das crianças em creches, contrariando ao princípio da separação de poderes;

1) Ofensa ao princípio da separação de poderes, em virtude de ingerência no direcionamento do dinheiro público;

Inicialmente, cabe destacar que a EI é assegurada na $\mathrm{CF} / 88$ ao especificar e detalhar os deveres do Estado para com a educação (art. 208):

O dever do Estado para com a educação será efetivado mediante a garantia de: [...] 
IV- atendimento em creche e pré-escola às crianças de 0 a 5 anos de idade ${ }^{55}$. (BRASIL, 1988, art. 208).

Com relação ao estabelecimento dos direitos educacionais, o ECA reafirma o que foi estabelecido pela $\mathrm{CF} / 88$, declarando, também, outros direitos complementares, como "acesso à escola pública e gratuita próxima de sua residência” (art. 53, inc. V).

A LDB/96, no que concerne à EI, trouxe importantes inovações, como a introdução do atendimento gratuito em creches e pré-escolas (art. $4^{\circ}$, inc.IV), o seu reconhecimento como primeira etapa da educação básica (art. 29) e a obrigação da integração das creches e préescolas ao sistema de ensino (art. 89).

Também, a LDB/96 definiu a nomenclatura e o estabelecimento de faixa etária para atendimento, dividindo a EI em duas etapas: atendimento em creche (crianças de 0 a 3 anos) e em pré-escolas (4 a $6 \operatorname{anos}^{56}$ ).

Neste contexto, a EI é assegurada como dever do Estado, sendo opção da família a matrícula de seus filhos. Ao contrário do EF, dever do Estado e cuja frequência é obrigatória a todos, pois configura um direito público subjetivo.

Além das determinações constitucionais, da LDB/96 e do ECA a EI também é assegurada na Constituição Estadual paulista e nas Leis Orgânicas municipais. Assim, o acesso à primeira etapa da educação básica não deve ser considerado como norma programática, conforme alegam alguns municípios; antes, trata-se de um direito que deve ser assegurado pelo Poder Público municipal. Posição confirmada em relatório do Desembargador Nogueira Diefenthaler do TJ-SP:

Na dogmática constitucional, a educação não é concebida tão-só como uma diretriz a
ser observada pelos órgãos públicos, orientação abstrata destituída de maiores
repercussões. A educação é prevista como direito social (art. $6^{\circ}$, caput da
Constituição Federal), direito este que alberga um dever de prestação positiva do
Estado, bem como um direito subjetivo dos titulares em exigir seu cumprimento. (APELAÇÃO CÍVEL nº 601.392-5/8-00, 2008, relator Des. Nogueira Diefenthaler).

Reconhecer a educação como direito público subjetivo significa, segundo o posicionamento do desembargador acima citado, poder exigir o seu cumprimento. Posição também defendida pela Desembargadora Maria Olivia Alves, afirmando que os direitos sociais são direitos subjetivos, não são "poderes de agir", mas "poderes de exigir". (APELAÇÃO CÍVEL n ${ }^{\circ}$ 152.802-0/5-00, 2007).

A Desembargadora Maria Olivia Alves, sobre a identificação do direito à EI afirma:

\footnotetext{
${ }^{55}$ Com a Emenda Constitucional (EC) n 53 de 2003, a idade para o atendimento da criança na EI foi alterada para crianças até cinco anos, devido ao ingresso no Ensino Fundamental aos seis anos.

${ }_{56}$ Com a EC n 53 de 2006, o atendimento a EI é alterado para até cinco anos, devido à antecipação do ingresso do EF aos seis anos.
} 
[...] as crianças de zero a seis anos têm garantido, por expressa disposição constitucional, o direito, não em tese, não imaginário, não meramente ideal, mas concreto, efetivo, de atendimento em creche e pré-escola.

Nada mais é necessário se dizer que um tal direito seja exercido. Nenhuma outra lei ou qualquer medida legislativa é necessária para a exeqüibilidade dessa prestação. Está claramente identificada a pessoa obrigada à prestação. Está também precisamente identificado, da mesma forma com singular clareza, o objeto dessa prestação social. [...] É direito líquido e certo. (APELAÇÃO CÍVEL nº 152.802-0/500, 2007).

Destaca-se, também, a posição do Desembargador Sidnei Beneti, com relação ao reconhecimento do direito líquido e certo à EI:

Analisando o caso concreto dentro deste contexto, seria inconcebível, após reconhecer o direito líquido e certo das crianças à educação infantil, negar-lhes tutela jurisdicional satisfativa sob o fundamento, equivocado, de que isto representaria violação do princípio da independência dos Poderes. Pensamento diverso conduziria à negação da própria atividade jurisdicional. (APELAÇÃO CÍVEL nº 142. 040-0/9-00, 2007).

Esta posição, favorável ao reconhecimento da exigibilidade do direito à vaga em instituições de EI, não foi sempre consenso entre os desembargadores do TJ-SP (TABELA 11). Alguns reconhecem que a legislação determina que os municípios sejam responsáveis pelo oferecimento da EI, todavia afirmam que:

[...] a conveniência e a oportunidade de realizar atos físicos de administração (obras e contratações, por exemplo), cabe, com exclusividade, ao Poder Executivo, não sendo possível ao Poder Judiciário, sob o argumento de estar protegendo direitos coletivos, ordenar que tais atos sejam efetivados. (EMBARGOS INFRINGENTES $\mathrm{n}^{\circ}$ 70.903.0/2-2-02, 2002, relator Des. Mohamed Amaro).

Tabela 11 - Resultados das votações do TJ-SP: decisões unânimes e por maioria

\begin{tabular}{c|c|c|c}
\hline ANO & $\begin{array}{c}\text { Total de } \\
\text { decisões }\end{array}$ & $\begin{array}{c}\text { \% } \\
\text { unânimes }\end{array}$ & $\begin{array}{c}\text { \% } \\
\text { maioria }\end{array}$ \\
\hline 1999 & $2^{*}$ & 50 & - \\
\hline 2000 & $4^{*}$ & 75 & - \\
\hline 2001 & 7 & 85,7 & 14,3 \\
\hline 2002 & 32 & 62,5 & 37,5 \\
\hline 2003 & 10 & 40,0 & 60 \\
\hline 2004 & 1 & 100,0 & 0 \\
\hline 2005 & 9 & 66,7 & 33,3 \\
\hline 2006 & 43 & 100,0 & 0 \\
\hline 2007 & 36 & 88,9 & 11,1 \\
\hline 2008 & 31 & 100,0 & 0 \\
\hline TOTAL & $\mathbf{1 7 5}$ & $\mathbf{8 3 , 9}$ & $\mathbf{1 4 , 9}$ \\
\hline
\end{tabular}

Fonte: a autora com base na coleta de decisões julgadas pelo TJ-SP.

Obs.:*A informação sobre o resultado da votação está ausente. 
Decisões com esse tipo de voto são manifestadas, principalmente, na Câmara Especial, que julgou 95 das 175 decisões de EI analisadas no âmbito deste trabalho ${ }^{57}$. Nos casos em que o recurso contestava a concessão, ou requisitava a reforma de decisão de primeira instância que negou o direito à vaga em creche ou pré-escola, votaram contra esse direito, ensejando que não seria possível ao Poder Judiciário interferir em poder discricionário do Executivo, principalmente os Desembargadores Mohamed Amaro, Luís Macedo e Vallim Bellocchi.

A partir de 2004, as decisões do TJ-SP são mais unânimes. As divergências dos anos de 2005 e 2007 são apresentadas por um desembargador (Marco César) nos recursos que concedem liminares. Entretanto, este desembargador não manifesta seu voto contrário.

Com base nos julgamentos anteriores, e levando-se em conta a composição dos desembargadores nas Câmaras, torna-se possível prever com certa segurança o padrão de decisão deste tipo de demanda. Observou-se que, nos últimos anos, os Desembargadores que apresentavam votos contrários não estavam na composição da Câmara Especial (QUADRO 4).

A falta de consenso entre os desembargadores nas decisões gerou dezenas de Embargos Infringentes, apoiados em voto minoritário divergente. Alguns desses recursos foram apresentados pelo Ministério Público (MP) contra os acórdãos do TJ-SP que alteraram sentença de ação civil pública que compelia o município de Santo André a providenciar a vaga em creches e pré-escolas.

Em pesquisa realizada no sítio eletrônico do STF, sobre as decisões envolvendo a EI, foram localizados 51 julgados, englobando acórdãos e decisões monocráticas, entre 2003 e 2008. Dessas decisões, somente duas não são de municípios paulistas: uma Petição do município do Rio de Janeiro, de 2003; e um Recurso Extraordinário de Criciúma, Santa Catarina, de 2008. Com base nesses dados, são elaboradas algumas hipóteses: se o problema da falta de vagas em creches e pré-escolas é um problema paulista; se os municípios recorrem mais ao Poder Judiciário na tentativa de bloquear a demanda, em contexto de oferta insuficiente; ou, ainda, se o acesso à justiça é mais requerido em São Paulo. Dos municípios paulistas, Santo André detém o recorde absoluto de recursos ao STF. Em uma decisão, o Ministro Cezar Peluso questiona o uso excessivo de recursos quando da existência de jurisprudências dominantes no STF. (SILVEIRA, 2009a).

As decisões proferidas pelo STF sobre os recursos do TJ-SP contribuem para um posicionamento favorável à exigibilidade do direito à EI, principalmente a do Ministro Celso

\footnotetext{
${ }^{57}$ Os demais recursos sobre EI foram julgados pela Sessão Plenária (53 decisões), Câmaras de Direito Público (25 decisões) e em duas a informação estava ausente.
} 
de Melo ${ }^{58}$, ao definir que a EI representa "prerrogativa constitucional indisponível" e seu processo de concretização não se expõe "a avaliações meramente discricionárias da Administração Pública, nem se subordina a razões de puro pragmatismo governamental”.

As decisões do STF foram unânimes em afirmar a não inconstitucionalidade das decisões dos Tribunais inferiores, exceto uma ação do Rio de Janeiro ${ }^{59}$ sobre a construção de creche para atendimento de toda a demanda ${ }^{60}$. As decisões contestando a inconstitucionalidade de sentença que determinava a matrícula de criança em creche municipal próxima à sua residência foram favoráveis para o não seguimento do recurso, ou para restabelecer a decisão da $1^{\mathrm{a}}$ instância.

Sobre a requisição de tutela a direitos individuais, os Tribunais foram mais favoráveis em reconhecer este direito como líquido e certo ${ }^{61}$. No entanto, as demandas envolvendo a construção de estabelecimentos para atendimento de toda a demanda (como no caso do recurso do Rio de Janeiro, no STF) ou para um número não delimitado de crianças, interesses transindividuais (difusos e coletivos) as decisões são mais divergentes, observando-se a ausência de uma jurisprudência consolidada.

Na Apelação Cível 63.951-0/0-00, de 2001, o MP propôs ação civil pública pretendendo que o município de Campinas fosse compelido a abrir 9.500 vagas. O TJ-SP, em análise do recurso, decidiu favoravelmente ao pedido do MP, relator Desembargador Nigro Conceição. Já na Apelação Cível 68.863-0/5-00, de 2001, o MP ingressou, também, com ação civil pública contra o Município de São Paulo, visando obter a prestação de serviços em creche para as crianças cujos pais desejarem e o pagamento de mensalidade em unidade particular aos alunos que não obtivessem vaga na rede própria ou indireta. O TJ-SP considerou a ausência de dados concretos a respeito do não atendimento e a inviabilidade de rápida implementação:

[...] pedido de condenação genérica sem que se tenha comprovado o descumprimento pelo Município de sua obrigação quanto ao fornecimento de creche de forma objetiva, ou seja, com apoio em estatística ou relação de interessados que

\footnotetext{
${ }^{58}$ Recurso Extraordinário no 436996, 2005, de Santo André - SP.

${ }^{59}$ Questão de Ordem em Petição, no 2.836-8, de 2003.

${ }^{60}$ Esse recurso será analisado na abordagem do problema financeiro para o atendimento das decisões judiciais.

${ }^{61}$ De acordo com a posição de Hely Lopes Meirelles, direito líquido e certo "é o que se apresenta manifesto na sua existência, delimitado na sua extensão e apto a ser exercido no momento da impetração. Por outras palavras, o direito invocado, para ser amparável por mandado de segurança, há de vir expresso em norma legal e trazer em si todos os requisitos e condições de sua aplicação ao impetrante: se a sua existência for duvidosa; se a sua extensão ainda não estiver delimitada; se o seu exercício depender de situações e fatos ainda indeterminados, não rende ensejo à segurança, embora possa ser defendido por outros meios judiciais. [...] Em última análise, direito líquido e certo é direito comprovado de plano. Se depender de comprovação posterior não é líquido nem certo, para fins de mandado de segurança." (1989, p. 13, nota apud ACQUAVIVA, 1995, p. 539).
} 
não houvessem sido atendidos. (APELAÇÃO CÍVEL nº 68.863-0/5-00, 2001, relator Des. Álvaro Lazzarini).

Neste caso, o recurso do MP não é atendido, por não haver comprovação da negligência ou do descaso na prestação do serviço público. Semelhante decisão foi proferida na Apelação Cível n ${ }^{\circ}$ 70.869-0/2-00, de 2001, “sendo o pedido genérico, não havendo assertivas quanto à existência de crianças que não estão sendo atendidas e indicação do número de vagas que deveriam ser criadas", relator Desembargador Álvaro Lazzarini. Posições diferentes da ação relativa ao município de Campinas, que talvez tenha realizado uma prévia prospecção para identificar o déficit de vagas, ou o processo foi julgado por desembargadores favoráveis ao pedido.

Em outra Apelação Cível, do município de São Paulo, o TJ-SP, em maioria dos votos, proferiu contrariamente à decisão de primeira instância, julgando extinto o processo sem apreciação do mérito, considerando o pedido inicial "inepto e juridicamente impossível: “Cumpre ao Poder Judiciário, por função típica, dizer o direito, assinando, se o caso, norma de conduta individual, concreta, daí porque o pedido há de ser certo, em sua extensão, e determinado quanto ao seu objeto." (APELAÇÃO CÍVEL no 81.514-0/9-00, relator Des. Luiz Tâmbara).

Em voto divergente, o desembargador Gentil Leite declara que seria inconsistente o argumento do relator, pois "uma vez tratando-se de ação civil pública, a não determinação do pedido é corolário lógico da pretensão que visa proteger interesses difusos, ou seja, de um grupo indeterminado de pessoas, pelo que não é possível precisar-se desde logo o seu número". (APELAÇÃO CÍVEL nº 81.514-0/9-00, 2001).

Em pedido de ação cível pública para ampliação da rede de ensino, na região da Capela do Socorro - São Paulo ${ }^{62}$, com a construção de escolas, obedecendo à capacidade máxima de 35 alunos por sala de aula, o TJ-SP relator Desembargador Barreto Fonseca, julgou o pedido e favoreceu ao MP, discorrendo que a ação coletiva contém pedido certo e determinado, não importando o número definido de crianças e adolescentes beneficiados.

Em decisões que votam favoravelmente ao município, o Desembargador Roberto Solimene reconhece que os municípios devem oferecer EI, "todavia a conveniência e a oportunidade de realizar atos físicos de administração (obras, contratações, por exemplo), cabe com exclusividade ao Poder Executivo, não sendo possível ao Poder Judiciário, sob o

\footnotetext{
${ }^{62}$ Apelação Cível n 161.717-0/8-00, 2008.
} 
argumento de estar protegendo direitos coletivos, ordenar que tais atos sejam efetivados". (RECURSO EX OFFICIO n $\left.{ }^{\circ} 117.872-0 / 7-00,2005\right)$.

Os recursos judiciais com demandas cujo objeto são interesses difusos e coletivos têm fundamento para a negativa sob a alegação de que contém pedidos genéricos e indeterminados, não sendo possível a interferência do Judiciário no planejamento municipal, ou seja, na condução das políticas públicas e na questão orçamentária. Por outro lado, observando as votações do TJ-SP nos últimos anos, as solicitações englobando direitos individuais ou com o número preciso de vagas foram concedidas com maior consenso (TABELA 12).

Tabela 12 - Decisões sobre acesso Educação Infantil envolvendo demandas individuais, difusas e coletivas

\begin{tabular}{|r|r|r|r|r|r|}
\hline Ano & $\begin{array}{c}\text { Total de } \\
\text { decisões }\end{array}$ & $\begin{array}{c}\text { Demandas } \\
\text { individuais }\end{array}$ & $\begin{array}{c}\text { \% de decisões } \\
\text { favoráveis à } \\
\text { concessão do } \\
\text { direito à vaga }\end{array}$ & Transindividuais $^{\mathbf{6 3}}$ & $\begin{array}{c}\text { \% de decisões } \\
\text { favoráveis as } \\
\text { alegações dos } \\
\text { municípios }\end{array}$ \\
\hline 1999 & 2 & 2 & 100 & & \\
\hline 2000 & 4 & 4 & 50 & 4 & 75 \\
\hline 2001 & 7 & 3 & 100 & 2 & 50 \\
\hline 2002 & 32 & 24 & 62 & 2 & 100 \\
\hline 2003 & 10 & 6 & 100 & 1 & 100 \\
\hline 2004 & 1 & 1 & 25 & 2 & 50 \\
\hline 2005 & 9 & 8 & 100 & 1 & 0 \\
\hline 2006 & 43 & 41 & 100 & 1 & 0 \\
\hline 2007 & 36 & 36 & 100 & 13 & \\
\hline 2008 & 31 & 24 & & & \\
\hline
\end{tabular}

Fonte: a autora com base na coleta de decisões julgadas pelo TJ-SP.

Obs.: Em algumas decisões essas informações não estavam disponíveis, por isso os valores não correspondem à totalidade.

Os municípios também argumentam que a EI não estaria em primeiro plano para o atendimento, sendo obrigados a prestar atendimento prioritário ao EF. Sobre este argumento, os desembargadores favoráveis a considerar o município como obrigado a atender a demanda em creche e pré-escola contrapõem que a EC-14/96 é explícita quanto à responsabilidade do município em atender prioritariamente o EF e a EI (BRASIL, 1988, art.211,§2º).

Sobre os pedidos de matrícula em escola particular, as decisões que trataram desta demanda afastaram a condenação do município, pois a contratação deste tipo de serviço está vinculada às normas de direito público, acarretando riscos às finanças públicas.

\footnotetext{
${ }^{63}$ Nas demandas transindividuais estão computadas as que estão relacionadas às demandas que exigiam a construção de creches e pré-escolas, vagas para atendimento de demanda de alguns bairros/regiões. As ações que requisitam vagas para um número definido de crianças foram computadas em individual.
} 
Como a oferta é inferior à demanda, os municípios inscrevem as crianças que pretendem vaga em "listas de espera", "lista de inscrição", de acordo com critérios estabelecidos pela administração, devendo aguardar desistência ou ampliação do atendimento. Os municípios, nos recursos judiciais, alegaram que os pedidos individuais para assegurar vaga implicariam em violação do direito daqueles que estão na lista de espera, pois anularia o princípio da igualdade. E os desembargadores do TJ-SP, favoráveis à concessão da vaga, argumentaram, evocando o princípio da isonomia, que a possibilidade de ingresso em creche é um direito previsto não apenas para as crianças que procuram o Judiciário, mas também pelas demais. O Desembargador Celso Bonilha justifica que "o exercício desse princípio não pode derivar em tal raciocínio, pois se equiparou de forma indevida o necessitado ao seu igual, quando haveria de se equipará-lo aos demais infantes que já obtiveram a vaga junto à creche ou pré-escola". (APELAÇÃO CÍVEL n 345.816.5/0, 2004). O Desembargador destaca, ainda, que a CF/88 assegura igualdade de condições para o acesso e permanência na escola (art. 206, inc. I).

Entre as alegações municipais para a negativa do direito à concessão da vaga requerida judicialmente, o município de Santo André ${ }^{64}$ argumentou que as inúmeras concessões judiciais, exigindo o cumprimento desse dever, vêm acarretando a superlotação dos estabelecimentos, tendo como consequência o declínio da qualidade do serviço prestado.

Esta contestação precisa ser considerada, pois ao atenderem aos pedidos individuais as instituições existentes recebem mais alunos, e se o número de profissionais e a ampliação dos espaços não forem alterados a inclusão de novos alunos poderá ocasionar prejuízo do atendimento de todas as crianças.

Por outro lado, se os municípios não expandem sua oferta, não é possível deixar as crianças que precisam desse atendimento esperando as iniciativas da administração municipal. É preciso pensar, talvez, na exigibilidade de ações para que os municípios construam mais escolas e destinem mais recursos nos orçamentos públicos para essa etapa da educação básica.

Uma das principais alegações para a não concessão da vaga refere-se à falta de recursos financeiros para a expansão do atendimento em EI. Os municípios também apontam as dificuldades impostas pela legislação fiscal. Justificam que obedecem aos preceitos da

\footnotetext{
${ }^{64}$ Do total das decisões analisadas (175) no âmbito deste trabalho, 84 versam sobre o município de Santo André. No período que constam decisões no TJ-SP, envolvendo EI, requisições para vagas em EI nesta localidade, o executivo era administrado pelo Partido dos Trabalhadores nas gestões de 1996-2000, 2000-2004, 2004-2008.
} 
LRF, e que esta lei limita despesas com pessoal $^{65}$ e, portanto, a ampliação depende da contratação de mais funcionários, o que, em muitos casos, não seria viável.

Em alguns litígios, o prazo para o cumprimento da decisão judicial gera uma impossibilidade material. Determinada ação, por exemplo, estipulou prazo de cinco dias para que o município matriculasse 300 crianças. Para isso, seria preciso, de acordo com a municipalidade, incluir a construção de creches no Plano Plurianual, na Lei de Diretrizes Orçamentárias e na Lei Orçamentária Anual. Além do planejamento municipal, deve-se considerar a necessidade de licitação para a construção, fato que não seria solucionado em tempo tão curto. Essas constatações precisam ser analisadas, pois em muitas situações os municípios estão optando por estabelecer parcerias com entidades privadas (comunitárias, filantrópicas e escolas privadas stricto sensu) para realizar esse atendimento, deixando de expandir a rede oficial de ensino (ADRIÃO, GARCIA, BORGHI, ARELARO, 2009a; DOMICIANO, 2009; MIZUKI, SILVEIRA, 2009).

Com relação aos entraves legais para o cumprimento das decisões, a Desembargadora Teresa Ramos Marques explana que "situações de urgência legitimam medidas urgentes" (AGRAVO DE INSTRUMENTO $\mathrm{n}^{\circ}$ 711.901.5/1-01, 2008). De acordo com o Desembargador Álvaro Lazzarini, o argumento da limitação orçamentária para a não abertura de novas creches dependeria da "comprovação de o Administrador Municipal ter esgotado as verbas orçamentárias específicas destinadas a esse direito fundamental" (APELAÇÃO CÍVEL 70.606-0, 2001).

[...] a alegação de falta de previsão orçamentária específica para suportar tais despesas não pode servir de escudo à pessoa política, de sorte a possibilitar o descumprimento reiterado dos deveres prioritários que lhe são impostos pelo ordenamento jurídico. Em outras palavras, a satisfação do comando imposto pela tutela jurisdicional deve ser viabilizado com base nas receitas específicas já previstas no orçamento ou, se o caso, com base em créditos adicionais obtidos com a necessária autorização legislativa. (EMBARGOS INFRINGENTES nº 82.467-0/201, 2002, Des. Borelli Machado).

O Desembargador Nogueira Diefenthaler, em recurso do Município de Roseira, argumentou não ser possível impor aos órgãos públicos a obrigação de fazer que importe gastos sem que haja rubrica própria para atender à determinação, uma vez que o município alegava que o Poder Judiciário não poderia se imiscuir em questões de orçamentos. Eis o voto:

\footnotetext{
${ }^{65}$ A LRF, Lei Complementar $\mathrm{n}^{\circ}$ 101, de 4 de maio de 2000, prevê limites das despesas totais com pessoal para cada ente da federação. No caso dos municípios, 54\% para o Executivo e 6\% para o Legislativo, incluindo o Tribunal de Contas do Município, quando houver.
} 
[...] Logicamente que o Poder Judiciário não poderia determinar prestações impossíveis, ou até mesmo compelir a Administração a remanejar aportes financeiros de setores igualmente essenciais, como, v.g., a saúde. Tal discussão traz à tona o que a doutrina constitucional denomina de cláusula da reserva do possível, expediente limitador (desde que inserido nas esferas da proporcionalidade de razoabilidade) do cumprimento destes direitos de segunda geração. (APELAÇÃO CÍVEL nº 601.392-5/8-00, 12.05.2008, rel. Des. Nogueira Diefenthaler).

Ainda:

A alegação de falta de disponibilidade financeira, todavia, não pode implicar numa "negação de qualquer tipo de obrigação a ser cumprida na base dos Direitos Fundamentais Sociais", pois, exegese desta natureza "tem como conseqüência a renúncia de reconhecê-los como verdadeiros direitos". [...]

Daí que as alegações de inexistência de disponibilidade orçamentária, formuladas de maneira genérica, destituídas de maior respaldo probatório, suscitadas de maneira até mesmo irresponsável, não se constituem em motivação hábil a elidir, suprimir e negativar direito de tão grande magnitude. (APELAÇÃO CÍVEL nº 601.392-5/8-00, 12.05.2008, rel. Des. Nogueira Diefenthaler, grifos no original).

Este recurso do município de Roseira traz em sua decisão uma solução diferente das demais. O Desembargador Nogueira Diefenthaler, relator do processo, ratifica que não se pode deixar de considerar a "regra constitucional que veda o início de programas ou projetos não incluídos em lei orçamentária (art. 167, inciso I da CF/88), de forma que provimento jurisdicional não pode determinar, sem a adoção desta providência preliminar, a instalação de creches e pré-escolas". E, com base em decisão do STF, que aceitou a validez da questão orçamentária, suspendeu o cumprimento de decisão que obrigava o município à construção de creches para atender $100 \%$ da demanda dos bairros citados, no prazo de um ano. Nesse caso, levando em conta a probabilidade de graves prejuízos aos cofres públicos municipais ${ }^{66}$, o Desembargador votou para que o município fosse condenado a incluir as verbas necessárias à instalação das creches, no projeto de lei orçamentária.

Tal decisão pode ser uma das medidas para solucionar a problemática da exigência de construção de novas unidades, se preocupando em respeitar as imposições da legislação fiscal, mas obrigando o município a expandir o atendimento através da readequação do orçamento.

Alguns desembargadores defenderam o indeferimento de solicitações que obrigavam o município a oferecer as vagas na EI, pois consistiria indevida intromissão do Judiciário no Executivo. Justamente este ponto, como já reiterado, é a principal divergência entre os desembargadores. O município de Paulínia alegou que a interferência do Judiciário coloca em risco todo o planejamento municipal, afetando os interesses coletivos para atender individuais ${ }^{67}$.

\footnotetext{
${ }^{66}$ Questão de Ordem em Petição, no $2.836-8$, Rio de Janeiro.

${ }^{67}$ Apelação Cível 595.356.5/8-00, 2007.
} 
Segundo alguns desembargadores, com relação ao oferecimento da educação, o Estado não tem discricionariedade, pois está vinculado à norma constitucional e às normas infraconstitucionais, e estas legislações impõem obrigações. "Há discricionariedade, é certo, mas apenas quanto à forma de satisfazer essa obrigação". (APELAÇÃO CÍVEL nº 127.6590/3-00, 20.02.2006, rel. Des. Maria Olivia Alves).

O poder discricionário do município é compreendido pela forma como o chefe do executivo irá atender à determinação legal, decidindo-se pela construção de novas unidades, ampliação das existentes ou, ainda, firmando convênios com estabelecimentos privados. Desse modo, segundo o Ministro do STF, Sepúlveda Pertence, o poder discricionário, "não se confunde com a autorização para descumprir a lei" (AGRAVO DE INSTRUMENTO no 509.347).

Sobre a factibilidade ou não da intervenção do Judiciário na Administração Pública a resposta dos desembargadores é clara: “[...] simples exercício de sua missão constitucional de fazer cumprir e respeitar as normas legais em vigor". (AGRAVO DE INSTRUMENTO n ${ }^{\circ}$ 74.654-0, 21.09.2000, rel. Des. Gentil Leite). Ao Judiciário cabe atuar para que o município cumpra com seus deveres, garantindo a harmonia entre os poderes, funcionamento como um sistema de freios e contrapesos ${ }^{68}$.

Posição também sustentada pelo Ministro Celso de Mello:

Embora inquestionável que resida, primariamente, nos Poderes Legislativo e
Executivo, a prerrogativa de formular e executar políticas públicas, revela-se
possível, no entanto, ao Poder Judiciário, ainda que em bases excepcionais,
determinar, especialmente nas hipóteses de políticas públicas definidas pela própria
Constituição, sejam estas implementadas, sempre que os órgãos estatais
competentes, por descumprirem os encargos político-jurídicos que sobre eles
incidem em caráter mandatório, vierem a comprometer, com a sua omissão, a
eficácia e a integridade de direitos sociais e culturais impregnados de estatura
constitucional. (RECURSO EXTRAORDINÁRIO 410.715-5, 22.11.2005).

Esta decisão é citada em vários recursos do TJ-SP sendo uma referência para a concessão do direito à vaga em creche e pré-escola.

\footnotetext{
${ }^{68}$ Apelação Cível 146.315-0/3-00, 04.07.2007, rel. Des. Roberto Vallim Bellocchi.
} 


\subsubsection{Demandas por acesso ao Ensino Fundamental}

Do conjunto de decisões analisadas no âmbito deste trabalho, as demandas por acesso ao EF correspondem a 14,8\% dos julgados, perfazendo o segundo maior número de decisões. As decisões estão concentradas nos anos de 1996-2002, tendo sido localizadas apenas duas em anos posteriores (GRÁFICO 3).

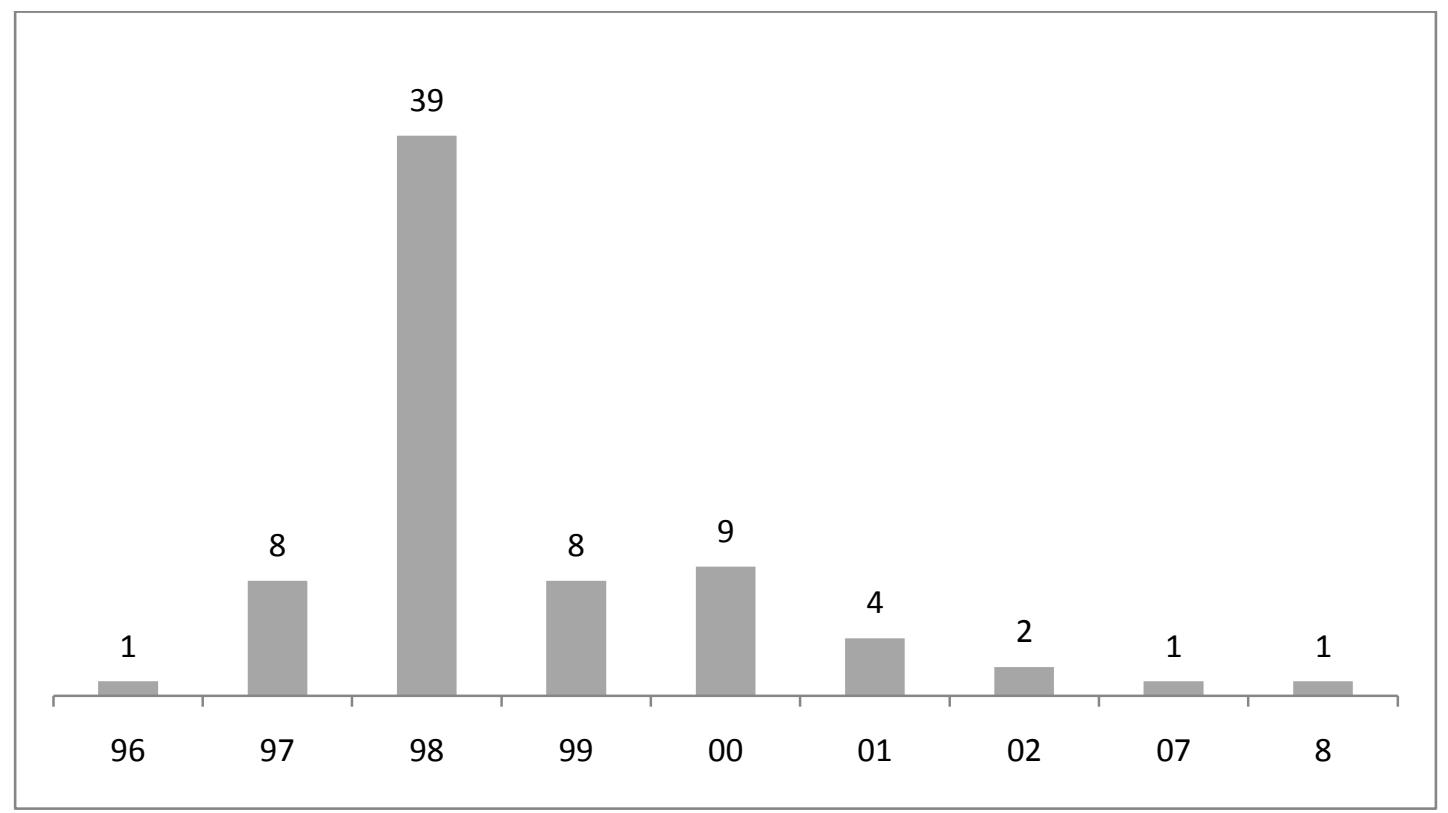

Gráfico 3 - Demandas por acesso ao EF

Fonte: a autora com base na coleta de decisões julgadas pelo TJ-SP.

Os litígios acerca do acesso ao EF podem ser agrupados segundo duas problemáticas: restrição do ingresso de alunos com sete anos incompletos ao EF e matrícula em escola próxima à residência dos alunos.

\subsubsection{Restrição à matrícula de crianças com sete anos incompletos}

Do total das demandas por acesso ao EF (73 decisões), 64 estão diretamente relacionadas a duas Resoluções da Secretaria da Educação Estadual (SEE), dos anos de 1996 e 1997, que estabeleciam como exigência para a matrícula na $1^{a}$ série do EF que a criança tivesse sete anos completos ou a completar até determinada data do ano letivo. Essas ações são julgadas pelo TJ-SP, entre os anos de 1997 a 2002. 
A Resolução da SEE no 169, de 20 de novembro de 1996, dispõe sobre as diretrizes para a continuidade do Programa de Reorganização da Rede Estadual de Ensino e no art. 18, inciso I, estabelece como exigência de matrícula:

I - para o Ciclo Básico, ter 7 (sete) anos completos ou a completar até 28 de fevereiro de 1.997, apresentando Certidão de Nascimento ou, na inexistência deste documento, declaração do pai ou responsável.

II $-[\ldots]$

$\S 1^{\circ}$ - Excepcionalmente, onde houver disponibilidade de vagas, as unidades escolares poderão abrir inscrição para o Ciclo Básico de alunos que vierem a completar 7 (sete) anos até 30/06/97 [...]. (SÃO PAULO, SEE, 1996).

A Resolução $\mathrm{n}^{\circ}$ 164, de 25 de novembro de 1997, dispõe sobre as diretrizes para o atendimento à demanda na rede estadual de ensino, em 1998, e mantém as mesmas exigências da Resolução anterior para a matrícula do aluno ingressante ao EF.

Essas Resoluções provocaram uma avalanche de processos judiciais, requerendo o direito à educação. Como exemplo, em 1997, a Promotoria de Justiça da Infância e Juventude de Ribeirão Preto impetrou 300 mandados de segurança, aproximadamente, contra o Estado, conseguindo que as crianças fossem matriculadas no EF (SILVEIRA, 2006).

Observe-se que não foi franqueado o acesso a todos os acórdãos dessas decisões, pois muitas estavam em segredo de justiça (36 no total) e disponibilizavam apenas as ementas, e algumas delas não continham informações suficientes para prover análise pormenorizada. Ainda assim, pôde-se inferir que as ações requisitando o direito individual à educação, para crianças com seis anos, foram julgadas a favor das crianças, concedendo-se liminares para garantir a frequência à escola.

Já a ação que postulava possibilidade de matrícula de todas as crianças que completassem sete anos de idade no decorrer do ano ${ }^{69}$, e a ação civil pública visando a compelir a SEE de abster-se de editar norma administrativa proibindo a matrícula de crianças com sete anos incompletos ${ }^{70}$ foram julgadas improcedentes pelo $\mathrm{TJ}-\mathrm{SP}$, pois não seria possível impor a obrigação de garantia de vagas no Ensino Fundamental a todas as crianças com sete anos incompletos, considerando o acesso deste grupo desde que atendida a demanda dos que já possuam a idade completa.

O argumento da Fazenda Pública do Estado de SP, nos recursos ao TJ-SP, está fundamentado na discussão de que a Resolução da SEE apenas regulamenta a matéria constitucional, não ferindo direito líquido e certo dos alunos.

\footnotetext{
${ }^{69}$ Apelação Cível no 41.630.0/5-0, 1998.

${ }^{70}$ Apelação Cível nº 64.281-0/0-00, 2001.
} 
Segundo o apelo da Fazenda do Estado de São Paulo, a LDB/96 e a Resolução Estadual da Secretaria de Educação no 169/96 são expressas no que se refere à obrigatoriedade do EF somente às crianças que já tenham atingido sete anos, e facultativamente às crianças que ainda tenham seis anos de idade. Portanto, não haveria obrigatoriedade destas matrículas. $\mathrm{O}$ apelo dispôs, também, que a própria $\mathrm{CF} / 88$ garante o atendimento das crianças com seis anos em estabelecimentos de pré-escola ${ }^{71}$. Ainda, alegou que haveria risco de grave lesão à ordem pública, na hipótese de procedência de ação, haja vista a impossibilidade dos estabelecimentos de ensino acolher toda a demanda. E a procedência da ação ocasionaria violação ao princípio da independência e harmonia de poderes.

A citação a seguir relata essa fundamentação:

[...] a Secretaria teve de adotar tal posicionamento, pois, caso contrário, se colocasse todas as vagas à disposição de todos os candidatos, sem qualquer critério de atendimento, correria o risco de subverter a ordem constitucional, uma vez que, independentemente de terem ou não sete anos completos, todos seriam matriculados, correndo-se o risco de se ver os mais novos ocupando as vagas daqueles de sete anos. (APELAÇÃO CÍVEL nº 46.784-5/1, 1998)

Ainda:

[...] a atividade de organização dos serviços públicos educacionais inserem-se no rol daquelas competências do Executivo que, na qualidade de administrador público, dispõe de certa margem de discricionariedade na definição de diretrizes, de prioridades das ações e na escolha dos meios necessários ao cumprimento de sua missão. (APELAÇÃO CÍVEL no 46.784-5/1, 1998).

Para os desembargadores do TJ-SP, a determinação da SEE fere direito líquido e certo das crianças. Esta posição foi unânime entre os desembargadores, em 42 recursos. Em quantidade considerável de processos (18), essa informação estava ausente; em dois recursos, a aprovação foi por maioria dos votos e em outros dois foi rejeitado parcialmente o pedido.

A fundamentação legal para a concessão deste direito é semelhante entre os desembargadores. Para eles, a Resolução é inconstitucional, pois a CF/88, ao definir no artigo 208, inciso I, a garantia do EF obrigatório e gratuito, não estabelece qual seria a idade própria. Presume-se que seria a partir dos sete anos, uma vez que no inciso IV deste mesmo artigo prevê a garantia de atendimento em creche e pré-escola às crianças de zero a seis anos de idade. O ECA também não dispõe sobre a idade mínima para o ingresso no EF.

Vale enfatizar, ainda, que a Resolução foi editada na vigência da Lei no 5.692/71, a qual estipulava a idade mínima de sete anos para o ingresso no EF, e que as normas de cada sistema de ensino tratariam da possibilidade de ingresso das crianças de sete anos de idade. A

\footnotetext{
${ }^{71}$ Como já destacado anteriormente, a idade mínima para ingresso ao EF fundamental foi antecipada para seis anos com a Lei 11.114/2005. E a ampliação da duração para nove anos com a Lei n 11.274/2006.
} 
LDB/96 estabelece (art. 87) a matrícula obrigatória a partir dos sete anos de idade e facultativa a partir dos seis anos de idade.

Segundo alguns desembargadores, a restrição estabelecida pela Resolução afronta a Constituição do Estado de São Paulo:

Artigo 249: O ensino fundamental, com oito anos de duração, é obrigatório para todas as crianças, a partir dos sete anos de idade, visando propiciar formação básica e comum indispensável a todos.

$\$ 5$ - É permitida a matrícula no ensino fundamental, a partir dos seis anos de idade, desde que plenamente atendida a demanda das crianças de sete anos de idade. (SÃO PAULO, 1989, art. 249).

Portanto, o único obstáculo para a matrícula das crianças de seis anos de idade seria a existência de outras, com sete anos completos, necessitando ser matriculadas. Nos casos concretos apreciados a recusa não estava vinculada à essa circunstância, mas exclusivamente ao aspecto da idade, portanto as decisões foram favoráveis aos alunos.

Então, segundo o Desembargador Alves Braga, a resolução "não tem efeito legal ou deveres podem ser baseados nela", sendo inaplicável às matrículas nas séries seguintes do EF. Esta posição é importante, pois em dado recurso um aluno que cursou a primeira série em escola particular teve sua matrícula negada na segunda série em estabelecimento da rede pública estadual, devido à idade ${ }^{72}$ (RECURSO EX OFFICIO nº 49.732-0, 1998).

Em outro acórdão ${ }^{73}$, a decisão do Desembargador Cunha Bueno reflete a jurisprudência do TJ-SP a respeito da concessão de matrículas às crianças com idade inferior à estabelecida pela Resolução da SEE, com decisão para o não seguimento do recurso de apelação:

\begin{abstract}
A Jurisprudência dominante deste E. Tribunal de Justiça por sua Câmara Especial entende da obrigatoriedade da realização da matrícula de menor com seis anos de idade no primeiro ano do ensino fundamental, salvo na hipótese em que não atendida a demanda de vagas para a matrícula de menores com sete anos de idade, e o faz com fundamento nas Constituições Federal e Estadual, esta última estabelecendo expressamente da possibilidade da matrícula dos menores com seis anos de idade desde que existam vagas suficientes para as crianças que já atingiram sete anos. (AGRAVO REGIMENTAL nº 58.270-0, 1999).
\end{abstract}

No mérito da ação, o Desembargador Oetterer Guedes pontua que a "Resolução restringiu o alcance do dispositivo constitucional e da legislação da infância e juventude, inviabilizando a matrícula de menores com seis anos de idade, sem qualquer justificativa além da provocação de suposta discricionariedade Estatal que no caso inexiste”. (APELAÇÃO CÍVEL no 44.586-0/5-00, 1998).

\footnotetext{
${ }^{72}$ Recurso ex officio $\mathrm{n}^{\circ}$ 49.732-0, 1998.

${ }^{73}$ Agravo Regimental no $58.270-0,1999$.
} 
A SEE, em comunicado de 11 de março de 1998, permitiu às autoridades escolares a admissão das crianças de seis anos de idade, depois de atendidas as matrículas das que já tinham sete anos de idade completos e, remanescendo vagas, independentemente do mês em que deveriam as primeiras completar sete anos de idade ${ }^{74}$.

Sobre o prazo do julgamento das ações, a Apelação Cível no 48.676-5, da Comarca de São Paulo, julgada em 1999, retrata a demora no julgamento. O MP recorreu ao TJ-SP, insistindo na concessão de liminar para assegurar a duas crianças o direito à vaga no EF, no ano de 1997. Inicialmente, não foi concedida, pois para o juiz cabia a retificação do pólo passivo do acionamento, a fim de que a impetração fosse dirigida contra ato praticado pela SEE e não ao Diretor do estabelecimento de ensino. No entendimento do Desembargador Jovino de Sylos, relator da decisão, o diretor da escola é o agente do Estado e, portanto, parte passiva legítima para a causa e para o processo. O TJ-SP decidiu pelo retorno dos autos à origem, para que outra decisão fosse proferida, com apreciação do mérito da demanda, incluso o ressarcimento, tendo em vista a perda do ano letivo devido à demora no julgamento.

Em ação civil pública, ingressada pelo MP, objetivando proibir a SEE de editar norma administrativa que inibisse o acesso de crianças com sete anos incompletos ao ensino obrigatório, a Fazenda Pública do estado de SP alega incompetência do juízo da Infância e Juventude para o julgamento da demanda. Referente ao mérito defende que a decisão proferida em $1^{\mathrm{a}}$ instância ofende o princípio constitucional da separação e independência de poderes $^{75}$.

Para o Desembargador Gentil Leite, relator do julgamento, os recursos comportam parcial acolhimento. Quanto à competência da Vara da Infância e Juventude para conhecer a demanda, o ECA, art. 209, ratifica a absoluta competência para o julgamento das causas dessa natureza. No mérito exclui a condenação imposta à SEE de garantir vaga no EF às crianças com sete anos incompletos, com a seguinte justificativa:

\footnotetext{
Assim, sem a prova de que não dispõe de vagas para atender a todas as crianças com sete anos completos, não é dado à apelante de forma apriorística editar Resolução restringindo o acesso de crianças de sete anos incompletos à escola, com base em suposta incapacidade da rede pública para atender a toda a demanda de interessados. Nessas condições, a sentença que assegura à parte o respeito a um direito individual, não configura indevida ingerência do Judiciário em poder discricionário do Executivo, mas simples exercício de sua missão constitucional de fazer cumprir e respeitar as normas legais em vigor.

Entretanto, pela mesma razão acima, não era possível ao juízo "a quo" impor à Fazenda Estadual a obrigação de garantia de vaga no ensino fundamental às crianças com sete anos incompletos.
}

\footnotetext{
${ }^{74}$ Apelação Cível no 49.626-5/3, 1999.

${ }^{75}$ Apelação Cível nº 64.281-0/0-00, 2001.
} 
Como já salientado, a Constituição Estadual em seu artigo 249, $\S 5^{\circ}$ apenas admitiu o acesso desse grupo de menores ao ensino básico desde que atendida a demanda de crianças com sete anos completos. (APELAÇÃO CÍVEL nº 64.281.0/0, 2001).

Em declaração de voto vencido, o Desembargador Nigro Conceição postulou que as Resoluções da SEE n 169/96 e 164/07 estariam "cerceando o direito à escola de criança em idade escolar", limitando à matrícula aqueles com sete anos completos até 28 de fevereiro.

Pela Resolução 164/97, havendo vagas seria permitida a inscrição no primeiro ano do EF somente às crianças que completem sete anos até 30 de junho do respectivo ano letivo. Para o Desembargador Nigro Conceição, esse critério vedava a matrícula das crianças que completam sete anos após esse período, pois a "matrícula somente poderá ser recusada se não houver vagas em número suficiente para atender à demanda de todas as crianças que alcancem idade própria, isto é, sete anos de idade". E a CF/88, ECA e a Constituição estadual paulista, todos hierarquicamente superiores às Resoluções da SEE, "não discriminam a respeito do momento em que a criança completa sete anos de idade". E pondera, também:

Correta também se mostra a r. sentença ao demonstrar que a norma violada com a resolução não é meramente programática, de sorte que existe um dever para o Estado, de criar todas as vagas necessárias em razão da idade das crianças, não podendo ser aceita a idéia de falta de verba orçamentária que se coloque com destaque superior aos interesses protegidos por aqueles preceitos, até porque decorridos mais de dez anos da vigência do Estatuto, portanto com prazo suficiente para a satisfação dos direitos fundamentais das crianças e adolescentes. (APELAÇÃO CÍVEL nº 64.281.0/0, 2001).

Sobre a interferência do Judiciário em atividade administrativa do Poder Executivo destaca a sua posição:

Cabe frisar, por outro lado, que a atividade administrativa do Estado pode ser controlada judicialmente, como informam as regras legais já citadas, não havendo, portanto, quebra ao princípio constitucional da separação e independência dos Poderes quando o Judiciário é invocado a prestar a tutela jurisdicional em termos de ações que tenham como finalidade a reafirmação de direitos individuais, difusos ou coletivos fundamentais. Atenta até mesmo contra o Estado Democrático de Direito pensar-se que os Poderes são herméticos e indevassáveis, sendo plenamente possível o exame das atividades administrativas quando ponham em cheque os direitos referidos. (APELAÇÃO CÍVEL nº 64.281.0/0, 2001).

A posição defendida pelo Desembargador Gentil Leite não se afasta da do Desembargador Nigro Conceição, pois ambos explicitam que a SEE não deve proibir a matrícula das crianças com sete anos incompletos se existirem vagas. Contudo, também é preciso definir uma data limite para que a criança ingresse no EF, pois seu direito não estaria sendo negado se a SEE e Secretarias municipais definissem, em conjunto, a idade para a conclusão da pré-escola e o início do EF, considerando a legislação deste período, que prevê obrigatoriedade do atendimento em creche e pré-escolas as crianças entre zero e seis anos. 
Sobre o princípio da independência dos Poderes, o Desembargador Cunha Bueno frisa:

[...] Logo, não se poderia afastar do Poder Judiciário a aferição, mediante provocação, da legalidade ou não da Resolução 169/96 e não decorre daí qualquer ingerência nas decisões do Poder Executivo que permanece soberano no exercício da atividade que lhe é pertinente, submetendo-se, contudo, ao controle de sua atividade desde que nesta haja violação ao direito de terceiros. (APELAÇÃO CÍVEL n ${ }^{\circ}$ 41.630.0/5, 1998).

As ações em primeira instância tiveram parecer favorável às crianças, concedendo-lhes o direito. Entretanto, em quatro julgados os juízes acataram o impedimento da Vara da Infância e Juventude para processar e julgar a demanda. A competência da Justiça da Infância e Juventude para o julgamento deste tipo de demanda é garantida pelo ECA, artigo 148, inciso IV: "conhecer de ações civis fundadas em interesses individuais, difusos ou coletivos afetos à criança e ao adolescente, observado o disposto no art. $209^{76,}$.

O MP foi o principal autor na propositura dessas ações e, por isso, questionado pelo Estado quanto à sua legitimidade para a causa. Segundo o Desembargador Oetterer Guedes ${ }^{77}$, tal argumento não tem amparo legal, pois o ECA, art. 201, define que uma das funções do MP é "promover o inquérito civil e a ação civil pública para a proteção dos interesses individuais, difusos e coletivos relativos à infância e à juventude" (inciso V). Ainda, que deve "zelar pelo efetivo respeito aos direitos e garantias legais assegurados às crianças e adolescentes, promovendo as medidas judiciais e extrajudiciais cabíveis" (inciso VIII).

O artigo 15, da Resolução SEE $n^{\circ}$ 164/97, que determinava o cancelamento da matrícula de crianças e adolescentes que faltarem sem justificativa nos primeiros dez dias letivos, gerou uma ação civil pública por parte do MP de São Paulo. Essa determinação viola, segundo a decisão do TJ-SP, o "direito de acesso à educação" (RECURSO EX OFFICIO n 60.258-0, 1999). Em primeira instância, a ação foi julgada favoravelmente ao pedido do MP e confirmada no TJ-SP, dada que a Secretaria de Educação já havia modificado o artigo, reconhecendo juridicamente o pedido.

Em 1999, o MP ingressou com uma ação civil pública, acolhida pelo juiz de Direito da Infância e Juventude do Foro Distrital de Pinheiros, versando sobre a criação e manutenção de vagas na rede estadual de EF. A apelação da Fazenda Pública do estado de SP colocou em xeque, no mérito da ação, a interferência do Poder Judiciário na esfera de atribuição própria do Executivo. A tese da apelação foi aceita pelo Desembargador Mohamed Amaro:

\footnotetext{
${ }^{76}$ Art. 209: “As ações previstas neste Capítulo serão propostas no foro do local onde ocorreu ou deva ocorrer a ação ou omissão, cujo juízo terá competência absoluta para processar a causa, ressalvadas a competência da Justiça Federal e a competência originária dos tribunais superiores.” (BRASIL, 1990, art.209).

${ }^{77}$ Apelação Cível no 44.586-0/5-00, 1998.
} 
[...] a imposição de obrigação de fazer consistente na criação e manutenção de vagas na rede estadual de ensino constitui invasão de ato da gestão governamental, que toca exclusivamente à conveniência e à oportunidade da Administração Pública. Dessa maneira, a determinação almejada pelo Ministério Público e recepcionada pelo Juízo de Primeiro Grau de Jurisdição caracterizou-se, data maxima venia, como ingerência indevida de um poder em outro, ao arrepio da Constituição Federal. Fundamentalmente, constitui-se em uma adoção de critério administrativo vinculado, próprio do Executivo Estadual, malferindo a norma constitucional que atribui ao Executivo assinalar suas prioridades administrativas e demais realizações, as quais se sujeitam as limitações legais, razão pela qual não pode o Poder Judiciário emitir juízo de verdadeiro mérito administrativo, como se administração fosse. (APELAÇÃO CÍVEL nº 60.084-0, 2001).

E, ainda, justifica como sendo improcedente a demanda proposta, porque sanar eventual falta de vagas nas escolas públicas estaduais importa em dispêndio ao erário público:

[...] improcedente a demanda proposta, pois embora tenha o legislador constitucional pretendido realmente trazer aprimoramento ao ensino fundamental do Brasil, o fez esquecendo-se da dotação orçamentária necessária, como se fosse possível desenhar, como por encanto, a realidade por força da escrita. (APELAÇÃO CÍVEL nº 60.084$0,2001)$.

Pelo acórdão, não é possível depreender o contexto que gerou essa demanda ao MP, mas algumas inferências são viáveis, a partir da análise das políticas educacionais da SEE no período. A solicitação para a criação e a manutenção de vagas na rede estadual pode ter sido motivada pela crescente retração do oferecimento de matrículas na rede estadual, promovida tanto pela municipalização como por outras medidas desenvolvidas pelo governo estadual paulista no período de 1995-1998. Segundo Theresa Adrião (2006), as intervenções do governo paulista na educação, visando à produtividade dos recursos educacionais, estavam relacionadas a três diretrizes: reforma e racionalização, descentralização e desconcentração administrativa e introdução de novos padrões de gestão.

Entre as reformas executadas estava a reorganização das escolas ${ }^{78}$, separando em prédios distintos a oferta das quatro primeiras séries e das quatro últimas séries do EF e EM e o estímulo às parceiras entre os governos do Estado e dos municípios, objetivando que estes últimos aumentassem a sua oferta no $\mathrm{EF}^{79}$. A separação do atendimento facilitou a municipalização do EF, sendo incentivado aos municípios assumirem as escolas de $1^{\mathrm{a}}$ a $4^{\mathrm{a}}$ séries.

\footnotetext{
${ }^{78}$ O Programa de Reorganização das Escolas da Rede Pública Estadual, iniciado no final de 1995, tinha como uma das justificativas o problema pedagógico gerado pelo atendimento em uma única unidade das oito séries do $\mathrm{EF}$, melhorando desta forma o atendimento pedagógico com algumas iniciativas como sala ambiente, laboratórios e espaços adequados às diferentes idades/séries

${ }^{79}$ O Decreto no 40.673, de 16 de fevereiro de 1996, que instituiu o "Programa de Ação de Parceria Educacional Estado-Município para Atendimento do Ensino Fundamental" estimulou à transferência do EF para os municípios (ADRIÃO, 2006).
} 
Com a reorganização das escolas estaduais, também influenciada pela fixação do número mínimo de alunos por classe, houve uma diminuição do número total de escolas e de turno, entre 1995 e 1998. "Em nome da 'racionalização', foram desativadas 864 escolas e 2.031 deixaram de oferecer aulas no período noturno" (ADRIÃO, 2006, p. 141).

A fixação de data para o ingresso de alunos com seis anos no EF também pode ser compreendida no conjunto das medidas adotadas pela SEE para ampliar a oferta do atendimento pelos municípios nesta etapa da educação básica. Para exemplificar, em 1997, no município de Rio Claro, cerca de 500 crianças que completariam sete anos após 28 de fevereiro, concluintes do último estágio da EI, não tiveram a sua matrícula garantida na rede estadual. O fato gerou uma ação civil pública, promovida pela Promotoria da Infância e Juventude, solicitando que o município matriculasse essas crianças. No entendimento do Promotor de Justiça, a municipalidade deveria priorizar o atendimento ao EF e o estado ao EM. No conjunto de documentos deste processo, foi encontrada cópia da representação da Secretária de Estado da Educação de SP, Rose Neubauer, na qual solicitava ao MP providências quanto ao descumprimento, por parte dos municípios paulistas, das obrigações legais para a prestação do EF, e requeria a tomada de medidas cabíveis. Com essa ação judicial, o município iniciou o processo de expansão do atendimento do EF, visando atender às crianças que não obtiveram a vaga na rede estadual (SILVEIRA, 2006).

A reorganização das escolas estaduais pode ter dificultado o acesso e a locomoção da população usuária à escola próxima a residência dos alunos, mas essa problemática foi objeto de litígio no TJ-SP em apenas três julgados, e um requerendo o direito de escolher a escola para efetuar a matrícula.

\subsubsection{Direito de frequentar escola mais próxima de sua residência e escolha da escola}

Em mandado de segurança impetrado por criança ou adolescente, assistido por sua mãe, contra ato praticado pelo Dirigente de Ensino do município de Assis, que se negou a efetuar a matrícula do aluno no período noturno, sob alegação de não existir vaga para a $6^{\mathbf{a}}$ série neste período, no curso supletivo, a sentença em primeira instância concedeu a segurança, determinando a "abertura de vaga". A decisão embasou-se na CF/88 e no ECA: 
O dever do Estado em garantir o ensino fundamental deriva de norma constitucional e vem estampado no artigo 208 da Constituição da República.

Teve assim o impetrante seu direito líquido e certo violado.

[...] tem a autoridade coatora condições de tomar medidas concretas de ordem administrativa para receber o impetrante na escola mais próxima a sua residência, bastando para tanto distribuir de outra forma o espaço físico. (APELAÇÃO CÍVEL $\left.\mathrm{n}^{\circ} 87.482-5,1999\right)$.

Todavia, o relatório do Desembargador Viana Santos, seguido pelos demais desembargadores, acatou o recurso do Poder Executivo estadual da interferência do Poder Judiciário no poder discricionário do Executivo. E ratificou, alicerçado no princípio da separação de poderes e da discricionariedade estatal, que "o correto é que não cabe ao Poder Judiciário determinar aos órgãos administrativos, que se criem condições (vagas), para assegurar direitos dos cidadãos". Ainda, "não cabe ao Poder Judiciário determinar que seja desmontada toda uma estrutura planejada, em conformidade com regras internas e, até mesmo, delineada pela Secretaria de Educação e outras a ela ligada, para garantir direitos, pelo já consignado" (APELAÇÃO CÍVEL nº 87.482-5, 1999).

Como a sentença inicial foi proferida em abril de 1998, e a decisão do TJ-SP em contrário, em julho de 1999, em tese a cassação da segurança não teria nenhum efeito prático, pois o aluno já deveria ter cursado a série pretendida, não resultando qualquer prejuízo ao adolescente.

Em mandado de segurança, impetrado contra ato do Dirigente Regional de Assis, sobre o indeferimento da criação de uma turma de segunda série em uma dada escola estadual e revogação de matrícula da impetrante, o Desembargador José Raul Gavião de Almeida proferiu que "a quantificação e a localização das salas de aula, postas à disposição para a matrícula em cada um das séries, é tarefa do administrador, que age com liberdade, desde que sua escolha não dificulte excessivamente o estudo das crianças". E, no litígio em questão, há outras escolas mais próximas à residência que podem atender a impetrante (APELAÇÃO CÍVEL no $128.541-5,2001)$.

No mesmo sentido, a Apelação Cível no 96.816-0/5-00, que solicita a matrícula do aluno em escola municipal próxima à residência da criança, o Desembargador Moura Ribeiro insistiu que o dever do Estado em promover a educação não "significa que as vagas disponibilizadas devam estar próximas das residências dos estudantes, pois tal direito não foi consagrado nas normas em destaque".

Além disso, o inciso $\mathrm{V}$, do art. 53, do ECA, assegura à criança ou adolescente o acesso a escola pública e gratuita próxima de sua residência, mas não a mais próxima, valendo anotar que na data da impetração a beneficiária nem sequer tinha idade legal para a postulação do direito. (APELAÇÃO CÍVEL n 96.816-0/5-00, 2002, grifos no original). 
Em decisão do TJ-SP, de 1996, discute-se a permissão para que aluno tenha a matrícula efetuada em escola distante de sua residência, em uma unidade de sua escolha. A decisão, em primeira e segunda instância, favoreceu o aluno, pois a Resolução da SEE nº 211, de 11 de novembro de 1994, que estabelece diretrizes para a organização das escolas da rede estadual de ensino em 1995, não proibira a matrícula do aluno em escola distante da residência, desde que subordinada à existência de vagas suficientes para os alunos que morem perto da escola. Na escola que a impetrante pretendia estudar havia vagas ${ }^{80}$.

No âmbito dessa decisão, os desembargadores analisaram o teor da Resolução da SEE, não fazendo uso na argumentação de outras leis.

Pelos acórdãos analisados, a escolha da escola pelos alunos, dentre as mais próximas de sua residência, não é assegurada legalmente no entendimento do TJ-SP, ficando restrita à existência de vagas na escola pretendida.

Porém, é importante reiterar que o direito de acesso à escola pública e gratuita próxima da residência é assegurado pelo ECA, art. 53, e o poder discricionário da SEE em distribuir a demanda de alunos não pode infringir este direito.

\subsubsection{Educação Profissionalizante: critérios para ingresso}

Dentre as dez decisões focadas na Educação Profissionalizante, nove questionaram a forma de ingresso nesses cursos. O cerne da discussão relacionava-se aos princípios de igualdade de acesso e da não-discriminação. O curso de magistério no Centro Específico de Formação e Aperfeiçoamento de Magistério (Cefam) ${ }^{81}$ foi objeto de cinco ações, distribuídas entre 1996 e 2006; o Centro Estadual de Educação Tecnológica "Paula Souza" (CEETEPS),

\footnotetext{
${ }^{80}$ Apelação Cível no 265.465-1, 1996.

${ }^{81}$ Os Centros Específicos de Formação e Aperfeiçoamento do Magistério foram criados no âmbito da rede estadual de ensino pelo Decreto $n^{\circ}$ 28.089, de 13 de janeiro de 1988. São objetivos do Cefam: "recuperar a especificidade dos cursos de formação para o magistério e colaborar para suprir as deficiências do atendimento às séries iniciais da escolaridade na rede estadual de ensino; oportunizar aos alunos, trabalhadores e demais concluintes do $1^{\circ}$ grau da rede pública um curso de formação de professores de boa qualidade, em período integral; oferecer programas de aperfeiçoamento aos docentes que atuam na rede pública estadual, de pré-escola à $4^{\mathrm{a}}$ série do $1^{\circ}$ grau e nos cursos de $2^{\circ}$ grau com Habilitação Específica de Magistério; coordenar a nível regional estudos e ações sobre a habilitação do magistério e atender a política de ação de diretrizes da Secretaria da Educação" (RESOLUÇÃO SEE n 14, de 28 de janeiro de 1988). Através da Resolução da SEE n. ${ }^{\circ} 119$, de 8 de novembro de 2003, que dispõe sobre o processo de atendimento à demanda de alunos do curso normal das escolas estaduais, em 2004, determina que essa demanda será atendida, exclusivamente, para os alunos que vierem a ser matriculados, em continuidade, nas 3. ${ }^{a}$ e $4 .^{a}$ séries, significando a extinção deste curso na rede estadual paulista.
} 
em três ações, em 2007; e um curso oferecido pelo Serviço Nacional de Aprendizagem Comercial (Senac) foi contestado sobre a idade mínima para ingresso, ação julgada em 2001. Somente uma ação questionava a implantação do ensino técnico nas unidades de $\mathrm{EM}^{82}$, mas não foi julgada no mérito, considerando a ilegitimidade do Sindicato dos trabalhadores do ensino público estadual técnico, tecnológico e profissional do estado de São Paulo para a propositura da ação civil pública, por não provar estar constituído há mais de um ano, e ao pleitear a suspensão de Decreto Presidencial n.2.208/97, resvalava em assunto de competência da Justiça Federal.

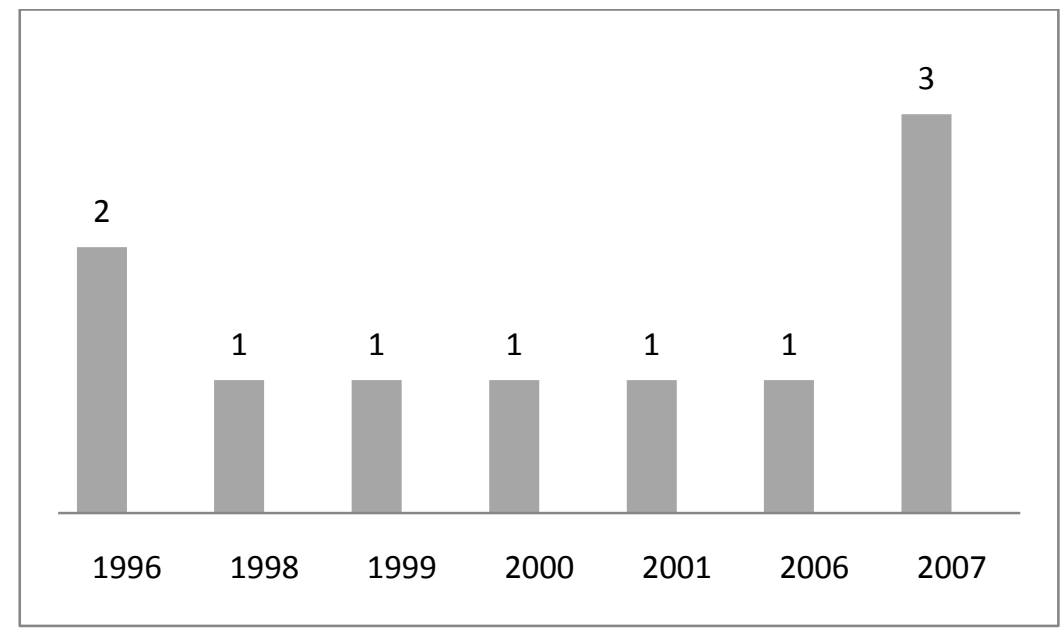

Gráfico 4 - Distribuição anual das decisões sobre acesso ao ensino profissionalizante Fonte: a autora com base nas decisões coletadas no TJ-SP.

Para a inscrição no processo de seleção do curso de Magistério do Cefam $^{83}$, o candidato deveria comprovar no ato de inscrição:

a) encontrar-se na faixa etária dos 14 aos 21 anos;

b) ser concluinte de $1^{\circ}$ grau ou estar cursando a $8^{\circ}$ série de escola pública (estadual ou municipal) ou particular;

c) o período (diurno ou noturno) em que cursou a última série do $1^{\circ}$ grau.

Para o preenchimento das vagas deveriam ser observados os seguintes critérios:

I - As vagas da $1^{\text {a }}$ série deverão atender, respeitada a faixa etária dos 14 aos 21 anos, aos alunos:

egressos da escola pública (estadual ou municipal) na seguinte conformidade: mínimo de $50 \%$ aos alunos egressos do período noturno; o percentual restante aos alunos egressos do período diurno.

II - As vagas não preenchidas na conformidade do item anterior deverão atender, aos alunos egressos da escola particular [...] (ANEXO RESOLUÇÃO SEE $n^{\circ}$ 279/88, INSTRUÇÃO 1).

\footnotetext{
${ }^{82}$ Apelação Cível no 77.819.5/4-00, 1999.

${ }^{83}$ Instrução 1 Anexa à Resolução SEE nº 279, de 28 de dezembro de 1988.
} 
A Apelação Cível no 238.454-1, de Pirassununga, julgada em 1996, questionou a limitação da idade estabelecida pela Resolução, pois uma adolescente no ato da inscrição não tinha ainda completado 14 anos. O Desembargador Telles Corrêa, relator da decisão, confirmou a decisão para a efetivação da matrícula, que ocorreu em 1994:

\begin{abstract}
Seja como for, em caso que tais, em que pese estabelecer-se idades-limites para o exercício daquele direito, deverá sempre bafejar o princípio de razoabilidade para a solução dessas hipóteses, afastável o requisito idade como obstáculo, máxime em se cuidando de ingresso ao Curso de Formação do Magistério, quando se sabe que ao menor de quatorze anos permite-se o início do aprendizado nos vários ramos de trabalho [...]. (APELAÇÃO CÍVEL nº 238.454-1, 1996, relator Des. Telles Corrêa).
\end{abstract}

Em outra Apelação Cível ${ }^{84}$, excluída do conjunto das decisões deste trabalho, devido à idade da pleiteante à vaga, foi questionado o limite etário de vinte e um anos para o ingresso no Curso de Magistério. Em recurso ao TJ-SP, a Fazenda do Estado alegou que o curso de magistério se destinava a um público adolescente e, por essa razão, a impetrante não teria condições de acompanhá-lo. Na decisão do TJ-SP, a idade da impetrante não seria incompatível com a profissionalização e com o exercício da função. Segundo o Desembargador Antonio Villem, a jurisprudência adota o entendimento, concebendo a discriminação quando se compatibilizar com a natureza das atribuições. Portanto, o limite etário previsto pela Resolução choca-se com os princípios constitucionais.

A priorização de vagas para os alunos egressos da escola pública, pela Resolução estadual, foi julgada pelo TJ-SP em cinco processos ${ }^{85}$. A Fazenda Pública alegava que não havia direito público subjetivo, uma vez que o dever do Estado de assegurar o direito ao ensino público restringia-se ao EF. Também, que os candidatos ao fazerem sua inscrição, no concurso para o provimento das vagas, conheciam os critérios da respectiva distribuição.

Três decisões que envolviam candidatos advindos do Serviço Social da Indústria (Sesi) e todas foram julgadas favoravelmente aos candidatos, considerando que a entidade oferece ensino gratuito, portanto seus egressos têm o mesmo direito de concorrer em igualdade de condições com os alunos da rede pública ${ }^{86}$.

Seguindo o mesmo entendimento, o Desembargador Demóstenes Braga frisa: "é indiscutível que a observância do organograma para atendimento da demanda estabelece ilegalidade, discriminando o educando vindo da escola particular que se sujeitou ao processo

\footnotetext{
${ }_{85}^{84}$ Apelação Cível no $11.288-5$ de Casa Branca.

${ }^{85}$ Em um processo (Apelação Cível $\left.n^{\circ} 239.376-1,1996\right)$ estava em segredo de justiça, não possibilitando o acesso a informações. Na ementa consta que a preterição de vagas foi julgada inconstitucional diante da diretriz constitucional.

${ }^{86}$ Apelação Cível no 35.389-5, 1998.
} 
seletivo, logrando êxito e assegurando o direito à matrícula" (AGRAVO DE INSTRUMENTO $\left.\mathrm{n}^{\circ} 156.812-5,2000\right)$.

Na Apelação Cível no 309.668.5-9-00, de 2000, na qual adolescente teve sua matrícula indeferida no Cefam, porque egressa de escola particular, o TJ-SP em consonância com a $1^{\mathrm{a}}$ instância enfatizou que a Resolução estadual que criou o Cefam não tem "poderes para restringir direitos", descumprindo o princípio da igualdade. Nesta ação, a Fazenda do Estado justificou o tratamento desigual porque se tratava de candidatos desiguais.

O Desembargador Francisco Vicente Rossi argumentou que a $\mathrm{CF} / 88$ não admite distinção de qualquer natureza e citou Aristóteles:

[...] parece que a igualdade seja justiça, e o é, com efeito, mas não para todos, e sim somente para os iguais. A só desigualdade também parece ser, e o é com efeito, mas não para todos, só o é entre aqueles que não são iguais (A Política, Livro III, cap. V, $\left.\S 8^{\circ}\right)$.

Aqui, que desigualdade substancial, do ser enquanto ser, pode haver entre jovens que almejam ser professores? Que buscam acesso à educação? Situações periféricas, secundárias, acidentais, não podem atingir a igualdade essencial dos cidadãos, sob pena de tratar desigualmente a iguais e fazer da pretensa igualdade uma injustiça. (APELAÇÃO CÍVEL n ${ }^{\circ}$ 309.668.5-9-00, 2006).

A destinação de reserva de vagas a alunos provenientes de escolas públicas também foi objeto de questionamento no âmbito da Apelação Cível no 566.156-5/8-00, de 2007. A decisão em recurso julgou o cancelamento de matrícula de candidata em curso técnico do CEETEPS porque foram considerados erroneamente pontos decorrentes da declaração equivocada de que a adolescente seria egressa da escola pública. Contudo, estudara na Fundação Bradesco, entidade privada de caráter assistencial. A adolescente argumentou que a Fundação Bradesco devia ser equiparada à escola pública.

Esses questionamentos estão fundamentados no Decreto 49.602, de 13 de maio de 2005, que estabelece o "sistema de pontuação acrescida" para egressos do sistema de ensino público e para afro-descendentes nos exames seletivos para ingresso nas Escolas Técnicas Estaduais (ETE) e nas Faculdades de Tecnologia (Fatec) do CEETEPS.

$\mathrm{O}$ art. $3^{\circ}$ deste Decreto estabelece um acréscimo de pontos à nota final obtida no exame seletivo pelo candidato que:

I - declare ser afrodescendente;

II - apresente histórico escolar demonstrando ter estudado em instituições públicas:

a) o ensino fundamental, a partir da $5^{\text {a }}$ série, para o ensino médio e/ou técnico;

b) ensino médio, integralmente, para o ensino tecnológico;

III - atenda cumulativamente aos incisos I e II. (SÃO PAULO, 2005). 
E, o artigo $6^{\circ}$, dispõe que constatada, a qualquer tempo, a falsidade das informações constantes dos documentos a que se referem os incisos I e II do art. $3^{\circ}$, o infrator ficará sujeito às penalidades previstas na legislação civil e penal e terá a sua matrícula cancelada.

Para o Desembargador Urbano Ruiz, a Fundação Bradesco não se equipara à escola pública, porque é entidade privada, ainda que de caráter assistencial. No entendimento da Comissão Executiva do Vestibulinho, o Senai, Sesc, Senac não são considerados escolas públicas, pois "a entidade, não obstante ministre cursos gratuitamente, por óbvio não se submete aos rigores da estrutura de ensino público, inclusive quanto à grade curricular". Desta forma, o TJ-SP mantém a decisão inicial, não considerando direito líquido e certo de matrícula no curso, como pleiteava a adolescente.

Essa decisão, ao concordar com o entendimento da Comissão do CEETPS de que as escolas do sistema "S" não são escolas públicas, apresenta posicionamento contrário à decisão proferida anteriormente ${ }^{87}$; além de duas outras, no mesmo ano, que reconheceram o direito aos alunos egressos do Sesi de concorrerem em igualdade de condições com os alunos provenientes da rede pública de ensino ${ }^{88}$.

\subsubsection{Educação de Jovens e Adultos: idade mínima para ingresso e gratuidade dos exames}

A LDB/96 dispõe, no artigo 38, que os "sistemas de ensino manterão cursos e exames supletivos, que compreenderão a base nacional comum do currículo, habilitando ao prosseguimento de estudos em caráter regular" e os exames para o nível de conclusão do EM realizar-se-ão para os maiores de dezoito anos.

Assim, na decisão ${ }^{89}$ que discutiu o indeferimento da matrícula de vários adolescentes no primeiro ano do curso supletivo do EM, por não terem completado a idade mínima de 19 anos, estabelecida pela Deliberação SEE $n^{\circ} 23$ de 1983, o Desembargador Gonzaga Fransceschini julgou que a idade estabelecida pela LDB/96 refere ao exame, não existindo exigência de idade mínima para a matrícula e frequência ao curso.

\footnotetext{
${ }^{87}$ Apelação Cível no 35.389-5, 1998.

${ }^{88}$ Apelação Cível no 609.618-5/9-00, 2007 e 625.397-5/6-00, 2007.

${ }^{89}$ Apelação Cível no 72.885-5, 1999.
} 
Em decisão com o mesmo questionamento ${ }^{90}$ o TJ-SP confirma a segurança, entendendo que a adolescente, embora tendo menos de 18 anos e ao término do curso supletivo com dezessete anos e onze meses, na hipótese de aprovação, poderia aguardar oportunidade para a realização dos exames finais.

A Apelação Cível no 67.758.0/9 analisou o recurso da Fazenda Pública do Estado de SP contra ação civil pública proposta pelo MP, visando à garantia de continuidade das classes de curso supletivo do ensino obrigatório para alunos de 18 anos, em decorrência da Resolução SEE $n^{\circ} 164 / 96$.

A Fazenda alegou, no mérito, "que a política de distribuição do ensino público está incluída dentro de sua esfera de discricionariedade administrativa, razão pela qual está autorizada a editar norma administrativa dispondo sobre sua oferta, assim como ajustar com o Executivo Municipal a divisão das áreas de atuação, priorizando o Estado a suplência de $5^{\mathrm{a}}$ a $8^{\text {a }}$ série e de nível médio".

O Desembargador Gentil Leite justificou seu posicionamento com a $\mathrm{CF} / 88$, ao considerar a educação como direito de todos e dever do Estado, sendo o EF obrigatório e gratuito (art. 208); com a Constituição paulista compete ao Poder Público promover a educação supletiva adequada às condições de vida do educando que já tenha ingressado no mercado de trabalho (art. 249, $\S 4^{\circ}$ ). Portanto, é inegável o reconhecimento do direito de menores de 18 de ter acesso ao EF, não sendo lícito ao Governo estadual alterar a obrigação constitucional por meio de uma "simples resolução". E "a interrupção da oferta pelo Estado somente se legitimaria se demonstrado que o município de São Paulo já supre toda a demanda, o que não ocorre no caso dos autos" (APELAÇÃO CÍVEL nº 67.758.0/9, 2001, relator Des. Gentil Leite).

Sobre a interferência do Judiciário, na autonomia administrativa e financeira do Executivo, o Desembargador explana que "não se pode confundir o exercício do poder discricionário do administrador público com sua inércia diante das obrigações que lhe impõe a Lei”. Assim, a discricionariedade seria exercida na escolha de duas ou mais providências possíveis para atender a lei:

Nessa hipótese cabe exclusivamente à Administração Pública a opção pela medida que se lhe apresente mais conveniente e oportuna. Desde que não desrespeitando o objetivo da lei, é vedado ao Poder Judiciário substituir o Executivo na decisão de dizer tal ou qual solução deve ser adotada, se ambas se configuram como hábeis e legítimas. (APELAÇÃO CÍVEL nº 67.758.0/9, 2001, relator Des. Gentil Leite).

\footnotetext{
${ }^{90}$ Apelação Cível n ${ }^{\circ}$ 120.925-5, 2001.
} 
Estabeleceu multa diária de $\mathrm{R} \$ 3.000,00$ (três mil reais) por adolescente desassistido por omissão do Estado, sendo os valores revertidos ao fundo gerido pelo Conselho dos Direitos da Criança e do Adolescente.

As decisões sobre questionamento para a idade mínima para ingresso e realização de certificação nos exames de EJA foram proferidas entre os anos de 1999 e 2001. Neste período, destaca-se a Resolução CNE/CEB $n^{\circ} 1 / 2000$, que estabelece as Diretrizes Curriculares Nacionais para a Educação de Jovens e Adultos. Esta normatização do CNE define a idade mínima para a inscrição e realização de exames nos cursos de EJA para o EF e EM:

Art. $7^{\circ}$ Obedecidos o disposto no Art. $4^{\circ}$, I e VII da LDB e a regra da prioridade para o atendimento da escolarização universal obrigatória, será considerada idade mínima para a inscrição e realização de exames supletivos de conclusão do ensino fundamental a de 15 anos completos.

Parágrafo único. Fica vedada, em cursos de Educação de Jovens e Adultos, a matrícula e a assistência de crianças e de adolescentes da faixa etária compreendida na escolaridade universal obrigatória ou seja, de sete a quatorze anos completos.

Art. $8^{\circ}$ Observado o disposto no Art. $4^{\circ}$, VII da LDB, a idade mínima para a inscrição e realização de exames supletivos de conclusão do ensino médio é a de 18 anos completos.

$\S 1^{\circ} \mathrm{O}$ direito dos menores emancipados para os atos da vida civil não se aplica para o da prestação de exames supletivos.

$\S 2^{\circ}$ Semelhantemente ao disposto no parágrafo único do Art. $7^{\circ}$, os cursos de Educação de Jovens e Adultos de nível médio deverão ser voltados especificamente para alunos de faixa etária superior à própria para a conclusão deste nível de ensino ou seja, 17 anos completos. (BRASIL, CNE/CEB, 2000).

A Resolução do CNE/CEB No 3, de 15 de junho de 2010, que institui as Diretrizes Operacionais para a Educação de Jovens e Adultos nos aspectos relativos à duração dos cursos e idade mínima para ingresso nos cursos de EJA; idade mínima e certificação nos exames de EJA; e Educação de Jovens e Adultos desenvolvida por meio da Educação a Distância amplia o que foi disposto no art. $7^{\circ}$ da Resolução CNE/CEB n ${ }^{\circ}$ 1/2000 também para a frequência em cursos de EJA:

Art. $5^{\circ}$ Obedecidos o disposto no artigo $4^{\circ}$, incisos I e VII, da Lei n ${ }^{\circ}$ 9.394/96 (LDB) e a regra da prioridade para o atendimento da escolarização obrigatória, será considerada idade mínima para os cursos de EJA e para a realização de exames de conclusão de EJA do Ensino Fundamental a de 15 (quinze) anos completos.

[...]

Art. $6^{\circ}$ Observado o disposto no artigo $4^{\circ}$, inciso VII, da Lei $\mathrm{n}^{\circ}$ 9.394/96, a idade mínima para matrícula em cursos de EJA de Ensino Médio e inscrição e realização de exames de conclusão de EJA do Ensino Médio é 18 (dezoito) anos completos. (BRASIL, CNE/CEB, 2010).

Essas normatizações do CNE poderiam auxiliar os membros do Poder Judiciário na resolução de conflitos abrangendo esta temática. 
A gratuidade dos exames finais foi demandada em ação civil pública ingressada pelo MP contra a Fazenda Pública do Estado de SP, através da SEE. A Portaria DRHU- I, de 9 de janeiro de 1998, estabeleceu normas para a realização das inscrições aos Exames Supletivos de EF e EM, para o primeiro semestre de 1998. Para o MP, essa Portaria cerceava o direito de acesso a EJA ao cobrar a taxa de $\mathrm{R} \$ 14,00$ por disciplina, inviabilizando a realização do exame para muitos jovens e adultos por insuficiência econômica. O MP pediu que a Fazenda Pública fosse condenada à obrigação de não fazer a cobrança da taxa, contribuição ou pagamento para a inscrição ao exame supletivo sob pena de multa diária, condenação nos termos do art. 12, inciso III, da Lei 8.429/92, na perda da função pública, na suspensão dos direitos políticos, ao pagamento de multa civil, e a proibição de contratar com o Poder Público ou receber benefícios ou incentivos fiscais ou creditícios, direta ou indiretamente, pelo prazo de três anos ${ }^{91}$. Em primeira instância, a petição inicial dessa ação foi indeferida e o processo julgado extinto.

O Desembargador Toledo Silva, relator da decisão no TJ-SP, defendeu que o MP é parte legítima para propor ação em defesa dos interesses difusos e coletivos, respaldada a ação civil pública, no art. 129 da CF/88, pois é evidente o interesse social. E o "Poder Judiciário pode rever os atos administrativos, sob o aspecto da legalidade". O recurso do MP é provido para afastar a extinção do processo, determinando o prosseguimento da ação.

A Apelação Cível no 76.640-0, de 2001, também contestou a cobrança de taxa de inscrição para os exames supletivos no primeiro semestre de 1999. Alegou o MP que a cobrança violava o princípio constitucional da gratuidade do ensino público. Em primeira instância, a ação foi julgada improcedente e o TJ-SP concedeu a apelação do MP, afirmando que o "Estado não pode instituir taxa de inscrição para os exames supletivos, em razão de imunidade constitucional objetiva".

Em outra ação civil pública proposta pelo MP, todavia julgada procedente em $1^{a}$ instância, para que a Fazenda Pública se abstenha de cobrar taxa de inscrição para os exames supletivos, o Desembargador Evaristo dos Santos afirmou que a questão não é nova no TJ-SP e citou a Apelação Cível comentada anteriormente ${ }^{92}$, e outras, para decidir que os argumentos da Fazenda Pública não devem prosperar.

As seis decisões acerca do ingresso nos cursos de EJA foram proferidas em votação unânime, e concedidas favoravelmente ao pedido dos jovens, julgando ilegal a definição da idade pela SEE e repudiando, por descabida, a exigência de cobrança de taxa para a realização

\footnotetext{
${ }^{91}$ Apelação Cível no 77.912-5/9, 1999.

${ }^{92}$ Apelação Cível no 76.640-0/1, 2001.
} 
de exames supletivos. Porém, cabe destacar que as ações ${ }^{93}$ que pediam a não cobrança das taxas foram julgadas após o término do ano requerido. A primeira solicitava para o $1^{\mathrm{o}}$ semestre de 1998, e o recurso somente foi julgado pelo TJ-SP em junho de 1999. A segunda ação, relativa ao $1^{\text {o }}$ semestre de 1999, foi julgada em $2^{\mathrm{a}}$ instância somente em julho de 2001 . Portanto, manteve-se o descumprimento de um princípio constitucional no ano em que se ingressou com a ação, dado que em primeira instância a decisão foi favorável à cobrança da taxa, pois inicialmente as ações foram consideradas improcedentes. Supõe-se que depois do julgamento da decisão no TJ-SP a cobrança passou a ser irregular.

\subsubsection{Acessibilidade e atendimento especializado às crianças e aos adolescentes com necessidades educacionais especiais}

De acordo com Resolução CNE/CEB n 2, de 11 de setembro de 2001, que institui as Diretrizes Nacionais para a Educação Especial na Educação Básica, os educandos com necessidades educacionais especiais são aqueles que apresentarem durante o processo educacional:

I - dificuldades acentuadas de aprendizagem ou limitações no processo de desenvolvimento que dificultem o acompanhamento das atividades curriculares, compreendidas em dois grupos:

a) aquelas não vinculadas a uma causa orgânica específica;

b) aquelas relacionadas a condições, disfunções, limitações ou deficiências;

II - dificuldades de comunicação e sinalização diferenciadas dos demais alunos, demandando a utilização de linguagens e códigos aplicáveis;

III - altas habilidades/superdotação, grande facilidade de aprendizagem que os leve a dominar rapidamente conceitos, procedimentos e atitudes. (BRASIL, CNE/CBE, 2001 , art. $\left.5^{\circ}\right)$

Desde a CF/88, o atendimento a esses alunos deve ser realizado preferencialmente na rede regular de ensino. Ao longo dos anos, as normatizações sobre a educação especial buscam integrá-los às classes comuns de ensino regular desde a educação infantil, obedecendo à perspectiva de educação inclusiva. Igualmente, para que isso ocorra é preciso que algumas condições estejam presentes, como por exemplo, a eliminação de barreiras que impedem o acesso à escolarização, a criação de serviços de apoio especializado, ações de formação de professores, assegurando as condições necessárias para o acesso, a participação e a aprendizagem desses alunos.

\footnotetext{
${ }^{93}$ Apelação Cível no 77.912-5/9, 1999; Apelação Cível no 76.640-0, 2001.
} 
Questionamentos judiciais envolvendo crianças e adolescentes com necessidades educacionais especiais foram localizados em 17 decisões do TJ-SP, distribuídas entre os anos de 1999 a 2008, conforme o próximo gráfico.

Essas decisões versam sobre a acessibilidade dessas crianças e adolescentes à escola, com a adaptação do prédio escolar para possibilitar livre acesso dos alunos (seis decisões) e transporte escolar (duas decisões); e atendimento especializado das áreas educacional e de saúde (nove decisões).

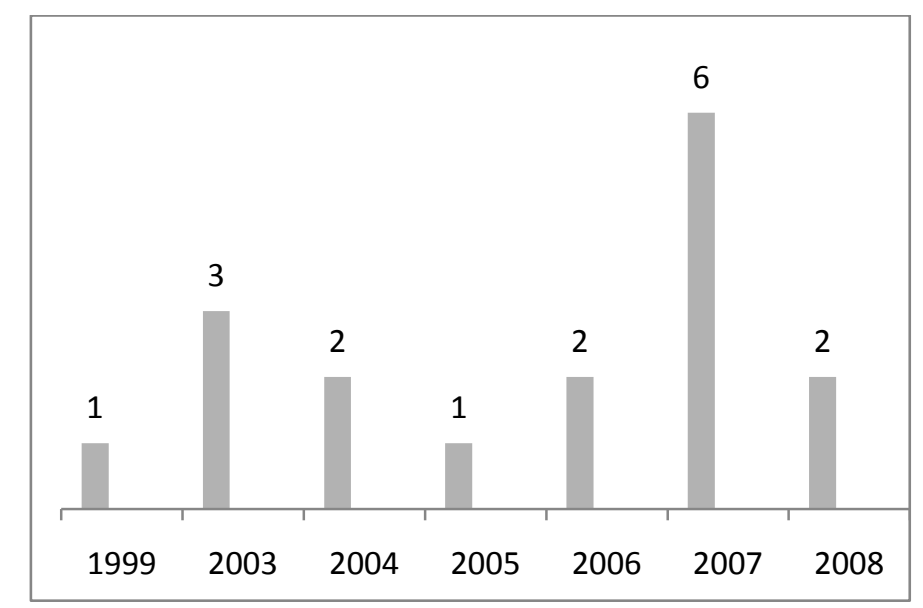

Gráfico 5 - Distribuição anual das decisões envolvendo crianças e adolescentes com necessidades educacionais especiais

Fonte: a autora

Nota-se que, das 17 decisões, em dez o MP atuou como apelante da decisão da $1^{\text {a }}$ instância ou como apelado em confronto com a municipalidade ou com a Fazenda Pública estadual, denotando a importância desta instituição na defesa desses direitos.

As decisões referentes às crianças e adolescentes com necessidades educacionais especiais tiveram maior consenso entre os desembargadores do TJ-SP, pois apenas duas foram aprovadas em maioria, as que solicitavam a remoção de barreiras nas edificações escolares e, em uma delas, decidiu-se pela transferência provisória do aluno para escola já adaptada.

A primeira decisão localizada, versando sobre este tema, foi julgada pelo TJ-SP, em 1999. A Apelação Cível $n^{\circ}$ 56.048-5 foi favorável ao MP, que solicitava a condenação da Fazenda Pública do Estado de SP para a construção de rampa de acesso para pessoa com deficiência física ao pavimento superior de determinada escola estadual. Esse pedido estava fundamentado na $\mathrm{CF} / 88$, nos seguintes artigos que tratam sobre a necessidade de construção e de adaptação dos espaços físicos, garantindo a acessibilidade de todos os cidadãos:

Art. 227, § $2^{\circ}$ A lei disporá sobre normas de construção dos logradouros e dos edifícios de uso público e de fabricação de veículos de transporte coletivo, a fim de garantir acesso adequado às pessoas portadoras de deficiência. 
Art. 244 A lei disporá sobre a adaptação dos logradouros, dos edifícios de uso público e dos veículos de transporte coletivo atualmente existentes a fim de garantir acesso adequado às pessoas portadoras de deficiência, conforme o disposto no art. $227, \S 2^{\circ}$. (BRASIL, 1988).

Na Lei 7.853/89, art. 2º inciso V, alínea a: “a adoção e a efetiva execução de normas que garantam a funcionalidade das edificações e vias públicas, que evitem ou removam os óbices às pessoas portadoras de deficiência, permitam o acesso destas aos edifícios, a logradouros e a meios de transporte".

Na Lei Estadual 9.086/95, art. $1^{\text {o. }}$

Os órgãos da Administração direta e indireta do Estado deverão adequar seus projetos, suas edificações, suas instalações e seu mobiliário ao uso de pessoas portadoras de deficiências, observadas as Normas NBR 9050 da Associação Brasileira de Normas Técnicas. (SÃO PAULO, 1995).

E no ECA, artigo 53:

A criança e o adolescente têm direito à educação, visando ao pleno desenvolvimento de sua pessoa, preparo para o exercício da cidadania e qualificação para o trabalho, assegurando-se-lhes:

I - igualdade de condições para o acesso e permanência na escola;

II - direito de ser respeitado por seus educadores;

III - direito de contestar critérios avaliativos, podendo recorrer às instâncias escolares superiores;

IV - direito de organização e participação em entidades estudantis;

V - acesso à escola pública e gratuita próxima de sua residência.

Parágrafo único. É direito dos pais ou responsáveis ter ciência do processo pedagógico, bem como participar da definição das propostas educacionais. (BRASIL, 1990, art. 53).

A fundamentação legal, para o pedido de condenação, baseava-se na legislação até então promulgada sobre o tema. Normatizações posteriores, como a Lei 10.098, de 19 de dezembro de 2000, e o Decreto $\mathrm{n}^{\circ}$ 5.296, de 02 de dezembro de 2004, que a regulamenta, estabelecem normas gerais e critérios básicos para a promoção da acessibilidade das pessoas portadoras de deficiência ou com mobilidade reduzida.

A liminar solicitava que as aulas fossem ministradas no andar térreo, e a sentença suspendeu o provimento cautelar, que atua como instrumento provisório e antecipado de decisão favorável ao autor, no qual obrigava a Fazenda Pública do Estado de SP a erigir a rampa de acesso ao pavimento superior.

A Fazenda Pública, no recurso ao TJ-SP, alegou ingerência do Poder Judiciário em atividade do Executivo e, no mérito, que havia vaga na escola próxima para atender às necessidades do aluno com deficiência física.

O TJ-SP, em decisão unânime, o relator Desembargador José Raul Gavião de Almeida, determinou uma solução provisória de transferência da aluna para escola mais 
próxima já adaptada, apesar de considerar que a legislação impõe há anos que as escolas e outros estabelecimentos disponham de condições para o trânsito adequado às pessoas com deficiência física. Abaixo, transcreve-se trecho ilustrativo da posição do Desembargador:

Ao juiz não é dado julgar a causa à vista do exclusivo idealismo, afastado da realidade da vida. Não pode desprezar o limite temporal, as restrições materiais e o meio sobre o qual deverá refletir a decisão, como se a semente pudesse produzir o mesmo resultado se lançada em solo fértil ou em chão de cimento duro.

[...] certamente seria ideal que surgisse na escola [...] só "penada" judicial, o acesso adequado a deficientes físicos às salas de aula. Como tal não ocorre, todavia, impõese solução provisória, que mitigue as dificuldades decorrentes da necessária fase antecedente à efetivação do comando inserido na sentença. (APELAÇÃO CÍVEL N ${ }^{\circ}$ 50.048-5, 1999, relator Des. José Raul Gavião de Almeida).

Assim, considerando essas "complicações", o Desembargador optou em sua decisão

por:

[...] submeter uma aluna à escolha entre o transtorno de ser carregada ao andar superior estadual onde está matriculada ou cursar outra, já adaptada e situada cerca de 500m mais longe da casa da menina, a desativar laboratório de línguas que beneficia a educação de quase 500 alunos.

Não se trata da submissão do interesse da minoria ao da maioria, mas de valoração do grau de sacrifício de ambos os lados. A exigência a ser feita da aluna deficiente, de prorrogação dos inconvenientes de ser carregada ou de mudar para escola não distante, é menor que o dano irreversível de tolher, de massa escolar considerável, período de estudo específico. (APELAÇÃO CÍVEL No 50.048-5, 1999, relator Des. José Raul Gavião de Almeida).

Nesta ação, a solução dada pelo TJ-SP, transferindo a aluna para uma escola já adaptada, manteve a situação atual de não atendimento à legislação que dispõe sobre a adaptação dos prédios, tendo o aluno que buscar outra escola para que seu direito à educação fosse respeitado.

O MP também ingressou com várias ações civis públicas no município de Ribeirão Preto, requerendo a condenação da Prefeitura Municipal com relação à obrigação de fazer as devidas reformas e adaptações em determinados prédios escolares, com a instalação de elevador, colocação de corrimão em todas as escadas e reativação do banheiro existente para pessoas com deficiência. Em primeira instância, o processo foi extinto por ilegitimidade ativa do MP, sendo revisto pelo TJ-SP, em 2003. Em recurso, o MP sustentou a sua legitimidade para propor a ação "pois não objetiva proteger pequeno grupo de pessoas portadoras de deficiência, e sim garantir, no âmbito difuso, o acesso, na atualidade e no futuro, de qualquer pessoa portadora de deficiência à aludida escola, seja aluno, pai de aluno, professor ou qualquer interessado em ingressar no local” (APELAÇÃO CÍVEL nº 231.136-5/9-00, 2003).

Para o TJ-SP, o MP tem legitimidade para propor a ação e a ré (Prefeitura Municipal), "no tocante ao prédio escolar mencionado na inicial, deixou de cumprir preceitos constitucionais e a legislação infraconstitucional”. Portanto, o recurso do MP é julgado 
procedente e a ré condenada ao cumprimento da obrigação no prazo de um ano, sob pena diária de $\mathrm{R} \$ 120,00$.

Já em outra ação, também do município de Ribeirão Preto, o juiz em $1^{\text {a }}$ instância julgou improcedente o pedido por não haver "comprovação da essencialidade da alteração arquitetônica para o fim pleiteado, inexiste prova da existência de alunos portadores de deficiência ali matriculados, por tal imprópria a pretensão à implantação, sem prévio levantamento e apuração da necessidade". O recurso do MP no TJ-SP foi provido por maioria. O Desembargador Laerte Sampaio, em declaração de voto vencido, defendeu que a adaptação com a instalação de elevadores, rampas e banheiros implicaria em gastos elevados para a administração municipal, sendo possível mediante divisão por diversos orçamentos anuais (APELAÇÃO CÍVEL no 244.253-5/2-00, 2004).

Sob certos aspectos, concorda-se parcialmente com o argumento do Desembargador, pois a adaptação de todos os prédios escolares em um único ano pode comprometer o desenvolvimento de demais políticas educacionais, sendo preciso criar um cronograma para a adaptação e exigir que os novos prédios já sejam construídos para a acessibilidade de todas as pessoas.

Em outra decisão da Comarca de Ribeirão Preto, também versando sobre a obrigação da Fazenda Pública proceder às devidas reformas e adaptações necessárias no prédio de uma escola estadual, o juízo em $1^{\mathrm{a}}$ instância aceitou como procedente o pedido do MP, ao contrário das duas anteriores que traziam o mesmo pedido. Determinando que a obra fosse realizada até o término do segundo ano após o trânsito em julgado desta sentença, o que possibilitaria a adaptação das respectivas despesas no orçamento.

Nessa ação, a Fazenda Pública alegou que a Lei Federal n n $^{\circ} .853$, de 24 de outubro de 1989, que estabelece normas gerais acerca da proteção e integração social das pessoas portadoras de deficiência física, "é inaplicável ao Estado de São Paulo, uma vez que depende de regulamentação para tornar-se exigível, e que tal matéria, ainda que relevante do ponto de vista social, deverá conformar-se aos critérios de conveniência e oportunidade da Administração Pública" (APELAÇÃO CÍVEL no 275.964-5/9-00, 2005).

O TJ-SP ratificou a decisão de $1^{a}$ instância, e o relator Desembargador Nilton Gordo postulou que a sentença deu "exemplar solução à controvérsia" ao determinar prazo para a conclusão da adaptação, e alegou que condicionar a aplicabilidade de um direito à "edição de lei estadual, que passados dezesseis anos da Constituição Federal, não foi providenciada, constitui sem dúvida, reprovável conduta, que fere, inclusive, princípios éticos e ostenta 
flagrante inconstitucionalidade por omissão". Ainda, justificou: "A obra é de pequena monta, a sua repercussão financeira é mínima, enquanto que o direito humano protegido é imensurável” (APELAÇÃO CÍVEL no 275.964-5/9-00, 2005).

Em um Agravo de Instrumento $\mathrm{n}^{\circ}$ 668.490-5/5, de 2007, questionando as adaptações necessárias para a frequência de aluno com deficiência física, o recurso invocava o art. $1^{\circ}$, inciso III da $\mathrm{CF} / 88$ : "ninguém será submetido a tortura nem a tratamento desumano ou degradante", o art. 227, inciso II, 208 da CF/88 e art. 11 da Lei n ${ }^{\circ}$ 10.098/00. O TJ-SP concedeu o prazo de dez dias para que se fizessem as adaptações necessárias no banheiro, e o deslocamento temporário da turma para uma sala situada no pavimento térreo.

Depreende-se, da análise dessas decisões, que as adaptações requeridas são restritas aos obstáculos de natureza arquitetônica, contemplando às pessoas com deficiência física, não sendo localizadas ações e alegações nas ações sobre as adaptações que garantiriam a eliminação de barreiras envolvendo a comunicação.

O Decreto $\mathrm{n}^{\mathrm{o}}$ 5.296, de 02 de dezembro de 2004, define acessibilidade como “condição para utilização, condição para utilização, com segurança e autonomia, total ou assistida, dos espaços, mobiliários e equipamentos urbanos, das edificações, dos serviços de transporte e dos dispositivos, sistemas e meios de comunicação e informação, por pessoa portadora de deficiência ou com mobilidade reduzida" (art. $8^{\circ}$, inciso I). As barreiras, obstáculos que limitem ou impedem o acesso, a liberdade de movimento, circulação com segurança e possibilidade de as pessoas se comunicarem ou terem acesso à informação devem ser eliminados nas áreas urbanísticas, edificações, transportes, comunicações e informações (art. $8^{\circ}$, inciso II).

O transporte adaptado às crianças e adolescentes com necessidades educacionais especiais foi requerido em duas ações ${ }^{94}$ e concedido em ambas, através de liminares. Segundo o TJ-SP, o direito líquido e certo está patente no artigo 54, inciso VII do ECA, ao enfatizar que é dever do Estado assegurar à criança e ao adolescente atendimento no EF, através de programas suplementares de material didático-escolar, transporte, alimentação e assistência à saúde $^{95}$.

O atendimento especializado às crianças e adolescentes com necessidades especiais foi julgado em nove ações, como já referido. As contestações dos réus, municípios e Fazenda Pública Estadual estavam fundamentadas, entre outros argumentos: normas constitucionais que regem a matéria são de eficácia reduzida, impossibilitando a sua aplicação imediata;

\footnotetext{
${ }^{94}$ Agravo de Instrumento no 326.326-5/3-00, 2003, Apelação Cível no 110.690-0/5-00, 2004.

${ }^{95}$ Apelação Cível no 110.690-0/5-00, 2004.
} 
limitações orçamentárias para o cumprimento da sentença; ingerência do Poder Judiciário na esfera de atuação do Executivo; impossibilidade de multa contra a Fazenda Pública.

Sobre essas alegações, o Desembargador Canguçu de Almeida discorreu, na Apelação Cível $\mathrm{n}^{\circ}$ 149.235.0/0-00, 2007, que a saúde é um direito social assegurado na CF/88 e no ECA, ao estabelecer atendimento educacional especializado às pessoas com deficiência (art. 11). E, explanou que "insuficiência de verbas ou dificuldades impostas pela legislação não podem impedir que menores que necessitam de atendimento fiquem à mercê de planejamento orçamentário". A respeito da inaplicabilidade "imediata das normas constitucionais invocadas pelo autor, eis que o bem estar e a vida das crianças e adolescentes são bens jurídicos que devem ser protegidos pelo Estado incondicionalmente", não podendo também abordar a indevida intromissão do Judiciário no âmbito de atuação de outro Poder. Assim, a compreensão é de que:

[...] a todo direito corresponde uma ação que o assegura, e se todas as crianças nas condições estipuladas pelo Estatuto da Criança e do Adolescente são titulares do direito e podem exigi-lo em juízo, a determinação judicial do cumprimento desse dever pelo Estado não significa uma suposta ingerência do Judiciário no âmbito da administração, eis que não há discricionariedade do administrador quando se trata de direitos imediatamente aplicáveis. (APELAÇÃO CÍVEL nº 149.235.0/0-00, 2007, relator Des. Canguçu de Almeida).

Nesta decisão foi estipulada uma multa, segundo o desembargador, para servir de meio de coerção do réu para o cumprimento da obrigação. A apelação foi provida quanto ao pedido de redução do montante para $\mathrm{R} \$ 1.000,00$ por dia, com os valores destinados ao Conselho dos Direitos da Criança e do Adolescente do Município de SP.

$\mathrm{O}$ atendimento educacional especializado também foi objeto de dois recursos ${ }^{96}$ no TJSP, julgados em 2009, com concessão do direito à criança sob o argumento da norma constitucional de proteção à saúde pública. Numa das ações, a criança tinha acompanhamento multidisciplinar (médico e fisioterapêutico) junto à Associação de Assistência à Criança Deficiente (AACD), mas nunca frequentara qualquer estabelecimento de ensino por falta de vagas; julgou-se procedente a condenação do município a prestar ao autor atendimento educacional especializado, em estabelecimento público próximo de sua residência ou a ressarcir as despesas de frequência em estabelecimento privado, além do dever de garantir transporte adequado, também gratuito. Em outro recurso, reivindicava-se a continuidade da concessão de bolsa de estudo especial para aluno com paralisia cerebral, sendo também julgado procedente.

\footnotetext{
${ }^{96}$ Apelação cível com revisão n o 564.314-5/5-00, 2007 e Apelação Cível nº 644.051-5/7-00; 2007.
} 
Os municípios de São Paulo e Araraquara alegaram nos recursos que a sentença ofendia a discricionariedade administrativa e a independência de poderes. O Desembargador Magalhães Coelho, relator das decisões no TJ-SP, contrapôs:

Longe de se ver aqui, uma norma programática, recurso pelo qual usualmente os administradores públicos se escusam de cumprir as obrigações que lhes são dirigidas pela Constituição Federal, há que se ver uma norma impositiva de eficácia plena, que objetiva tornar real e não meramente retórico o direito à vida proclamado no art. $5^{\circ}$ da Constituição Federal.

$[\ldots]$

A Municipalidade de São Paulo não compreendeu bem, o que é profundamente lamentável, que o que está em causa é o direito à vida, bem supremo que é tutelado constitucionalmente.

$[\ldots]$

$\mathrm{O}$ argumento tão ao gosto dos burocratas de que o reconhecimento desse direito essencial ao cidadão do acesso a saúde, pode implicar em comprometimento de outras políticas públicas de saúde não prevalece.

Basta se proceda a uma gestão racional, eficiente e honesta da coisa pública.

Se o Estado não atingiu, ainda, o grau ético necessário a compreender essa questão, deve ser compelido pelo Poder Judiciário, guardião da Constituição, a fazê-lo. Não há, por outro lado, qualquer ofensa à discricionariedade administrativa.

[...] Portanto, implementar ou deixar de implementar políticas de saúde pública não é questão afeta à subjetividade do administrador.

Essa postura do administrador público pode e deve ser controlada pelo Poder Judiciário que é, também, um Poder político no sentido de que comprometido com o bem comum - e com a implementação dos valores que formam a base do Estado Democrático e Social de Direito albergado na Constituição Federal. (APELAÇÃO CÍVEL nº 644.051-5/7-00, 2007, relator Des. Magalhães Coelho, grifos do autor).

Para a sua fundamentação, o Desembargador Magalhães Coelho citou um acórdão do Tribunal de Justiça do Rio Grande do Sul, do Desembargador Sergio Gischkow Pereira, sobre a implementação de programa de internação e semiliberdade para adolescentes infratores, na qual consta uma extensa análise da discricionariedade administrativa e independência dos poderes, valendo-se de diversos juristas, como Celso Antonnio Bandeira de Mello, Maria Sylvia Zanela Di Pietro, Mauro Capelletti. Em síntese, sua posição é pelo não provimento do recurso da municipalidade:

Portanto, desenvolver políticas de assistência educacional e de saúde especifica aos deficientes físicos e mentais não é questão afeta à subjetividade do administrador.

Nessa implementação terá espaços de liberdade, de discricionariedade, mas não pode ele, simplesmente, ignorar as diretrizes que lhe são dirigidas pela Constituição Federal. (APELAÇÃO CÍVEL n 644.051-5/7-00, 2007, relator Des. Magalhães Coelho).

A posição do TJ-SP, na confirmação de decisões obrigando a municipalidade a oferecer atendimento educacional especializado às crianças e aos adolescentes com necessidades especiais, é também ressaltada na seguinte decisão, proferida pelo Desembargador Sidnei Beneti:

Feitas tais considerações, infere-se, do caso em exame, o direito concedido às crianças e adolescentes portadores de deficiência física ou mental de receberem 
atenção especial no âmbito educacional. Com efeito, emerge com clareza ser dever do Estado, em suas três esferas de atuação, proporcionar atenção especial à criança e ao adolescente portador de deficiência física. Já quanto à educação, a ela garante-se o efetivo acesso, incluindo-se o transporte aos estabelecimentos de ensino (artigo 208, inciso VII, da Constituição Federal), conferindo-se atenção especial àqueles portadores de deficiência física ou mental (inciso III, do mesmo dispositivo constitucional). Por evidente que esta prioridade se estende à proteção à saúde, conforme se depreende no artigo $11, \S \S 1^{\circ}$ e $2^{\circ}$ do ECA. (APELAÇÃO CÍVEL n ${ }^{\circ}$ 138.002-0/1-00, 2006, relator Des. Sidnei Beneti).

Portanto, fica definida a obrigação da Administração Pública no sentido de proporcionar atendimento educacional especializado, subsistindo, no âmbito da discricionariedade administrativa, o modo como irá efetivar essa obrigação, custeando-a diretamente ou mediante isenção tributária.

Nos municípios que não dispunham de instituição especializada para o atendimento específico às necessidades das crianças e dos alunos foi requerido o pagamento de bolsa de estudo em instituições privadas; todas as decisões concederam às crianças e aos adolescentes o direito à provisão, por parte do município, da manutenção da matrícula em estabelecimentos de EF e EI.

Cumpre lembrar que a LDB/96, art. 60, prevê que os órgãos normativos estabeleçam critérios de caracterização das instituições privadas sem fins lucrativos, especializadas e com atuação exclusiva em educação especial, para apoio técnico e financeiro. Sendo que a alternativa preferencial é a ampliação do atendimento na própria rede pública regular de ensino.

\subsection{Permanência do aluno na escola}

O atendimento ao direito à educação não se faz somente garantindo a vaga para todos os cidadãos. A legislação brasileira contempla diversos outros direitos, como a garantia de "programas suplementares de material didático-escolar, transporte, alimentação e assistência saúde (CF, art, 208, inciso VII), escola gratuita próxima de sua residência (ECA, art. 53, inciso V), facultando a requisição de transporte escolar na falta de unidade próxima, gratuidade do ensino público em estabelecimentos oficiais (CF, art. 206, inciso IV), igualdade de condições para acesso e permanência na escola (CF, art. 206, inciso V), garantia do padrão de qualidade (CF, art. 208, inciso VII). Essas declarações criam mecanismos que contribuem 
para a permanência do aluno na escola, fazendo com que o Poder Público mantenha uma oferta regular da prestação da educação e que esta seja de qualidade para todos.

Ao todo 36 decisões discutiram a permanência das crianças e adolescentes nas escolas, sejam ela por meio de impedimentos dados como punição por violação às normas das escolas, cancelamento de matrícula em cursos de língua estrangeira e evasão escolar.

\subsubsection{Penalidades por violação às normas escolares}

O TJ-SP entendeu como inválida a transferência compulsória de alunos, da escola que cursavam para outra, seja por violação às normas escolares em ato ilegal, seja por agressão física a outro aluno, quando não foram precedidas do cumprimento das formalidades legais.

O Decreto Estadual no 10.623, de 26 de outubro de 1977, sobre o Regimento Comum das Escolas Estaduais de Primeiro Grau" ${ }^{97}$, dispõe no seu art. 63, § $3^{\text {o }}$ que "nos casos de transferência compulsória a apuração da culpabilidade será procedida por uma comissão de professores da escola, designados pelo Diretor, tendo o aluno direito à defesa, assistido, se menor, por seu pai ou responsável”.

Discussão do assunto em reunião de Conselho de Escola ou de professores, direito de ampla defesa do aluno sob responsabilidade dos pais, por meios e recursos adequados são algumas das normas constantes nos próprios Regimentos das escolas que precisam ser seguidas para a imputação de transferência compulsória aos alunos indisciplinados, segundo as decisões proferidas pelo TJSP. Também é preciso que a convocação para a reunião do Conselho de Escola especifique a imputação feita ao aluno.

Segundo o TJ-SP, a ampla defesa aos alunos que violaram as normas disciplinares dos Regimentos Escolares é, também, um procedimento que deve obedecer ao que prescreve a $\mathrm{CF} / 88$, art. 5', inciso LV: "aos litigantes, em processo judicial ou administrativo, e aos acusados em geral são assegurados o contraditório e ampla defesa, com os meios e recursos a ela inerentes".

Para o Desembargador Dirceu de Mello, o ato infracional cometido pelo aluno não foi recusado, mas é preciso respeitar as formalidades legais para a realização da transferência:

\footnotetext{
${ }^{97}$ Normatização citada na Apelação Cível no 28.805-0, 1999.
} 
Mas não é por causa da gravidade da conduta do aluno, ou por causa de sua inadaptação ao meio, que se poderá atropelar as formalidades legais para sua transferência forçada. O comportamento que ele apresenta torna-o em tese, passível de sanção disciplinar, não há dúvida. Mas há que se observar, que para aquele fim, a estreita legalidade. Na espécie, descurou-se desse dever. (APELAÇÃO CÍVEL n ${ }^{\circ}$ 28.805-0, 1999, relator Des. Dirceu de Mello).

Já a penalidade de transferência de aluno com atos de indisciplina para outro turno escolar foi confirmada pelo TJ-SP, pois a ampla defesa e o contraditório foram assegurados ao aluno, ao conceder-lhe participação na reunião do Conselho Escolar que decidiu sobre a transferência, acompanhado dos pais e advogado, em alguns casos. Segundo o Desembargador José Raul Gavião de Almeida, o Conselho de Escola tem competência para a aplicação da penalidade. Posição também defendida pelo Procurador do Estado sobre a atuação do Conselho de Escola: “o rigor formal do processo não existe para os atos administrativos escolares. $\mathrm{Na}$ escola a informalidade administrativa prevalece, pois o ambiente de ensino impõe postura distinta daquela processual. Daí o fato de o Conselho Escolar ter doze professores para suprir a falta de prévio pronunciamento do corpo docente". O Desembargador afirmou ainda que a penalidade além das vantagens pedagógicas preserva a hierarquia escolar e o necessário respeito aos educadores (APELAÇÃO CÍVEL nº 83.093-5, 1999).

Em recurso sobre medida aplicada a aluno da pré-escola, com afastamento das aulas por período indeterminado, o TJ-SP julgou que a conduta disciplinadora foi ausente de proporcionalidade com o ato, e a legislação não prevê a prática de afastamento sumário. A escola argumentou que durante quatro anos a criança cometeu duas indisciplinas, uma por eventuais refúgios no sanitário, e outra, pela negação de participação em atividade escolar. $\mathrm{Ou}$ seja, os atos cometidos pela criança, que deveria ter entre quatro e seis anos, podem ser considerados normais para essa idade, cabendo à escola, no conjunto das suas funções, orientar esse aluno e não simplesmente afastá-lo do ambiente escolar.

A aplicação de sanção maior do que a prevista no Regimento Escolar, e antes do final da sindicância, concedendo o devido processo de defesa do aluno, também foi julgada como incorreta pelo $\mathrm{TJ}-\mathrm{SP}^{98}$.

O Tribunal, em recurso sobre a aplicação de pena de advertência e de suspensão em estabelecimento escolar, em razão da distribuição de folhetins, com o uso de pseudônimo, sem permissão legal da direção da escola ${ }^{99}$, decidiu pela inexistência do direito líquido e certo da aluna. Isso porque a $\mathrm{CF} / 88$, ao assegurar a livre manifestação do pensamento, veda o

\footnotetext{
${ }^{98}$ Apelação Cível no $107.687-5,2000$.

${ }^{99}$ Apelação Cível no 27.984-5, 1998.
} 
anonimato, inexistindo ilegalidade ou abuso de poder da direção. A aluna alegou que não infringiu as normas do Regimento Interno da escola, e que o ato da direção da escola violou as normas constitucionais da livre manifestação do pensamento (art. $5^{\circ}$, inciso IX; 206, inciso II; 216, inciso I e $220, \S 6^{\circ}$ ).

A proibição da entrada na escola foi imposta ao aluno que estava sem o uniforme completo, camisa escolar e calça tipo tactel de cor azul marinho. $\mathrm{O}$ aluno registrou boletim de ocorrência, pois trajava somente a camiseta da escola. O TJ-SP entendeu que a exigência era abusiva, confirmando a tutela antecipada ${ }^{100}$, embasada na Lei Estadual $\mathrm{n}^{\circ} 3.913 / 83$, que proibia expressamente a instituição do uso obrigatório de uniforme pelos estabelecimentos oficiais, sem maior aprofundamento.

Todas essas ações foram ajuizadas individualmente, tendo como apelados ou apelantes as crianças e adolescentes representados pelos seus pais e os diretores das unidades escolares.

\subsubsection{Indeferimento de matrícula em cursos de língua estrangeira}

Entre os anos de 2006 a 2008, surge no TJ-SP um novo conflito envolvendo a SEE. São questionamentos sobre o indeferimento de matrícula de adolescentes em cursos de língua estrangeira oferecidos pela rede estadual.

Os Centros de Estudos de Línguas (CELs) foram criados na rede estadual de ensino, pelo Decreto $n^{\circ}$ 27.270, de 10 de agosto de 1987, como uma medida para a introdução da língua espanhola, já que no currículo estadual paulista o estudo da língua estrangeira moderna concentrava-se no ensino do inglês. A Resolução SEE nº 271, de 20 de novembro de 1987, dispôs sobre o funcionamento e as atividades dos CELs. No primeiro ano, ficou autorizado exclusivamente o ensino de língua espanhola.

A Resolução SEE $n^{\circ}$ 85, de 13 de agosto de 2001, dispõe sobre o funcionamento dos CELs, tendo estes a finalidade de ampliar as oportunidades de acesso aos estudantes da rede estadual a uma segunda língua estrangeira moderna.

${ }^{100}$ Agravo de Instrumento n ${ }^{\mathrm{o}} 530.756-5 / 8-00,2006$. 
Segundo a SEE, em 2009 os CELs atendiam, por semestre, cerca de 50 mil alunos da rede estadual, distribuídos em 77 Centros, 17 no município de São Paulo, 12 na Região Metropolitana e 44 em diferentes municípios do Estado ${ }^{101}$.

Para matricular-se o aluno deve comprovar, mediante atestado de matrícula, ser atendido pela rede estadual de ensino, e optar por um idioma de seu interesse.

As ações versando sobre o impedimento de matrícula ou rematrícula foram ingressadas pelos alunos individualmente ou em conjunto com demais interessados, representados por seus pais. Os motivos para a negativa da SEE vinculavam-se ao não preenchimento dos requisitos necessários para frequentar os CELs, dispostos na Resolução SEE $n^{\circ} 85 / 2001$, sendo o principal não estar mais matriculados na rede estadual. Muitos alunos cursaram vários estágios no CEL e tiveram sua rematrícula indeferida, porque estavam frequentando escolas particulares ou porque concluíram o EM.

A Fazenda Pública estadual justificou, no recurso, o não preenchimento dos requisitos necessários para a matrícula, e que a rede estadual não estaria obrigada a atender a todos que procuram o curso de línguas, além do que a obrigação estabelecida na $\mathrm{CF} / 88$ não se refere às atividades extracurriculares.

O TJ-SP julgou que o impedimento de rematrícula afrontava o direito líquido e certo dos adolescentes, não admitindo a interpretação restritiva dada pela Fazenda Pública sobre a obrigatoriedade de oferta dos cursos, observando que "os cursos de línguas estrangeiras, a toda evidência, não podem ser havidos como estranhos ao dever do Estado com a educação, além do que o artigo 208, inciso $\mathrm{V}$, da CF/88 garante o acesso aos níveis mais elevados do ensino, da pesquisa e da criação artística, segundo a capacidade de cada um”. Outro argumento do TJ-SP relaciona-se ao Decreto que criou os CELs, pois este não determinou o desligamento dos alunos que estejam frequentando escolas particulares. Além de a determinação legal ser discriminatória ao "tratar os iguais de modo desigual, sem qualquer razoabilidade" (APELAÇÃO CÍVEL no 253.606-5/5-00, 2006, relatora Desembargadora Constança Gonzaga).

Em uma ação ${ }^{102}$, o Desembargador Oliveira Santos postulou que os CELs têm suas vagas destinadas aos alunos da rede pública estadual de ensino, contudo a Resolução regulamentadora desse critério não disciplinou a situação do aluno que concluiu o EM, sem o término do curso de línguas. Então, se na Resolução não existe esta norma, não é possível restringir a matrícula, sob pena de ofensa aos princípios constitucionais. Para o

\footnotetext{
${ }^{101}$ Informações disponíveis em: http://cenp.edunet.sp.gov.br/CEL/historia.asp. Acesso em 28 out. 2009.

102 Apelação Cível no 265.433-5/8-00, 2006.
} 
Desembargador Antonio C. Malheiros ${ }^{103}$, o fato de ter concluído o EM não deve ser obstáculo à conclusão de curso complementar oferecido pela escola pública.

A aluna que pediu sua transferência para escola privada, no caso em exame para o Sesi, teve também assegurada a sua matrícula pelo TJ-SP:

É verdade que a matrícula em curso de línguas não está expressamente elencada como modalidade de ensino obrigatório na Constituição Federal. Porém, não é menos verdade que a conclusão de tal curso propiciará à apelada melhor capacitação profissional, o que indubitavelmente, é garantido pelo preceito constitucional. (APELAÇÃO CÍVEL nº 465.757-5/4-00, 2008, relator Des. Rubens Rihl).

Decisão da $2^{\text {a }}$ Câmara de Direito Público, relatada por Samuel Júnior, refere que a escola ao efetuar a matrícula inicial de um aluno tinha pleno conhecimento que ele poderia concluir o EM antes do término do curso de língua. Portanto, "não pode no meio do curso, levantar objeções de ordem puramente burocráticas, tirando a oportunidade da diligente aluna em aprender uma segunda língua estrangeira, o que contraria a própria finalidade da prestação de serviços de ensino de caráter público". (APELAÇÃO CÍVEL no 335.747-5/5-00, 2007).

Posição contrária é apresentada em ação julgada em 2007, também na $2^{\mathrm{a}}$ Câmara de Direito Público, com votação unânime, fazendo parte do julgamento o Desembargador Samuel Júnior, relator da decisão analisada anteriormente, acatando que os dispositivos da Resolução SEE 271/87 que cria os CELs, e a Resolução 85/2001 vedam a rematrícula de exalunos que concluíram o EM, considerando que esta somente pode ser efetuada por aqueles que comprovem, na data da matrícula, sua condição de aluno da rede pública estadual. Não podendo cursar os módulos restantes após a conclusão do EM pela "ausência de direito adquirido na espécie". (APELAÇÃO CÍVEL n n 276.057-5/7-00, 2007, relatora Desembargadora Christine Santini). Destaca-se que essa foi a única decisão contrária ao pedido dos alunos em $1^{\mathrm{a}}$ instância, oriunda da Comarca de São Paulo.

A SEE, na Resolução n ${ }^{\circ}$ 91, de 13 de dezembro de 2005, acrescentou um dispositivo permitindo "ao aluno concluinte do $3^{\circ}$ ano do Ensino Médio a continuidade de estudos no Centro de Estudos de Línguas - CEL, por até 2 (dois) semestres, desde que esses estudos sejam subseqüentes ao ano de certificação do Ensino Médio".

Essa alteração pode ter sido influenciada pelas diversas ações judiciais ingressadas por alunos concluintes do EM na rede estadual, que concederam o direito à continuidade no curso.

Outro aspecto referente a esta alteração diz respeito à data da legislação, todavia as ações judiciais versando sobre esta questão são apreciadas em recurso pelo TJ-SP nos anos de 2006 a 2008, evidenciando a demora na apreciação da ação.

\footnotetext{
${ }^{103}$ Apelação Cível no 292.581-5/5-00, 2007.
} 


\subsubsection{Evasão escolar}

A requisição de abertura de sindicância para a apuração de evasão escolar foi abordada em quatro ações. Em uma ação ${ }^{104}$, proposta pelo MP de Sumaré, essa verificação era solicitada ao Poder Judiciário, e foi julgada como improcedente, com a justificativa de que tanto o ECA como a Lei de ação civil pública fixaram ao MP poderes requisitórios para apuração de fatos ofensivos aos direitos difusos e coletivos, no caso em exame, da infância e juventude e não ao Judiciário.

No mesmo sentido, em recurso do MP pleiteando para que fossem levadas a efeito as investigações a respeito de faltas injustificadas de diversos alunos, o TJ-SP julgou que a “função supletiva, do juízo da infância e da juventude, nos locais onde não tenha sido constituído o Conselho Tutelar, deve respeitar as limitações da estrutura disponível, procedendo-se a apurações somente dos casos, que, por sua singularidade, venham a apresentar contornos de anormalidades e demandem a adoção de medidas protetivas". (APELAÇÃO CÍVEL nº 62.956-0/6, 2000, relator não informado).

Porém, em decisão também de Sumaré, o TJ-SP proveu o recurso, determinando o prosseguimento do procedimento com vistas a apurar a responsabilidade por evasão escolar na Comarca. O Desembargador Álvaro Lazzarini, relator do recurso, e também integrante do julgamento anterior que não concedeu o recurso. Afirmou que embora o ECA outorgasse ao MP poderes investigatórios afetos à criança e ao adolescente o Magistrado também tem competência para apurar, mesmo de ofício, eventual infração:

Trata-se de fardo pesado, mas que não pode ser aliviado com a mera não realização destes atos.

Os anseios e carências de nosso povo não podem ser resolvidos, infelizmente, de forma isolada, pelo Poder Judiciário, mas não é possível deixar de corresponder àquelas expectativas, ainda que sob duras penas, quando se percebe que os demais órgãos do Estado não estariam cumprindo o papel que prioritariamente lhes fora destinado. (APELAÇÃO CÍVEL no 72.407.0/0-00, 2001, relator Des. Álvaro Lazzarini).

Em outra ação, com pedidos de providência para a apuração da evasão escolar ${ }^{105}$, o TJ-SP julgou que não houve esgotamento dos recursos escolares, determinando a expedição de ofício à Diretoria Regional de Ensino para que tomasse as medidas pertinentes.

\footnotetext{
${ }^{104}$ Apelação Cível no 64.579.0/0-00, 2000.

${ }^{105}$ Apelação Cível no 63.069-0/5, 2000.
} 
O ECA, art. 56, inciso II, determina que os dirigentes de estabelecimentos de Ensino Fundamental comuniquem ao Conselho Tutelar os casos de "reiteração de faltas injustificadas e de evasão escolar". E a LDB/96, com o inciso VIII, art. 12, incluído pela Lei $\mathrm{n}^{\circ} 10.287$, de 20 de setembro de 2001, estabelece que os estabelecimentos de ensino deverão "notificar ao Conselho Tutelar do Município, ao juiz competente da Comarca e ao respectivo representante do Ministério Público a relação dos alunos que apresentem quantidade de faltas acima de cinqüenta por cento do percentual permitido em lei”.

Embora essa legislação determine o encaminhamento da relação dos alunos com número excessivo de faltas, para que medidas sejam adotadas para evitar a evasão da escola torna-se importante estabelecer uma divisão de competência para cada uma das três entidades (Conselho Tutelar, Ministério Público e Vara da Infância e Juventude) no que concerne a citado problema, pois como visto nas decisões, os juízes possuem limites para a ação investigativa.

\subsection{Responsabilidade estatal}

Esta seção discute as decisões que versam sobre a responsabilidade do Estado quanto ao oferecimento de transporte escolar, às condições de funcionamento das escolas e aos acidentes, agressões, mortes ocorridas com alunos nos estabelecimentos de ensino, visando, neste último grupo, indenizações morais e/ou materiais.

\subsubsection{Transporte escolar}

A implantação de programas de transporte escolar aos alunos do Ensino Fundamental é assegurada pela $\mathrm{CF} / 88$, art. 208, inciso VII, como um dos deveres do Estado para com a educação; reafirmada pela LDB/96, art. $4^{\circ}$, inciso VIII. O ECA, ao assegurar às crianças e aos adolescentes o direito de acesso à escola pública e gratuita próxima de sua residência, favorece a exigibilidade do transporte escolar para aqueles que estão matriculados em escolas distantes. 
As ações em recurso julgadas pelo TJ-SP, requerendo esse direito, são majoritariamente propostas pelo MP, com demandas que focalizam interesses difusos e coletivos. Ou seja, exigindo a implementação e/ou continuidade de um programa essencial para que as crianças tenham acesso às escolas e nelas permaneçam. Esses litígios foram decididos de maneira diferenciada pelo TJ-SP, como indicado na análise das decisões abaixo.

Em uma ação sobre a obrigação da municipalidade de São Carlos de oferecer transporte para alunos residentes na zona rural, o TJ-SP entendeu que esse serviço deveria ser implementado, segundo a $\mathrm{CF} / 88$, por programas suplementares. E, prevalecendo a ausência de dados que comprovassem que o município não garantia o acesso das crianças ao EF, salvo a alegação de que não há transporte de um local para o outro, concedeu o recurso à municipalidade, sob o argumento da não ingerência do Judiciário em atividade do Poder Executivo:

Como ao Executivo-Municipal cabe o dever de fixar as prioridades de sua administração, frente a alegações iniciais, ora reavaliadas, numa análise preliminar da questão posta em Juízo constata-se inexistir elementos suficientes para entender deva ser garantido, aos educandos, o transporte ao seu acesso e permanência na escola, conforme ocorreu, sob pena de o Judiciário vir a deliberar sobre atos próprios do Executivo, pois não há a identificação clara da ação Municipal nesse sentido, o que é imprescindível. (AGRAVO DE INSTRUMENTO nº 55.367-0/1, 1999, relator Des. Alvaro Lazzarini).

A partir dessa decisão, indaga-se: como os alunos chegariam até a escola se foi comprovada a inexistência do serviço? Este fato não bastaria para comprovar a ausência de um dever que deveria ser assegurado?

Em outro recurso ao TJ-SP, a Câmara Especial julgou improcedente o pedido que determinava ao município que providenciasse transporte escolar para um adolescente. Entendeu que o pedido era abusivo, dada a ingerência na Administração Pública Municipal e que a determinação do art. 208 da $\mathrm{CF} / 88$ é uma norma programática, devendo ser regulamentada:

[...] não aflorou legislação ordinária que regrasse o transporte escolar como norma programática, no simples fato de que depende de disciplina específica, por exemplo, se o transporte será individual ou coletivo, limitando-se ou não a escolas públicas, se do dever do transporte é do Estado ou do Município ou, de cada qual, tendo-se como norte o fato da escola ser municipal ou estadual, além de tantas outras questões que orbitam a temática. (AGRAVO DE INSTRUMENTO n 71.061-0, 2000, relator Des. Hermes Pinotti).

Como o aluno estava matriculado na rede estadual, e requisitava a obrigação do oferecimento do serviço ao município, o TJ-SP entendeu que este não tem o dever de fornecer o transporte para as escolas estaduais. 
O pagamento do serviço de transporte escolar é realizado, na maioria dos casos, pelos municípios. Somente em 2003, com a alteração na LDB/96, pela Lei no 10.709, de 31 de julho de 2003, os artigos 10 e 11 indicaram a co-responsabilização de Estados e Municípios na oferta de transporte escolar da sua rede.

Outra justificativa apresentada pelo TJ-SP para a não concessão refere-se à ingerência do Poder Judiciário em ato administrativo ligado à destinação de recursos:

\begin{abstract}
Assim, sem adentrar no mérito da Ação Civil Pública proposta, é possível adiantar que o pedido de antecipação de tutela, conquanto revelador do zelo e da preocupação da nobre Promotoria de Justiça, gira em esfera imprópria, porquanto a assinação de obrigação que envolva análise do juízo de conveniência e oportunidade da Administração Pública, com ordem de aplicação dos recursos públicos em área cuja dotação original não se discute na ação (se os recursos destinados estão sendo aplicados ou não), escapa do controle de legalidade dos atos administrativos, na medida em que invade-se o próprio exame do mérito administrativo, constituindo verdadeira ingerência na administração pública. (AGRAVO DE INSTRUMENTO no 71.061-0, 2000, relator Des. Hermes Pinotti).
\end{abstract}

Já em outro recurso ${ }^{106}$, relatado pelo Desembargador Nigro Conceição, de ação civil pública para matrícula de crianças em escolas próximas de suas residências e efetivação de transporte gratuito, enquanto não implementadas as matrículas, o TJ-SP, por unanimidade, proveu favoravelmente o pedido do MP. A Fazenda Pública do Estado de São Paulo alegava não ser possível atender a todas as necessidades de transporte da região, por indisponibilidade de recursos, importando a decisão em risco de grave e irreparável lesão aos seus interesses. A ação tinha como réus o Estado e o município, considerando que ambos são responsáveis pela oferta do EF.

A divergência entre os desembargadores sobre esta questão é evidenciada em recurso Ex Officio do município de Gavião Peixoto, julgado em $2000^{107}$. O MP ingressou com ação civil pública contra a Fazenda do Estado e contra o município de Gavião Peixoto, acatando a representação da Dirigente Regional de Ensino. Esta informava que mais de 200 crianças encontravam-se privadas do acesso à escola, pois a prefeitura municipal cortou o fornecimento do serviço de transporte escolar. Segundo o relator Desembargador Fonseca Tavares, o município recebeu, através de convênio, verba para o custeio do serviço. E, também, o município não ingressou com recurso voluntário, sendo este por força de lei. No entanto, o Desembargador Hermes Pinotti, em voto vencido contrário, opinou pelo provimento do recurso, pois julgou que a ação envolvia questão de conveniência e

\footnotetext{
${ }^{106}$ Agravo de Instrumento $\mathrm{n}^{\mathrm{o}} 72.324 .0 / 0,2000$.

${ }^{107}$ Recurso Ex Officio n ${ }^{\circ}$ 62.937.0/0-00, 2000.
} 
oportunidade da Administração Pública, como no recurso de ação que atuou como relator, analisada anteriormente.

Em ação julgada em $1999^{108}$, o MP solicitou a condenação do município de Guará para "oferecer e manter o programa suplementar de transporte escolar para as crianças e adolescentes que residam na zona urbana como rural, propiciando número suficiente de vagas nos meios de transporte para o atendimento de toda a demanda existente no município". O TJSP confirmou a decisão da $1^{\mathrm{a}}$ instância, afirmando que esta não deveria ser outra. $\mathrm{O}$ município apenas alegou dificuldades financeiras, não contestando a legalidade do pedido. Com a concessão da liminar o município tomou providências urgentes para a solução do problema ${ }^{109}$.

Em 2004, em ação civil pública também ajuizada pelo MP, ${ }^{110}$ e com concessão ao pedido para que o Município de Teodoro Sampaio e a Fazenda Pública de SP fossem compelidos a providenciar o serviço de transporte escolar, o TJ-SP confirmou a decisão, pois ambos têm responsabilidade na execução, de acordo com a LDB/96, art. 10, inciso II: “definir, com os Municípios, formas de colaboração na oferta do ensino fundamental, as quais devem assegurar a distribuição proporcional das responsabilidades, de acordo com a população a ser atendida e os recursos financeiros disponíveis em cada uma dessas esferas do Poder Público".

O pedido de antecipação de tutela para oferta de transporte escolar voltada a alunos do EM que residam a dois ou mais quilômetros da escola onde estão matriculados foi questionado no TJ-SP. A Fazenda Pública do Estado de SP alegou que o pedido era juridicamente impossível, pois o oferecimento do EM não é obrigatório. No conjunto da ação, também foi requerida a condenação do governo estadual, obrigando-o a disponibilizar vagas no EM nos próximos anos letivos, a fim de atender a todos os adolescentes que necessitarem, garantindo matrículas em escolas próximas de suas residências. Igualmente, que o Poder Executivo fosse compelido a incluir no orçamento verbas para o atendimento dos pedidos. Entretanto, no âmbito deste recurso foi questionado apenas o serviço de transporte escolar; o TJ-SP manteve a tutela antecipada, reduzindo a multa diária. Cabe destacar que essa decisão foi proferida em maioria, inexistindo consenso entre os desembargadores da Câmara Especial.

Ao contrário das decisões anteriores, a Apelação Cível, julgada em 2006, teve seu recurso ao TJ-SP, pois em $1^{\mathrm{a}}$ instância o processo que requisitava a manutenção do transporte escolar para alunos do EM que estudam distantes da residência foi extinto, sem apreciação do

\footnotetext{
${ }^{108}$ Apelação Cível no 103.071.5/2-00, 1999.

${ }^{109}$ No mesmo sentido Recurso Ex Officio no 105.448-5/8-00.

${ }^{110}$ Apelação Cível no 241.185-5/0-00, 2004.
} 
mérito. Essa ação partiu de alunos representados por seus pais, e não do $\mathrm{MP}$, como as anteriores. Segundo o Desembargador relator Antonio Rulli, os jovens dependem do transporte para estudarem, e a descontinuidade do serviço ofende direito à educação, assegurado pela $\mathrm{CF} / 88$, e o princípio da igualdade de condições para o acesso à escola:

\footnotetext{
Os impetrantes têm direito de serem transportados gratuitamente para os estabelecimentos de ensino [distantes] às suas moradias, pois o princípio constitucional é amplo e impede ao legislador e ao administrador a adoção de qualquer iniciativa que venha a contrariá-la.

Leva em conta, sobretudo, a igualdade de condições para acesso e permanência na escola, sendo [...]

Neste, contexto, a única forma de igualar condições entre os alunos que residem perto e longe das escolas, é proporcionar a estes últimos transporte gratuito, evitando com isso a evasão escolar e a baixa escolaridade da população. (APELAÇÃO CÍVEL nº 320.962-5/1-00, 2006, relator Des. Antonio Rulli).
}

Ao TJ-SP também chegaram recursos individuais peculiares, como de um aluno, assistido por sua mãe, requerendo o transporte escolar para o período matutino, pois alegava ser portador de asma alérgica, condição que o impossibilitava de frequentar as aulas no período da tarde ${ }^{111}$. O Desembargador Antonio Carlos Villen decidiu pela cassação da ordem judicial anterior, pois atender esse pedido individual poderia comprometer todo o sistema municipal de transporte escolar e prejudicar os demais alunos.

Contudo, em outro recurso ${ }^{112}$, também para o fornecimento de transporte escolar em período específico, o TJ-SP julgou procedente, obrigando o município a oferecer o transporte ao aluno que se mudou para a zona rural.

Numa ação que envolvia divergência acerca de oferecimento do serviço de transporte a alunos residentes em regiões fronteiriças entre municípios ${ }^{113}$, o TJ-SP e o juízo em $1^{\text {a }}$ instância entenderam que o direito à educação está acima de qualquer exigência formal, por exemplo, a cláusula contratual de impedimento para o transporte de alunos de outro município. Assim, ordenou que o município com escola mais próxima da moradia dos estudantes adequasse o caso concreto às normas.

\footnotetext{
111 Apelação Cível no 375.635-5/7-00, 2006.

112 Apelação Cível no 538.341-5/2-00, 2008.

113 Apelação Cível no 683.982-5/0-00, 2008.
} 


\subsubsection{Reparação de danos morais e/ou materiais}

Entre os anos de 1995 e 2008, dezoito decisões relacionavam-se a pedidos de indenizações a reparação de danos materiais e/ou morais por acidentes, agressões e morte de alunos em estabelecimentos de ensino. Nestes litígios, sobressaem os debates que argumentam se o evento que ocasionou o acidente ou a morte esteve vinculado à ação ou omissão de agentes públicos. Portanto, focalizaram a existência de relação de nexo de responsabilidade, e não os fundamentos para a indenização por danos morais e materiais.

A responsabilidade da Administração Pública foi acatada pelo TJ-SP, em processo ${ }^{114}$ que comprovou a falta de manutenção no parque, pois se estivesse conservado não haveria gravetos que foram utilizados para a agressão do aluno de seis anos. Em duas ações semelhantes ${ }^{115}$, favoráveis ao pedido de indenização dos alunos, a negligência foi comprovada pela falta de manutenção no prédio escolar. Numa delas, ocasionou a amputação de dedos; noutra, houve lesão corporal devido ao desmoronamento do reboco do teto de uma creche municipal.

Determinada ação ${ }^{116}$ tratava do caso de aluno humilhado e agredido no pátio de estabelecimento escolar privado. Caracterizando-se a ausência de vigilância, o TJ-SP julgou que a escola tem obrigação de zelar pela integridade física e moral dos alunos.

Numa ação, certo aluno foi alvejado por um tiro disparado por outro aluno, dentro de estabelecimento de ensino, e, em decorrência, ficou paraplégico. O debate girou em torno da responsabilidade estatal pelos acontecimentos. O Desembargador Xavier de Aquino, relator da decisão, citou Rui Stoco, em sua obra "Responsabilidade Civil e sua Interpretação Jurisprudencial":

Ao receber o estudante menor, confiado ao estabelecimento de ensino da rede oficial ou da rede particular para as atividades curriculares, de recreação, aprendizado e formação escolar, a entidade de ensino fica investida no dever de guarda e preservação da integridade física do aluno, com a obrigação de empregar a mais diligente vigilância, para prevenir e evitar qualquer ofensa ou dano aos seus pupilos, que possam resultar do convívio escolar.

Responderá no plano reparatório se, durante a permanência no interior da escola, o aluno sofrer violência física por inconsiderada atitude comissiva ou omissiva da direção do estabelecimento, se lhe sobrevierem lesões que exijam reparação e emerja daí uma ação ou omissão culposa (APELAÇÃO CÍVEL nº 58.495-5, 2000).

\footnotetext{
${ }_{114}$ Apelação Cível no 2.421-5, 1997.

115 Apelação Cível no 82.692-4, 1999; Apelação Cível no 390.807-5/2-00, 2007.

${ }^{116}$ Apelação Cível no 24.150-4, 1998.
} 
O nexo de responsabilidade da Administração Pública também foi aceito num caso de certa creche, onde uma criança teve o dedo prensado na porta do banheiro por outra criança, tendo como conseqüência a amputação de falange do dedo. O TJ-SP considerou a "responsabilidade objetiva da escola pelos danos causados a seus alunos, seja por força de seus prepostos, seja pela conduta de outras crianças, que estão sob sua guarda". Ainda:

[...] A ausência do serviço ou o seu defeituoso funcionamento, inclusive pela demora do atendimento às crianças e de falta de acompanhamento das mesmas a um local que, pela experiência comum, é sempre perigoso para infantes, a responsabilidade é insofismável. Não se sabe se foi a falta de serviço, a falha do serviço ou a culpa do serviço ou a culpa individual de cada uma das empregadas, que cuidavam dos infantes. Mas, em realidade, qualquer uma dessas modalidades, conduzem para a responsabilidade da Administração Pública. O nexo está comprovado e o rompimento do mesmo jamais poderia ocorrer, por se cuidar de criança, que exigia os cuidados e a guarda de pessoas responsáveis pela sua vigilância. (APELAÇÃO CÍVEL COM REVISÃO no 301.167.5/4-00, 2005, relator Des. Guerrieri Rezende).

Em ação semelhante, o TJ-SP aceitou o nexo de causalidade existente entre a amputação de falange do dedo de uma criança em armário e a responsabilidade das funcionárias da creche. O Desembargador Henrique Nelson Calandra justificou a sua decisão, com a posição de Hely Lopes Meirelles, na obra "Direito Administrativo Brasileiro":

[...] incide a responsabilidade civil objetiva quando a Administração Pública assume o compromisso de velar pela integridade física da pessoa e esta vem a sofrer um dano decorrente da omissão do agente público naquela vigilância. Assim, alunos da rede oficial de ensino, pessoas internadas em hospitais ou detentos, caso sofram algum dano quando sob a guarda imediata do Poder Público, têm direito à indenização, salvo se ficar comprovada a ocorrência de alguma causa excludente daquela responsabilidade estatal. (APELAÇÃO CÍVEL nº 290.440-5/8-00, 2006).

O Tribunal também entendeu como negligência o caso ocorrido em creche municipal, envolvendo a entrega de um bebê a adolescente não autorizado expressamente pela mãe a retirar a criança. $O$ fato desencadeou uma situação que culminou na morte da criança ${ }^{117}$.

O TJ-SP considerou improcedentes os pedidos de indenização por reparação civil e danos morais em três ações. Uma ${ }^{118}$, relativa ao falecimento de uma criança após queda no intervalo das aulas; os pais alegaram omissão da administração no exercício do seu dever de vigilância. Os desembargadores entenderam que o número adequado de vigilantes para a quantidade de alunos no recreio "em nada concorreu para o evento letal". Em outra ação, tratava-se do falecimento de bebê por asfixia, ocorrido em creche municipal; os Desembargadores entenderam que a omissão dos agentes estatais não ficou caracterizada, pois a vítima fora atendida sem demora, e encaminhada rapidamente ao pronto socorro. Portanto,

\footnotetext{
${ }^{117}$ Apelação Cível com revisão no 265.222-5/5-00, 2006.

${ }^{118}$ Apelação Cível no 230.504-1, 1995.
} 
inexistia a responsabilidade objetiva do Estado. O Desembargador Peiretti de Godoy também citou a obra de Rui Stoco:

Improcede a ação de indenização contra o Município por ato ilícito se não demonstrada a culpa da administração por negligência, imprudência ou imperícia, sendo inaplicáveis à espécie a teoria do risco ou a teoria da culpa objetiva por falta de serviço respectivo, se de serviço não se cogita. (APELAÇÃO CÍVEL no 269.3845/2-00, 2002).

Também não foi configurada a culpabilidade do município por aluno, que, sem entrar na escola, sofreu dano no horário escolar. Objetou-se que a Administração Pública não é responsável pelo acompanhamento das crianças no trajeto da creche à escola ${ }^{119}$. A ação teve entendimentos opostos em $1^{\mathrm{a}}$ e $2^{\mathrm{a}}$ instância, dado que o aluno frequentava, no período diverso da escola, um estabelecimento de assistência e educação (creche-escola), percorrendo o trajeto deste local até a escola regular sozinho. Para o TJ-SP, não existia regulamento sobre a obrigação dos monitores da creche, no sentido de acompanhar as crianças nesse trajeto. Assim, não havia como responsabilizar o município pelos momentos em que a criança está em trânsito entre uma e outra atividade, um e outro local, fora dos limites dos cuidados devidos pela municipalidade.

A responsabilidade objetiva da Administração Pública após o término do horário de funcionamento da creche também foi questionada em processo no qual o aluno foi encontrado pelos pais trancado no banheiro. O poder público municipal alegou não ter responsabilidade, dado que o fato ocorreu no período posterior às $17 \mathrm{~h} 00$, e, neste horário, as crianças da creche ficavam sob a responsabilidade do programa "mãe voluntária". As mães voluntárias, no sistema de revezamento, ficavam com as crianças, aguardando as demais que retornam do trabalho. Segundo a ótica da Prefeitura, não cabia à mesma responsabilidade pela prestação desse serviço, já que apenas cedera o local para o funcionamento do programa. O TJ-SP julgou devida a responsabilidade objetiva do município, pois o programa se desenvolvia em seu próprio recinto, não havendo rompimento da prestação do serviço. Destaca-se um trecho da decisão:

Todavia, o serviço público deve ser efetivo, atendendo às necessidades reais da sociedade que dele se vale, não podendo o Estado eximir-se de tal responsabilidade quando entrega a terceiros suas funções ou parcelas destas. É bastante cômodo ao ente público abster-se de solucionar o impasse de horário na creche, deixando que os próprios cidadãos administrem um programa exclusivamente para cumprir uma das etapas primordiais do atendimento que é a entrega das crianças com garantia aos pais [...]. (APELAÇÃO CÍVEL COM REVISÃO no 392.631-5/3-00, 2008, relator Des. Nelson Calandra).

\footnotetext{
${ }^{119}$ Apelação Cível com revisão nº 537.551-5/3-00, 2007.
} 
De acordo com o Desembargador Oliveira Santos, a responsabilidade do Estado pode ser afastada "no caso de força maior, caso fortuito, ou ainda, se comprovada a culpa exclusiva da vítima" (APELAÇÃO CÍVEL nº 390.807-5/2-00, 2007).

Da análise dessas ações é possível depreender que há uma jurisprudência favorável ao entendimento de que compete ao Estado o dever de guarda e vigilância dos alunos no estabelecimento escolar. Nas situações em que foi comprovado o nexo de causalidade existente entre o dano e a conduta omissa da Administração Pública, o TJ-SP julgou favoravelmente ao pagamento dos danos morais e materiais pleiteados, alterando em algumas ações os valores e o tempo de recebimento.

\subsubsection{Condições de funcionamento das escolas}

Das decisões que podem ser associadas à qualidade de ensino, duas discutiram a construção de instalações educacionais adequadas, e a terceira, o número máximo de alunos por sala de aula.

Em uma das ações ${ }^{120}$, o MP compelia o Estado, por meio da Fazenda Pública, a providenciar instalações adequadas para servir alunos da primeira a quarta séries, tendo em vista que a escola encontrava-se em condições precárias. Objetivava-se elevar a qualidade do ensino com a construção do novo prédio, pois as crianças eram atendidas em galpões metálicos.

A decisão em $1^{a}$ instância condenou o Estado a transferir os alunos para local provisório adequado até que fossem concluídas as obras do prédio definitivo; também, que fosse construído o estabelecimento de ensino para atender à demanda por vagas, com as condições de segurança, conforto, higiene e saúde exigidas pela $\mathrm{CF} / 88$, pelo ECA e pelo Decreto Estadual $n^{\circ} 12.342$, de 1978, realizando as obras necessárias ou concluindo as já iniciadas, no prazo de 180 dias, sob pena de multa diária.

No recurso ao TJ-SP, a Fazenda Pública alegou que o Judiciário não poderia intervir em atribuição típica do Executivo, que a construção da escola emergencial atendia às suas finalidades e que não foi comprovada a culpa do Estado.

\footnotetext{
${ }^{120}$ Apelação Cível nº 39.375-0, 1997.
} 
O TJ-SP, por unanimidade, negou o recurso da Fazenda Pública confirmando a sentença da $1^{\mathrm{a}}$ instância, discordando dos argumentos do Estado. Dos argumentos da apelante destaca o da comprovação da culpa, pois, como afirmou a decisão do Tribunal, a responsabilidade é comprovada pela constatação do estado lastimável em que se encontrava a escola.

Em ação civil pública semelhante ${ }^{121}$, julgada pelo TJ-SP, em 1998, objetivava-se compelir a Fazenda do Estado à construção de salas de aulas no prazo de 90 dias. O juízo em $1^{\text {a }}$ instância julgou o MP carecedor da ação, por impossibilidade jurídica do pedido em demanda. O TJ-SP, em voto do relator Oetterer Guedes, confirmou a indevida ingerência na administração do Estado, devendo ser respeitada a separação de poderes.

O MP, em outra ação civil pública, solicitou que o Estado fosse obrigado a matricular em dada escola não mais que trinta alunos por classe, no ano de 1999 e seguintes. No decorrer do processo, a escola remanejou os alunos. A decisão em $1^{\mathrm{a}}$ instância foi favorável à antecipação do pedido do MP, e como a SEE providenciou a adequação do número de alunos, o recurso judicial perdeu a sua utilidade.

Nesta ação, o TJ-SP entendeu que o pedido do MP para a limitação para os anos seguintes deveria "ser claro e específico, se sujeitando apenas a interpretação literal, isto é, o pedido que escrito foi, nem mais, nem menos"; igualmente, que o "reflexo nos anos seguintes deveria ter sido pedido expressamente, sendo defeso ao julgador ir além do pedido". Então, julgou ser nula a decisão em $1^{\mathrm{a}}$ instância quanto aos reflexos futuros (APELAÇÃO CÍVEL $\mathrm{n}^{\circ}$ 70.178-0/9-00, 2001, relator Des. Hermes Pinotti).

Essa ação representa uma tentativa de limitação do número de alunos nas salas de aulas da rede estadual, mas a restrição para providências em uma escola específica e o entendimento do TJ-SP sobre a extensão do pedido para os próximos anos inviabilizaram alteração significativa na política de distribuição dos alunos.

\subsection{Poder de regulação estatal}

Do conjunto das decisões analisadas, 70 tratam de problemas específicos do ensino privado, discutindo o poder de regulação do Estado para com essas instituições, como

\footnotetext{
${ }^{121}$ Apelação Cível no 44.389-0/6, 1998.
} 
cobranças, reajustes e demais conflitos referentes às mensalidades escolares, autorização e credenciamento das instituições educacionais privadas e os subsídios públicos para esses estabelecimentos.

\subsubsection{Mensalidade escolar}

As decisões envolvendo as mensalidades escolares totalizaram 46, podendo ser distribuídas da seguinte maneira:

Tabela 13 - Decisões do TJ-SP versando sobre mensalidades escolares

\begin{tabular}{l|l}
\hline \multicolumn{1}{c|}{ ASSUNTOS } & \multicolumn{1}{c}{$\mathbf{N}^{\mathbf{0}}$ de decisões } \\
\hline Reajuste & 19 \\
\hline Cobrança & 12 \\
\hline Redução das taxas para alunos consanguíneos & 7 \\
\hline Retenção de documentos por inadimplência & 4 \\
\hline Contrato & 2 \\
\hline Restituição do valor da matrícula em desistência do curso & 1 \\
\hline Dúvida de competência de Câmara & 1 \\
\hline TOTAL & $\mathbf{4 6}$ \\
\hline
\end{tabular}

Fonte: a autora com base nas decisões coletadas no TJ-SP.

As ações que discutem o reajuste de mensalidade foram levadas a litígio, principalmente, no início da década de 1990, e estão associadas ao constante processo inflacionário desse período, que gerou diversos desentendimentos sobre a correção monetária para reajustes dos preços dos bens e serviços.

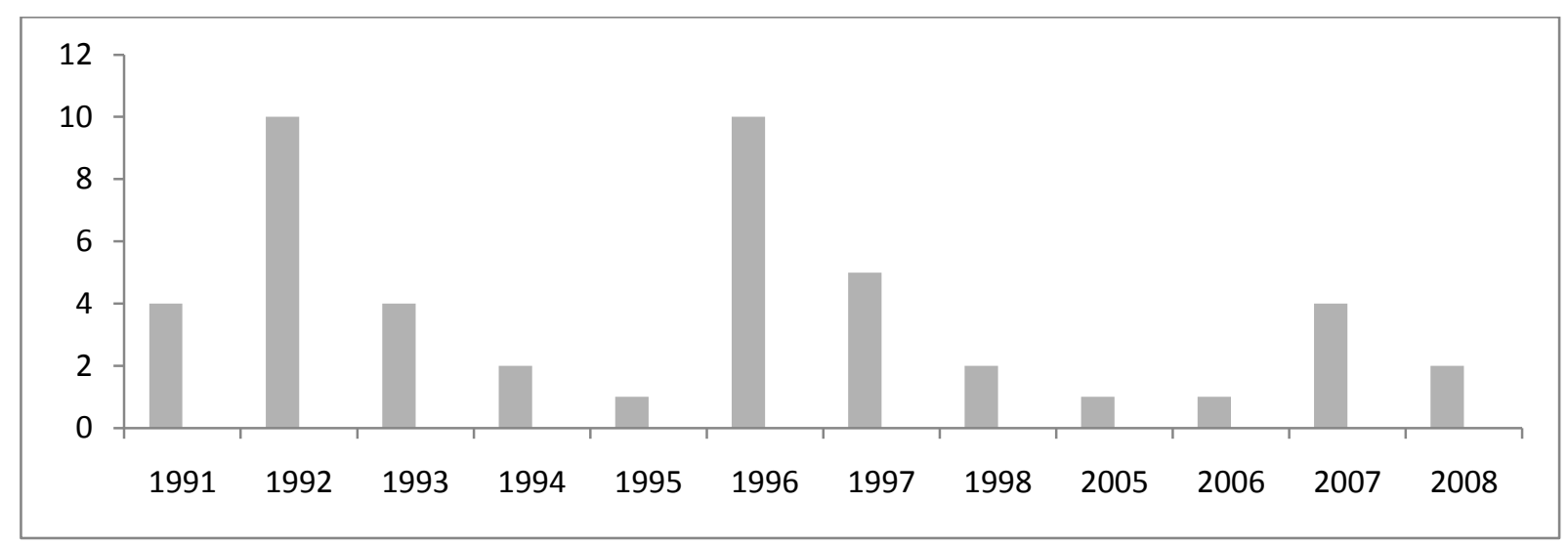

Gráfico 6 - Distribuição anual das decisões envolvendo mensalidades escolares Fonte: a autora com base nas decisões coletadas no TJ-SP. 
Para a análise dessas decisões, optou-se pela ênfase nas discussões concentradas na responsabilidade do Estado, relativa ao controle dos contratos e dos reajustes dos mesmos entre os estabelecimentos de ensino privado e os alunos. Não houve aprofundamento no debate acerca das relações contratuais e das regras de reajuste, tendo em vista que essas questões não são essenciais para o objetivo deste trabalho.

Diversos processos focavam a questão sobre a autonomia das instituições privadas no que concerne às mensalidades escolares. Esse assunto revelou posições diversas no TJ-SP.

Determinado recurso discutia qual Câmara do TJ- SP teria competência para o julgamento de ação sobre reajuste de mensalidades escolares. Nesse caso, o Desembargador Hermes Pinotti destacou que a escola "não tem autonomia para estabelecer livremente o preço de mensalidades e de outras contribuições, pois está subordinada à fiscalização do Poder Público". No mesmo sentido, o Desembargador Cesar de Moraes afirmou que não se tratava da prestação de serviços de forma indiscriminada, porque "é funda a intervenção publicística nesses contratos, seja quanto ao regime pedagógico, seja quanto duração do ano letivo, seja quanto às mensalidades escolares”. Mas, para o Desembargador Márcio Bonilha, em voto contrário:

A relação entre a escola e a Administração Pública, no que se refere à observância das normas impositivas de educação nacional, não se pode negar, é de caráter administrativo. Mas, a relação entre alunos e estabelecimento particular de ensino, é de natureza privada, quando inexiste questão correspondente à delegação do Poder Público. [...] No tema do reajuste das mensalidades, inexiste delegação do Poder Público [...] (DÚVIDA DE COMPETÊNCIA NA APELAÇÃO CÍVEL nº 146.726$2,1991)$.

Para o Desembargador Campos de Mello, a CF/88, no artigo 209, ao declarar ser livre o ensino à iniciativa privada, não pretendeu significar que ela detém o poder de disciplinar os aspectos econômicos das relações jurídicas decorrentes. Mas, pelo artigo 170, sobre a defesa do consumidor, é possível a intervenção, respeitando o ato jurídico perfeito e o direito adquirido $^{122}$.

Segundo o Desembargador Cezar Peluso, a autonomia empresarial, em matéria de ensino, está "submissa a limitações de regras que, nem por serem de cunho econômicofinanceiro, deixam de respeitar à educação em si, como processo" (Apelação Cível no 157.970-1, 1992). Portanto, não havendo autonomia na fixação dos preços das mensalidades.

De maneira semelhante, o Desembargador Reis Kuntz destacou que: "sendo o ensino, de interesse social, é de ordem pública. Por isso, de todo legítima a intervenção da Administração Pública nas relações jurídicas referentes à atividade educacional. A liberdade

\footnotetext{
${ }^{122}$ Apelação Cível no 163.940-1, 1992.
} 
de ensino não é absoluta, mas sujeita a condições, relativa [...]” (Apelação Cível nº 191.777-1, 1993).

Em oposição, o Desembargador Ney Almada argumentou que a relação jurídica entre os pais de alunos e estabelecimentos de ensino tem caráter privado e "a escola particular não se converte em ente público pelo só fato de desempenhar tão relevante missão social”. (APELAÇÃO CÍVEL nº 152.203-1, 1991).

Ainda, nesta direção o Desembargador Toledo Cesar ressaltou que a atuação do Poder Público aos estabelecimentos de ensino pela CF/88 (artigo 209) está limitada à fiscalização quanto ao cumprimento das normas gerais da educação nacional. Desse modo, "o Poder Público não pode físcalizar a remuneração pelos serviços prestados - mas sim os próprios serviços - sob pena de violação da mencionada regra constitucional" (APELAÇÃO CÍVEL no 002.645, 1997).

A decisão relatada pelo Desembargador Costa de Oliveira representa com clareza essa posição:

\begin{abstract}
A escola privada, por isso que autorizada a funcionar como tal, e por o seu currículo ser aprovado pelo Estado, e por a sua sistemática de avaliação estar sob a constante fiscalização pública, por isso - dizemos - a escola particular põe-se em relação jurídica de direito público (administrativo e constitucional) com os seus 'usuários', isto é, com os alunos. Mas não deixa ela de ser pessoa jurídica de direito privado. [...] Ou seja, no que diga respeito a ensino na escola de nível secundário - mais amplamente: no respeitante à educação -, a matéria é própria de relação jurídica de direito público. [...] Diversamente ocorre em outras relações jurídicas da escola privada: como os assuntos de sua administração pessoal, de material, de serviços extracurriculares, dos preços de seus serviços. No seu preço, nada entra de 'ensino'; é sem conteúdo educacional. É o preço de um serviço de direito privado. [...] E esse conteúdo é de prevalente interesse privado. Está a escola privada, aí, fora de relação jurídica de direito público. As próprias regras jurídicas que regem o procedimento de 'negociação' (institucionalização do conflito) entre pais e colégio são regras de direito privado. O Estado está fora das relações jurídicas aí formadas e daí oriundas. (APELAÇÃO CÍVEl nº 150.276-1, 1992).
\end{abstract}

De acordo com o Desembargador Cunha Bueno, as consequências da inflação deveriam ser transferidas, pois a entidade de ensino é uma empresária cobrando mensalidades. (Apelação Cível no 171.571-1, 1992).

Limites para reajustes das mensalidades escolares foram fixados pela Medida Provisória $\mathrm{n}^{\circ} 932$, de $1^{\circ}$ de março de 1995 , e reeditadas por outras. A Lei $\mathrm{n}^{\circ} 9.870$, de 23 de novembro de 1999, dispõe sobre o valor das anuidades escolares, sua forma de reajuste, contratos e penalidades pedagógicas para os inadimplentes.

Em uma ação de cobrança, os pais de uma aluna, defendendo que a educação é direito de todos e dever do Estado, argumentaram que as parcelas das mensalidades em atraso poderiam ser suportadas pelo Estado ou pelo estabelecimento de ensino, considerando que, 
durante cinco anos, cobrou as prestações mensais. Sobre esta apelação, o Desembargador Clóvis Castelo afirmou que "o invocado direito constitucional à educação não significa tenha o Estado o dever de arcar com as prestações escolares de estabelecimentos particulares de ensino" (APELAÇÃO CÍVEL COM REVISÃO nº 940028-0/1, 2007).

Alguns recursos contestaram a legalidade das instituições privadas de reter documentos de alunos inadimplentes. Esse ato foi considerado abusivo, não existindo norma contratual que o estabeleça, não podendo impedir ou dificultar o acesso de aluno a outro estabelecimento de ensino ${ }^{123}$

Todavia, em uma ação na qual foi invocado o direito constitucional, que garante a obtenção de certidões independentemente do pagamento de taxas, para esclarecimento de situações de interesse do cidadão (CF/88, artigo $5^{\circ}$, inciso XXXIV, a), o Desembargador Silvério Ribeiro argumentou que o direito não pode favorecer aquele que é devedor de obrigação $^{124}$.

O estabelecimento de ensino sustentou a legitimidade para a retenção de documentos escolares até que o aluno ou seu responsável quitassem as mensalidades atrasadas, de acordo com a Lei n 8.170 , de 17 de janeiro de 1991, artigo 4": "São proibidas a suspensão de provas escolares, a retenção de documentos de transferências ou o indeferimento das matrículas dos alunos cuja inadimplência não decorrer de encargos fixados definitivamente e reajustados nos termos desta lei".

Para o Desembargador José Malerbi, em voto vencido, o ato da instituição de ensino impede indiretamente o acesso ao ensino, o que é vedado pela $\mathrm{CF} / 88$, sendo a Lei $\mathrm{n}^{\circ}$ 8.170/91, nesta parte inconstitucional. Devendo o estabelecimento de ensino cobrar as mensalidades por vias próprias, sem reter os documentos.

A Lei $n^{\circ} 8.170 / 91$ foi revogada pela Lei 9.870/99. E o art. $6^{\circ}$ proíbe a retenção de documentos escolares em razão de inadimplência:

Art. $6^{\circ}$ São proibidas a suspensão de provas escolares, a retenção de documentos
escolares ou a aplicação de quaisquer outras penalidades pedagógicas por motivo de
inadimplemento, sujeitando-se o contratante, no que couber, às sanções legais e
administrativas, compatíveis com o Código de Defesa do Consumidor, e com os
arts. 177 e 1.092 do Código Civil Brasileiro, caso a inadimplência perdure por mais
de noventa dias.
$\S 1^{\circ}$ O desligamento do aluno por inadimplência somente poderá ocorrer ao final do
ano letivo ou, no ensino superior, ao final do semestre letivo quando a instituição
adotar o regime didático semestral. (Incluído pela Medida Provisória n ${ }^{\circ} 2.173-24$,
23.8 .2001 ).
$\S 2^{-}$Os estabelecimentos de ensino fundamental, médio e superior deverão expedir,
a qualquer tempo, os documentos de transferência de seus alunos,

${ }^{123}$ Apelação Cível no 160.526-1, 1991.

${ }^{124}$ Apelação Cível no $179.842-1,1992$. 
independentemente de sua adimplência ou da adoção de procedimentos legais de cobranças judiciais. (Renumerado pela Medida Provisória $n^{\circ}$ 2.173-24, 23.8.2001). $\S 3^{\circ}$ São asseguradas em estabelecimentos públicos de ensino fundamental e médio as matrículas dos alunos, cujos contratos, celebrados por seus pais ou responsáveis para a prestação de serviços educacionais, tenham sido suspensos em virtude de inadimplemento, nos termos do caput deste artigo. (Renumerado pela Medida Provisória $\left.n^{\mathrm{o}} 2.173-24,23.8 .2001\right)$.

$\S 4^{\underline{0}} \mathrm{Na}$ hipótese de os alunos a que se refere o $\S 2^{\underline{0}}$, ou seus pais ou responsáveis, não terem providenciado a sua imediata matrícula em outro estabelecimento de sua livre escolha, as Secretarias de Educação estaduais e municipais deverão providenciá-la em estabelecimento de ensino da rede pública, em curso e série correspondentes aos cursados na escola de origem, de forma a garantir a continuidade de seus estudos no mesmo período letivo e a respeitar o disposto no inciso V do art. 53 do Estatuto da Criança e do Adolescente. (Renumerado pela Medida Provisória nº 2.173-24, 23.8.2001) (BRASIL, Lei 8.170/91).

Outro assunto que foi debatido no âmbito dessas decisões refere-se à redução das taxas escolares para irmãos consanguíneos matriculados em um mesmo estabelecimento de ensino. Tais recursos questionaram a vigência do artigo 24, do Decreto-lei $\mathrm{n}^{\circ} 3.200$, de 19 de abril de 1941. Em ação julgada em 1993, o Desembargador Reis Kuntz considerou essa norma compatível com os princípios constitucionais atuais de proteção à família ${ }^{125}$. O Desembargador Munhoz Soares pontuou ${ }^{126}$ que não se conhece lei ordinária que tivesse revogado o decreto-lei, além disso, a $\mathrm{CF} / 88$, ao elevar a educação a direito fundamental, consagrou essa proteção.

Noutra Apelação ${ }^{127}$, a $8^{\text {a }}$ Câmara Civil, em votação unânime, entendeu que o Decretolei estava revogado, por ser inconciliável com a nova ordem constitucional, considerando que essa lei foi instituída no âmbito do regime autoritário brasileiro e tinha como objetivo organizar e proteger a família numerosa e de incrementar maior densidade demográfica. Ademais, com a Constituição de 1967, foi editado o Decreto-lei no 532, de 16 de abril de 1969, que instituiu novo regime remuneratório para os serviços prestados pelas escolas particulares.

Das ações sobre cobrança (12 ao todo), seis foram favoráveis aos pedidos dos estabelecimentos de ensino; as que foram favoráveis aos pedidos dos alunos relacionavam-se com pedido de prescrição de prazo e devolução de matrícula com a desistência do curso, evidenciando a posição do TJ-SP de cobrança dos débitos.

\footnotetext{
125 Apelação Cível no $191.777-1,1993$.

${ }^{126}$ Apelação Cível no 204.006-1, 1994.

${ }^{127}$ Apelação Cível nº 200.503-1, 1991.
} 


\subsubsection{Autorização e credenciamento de instituições privadas}

Litígios oriundos da necessidade de autorização e credenciamento de instituições privadas de educação são discutidos em 21 recursos ao TJ-SP, entre os anos de 1996 e 2007. No último ano, foram julgadas oito ações em recurso. Nove delas questionavam o direito dos órgãos normativos da educação, como o Conselho Estadual de Educação (CEE) e o Conselho Municipal de Educação (CME) para a supervisão das instituições privadas, principalmente quando estes exigiram condições para a continuidade do funcionamento. A regularização dos cursos de educação à distância, na modalidade de EJA, após a aprovação da LDB/96, foi objeto de vários destes desentendimentos entre as escolas e o CEE, conduzindo à resolução do conflito judicialmente.

Nessas ações se discutiu a competência do Estado para disciplinar questão referente aos exames e às emissões de certificados de conclusão de cursos à distância. Para o Desembargador Rui Cascaldi "se o curso está irregular face às posturas estaduais pode ser fechado no Estado e pelo Estado em que se deu a violação" (Agravo de Instrumento $\mathrm{n}^{\mathrm{o}}$ 249.569-5, 2001).

Em outro recurso semelhante, o CEE indeferiu o credenciamento e autorização para ministrar cursos à distância, pois não atendia os pré-requisitos. A instituição de ensino alegou que o prazo de 90 dias foi exíguo para a adaptação às exigências da nova lei e requisitou nulidade do ato do Conselho, considerando que a Lei $n^{\circ}$ 10.403/71, exigia a homologação do Secretário de Educação para ratificar as deliberações do CEE. O TJ-SP decidiu que não existiu lesão de direito líquido e certo.

O TJ-SP manteve a decisão do órgão colegiado, relativo a todos os recursos que contestavam os atos do CEE no indeferimento de credenciamento e autorização dos cursos. Isso porque, com o advento de nova legislação (LDB/96), as instituições estavam obrigadas a adaptar-se à nova disciplina legal, cabendo ao CEE a atribuição de "promover o ato de credenciamento, fiscalizar e até, verificada a falta de atendimento a padrões de qualidade ou a existência de irregularidades, no âmbito do Estado, deliberar, como aqui se deliberou, pelo descredenciamento" (APELAÇÃO CÍVEL no 175.902-5/8-00, 2004).

Também se destacam, neste conjunto, as discussões relacionadas à regularização da publicação dos certificados de conclusão de cursos de instituições com reconhecimento e/ou autorização cassados, ou que estavam sofrendo processos administrativos (nove recursos). 
A necessidade de realização de exames pelos alunos para a validação da aprovação dos cursos de educação à distância foi objeto de dois recursos. Também foi localizado o questionamento de uma aluna, concernente à propaganda enganosa ${ }^{128}$, porque após concluir um curso técnico foi-lhe impedido o exercício profissional, pois o curso que frequentara não estava autorizado pelo Conselho Regional de Fisioterapia e Terapia Ocupacional. O TJ-SP, em maioria, considerou que ninguém pode alegar ignorância perante a lei, mas o Desembargador Sá Duarte considerou que a escola deveria informar que o curso não possibilitaria registro profissional, indicando a condenação da instituição na devolução do dinheiro.

Em recurso de ação, favorável em $1^{\mathrm{a}}$ instância, para instituição de ensino privada que não teve a publicação da conclusão do curso de seus alunos porque estava sofrendo sindicância que apurava, dentre outros fatos, a "venda de diplomas", o TJ-SP considerou que as regras regulamentadoras desse processo de publicação estão perfeitamente em vigor. Assim, o "ato do administrador público que não chancela como corretos os certificados expedidos por escola irregular não pode ser taxado de ilegal, abusivo ou editado com desvio de finalidade". (APELAÇÃO CÍVEL no 335.871-5/0-00, 2006, relator Des. Regina Capistrano).

Sobre os direitos dos alunos a Desembargadora argumentou:

Anoto que o especialíssimo direito dos alunos que desejam continuar seus estudos,
se houver este direito em vista das peculiaridades que envolvem a questão posta 'sub
judice' deverá ser pleiteado e provado em ação própria, por eles demandada, até
porque não pode a escola pleitear em nome próprio direito alheio [...]. (APELAÇÃO
CÍVEL 335.871-5/0-00, 2006, relatora Des. Regina Capistrano).

O funcionamento de instituição de EI sem autorização foi questionado em uma ação promovida pelo MP de Ribeirão Preto. O TJ-SP manteve a decisão do juiz de $1^{\mathrm{a}}$ instância, considerando o descumprimento de Deliberação do Conselho Municipal de Educação (CME) de Ribeirão Preto, destacando a observação do Juiz: “funcionar sem a expressa autorização do Poder Público Municipal, toda expectativa de cumprimento do padrão de qualidade no fornecimento de educação preconizado pelo artigo 206, inciso VII, da Carta Magna fica frustrada" (APELAÇÃO CÍVEL no 142.443-0/8-00, 2007). Em ação com sentença semelhante $^{129}$, foi mantida a determinação de encerramento das atividades de EI em unidade educacional de São Paulo, considerando as irregularidades apontadas com risco à saúde dos alunos.

\footnotetext{
${ }^{128}$ Apelação Cível com revisão no 940429, 2007.

${ }^{129}$ Agravo de Instrumento $\mathrm{n}^{\circ}$ 143.612-0/7-00, 2007.
} 
A sentença do TJ-SP manteve a decisão de $1^{\mathrm{a}}$ instância ${ }^{130}$, em favor do pedido de um aluno, objetivando a aposição do "visto-confere" no certificado de conclusão de curso de EJA, com atendimento individualizado e presença flexível em nível médio. Alegava-se que, por ocasião da conclusão do curso e expedição do certificado, a instituição privada de ensino estava legalmente autorizada a funcionar, e as irregularidades foram encontradas posteriormente.

Em outra situação ${ }^{131}$, uma aluna requereu a regularização da sua vida escolar; o Desembargador Jonivo de Sylos enfatizou que "isso só é possível diante de absoluta certeza de que o ensino no caso processou-se dentro dos padrões legais exigidos, tanto com relação ao trabalho do aluno quanto ao da própria instituição de ensino. Tal certeza não subsiste na hipótese em tela, sendo muitíssimas as irregularidades relacionadas às atividades dos alunos em geral". Lembrou, ainda, que o direito reclamado poderia ser tentado por outras vias judiciais.

Não é possível fazer afirmações, pois nos acórdãos não são descritas as irregularidades das instituições de ensino que tiveram sua autorização de funcionamento cassada. No entanto, provavelmente os alunos acreditaram nas propostas dessas instituições, na probabilidade de receber o certificado, e, após terem realizado o pagamento por tal serviço, não obtiveram a documentação pretendida.

\subsection{Decisões administrativas e políticas}

Das 35 decisões que foram agrupadas neste conjunto das "decisões administrativas e políticas", a maioria (23 decisões) refere-se à iniciativa do Legislativo em propor leis que foram questionadas pelo Executivo. As demais focalizam ações políticas dos governos municipais e estadual para com a educação; sobretudo, questionamentos sobre os programas de reorganização da rede estadual paulista, realização de convênios da SEE para a municipalização do EF, fechamento de creches nos períodos de férias escolares e outras ações com questionamentos envolvendo atos da administração pública municipal ou estadual.

\footnotetext{
${ }^{130}$ Apelação Cível sem revisão no 334.194-5/3-00, 2007.

${ }^{131}$ Apelação Cível no 105.026-5, 2000.
} 


\subsubsection{Competência para legislar}

Segundo o Anuário da Justiça Paulista (2008), de cada dez ações de inconstitucionalidade das leis municipais submetidas ao TJ-SP, nove são consideradas inválidas por estarem em desacordo com a Constituição do estado. Todas as leis envolvendo temáticas educacionais foram consideradas inconstitucionais.

O julgamento de inconstitucionalidade de lei ou ato normativo municipal é de competência do Órgão Especial do TJ-SP.

Do conjunto das decisões analisadas, 21 se concentram na constitucionalidade de Leis municipais, uma Lei estadual e uma Resolução da SEE. Esta última versava sobre um Mandado de Segurança impetrado pelo Sindicato dos Professores do Ensino Oficial do Estado de São Paulo (Apeoesp) contra ato do Secretário do Estado da Educação (Resolução 247/91), que determinava o número mínimo de 200 dias letivos e 800 horas para o EF e EM. O TJ-SP entendeu que é da competência dos estados a normativa de funcionamento das escolas públicas estaduais, e que o regulamento não afetava direito subjetivo ou individual dos professores $^{132}$.

As leis consideradas inconstitucionais tratavam de:

- Fixação do valor mínimo da receita destinada à educação;

- Transporte escolar: concessão da gratuidade e descontos nas tarifas nos transportes coletivos urbanos para estudantes, fiscalização dos veículos destinados ao transporte escolar, criação do serviço de transporte escolar para os alunos da EI;

- Obrigatoriedade de implantação de escolas municipais de EI em conjuntos habitacionais populares;

- Autorização para a criação de classes especiais nas escolas públicas municipais;

- Projeto para o funcionamento da rede municipal de ensino nos finais de semana;

- Instituição do Programa escola e esportes;

- Inclusão do ensino de informática nos currículos das escolas de EF e EM da rede municipal;

- Proibição da rede municipal de ensino de adotar livros não recomendados ou excluídos pelo MEC;

- Implantação do Exame Municipal de Avaliação Escolar;

- Execução do Hino Nacional e do Hino do município nas escolas estaduais, municipais e particulares;

- Concessão de subvenção à creche filantrópica, para reparar danos ocasionados por incêndio;

- Inclusão do estudo do ECA no currículo escolar do EF;

\footnotetext{
${ }^{132}$ Apelação Cível nº 187.552 1, 1993.
} 
- Doação de kits escolares às crianças de famílias que não possuam condições financeiras, possibilitando ao Departamento de Educação buscar a doação na iniciativa privada em troca de publicidade;

- Realização de exames médicos nos alunos da EI;

- Criação do Programa Estadual para Identificação e Tratamento da Dislexia na rede oficial de educação;

A principal causa da inconstitucionalidade das leis guarda relação com o vício de iniciativa dos vereadores e deputados sobre assuntos que são de competência do Poder Executivo. Em geral, essas leis ofendem aos princípios da independência e harmonia dos Poderes do Estado, previstos no artigo $5^{\circ}$ da Constituição do Estado de São Paulo (1989). Também, é enfatizado o artigo 119, que trata da exclusividade do Poder Executivo para a prestação de serviço público: "Os serviços concedidos ou permitidos ficarão sempre sujeitos à regulamentação e fiscalização do Poder Público e poderão ser retomados quando não atendam aos seus fins ou às condições de contrato.” (SÃO PAULO, 1989, art. 119).

As decisões do TJ-SP salientaram as competências dos prefeitos e vereadores. "A atribuição primordial do Legislativo é editar normas abstratas, gerais e obrigatórias de conduta, ao passo que a missão do Executivo é a de praticar atos concretos da administração, de conformidade com a lei”. (AÇÃO DIRETA DE INCONSTITUCIONALIDADE DE LEI $n^{\circ}$ 16.833-0, 1994). “A Câmara não pode delegar funções ao Prefeito, nem receber delegações do Executivo (Const. Est., art. $5^{\circ}, \S 1^{\circ}$ ), posto que suas atribuições são incomunicáveis, estanques, intransferíveis." (AÇÃO DIRETA DE INCONSTITUCIONALIDADE DE LEI n ${ }^{\circ}$ 58.859-0/9, 2000).

Em uma decisão, o Desembargador Flávio Pinheiro discorreu sobre a função do Executivo e do Legislativo, que ilustra o posicionamento dos membros do TJ-SP sobre essas ações:

O administrador do Município é o Prefeito. Por sua vez, a prestação de serviços públicos ou de utilidade pública, bem como a condução de políticas e administração públicas, são atribuições primordiais do governo. Sem dúvida, a Câmara Municipal integra o governo local. Entretanto, tem atribuições e exerce funções inconfundíveis com as do Chefe do Executivo.

$[\ldots]$

A Câmara, por sua vez, "não administra o Município, estabelece, apenas, normas de administração", realizando sua missão normativa, deliberando e atuando com caráter regulatório, genérico e abstrato. (Hely Lopes Meirelles, Direito Municipal Brasileiro, ed. RT, páginas 870/873). (AÇÃO DIRETA DE INCONSTITUCIONALIDADE DE LEI nº 101.568-0/8-00, 2003).

As leis que tratavam da obrigatoriedade de implantação de serviços nas escolas foram consideradas em desacordo, pois esta matéria é exclusiva do executivo ao afetar o planejamento, a organização e a direção de serviços municipais. 
Outra justificativa para a inconstitucionalidade das leis vincula-se ao estabelecido no art. 25 da Constituição Estadual: "Nenhum projeto de lei que implique a criação ou aumento de despesa pública será sancionado sem que dele conste a indicação dos recursos disponíveis, próprios para atender aos novos encargos". Várias leis que criaram programas, como: implantação das escolas nos finais de semana, inclusão de novas disciplinas no currículo, obrigatoriedade da execução do hino nacional, criação do serviço de transporte escolar para EI, doação de kits escolares para os alunos, realização de exames médicos nos alunos, não indicaram a fonte de recursos para que os novos projetos fossem executados.

$\mathrm{O}$ art. 176, inciso I, da Constituição Estadual, que veda o início de programas, projetos e atividades sem previsão na lei orçamentária anual também foi utilizado para justificar a inconstitucionalidade das leis.

Segundo o TJ-SP, a Lei municipal de Taubaté, que criava o programa para a doação de kits aos alunos das escolas, afrontava, também, o princípio da impessoalidade ao possibilitar que as empresas privadas que fizessem doações colocassem suas propagandas nos materiais.

O legislativo do município de Ribeirão Preto foi o autor de quatro dessas leis, questionadas pelo Prefeito Municipal junto ao TJ-SP; seguido dos municípios de Guarulhos e Taubaté, com duas decisões. O levantamento realizado pelo Anuário da Justiça Paulista (2008) também constatou que Ribeirão Preto é o líder no ranking de inconstitucionalidade no estado. Esse número expressivo de leis vetadas pelo prefeito pode ser relacionado à disputa política entre a maioria legislativa e o executivo, mas também pode estar vinculado a um despreparo dos vereadores e ausência de assessoria jurídica adequada.

\subsubsection{Reorganização das escolas estaduais}

O Programa de Reorganização das Escolas da rede pública estadual foi regulamentado pelo Decreto Estadual no 40.473, de 21 de novembro de 1995. Ação julgada pelo TJ-SP, em 1997, discutiu a competência da Vara da Infância e da Juventude para o processamento e julgamento ${ }^{133}$ de ação que questionava essa política, pois em $1^{\mathrm{a}}$ instância foi determinada a remessa dos autos para uma das Varas da Fazenda Pública da Capital, pelo fato do Estado figurar como entidade que sofre a ação. Os desembargadores, em votação unânime, acataram

\footnotetext{
${ }^{133}$ Agravo de Instrumento no 36.139-0, 1997.
} 
o argumento do MP, de que, segundo o ECA (art. 148) a Justiça da Infância e Juventude é competente para conhecer ações civis públicas fundadas em interesses difusos ou coletivos, afetos à criança e ao adolescente, não fazendo qualquer menção quanto à qualidade do demandado.

Outra ação civil pública proposta pelo MP, em Cerquilho, foi julgada favoravelmente em $1^{a}$ instância, objetivando a suspensão da implantação do Programa de Reorganização das Escolas da rede pública estadual.

O pedido do MP consistia em obrigar o Estado a:

[...] submeter proposta de reorganização à discussão e deliberação da comunidade escolar, Conselho de Escola, Municipal, dos Direitos da Criança, Tutelar, autoridades municipais ligadas à educação; definição clara dos mecanismos de articulação entre as escolas; garantia do direito de acesso da criança e do adolescente à escola pública próxima de sua residência, oferta do ensino noturno regular e adequado às condições do adolescente trabalhador; implantação do programa às especificidades locais a serem apuradas. (APELAÇÃO CÍVEL no 39.019-5, 1999, relator Des. Prado Pereira).

O TJ-SP ponderou que as obrigações impostas ao governo estadual não estavam previstas no Decreto no 40.473/95 e que a "exigência da sujeição dos encargos alvitrados se ressentem de legalidade, constituindo indevida intromissão na competência do Poder Executivo". Ainda:

Louva-se o espírito democrático que a ação pretende seja observado no Programa de Reorganização das Escolas da Rede Pública Estadual, todavia, compete à Secretaria da Educação, através de seus técnicos fixar os objetivos a serem cumpridos e como executá-los, já que ao Estado compete legislar concorrentemente sobre matéria de educação e cultura (inciso IX do artigo 24 da Constituição Federal), observando os princípios da mencionada Carta Política. (APELAÇÃO CÍVEL n 39.019-5, 1999, relator Des. Prado Pereira).

Outrossim, o relator citou decisão da suspensão de liminar da ação da Vara da Infância de Ribeirão Preto:

A estruturação do ensino inclui-se entre as atividades de império que a Administração Pública possui, e não existindo evidente prejuízo para a coletividade e nem especificadamente ao menor é obstado ao Poder Judiciário impor-lhe procedimentos. A análise restringe-se à legalidade do decreto e, no caso, não se apresenta qualquer vício flagrante que legitime a liminar. (SUSPENSÃO DE LIMINAR no 31.580.0/8, apud APELAÇÃO CÍVEL no 39.019-5, 1999, relator Des. Prado Pereira

Em síntese, considerou que a sentença não poderia subsistir porque, em matéria de interesses difusos e coletivos, a tutela jurisdicional somente pode definir obrigação do que está estabelecido em lei, não sendo permitido impor encargos aos demandados. 


\subsubsection{Municipalização}

As três decisões versando sobre o Programa de Municipalização do EF foram proferidas pelo TJ-SP, em 2007.

Em uma ação, a Apeoesp recorreu de sentença que julgou extinto o mandado de segurança impetrado contra o Prefeito e a Secretaria da Educação do Município de Assis para discutir o convênio firmado entre a Prefeitura e o Governo Estadual para a municipalização da educação $^{134}$.

O Desembargador Samuel Júnior considerou que no âmbito do mandado de segurança não seria possível saber se houve ou não prejuízos aos alunos e professores, além do Sindicato não ser parte legítima para pleitear direitos dos alunos. O representante do MP salientou, também, que como o Sindicato não representa todos os servidores estaduais e municipais, pois nem todos são associados, pairam dúvidas de que todos os servidores gostariam de ter seus direitos representados pela instituição.

Noutra ação, novamente um mandado de segurança, alguns professores da rede pública estadual pretendiam a anulação do convênio da municipalização em Carapicuíba. Alegavam ilegalidade, em razão de inexistência de recursos municipais suficientes para manter as unidades escolares e por não ter sido editada lei que autorizasse a municipalização do ensino.

O Tribunal considerou que o convênio não atingia os impetrantes, pois como docentes de cargo efetivo professor de educação básica (PEB II) não atuavam em escolas de EF. Com relação a esta argumentação, o Desembargador deve ter se equivocado, pois um professor PEB II pode atuar tanto no EF, séries finais, como no EM.

$\mathrm{O}$ argumento principal para a negativa do recurso respaldou-se em que o ato se insere no âmbito da discricionariedade da administração, de acordo com o art. 11, inciso V da LDB. Este artigo trata da incumbência dos municípios no oferecimento do EF e EI.

Assim, sendo inviável interferir nos poderes administrativos. Esta argumentação é baseada na seguinte posição de Diógenes Gasparini:

[...] limita-se o controle do ato judicial do ato administrativo, nos casos concretos, ao exame da legalidade do ato ou da atividade administrativa. Escapa-lhe, por conseguinte, o exame do mérito do ato ou atividade administrativa. Assim, os aspectos de conveniência e oportunidade não podem ser objeto desse controle. A autoridade judicial pode dizer o que é legal e o que é ilegal, mas não o que é

\footnotetext{
${ }^{134}$ Apelação Cível n 330.648-5/0-00, 2007.
} 
oportuno ou conveniente, e inoportuno e inconveniente. (Direito Administrativo, Diógenes Gasparini, p. 545, Saraiva, 1995). (APELAÇÃO CÍVEL n ${ }^{\circ}$ 527.224-5/300, 2007, relator Des. Oliveira Santos).

Ressaltou, ainda, que os professores efetivos tiveram a oportunidade de optar pela permanência ou não nas escolas municipalizadas. Porém, essa opção não permite aos profissionais uma escolha justa, pois os que optarem por não assinar o convênio precisam se deslocar para outros municípios, onde existem vagas em escolas estaduais não municipalizadas.

A decisão final do TJ-SP considerou a inexistência de ato ilegal, e os impetrantes (professores) não possuindo direito líquido e certo. A decisão não analisou o argumento da inexistência de recursos municipais insuficientes para a manutenção das escolas.

A Apeoesp também ingressou com ação no município de Votuporanga, requerendo que os alunos fossem atendidos integralmente pela rede pública estadual e determinando a regularização da situação funcional dos profissionais da educação, retornando à situação anterior. O sindicato, no recurso ao TJ-SP, utilizou entre outros argumentos a demissão dos professores admitidos nos termos da Lei $n^{\circ}$ 500/74 (Lei que autoriza a contratação de funcionários no estado de SP), a inconstitucionalidade da EC nº14, de 1996, e, por consequência, da Lei 9424/96, que implantou o Fundef com base no princípio federativo.

O Desembargador Danilo Panizza acatou a pertinência da inconstitucionalidade da EC nº14/96 e, por consequência, da Lei no 9424/96, por dois aspectos técnico-constitucionais:

1- Descabimento de emenda constitucional de dispositivo transitório da Carta Federal, sob o risco de tornar o transitório permanente.

2 - Risco de infringência do princípio federativo, a partir do momento em que as alterações constitucionais passam a alterar ou reduzir a autonomia de Estado. Estes aspectos apenas sugerem reflexão ao respeito do tema. (APELAÇÃO CÍVEL COM REVISÃO no 642.103-5/00, 2007, relator Des. Danilo Panizza).

Para o relator esses dois pontos são relevantes, entretanto a demanda judicial tinha como ponto fundamental a preservação da permanência dos professores na rede estadual de ensino, pois a ação foi proposta por uma entidade de classe. Desta forma, a situação não decorre para a nulidade do convênio entre a prefeitura de Votuporanga e a Secretaria de Estado da Educação de SP.

As três ações tiveram como autores os professores e o questionamento da municipalização do ensino a partir da análise dos riscos causados a esses profissionais. Os argumentos para a nulidade do convênio eram pertinentes, mas vinculando-se ao interesse da classe trabalhadora, não foi considerado pelo TJ-SP. O Judiciário pode ter se valido dessas 
justificativas, baseadas em argumentos formais, para não interferir nas questões relativas às decisões políticas e administrativas.

\subsubsection{Fechamento de creche em período de férias escolares}

O fechamento da creche em período de férias foi contestado em duas ações ${ }^{135}$. No município de Taiuva o prefeito alegou a necessidade administrativa de reforma e formação dos profissionais. E, como no ato do julgamento do recurso a creche já estava em funcionamento, perdeu-se o objeto da ação. Mas o argumento do Desembargador Luís de Macedo foi para a não interferência do Judiciário no poder discricionário do Executivo, para tanto se fundamenta em decisão do Desembargador Mohamed Amaro:

[...] a conveniência e a oportunidade de realizar atos físicos de administração (obras e contratações, por exemplo), cabe, com exclusividade, ao Poder Executivo, não sendo possível ao Poder Judiciário, sob o argumento de estar protegendo direitos coletivos, ordenar que tais atos sejam efetivados. (APELAÇÃO CÍVEL nº 82.0890/5-00 apud APELAÇÃO CÍVEL n ${ }^{\circ}$ 104.360-0/0, 2003, relator Des. Luís de Macedo).

A outra ação, proposta pela Defensoria Pública do Estado de São Paulo, tratou da decisão preliminar que suspendeu parte da Portaria nº 4.474/2006, da Secretaria Municipal de Educação, que estabelecia recesso escolar e férias coletivas no mês de janeiro nas creches municipais diretas e conveniadas. Neste recurso, analisou-se a lesão à ordem, à saúde, à segurança e à economia pública. Para o desembargador Roberto Vallim Bellochi, a concessão da medida liminar afetava a ordem e a economia política, pois mantida a decisão, o município teria de convocar todos os professores e funcionários para que retomassem as suas atividades nas creches.

O município argumentou que as creches conveniadas, que atendem mais da metade dos alunos, entram em recesso durante as férias escolares há muito tempo; justificou, também, sobre a existência de uma rede de plantão de creches municipais para atender a baixa demanda nesta época do ano e a necessidade de reparos, pintura, dedetização e desratização que precisam ser realizadas na ausência de crianças.

O Desembargador Roberto Vallim Bellochi, ainda destacou que "os atos administrativos gozam de presunção de legalidade e boa-fé, não havendo, nos autos, nenhuma

\footnotetext{
${ }^{135}$ Apelação Cível no 104.360-0/0, 2003 e Agravo Regimental nº 158.214.0/7-01, 2008.
} 
prova pré-constituída a evidenciar de modo contrário". (AGRAVO REGIMENTAL n⿳ 158.214.0/7-01, 2008.

Em voto vencido, o Desembargador Palma Bisson argumentou que as crianças que deixariam de ser atendidas no período de férias seriam colocadas em situação de risco, pois poderiam ficar sozinhas, para que seus pais fossem trabalhar. Esclareceu, também, que o regime de plantão, com a oferta de apenas 46 unidades, não seria suficiente, a julgar pelo fato de que 1.109 unidades são disponibilizadas durante o ano. Além disso, essas unidades podem não ficar próximas da residência ou do trabalho dos pais, obstaculizando o direito garantido pelo ECA, de escola pública e gratuita próxima da sua residência.

\subsubsection{Outras decisões referentes às decisões administrativas e políticas}

Este grupo é composto por seis decisões sobre diferentes temas que questionaram as medidas adotadas pelo Poder Executivo com relação à educação: transformação de escola de EI em unidade para EF e EI; fechamento de escola de EI estadual; redução da carga horária; promoção automática em escola particular; recomposição e agrupamento de classes escolares com base na Resolução SEE n $169 / 96$; uso de prédio municipal de escola de EF para destino de Ensino Superior. Apresentar-se-á a análise das três primeiras ações, especificando-se que as demais não trazem uma discussão aprofundada nos acórdãos, inviabilizando a compreensão do processo.

A ação que questionou ato do prefeito municipal, criando séries de EF em uma escola de EI, sem consultar o Poder Legislativo, foi proposta pelos vereadores de Rinópolis. Em primeira instância, a ação foi julgada procedente, declarando a nulidade do Decreto municipal.

$\mathrm{Na}$ análise do recurso, o TJ-SP entendeu que a $\mathrm{CF} / 88$, artigo $211, \S 2^{\circ}$, outorgou competência para o município atuar, com prioridade, no EF e na EI. Previsão também expressa na LDB/96 e na Lei Orgânica de Rinópolis. O município não poderia criar séries de EF em escola cuja lei municipal a criou para EI. Nesta direção, apesar de ser "louváveis os propósitos do prefeito", o ato "constitui opção político-administrativa que exige consulta aos representantes do povo, como também implica a criação de cargos e a assunção de despesas, matéria cuja aprovação depende necessariamente de lei formal." (APELAÇÃO CÍVEL no 
117.680-5, 2000, relator Des. Ricardo Levandowski). O voto do relator, acompanhado pelos demais membros da $9^{\text {a }}$ Câmara de Direito Público, decidiu pelo não provimento do recurso do executivo.

A divisão de responsabilidades entre os entes federativos, com relação à educação básica, também foi utilizada para a decisão de ação promovida por alguns cidadãos que contestaram o fechamento de unidade de EI mantida pela rede estadual ${ }^{136}$. O TJ-SP pontuou ser prioridade do Estado o EM e EF (art. 211, $\S 3^{\circ} \mathrm{CF} / 88$ ). Portanto, segundo o Desembargador Henrique Nelson Calandra, a responsabilidade do Estado para com a EI seria configurada caso os impetrantes comprovassem que o Estado já cumprira com todos os seus deveres em relação à sua prioridade educacional, e desde que existissem recursos acima dos $25 \%$ afixados pela $\mathrm{CF} / 88$, art. 212. A não comprovação implicava na inexistência do direito líquido e certo dos impetrantes. Porém, cabe salientar que a LDB/96 fixa a permissão de atendimento em "outros níveis de ensino somente quando estiverem atendidas plenamente as necessidades de sua área de sua competência e com recursos acima dos percentuais mínimos vinculados pela Constituição Federal à manutenção e desenvolvimento do ensino" (art. 11, inciso V), quando trata das incumbências dos municípios, não fazendo esta referência nas obrigações do Estado.

Deste grupo, também consta uma ação que discutia a redução da carga horária no município de Presidente Prudente, de 1.000 para 800 horas anuais. A argumentação do MP baseou-se na progressividade de aumento do período de permanência do aluno na escola, previsto no art. 34 da LDB/96, a inadmissibilidade do retrocesso social e a "importância de se considerar as horas-aulas como parâmetro de aferição da qualidade do ensino”. (APELAÇÃO CÍVEL n ${ }^{\circ}$ 423.994.5/8-00, 2006, relator Des. Henrique Nelson Calandra).

Para o membro do TJ-SP, relator da decisão, a progressividade da jornada escolar prevista na LDB/96 não "tomou caráter imperativo, já que a lei não forneceu parâmetros para a sua exigibilidade, figurando-se apenas como diretriz aos sistemas de ensino". Quanto ao retrocesso social, para que se caracterizasse não bastaria a redução da carga horária. "Por exemplo, se a diminuição da carga horária escolar implicar a possibilidade de melhor preparação dos educadores, não terá havido retrocesso social, mas apenas mudança do mecanismo para se conseguir avanço social". E a qualidade do ensino não se vincula necessariamente ao número de aulas:

[...] a fixação de uma jornada escolar mínima é imprescindível à efetiva prestação educacional, mas uma carga horária grande ou até mesmo integral não equivale

\footnotetext{
${ }^{136}$ Apelação Cível no 356.870-5/0-00, 2008.
} 
necessariamente a avanço social. Há outros mecanismos verdadeiramente mais significativos para o sucesso educacional. (APELAÇÃO CÍVEL nº 423.994.5/8-00, 2006, relator Des. Henrique Nelson Calandra).

Desta forma, o Desembargador considerou que do ato praticado pelo Poder Executivo não decorre dano moral, inexistindo razão para a reparação civil.

\subsection{Financiamento da educação}

Litígios envolvendo os recursos financeiros destinados à educação foram objetos de 14 decisões do TJ-SP. Oito delas concernentes à aplicação irregular dos citados recursos; uma, especificamente sobre o Fundo de Manutenção e Desenvolvimento do Ensino e de Valorização do Magistério (Fundef); duas sobre contratos entre o Poder Público municipal e empresas privadas para a compra de material didático apostilado e três sobre repasse de recursos públicos às instituições privadas. Seis ações estão distribuídas entre 1994 e 2006 e as demais em 2007 (GRÁFICO 7):

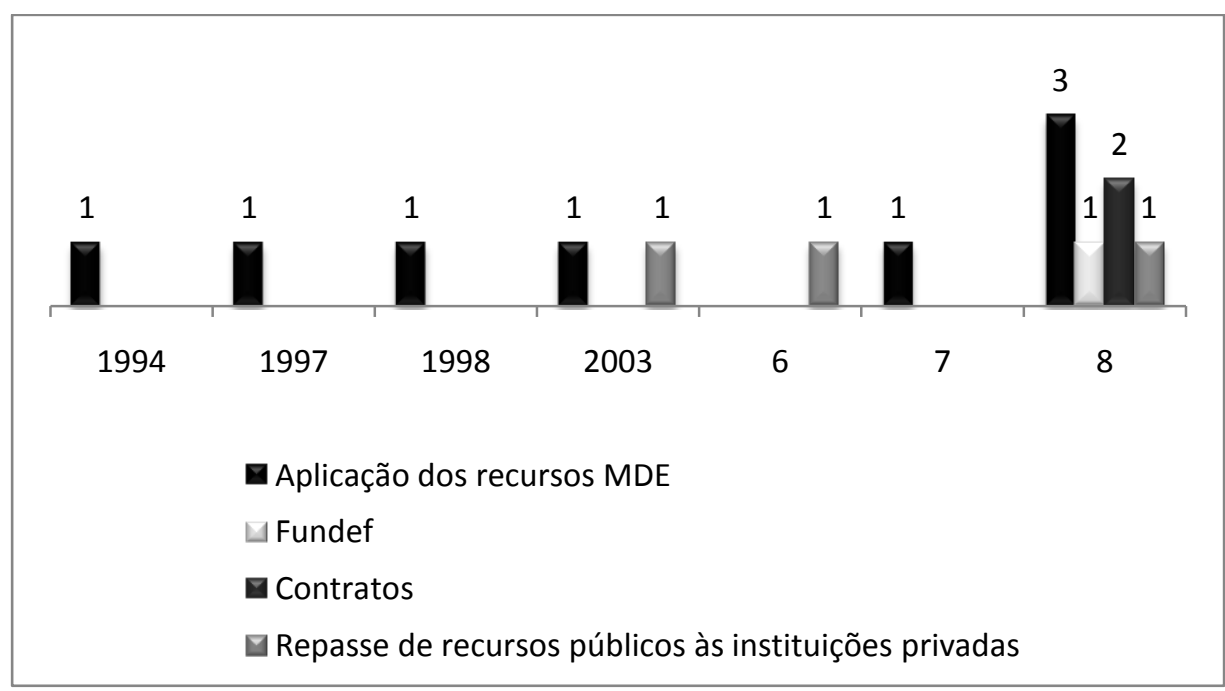

Gráfico 7 - Distribuição anual das decisões versando sobre financiamento da educação Fonte: a autora com base nas decisões coletadas no TJ-SP. 
Uma ação de 1994, objetivando que o município de Dourado incluísse o percentual de $11,27 \%$ da arrecadação de impostos na verba destinada à educação no exercício de $1987^{137}$ foi tida como improcedente, em $1^{\mathrm{a}}$ instância, considerando a liberdade e a independência entre os Poderes. O MP insistiu na procedência da ação em recurso e alegou sua legitimidade, embasado na defesa do cumprimento das normas constitucionais. Sobre o argumento da independência entre os Poderes, o Desembargador Villa da Costa discorreu:

São independes, enquanto praticam os atos administrativos de competência interna corporis. Não são independentes para, a seu talante, desobedecerem à Carta Política, às leis e, sob tal pálio, permanecerem, cada um a seu lado, imunes à reparação das ilegalidades. O ilícito não tem amparo em princípios que corroam as instituições, porque descumprir a norma, no caso a maior, é minar o alicerce, e o Judiciário, se provocado, como o foi, deve dar guarida aos legítimos anseios. (APELAÇÃO CÍVEL no 201.109-1, 1994, relator Des. Villa da Costa).

Assim, o TJ-SP reconheceu que o MP exerceu legitimidade para a propositura da ação, tendo em vista que o município não aplicou o percentual previsto na legislação em vigor (Emenda Constitucional $\mathrm{n}^{\mathrm{o}} 1$ de 1969, artigo 176, §4º).

Em ação civil pública que questionava o desrespeito à Lei Orgânica do município de São Paulo, de não destinar 30\% das verbas orçamentárias à manutenção e desenvolvimento do ensino (MDE), a Câmara Especial do TJ-SP considerou que o tema compete à Vara da Fazenda Pública, e não à Vara da Infância da Juventude, ferindo o direito difuso de crianças e adolescentes. Para o Desembargador Dirceu de Mello, a não destinação de receitas mínimas em educação é temática de natureza puramente orçamentária. Desse modo, atingindo indiretamente a esfera jurídica das crianças e adolescentes, e visando a uma melhor distribuição da justiça, fixou que a ação deveria ser julgada pela Vara da Fazenda Pública ${ }^{138}$. Igualmente, decisões semelhantes foram proferidas em outros dois recursos providos pelo MP contra o município de São Paulo ${ }^{139}$ e de Guarulhos ${ }^{140}$, considerando que aplicação de recursos orçamentários é matéria tributária e orçamentária, afastando a competência da Vara da Infância e da Juventude. Não foram localizadas as decisões finais dessas ações no conjunto analisado para este trabalho.

A não aplicação dos percentuais mínimos em MDE e abertura de créditos suplementares sem respaldo financeiro, no ano de 1995, acarretaram ajuizamento de ação

\footnotetext{
${ }^{137}$ A destinação de um percentual mínimo para a educação foi incluída na EC no 1 de 1969 , conhecida como Constituição de 1969, pela EC no 24 de 1983 e previa que a União aplicasse no mínimo $13 \%$ e os Estados, Distrito Federal e os Municípios 25\%. Com a CF/88 o percentual da União foi alterado para $18 \%$. Sobre o percentual requerido pelo MP $(11,27 \%)$ não há no acórdão discussão mais aprofundada, considerando que o recurso no TJ-SP discutiu a legitimidade do MP para atuar sobre este tema.

${ }_{138}$ Agravo de Instrumento $n^{\circ} 40.865-0,1997$.

${ }^{139}$ Agravo de Instrumento $\mathrm{n}^{\circ} 47.081-0,1998$.

${ }^{140}$ Apelação Cível no 146.539-0/5-00, 2007.
} 
civil pública pelo MP ao ex-prefeito de Braúna, acusado de improbidade administrativa, exigindo a sua condenação ao pagamento de multa civil no valor equivalente a cinco vezes o valor de sua última remuneração $^{141}$.

A Lei $\mathrm{n}^{\mathrm{o}}$ 8.429/92 disciplina as hipóteses de improbidade administrativa e as respectivas sanções; sua finalidade é regulamentar o art. 37, $\S 4^{\circ}$, da $\mathrm{CF} / 88$, de seguinte teor: “Os atos de improbidade administrativa importarão a suspensão dos direitos políticos, a perda da função pública, a indisponibilidade dos bens e o ressarcimento ao erário, na forma e gradação previstas em lei, sem prejuízo da ação penal cabível”.

O ex-prefeito de Braúna argumentou que o parecer da Assessoria Técnica do Tribunal de Contas pronunciou-se favoravelmente à aprovação de suas contas, aceitando-se que, após as glosas efetuadas pela auditoria, atingiu o percentual de $24,66 \%$, e que esta diferença, no montante de $\mathrm{R} \$ 4.882,62$, poderia ser compensada no exercício seguinte. Contudo, a Primeira Câmara do Tribunal de Contas emitiu decisão desfavorável às contas da prefeitura de Braúna.

Ao TJ-SP o ex-prefeito justificou também sobre as suas dificuldades administrativas:

Infelizmente, no último exercício econômico-financeiro de 1995, incorremos em algumas lamentáveis, porém desintencionais falhas administrativas, procedimentos esses que nos levam à presente justificação.

Esclareça-se ainda; a bem verdade; que nosso quadro de funcionários, malgrado composto de pessoas humildes, mas todavia honestas e bem intencionadas, pode ter influenciado para que incorrêssemos naquelas malsinadas falhas já apontadas, isso em vista a grande dificuldade em freqüentarem cursos de especialização (freqüentemente realizados em São Paulo, o que demandaria dias naquela capital, afora o dispêndio aos cofres públicos e aos próprios servidores). (APELAÇÃO CÍVEL no 212.177.5/6, 2003).

O TJ-SP, em votação unânime, considerou que apesar do Tribunal de Contas não ter aprovado as contas, pela não aplicação dos percentuais mínimos na MDE e pela abertura de créditos adicionais sem recursos, esses fatos não caracterizaram improbidade administrativa, citando os ensinamentos de Fábio Medina ${ }^{142}$, pois "o ato além de ilegal, se mostre fruto da desonestidade ou inequívoca e intolerável incompetência do agente público".

As argumentações do Desembargador Celso Bonilha, relator da decisão, são justificadas, ainda, com decisão do STJ (Recurso Especial no 213.994-0 MG, Relator Min. Garcia Vieira, DJ de 27/9/99) e por citação de Hely Lopes Meirelles ${ }^{143}$ :

[...] Nessa missão político-administrativa é admissível que o governante erre, que se equivoque na interpretação e aplicação da lei, que se confunda na apreciação da conveniência e oportunidade das medidas executivas sujeitas à sua decisão e determinação. Desde que o chefe do executivo erre em boa-fé, sem abuso de poder, sem intuito de perseguição ou favoritismo, não fica sujeito à responsabilização civil,

\footnotetext{
${ }^{141}$ Apelação Cível no 212.177.5/6, 2003.

${ }^{142}$ MEDINA, Fábio. Improbidade Administrativa. Ed. Síntese, 2ª ed., p. 129.

${ }^{143}$ MEIRELLES, Hely Lopes. Direito Municipal Brasileiro. São Paulo: Malheiros, 1994, p. 585.
} 
ainda que seus atos lesem a Administração ou causem danos patrimoniais a terceiros. E assim é porque os agentes políticos, no desempenho de suas atribuições de governo, defrontem-se a todo momento com situações novas e circunstâncias imprevistas, que exigem pronta solução, à semelhança do que ocorre na Justiça, em que o juiz é obrigado a decidir ainda que na ausência ou na obscuridade da lei. Por isso mesmo, admite-se para essas autoridades uma margem razoável de falibilidade nos seus julgamentos. (APELAÇÃO CÍVEL nº 212.177.5/6, 2003).

Desta forma, o TJ-SP considerou que, não havendo enriquecimento ilícito, mas inabilidade do administrador, não caberiam as sanções da Lei nº 8.429/92.

No caso do prefeito de Palestina, que recebeu recursos da SEE para aplicar no transporte de alunos e destinou os valores para outros fins, o TJ-SP confirmou a sentença de condenação da municipalidade, em $1^{\text {a }}$ instância, obrigando a devolver ao Estado a importância recebida. O Tribunal entendeu que houve conduta de má fé do prefeito, pois poderia ter solucionado a questão administrativamente quando da indicação do Tribunal de Contas.

O prefeito de Palestina, como apontado na decisão, responde a diversos processos de corrupção e não tem bens em seu nome para ser penhorados, sequestrados ou arrestados para ressarcimento ao erário público. Esse fato, segundo o Desembargador Guerrieri Rezende, é demonstrativo da conduta "de homem ímprobo e que despreza a coisa pública" (APELAÇÃO CÍVEL no 416.740-5/3-00, 2006).

A rejeição das contas do município de Ribeirão Pires, pelo desrespeito à determinação constitucional de aplicação mínima de $25 \%$ em MDE, levou o prefeito a questionar o julgamento da Câmara Municipal. O prefeito alegou: “a) nulidade por não observar as garantias constitucionais do contraditório e da ampla defesa, dado que a Câmara Municipal deixou de notificar o autor para se defender antes de julgar as suas contas; b) excesso de rigor quanto à aplicação de recursos no ensino fundamental, dado que o percentual de $24,33 \%$ é muito próximo dos $25 \%$ exigidos pela Constituição Federal". Relativoa essa argumentação, o TJ-SP pronunciou-se que a falta de oportunidade de defesa não foi prejudicada, pois pode se justificar para o Tribunal de Contas. Quanto ao percentual aplicado, o Desembargador Edson Ferreira da Silva, relator, enfatizou: "a Constituição impõe aplicação de um percentual mínimo no ensino fundamental, a não observância desse mínimo, não importa se pouco ou muito, constitui irregularidade que determina a rejeição das contas" (APELAÇÃO CÍVEL n ${ }^{\circ}$ 221.575.5/3-00, 2007). Portanto, o Tribunal votou pela validação do julgamento da Câmara Municipal. 
O convênio entre o Estado e o Município para aquisição de ônibus escolar também foi objeto de ação popular no município de Juquitiba ${ }^{144}$, pois o prefeito empregou os recursos de outra forma, na contratação de empresa de transporte e no repasse do duodécimo atrasado, devido aos vereadores do município. A ação em $1^{\text {a }}$ instância declarou a nulidade dos pagamentos, e a obrigação da devolução dos valores desviados pela empresa; quanto ao prefeito, devolução ao Estado, por aplicação indevida. O TJ-SP confirmou a decisão da $1^{\text {a }}$ instância.

Sobre os recursos do Fundef ${ }^{145}$, apenas uma decisão foi localizada. Nesta ação, também se discutiu o desvio de finalidade de recursos, que foram empregados na compra de veículo. A ação popular questionava a ilegalidade da compra, desde que os recursos do Fundo deveriam ser aplicados com a manutenção e o desenvolvimento do EF. Em $1^{\text {a }}$ instância, a ação foi julgada improcedente, pois se comprovou que a aquisição do carro objetivou o uso no transporte de servidores para atender às necessidades da educação, sendo realizada com verba municipal orçamentária destinada a MDE e não do Fundef. Assim, considerou-se inexistente a ilegalidade da compra. No âmbito do recurso ao TJ-SP, o autor da ação popular questionou o desvio de finalidade da compra, porque o veículo não poderia ser inserido no âmbito da educação. Para o julgamento da ação, o Desembargador Laerte Sampaio destacou que o litígio derivava da interpretação do conceito da expressão "manutenção e desenvolvimento do ensino", previsto no artigo 212 da CF/88. Para a sua análise recorreu à LDB/96. Compila-se trecho de sua argumentação sobre a especificação das despesas em MDE pelos artigos 70 e 71 da LDB/96:

\footnotetext{
Diante desse quadro, forçoso é reconhecer que a lei ordinária discriminou, taxativamente, o que não pode ser considerado como despesas de manutenção e desenvolvimento. Por isso o art. 71 da Lei $n^{\circ}$ 9.394/96 deve ser interpretado literalmente, sem quaisquer ampliações.

Diversamente, o art. 70 da mesma lei tem notável intuito exemplificativo, porque se mostra inviável discriminar todas as hipóteses possíveis de despesas com manutenção e desenvolvimento. Dentro desse prisma, é perfeitamente lógico aceitarse que a despesa com veículo pode ser considerada aquisição de equipamentos necessários ao ensino (II) desde que destinado ao uso de professores e outros servidores para atender às necessidades de manter contato com repartições e escolas situadas em locais distantes, como em bairros ou outras cidades. Seria o mesmo raciocínio a ser desenvolvido com a despesa para aquisição de ônibus ou peruas para a manutenção de programas de transporte escolar (VIII). (APELAÇÃO CÍVEL COM REVISÃO n 357.013-5/7-00, 2007, relator Des. Laerte Sampaio).
}

\footnotetext{
${ }^{144}$ Apelação Cível com revisão no 329.329-5/9-00, 2007.

${ }^{145}$ Apelação Cível com revisão no 357.013-5/7-00, 2007.
} 
O Desembargador ressaltou que a aquisição do veículo era legal; porém, acredita-se que a utilização do veículo pela SME deveria ser fiscalizada pelos autores da ação popular, como mecanismo de controle, pois muitos bens podem ter sua aquisição com recursos destinados à educação e, depois de algum tempo, acabam servindo a outros órgãos municipais.

A compra de material didático na rede municipal de Lorena foi contestada pelo MP, com pedido de suspensão do pagamento devido, relativo a contrato celebrado entre a Prefeitura e o Sistema de Ensino Aprende Brasil (SABE). A realização do contrato não decorreu de processo licitatório, pois tratava-se de "bem singular" e, portanto, inexigível de licitação, conforme o art. 25, incisos I e II da Lei 8.666/93 ${ }^{146}$.

O Desembargador Oscild de Lima Júnior, relator, argumentou que não caberia, no contexto deste recurso, manifestar-se acerca da legalidade ou não do contrato, mas julgar a concessão da liminar que determinou a suspensão dos pagamentos devidos à empresa fornecedora do material didático. A decisão anterior julgara favoravelmente a liminar pleiteada, devido ao "perigo de demora em face do risco de dano de difícil reparação ao erário municipal". Contudo, este desembargador julgou que a cessão do fornecimento das apostilas e disponibilização dos sistemas de tecnologia da informação, se interrompida pelo não pagamento dos valores, poderia "incorrer em grave dano aos alunos beneficiários do sistema, esse também de difícil reparação", pois os alunos não poderiam ficar impossibilitados da utilização desse material. Desta forma, julgou-se pela suspensão da decisão anterior.

Dois meses após o julgamento deste recurso, o TJ-SP novamente decidiu sobre esse processo mantendo a decisão anterior, considerando que o ato de improbidade administrativa seria julgado no mérito da ação ${ }^{147}$.

No âmbito desses dois recursos não se discutiu a legalidade do contrato, segundo os vieses da inexigibilidade de licitação e da imputação de responsabilidades, relativa ao prefeito e ao secretário municipal de educação, mas somente a suspensão do pagamento à Gráfica.

Seria pertinente, e até mesmo relevante, uma decisão do Tribunal de Justiça sobre o mérito deste tipo de contrato, considerando que nos últimos anos dezenas de municípios paulistas realizaram a compra de "sistemas de ensino".

Levantamento realizado em pesquisa junto aos municípios paulistas indicou que, no período de 1994 a 2006, dos 645 municípios, 161 adotavam o "sistema apostilado" em parceria com instituições privadas, para a EI e EF (ADRIÃO, GARCIA, BORGHI,

\footnotetext{
${ }^{146}$ Agravo de Instrumento $n^{\mathrm{o}}$ 643.636.5/0-00, 2007.

${ }^{147}$ Agravo de Instrumento no 647.768-5/0-00, 2007.
} 
ARELARO, 2009b). Muitas dessas parcerias foram efetivadas sem a realização do devido processo licitatório. Os municípios justificam a escolha de empresas para a aquisição de "sistemas de ensino" nos incisos I e II, do art. 25 da Lei no 8.666/93:

\footnotetext{
Art. 25 - É inexigível a licitação quando houver inviabilidade de competição, em especial:

I - para aquisição de materiais, equipamentos, ou gêneros que só possam ser fornecidos por produtor, empresa ou representante comercial exclusivo, vedada a preferência de marca, devendo a comprovação de exclusividade ser feita através de atestado fornecido pelo órgão de registro do comércio do local em que se realizaria a licitação ou a obra ou o serviço, pelo Sindicato, Federação ou Confederação Patronal, ou, ainda, pelas entidades equivalentes;

II - para a contratação de serviços técnicos enumerados no art. 13 desta Lei, de natureza singular, com profissionais ou empresas de notória especialização, vedada a inexigibilidade para serviços de publicidade e divulgação; (BRASIL, 1993).
}

Os argumentos da exclusividade e de serviços técnicos de natureza singular também não se enquadram neste tipo de contrato, pois neste setor existem várias empresas privadas especializadas, aptas a fornecerem esse serviço.

Assim, observou-se que, em alguns casos a Administração Pública realizava processo licitatório para compra de sistemas de ensino, noutros, justificava-se através da inexigibilidade ou dispensa de licitação. Para solucionar este problema, o Tribunal de Contas do estado de SP editou, em 22 de agosto de 2007, a Deliberação TC-A- 21176/026/06, definindo que a contratação de sistemas de ensino deverá ser precedida do correspondente processo licitatório, preferencialmente do tipo técnica e preço (SILVEIRA, 2009b).

Sobre o repasse de recursos públicos às instituições privadas de ensino, a $\mathrm{CF} / 88$ prevê essa possibilidade de destinação às escolas comunitárias, confessionais ou filantrópicas (art. 213), desde que: "I - comprovem finalidade não-lucrativa e apliquem seus excedentes financeiros em educação; II - assegurem a destinação de seu patrimônio a outra escola comunitária, filantrópica ou confessional, ou ao Poder Público, no caso de encerramento de suas atividades”. A LDB/96 (art. 77, inciso IV) acrescenta que estas instituições devem prestar contas ao Poder Público dos recursos recebidos.

Para viabilizar a transferência de recursos entre a Administração Pública e as entidades privadas se faz necessária a celebração de um convênio.

À celebração de convênio, no que couber se aplicam as disposições da Lei 8.666/93, que institui normas para licitações e contratos da Administração Pública, a qual deverá aprovar previamente o plano de trabalho da instituição interessada. O citado plano precisa especificar a identificação do objeto a ser executado; metas a serem atingidas; etapas ou fases de execução; plano de aplicação dos recursos financeiros; cronograma de desembolso; previsão de início e fim da execução do objeto (BRASIL, 1993, artigo 116, § $1^{\circ}$ ). 
A rescisão ou extinção de um convênio implica em que os saldos financeiros remanescentes sejam devolvidos à entidade ou órgão repassador dos recursos, inclusive os valores decorrentes de aplicação financeira no prazo de 30 dias do evento, sob pena da imediata instauração de tomada de contas especial do responsável (BRASIL, 1993, art. 116, $\left.\S 6^{\circ}\right)$.

Três decisões do TJ-SP versaram sobre os convênios celebrados entre municípios e instituições, todas elas tinham como objeto o atendimento de crianças em creche. No Brasil, historicamente o atendimento às crianças pequenas, fora do ambiente familiar, ocorre por instituições filantrópicas conveniadas, tendo o Poder Público uma ação secundária ou até mesmo ausente em muitas localidades.

A prefeitura de Teodoro Sampaio foi acionada judicialmente por não cumprir o repasse de verbas a uma entidade sem fins lucrativos do município ${ }^{148}$. O convênio foi celebrado, objetivando o serviço de creche. O prefeito alegou que não recebera os recursos da Secretaria de Assistência Social. O Desembargador Afonso Faro afirmou que o dever de atender a crianças em creche é da municipalidade, de acordo com a CF/88, ECA e LDB/96, e esta terceirizara sua obrigação. Pontuou que o fato de não receber verbas não exonerava a responsabilidade da Administração Pública de cumprir com as obrigações dispostas no convênio celebrado.

Em outro processo, o MP em Florinéa ingressou com ação civil pública, visando que o município se abstivesse de repassar dinheiro a uma associação privada, assumindo diretamente a implantação e execução do Programa de Saúde da Família e da Creche ${ }^{149}$.

A municipalidade questionou, no mérito da ação, que o Poder Judiciário não poderia conceder a antecipação da tutela requerida pelo MP, considerando a violação do princípio da separação e independência dos poderes, alegando, ainda, que a legislação autoriza o repasse de recursos.

Sobre a interferência do Poder Judiciário no Executivo, o relator destacou: "cabe ao Administrador o dever da boa gestão da coisa pública. E, uma vez que se desvia dos princípios da legalidade, da moralidade, da finalidade e da publicidade é possível a interveniência do Poder Judiciário, se provocado". (AGRAVO DE INSTRUMENTO n ${ }^{\circ}$ 409.465-5/1-00, 2006, relator Des. Reinaldo Miluzzi).

Consta no acórdão parecer do Procurador de Justiça, afirmando que a Associação era presidida pela esposa do prefeito, que os mesmos celebraram o contrato sem licitação e que a

\footnotetext{
${ }^{148}$ Apelação Cível no 132.714-5/5-00, 2003.

${ }^{149}$ Agravo de Instrumento $\mathrm{n}^{\circ}$ 409.465-5/1-00, 2006.
} 
parceria tinha a função real de burlar as regras do concurso público, configurando-se um mecanismo de contratação de cabos eleitorais. A decisão do TJ-SP, em votação unânime, foi para o não provimento do recurso da Prefeitura Municipal.

Em sentido oposto, foi ajuizada uma ação popular porque a Prefeitura Municipal de Guaíra manifestara interesse de não renovar convênio com sociedade sem fins lucrativos, prestadora de serviços de Educação Infantil no município, para que a própria municipalidade administrasse diretamente os serviços educacionais. Para tanto, enviou Projeto de Lei à Câmara Municipal para a criação dos cargos necessários para o atendimento direto. Entretanto, os vereadores rejeitaram o projeto sob alegação de que "a prestação do serviço pelo convênio era mais vantajosa à administração, sendo que a prestação direta acarretaria aumento de despesa". Para a realização do atendimento, o prefeito efetivou a contratação temporária de servidores (APELAÇÃO CÍVEL COM REVISÃO nº 667.424-5/8-00, 2008).

A autora da ação popular justificou seus pedidos na "ilegalidade dos atos do prefeito, que seriam contrários ao interesse público, afirmando que a formação de pessoal próprio para a prestação do serviço em referência seria afastada da razoabilidade, por implicar aumento abrupto de despesa", e o encerramento do convênio "ofensa aos princípios da legalidade e do interesse público".

O TJ-SP considerou que não houve extinção unilateral dos ajustes firmados, levando em conta que a Administração Municipal aguardara o término do prazo estipulado e comunicara a entidade. Com o término do convênio, as crianças passaram a ser atendidas pela municipalidade, e as testemunhas afirmaram que as creches e as escolas de Educação Infantil estavam prestando serviço de boa qualidade, com aumento do espaço físico e do número de crianças atendidas. Sobre o aumento das despesas, o Desembargador Nogueira Diefenthäler ponderou que a autora da ação não produziu provas convincentes. Portanto, a municipalização da EI neste município não seria irregular.

A iniciativa do prefeito de Guaíra é muito louvável, sobretudo reconhecendo-se que, atualmente, os convênios entre municípios e entidades privadas para ampliação da oferta da EI, principalmente, creches, estão em franca expansão, respaldados por um contexto de incentivo da legislação para a transferência de serviços sociais para as chamadas instituições privadas (BEZERRA, 2008; DOMICIANO, 2009; BORGHI, ADRIÃO, ARELARO, 2009). 


\subsection{Deveres dos pais}

Onze decisões do TJ-SP versaram sobre os deveres dos pais para com a obrigatoriedade de matricular e garantir a frequência de seus filhos ou dependentes na escola. Todos os recursos foram julgados pela Câmara Especial e com votação unânime.

O dever dos pais em assistir, criar e educar os filhos está fundamentado no artigo 229 da CF/88; no Código Civil de 2002 (art. 1634, inciso I), ao tratar da competência dos pais quanto aos filhos menores, determinando aos primeiros a autoridade de "dirigir-lhes a criação e educação"; ECA, artigo 22, com o dever dos pais "de sustento, guarda e educação dos filhos menores" e artigo 129, inciso V, "obrigação de matricular o filho ou pupilo e acompanhar sua freqüência e aproveitamento escolar". Também, é considerado crime de abandono intelectual pelo Código Penal de 1940, art. 246: "Deixar, sem justa causa, de prover à instrução primária de filho em idade escolar", com pena de detenção, de 15 dias a um mês, ou multa.

A sanção para o descumprimento dos deveres inerentes ao pátrio poder, quando os filhos deixam de frequentar a escola, está baseada no artigo 249 do ECA: "Descumprir, dolosa ou culposamente, os deveres inerentes ao pátrio poder ou decorrentes de tutela ou guarda, bem assim determinação da autoridade judiciária ou Conselho Tutelar. Pena: multa de três a vinte salários de referência, aplicando-se o dobro em caso de reincidência".

Em ação que julgava a negligência dos pais, que "além de não cuidar do aproveitamento escolar do menor, não fazia questão que o mesmo cumprisse suas tarefas, e se mostrou inconformado com as repreensões corretamente aplicadas ao filho", a penalidade imposta pelo TJ-SP, baseada no artigo art. 129, inciso II, do ECA, determinou que o pai frequentasse, pelo prazo a ser aferido pela própria instituição, obrigatoriamente, as reuniões da Associação Antialcoólica; à mãe, impôs-se a obrigação de "matricular o filho e acompanhar sua frequiência e aproveitamento escolar, com a necessidade de, mensalmente, prestar contas de seu encargo, também sob pena de desobediência" (APELAÇÃO CÍVEL n ${ }^{\circ}$ 27.678-0, 1996, relator Des. Prado de Toledo).

Em outros cinco litígios sobre faltas reiteradas e injustificadas de adolescente à escola $^{150}$, o TJ-SP foi favorável à alteração da sanção, destacando a necessidade de ajuda técnica capaz de identificar as causas do desinteresse do adolescente em frequentar a escola, e a impossibilidade dos pais de fazer valer sua autoridade, determinando, desta forma, a

\footnotetext{
${ }^{150}$ Apelação Cível no 68.831-0, 2001; Apelação Cível no 104.182.0/8-00, 2004; Apelação Cível nº 106.965.0/600, 2004; Apelação Cível n 110.231.0/1-00, 2004; Apelação Cível nº 129.675-0/0-00, 2006.
} 
inclusão dos alunos e dos pais em programas de tratamento psicológico, de inclusão social e de orientação, eximindo-os da aplicação de multa, pois esta não resolveria o problema. Nessas ações, os pais alegavam dificuldade em exercer o controle sobre a conduta dos filhos, em razão da ausência dos pais devido ao trabalho ou pela desobediência dos filhos.

Sobre o descumprimento dos deveres dos pais e a imposição de multa o Desembargador Gentil Leite argumentou:

[...] se a simples falta de domínio dos pais sobre os atos dos filhos pudesse gerar a imposição de multas, certamente os fundos destinatários dessa espécie de renda estariam abarrotados de recursos, tal é o número de menores infratores e de atos infracionais praticados no país por incapacidade dos pais em controlar a sua prole. (APELAÇÃO CÍVEL nº 104.182.0-00, 2004, relator Des. Gentil Leite).

A alteração da pena pecuniária para de advertência foi adotada em ação judicial ${ }^{151}$, na qual os pais alegavam não ter condições econômicas para o pagamento.

Noutra ação semelhante, o adolescente também se recusara a frequentar a escola ${ }^{152}$, ao que fora obrigado por remissão concedida após a prática de ato infracional, com multa imposta aos pais, o TJ-SP julgou que a obrigação de frequência deveria ser cumprida pelo adolescente e, portanto, improcedente a representação do MP para penalizar os pais.

Em outras ações, requisitando a destituição do pátrio $\operatorname{poder}^{153}$, o TJ-SP julgou que não havia prova da negligência, constando, entre os itens avaliados, a declaração de matrícula dos alunos. Somente em uma ação foi comprovado o descumprimento dos deveres dos pais, não tendo providenciado instrução ao filho, com aplicação de multa como sanção ${ }^{154}$.

\subsection{Considerações sobre os litígios julgados pelo TJ-SP: lições aprendidas}

O levantamento das decisões judiciais, versando sobre os direitos de crianças e adolescentes à educação, denota o uso do Poder Judiciário para a resolução de conflitos nessa área, mas não em todos os assuntos. $O$ recurso judicial para requisição de uma vaga na educação básica e para o oferecimento de serviços que impedem a permanência do aluno na escola foram os conflitos mais presentes no conjunto estudado.

\footnotetext{
${ }^{151}$ Apelação Cível no 95.975-0-00, 2002.

152 Apelação Cível no 71.734-0, 2001.

${ }^{153}$ Apelação Cível no 65.199-0, 2001.

${ }^{154}$ Apelação Cível nº 152.190/0-00, 2007.
} 
Os últimos anos apresentaram um número maior de decisões, todavia não se trata de expansão das mesmas demandas. Com exceção das que requisitaram vagas em instituições de EI, a maioria das ações é levada a litígio em períodos específicos, ocasionadas por alterações nas políticas de oferta do atendimento educacional e na legislação.

A expressiva demanda de ações envolvendo a EI está relacionada à especificação deste direito na legislação educacional, principalmente na LDB/96, como primeira etapa da educação básica. Também, ao contexto de restrição de recursos destinados a esta etapa de ensino com a EC n 14/96 e com a criação do Fundef, que subvincularam recursos ao ensino obrigatório, ou seja, ao EF. A inclusão das creches e pré-escolas no Fundeb, que substituiu o anterior, cria a expectativa de mais recursos para o atendimento de uma demanda em constante crescimento.

Ainda, na direção da especificação de direitos, a requisição de mecanismos de adaptação nos prédios escolares e transporte que garantissem a acessibilidade e o atendimento especializado às crianças e adolescentes com necessidades educacionais especiais tiveram uma expressiva recorrência no Judiciário paulista, e com maior consenso entre os desembargadores, com aprovação por maioria dos membros do TJ-SP em apenas duas ações que requisitavam a adaptação dos prédios escolares.

Concernente às ações que discutiam a obrigatoriedade do atendimento especializado às crianças e adolescentes com necessidades educacionais especiais destaca-se, entre as argumentações dos municípios para a negativa do pedido, a eficácia reduzida da legislação que rege o assunto, impossibilitando o atendimento imediato.

Das ações versando sobre demandas envolvendo crianças e adolescentes com necessidades educacionais especiais, pode-se ressaltar que a ideia de acessibilidade ainda é restrita. As requisições envolvendo adaptações físicas apontam para a prevalência de ações sobre obstáculos arquitetônicos, estando ausente a necessidade de remoção de barreiras relacionadas à comunicação. Seguindo essa mesma orientação, não se questiona o caráter educacional do atendimento especializado, apenas requer-se a vaga.

Entre as demandas educacionais mais discutidas no TJ-SP, no início da década de 90, sobressaem aquelas referentes às relações contratuais entre alunos e escola, sobretudo focadas no reajuste das mensalidades escolares. Não se estabeleceu o consenso entre os desembargadores sobre a ação do Estado para a regulação das taxas escolares.

No mesmo sentido, o estudo realizado por Lopes, sobre casos cujos objetos eram os direitos à saúde e à educação, mostrou que as ações civis públicas foram propostas 
fundamentalmente no período de 1989 a 1996, contra os prestadores privados de serviços educacionais ou planos de saúde. Já nos casos estudados a partir de 1997, evidenciou-se o incremento do número de ações propostas contra o setor público, refletindo, em princípio, uma nova abordagem para os direitos sociais (LOPES, 2006).

Com base em Sousa Santos (1996), a busca pelo Judiciário, como já enfatizado, é sempre um processo em recurso, pois tentativas informais, visando à resolução do conflito, são feitas com as próprias instituições encarregadas de garantir o direito, como a procura pelos pais, na escola; as intervenções do Conselho Tutelar e do MP, valendo-se de instrumentos extrajudiciais. Em outros casos, o ingresso com a ação judicial corresponde a uma tentativa de evitar reformas nas políticas educacionais, como a municipalização do EF e reorganização das escolas estaduais, sendo a tutela jurisdicional, para as entidades de classe como a Apeoesp, uma das tentativas de reversão da política e de defesa dos interesses da categoria. Porém, como destacado por Carvalho (2004), as demandas sociais que não agregam interesse suficiente, ou que envolvem altos custos para que sejam efetivadas, têm mais dificuldade de ser acatadas pelo Judiciário, que opta por posição de não-interferência.

Taylor (2007) destaca que os Tribunais inferiores, por suas decisões serem passíveis de recursos, acabam funcionando como mecanismo de protelação, atrasando a implementação de uma política ou limitando as alternativas; como exemplo, as liminares que concederam o direito aos alunos com seis anos incompletos a se matricularem no $\mathrm{EF}$, a alteração na legislação para a permanência dos alunos que concluíram o EM nos cursos de língua estrangeira oferecidos pela rede estadual, a paralisação do processo de reorganização das escolas estaduais em dado município.

A partir da análise das decisões, salienta-se, também, o papel importante do MP para o acesso à justiça. Em 56 decisões, a instituição atuou nos recursos como apelante ou recorrente; em 90, como apelados ou recorridos, seja diretamente pelos Promotores da Infância e Juventude, dos Interesses Difusos e Coletivos ou pela Procuradoria-Geral de Justiça.

Em várias ações questionou-se a legitimidade do MP para propor ações versando sobre interesses difusos e coletivos. As decisões do TJ-SP foram unânimes em afirmar a possibilidade de atuação do MP com base na CF/88 e no ECA.

Nos últimos anos, as requisições individuais, ou para um número determinado de vagas, consolidou jurisprudência favorável, dominante no TJ-SP. Contribuindo para isso as decisões do STF, com o reconhecimento da EI como direito fundamental, assegurado nas 
normas constitucionais e ordinárias, não sendo sua concretização uma avaliação discricionária da Administração Pública, definindo que a não observância do atendimento pelo Poder Executivo enseja sua proteção pelo Poder Judiciário.

Os números apresentados, principalmente nas tabelas 3-7, compiladas no início deste capítulo, evidenciam o acionamento do Judiciário, mas, como já discutido anteriormente, para que o fenômeno da judicialização da política ocorra é preciso analisar as respostas do Judiciário, com as mudanças produzidas a partir da participação de seus membros no processo decisório de implementação dos direitos sociais.

Ao longo deste capítulo, na descrição das decisões do TJ-SP, muitas ações permitem observar a discordância entre os próprios membros do Tribunal, e distintos resultados da $1^{\mathrm{a}} \mathrm{e}$ $2^{\mathrm{a}}$ instância do Poder Judiciário. Como afirma Dworkin, “os juristas não precisam de provas para mostrar que os juízes divergem e que suas decisões com frequência refletem sua formação e seu temperamento" (2007, p. 10).

Nas ações que requisitavam vagas em instituições de EI, os municípios, como réus ou recorrentes das ações judiciais, alegaram que são obrigados a oferecer somente o EF; que não possuem estrutura, pois operam no limite da capacidade, e que a ampliação do atendimento na EI é inviabilizada pelo problema orçamentário, não sendo possível ao Poder Judiciário interferir em atos do poder executivo. As decisões judiciais, tanto em primeira instância como em recurso no TJ-SP, apresentaram resultados diferentes, não havendo consenso entre os desembargadores acerca da interferência do Judiciário sobre a determinação do município em atender, por exemplo, aos pedidos de vaga, pois essa tarefa consiste numa atividade discricionária do Poder Executivo.

As ações que exigiam a implementação e/ou continuidade de programa de transporte escolar também foram decididas de maneira muito distinta pelos membros do TJ-SP que apreciaram essas demandas.

As ações versando sobre o acesso ao EF foram prontamente atendidas em primeira instância, e confirmadas pelo TJ-SP devido à existência de vagas. Já a EI teve seu reconhecimento como direito líquido e certo para as ações que requisitavam vagas individualmente ou para um número definido de crianças.

Em alguns conflitos, a utilização de atos normativos dos Conselhos de Educação (CNE e CEE) poderia favorecer o julgamento pelos membros do Judiciário, esclarecendo as questões educacionais já debatidas por estes órgãos normativos. Todavia, este trabalho evidenciou que não há referências a pareceres, resoluções e/ou indicações dos Conselhos. 
Mesmo não tendo informações para todo o conjunto de decisões analisadas, pode-se perceber a demora para uma resposta definitiva do Judiciário. As ações que obtiveram liminares de tutela antecipada favoráveis em primeira instância asseguraram que o direito requisitado fosse garantido, como por exemplo, a matrícula, o transporte. Esperar a decisão do mérito do pedido poderá não surtir mais o efeito pretendido, pois, como no exemplo, a criança já poderá ter perdido a oportunidade de frequentar a escola naquele ano.

Para que esse recurso jurídico possa ser utilizado devem-se preencher dois requisitos: o fumus boni uiris (fumaça do bom direito) e o periculum in mora (perigo na demora).

A partir desta análise geral das decisões versando sobre o direito de crianças e adolescentes à educação, denota-se que os argumentos contra o acatamento das demandas por efetivação do direito à educação entre os próprios membros do Tribunal, e os distintos resultados da $1^{\mathrm{a}}$ e $2^{\mathrm{a}}$ instâncias estão relacionados, sobretudo, às seguintes questões: impossibilidade de atender ao pedido devido à criação de despesa ao Poder Executivo; interferência do Judiciário no poder discricionário do Poder Executivo; atendimento às demandas difusas e coletivas.

Essas questões serão analisadas no próximo capítulo, recorrendo à literatura sobre o tema e às decisões dos desembargadores, procurando depreender as possibilidades de ampliação da exigibilidade do direito à educação por meio dos argumentos jurídicos, para, assim, superar os obstáculos. 


\section{CONSENSOS E CONFLITOS NA EXIGIBILIDADE JUDICIAL DO DIREITO À EDUCAÇÃO BÁSICA}

Esse capítulo objetiva, a partir de questões construídas pela análise das decisões proferidas pelo TJ-SP, apresentar algumas proposições para enfrentar os principais obstáculos localizados para a garantia do direito à educação por meio do Poder Judiciário: falta de recursos; impossibilidade de interferência do Judiciário no poder discricionário do Poder Executivo; dificuldade de questionamento das demandas envolvendo a formulação e a implementação de políticas públicas por meio de ações com interesses difusos e coletivos.

\subsection{Capacidade econômico-financeira do Estado para a implementação dos direitos educacionais}

Em diversas ações julgadas pelo TJ-SP, os municípios, como principais réus nas ações judiciais que reivindicavam matrículas em creches e pré-escolas, atendimento especializado às crianças e adolescentes com necessidades educacionais especiais, assim como programas de transporte escolar, argumentaram que sua atuação deveria ser realizada na medida das suas possibilidades estruturais e financeiras, ou seja, na reserva do possível ${ }^{155}$.

De acordo com Sarlet e Figueiredo (2008, p.27), uma das principais objeções para a concretização dos direitos sociais ${ }^{156}$, e a educação integra este conjunto de direitos, refere-se à dimensão econômica desses direitos, pois se sustenta na alegação de que as prestações necessárias para a sua efetivação dependem da "disponibilidade financeira e da capacidade jurídica de quem tenha o dever de assegurá-las”.

Os Estados e municípios, com competências expressamente declaradas na legislação, poderiam utilizar da ponderação referente ao limite orçamentário, por meio do limite da reserva do possível, para o atendimento aos pedidos relacionados à educação, principalmente, fora do conceito abarcado pelo direito público subjetivo, por exemplo, a EI e o EM,

\footnotetext{
${ }^{155}$ Parte das discussões sobre os desafios de natureza orçamentária para a garantia do direito à educação foi apresentada no intercâmbio do GT5 da Anped "Federalismo e Políticas educacionais na efetivação do direito à educação no Brasil".

${ }^{156}$ Como já discutido, os direitos civis e políticos também apresentam obrigações estatais de natureza negativa e positiva (ABRAMOVICH, COURTIS, 2002).
} 
considerando apenas o EF como obrigatório? E as creches, após a ampliação da obrigatoriedade com a EC no 59 de 2009 ?

Para alguns autores, estabelece-se uma controvérsia sobre os limites e possibilidades do reconhecimento de direitos subjetivos por parte do Judiciário, quando estes direitos estão relacionados à existência de limites do orçamento público.

Assim, sustenta-se que a prestação desses direitos estaria condicionada à reserva do possível, e pela relação desta com as competências constitucionais, com o princípio da separação dos Poderes, com a lei orçamentária e com o princípio federativo.

De acordo com Andreas Krell, a construção teórica da reserva do possível tem sua origem na Alemanha e representa uma adaptação, cujo entendimento pressupõe que a:

\footnotetext{
[...] construção de direitos subjetivos à prestação material de serviços públicos pelo Estado está sujeita à condição da disponibilidade dos respectivos recursos. Ao mesmo tempo, a decisão sobre a disponibilidade dos mesmos estaria localizada no campo discricionário das decisões governamentais e dos parlamentos, através da composição dos orçamentos públicos. (KRELL, 2002, p. 52).
}

A Corte alemã embasou-se nessa teoria quando "recusou a tese de que o Estado seria obrigado a criar a quantidade suficiente de vagas nas universidades públicas para atender a todos os candidatos" (KRELL, 2002, p. 52), entendendo que existem limitações para o atendimento de todas as demandas.

De acordo com Leandro Martins Zanitelli (2008), as opiniões sobre a doutrina, ou cláusula da reserva do possível podem ser divididas em três grupos: a) dos que concordam com o entrave à realização de direitos em razão da escassez de recursos; b) dos que rejeitam a doutrina; c) o das que admitem, mas com alguma importante ressalva (p. 210).

Segundo Krell (2002), a reserva do possível é fruto de um direito constitucional comparado equivocado, sendo questionável a transferência de teorias jurídicas, desenvolvidas em países "centrais", com base em realidades completamente diferentes, para países como o Brasil, que não implantaram um Estado de bem-estar social.

Sobre a adaptação de conceitos para as circunstâncias particulares de um contexto cultural e sócio-econômico diferente, Krell (2002) ressalta que o grupo dos países periféricos, do qual o Brasil faz parte, têm uma realidade específica, não podendo ser aplicadas descuidadamente teorias de países ricos. A “discussão européia sobre os limites do Estado Social e a redução de suas prestações e a contenção dos respectivos direitos subjetivos não pode absolutamente ser transferida para o Brasil, onde o Estado Providência nunca foi implantado" (p. 54). 
A Lei Fundamental da República Federal da Alemanha, de 1949, "não incorporou nenhum ordenamento sistemático dos direitos sociais da "segunda geração" (dos trabalhadores, educação, saúde, assistência, etc.), fato que se deve às más experiências com a Carta anterior de Weimar" (KRELL, 2002, p. 45).

$\mathrm{Na}$ verdade, o legislador alemão renunciou à formulação de normas que conferem direitos subjetivos a prestações positivas por parte do Estado, sendo que os direitos sociais, que dependem de vários fatores econômicos e políticos para a sua efetivação não constaram da Lei Fundamental, com exceção do direito da mãe à proteção e assistência por parte da comunidade. Todavia, quase todas as constituições dos estados federados alemães contêm direitos sociais (KRELL, 2002).

A Alemanha optou pela não-inclusão de direitos sociais na Lei Fundamental, representando o conceito do "Estado Social" uma "norma-fim de Estado", que "fixa, de maneira obrigatória, as tarefas e a direção da atuação estatal presente e futura, sem, no entanto, criar direitos subjetivos para a sua realização". A doutrina alemã se refere a essas normas constitucionais como "mandados" e não propriamente "direitos". (KRELL, 2002, p. 48).

A CF/88 brasileira, ao contrário da alemã, inseriu uma vasta gama de direitos sociais, sendo estes reconhecidos também como fundamentais. E a "tentativa de relativizá-los e de retirar-lhes a qualidade da 'fundamentalidade' não traz nenhuma vantagem, mas é, ao contrário, perigosa [...]" (KRELL, 2002, p. 49).

Nesse sentido, segundo Krell (2002, p. 54), condicionar a realização dos direitos econômicos, sociais e culturais à existência de recursos do Estado significa relativizar a sua "universalidade, condenando-os a serem considerados 'direitos de segunda categoria".

Para Sarlet e Figueiredo (2008, p. 37) as objeções atreladas à reserva do possível não podem prevalecer nas hipóteses em que já se reconheceu como "direito subjetivo definitivo a prestações" e para afastar a responsabilidade do Estado com relação ao mínimo existencial.

Ricardo Lobo Torres (2007) ressalta que "os direitos econômicos e sociais existem, portanto, sob a 'reserva do possível' ou da 'soberania orçamentária do legislador'”. Assim, a “pretensão do cidadão é à política pública e não à adjudicação individual de bens públicos" (p.81). Todavia, a “proteção positiva do mínimo existencial não se encontra sob a reserva do possível, pois a sua fruição não depende do orçamento nem das políticas públicas, ao contrário do que acontece com os direitos sociais". O Judiciário pode "determinar a entrega das prestações positivas, eis que tais direitos fundamentais não se encontram sob a 
discricionariedade da Administração e do Legislativo, mas se compreendem nas garantias institucionais da liberdade, na estrutura dos serviços públicos essenciais e na organização de estabelecimentos públicos (hospitais, clínicas, escolas primárias, etc.)” (TORRES, 2007, p. $81-2)$.

Para Lopes "a reserva do possível”, de caráter econômico, se confunde com a impossibilidade técnica ou com a escassez de recursos:

Impossibilidade técnica existe, por exemplo, quando se requer a distribuição geral e gratuita de um medicamento ainda em fase experimental. O remédio existe, mas não é produzido em escala industrial (está em fase experimental). Não é produzido porque não se sabem ainda os resultados de sua aplicação a todas as populações. Há escassez quando o nível de produção industrial, embora existente, não é suficiente para garantir a todos. Assim, há escassez quando se verifica que um determinado medicamento (ou tratamento) existe, mas seu custo é tal que sua provisão impedirá o fornecimento de outros medicamentos (ou tratamento) ou mesmo que exigirá o corte de outras despesas em outras áreas. Impossibilidade econômica, não técnica, existe quando se requer a distribuição de um medicamento já testado e comercializado cujo custo faz dele um remédio para poucos. Note-se que em casos assim, está em jogo o caráter igualitário do acesso à saúde. (LOPES, 2008, p. 181, grifo nosso).

Desta maneira, o que deveria ser pedido e concedido, precisaria estar relacionado ao caráter universal e igualitário, contemplando a todos os que se encontram naquela situação e não podendo conceder a uns e não a outros (LOPES, 2008).

Relacionando esta análise com as solicitações judiciais ao TJ-SP envolvendo a educação básica, a maior parte versa sobre matrículas em creches. Observando-se os dados de atendimento da população de 0 a 3 anos $(18,1 \%)$, torna-se perceptível que o grupo mais alijado é a população preta/parda (14,9\%) e mais pobre (11,5\%) (OBSERVATÓRIO DA EQUIDADE, 2008). Nessa situação, quando se reivindica a matrícula e os municípios as negam, tendo em vista a limitação de recursos, está em jogo o caráter universal e igualitário deste atendimento, pois para algumas crianças a matrícula é concedida e a outras faltam vagas.

Considerando as dificuldades orçamentárias para a implementação dos direitos sociais, Lopes (2008) explana que a decisão judicial deveria permitir a adequação do Estado, fixando prazos e metas a ser atingidos, o que já ocorre no âmbito dos inquéritos civis promovidos pelo Ministério Público, com Termo de Ajustamento de Conduta (TAC).

Neste sentido, está a decisão do desembargador Nogueira Diefenthaler, reconhecendo que a regra constitucional veda o início de programas ou projetos não incluídos em lei orçamentária, "de forma que o provimento jurisdicional não pode determinar, sem a adoção desta providência preliminar, a instalação de creches e pré-escolas", estipulou que o 
município fosse condenado a incluir as verbas necessárias à instalação das creches no projeto de lei orçamentária (APELAÇÃO CÍVEL 601.392-5/8-00, 2008).

Outro fator relevante a se considerar na análise da reserva do possível e o litígio de direitos sociais está relacionado ao caráter do pedido. Para Lopes (2008), as demandas na esfera orçamentária para a implementação de direitos têm a vantagem de minimizar os tratamentos desiguais.

[...] a reserva do possível é uma defesa perfeitamente legítima para os casos de litígios de direito público especialmente quando o pedido e a decisão visarem beneficiar alguém em particular e de forma imediata e isolada. Ela já não será uma defesa tão facilmente acatável quando o que estiver em litígio seja o orçamento ou o programa. Nesses casos também não quero dizer que o julgamento seja fácil, mas afirmo que é possível julgar, e então sim a questão se converte em avaliação concreta e empírica de certas circunstâncias, cujo resultado final será a procedência ou não da defesa pela reserva do possível. (LOPES, 2008, p. 193).

A requisição da implementação de direitos pela esfera orçamentária constitui-se, também, numa maneira de ampliar o acesso à justiça, considerando, discussão realizada no capítulo dois deste trabalho, que nem todos os cidadãos procuram a justiça para requerer os seus direitos (SOUSA SANTOS, 2007).

A posição de Lopes ainda está distante das decisões dos Tribunais. A análise das decisões do TJ-SP indica que as ações com pedidos individuais são atendidas com mais facilidade, mas quando requisitam medidas para ampliação do atendimento ou para criação de políticas o Tribunal não se mostrou coeso para a concessão, tendo em vista o argumento da impossibilidade de interferência do Judiciário na condução de políticas públicas e na questão orçamentária. Esta discussão será aprofundada nas próximas seções deste trabalho.

Duarte (2007) observa que, aceitando-se que o objetivo dos direitos sociais "é corrigir desigualdades próprias das sociedades de classes, aproximando grupos ou categorias marginalizadas", a sua implementação, não obstante o reconhecimento expresso da universalidade, demanda "a escolha de alvos prioritários, ou seja, grupos de pessoas que se encontram em uma mesma posição de carência ou vulnerabilidade" (p.700). Para reiterar sua afirmação, a autora destaca a noção de progressividade dos direitos sociais e a cláusula de proibição do retrocesso social.

A autora discute a noção de progressividade para a plena realização dos direitos econômicos, sociais e culturais, de acordo com o Comentário Geral n.3, de 1990, do Comitê de Direitos Econômicos, Sociais e Culturais da Organização das Nações Unidas (ONU).

De acordo com as Nações Unidas, o conceito de progressividade indica que a plena realização dos direitos econômicos, sociais e culturais, de modo geral, não poderá ser atingida em um curto período de tempo. Entretanto, para o Comitê, a progressividade não deve ser interpretada como uma forma de esvaziar a obrigação 
de conteúdo substantivo. Ela seria apenas uma forma de levar em conta a realidade do mundo concreto e as dificuldades envolvidas no que concerne à tarefa de assegurar a plena realização dos direitos econômicos, sociais e culturais. (DUARTE, 2007, p. 699).

Assim, a progressividade impõe ao Estado deveres, adotando medidas "até o máximo de seus recursos disponíveis" (art. $2^{\circ}$ do PIDESC), visando assegurar progressivamente o pleno exercício dos direitos garantidos pelo Pacto, sempre como observa Duarte (2007, p.701) em "evolução ascendente contínua".

Assim, a progressividade cria um "empecilho ao retrocesso da política social do Estado que, tendo alcançado um certo nível de proteção dos respectivos direitos, não pode retroceder e baixar o padrão de vida da comunidade, já que a cláusula de proibição do retrocesso social protege o núcleo essencial dos direitos sociais” (DUARTE, 2007, p. 700).

Para a avaliação do cumprimento das obrigações estatais, Duarte salienta, também, o conceito de núcleo mínimo obrigatório (minimum core obligation). "Assim, diante de recursos escassos, o Estado deverá demonstrar que empenhou todos os esforços para utilizar os recursos disponíveis, tendo em vista, no mínimo, a satisfação daquilo que foi eleito como prioritário, ou seja, suas obrigações mínimas essenciais. (2007, p. 701).

$\mathrm{E}$, com relação ao direito à educação, o que se estabeleceria como o mínimo existencial ou núcleo mínimo obrigatório? Somente o ensino obrigatório, considerado como direito público subjetivo, ou o conceito de educação básica, definido pela LDB/96, da creche ao ensino médio?

Acredita-se que o argumento da progressividade e da proibição do retrocesso social contribui apenas para a não redução do atendimento. Porém, considerando que os principais pedidos das decisões julgadas pelo TJ-SP referem-se à matrícula em creche, refletindo o contexto de crescimento da demanda pelo atendimento da primeira etapa da educação básica, esses conceitos não favorecem a superação do obstáculo concernente ao limite orçamentário para atendimento dessas demandas. Da mesma maneira, o conceito do núcleo mínimo obrigatório, pois se for aceito que o mínimo obrigatório vincula-se ao que estaria abarcado pelo conceito de "obrigatório" na Constituição a creche não estaria contemplada.

Outra declaração legal, que pode não facilitar a ampliação dos demais níveis e modalidades da educação, refere-se ao artigo 212 da $\mathrm{CF} / 88, \S 2^{\circ}$, o qual define que a distribuição dos recursos assegurará prioridade ao atendimento das necessidades do ensino obrigatório. 
Desse modo, poderiam os municípios utilizar-se do limite orçamentário para atender aos pedidos judiciais, alegando limites orçamentários para a ampliação do atendimento ou para a garantia de um conceito mais amplo de direito à educação, como Tomasevski (2001), incorporando obrigações governamentais para tornar a educação disponível, acessível, aceitável e adaptável a todos?

Algumas decisões de desembargadores do TJ-SP, como já evidenciado, não concordam com a alegação da falta de previsão orçamentária para atendimento da educação infantil. Compila-se excerto da decisão do desembargador Borelli Machado: "a satisfação do comando imposto pela tutela jurisdicional deve ser viabilizado com base nas receitas específicas já previstas no orçamento ou, se o caso, com base em créditos adicionais obtidos com a necessária autorização legislativa" (EMBARGOS INFRINGENTES nº 82.467-0/2-01, 2002).

O Ministro Celso de Mello, do STF, em análise de recurso impetrado pelo MP contra a decisão do TJ-SP, que reivindicava o acesso à educação infantil, argumentou sobre a cláusula da reserva do possível, para efetivação dos direitos de segunda geração:

\begin{abstract}
Não se ignora que a realização dos direitos econômicos, sociais e culturais - além de caracterizar-se pela gradualidade de seu processo de concretização - depende, em grande medida, de um inescapável vínculo financeiro subordinado às possibilidades orçamentárias do Estado, de tal modo que, comprovada, objetivamente, a alegação de incapacidade econômico-financeira da pessoa estatal, desta não se poderá razoavelmente exigir, então, considerada a limitação material referida, a imediata efetivação do comando fundado no texto da Carta Política.

Não se mostrará lícito, contudo, ao Poder Público, em tal hipótese, criar obstáculo artificial que revele - a partir de indevida manipulação de sua atividade financeira e/ou política - administrativa - o ilegítimo, arbitrário e censurável propósito de fraudar, de frustrar e de inviabilizar o estabelecimento e a preservação, em favor da pessoa e dos cidadãos, de condições materiais mínimas de existência.

[...] a cláusula da "reserva do possível" - ressalvada a ocorrência de justo motivo objetivamente aferível - não pode ser invocada, pelo Estado, com a finalidade de exonerar-se dolosamente, do cumprimento de suas obrigações constitucionais, notadamente quando, dessa conduta governamental negativa, puder resultar nulificação ou, até mesmo, aniquilação de direitos constitucionais [...] (RECURSO

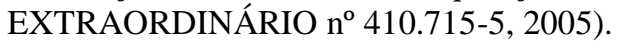

Cabe pontuar que o Ministro Celso de Mello apresenta uma ressalva para que a reserva do possível seja invocada: "justo motivo objetivamente aferível”. A escassez de recursos, comprovada pelo orçamento, poderia estar nesta classificação?

Para o desembargador do TJ-SP, Álvaro Lazzarini, o argumento da limitação orçamentária para a não abertura de novas creches dependeria da "comprovação de o Administrador Municipal ter esgotado as verbas orçamentárias específicas destinadas a esse direito fundamental" (APELAÇÃO CÍVEL 70.606-0, 2001). 
Segundo Lopes (2008, p. 179), "há sim limites orçamentários que se podem alegar, mas como orçamentos não são coisas da natureza, mas frutos de decisões políticas", a reserva do possível "não pode ser acatada quando Executivo e Legislativo manipulam de tal forma o orçamento a criá-la de forma artificial ou, melhor, de criá-la, quando observadas as outras condições, ela não existiria" (p. 191).

Segundo Paulo Caliendo, "se fizermos uma leve comparação entre o que o governo orça para gastar em saúde, educação e segurança e o que gasta pagando a dívida pública veremos que existe uma reserva do possível geral no Brasil que impede os gastos sociais que se chama dívida pública" (CALIENDO, 2008, p. 202, grifos do autor).

Neste mesmo sentido, Barcellos aponta que "pode ser juridicamente consistente, por exemplo, sustentar que os gastos com publicidade governamental não poderão ser superiores aos investidos com saúde ou educação, uma vez que necessidades importantes de tais áreas sofram com carências de recursos" (2008, p.132).

O principal problema, como expõe Flávio Galdino (2007), e, neste aspecto concordase com o autor, reside na opção política:

O que verdadeiramente frustra a efetivação de tal ou qual direito reconhecido como fundamental não é a exaustão de um determinado orçamento, é a opção política de não se gastar dinheiro com aquele mesmo 'direito'. A compreensão dos custos como meios de promoção dos direitos, e a observação empírica de que tais meios são insuficientes para atender a todas as demandas, leva necessariamente à conclusão de que não é propriamente a 'exaustão da capacidade orçamentária' que impede a realização de um determinado direito. $\mathrm{O}$ argumento da 'exaustão orçamentária' presta-se unicamente a encobrir as trágicas escolhas que deixaram de fora do universo do possível a tutela de um determinado 'direito'. (GALDINO, 2007, p. 284 , grifos do autor).

Sobre a ineficácia do argumento da insuficiência de recursos, enfatiza a decisão do ministro do STF, Marco Aurélio:

Conforme preceitua o artigo 208, inciso IV, da Carta Federal, consubstancia dever do Estado a educação, garantindo o atendimento em creche e pré-escola às crianças de zero a seis anos de idade. O Estado - União, Estados propriamente ditos, ou seja, unidades federadas, e Municípios - deve aparelhar-se para a observância irrestrita dos ditames constitucionais, não cabendo tergiversar mediante escusas relacionadas com a deficiência de caixa. (RECURSO EXTRAORDINÁRIO nº 431.773, 2004).

Cabe destacar, ainda, que o argumento da teoria da reserva do possível está relacionado com o princípio da separação de poderes, como destaca Zanitelli (2008),

[...] ao invocar a reserva do possível como justificativa para o não atendimento de pretensões baseadas em direitos fundamentais, os juízes tornam, em alguma medida, a realização desses direitos dependente de políticas governamentais. Desta forma, a aplicação da reserva do possível livra o órgão judicial da acusação de violar o princípio da separação de poderes ou, como também se pode dizer, ajusta-se a uma concepção mais tradicional e estrita sobre o que requer esse princípio. (ZANITELLI, 2008, p. 212) 
É preciso mudar a concepção de que a efetivação dos direitos deve estar condicionada aos recursos financeiros, o argumento deve ser o contrário, os recursos devem ser direcionados à concretização dos direitos já definidos pela nossa legislação.

Considerando o que foi apresentado, ressalta-se a necessidade de discussão acerca da relação entre o orçamento público e a garantia do direito à educação, ainda mais em um contexto de extensão da educação básica obrigatória, para que o reconhecimento judicial dos direitos proclamados em nossa legislação não se torne inviável quando a sua efetivação estiver relacionada aos limites orçamentários. Fazendo-se necessário o aprimoramento dos mecanismos de gestão democrática do orçamento público e do processo de administração das políticas públicas.

\subsection{Interferência do Judiciário no poder discricionário do Executivo: princípio da separação de poderes}

Nos últimos anos, como já abordado em capítulos anteriores, o Judiciário vem enfrentando questões inéditas, nas quais precisa definir conceitos a partir da interpretação constitucional. De acordo com Frischeisen (2000), essa ação leva ao enfrentamento dos limites da discricionariedade do administrador e do campo decisório do juiz.

A garantia da educação, assim como dos direitos sociais, se realiza por meio de políticas públicas. E essas expressam escolhas que, por sua vez, são influenciadas pelas normas constitucionais e infraconstitucionais, "estando os poderes públicos obrigados a incluir em suas previsões orçamentárias rubricas capazes de atender essa necessidade" (BARCELLOS, 2008, p.129-130)

Para parte da doutrina jurídica, o controle dos atos administrativos esbarra na análise da discricionariedade da administração, considerando o princípio da separação de poderes.

A definição da política pública, como destacado no primeiro capítulo deste trabalho, concentra-se no Executivo e Legislativo. Todavia, segundo Krell (2002, p.101), onde “o processo político (Legislativo, Executivo) falha ou se omite na implementação de políticas públicas e dos objetivos sociais nelas implicados, cabe ao Poder Judiciário tomar uma atitude ativa na realização desses fins sociais através da correição da prestação dos serviços básicos”. 
Esse fato implicaria em que o Judiciário está invadindo áreas do Executivo, ou cumprindo uma tarefa desenhada pela própria constituição?

Como já referido por Bonavides (2009b), o princípio da separação dos poderes, no Estado social, tem outro caráter e dimensões. Ele não pode ser utilizado para negar as características deste Estado, servindo para paralisar as reivindicações relacionadas aos direitos sociais.

O princípio da separação dos poderes, segundo Bonavides (2009b), representou seu papel histórico, ajudando a implantar a consciência dos direitos e garantias individuais e uma arma eficaz no combate aos déspotas do absolutismo. Contudo,

Quando cuidamos dever abandoná-lo no museu da Teoria do Estado queremos, com isso, evitar apenas que seja ele, em nossos dias, a contradição dos direitos sociais, a cuja concretização se opõe, de certo modo, como técnica dificultosa e obstrucionista, autêntico tropeço, de que inteligentemente se poderiam socorrer os conservadores mais perspicazes e renitentes da burguesia, aqueles que ainda supõem possível tolher e retardar o progresso das instituições no rumo da social-democracia (BONAVIDES, 2009b, p. 64).

$\mathrm{Na}$ lógica do Estado social é preciso diálogo entre os poderes para a efetivação dos direitos fundamentais, tornando-se desejável a releitura da teoria da separação dos poderes:

[...] torna-se evidente que o apego exagerado de grande parte dos juízes brasileiros à teoria da Separação dos Poderes é resultado de uma atitude conservadora da doutrina constitucional tradicional, que ainda não adaptou as suas 'lições' às condições diferenciadas do moderno Estado Social e está devendo a necessária atualização e re-interpretação de velhos dogmas do constitucionalismo clássico. (KRELL, 2002, p. 91).

Sendo assim, a intervenção do Judiciário, quando comprovado o não cumprimento de um dever, não significa transferência de competências, mas exigência de uma tarefa constitucional (SOUSA SANTOS, 2007; ALEXY, 2008).

Segundo Barroso (2009), quando os juízes são capazes de fundamentar racionalmente suas decisões, com base na Constituição, atuam de maneira legítima. A jurisdição constitucional "quando bem exercida é antes uma garantia para a democracia do que um risco" (p.340).

Todavia, importa ressaltar que "já não subsiste no mundo contemporâneo a crença na idéia liberal - positivista de objetividade plena do ordenamento e de neutralidade absoluta do intérprete" (BARROSO, 2009, p. 340-1).

Mesmo o Judiciário tem seus limites:

Note-se que os três Poderes interpretam a Constituição, e sua atuação deve respeitar os valores e promover os fins nela previstos. No arranjo institucional em vigor, em caso de divergência na interpretação das normas constitucionais ou legais, a palavra final é do Judiciário. Essa primazia não significa, porém, que toda e qualquer 
matéria deva ser decidida em um tribunal. Nem muito menos legitima a arrogância judicial (BARROSO, 2009, p. 343).

No conjunto das decisões analisadas pode-se dizer que ocorre o processo de judicialização (BARROSO, 2009), como uma consequência natural da CF/88 e dos seus instrumentos, não podendo ser atribuído um ativismo judicial.

No que concerne à efetividade do direito à educação, a intervenção do Judiciário é uma possibilidade de fazer valer os direitos já proclamados na $\mathrm{CF} / 88$, diferente das decisões que envolvem aspectos referentes ao "fazer pedagógico". Não sendo o Judiciário, nessas questões, a instituição mais habilitada a produzir melhor decisão. "Temas envolvendo aspectos técnicos ou científicos de grande complexidade podem não ter no juiz de direito o árbitro mais qualificado, por falta de informação ou conhecimento específico. (BARROSO, 2009, p. 344).

A decisão, para não estar relacionada ao ativismo do juiz, deve observar as normas jurídicas. E, na educação há um rol de definições como deveres do Estado, divisão de responsabilidades, destinação de recursos. Normatização que foi se consolidando com as decisões dos Tribunais, como a possibilidade de exigibilidade judicial da educação infantil.

Segundo Torres (2007, p. 82), o Judiciário pode determinar a "a entrega das prestações positivas, eis que tais direitos fundamentais não se encontram sob a discricionariedade da Administração e do Legislativo, mas se compreendem nas garantias institucionais da liberdade, na estrutura dos serviços públicos essenciais e na organização de estabelecimentos públicos (hospitais, clínicas, escolas primárias, etc.)”.

Das decisões do TJ-SP, muitas discutiram o limite do poder discricionário do Executivo no que se refere à educação. Segundo Frischeisen (2000), o administrador público está vinculado à Constituição e às leis infraconstitucionais, pois a CF/88 estabelece claramente políticas públicas a serem cumpridas, tendo como finalidade o bem-estar e a justiça social, sendo "que os atos emanados da administração no cumprimento podem ser mencionados como vinculados e não discricionários" (p.94).

Os atos vinculados, segundo Frischeisen (2000, p. 94-5), "são aqueles em que não existe margem de subjetividade para a Administração decidir sobre a melhor forma de solucionar determinado caso concreto".

Portanto, parece pertinente dizer que a discussão sobre a discricionariedade do administrador público não se dá quanto ao dever, mas "quanto aos meios que está usando para a implementação de políticas públicas, se o escolhido era o melhor, o mais adequado, o 
mais razoável para possibilitar o eficaz exercício dos direitos sociais" (FRISCHEISEN, 2000, p.114, grifo do autor).

Para esta autora, as dúvidas sobre essa margem de discricionariedade deveriam ser dirimidas pelo Judiciário, verificando se o ato administrativo, omissivo ou comissivo, "não contraria sua finalidade constitucional, no caso, a concretização da ordem social constitucional (p.97). O Judiciário e o MP, ao decidirem sobre isto, não estariam substituindo o Executivo, mas realizando o cumprimento da Constituição.

Das demandas julgadas pelo TJ-SP, que abordaram o poder discricionário do Executivo para com a educação, emergem diferentes opiniões entre os desembargadores.

Os desembargadores favoráveis à interferência do Judiciário afirmam que, com relação à educação, o Poder Público não tem discricionariedade, considerando as obrigações impostas pelas normas constitucionais e infraconstitucionais. O exercício da discricionariedade seria cumprido na maneira de satisfazer as obrigações.

Nas ações questionando a exigibilidade da EI, por exemplo, os desembargadores Mohamed Amaro, Luís Macedo, Roberto Solimene e Vallim Bellocchi esclareceram que a decisão sobre a conveniência e a oportunidade de realizar atos físicos como obras e contratações cabem, com exclusividade, ao Poder Executivo, não sendo possível o Judiciário intervir.

Esses posicionamentos são favoráveis aos argumentos das Fazendas Públicas, que justificam a margem de discricionariedade do administrador público na "definição de diretrizes, de prioridades das ações e na escolha dos meios necessário ao cumprimento de sua missão" (APELAÇÃO CÍVEL nº 46.784-5/1, 1998).

Neste entendimento, fica patente a divergência entre as normas dos princípios e regras. Neste sentido, a EI é vista como um princípio, sendo realizada na "maior medida do possível" (ALEXY, 2008).

Todavia, para o desembargador Sidnei Beneti, defender a não interferência do Judiciário, após reconhecer o direito das crianças, seria negar a própria atividade do Judiciário (APELAÇÃO CÍVEL no 142. 040-0/9-00, 2007).

O ministro Celso de Melo, sobre ação envolvendo EI, afirmou em sua decisão que a mesma, por qualificar-se como direito fundamental, não se expõe a avaliações discricionárias (RECURSO EXTRAORDINÁRIO n 410.715-5, 2005). Esta decisão, como exposto no capítulo anterior, colaborou para as decisões favoráveis do TJ-SP, como as da desembargadora Maria Olivia Alves. Para ela, a discricionariedade do administrador público 
quanto à EI se realizaria apenas sobre a forma de satisfazer essa obrigação (APELAÇÃO CÍVEL no 127.659-0/3-00, 2006).

Nos processos que reivindicaram a matrícula para crianças com seis anos no EF, o desembargador Gentil Leite também argumenta que a norma violada não é meramente programática.

O mesmo entendimento prevaleceu numa ação sobre questionamento da idade para matrícula em curso de EJA: "não se pode confundir o exercício do poder discricionário do administrador público com sua inércia diante das obrigações que lhe impõe a Lei”. Sendo exercida a discricionariedade na escolha das providências para atender a lei (APELAÇÃO CÍVEL n ${ }^{\circ}$ 67.758.0/9, 2001).

O desembargador Canguçu de Almeida, em decisão na qual atuou como relator, referente à ação que solicitava tratamento de reabilitação e ensino pedagógico para pessoa com deficiência, também destacou que "não há discricionariedade do administrador quando se trata de direitos imediatamente aplicáveis" (APELAÇÃO CÍVEL nº 149.235.0/0-00, 2007). Posição também defendida pelo desembargador Magalhães Coelho, envolvendo este tipo de demanda. Não considerou as "políticas de assistência educacional e de saúde especifica aos deficientes físicos e mentais não é questão afeta à subjetividade do administrador" como normas programáticas, mas como "norma impositiva de eficácia plena", não podendo ignorar as diretrizes constitucionais (APELAÇÃO CÍVEL nº 644.051-5/7-00, 2007).

Assim, na Educação Especial a discricionariedade administrativa é definida pelo modo como se procederá ao atendimento: oferta pública ou mediante convênio com o setor privado.

A violação do princípio da separação e independência dos poderes também foi analisada na decisão sobre a concessão de subsídios públicos às instituições privadas. Segundo o desembargador Reinaldo Miluzzi é possível a interferência do Judiciário nos casos em que o administrador público se desvia dos "princípios da legalidade, da moralidade, da finalidade e da publicidade" (AGRAVO DE INSTRUMENTO nº 409.465-5/1-00, 2006).

Em ação civil pública que questionava a criação e manutenção de vagas na rede estadual, a tese da apelação da Fazenda Pública do estado de SP, focada na interferência do Poder Judiciário na esfera de atribuição própria do Executivo, foi aceita pelo desembargador Mohamed Amaro, pois consistiria invasão em ato pertinente à conveniência e à oportunidade da administração pública (APELAÇÃO CÍVEL nº 60.084-0, 2001). 
Em ação sobre matrícula próxima à residência, a decisão do desembargador Viana Santos foi favorável à tese da não intervenção no poder discricionário do Executivo (APELAÇÃO CÍVEL nº 87.482-5, 1999).

A quantificação e a localização das salas de aula postas à disposição para a matrícula em cada uma das séries também foi definida como tarefa do administrador, em ação que discutia o direito de acesso à escola pública e gratuita próxima da residência (APELAÇÃO CÍVEL nº 128.541-5, 2001, Des. José Raul Gavião).

Fundamentado no mesmo argumento, concedeu-se o recurso ao município em ação que reivindicava programa de transporte escolar (AGRAVO DE INSTRUMENTO n ${ }^{\circ}$ 55.3670/1, 1999, relator Des. Alvaro Lazzarini). O desembargador Hermes Pinotti argumentou, igualmente, que a determinação do art. 208 da CF/88 sobre o transporte escolar é uma norma programática (AGRAVO DE INSTRUMENTO n 71.061-0, 2000).

A indevida ingerência na administração do Estado foi aceita, também, no recurso de ação civil pública que requisitava do governo estadual a construção de salas de aulas (APELAÇÃO CÍVEL no 44.389-0/6, 1998, rel. des. Oetterer Guedes). No processo que discutiu a reorganização das escolas no estado de SP, esta tese também foi acatada, considerando que a exigência de submeter encargos constitui indevida intromissão na competência do Poder Executivo, pois caberia à SEE fixar os objetivos a serem cumpridos e os meios de executá-los, sabendo-se que compete ao Estado legislar concorrentemente sobre matéria educacional (APELAÇÃO CÍVEL no 39.019-5, 1999).

Notadamente, os recursos judiciais envolvendo demandas concentradas em interesses difusos e coletivos evidenciaram a maior divergência entre os desembargadores, como já explanado, no que se refere à interferência do Judiciário no planejamento do Executivo, ou seja, à elaboração e à implementação de políticas públicas.

\subsection{Tutela dos direitos educacionais por meio de demandas individuais e coletivas}

Segundo enfatizado por Lopes (2008), os direitos sociais extrapolam os mecanismos individuais. Todavia, nas ações julgadas pelo TJ-SP que demandaram a requisição de tutela a direitos individuais, os desembargadores foram mais favoráveis em reconhecer este direito como líquido e certo e sua exigibilidade perante o Judiciário. 
Os pedidos que abrangiam interesses transindividuais (difusos e coletivos) tiveram suas justificativas para a não concessão, baseadas no argumento da titularidade do pedido, sendo o mesmo genérico (Apelação Cível no 70.869-0/2-00, de 2001, relator des. Álvaro Lazzarini).

Sobre a concessão dos pedidos individuais para vaga em instituição de EI, o desembargador Luiz Tâmbara postulou que: "Cumpre ao Poder Judiciário, por função típica, dizer o direito, assinando, se o caso, norma de conduta individual, concreta, daí porque o pedido há de ser certo, em sua extensão, e determinado quanto ao seu objeto." (APELAÇÃO CÍVEL no 81.514-0/9-00, 2001, grifo nosso).

Já o desembargador Gentil Leite, em ação que também pleiteava vagas em EI, apontou que seria inconsistente o argumento de determinação do seu objeto, aceitando que a não determinação do pedido em ação civil pública faz parte da natureza deste instrumento que visa proteger interesses difusos de um grupo indeterminado de pessoas. Justificando sua declaração com o disposto no ECA, art. 208, Parágrafo Único: “As hipóteses previstas neste artigo não excluem da proteção judicial outros interesses difusos ou coletivos, próprios da infância e da adolescência, protegidos pela Constituição e pela Lei” e no Código de Processo Civil, artigo 286, inciso II, “permite a indicação de pedido genérico, quando não foi possível determinar de modo definitivo, as conseqüências do ato ou do fato ilícito". (APELAÇÃO CÍVEL nº 81.514-0/9-00, 2001).

Além das demandas relativas à EI, a ação que requereu a implementação do serviço de transporte escolar também não obteve consenso entre os desembargadores, considerando a titularidade do pedido (AGRAVO DE INSTRUMENTO No 55.367-0/1, 1999).

De acordo com Frischeisen (2000), o processo de judicialização das demandas coletivas é consequência da positivação dos direitos sociais na Constituição.

No que se refere aos instrumentos jurídicos para a exigibilidade de demandas coletivas, destaca-se ação civil pública e a legitimação do MP para atuar como defensor dos interesses coletivos, principalmente no que se refere aos direitos concernentes à infância e juventude, as atribuições conferidas ao MP pelo ECA, com destaque para o art. 208 deste Estatuto.

Se a concretização da educação se dá por meio de políticas públicas, Bucci (2006) sublinha que a ação coletiva é o mecanismo mais adequado de acionar o controle judicial para a "solução de conflitos envolvendo os direitos sistematizados em políticas públicas" (p.31). 
Desse modo, a exigibilidade da educação, enquanto direito social, e efetivada por meio de instrumentos individuais, seria um processo socialmente justo, sabendo-se que o atendimento de demandas individuais pode privilegiar somente aqueles que tiveram a oportunidade de acesso ao Judiciário e tiveram seu pedido atendido em detrimento de outros que também aguardam a prestação do mesmo direito pelo Poder Público e não recorreram a esta forma de exigibilidade?

Neste sentido, Lopes (2002) destaca a dificuldade da defesa de direitos sociais por meio de instrumentos individuais:

[...] a prestação do serviço depende da real existência dos meios: não existindo escolas, hospitais e servidores capazes e em número suficiente para prestar o serviço o que fazer? Prestá-lo a quem tiver tido a oportunidade e a sorte de obter uma decisão judicial e abandonar a imensa maioria à fila de espera? Seria isto viável de fato e de direito, se o serviço público deve pautar-se pela sua universalidade, impessoalidade e pelo atendimento a quem dele mais precisar e cronologicamente anteceder os outros? (LOPES, 2002, p. 131).

De acordo com Lopes (2006), o Judiciário, ao decidir os casos em bases individuais, corre o risco de julgar com critérios de justiça comutativa (questões individuais) problemas de justiça distributiva (questões coletivas).

Da mesma maneira, Barcellos (2008) e Tim (2008) defendem que as ações coletivas são o caminho mais justo para implementação de um direito social, pois favorecem a isonomia e são passíveis de concessão a todos que se encontram naquela situação. Além de evitar sobrecarga ao Judiciário, reduzindo o número de processos semelhantes em ações individuais.

Porém, se concessão de direitos por meio de ações coletivas ainda não consolidou possível posição favorável no Judiciário, como evidenciado no capítulo anterior, as demandas individuais podem ser uma estratégia, talvez, não a mais adequada, mas a possível, de fazer com que o Poder Público implemente ou reformule uma política pública.

Quando se trata da educação enquanto direito social, não se pode esquecer que se trata, também, de um direito fundamental de cada pessoa. Justamente, por esta razão não se poderia negar a tutela individual deste direito. Por exemplo, nas ações que reivindicaram a vaga em instituições de EI, os processos individuais procuram dar proteção ao princípio da isonomia entre os cidadãos, pois alguns têm o direito e outros não.

Cabe, ainda, explicitar que a pulverização dos conflitos envolvendo ações coletivas na arena judicial pode ensejar efeitos indesejados, como expõe Bucci (2006), pois a perspectiva, mesmo nessas ações, é a titularidade do indivíduo ou grupo de indivíduos, não se configurando a abrangência do processo de seleção de prioridades e reserva de meios na 
elaboração do orçamento público. Assim, para uma ampliação dos direitos sociais, e, em seu esteio, da educação, a defesa coletiva deveria caminhar alinhada com a possibilidade de planejamento do orçamento público, e não alijada deste.

Sobre as dificuldades do questionamento judicial de demandas coletivas, ressalte-se, igualmente, que o Judiciário, pela sua estrutura, e, neste contexto, o juiz pela sua formação, estão preparados para analisar conflitos individuais. Nesse caso, a aceitação das demandas coletivas surge como um obstáculo a ser enfrentado, considerando que o principal argumento para a não aceitação dessas demandas reside na posição dos julgadores de não interferência do Judiciário nas atividades do Executivo. 


\section{CONSIDERAÇÕES FINAIS}

O levantamento das decisões proferidas pelo TJ-SP, no período de 1991 a 2008, possibilitou verificar o uso expressivo do Judiciário para a busca de resolução de conflitos na área educacional, principalmente na última década. Conforme exposição realizada no decorrer do trabalho, o processo de expansão do Judiciário para efetivar os direitos sociais garantidos na legislação está relacionado ao contexto de especificação dos direitos, mas também de crise do Estado-providência, de precarização dos direitos econômicos e sociais, com a desresponsabilização do Estado de seu papel provedor (ARANTES, 2007; SOUSA SANTOS, 2007).

$\mathrm{O}$ crescimento da procura pelo Judiciário também está relacionado à ampliação dos mecanismos de acesso à Justiça para os atores coletivos (ARANTES, 2007), ao fortalecimento de instituições e instrumentos processuais para a proteção dos direitos transindividuais.

Efetivamente, neste contexto, se observa o uso dos Tribunais para requerer ou questionar ações do Poder Público, relativas aos direitos educacionais no Brasil e, como foi objeto de análise neste trabalho, em São Paulo.

No que diz respeito ao acionamento do Judiciário paulista para os conflitos educacionais, cumpre reafirmar que este é realizado em períodos específicos, guardando inequívoca relação, sobretudo, com mudanças no contexto econômico; relacionando-se, ainda, às ações sobre reajustes de mensalidades e à normatização nos processos sobre ingresso dos alunos com seis anos no EF, orientações para autorização e credenciamento das instituições privadas na oferta de EJA, critérios para as matrículas nos cursos de língua estrangeira oferecidos pela rede estadual. As demandas por vagas em instituições de EI, iniciadas no final da década de 90 e constantemente apreciadas pelo TJ-SP, podem estar ligadas à restrição de recursos mediada pela $\mathrm{EC} \mathrm{n}{ }^{\circ} 14 / 96$, que priorizou o financiamento ao $\mathrm{EF}$, e à declaração como primeira etapa da educação básica pela LDB/96. Também, é importante ressaltar nesse processo a valorização por parte da sociedade da educação anterior ao período obrigatório como uma etapa fundamental de formação das crianças.

Neste cenário de crescente exigibilidade do direito à educação merece destaque o papel exercido pelo MP, que atuou como parte em número considerável de decisões proferidas pelo TJ-SP. Pesquisa anterior (SILVEIRA, 2006) evidenciara que, apesar dos 
limites relacionados principalmente à atuação mais ativa vinculada ao perfil do Promotor de Justiça, e à possível influência das condições efetivas de trabalho na ação dos membros do MP, esta instituição, operando judicial ou extrajudicialmente pode contribuir para assegurar a real manutenção do direito à educação.

Sobre a utilização do Judiciário para reivindicar junto ao Poder Público a implementação de direitos, e para questionar políticas envolvendo a educação, não é possível ignorar a conscientização da população e da sociedade civil organizada sobre seus direitos e sobre a viabilidade de recorrerem aos Tribunais nestas questões, facultando que o Judiciário já não seja apenas uma instituição focada na resolução de conflitos entre particulares. Antes, os Tribunais, como já referido por Sousa Santos (2007), são vistos como uma arma dos movimentos sociais para fazer com que os direitos sejam levados a sério. Nesse sentido, ressalta-se o Programa "Ação na Justiça", realizado pela Organização Não-Governamental "Ação Educativa", com importantes contribuições para a exigibilidade do direito à educação, atuando na "produção e difusão de informação sobre o direito humano à educação e sobre os mecanismos de justiciabilidade"; "formação de atores estratégicos"; "monitoramento das garantias legais"; "recurso ao sistema de justiça em ações paradigmáticas e/ou coletivas"; "fortalecimento da perspectiva de justiciabilidade em redes de defesa e promoção de direitos humanos" $" 157$.

Do ponto de vista da declaração, os direitos educacionais estão amplamente garantidos na legislação brasileira (CURY, 1998; RANIERI, 2009); a educação é o direito social mais reforçado em termos de proteção judicial (DUARTE, 2003). Assim, se os direitos são reconhecidos por um ordenamento jurídico, torna-se imprescindível que haja a possibilidade de fazer com que o Poder Público cumpra com seus deveres em caso de omissão ou ação irregular.

Como já enfatizado, utilizar o Judiciário para a implementação dos direitos educacionais vai além do conceito abarcado pelo direito público subjetivo relativo ao ensino obrigatório, pois é viável acionar o Estado para que cumpra com os deveres elencados no art. 208 da CF/88, respeite os princípios correlacionados no art. 206, destine o percentual mínimo vinculado à educação, bem como outras regras e princípios relacionados à educação,

\footnotetext{
${ }^{157}$ Os objetivos do Programa “Ação na Justiça”, da Ação Educativa, assim como acesso ao Boletim Obstáculos e Possibilidades de Acesso à Justiça (OPA) que traz informações sobre o direito à educação e sobre o comportamento do Judiciário e do MP com relação às demandas educacionais podem ser acessadas no endereço eletrônico:

http://www.acaoeducativa.org.br/portal/index.php?option=com_content\&task=category\&sectionid=1\&id=1\&Ite mid=3, acesso em 20 out. 2010 .
} 
declarados na Constituição e na legislação infraconstitucional, como a LDB/96, o ECA, o Plano Nacional de Educação. Concernente à capacidade jurídica de exigir judicialmente esses direitos, define-se o papel relevante do reconhecimento pelo ECA, art. 208, dos direitos versando sobre interesses individuais, difusos e coletivos relativos à criança e ao adolescente, que podem ser objeto de proteção judicial.

Mas, o Judiciário, quando demandado, reconheceu que a Administração Pública tem se omitido na concretização dos direitos educacionais? Das decisões proferidas pelo TJ-SP, envolvendo direitos educacionais, pode-se inferir que em algumas demandas consolidou-se uma jurisprudência favorável à exigibilidade por meio do Judiciário, determinando que o Executivo cumprisse com suas atribuições. Por outro lado, persiste uma tendência, ainda que minoritária no TJ-SP, de recorrer ao argumento central da impossibilidade de o Judiciário intervir em atos que sejam da esfera exclusiva do Executivo, tendência, essa, prevalente em demandas concentradas na deliberação política.

$\mathrm{O}$ quadro a seguir apresenta uma síntese das argumentações em consenso entre os membros do TJ-SP para a aceitação das principais demandas de recursos, assim como dos fundamentos para a sua negativa:

\begin{tabular}{|c|c|c|}
\hline DEMANDAS REQUERIDAS & $\begin{array}{c}\text { CONSENSOS PARA A } \\
\text { AFIRMATIVA DO DIREITO } \\
\text { REQUERIDO }\end{array}$ & $\begin{array}{l}\text { FUNDAMENTOS PARA A } \\
\text { NEGATIVA DO DIREITO } \\
\text { REQUERIDO }\end{array}$ \\
\hline \multicolumn{3}{|c|}{ ACESSO Å EDUCAÇÃO BÁSICA } \\
\hline Matrícula educação infantil & $\begin{array}{l}\text { Não deve ser considerada como } \\
\text { uma norma programática; } \\
\text { Não se expõe a avaliações } \\
\text { meramente discricionárias da } \\
\text { administração pública; } \\
\text { Discricionariedade quanto à forma } \\
\text { de satisfazer essa obrigação; } \\
\text { Direito subjetivo dos titulares em } \\
\text { exigir seu cumprimento; } \\
\text { Responsabilidade do município em } \\
\text { atender prioritariamente o EF e a } \\
\text { EI } \\
\text { Pedidos individuais ou coletivos } \\
\text { quando apoiados em estatística ou } \\
\text { com relação de interessados }\end{array}$ & $\begin{array}{l}\text { Demandas envolvendo interesses } \\
\text { difusos e coletivos: } \\
\text { Pedidos genéricos } \\
\text { indeterminados } \\
\text { Impossibilidade de interferência do } \\
\text { Judiciário no planejamento } \\
\text { municipal e na questão } \\
\text { orçamentária }\end{array}$ \\
\hline $\begin{array}{l}\text { Restrição à matrícula de crianças } \\
\text { com sete anos incompletos no EF }\end{array}$ & $\begin{array}{l}\text { Existindo vagas, a SEE não deveria } \\
\text { proibir a matrícula das crianças } \\
\text { com sete anos incompletos }\end{array}$ & \\
\hline $\begin{array}{l}\text { Criação e manutenção de vagas na } \\
\text { rede estadual de EF }\end{array}$ & & $\begin{array}{l}\text { Esfera de atribuição própria do } \\
\text { Executivo }\end{array}$ \\
\hline $\begin{array}{l}\text { Frequência à escola mais próxima } \\
\text { da residência do aluno }\end{array}$ & & $\begin{array}{l}\text { Tarefa do administrador } \\
\text { Escolha de vaga restrita à } \\
\text { existência de vagas na escola } \\
\text { pretendida }\end{array}$ \\
\hline $\begin{array}{l}\text { Definição da idade pela SEE para } \\
\text { ingresso em cursos de EJA }\end{array}$ & $\begin{array}{l}\text { A idade estabelecida pela LDB } \\
\text { refere-se ao exame }\end{array}$ & \\
\hline
\end{tabular}




\begin{tabular}{|c|c|c|}
\hline DEMANDAS REQUERIDAS & $\begin{array}{c}\text { CONSENSOS PARA A } \\
\text { AFIRMATIVA DO DIREITO } \\
\text { REQUERIDO }\end{array}$ & $\begin{array}{l}\text { FUNDAMENTOS PARA A } \\
\text { NEGATIVA DO DIREITO } \\
\text { REQUERIDO }\end{array}$ \\
\hline $\begin{array}{l}\text { Cobrança de taxas para } a \\
\text { realização de exames supletivos }\end{array}$ & Cobrança ilegal & \\
\hline Adaptação dos prédios escolares & $\begin{array}{l}\text { Concedido o pedido com base na } \\
\text { legislação vigente }\end{array}$ & \\
\hline $\begin{array}{l}\text { Transporte adaptado às crianças e } \\
\text { adolescentes com necessidades } \\
\text { educacionais especiais }\end{array}$ & Dever do Estado & \\
\hline $\begin{array}{l}\text { Atendimento especializado às } \\
\text { crianças com necessidades } \\
\text { educacionais especiais }\end{array}$ & Não é uma norma programática & \\
\hline \multicolumn{3}{|c|}{ PERMANÊNCIA } \\
\hline $\begin{array}{l}\text { Transferência compulsória de } \\
\text { alunos indisciplinados }\end{array}$ & $\begin{array}{l}\text { Aceita, desde que garantida a } \\
\text { ampla defesa aos alunos }\end{array}$ & \\
\hline Obrigatoriedade de uniforme & Medida escolar julgada abusiva & \\
\hline $\begin{array}{l}\text { Direito de continuidade nos cursos } \\
\text { de língua estrangeira após a } \\
\text { conclusão do EM ou dada a } \\
\text { transferência para escola privada }\end{array}$ & $\begin{array}{l}\text { Os cursos de língua estrangeira não } \\
\text { podem ser estranhos ao dever do } \\
\text { Estado; } \\
\text { Como não havia norma clara na } \\
\text { Resolução não seria possível } \\
\text { restringir a matrícula }\end{array}$ & \\
\hline $\begin{array}{lcr}\text { Competência } & \text { para } & \text { apurar } \\
\text { responsabilidades } & \text { por } & \text { evasão } \\
\text { escolar } & & \end{array}$ & $\begin{array}{l}\text { Poderes investigatórios para } \\
\text { apuração desses fatos fixados ao } \\
\text { MP; }\end{array}$ & $\begin{array}{l}\text { Função supletiva do juízo da } \\
\text { infância e juventude nos locais sem } \\
\text { Conselho Tutelar; } \\
\text { Magistrado tem competência para } \\
\text { apurar infração por meio de ofício }\end{array}$ \\
\hline \multicolumn{3}{|c|}{ RESPONSABILIDADE ESTATAL } \\
\hline Transporte escolar & $\begin{array}{l}\text { Direito assegurado pela } \mathrm{CF} / 88, \\
\text { cuja negação infringe o princípio } \\
\text { constitucional da igualdade de } \\
\text { condições para o acesso à escola }\end{array}$ & $\begin{array}{l}\text { Ingerência em ato administrativo } \\
\text { na destinação de recursos de } \\
\text { conveniência e oportunidade da } \\
\text { Administração Pública. } \\
\text { Norma programática. }\end{array}$ \\
\hline $\begin{array}{l}\text { Indenizações por reparação de } \\
\text { danos materiais e/ou morais por } \\
\text { acidentes, agressões, morte de } \\
\text { alunos em estabelecimentos de } \\
\text { ensino }\end{array}$ & $\begin{array}{l}\text { Responsabilidade objetiva da } \\
\text { Administração Pública. } \\
\text { Escola tem obrigação de zelar pela } \\
\text { integridade física e moral dos } \\
\text { alunos. }\end{array}$ & $\begin{array}{l}\text { Improcedente a indenização } \\
\text { quando não foi demonstrada a } \\
\text { culpa da administração por } \\
\text { negligência, imprudência ou } \\
\text { imperícia, no caso de força maior, } \\
\text { caso fortuito, ou se comprovada a } \\
\text { culpa exclusiva da vítima. }\end{array}$ \\
\hline $\begin{array}{l}\text { Construção de instalações } \\
\text { educacionais adequadas }\end{array}$ & $\begin{array}{l}\text { Transferência dos alunos para local } \\
\text { provisório adequado até que } \\
\text { fossem concluídas as obras do } \\
\text { prédio definitivo }\end{array}$ & $\begin{array}{l}\text { Indevida } \text { ingerência } \\
\text { administração do Estado, devendo } \\
\text { ser respeitada a separação de } \\
\text { poderes }\end{array}$ \\
\hline \multicolumn{3}{|c|}{ PODER DE REGULAÇÃO ESTATAL } \\
\hline $\begin{array}{l}\text { Responsabilidade do Estado no } \\
\text { controle dos contratos e dos } \\
\text { reajustes dos mesmos entre os } \\
\text { estabelecimentos de ensino privado } \\
\text { e os alunos }\end{array}$ & 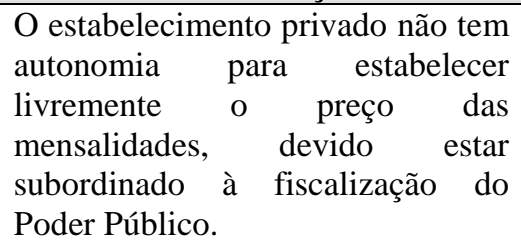 & $\begin{array}{l}\text { Relação entre alunos } \\
\text { estabelecimento particular de } \\
\text { ensino é de natureza privada. } \\
\text { O preço de um serviço de direito } \\
\text { privado é de interesse privado }\end{array}$ \\
\hline $\begin{array}{l}\text { Retenção de documentos de alunos } \\
\text { inadimplentes em instituições } \\
\text { privadas }\end{array}$ & Considerado ato abusivo & $\begin{array}{l}\text { O direito não pode favorecer } \\
\text { aquele que é devedor de obrigação }\end{array}$ \\
\hline
\end{tabular}




\begin{tabular}{|c|c|c|}
\hline DEMANDAS REQUERIDAS & $\begin{array}{c}\text { CONSENSOS PARA A } \\
\text { AFIRMATIVA DO DIREITO } \\
\text { REQUERIDO }\end{array}$ & $\begin{array}{c}\text { FUNDAMENTOS PARA A } \\
\text { NEGATIVA DO DIREITO } \\
\text { REQUERIDO }\end{array}$ \\
\hline $\begin{array}{l}\text { Vigência do artigo } 24 \text {, do Decreto- } \\
\text { lei no } 3.200 \text {, de } 19 \text { de abril de 1941: } \\
\text { redução das taxas escolares para } \\
\text { irmãos consanguíneos } \\
\text { matriculados em um mesmo } \\
\text { estabelecimento de ensino }\end{array}$ & $\begin{array}{l}\text { Norma compatível com os } \\
\text { princípios constitucionais atuais de } \\
\text { proteção à família }\end{array}$ & $\begin{array}{l}\text { Estava revogado, por ser } \\
\text { inconciliável com a nova ordem } \\
\text { constitucional }\end{array}$ \\
\hline $\begin{array}{l}\text { Autorização e credenciamento de } \\
\text { instituições privadas de educação }\end{array}$ & $\begin{array}{l}\text { Necessidade das } \text { instituições } \\
\text { seguirem normatização dos órgãos } \\
\text { da educação }\end{array}$ & \\
\hline \multicolumn{3}{|c|}{ DECISÕES ADMINISTRATIVAS E POLÍTICAS } \\
\hline $\begin{array}{l}\text { Iniciativa do Legislativo em propor } \\
\text { leis sobre implantação de serviços } \\
\text { educacionais }\end{array}$ & $\begin{array}{l}\text { Consideradas inconstitucionais. } \\
\text { Vício de iniciativa dos vereadores } \\
\text { e deputados sobre assuntos que são } \\
\text { de competência do Poder } \\
\text { Executivo ao afetar o } \\
\text { planejamento, a organização e a } \\
\text { direção de serviços ou que } \\
\text { implique a criação ou aumento de } \\
\text { despesa pública }\end{array}$ & \\
\hline $\begin{array}{l}\text { Programa de Reorganização das } \\
\text { Escolas da rede pública estadual, } \\
\text { de } 1995\end{array}$ & & $\begin{array}{l}\text { Indevida intromissão na } \\
\text { competência do Poder Executivo } \\
\text { Legalidade do decreto }\end{array}$ \\
\hline $\begin{array}{l}\text { Convênio de Municipalização do } \\
\text { EF }\end{array}$ & & $\begin{array}{l}\text { Ato se insere no âmbito da } \\
\text { discricionariedade } \\
\text { administração } \\
\begin{array}{l}\text { Inexistência de ato ilegal no } \\
\text { convênio }\end{array}\end{array}$ \\
\hline $\begin{array}{l}\text { Fechamento da creche em período } \\
\text { de férias }\end{array}$ & & $\begin{array}{l}\text { Não interferência do Judiciário no } \\
\text { poder discricionário do Executivo } \\
\text { Concessão da medida liminar } \\
\text { afetava a ordem e a economia } \\
\text { política }\end{array}$ \\
\hline \multicolumn{3}{|c|}{ GESTÃO DOS RECURSOS PÚBLICOS } \\
\hline $\begin{array}{l}\text { Aplicação irregular dos recursos } \\
\text { vinculados à educação }\end{array}$ & $\begin{array}{l}\text { Condenação do administrador } \\
\text { público quando entendeu que } \\
\text { houve conduta de má fé do prefeito } \\
\text { Constitui irregularidade a não } \\
\text { observância do percentual mínimo } \\
\text { constitucional em educação }\end{array}$ & $\begin{array}{l}\text { Compete à Vara da Fazenda } \\
\text { Pública e não à Vara da Infância da } \\
\text { Juventude }\end{array}$ \\
\hline $\begin{array}{l}\text { Suspensão dos pagamentos devidos } \\
\text { à empresa fornecedora do material } \\
\text { didático realizado sem processo } \\
\text { licitatório }\end{array}$ & & $\begin{array}{l}\text { Interromper a Cessão do } \\
\text { fornecimento das apostilas e } \\
\text { disponibilização dos sistemas de } \\
\text { tecnologia da informação pelo não } \\
\text { pagamento dos valores poderia } \\
\text { incorrer em grave dano aos alunos } \\
\text { beneficiários do sistema }\end{array}$ \\
\hline $\begin{array}{l}\text { Convênios celebrados entre } \\
\text { municípios e instituições privadas } \\
\text { para o atendimento de crianças em } \\
\text { creche }\end{array}$ & $\begin{array}{l}\text { Dever de atender a crianças em } \\
\text { creche é da municipalidade } \\
\text { Término do repasse do dinheiro à } \\
\text { associação privada e para que a } \\
\text { Administração Pública assumisse a } \\
\text { oferta }\end{array}$ & \\
\hline
\end{tabular}




\begin{tabular}{|l|l|l|}
\hline \multicolumn{1}{|c|}{ DEMANDAS REQUERIDAS } & \multicolumn{1}{c|}{$\begin{array}{c}\text { CONSENSOS PARA A } \\
\text { AFIRMATIVA DO DIREITO } \\
\text { REQUERIDO }\end{array}$} & $\begin{array}{c}\text { FUNDAMENTOS PARA A } \\
\text { NEGATIVA DO DIREITO } \\
\text { REQUERIDO }\end{array}$ \\
\hline \multicolumn{3}{|c|}{ DEVERES DOS PAIS } \\
\hline $\begin{array}{l}\text { Deveres dos pais para com a } \\
\text { obrigatoriedade de matricular e } \\
\text { garantir a frequência de seus filhos } \\
\text { ou dependentes à escola }\end{array}$ & $\begin{array}{l}\text { Obrigação de matricular o filho e } \\
\text { acompanhar sua frequência e } \\
\text { aproveitamento escolar, com a } \\
\text { necessidade de prestar contas de } \\
\text { seu encargo; } \\
\text { Alteração da sanção de multa para } \\
\text { a inclusão dos pais em programas } \\
\text { de tratamento psicológico; }\end{array}$ & \\
\hline
\end{tabular}

Quadro 6 - Síntese dos principais consensos para a afirmativa e negativa da exigibilidade das demandas educacionais julgadas pelo TJ-SP

Fonte: a autora.

Abramovich e Courtis (2002), no que tange à justiciabilidade dos direitos econômicos, sociais e culturais, ou seja, sobre a possibilidade de reclamar perante o juiz ou Tribunal de Justiça em caso de descumprimento da obrigação devida desses direitos, sublinham alguns obstáculos como: (i) a falta de especificação concreta do conteúdo dos direitos; (ii) autorestrição do Poder Judiciário frente a questões políticas e técnicas; (iii) ausência de mecanismos processuais adequados para a sua tutela;(iv) escassa tradição de controle judicial envolvendo a matéria.

Se relacionarmos esses obstáculos aos litígios educacionais, discutidos no âmbito do TJ-SP, verifica-se que na educação subsiste um conjunto bem definido de direitos, indicando que os principais problemas ligados a esta questão não se referem à qualquer suposta indefinição. Em algumas áreas como EI e educação especial o Judiciário contribuiu para esclarecer a legislação, principalmente quanto aos deveres do Estado.

As análises do Judiciário, sobretudo quanto às demandas envolvendo matrícula na EI, consolidaram o dever do Estado, com responsabilidade do município pelo atendimento, ao decidirem que a primeira etapa da educação básica se constituiu em direito subjetivo dos seus titulares em exigir o seu cumprimento perante o Judiciário, quando da sua violação. Assim como definiu que não deve ser considerada uma norma programática, como justificaram vários municípios quando compelidos judicialmente para garantir esse direito às crianças que não obtiveram vagas nas creches e pré-escolas. Outrossim, foi claramente entendido pelo TJSP que o atendimento especializado às crianças e adolescentes com necessidades educacionais especiais não configura meramente uma norma programática.

De modo específico, referente à declaração do direito à educação e seu aprimoramento para possível exigibilidade perante o Judiciário, sobressai a necessidade de definição de regras para o princípio da "qualidade do ensino", contendo determinações e competências entre os 
entes responsáveis para que possa ser juridicamente exequível definir quando da sua não satisfação. Pois, como visto, as demandas que de certa maneira reivindicavam este aspecto do direito foram escassas, e as que solicitavam medidas com relação à construção de instalações educacionais adequadas, bem como a definição do número de alunos por sala de aula, não tiveram solução favorável no âmbito do Judiciário. Ainda, estabelecer a extensão do conteúdo da qualidade do ensino não cabe aos membros do Judiciário, é uma tarefa técnica e política: “definir insumos e parâmetros para um ensino de qualidade requer uma análise dos custos, das condições reais, dos objetivos que se almeja e das expectativas sociais em torno do processo de escolarização" (OLIVEIRA; ARAUJO, 2005, p. 18).

O Conselho Nacional de Educação (CNE), Câmara da Educação Básica (CEB), aprovou em cinco de maio de 2010, o Parecer $n^{\circ}$ 8/2010, que apresenta um projeto de Resolução que estabelece normas para a aplicação do inciso IX do art. $4^{\circ}$ da LDB, o qual dispõe sobre a viabilidade de o dever do Estado para com a educação escolar pública ser efetivado mediante a garantia de "padrões mínimos de qualidade de ensino, definidos como a variedade e quantidade mínimas, por aluno, de insumos indispensáveis ao desenvolvimento do processo de ensino-aprendizagem".

Os padrões mínimos de qualidade para a educação pública têm como referência o Custo Aluno Qualidade inicial (CAQi), desenvolvido pela Campanha Nacional pelo Direito à Educação (CARREIRA; PINTO, 2007).

A Resolução sobre os padrões mínimos de qualidade de ensino, quando da sua homologação pelo Ministro da Educação, poderá ser uma importante normatização para reivindicar ações do Poder Executivo por meio do Judiciário, já que apresenta com clareza os insumos necessários.

A definição de insumos mínimos a serem disponibilizados para a educação de qualidade é uma medida importante e necessária para precisar parâmetros de investimentos para atingir a qualidade, todavia a existência dessas condições não é suficiente, por si só, para garantir um ensino de qualidade. Segundo Oliveira (2007, 2010), um indicador de qualidade adequado deveria articular também outras duas dimensões importantes: os resultados e os processos.

No que diz respeito aos resultados, o Índice de Desenvolvimento da Educação Básica $(\mathrm{Ideb})^{158}$ representa uma contribuição, mas este instrumento tem como base apenas a medida

\footnotetext{
158 O Ideb combina informações de desempenho em exames padronizados (Saeb e Prova Brasil) obtidos pelos alunos ao final das etapas de ensino $\left(4^{\mathrm{a}}\right.$ e $8^{\mathrm{a}}$ série do EF e $3^{\mathrm{a}}$ série do $\left.\mathrm{EM}\right)$ com informação sobre rendimento
} 
da proficiência em linguagem e matemática, sendo necessária a medida em outros componentes curriculares, igualmente importantes (OLIVEIRA, 2007, 2010).

Além da definição dos insumos mínimos e dos resultados desejáveis do processo educacional e da forma de medi-los, se faz necessário incorporar às dimensões do indicador de qualidade o que acontece no interior da escola, ou seja, os processos educativos "que têm valor formativo em si, e não que sejam apenas meios para se atingir outro objetivo, a proficiência" (OLIVEIRA, 2010, p.08). Com relação a esta dimensão, segundo Oliveira, surge uma "questão de fronteira" de pesquisa em política educacional. Desta forma, sem um acordo sobre os critérios mínimos e uma formulação objetiva, é mais difícil valer-se desse elemento para tornar o direito exigível perante o Sistema de Justiça, pois se corre o risco dos membros do Judiciário ter que julgar conteúdos que não pertencem ao campo dos seus conhecimentos específicos, o que poderia implicar em que não ofereçam as melhores soluções.

Quanto ao obstáculo referente à auto-restrição do Poder Judiciário sobre as decisões do TJ-SP, observou-se que nas demandas relacionadas às questões técnicas ou políticas os desembargadores foram mais resistentes em aceitar os pedidos, justificando com a impossibilidade de interferência do Judiciário em matéria específica do Executivo. Todavia, Abramovich e Courtis (2002), evidenciam que a possibilidade de êxito do caso será maior se for factível demarcar de maneira clara, por exemplo, o desenho, as prioridades ou a implementação das políticas públicas.

Com relação aos instrumentos jurídicos para a exigibilidade do direito à educação, destaca-se o impacto do ECA ao ampliar a atuação do MP para a garantia dos direitos individuais indisponíveis, difusos e coletivos referentes à criança e ao adolescente, e os diferentes instrumentos processuais existentes (ação civil pública, mandado de segurança, ação coletiva), não se constituindo, no âmbito educacional, em um obstáculo na perspectiva de Abramovich e Courtis (2002).

A utilização do Judiciário para reivindicar e questionar políticas relacionadas à educação, principalmente nesta década, tem permitido mudança de atitude por parte dos membros do Judiciário. Um exemplo paradigmático refere-se à exigibilidade da EI. Inicialmente, com sentenças diferenciadas em primeira instância, e até mesmo por parte dos desembargadores do TJ-SP. Desse modo, consolidou-se uma jurisprudência favorável ao longo dos anos, sobretudo, com as decisões proferidas pelo STF. Sabe-se que as decisões

escolar (taxa média de aprovação). Para outras informações ver Nota Técnica, disponível em http://www.inep.gov.br/download/Ideb/Nota_Tecnica_n1_concepcaoIDEB.pdf, acesso em 16 out. 2010. 
favoráveis conferem maior visibilidade à possibilidade de reclamar e conseguir judicialmente o direito pretendido.

A aceitação diferenciada da exigibilidade do direito à educação pelo Judiciário não se refere à proteção distinta no ordenamento jurídico brasileiro às etapas e modalidades da educação brasileira, mas ao caráter das disputas.

Nos processos que discutiam a omissão, principalmente para a criação de oportunidades que garantam a fruição do direito, como vagas, notou-se que há mais facilidade dos desembargadores acatarem a possibilidade de exigir o cumprimento por parte da autoridade competente. Sob outro aspecto, nos litígios que questionavam medidas já tomadas pela Administração Pública, ou seja, por ação do Executivo, o Judiciário tende à não interferência, considerando que a atividade faz parte do poder discricionário do Executivo, sendo aceitas as que individualmente impediam o acesso das crianças e dos adolescentes a vagas, como nos processos sobre restrição da idade para ingresso no EF e extinção de classes de EJA. Mesmo nas disputas que envolviam critérios para ingresso no Ensino Profissionalizante, as decisões do TJ-SP, em sua maioria, não invalidaram os critérios estabelecidos pela Administração, as decisões apenas garantiram que os alunos oriundos do Sesi, por exemplo, fossem equiparados aos alunos das escolas públicas no processo de seleção.

Quanto à discricionariedade da Administração Pública no que se refere ao direito à educação há uma tendência majoritária entre os desembargadores do TJ-SP em considerá-la como sendo a maneira, a forma de satisfazer uma obrigação já estabelecida, não podendo ser utilizada como justificativa para adiamento na criação de oportunidades que garantam a fruição do direito. Posição apresentada por Frischeisen (2000), de que o administrador tem discricionariedade na escolha dos meios para implementar as políticas, mas essas "escolhas" não podem contrariar os valores e princípios constitucionais.

A tese da ingerência do Judiciário em atividade discricionária do Poder Executivo foi apresentada, principalmente, nos processos que discutiam as medidas administrativas e políticas adotadas pelo Poder Público, como a reorganização das escolas no estado de SP, construção de salas de aulas e programas de transporte escolar. Neste último caso, entende-se que um direito claramente assegurado pela Constituição e pela LDB, como dever do Estado, deixou de ser cumprido. Nestas ações, o Tribunal não enfrentou as demandas colocadas a este Poder, seja por não acreditar que tivesse 'força' para tanto ou porque não desejasse enfrentálas, decidindo com base em critérios formais para o não prosseguimento da ação. 
De acordo com Bucci (2006), o sucesso de certas ações judiciais está relacionado à afinidade política dos integrantes do tribunal ao governante que as implementa. Esse fator foi observado em várias decisões com conteúdo semelhante do pedido, mas resultado diferenciado, considerando o julgador e o réu.

Quanto à aceitação das demandas, observou-se que as concernentes a pedidos individuais ou para um número definido de interessados apresentaram tendência majoritariamente favorável entre os membros do TJ-SP, ao contrário das que abrangiam interesses coletivos, com argumentos de pedidos genéricos e indeterminados e, sobretudo, com o fundamento de impossibilidade de interferência do Judiciário no planejamento municipal e na questão orçamentária. Essa tendência de facilidade de aceitação das ações quando os demandantes são nomeados e identificados também foi captada por Oliveira (1995).

O levantamento das decisões do TJ-SP, entre 1996-2003, realizado por Lopes (2006), também propusera que as "ações civis públicas tendem a ter mais sucesso quando propostas para defender interesses divisíveis e singulares do que quando propostas para defender “interesses difusos" (p.255).

Uma das razões para isto, como dito, é que a doutrina constitucional ainda está
baseada no conceito de direito subjetivo individual e no Brasil não incorpora jamais
o problema central de um regime democrático, qual seja o da universalidade, da
simultaneidade do gozo e da isonomia abstrata e universal. Com isto, como já foi
dito, não é difícil ver o desvio da proteção constitucional democrática converter-se
em concessão de privilégios (LOPES, 2006, p. 256).

Se as demandas judiciais com pedidos individuais são acatadas de modo mais favorável pelo Judiciário, salienta-se a relevância de identificar as crianças que necessitam das vagas nas instituições de ensino, principalmente com a realização de Censos.

Mas, como discutido previamente, atender aos pedidos individualizados pode favorecer os que têm mais consciência de seus direitos e da possibilidade de recorrer ao Judiciário para obtê-los. Todavia, o que fazer? Atender os que procuram individualmente, pois também têm direito, porque o direito à educação tem uma dimensão individual, e exigir políticas públicas para a ampliação. As demandas individuais com ganhos judiciais podem provocar respostas do Executivo e do Legislativo na adoção de políticas públicas, como medida de garantia das reivindicações dos direitos e até mesmo como prevenção de novas ações judiciais.

Entretanto, concorda-se com Duarte (2003), ao considerar que a tutela dos direitos educacionais por meio da exigibilidade de políticas públicas deve ser prioritária, envolvendo 
desta forma, interesses que transcendem a esfera individual, influenciando o planejamento do orçamento público e o estabelecimento de prazos para o cumprimento das metas a serem atingidas.

No que se refere especificamente à possibilidade de planejamento do orçamento público por meio de demandas coletivas destaca-se a decisão do TJ-SP em apelação cível do município de Roseira, julgada em 2008, sobre processo que requisitava do Poder Público municipal a instalação de creches e pré-escolas para atendimento das crianças que necessitassem. A decisão foi pela condenação da municipalidade a incluir verbas necessárias no projeto de lei orçamentária para a sua instalação. Nessa direção, o Executivo, respeitando as determinações da legislação sobre planejamento fiscal, poderá expandir o atendimento, prioritariamente em creches, que constituiu na principal reivindicação ao TJ-SP.

Com relação às dificuldades orçamentárias para a efetivação dos direitos sociais, alguns desembargadores e Ministros do STF reforçaram a tese sobre a ineficácia do argumento da insuficiência de recursos. Neste sentido, é preciso mudar a maneira de pensar o orçamento público, ele deve contemplar os direitos já consagrados na legislação e não a efetivação estar condicionada à existência dos recursos financeiros.

Há que se lembrar, também, que a aceitação do argumento da reserva do possível, das limitações orçamentárias para o atendimento de toda a demanda, configura a maneira que os membros do Judiciário encontraram para se livrarem de ser acusados de violar o princípio da separação de poderes, como enfatizado por Zanitelli (2008).

Porém, cumpre salientar que a Constituição de 1988 definiu como um dos fundamentos para a República Federativa do Brasil a dignidade humana; neste sentido, este princípio deve assumir a preponderância nos litígios que confrontam com a separação de poderes, como destacado anteriormente por Alexy (2008) e Barcellos (2007).

Não é possível deixar que a justificativa da não interferência do Judiciário em atividades do poder discricionário do Executivo seja utilizada para manter a omissão com relação aos direitos já proclamados na legislação, pois a negativa para o acesso, por exemplo, à creche, à pré-escola, na acessibilidade e atendimento educacional especializado às pessoas com deficiências infringe o respeito devido à dignidade humana. Portanto, como afirma Sousa Santos (2007, p. 34), o Judiciário precisa assumir sua "quota-parte" na responsabilidade para a resolução dos problemas relacionados às injustiças, ou será cada vez mais irrelevante tanto social como politicamente. 
Com relação aos litígios educacionais, no âmbito do TJ-SP, acredita-se que seus membros não demonstraram, em seus julgamentos, uma atitude relacionada ao "ativismo judicial” (BARROSO, 2009), mas decidiram com base no que foi definido pela legislação. Em algumas decisões denota-se uma postura, como classifica Barroso (2009), muito mais relacionada à "autocontenção judicial” por parte dos desembargadores, ao utilizarem critérios rígidos, formais e até mesmo conservadores diante do entendimento da $\mathrm{CF} / 88$ para declararem a impossibilidade de interferência do Judiciário na definição das políticas educacionais.

Apesar do papel do Judiciário na educação ter se ampliado de forma expressiva, é patente a necessidade de discutir a utilização deste meio para a resolução de litígios envolvendo questões pedagógicas e educativas, pois esta instituição nem sempre será o mecanismo mais eficaz, devido ao despreparo dos seus membros para as dinâmicas envolvendo o cotidiano educacional.

Em decorrência do processo de acionamento do Judiciário, é preciso, também, considerar a sobrecarga de trabalho existente nos Tribunais, como referido no terceiro capítulo deste trabalho. A morosidade no julgamento e os diversos recursos para uma decisão final podem afetar as expectativas de utilização do Judiciário como um mecanismo capaz de responder às demandas da sociedade que reivindicam a efetivação dos direitos sociais.

As reformas realizadas no âmbito do Judiciário, como a do impedimento de recursos quando a sentença estiver em conformidade com súmula do STJ ou STF (Lei 11.276/2006) poderão contribuir para a agilidade no julgamento e para reduzir recursos com processos repetitivos.

Retomando os limites da eficácia das normas relacionadas à educação, discutidos principalmente no primeiro capítulo deste trabalho, considera-se que o principal obstáculo para a efetivação dos direitos consagrados em nossa legislação não reside na qualidade das normas constitucionais existentes, não se refere à imprecisão dos enunciados, se sua normatização se dá por meio de um princípio ou de uma regra, de uma norma programática ou de um objetivo para a realização da atuação do Poder Público. Antes, vincula-se, sobretudo, às prioridades que os direitos sociais e, neste contexto, a educação, têm na destinação dos recursos por parte de nossos governantes.

O principal obstáculo à efetivação consiste em cumprir o que foi consagrado pela legislação, colocar em ação as prioridades e as metas estabelecidas para garantir o atendimento dos deveres impostos ao Estado, construindo instituições educacionais com infra-estrutura adequada, principalmente nos locais em áreas de expansão na cidade e no 
campo, equipando os estabelecimentos de ensino com materiais necessários ao ensino e aprendizagem adequados, promovendo capacitação dos profissionais da educação, remunerando-os com dignidade para que possam se dedicar exclusivamente ao exercício do magistério. Ou seja, é preciso sair da igualdade jurídica e implantar políticas públicas que garantam, de fato, igualdade de oportunidades e de conhecimentos a todos os cidadãos brasileiros.

De acordo com Piovesan (2007, p. 74), a justiciabilidade dos direitos econômicos, sociais e culturais no Brasil é capaz de gerar um legado transformador e emancipatório. Para a consolidação do Judiciário em "locus de afirmação de direitos", a autora destaca como fundamental a participação da sociedade civil organizada, para que esta "acione de forma crescente o Poder Judiciário, otimizando o potencial emancipatório e transformador que o direito pode ter. Só assim haverá maior transparência e accountability dos deveres do Estado no tocante à implementação dos direitos à saúde e à educação (PIOVESAN, 2007, p. 74).

Com relação à educação, para que o Judiciário se converta, utilizando-se da expressão da autora, em um "locus de afirmação de direitos", torna-se fundamental, também como reiterou essa pesquisa, a mudança de concepção de parcela dos membros do Judiciário no que se refere à interferência do Judiciário no controle da ação da Administração Pública, quando esta deixa de cumprir a sua função. Pois, se a administração não cumpre a lei, há fundamento para que os cidadãos exercitem seu direito contra o Estado. Segundo essa diretriz, o Judiciário não está invadindo atribuições do Poder Executivo ou Legislativo, mas respeitando uma exigência da Constituição.

Ao discutir neste trabalho o controle exercido pelo Poder Judiciário para a garantia do direito à educação não se desconsidera ou desvaloriza a participação como mecanismo de construção da democracia, mas ressalta-se que o Sistema de Justiça pode ser um espaço fundamental para o seu aprimoramento, ao possibilitar a reivindicação dos direitos proclamados para além da defesa dos direitos civis. Assim, como enfatiza Sousa Santos (2007, p. 90) "sem direitos de cidadania efetivos a democracia é uma ditadura mal disfarçada".

As demandas judiciais constituem, nesse sentido, importante instrumento para a consolidação da democracia, ao problematizar os deveres do Estado a partir dos princípios Constitucionais, e de extensão de sua concepção formal, associada à forma de governo e aos mecanismos de seleção dos representantes, para uma democracia substancial, na concretização da igualdade jurídica, social e econômica, materializando direitos fundamentais 
para todos, em igual conteúdo e qualidade. Como afirma Comparato (1998, p. 48), a democracia "nunca é o fruto de uma evolução natural e inelutável da sociedade política", ela se institucionaliza "ao longo de um incessante e penoso trabalho de modelagem das instituições políticas, em defesa da dignidade humana".

Ainda, vale reiterar que este trabalho analisou uma instituição do Poder Judiciário, com decisões de um período específico (1991-2008). Após essa data, importantes decisões podem ter sido proferidas, com posicionamentos diferentes ou que consolidassem e/ou aprimorassem o entendimento sobre o direito à educação, assim como podem ter surgido novas demandas. Espera-se que este trabalho tenha contribuído para compreender como uma instância de recurso do Poder Judiciário atuou para a efetivação do direito à educação, destacando a jurisprudência favorável, assim como os mecanismos de resistência ainda existentes, facultando pensar em alternativas que visem contorná-las, no âmbito de luta nessa esfera. Acredita-se que o Poder Judiciário é uma instituição importante no processo de consolidação dos direitos educacionais, sendo um meio a mais de pressão, que deve ser utilizado após tentativas anteriores de diálogo e pressão da sociedade civil organizada junto ao Poder Executivo e Legislativo. 


\section{REFERÊNCIAS}

ACQUAVIVA, Marcus Cláudio. Dicionário Jurídico Brasileiro Acquaviva. São Paulo: Editora Jurídica Brasileira, 1995.

ABRAMOVICH, Víctor; COURTIS, Christian. Los derechos sociales como derechos exigibles. Madrid: Editorial Trotta, 2002.

ABRAMOVICH, Víctor. Linhas de trabalho em direitos econômicos, sociais e culturais: instrumentos e aliados. SUR - Revista Internacional de Direitos Humanos. Ano 2, número 2, 2005.

ADRIÃO, Theresa. Educação e produtividade: a reforma do ensino paulista e a desobrigação do Estado. São Paulo: Xamã, 2006.

; GARCIA, Teise; BORGHI, Raquel; ARELARO, Lisete. Relatório Final da

pesquisa: Estratégias Municipais para a oferta da educação básica: uma análise de parcerias público privado no estado de São Paulo. 2009a. (Relatório de pesquisa).

- Uma modalidade peculiar de privatização da educação pública: a aquisição de "sistemas de ensino" por municípios paulistas. Educação e Sociedade, v. 30, n. 108, p. 799818,2009 b.

ALEXY, Robert. Teoria dos direitos fundamentais. Tradução Virgílio Afonso da Silva. São Paulo: Malheiros, 2008.

ANUÁRIO da Justiça Paulista: 2008. São Paulo: ConJur Editorial, 2008.

ARANTES, Rogério B. Judiciário: entre a Justiça e a Política. In: AVELAR, Lúcia; CINTRA, Antônio Octávio. Sistema político brasileiro: uma introdução. 2. ed. Rio de Janeiro: KonradAdenauer-Stiftung; São Paulo: Editora Unesp, 2007.

BARCELLOS, Ana Paula de. O mínimo existencial e algumas fundamentações: Jonh Rawls, Michael Walzer e Robert Alexy. In: TORRES, Ricardo Lobo (Org.). Legitimação dos direitos humanos. 2 ed. revista e ampliada. Rio de Janeiro: Renovar, 2007.

. Constitucionalização das políticas públicas em matéria de direitos fundamentais: o controle político-social e o controle jurídico no espaço democrático. In: SARLET, Ingo 
Wolfgang; TIMM, Luciano Benetti. (Org.). Direitos Fundamentais: orçamento e "reserva do possível". Porto Alegre: Livraria do Advogado, 2008.

BARROSO, Luís Roberto. O controle de constitucionalidade no direito brasileiro: exposição sistemática da doutrina e análise crítica da jurisprudência. $4^{a}$ ed. São Paulo: Saraiva, 2009.

BENEVIDES SOARES, Maria Victoria de Mesquita. Cidadania e Direitos Humanos. Cadernos de Pesquisa. São Paulo, no 104, p. 39-46, jul. 1998.

BEZERRA, Egle Pessoa. Parceria público-privada nos municípios de Brotas e Pirassununga: estratégias para a oferta do ensino? 2008. Dissertação (Mestrado em Educação) - Universidade Estadual Paulista, Rio Claro - SP, 2008.

BOBBIO, Norberto. A era dos direitos. Nova ed. Rio de Janeiro: Elsevier, 2004.

BONAVIDES, Paulo. Curso de Direito Constitucional. 24ª ed. São Paulo: Malheiros Editores, 2009a.

Do Estado liberal ao Estado Social. 9 ed. São Paulo: Malheiros Editores, 2009b.

BONELLI, Maria da Gloria. Os Desembargadores do Tribunal de Justiça do Estado de São Paulo e a Construção do Profissionalismo, 1873-1997. Dados, v. 44, n. 2. Rio de Janeiro, 2001.

BORGHI, Raquel Fontes; ADRIÃO, Theresa; ARELARO, Lisete Regina Gomes. A relação público-privada na oferta da educação infantil: continuidades e rupturas. In: XXIV Simpósio Brasileiro III Congresso Interamericano de Política e Administração da Educação, 2009, Vitória, Espírito Santo. Anais ..., Porto Alegre: Anpae , Espírito Santo: UFES/PPGR, 2009a. CD-ROM.

BOTTINI, Píerpaolo Cruz. A reforma do Judiciário: aspectos relevantes. Revista da Escola Nacional de Magistratura, v.2, n.3, p. 89-99, abr. 2007.

BRASIL. Constituição da República Federativa do Brasil de 1988, Brasília. Disponível em: <http://www.senado.gov.br/sf/legislacao/const/>. Acesso em: 14 ago. 2009.

Decreto-Lei $n^{o} 2.848$, de 7 de dezembro de 1940. Código Penal. Disponível em:

<https://www.planalto.gov.br/ccivil_03/Decreto-Lei/del2848.htm>. Acesso em: 15 set. 2010. 
. Decreto-Lei $n^{\circ} 5.296$, de 2 de dezembro de 2004. Regulamenta as Leis $\mathrm{n}^{\mathrm{os}} 10.048$, de 8 de novembro de 2000 , que dá prioridade de atendimento às pessoas que especifica, e 10.098, de 19 de dezembro de 2000, que estabelece normas gerais e critérios básicos para a promoção da acessibilidade das pessoas portadoras de deficiência ou com mobilidade reduzida. Disponível em: <http://www.planalto.gov.br/ccivil/_ato20042006/2004/decreto/d5296.htm>. Acesso em: 14 jul. 2010.

Lei $n^{\circ} 5.869$, de 11 de janeiro de 1973. Institui o Código de Processo Civil. Disponível em: <http://www.planalto.gov.br/ccivil_03/Leis/L5869.htm>. Acesso em: 10 out. 2010.

Lei 7.853, 24 de outubro de 1989. Dispõe sobre o apoio às pessoas portadoras de deficiência, sua integração social, sobre a Coordenadoria Nacional para Integração da Pessoa Portadora de Deficiência - Corde, institui a tutela jurisdicional de interesses coletivos ou difusos dessas pessoas, disciplina a atuação do Ministério Público, define crimes. Disponível em: 〈http://www.planalto.gov.br/ccivil_03/Leis/L7853.htm>. Acesso em: 14 jul. 2010.

Lei $n^{o} 8.069$, de 13 de julho de 1990. Dispõe sobre o Estatuto da Criança e do Adolescente e dá outras providências. Diário Oficial da União: República Federativa do Brasil, Brasília, DF, 16 de julho de 1990.

. Lei $\mathrm{n}^{\circ} 8.078$, de 11 de setembro de 1990. Dispõe sobre a proteção do consumidor. Disponível em: <http://www.planalto.gov.br/ccivil_03/Leis/L8078.htm>. Acesso em: 15 fev. 2010.

. Lei $n^{\circ} 8.170$, de 17 de janeiro de 1991. Estabelece regras para a negociação de reajustes das mensalidades escolares. Disponível em:

<http://www.planalto.gov.br/CCIVIL/LEIS/L8170.htm>. Acesso em: 15 jan. 10.

. Lei $n^{\circ} 8.429$, de 2 de junho de 1992. Dispõe sobre as sanções aplicáveis aos agentes públicos nos casos de enriquecimento ilícito no exercício de mandato, cargo, emprego ou função na administração pública direta, indireta ou fundacional e dá outras providências. Disponível em: <http://www.planalto.gov.br/ccivil_03/Leis/L8429.htm>. Acesso em: 14 out. 2009.

. Lei $n^{\circ}$ 8.666, de 21 de junho de 1993. Regulamenta o art. 37, inciso XXI, da Constituição Federal, institui normas para licitações e contratos da Administração Pública. Disponível em: <http://www.planalto.gov.br/ccivil_03/LEIS/L8666cons.htm>. Acesso em: 05 jul. 09. 
Lei $n^{o}$. 9.394, de 20 de dezembro de 1996. Estabelece as Diretrizes e Bases da Educação Nacional. Disponível em:

<http://www.presidencia.gov.br/ccivil_03/Leis/L9394.htm >. Acesso em: 20 jan. 2009.

Lei 10.098, de 19 de dezembro de 2000. Estabelece normas gerais e critérios básicos para a promoção da acessibilidade das pessoas portadoras de deficiência ou com mobilidade reduzida, e dá outras providências. <http://www.planalto.gov.br/ccivil_03/Leis/L10098.htm> Acesso em: Acesso em: 14 jul. 2010

Lei 11.277, de 7 de fevereiro de 2006. Acresce o art. 285-A à Lei no 5.869, de 11 de janeiro de 1973, que institui o Código de Processo Civil. Disponível em: <http://www.planalto.gov.br/ccivil_03/_Ato2004-2006/2006/Lei/L11277.htm>. Acesso em: 02 set. 09.

Lei 11.276, de 7 de fevereiro de 2006. Altera os arts. 504, 506, 515 e 518 da Lei $\mathrm{n}^{\circ}$ 5.869, de 11 de janeiro de 1973 - Código de Processo Civil, relativamente à forma de interposição de recursos, ao saneamento de nulidades processuais, ao recebimento de recurso de apelação e a outras questões. Disponível em:

<http://www.planalto.gov.br/ccivil_03/_Ato2004-2006/2006/Lei/L11276.htm>. Acesso em: 02 set. 09.

Lei $n^{o}$ 11.417, de 19 de dezembro de 2006. Regulamenta o art. 103-A da Constituição Federal e altera a Lei no 9.784 , de 29 de janeiro de 1999, disciplinando a edição, a revisão e o cancelamento de enunciado de súmula vinculante pelo Supremo Tribunal Federal. Disponível em: < http://www.planalto.gov.br/ccivil_03/_ato2004-2006/2006/lei/111417.htm>. Acesso em: 02 set. 09.

Parecer $C N E / C E B$ n $^{\circ} 8$, de 5 de maio de 2010. Estabelece normas para aplicação do inciso IX do artigo $4^{\circ}$ da Lei $n^{\circ} 9.394 / 96$ (LDB), que trata dos padrões mínimos de qualidade de ensino para a Educação Básica pública. Disponível em: < http://portal.mec.gov.br/index.php?option=com_content\&view=article\&id=12992:diretrizespara-a-educacao-basica\&catid=323:orgaos-vinculados > Acesso em: 25 ago. 2010.

Resolução $C N E / C E B n^{o} 2$, de 11 de setembro de 2001. Institui Diretrizes Nacionais para a Educação Especial na Educação Básica. Disponível em: <http://portal.mec.gov.br/cne/arquivos/pdf/CEB0201.pdf>. Acesso em: 28 jul. 10.

Resolução CNE/CEB $n^{o}$ 1, 5 de julho de 2000. Estabelece as Diretrizes Curriculares Nacionais para a Educação e Jovens e Adultos. Disponível em: <http://portal.mec.gov.br/cne/arquivos/pdf/CEB012000.pdf>. Acesso em: 30 ago. 10. 
Resolução $n^{\circ} 3$, de 15 de junho de 2010. Institui Diretrizes Operacionais para a Educação de Jovens e Adultos nos aspectos relativos à duração dos cursos e idade mínima para ingresso nos cursos de EJA; idade mínima e certificação nos exames de EJA; e Educação de Jovens e Adultos desenvolvida por meio da Educação a Distância.

$<$ http://portal.mec.gov.br/index.php?option=com_content\&view=article\&id=12992\&Itemid= 866>. Acesso em 10 set. 2010.

. Supremo Tribunal Federal. Recurso Extraordinário 410.715-5, São Paulo, 22 de novembro de 2005. Relator: Ministro Celso de Mello. Disponível em: http://redir.stf.jus.br/paginador/paginador.jsp?docTP=AC\&docID=354801> Acesso em: 18 out. 2010.

. Supremo Tribunal Federal. Recurso Extraordinário 431.773-7, São Paulo, 22 de outubro de 2004. Relator Ministro Marco Aurélio. Disponível em:

<http://www.stf.jus.br/portal/jurisprudencia/listarJurisprudencia.asp?s1=((431773.NUME.\%2 0OU\%20431773.DMS.))\%20NAO\%20S.PRES.\&base=baseMonocraticas > Acesso em: 18 out. 2010.

BUCCI, Maria Paula Dallari. O conceito de política pública em direito. In: BUCCI, Maria Paula Dallari (Org.). Políticas Públicas: reflexões sobre o conceito jurídico. São Paulo: Saraiva, 2006.

CALIENDO, Paulo. Reserva do possível, direitos fundamentais e tributação. In: SARLET, Ingo Wolfgang; TIMM, Luciano Benetti. (Org.). Direitos Fundamentais: orçamento e "reserva do possível". Porto Alegre: Livraria do Advogado, 2008.

CAPPELLETTI, Mauro; GARTH, Bryant. Acesso à justiça. Porto Alegre: Fabris, 1988.

CARREIRA, Denise; PINTO, José Marcelino Rezende. Custo Aluno Qualidade Inicial: rumo à educação pública de qualidade no Brasil. São Paulo: Global, Campanha Nacional pelo Direito à Educação, 2007.

CARVALHO, Ernani Rodrigues de. Em busca da judicialização da política no Brasil: apontamentos para uma nova abordagem. Revista Brasileira de Ciências Sociais. Curitiba, n. 23, 2004.

CONSELHO NACIONAL DE JUSTIÇA. Justiça em números 2007: variáveis e indicadores do Poder Judiciário. Brasília, 2007.

COMPARATO, Fábio Konder. "Ensaio sobre o juízo de constitucionalidade de políticas públicas”. Revista de Informação Legislativa. Brasília, ano 35, n. 138, abr./jun. 1998. p. 3948. 
O Poder Judiciário no regime democrático. Revista Estudos Avançados. Vol. 18, número 51, agos/maio 2004. p 152-159.

CURY, Carlos Roberto Jamil. A educação infantil como direito. In: BRASIL, Ministério da Educação e do Desporto. Subsídios para credenciamento e funcionamento de instituições de educação infantil. Volume II. Brasília: MEC, 1998.

A educação básica como direito. Cadernos de Pesquisa, v. 38, n. 134, p. 293-303, maio/ago.2008.

; FERREIRA, Luiz Antonio Miguel. A judicialização da educação. Revista do Ministério Público do Estado de Goiás. n. 18, ano 12, p. 29-71, 2009.

CUNHA, José Ricardo. Direitos humanos e justiciabilidade: pesquisa no Tribunal de Justiça do Rio de Janeiro. SUR - Revista Internacional de Direitos Humanos. n.3, ano 2, p. 139-172, 2005.

DAMASCO, Denise Gisele de Britto. Direito à educação: a atuação das Promotorias de Justiça e de Defesa da Educação do Ministério Público do Distrito Federal e Territórios, entre 2001 e 2006. 2008. Dissertação (Mestrado em Educação) - Universidade de Brasília.

DOMICIANO, Cássia Alessandra. Programa 'Bolsa Creche' nos municípios paulistas de Piracicaba e Hortolândia: uma proposta para alocação de recursos estatais à educação privada? 2009. Dissertação (Mestrado em Educação) - Universidade Estadual Paulista.

DUARTE, Clarice Seixas. O direito público subjetivo ao ensino fundamental na Constituição Federal Brasileira de 1988. 2003. 328 p. Tese (Doutorado) - Faculdade de Direito, Universidade de São Paulo, São Paulo, 2003.

Direito público subjetivo e políticas educacionais. São Paulo em Perspectiva. São Paulo, n. 18 (2), p. 113-118. 2004.

Reflexões sobre a Justiciabilidade do Direito à Educação no Brasil In: HADDAD, Sérgio; GRACIANO, Mariângela (Org.) A educação entre os direitos humanos. Campinas, SP: Autores Associados; São Paulo, SP: Ação Educativa, 2006.

A educação como um direito fundamental de natureza social. Revista Educação e Sociedade, Campinas, vol. 28, n. 100 - Especial, p. 691-713, out. 2007. 
DWORKIN, Ronald. Levando os direitos a sério. Trad. Nelson Boeira. $2^{\mathrm{a}}$ ed. São Paulo: Martins Fontes, 2007.

FARIA, José Eduardo. O sistema brasileiro de Justiça: experiências recentes e futuros desafios. Revista Estudos Avançados. Vol. 18, número 51, ago/maio 2004. p 103-125.

FELLMAN, David. The Supreme Court and Education. 2. ed. New York: Teachers College, Columbia University, 1961. Classics in Education, n. 4.

FRISCHEISEN, Luiza Cristina Fonseca. Políticas Públicas: a responsabilidade do administrador e o Ministério Público. São Paulo: Max Limonada, 2000.

GALDINO, Flávio. O Custo dos Direitos. In: TORRES, Ricardo Lobo (Org.). Legitimação dos direitos humanos. 2 ed. revista e ampliada. Rio de Janeiro: Renovar, 2007.

GARCIA, Emerson. O direito à educação e suas perspectivas de efetividade. Jus Navigandi. 2004. Disponível em: <http://jus2.uol.com.br/doutrina/texto.asp?id=5847> Acesso em: 25 fev. 2009.

GRACIANO, Mariângela Graciano; MARINHO, Carolina; FERNANDES, Fernanda. As demandas judiciais por educação na cidade de São Paulo. In: HADDAD, Sérgio; GRACIANO, Mariângela (Org.) A educação entre os direitos humanos. Campinas, SP: Autores Associados; São Paulo, SP: Ação Educativa, 2006.

HOLMES, Stephen; SUSTEIN, Cass R. The cost of rights: why liberty depends on taxes. New York: W. W. Norton \& Companhy, 1999.

INSTITUTO NACIONAL DE ESTUDOS E PESQUISAS EDUCACIONAIS ANÍSIO TEIXEIRA/ MINISTÉRIO DA EDUCAÇÃO (Inep/MEC). Os desafios do Plano Nacional de Educação. Brasília: Inep/MEC, 2004.

KRELL, Andreas J. Direitos sociais e controle judicial no Brasil e na Alemanha: os (des)caminhos de um direito constitucional "comparado". Porto Alegre: Sergio Antonio Fabris Editor, 2002.

KUHLMANN JR, M. Histórias da educação infantil brasileira. Revista Brasileira de Educação. n. 14, Maio/jun./jul/ago. 2000. 
LIBERATI, Wilson Donizete. Comentários ao Estatuto da Criança e do Adolescente. $8^{\mathrm{a}}$ ed. São Paulo: Malheiros, 2004.

LOPES, José Reinaldo de Lima. Direito Subjetivo e Direitos Sociais: o Dilema do Judiciário no Estado Social de Direito. In: FARIA, José Eduardo (Org.). Direitos Humanos, Direitos Sociais e Justiça. São Paulo: Malheiros Editores, 2002.

Direitos sociais: teoria e prática. São Paulo: Método, 2006.

. Em torno da "reserva do possível". In: SARLET, Ingo Wolfgang; TIMM, Luciano Benetti. (Org.). Direitos Fundamentais: orçamento e "reserva do possível". Porto Alegre: Livraria do Advogado, 2008.

MACHADO, Edson. A Jurisprudência educacional do Supremo Tribunal Federal, na vigência da Constituição de 1988 da República Federativa do Brasil. 2003. p. 122.

Dissertação (Mestrado) - Faculdade de Educação, Universidade de São Paulo, São Paulo, 2003.

MACHADO JÚNIOR, César Pereira da Silva. O direito à educação na realidade brasileira. São Paulo: LTr, 2003.

MACIEL, Débora Alves; KOERNER, Andrei. Sentidos da judicialização da política: duas análises. Lua Nova. São Paulo, n. 57, 2002.

MARQUES, Silvia Badim; DALLARI, Sueli Gandolfi. Garantia do direito social à assistência farmacêutica no Estado de São Paulo. Rev. Saúde Pública [online]. 2007, vol.41, n.1, p. 101107.

MARSHALL, Thomas Humphrey. Cidadania, Classe Social e Status. Rio de Janeiro: Zahar, 1967.

MARTINES JÚNIOR, Eduardo. Educação, Cidadania e Ministério Público: o artigo 205 da Constituição e sua abrangência. 2006. 446f. Tese (Doutorado em Direito) - Pontifícia Universidade Católica de São Paulo, São Paulo, 2006.

MIZUKI, Vitor; SILVEIRA, Adriana A. Dragone. Parcerias entre os municípios paulistas e a esfera privada para a oferta de vagas na educação infantil? Influência da atuação do Ministério Público local? In: XXIV Simpósio Brasileiro III Congresso Interamericano de 
Política e Administração da Educação, 2009, Vitória, Espírito Santo. Anais ..., Porto Alegre: Anpae , Espírito Santo: UFES/PPGR, 2009. CD-ROM.

MONTESQUIEU, Charles Louis de Secondat. O espírito das leis. Brasília: Editora Universidade de Brasília, 1982.

MORRIS, Arval. Constitution and American Public Education. 2.ed. Durham: Carolina Academic Press, 1999.

NOGARA, Mônica de Azevedo Costa. Conflitos socioambientais na justiça: da formulação das normas à ação do poder judiciário no conflito entre os direitos à moradia e ao meio ambiente em assentamentos irregulares, um estudo de jurisprudência do Tribunal de Justiça de São Paulo (1985 a 2006). 2008. 200 p. Dissertação (Mestrado em Arquitetura e Urbanismo) Universidade de São Paulo, São Paulo, 2008.

OBSERVATÓRIO DA EQUIDADE. As desigualdades na escolarização no Brasil. 2008. Disponível em: <http://www.ibge.gov.br/observatoriodaequidade/relatorio2.htm>. Acesso em 12 fev. 2010.

OLIVEIRA, João Gualberto de. 100 anos do Tribunal de Justiça de São Paulo. São Paulo: [s. n.], 1975.

OLIVEIRA, Romualdo Luiz Portela de. Educação e Cidadania: o Direito à educação na Constituição de 1.988 da República Federativa do Brasil. 1995. 179 p. Tese (Doutorado) Faculdade de Educação, Universidade de São Paulo, São Paulo, 1995.

. O direito à educação. In: OLIVEIRA, Romualdo Portela de; ADRIÃO, Theresa (Org.). Gestão, financiamento e direito à educação: análise da LDB e da Constituição Federal. $3^{\mathrm{a}}$ ed. São Paulo: Xamã, 2007.

Qualidade com garantia de respeito às diversidades e necessidades de aprendizagem. In: GRACIANO, Mariângela (Coord.). O Plano de Desenvolvimento da Educação (PDE). São Paulo: Ação Educativa, 2007.

. A qualidade do ensino como parte do direito à educação: um debate em torno dos indicadores. Prova de concurso de professor titular Usp. São Paulo: Feusp, 2010. No prelo.

; ARAUJO Gilda Cardoso de. Qualidade do ensino: uma nova dimensão da luta pelo direito à educação. Revista Brasileira de Educação, no 28, p. 05-23, jan./fev./mar. 2005. 
OLIVEIRA, Vanessa Elias de. O poder judiciário brasileiro após a Constituição de 1988: existe uma judicialização da política? Uma análise do processo de privatizações. 2002. Dissertação (Mestrado). Faculdade de Filosofia, Letras e Ciências Humanas, Universidade de São Paulo, São Paulo, 2002.

PACHECO, Cristina Carvalho. O Supremo Tribunal Federal e a Reforma do Estado: uma análise das Ações Diretas de Inconstitucionalidade julgadas no primeiro mandato de Fernando Henrique Cardoso (1995-1998). 2006. Tese (Doutorado). Programa de pós-graduação em Ciências Sociais, Universidade Estadual de Campinas, Campinas, São Paulo, 2006.

PACTO INTERNACIONAL DOS DIREITOS ECONÔMICOS, SOCIAIS E CULTURAIS 1966. In: PIOVESAN, Flávia (Coord.) Código de direito internacional dos direitos humanos anotado. São Paulo: DPJ Editora, 2008.

PANNUNZIO, Eduardo. O Poder Judiciário e o Direito à Educação. In: RANIERI, Nina Beatriz Stocco (Coord.); RIGHETTI, Sabine. Direito à educação: aspectos constitucionais. São Paulo: Editora da Universidade de São Paulo, 2009.

PIOVESAN, Flávia. Justiciabilidade dos direitos sociais e econômicos: desafios e perspectivas. In: SILVA, Roberto B. Dias da (Coord.). Direito Constitucional. Temas atuais. Homenagem à Professora Leda Pereira da Mota. São Paulo: Método, 2007.

(Coord.) Código de direito internacional dos direitos humanos anotado. São Paulo: DPJ Editora, 2008a.

Direitos humanos e o Direito Constitucional Internacional. 9 ed. rev., ampl. e atual. São Paulo: Saraiva, 2008b.

RANIERI, Nina Beatriz Stocco. Os Estados e o direito à educação na Constituição de 1988: comentários acerca da jurisprudência do Supremo Tribunal Federal. In: RANIERI, Nina Beatriz Stocco (Coord.); RIGHETTI, Sabine. Direito à educação: aspectos constitucionais. São Paulo: Editora da Universidade de São Paulo, 2009.

RIGHETTI, Carmem Silvia. Poder Judiciário e Políticas Públicas: um estudo sobre as demandas sociais na área da Infância e da Juventude. Dissertação (Mestrado). Programa de mestrado em Serviço Social e Política Social, Universidade Estadual de Londrina, Londrina, Paraná, 2006. 
RIOS-FIGUEROA, Julio; TAYLOR, Matthew M. Institucional Determinats of the Judicialisation of policy in Brazil and México. Journal of Latin American Studies. Cambridge University Press, United Kingdom, 38, 2006, p. 739-766.

RODRIGUES, Irene. $O$ direito à escolarização da criança e do adolescente. 2005. 243f. Tese (Doutorado em Direito) - Faculdade de Direito, Universidade de São Paulo, São Paulo, 2005.

SADEK, Maria Tereza. Judiciário: mudanças e reformas. Revista Estudos Avançados. Vol. 18, número 51, ago./maio 2004. p 79-101.

SÃO PAULO (Estado). Constituição do Estado de São Paulo. Imprensa Oficial do Estado, 1989.

. Decreto 41.60, de 13 de maio de 2005. Institui e disciplina o Sistema de Pontuação Acrescida, para afro-descendentes e egressos do ensino público (fundamental e médio), nos exames seletivos para ingresso nas Escolas Técnicas Estaduais - ETEs e nas Faculdades de Tecnologia - FATECs, pertencentes ao Centro Estadual de Educação Tecnológica "Paula Souza" - CEETEPS e dá providências correlatas. Disponível em: < http://www.fatecsorocaba.edu.br/vestibular/legislacao/decreto49602.asp>. Acesso em: 23 out. 2010.

. Regimento Interno do Tribunal de Justiça de São Paulo. 1992. Disponível em: <http://www.tj.sp.gov.br/ConhecaTJSP/RegimentoInterno.aspx>. Acesso em: 05 maio 2008.

SECRETARIA DA EDUCAÇÃO ESTADUAL. Resolução nº 279, de 28 de dezembro de 1988. Disponível em: <http://cei.edunet.sp.gov.br/subpages/pedagogicos/educefam.htm>. Acesso em: 10 out. 09.

. SECRETARIA DA EDUCAÇÃO ESTADUAL. Resolução $n^{\circ}$ 169, de 20 de novembro de 1996. Disponível em:<http://lise.edunet.sp.gov.br/paglei/resolucoes/169_96.htm>. Acesso em: 15 set. 09.

SECRETARIA DA EDUCAÇÃO ESTADUAL. Resolução $n^{\circ} 164$, de 25 de novembro de 1997. Disponível em: < http://lise.edunet.sp.gov.br/paglei/resolucoes/164_1997.htm>. Acesso em: 15 set. 09.

. MINISTÉRIO PÚBLICO. Infância e juventude: interpretação jurisprudencial. Centro de Apoio Operacional das Promotorias de Justiça da Infância e Juventude. São Paulo: Imprensa Oficial do Estado: Ministério Público, 2002. 
SARLET, Ingo Wolfgang; FIGUEIREDO, Mariana Filchtiner. Reserva do possível, mínimo existencial e direito à saúde: algumas aproximações. In: SARLET, Ingo Wolfgang; TIMM, Luciano Benetti. (Org.). Direitos Fundamentais: orçamento e "reserva do possível". Porto Alegre: Livraria do Advogado, 2008.

SCAFF, Sentenças aditivas, direitos sociais e reserva do possível. In: SARLET, Ingo Wolfgang; TIMM, Luciano Benetti. (Org.). Direitos Fundamentais: orçamento e "reserva do possível”. Porto Alegre: Livraria do Advogado, 2008.

SCHEFFER, Mario Cesar. Os planos de saúde nos tribunais: uma análise das ações judiciais movidas por clientes de planos de saúde, relacionadas à negação de coberturas assistenciais no Estado de São Paulo. 2006. 156 p. Dissertação (Mestrado em Medicina Preventiva) Universidade de São Paulo, São Paulo, 2006.

SCHMEIDER, Marília Helena Paulos Leal. A magistratura paulista de 1889 a 1930: histórias e representações. O Tribunal de Justiça de São Paulo na Primeira República. 2001. 259 p. Tese (Doutorado em História) - Universidade de São Paulo, São Paulo, 2001.

SILVA, Cátia Aida. Participação e políticas públicas: os conselhos tutelares da criança em São Paulo. São Paulo: Humanitas/ FFLCH/USP: Fapesp, 2003.

SILVA, José Afonso da. Curso de Direito Constitucional Positivo. 19 ed. São Paulo: Malheiros Editores, 2001. 2007. Aplicabilidade das Normas Constitucionais. 7 ed. São Paulo: Malheiros Editores,

SILVEIRA, Adriana A. Dragone. Direito à educação e o Ministério Público: uma análise da atuação de duas Promotorias de Justiça da Infância e Juventude do interior paulista. 2006. 262p. Dissertação (Mestrado) - Faculdade de Educação, Universidade de São Paulo, São Paulo, 2006.

A exigibilidade do direito à educação básica pelo Sistema de Justiça: uma análise da produção brasileira do conhecimento. Revista Brasileira de Política e Administração da Educação. Associação Nacional de Política e Administração da Educação. Porto Alegre: Anpae, v.24, n.3, p. 537-555, set./dez. 2008.

Exigibilidade do direito à educação infantil: uma análise da jurisprudência. In: XXIV Simpósio Brasileiro III Congresso Interamericano de Política e Administração da Educação, 2009, Vitória, Espírito Santo. Anais ..., Porto Alegre: Anpae , Espírito Santo: UFES/PPGR, 2009a. CD-ROM. 
. Algumas considerações sobre as normas do processo de licitação pública, contratos e convênios no estabelecimento de parcerias educacionais entre a administração pública e a esfera privada. In: Educação: Teoria e Prática, v. 19, n. 32, 2009 b.

SOUSA SANTOS, Boaventura et al. Os tribunais nas sociedades contemporâneas: o caso português. Porto: Edições Afrontamento, 1996.

SOUSA SANTOS, Boaventura. Para uma revolução democrática da justiça. São Paulo: Cortez, 2007.

TATE, Neal; VALLINDER; Torbjorn (Ed.). The Global Expansion of Judicial Power. New York: New York University Press, 1995.

TAVARES, Divan Alves. Efetividade do direito ao ensino fundamental: uma questão de justiça. 2006. 200f. Dissertação (Mestrado em Direito) - Pontifícia Universidade Católica de Minas Gerais, Belo Horizonte, 2006.

TAYLOR, Matthew M. Veto and Voice in the Courts: Policy Implications of Institucional Design in the Brazilian Judiciary. Comparative Politics. Abril 2006. p. 337-35.

. O Judiciário e as políticas públicas no Brasil. Dados. Revista de Ciências Sociais, Rio de Janeiro, v. 50, n. 2, 2007, p. 229-257.

TOMASEVSKI, Katarina. Human rights obligations: making education available, accessible, acceptable and adaptable. Right to education primers n 3. Novum Grafiska AB: Gothenburg, 2001.

TORRES, Ricardo Lobo. A legitimação dos direitos humanos e os princípios da ponderação e da razoabilidade. In: TORRES, Ricardo Lobo (Org.). Legitimação dos direitos humanos. 2 ed. revista e ampliada. Rio de Janeiro: Renovar, 2007.

. O mínimo existencial, os direitos sociais e os desafios de natureza orçamentária. In: SARLET, Ingo Wolfgang; TIMM, Luciano Benetti. (Org.). Direitos Fundamentais: orçamento e "reserva do possível". Porto Alegre: Livraria do Advogado, 2008.

VIANNA, Luiz Werneck. et al. A judicialização da política e das relações sociais no Brasil. Rio de Janeiro: Editora Revan, 1999. 
ZANITELLI, Leandro Martins. Custos ou competências? Uma ressalva à doutrina da reserva do possível. In: SARLET, Ingo Wolfgang; TIMM, Luciano Benetti. (Org.). Direitos Fundamentais: orçamento e "reserva do possível". Porto Alegre: Livraria do Advogado, 2008. 


\section{APÊNDICE - Organização das decisões proferidas pelo TJ-SP sobre direito à educação (1991-2008)}

\begin{tabular}{|c|c|c|c|c|c|c|c|c|c|c|c|c|}
\hline $\begin{array}{l}\text { Número } \\
\text { decisão }\end{array}$ & Natureza & Ano & Categorias & Tema & Origem & $\begin{array}{l}\text { Apelante } \\
\text { recorrente }\end{array}$ & $\begin{array}{l}\text { Apelados } \\
\text { recorridos }\end{array}$ & Câmara & Votação & Resultado & Relator & $\begin{array}{l}\text { Localização } \\
\text { da ementa / } \\
\text { acórdão }\end{array}$ \\
\hline \multicolumn{13}{|l|}{1991} \\
\hline $12.240-0$ & ADIN & 1991 & $\begin{array}{l}\text { Decisões } \\
\text { administrati- } \\
\text { vas e políti- } \\
\text { cas }\end{array}$ & $\begin{array}{l}\text { Competência } \\
\text { para legislar }\end{array}$ & Tatuí & $\begin{array}{l}\text { Procurador- } \\
\text { Geral de Jus- } \\
\text { tiça }\end{array}$ & $\begin{array}{l}\text { Câmara Mu- } \\
\text { nicipal de } \\
\text { Tatuí }\end{array}$ & $\begin{array}{l}\text { Sessão Ple- } \\
\text { nária do TJ }\end{array}$ & Unânime & $\begin{array}{l}\text { Procedente a } \\
\text { ação }\end{array}$ & $\begin{array}{l}\text { Ney } \\
\text { Almada }\end{array}$ & $\begin{array}{l}\text { RJTJESP, } \\
\text { v.132, p. } 443\end{array}$ \\
\hline $139.890-1$ & $\begin{array}{l}\text { Apelação } \\
\text { Cível }\end{array}$ & 1991 & $\begin{array}{l}\text { Poder de } \\
\text { regulação } \\
\text { estatal }\end{array}$ & $\begin{array}{l}\text { Mensalidade } \\
\text { escolar }\end{array}$ & Campinas & W. C. B. & $\begin{array}{l}\text { Sociedade } \\
\text { Campineira } \\
\text { de Educação } \\
\text { e Instrução }\end{array}$ & $\begin{array}{l}\text { Segunda } \\
\text { Câmara } \\
\text { Civil }\end{array}$ & Unânime & Provido & $\begin{array}{l}\text { Urbano } \\
\text { Ruiz }\end{array}$ & $\begin{array}{l}\text { RJTJESP, } \\
\text { v.134, p. } 58\end{array}$ \\
\hline $146.726-2$ & $\begin{array}{l}\text { Dúvida de } \\
\text { Competência } \\
\text { na Apelação } \\
\text { Cível }\end{array}$ & 1991 & $\begin{array}{l}\text { Poder de } \\
\text { regulação } \\
\text { estatal }\end{array}$ & $\begin{array}{l}\text { Mensalidade } \\
\text { escolar }\end{array}$ & Campinas & $\begin{array}{l}\text { Segunda Seção } \\
\text { Civil do TJ }\end{array}$ & $\begin{array}{l}\text { Primeira } \\
\text { Seção Civil } \\
\text { do Tribunal } \\
\text { de Justiça }\end{array}$ & $\begin{array}{l}\text { Sessão Ple- } \\
\text { nária do TJ }\end{array}$ & $\begin{array}{l}\text { Maioria dos } \\
\text { votos }\end{array}$ & $\begin{array}{l}\text { Julgam pro- } \\
\text { cedente a } \\
\text { dúvida e dão } \\
\text { competência } \\
\text { à Primeira } \\
\text { Seção. }\end{array}$ & $\begin{array}{l}\text { Hermes } \\
\text { Pinotti }\end{array}$ & $\begin{array}{l}\text { RJTJESP } \\
\text { v.132, p. } 443\end{array}$ \\
\hline $152.230-1$ & $\begin{array}{l}\text { Apelação } \\
\text { Cível }\end{array}$ & 1991 & $\begin{array}{l}\text { Poder de } \\
\text { regulação } \\
\text { estatal }\end{array}$ & $\begin{array}{l}\text { Mensalidade } \\
\text { escolar }\end{array}$ & Batatais & $\begin{array}{l}\text { Ministério } \\
\text { Público }\end{array}$ & $\begin{array}{l}\text { Sociedade } \\
\text { Civil Colégio } \\
\text { São José }\end{array}$ & $\begin{array}{l}\text { Quarta Câ- } \\
\text { mara Civil }\end{array}$ & $\begin{array}{l}\text { Maioria dos } \\
\text { votos }\end{array}$ & $\begin{array}{l}\text { Negam pro- } \\
\text { vimento ao } \\
\text { recurso. }\end{array}$ & $\begin{array}{l}\text { Ney } \\
\text { Almada }\end{array}$ & $\begin{array}{l}\text { RJTJESP } \\
\text { v.136, p. } 38\end{array}$ \\
\hline $160.526-1$ & $\begin{array}{l}\text { Apelação } \\
\text { Cível }\end{array}$ & 1991 & $\begin{array}{l}\text { Poder de } \\
\text { regulação } \\
\text { estatal }\end{array}$ & $\begin{array}{l}\text { Mensalidade } \\
\text { escolar }\end{array}$ & São Paulo & $\begin{array}{l}\text { Informação } \\
\text { ausente }\end{array}$ & $\begin{array}{l}\text { Informação } \\
\text { ausente }\end{array}$ & $\begin{array}{l}\text { Informação } \\
\text { ausente }\end{array}$ & $\begin{array}{l}\text { Informação } \\
\text { ausente }\end{array}$ & $\begin{array}{l}\text { Recurso não } \\
\text { provido }\end{array}$ & $\begin{array}{l}\text { José } \\
\text { Malerbi }\end{array}$ & $\begin{array}{l}\text { Sítio eletrônico } \\
\text { biblioteca TJ- } \\
\text { SP }\end{array}$ \\
\hline \multicolumn{13}{|l|}{1992} \\
\hline $150.276-1$ & $\begin{array}{l}\text { Apelação } \\
\text { Cível }\end{array}$ & 1992 & $\begin{array}{l}\text { Poder de } \\
\text { regulação } \\
\text { estatal }\end{array}$ & $\begin{array}{l}\text { Mensalidade } \\
\text { escolar }\end{array}$ & São Paulo & $\begin{array}{l}\text { Grupo de } \\
\text { Ensino e Tec- } \\
\text { nologia Edu- } \\
\text { cacional S.C. } \\
\text { Ltda. e outro }\end{array}$ & R. I. e outros & $\begin{array}{l}\text { Segunda } \\
\text { Câmara } \\
\text { Civil }\end{array}$ & Unânime & $\begin{array}{l}\text { Extinto o } \\
\text { processo sem } \\
\text { julgamento } \\
\text { de mérito. }\end{array}$ & $\begin{array}{l}\text { Costa de } \\
\text { Oliveira }\end{array}$ & $\begin{array}{l}\text { RJTJESP } \\
\text { v. 136, p. } 213\end{array}$ \\
\hline
\end{tabular}




\begin{tabular}{|c|c|c|c|c|c|c|c|c|c|c|c|c|}
\hline $\begin{array}{l}\text { Número } \\
\text { decisão }\end{array}$ & Natureza & Ano & Categorias & Tema & Origem & $\begin{array}{l}\text { Apelante } \\
\text { recorrente }\end{array}$ & $\begin{array}{l}\text { Apelados } \\
\text { recorridos }\end{array}$ & Câmara & Votação & Resultado & Relator & $\begin{array}{l}\text { Localização } \\
\text { da ementa / } \\
\text { acórdão }\end{array}$ \\
\hline $157.970-1$ & $\begin{array}{l}\text { Apelação } \\
\text { Cível }\end{array}$ & 1992 & $\begin{array}{l}\text { Poder de } \\
\text { regulação } \\
\text { estatal }\end{array}$ & $\begin{array}{l}\text { Mensalidade } \\
\text { escolar }\end{array}$ & Campinas & $\begin{array}{l}\text { Criança ou } \\
\text { adolescente } \\
\text { representado } \\
\text { por seu pai. }\end{array}$ & SABER & $\begin{array}{l}\text { Segunda } \\
\text { Câmara } \\
\text { Civil }\end{array}$ & Unânime & $\begin{array}{l}\text { Recurso } \\
\text { provido }\end{array}$ & $\begin{array}{l}\text { Cezar } \\
\text { Peluso }\end{array}$ & $\begin{array}{l}\text { RJTJESP, } \\
\text { v.136, p.119 }\end{array}$ \\
\hline $158.394-1$ & $\begin{array}{l}\text { Apelação } \\
\text { Cível }\end{array}$ & 1992 & $\begin{array}{l}\text { Poder de } \\
\text { regulação } \\
\text { estatal }\end{array}$ & $\begin{array}{l}\text { Mensalidade } \\
\text { escolar }\end{array}$ & Itapetininga & $\begin{array}{l}\text { Sistema Edu- } \\
\text { cacional } \\
\text { Quintal }\end{array}$ & $\begin{array}{l}\text { A.C.T.de C. } \\
\text { L. e outros } \\
\text { menores } \\
\text { representados } \\
\text { pelos pais. }\end{array}$ & $\begin{array}{l}\text { Segunda } \\
\text { Câmara } \\
\text { Civil }\end{array}$ & $\begin{array}{l}\text { Maioria dos } \\
\text { votos }\end{array}$ & $\begin{array}{l}\text { Recurso não } \\
\text { provido }\end{array}$ & $\begin{array}{l}\text { Costa de } \\
\text { Oliveira }\end{array}$ & $\begin{array}{l}\text { RJTJESP v. } \\
136 \text {, p.79 }\end{array}$ \\
\hline $161.435-1$ & $\begin{array}{l}\text { Apelação } \\
\text { Cível }\end{array}$ & 1992 & $\begin{array}{l}\text { Poder de } \\
\text { regulação } \\
\text { estatal }\end{array}$ & $\begin{array}{l}\text { Mensalidade } \\
\text { escolar }\end{array}$ & Santos & Liceu Santista & $\begin{array}{l}\text { Ministério } \\
\text { Público }\end{array}$ & $\begin{array}{l}\text { Quinta Câ- } \\
\text { mara Civil }\end{array}$ & Unânime & $\begin{array}{l}\text { Recurso não } \\
\text { provido }\end{array}$ & $\begin{array}{l}\text { Matheus } \\
\text { Fontes }\end{array}$ & $\begin{array}{l}\text { RJTJESP, } \\
\text { p. v. 136, } \\
\text { p. } 215\end{array}$ \\
\hline $161.532-1$ & $\begin{array}{l}\text { Apelação } \\
\text { Cível }\end{array}$ & 1992 & $\begin{array}{l}\text { Poder de } \\
\text { regulação } \\
\text { estatal }\end{array}$ & $\begin{array}{l}\text { Mensalidade } \\
\text { escolar }\end{array}$ & Ituverava & $\begin{array}{l}\text { Informação } \\
\text { ausente }\end{array}$ & $\begin{array}{l}\text { Informação } \\
\text { ausente }\end{array}$ & $\begin{array}{l}\text { Informação } \\
\text { ausente }\end{array}$ & $\begin{array}{l}\text { Informação } \\
\text { ausente }\end{array}$ & $\begin{array}{l}\text { Recurso } \\
\text { provido }\end{array}$ & $\begin{array}{l}\text { Marcus } \\
\text { Andrade }\end{array}$ & $\begin{array}{l}\text { Sítio eletrônico } \\
\text { biblioteca TJ- } \\
\text { SP }\end{array}$ \\
\hline 163.940-1 & $\begin{array}{l}\text { Apelação } \\
\text { Cível }\end{array}$ & 1992 & $\begin{array}{l}\text { Poder de } \\
\text { regulação } \\
\text { estatal }\end{array}$ & $\begin{array}{l}\text { Mensalidade } \\
\text { escolar }\end{array}$ & Santos & $\begin{array}{l}\text { Fuschini\&Cia } \\
\text { Ltda. Mante- } \\
\text { nedora }\end{array}$ & $\begin{array}{l}\text { Crianças ou } \\
\text { adolescentes }\end{array}$ & $\begin{array}{l}\text { Sétima } \\
\text { Câmara } \\
\text { Civil } \\
\end{array}$ & Unânime & $\begin{array}{l}\text { Negm pro- } \\
\text { vimento ao } \\
\text { recurso. }\end{array}$ & $\begin{array}{l}\text { Campos } \\
\text { Mello }\end{array}$ & $\begin{array}{l}\text { RJTJESP, } \\
\text { v.136, p.76 }\end{array}$ \\
\hline $164.518-1$ & $\begin{array}{l}\text { Apelação } \\
\text { Cível }\end{array}$ & 1992 & Permanência & Outros & Campinas & $\begin{array}{l}\text { Juízo Ex Offi- } \\
\text { cio / } \\
\text { Unicamp/Co- } \\
\text { légio Técnico }\end{array}$ & $\begin{array}{l}\text { Criança ou } \\
\text { adolescente }\end{array}$ & $\begin{array}{l}\text { Primeira } \\
\text { Câmara } \\
\text { Civil }\end{array}$ & Unânime & $\begin{array}{l}\text { Negam pro- } \\
\text { vimento ao } \\
\text { recurso. } \\
\text { Segurança } \\
\text { concedida } \\
\text { em } 1^{\mathrm{a}} \text { instân- } \\
\text { cia e } \\
\text { sentença } \\
\text { confirmada } \\
\text { pelo TJ. }\end{array}$ & $\begin{array}{l}\text { Euclides de } \\
\text { Oliveira }\end{array}$ & $\begin{array}{l}\text { RJTJESP, v. } \\
139, \text { p. } 90\end{array}$ \\
\hline $165.203-1$ & $\begin{array}{l}\text { Apelação } \\
\text { Cível }\end{array}$ & 1992 & Permanência & Outros & $\begin{array}{l}\text { Pindamo- } \\
\text { nhangaba }\end{array}$ & Juiz Ex Offício & $\begin{array}{l}\text { Mãe da me- } \\
\text { nor e diretor } \\
\text { do colégio }\end{array}$ & $\begin{array}{l}\text { Quinta Câ- } \\
\text { mara Civil }\end{array}$ & Unânime & $\begin{array}{l}\text { Mandado de } \\
\text { segurança } \\
\text { concedido } \\
\text { em 1a instân- } \\
\text { cia e recurso } \\
\text { negado. }\end{array}$ & $\begin{array}{l}\text { Matheus } \\
\text { Fontes }\end{array}$ & $\begin{array}{l}\text { RJTJESP, } \\
\text { v.138, p.109 }\end{array}$ \\
\hline $166.899-1$ & $\begin{array}{l}\text { Apelação } \\
\text { Cível }\end{array}$ & 1992 & $\begin{array}{l}\text { Poder de } \\
\text { regulação } \\
\text { estatal }\end{array}$ & $\begin{array}{l}\text { Mensalidade } \\
\text { escolar }\end{array}$ & Campinas & $\begin{array}{l}\text { Escola de EI e } \\
\text { de Primeiro } \\
\text { Grau Dom } \\
\text { Barreto }\end{array}$ & $\begin{array}{l}\text { Crianças ou } \\
\text { adolescentes }\end{array}$ & $\begin{array}{l}\text { Oitava Câ- } \\
\text { mara Civil }\end{array}$ & Unânime & $\begin{array}{l}\text { Recurso } \\
\text { provido }\end{array}$ & $\begin{array}{l}\text { Antônio } \\
\text { Marson }\end{array}$ & $\begin{array}{l}\text { RJTJESP } \\
\text { v.139, p. } 141\end{array}$ \\
\hline
\end{tabular}




\begin{tabular}{|c|c|c|c|c|c|c|c|c|c|c|c|c|}
\hline $\begin{array}{l}\text { Número } \\
\text { decisão }\end{array}$ & Natureza & Ano & Categorias & Tema & Origem & $\begin{array}{l}\text { Apelante } \\
\text { recorrente }\end{array}$ & $\begin{array}{l}\text { Apelados } \\
\text { recorridos }\end{array}$ & Câmara & Votação & Resultado & Relator & $\begin{array}{l}\text { Localização } \\
\text { da ementa / } \\
\text { acórdão }\end{array}$ \\
\hline $171.571-1$ & $\begin{array}{l}\text { Apelação } \\
\text { Cível }\end{array}$ & 1992 & $\begin{array}{l}\text { Poder de } \\
\text { regulação } \\
\text { estatal }\end{array}$ & $\begin{array}{l}\text { Mensalidade } \\
\text { escolar }\end{array}$ & $\begin{array}{l}\text { S. José dos } \\
\text { Campos }\end{array}$ & $\begin{array}{l}\text { Fundação } \\
\text { Valeparaibana } \\
\text { de Ensino }\end{array}$ & $\begin{array}{l}\text { Criança ou } \\
\text { adolescente }\end{array}$ & $\begin{array}{l}\text { Quarta Câ- } \\
\text { mara de } \\
\text { Férias }\end{array}$ & Unânime & $\begin{array}{l}\text { Recurso } \\
\text { provido à } \\
\text { Fundação. }\end{array}$ & $\begin{array}{l}\text { Cunha de } \\
\text { Abreu }\end{array}$ & $\begin{array}{l}\text { RJTJESP } \\
\text { v. } 137, \text { p. } 85\end{array}$ \\
\hline $176.274-1$ & $\begin{array}{l}\text { Apelação } \\
\text { Cível }\end{array}$ & 1992 & $\begin{array}{l}\text { Poder de } \\
\text { regulação } \\
\text { estatal }\end{array}$ & $\begin{array}{l}\text { Mensalidade } \\
\text { escolar }\end{array}$ & $\begin{array}{l}\text { São Ber- } \\
\text { nardo do } \\
\text { Campo }\end{array}$ & $\begin{array}{l}\text { Informação } \\
\text { ausente }\end{array}$ & $\begin{array}{l}\text { Informação } \\
\text { ausente }\end{array}$ & $\begin{array}{l}\text { Informação } \\
\text { ausente }\end{array}$ & $\begin{array}{l}\text { Informação } \\
\text { ausente }\end{array}$ & $\begin{array}{l}\text { Recurso } \\
\text { parcialmente } \\
\text { provido }\end{array}$ & Reis Kuntz & $\begin{array}{l}\text { Sítio eletrônico } \\
\text { biblioteca TJ- } \\
\text { SP }\end{array}$ \\
\hline $179.842-1$ & $\begin{array}{l}\text { Apelação } \\
\text { Cível }\end{array}$ & 1992 & $\begin{array}{l}\text { Poder de } \\
\text { regulação } \\
\text { estatal }\end{array}$ & $\begin{array}{l}\text { Mensalidade } \\
\text { escolar }\end{array}$ & São Paulo & $\begin{array}{l}\text { Sociedade } \\
\text { Civil Padre } \\
\text { Faure }\end{array}$ & E. G. R. & $\begin{array}{l}\text { Terceira } \\
\text { Câmara } \\
\text { Civil }\end{array}$ & $\begin{array}{l}\text { Maioria dos } \\
\text { votos. Consta } \\
\text { de voto ven- } \\
\text { cedor e de } \\
\text { Desembarga- } \\
\text { dor vencido, } \\
\text { com declara- } \\
\text { ção de voto } \\
\text { em separado. }\end{array}$ & $\begin{array}{l}\text { Recurso } \\
\text { provido }\end{array}$ & $\begin{array}{l}\text { Alfredo } \\
\text { Migliore }\end{array}$ & $\begin{array}{l}\text { Sítio eletrônico } \\
\text { biblioteca TJ- } \\
\text { SP,/JTJ } \\
\text { v. } 143, \text { p.60 }\end{array}$ \\
\hline \multicolumn{13}{|l|}{1993} \\
\hline 187.5521 & $\begin{array}{l}\text { Apelação } \\
\text { Cível }\end{array}$ & 1993 & $\begin{array}{l}\text { Decisões } \\
\text { administrati- } \\
\text { vas e políti- } \\
\text { cas }\end{array}$ & \begin{tabular}{|l|} 
Competência \\
para legislar
\end{tabular} & São Paulo & Apeoesp & $\begin{array}{l}\text { Informação } \\
\text { ausente }\end{array}$ & $\begin{array}{l}\text { Informação } \\
\text { ausente }\end{array}$ & $\begin{array}{l}\text { Informação } \\
\text { ausente }\end{array}$ & $\begin{array}{l}\text { Recurso não } \\
\text { provido }\end{array}$ & $\begin{array}{l}\text { Benini } \\
\text { Cabral }\end{array}$ & $\begin{array}{l}\text { Sítio eletrônico } \\
\text { biblioteca TJ- } \\
\text { SP }\end{array}$ \\
\hline 191.160-1 & $\begin{array}{l}\text { Agravo de } \\
\text { Instrumento }\end{array}$ & 1993 & $\begin{array}{l}\text { Poder de } \\
\text { regulação } \\
\text { estatal }\end{array}$ & $\begin{array}{l}\text { Mensalidade } \\
\text { escolar }\end{array}$ & $\begin{array}{l}\text { S. José do } \\
\text { Rio Preto }\end{array}$ & $\begin{array}{l}\text { Sociedade } \\
\text { Riopretense de } \\
\text { Ensino e Edu- } \\
\text { cação Ltda. }\end{array}$ & $\begin{array}{l}\text { Ministério } \\
\text { Público }\end{array}$ & $\begin{array}{l}\text { Sétima } \\
\text { Câmara } \\
\text { Civil }\end{array}$ & Unânime & $\begin{array}{l}\text { Recurso não } \\
\text { provido }\end{array}$ & $\begin{array}{l}\text { Benini } \\
\text { Cabral }\end{array}$ & $\begin{array}{l}\text { Sítio eletrônico } \\
\text { biblioteca TJ- } \\
\text { SP, JTJ } \\
\text { v.147, p. } 210\end{array}$ \\
\hline $191.777-1$ & $\begin{array}{l}\text { Apelação } \\
\text { Cível }\end{array}$ & 1993 & $\begin{array}{l}\text { Poder de } \\
\text { regulação } \\
\text { estatal }\end{array}$ & $\begin{array}{l}\text { Mensalidade } \\
\text { escolar }\end{array}$ & Piracicaba & $\begin{array}{l}\text { Ministério } \\
\text { Público }\end{array}$ & $\begin{array}{l}\text { Anglo Colé- } \\
\text { gio da Cidade } \\
\text { de Piracicaba }\end{array}$ & $\begin{array}{l}\text { Sexta Câ- } \\
\text { mara Civil }\end{array}$ & Unânime & \begin{tabular}{|l|} 
Recurso \\
provido
\end{tabular} & Reis Kuntz & $\begin{array}{l}\text { JTJSP } \\
\text { v.149, p.34 }\end{array}$ \\
\hline
\end{tabular}




\begin{tabular}{|c|c|c|c|c|c|c|c|c|c|c|c|c|}
\hline $\begin{array}{l}\text { Número } \\
\text { decisão }\end{array}$ & Natureza & Ano & Categorias & Tema & Origem & $\begin{array}{l}\text { Apelante } \\
\text { recorrente }\end{array}$ & $\begin{array}{l}\text { Apelados } \\
\text { recorridos }\end{array}$ & Câmara & Votação & Resultado & Relator & $\begin{array}{l}\text { Localização } \\
\text { da ementa / } \\
\text { acórdão }\end{array}$ \\
\hline $192.248-1$ & $\begin{array}{l}\text { Apelação } \\
\text { Cível }\end{array}$ & 1993 & $\begin{array}{l}\text { Poder de } \\
\text { regulação } \\
\text { estatal }\end{array}$ & $\begin{array}{l}\text { Mensalidade } \\
\text { escolar }\end{array}$ & Ituverava & $\begin{array}{l}\text { Ministério } \\
\text { Público }\end{array}$ & $\begin{array}{l}\text { Fundação } \\
\text { Educacional }\end{array}$ & $\begin{array}{l}\text { Quinta Câ- } \\
\text { mara Civil }\end{array}$ & Unânime & $\begin{array}{l}\text { Recurso } \\
\text { provido em } \\
\text { parte }\end{array}$ & $\begin{array}{l}\text { Jorge } \\
\text { Tannus / } \\
\text { Declaração } \\
\text { de voto } \\
\text { vencedor do } \\
\text { desembar- } \\
\text { gador Sil- } \\
\text { veira Netto }\end{array}$ & $\begin{array}{l}\text { JTJ } \\
\text { v.151, p.20 }\end{array}$ \\
\hline $200.503-1$ & $\begin{array}{l}\text { Apelação } \\
\text { Cível }\end{array}$ & 1993 & $\begin{array}{l}\text { Poder de } \\
\text { regulação } \\
\text { estatal }\end{array}$ & $\begin{array}{l}\text { Mensalidade } \\
\text { Escolar }\end{array}$ & Botucatu & $\begin{array}{l}\text { Criança ou } \\
\text { adolescente. }\end{array}$ & $\begin{array}{l}\text { Diretor do } \\
\text { Colégio Ar- } \\
\text { quidiocesano } \\
\text { e outros }\end{array}$ & $\begin{array}{l}\text { Oitava Câ- } \\
\text { mara Civil }\end{array}$ & Unânime & $\begin{array}{l}\text { Recurso não } \\
\text { provido }\end{array}$ & $\begin{array}{l}\text { Antônio } \\
\text { Marson }\end{array}$ & $\begin{array}{l}\text { JTJ } \\
\text { v.153, p.42 }\end{array}$ \\
\hline \multicolumn{13}{|l|}{1994} \\
\hline $16.833-0$ & ADIN & 1994 & $\begin{array}{l}\text { Decisões } \\
\text { administrati- } \\
\text { vas e políti- } \\
\text { cas } \\
\end{array}$ & $\begin{array}{l}\text { Competência } \\
\text { para legislar }\end{array}$ & Araçatuba & $\begin{array}{l}\text { Procurador- } \\
\text { Geral de Jus- } \\
\text { tiça }\end{array}$ & $\begin{array}{l}\text { Câmara Mu- } \\
\text { nicipal de } \\
\text { Araçatuba }\end{array}$ & $\begin{array}{l}\text { Sessão Ple- } \\
\text { nária do TJ }\end{array}$ & Unânime & $\begin{array}{l}\text { Dão provi- } \\
\text { mento à } \\
\text { ADIN }\end{array}$ & $\begin{array}{l}\text { Francis } \\
\text { Davis }\end{array}$ & $\begin{array}{l}\text { JTJ } \\
\text { v.155, p.273 }\end{array}$ \\
\hline $17.063-0$ & ADIN & 1994 & $\begin{array}{l}\text { Decisões } \\
\text { administrati- } \\
\text { vas e políti- } \\
\text { cas }\end{array}$ & $\begin{array}{l}\text { Competência } \\
\text { para legislar }\end{array}$ & Itapetininga & $\begin{array}{l}\text { Prefeito e } \\
\text { Câmara Muni- } \\
\text { cipal de Itape- } \\
\text { tininga }\end{array}$ & $\begin{array}{l}\text { Procuradoria- } \\
\text { Geral do } \\
\text { Estado }\end{array}$ & $\begin{array}{l}\text { Sessão Ple- } \\
\text { nária do TJ }\end{array}$ & Unânime & $\begin{array}{l}\text { Julgam pro- } \\
\text { cedente a } \\
\text { ação. }\end{array}$ & $\begin{array}{l}\text { Villa da } \\
\text { Costa }\end{array}$ & $\begin{array}{l}\text { JTJ } \\
\text { v. } 154, \text { p. } 263\end{array}$ \\
\hline $200.158-1$ & $\begin{array}{l}\text { Agravo de } \\
\text { instrumento }\end{array}$ & 1994 & $\begin{array}{l}\text { Poder de } \\
\text { regulaçãao } \\
\text { estatal }\end{array}$ & $\begin{array}{l}\text { Mensalidade } \\
\text { escolar }\end{array}$ & São Paulo & $\begin{array}{l}\text { Escola Terra } \\
\text { Nova S.C } \\
\text { Ltda. }\end{array}$ & $\begin{array}{l}\text { Instituto } \\
\text { Brasileiro de } \\
\text { Defesa do } \\
\text { Consumidor } \\
\text { (IDEC). }\end{array}$ & $\begin{array}{l}\text { Quinta Câ- } \\
\text { mara Civil }\end{array}$ & Unânime & $\begin{array}{l}\text { Recurso } \\
\text { provido }\end{array}$ & $\begin{array}{l}\text { Marco } \\
\text { César }\end{array}$ & $\begin{array}{l}\text { JTJ } \\
\text { v.155, p.181 }\end{array}$ \\
\hline $201.109-1$ & $\begin{array}{l}\text { Apelação } \\
\text { Cível }\end{array}$ & 1994 & $\begin{array}{l}\text { Gestão dos } \\
\text { recursos } \\
\text { públicos }\end{array}$ & $\begin{array}{l}\text { Aplicação } \\
\text { dos recursos }\end{array}$ & Dourado & $\begin{array}{l}\text { Ministério } \\
\text { Público }\end{array}$ & $\begin{array}{l}\text { Municipali- } \\
\text { dade e Câ- } \\
\text { mara Munici- } \\
\text { pal de Doura- } \\
\text { dos }\end{array}$ & $\begin{array}{l}\text { Oitava Câ- } \\
\text { mara Civil } \\
\text { de Férias }\end{array}$ & Unânime & $\begin{array}{l}\text { Recurso } \\
\text { provido }\end{array}$ & $\begin{array}{l}\text { Villa da } \\
\text { Costa }\end{array}$ & $\begin{array}{l}\text { JTJ } \\
\text { v. } 155, \text { p.98 }\end{array}$ \\
\hline $204.006-1$ & $\begin{array}{l}\text { Apelação } \\
\text { Cível }\end{array}$ & 1994 & $\begin{array}{l}\text { Poder de } \\
\text { regulação } \\
\text { estatal }\end{array}$ & $\begin{array}{l}\text { Mensalidade } \\
\text { escolar }\end{array}$ & São Paulo & $\begin{array}{l}\text { Informação } \\
\text { ausente }\end{array}$ & $\begin{array}{l}\text { Informação } \\
\text { ausente }\end{array}$ & $\begin{array}{l}\text { Informação } \\
\text { ausente }\end{array}$ & $\begin{array}{l}\text { Informação } \\
\text { ausente }\end{array}$ & $\begin{array}{l}\text { Recurso não } \\
\text { provido }\end{array}$ & $\begin{array}{l}\text { Munhoz } \\
\text { Soares }\end{array}$ & $\begin{array}{l}\text { Sítio eletrônico } \\
\text { biblioteca TJ- } \\
\text { SP }\end{array}$ \\
\hline
\end{tabular}




\begin{tabular}{|c|c|c|c|c|c|c|c|c|c|c|c|c|}
\hline $\begin{array}{l}\text { Número } \\
\text { decisão }\end{array}$ & Natureza & Ano & Categorias & Tema & Origem & $\begin{array}{l}\text { Apelante } \\
\text { recorrente }\end{array}$ & $\begin{array}{l}\text { Apelados } \\
\text { recorridos }\end{array}$ & Câmara & Votação & Resultado & Relator & $\begin{array}{l}\text { Localização } \\
\text { da ementa / } \\
\text { acórdão }\end{array}$ \\
\hline \multicolumn{13}{|l|}{1995} \\
\hline $230.504-1$ & Apelação & 1995 & $\begin{array}{l}\text { Responsabi- } \\
\text { lidade estatal }\end{array}$ & \begin{tabular}{|l|} 
Ação de \\
reparação de \\
danos
\end{tabular} & Araraquara & $\begin{array}{l}\text { Criança ou } \\
\text { adolescente }\end{array}$ & $\begin{array}{l}\text { Fazenda do } \\
\text { Estado }\end{array}$ & $\begin{array}{l}\text { Segunda } \\
\text { Câmara } \\
\text { Civil do TJ }\end{array}$ & Unânime & $\begin{array}{l}\text { Recurso não } \\
\text { provido }\end{array}$ & $\begin{array}{l}\text { Donaldo } \\
\text { Armelin }\end{array}$ & $\begin{array}{l}\text { JTJ } \\
\text { v.178, p.98 }\end{array}$ \\
\hline $274.797-1$ & $\begin{array}{l}\text { Apelação } \\
\text { Cível }\end{array}$ & 1995 & $\begin{array}{l}\text { Poder de } \\
\text { regulação } \\
\text { estatal }\end{array}$ & $\begin{array}{l}\text { Mensalidade } \\
\text { escolar }\end{array}$ & São Paulo & $\begin{array}{l}\text { Criança ou } \\
\text { adolescente }\end{array}$ & $\begin{array}{l}\text { Jardim Escola } \\
\text { Dele e Dela } \\
\text { Ltda. }\end{array}$ & $\begin{array}{l}\text { Oitava Câ- } \\
\text { mara da } \\
\text { Seção Civil } \\
\text { de Direito } \\
\text { Privado }\end{array}$ & Unânime & $\begin{array}{l}\text { Recurso não } \\
\text { provido }\end{array}$ & $\begin{array}{l}\text { Aldo Ma- } \\
\text { galhães }\end{array}$ & $\begin{array}{l}\text { JTJ } \\
\text { v. } 178, \text { p. } 60\end{array}$ \\
\hline \multicolumn{13}{|l|}{1996} \\
\hline $27.678-0$ & $\begin{array}{l}\text { Apelação } \\
\text { Cível }\end{array}$ & 1996 & $\begin{array}{l}\text { Deveres dos } \\
\text { pais }\end{array}$ & $\begin{array}{l}\text { Negligência } \\
\text { dos pais/ } \\
\text { responsáveis }\end{array}$ & Ausente & $\begin{array}{l}\text { Promotoria de } \\
\text { Justiça da Vara } \\
\text { da Infância e } \\
\text { Juventude }\end{array}$ & $\begin{array}{l}\text { Criança ou } \\
\text { adolescente. }\end{array}$ & $\begin{array}{l}\text { Câmara } \\
\text { Especial do } \\
\text { TJ }\end{array}$ & Unânime & $\begin{array}{l}\text { Recurso } \\
\text { provido. }\end{array}$ & $\begin{array}{l}\text { Prado de } \\
\text { Toledo }\end{array}$ & $\begin{array}{l}\text { JTJ } \\
\text { v.192, p.64 }\end{array}$ \\
\hline $28.805-0$ & $\begin{array}{l}\text { Apelação } \\
\text { Cível }\end{array}$ & 1996 & Permanência & $\begin{array}{l}\text { Violação às } \\
\text { normas es- } \\
\text { colares }\end{array}$ & Ausente & $\begin{array}{l}\text { Recurso ex } \\
\text { officio }\end{array}$ & Ausente & $\begin{array}{l}\text { Câmara } \\
\text { Especial }\end{array}$ & Unânime & $\begin{array}{l}\text { Recurso não } \\
\text { provido }\end{array}$ & $\begin{array}{l}\text { Dirceu de } \\
\text { Mello }\end{array}$ & $\begin{array}{l}\text { JTJ } \\
\text { v. } 190, \text { p.109 }\end{array}$ \\
\hline $14.883-4$ & $\begin{array}{l}\text { Agravo de } \\
\text { Instrumento }\end{array}$ & 1996 & $\begin{array}{l}\text { Poder de } \\
\text { regulação } \\
\text { estatal }\end{array}$ & $\begin{array}{l}\text { Mensalidade } \\
\text { escolar }\end{array}$ & $\begin{array}{l}\text { S. José dos } \\
\text { Campos }\end{array}$ & $\begin{array}{l}\text { Esquema } \\
\text { Sociedade } \\
\text { Civil Ltda. }\end{array}$ & $\begin{array}{l}\text { Criança ou } \\
\text { adolescente }\end{array}$ & $\begin{array}{l}\text { Segunda } \\
\text { Câmara de } \\
\text { Direito } \\
\text { Privado }\end{array}$ & Unânime & $\begin{array}{l}\text { Recurso } \\
\text { provido }\end{array}$ & $\begin{array}{l}\text { J. Roberto } \\
\text { Bedran }\end{array}$ & $\begin{array}{l}\text { JTJ } \\
\text { v. } 192, \text { p.179 }\end{array}$ \\
\hline $34.093-0$ & $\begin{array}{l}\text { Mandado de } \\
\text { segurança }\end{array}$ & 1996 & $\begin{array}{l}\text { Poder de } \\
\text { regulação } \\
\text { estatal }\end{array}$ & $\begin{array}{l}\text { Autorização/ } \\
\text { credencia- } \\
\text { mento }\end{array}$ & São Paulo & $\begin{array}{l}\text { Associação } \\
\text { Brasileira dos } \\
\text { Consumidores } \\
\text { Democráticos }\end{array}$ & $\begin{array}{l}\text { Governador } \\
\text { do Estado / } \\
\text { Fazenda do } \\
\text { Estado }\end{array}$ & $\begin{array}{l}\text { Órgão Espe- } \\
\text { cial do TJ }\end{array}$ & Unânime & $\begin{array}{l}\text { Segurança } \\
\text { denegada }\end{array}$ & $\begin{array}{l}\text { Luiz Tâm- } \\
\text { bara }\end{array}$ & $\begin{array}{l}\text { JTJ } \\
\text { v. } 192, \text { p.256 }\end{array}$ \\
\hline $202.218-1$ & $\begin{array}{l}\text { Embargos } \\
\text { Infringentes }\end{array}$ & 1996 & $\begin{array}{l}\text { Poder de } \\
\text { regulação } \\
\text { estatal }\end{array}$ & $\begin{array}{l}\text { Mensalidade } \\
\text { escolar }\end{array}$ & São Paulo & $\begin{array}{l}\text { Instituto de } \\
\text { Ensino Santo } \\
\text { Ivo Sociedade } \\
\text { Educacional e } \\
\text { Pedagógica } \\
\text { Ltda. }\end{array}$ & $\begin{array}{l}\text { Criança ou } \\
\text { adolescente } \\
\text { representado } \\
\text { pelo pai e } \\
\text { outros }\end{array}$ & \begin{tabular}{|l} 
Sétima \\
Câmara \\
Civil de \\
Férias
\end{tabular} & $\begin{array}{l}\text { Maioria dos } \\
\text { votos }\end{array}$ & $\begin{array}{l}\text { Embargos } \\
\text { rejeitados }\end{array}$ & $\begin{array}{l}\text { Felipe } \\
\text { Ferreira }\end{array}$ & $\begin{array}{l}\text { JTJ } \\
\text { v. } 183, \text { p.223 }\end{array}$ \\
\hline
\end{tabular}




\begin{tabular}{|c|c|c|c|c|c|c|c|c|c|c|c|c|}
\hline $\begin{array}{l}\text { Número } \\
\text { decisão }\end{array}$ & Natureza & Ano & Categorias & Tema & Origem & $\begin{array}{l}\text { Apelante } \\
\text { recorrente }\end{array}$ & \begin{tabular}{|l|} 
Apelados \\
recorridos
\end{tabular} & Câmara & Votação & Resultado & Relator & $\begin{array}{l}\text { Localização } \\
\text { da ementa / } \\
\text { acórdão }\end{array}$ \\
\hline $229.957-1$ & $\begin{array}{l}\text { Apelação } \\
\text { Cível }\end{array}$ & 1996 & $\begin{array}{l}\text { Poder de } \\
\text { regulação } \\
\text { estatal }\end{array}$ & $\begin{array}{l}\text { Mensalidade } \\
\text { escolar }\end{array}$ & $\begin{array}{l}\text { Presidente } \\
\text { Prudente }\end{array}$ & $\begin{array}{l}\text { Juízo Ex Offi- } \\
\text { cio }\end{array}$ & \begin{tabular}{|l|} 
Criança ou \\
adolescente e \\
Diretor da \\
EEPSG e \\
Centro Espe- \\
cífico de \\
Formação e \\
Aperfeiçoa- \\
mento do \\
Magistério \\
"Pirassu- \\
nunga".
\end{tabular} & $\begin{array}{l}\text { Sexta Câ- } \\
\text { mara de } \\
\text { Direito } \\
\text { Público }\end{array}$ & Unânime & $\begin{array}{l}\text { Recurso não } \\
\text { provido }\end{array}$ & $\begin{array}{l}\text { Telles Cor- } \\
\text { rêa }\end{array}$ & \begin{tabular}{|l|} 
JTJ \\
v.194, p.47
\end{tabular} \\
\hline $238.454-1$ & $\begin{array}{l}\text { Apelação } \\
\text { Cível }\end{array}$ & 1996 & $\begin{array}{l}\text { Acesso à } \\
\text { educação } \\
\text { básica }\end{array}$ & $\begin{array}{l}\text { Acesso Ed } \\
\text { Profissional }\end{array}$ & \begin{tabular}{|l} 
Pirassu- \\
nunga
\end{tabular} & Ex officio & Menor & $\begin{array}{l}6^{\circ} \text { Câmara } \\
\text { de Direito } \\
\text { Público }\end{array}$ & Unânime & $\begin{array}{l}\text { Recurso não } \\
\text { provido }\end{array}$ & $\begin{array}{l}\text { Telles Cor- } \\
\text { rêa }\end{array}$ & \begin{tabular}{|l|} 
JTJ \\
v.190, p.53
\end{tabular} \\
\hline $238.567-1$ & $\begin{array}{l}\text { Apelação } \\
\text { Cível }\end{array}$ & 1996 & \begin{tabular}{|l|} 
Poder de \\
regulação \\
estatal
\end{tabular} & $\begin{array}{l}\text { Mensalidade } \\
\text { escolar }\end{array}$ & São Paulo & $\begin{array}{l}\text { Criança ou } \\
\text { adolescente }\end{array}$ & $\begin{array}{l}\text { Cólegio Ba- } \\
\text { tista Brasi- } \\
\text { leiro }\end{array}$ & $\begin{array}{l}\text { Segunda } \\
\text { Câmara do } \\
\text { TJ }\end{array}$ & Unânime & $\begin{array}{l}\text { Recurso não } \\
\text { provido }\end{array}$ & $\begin{array}{l}\text { J. Roberto } \\
\text { Bedran }\end{array}$ & \begin{tabular}{|l|} 
JTJ \\
v. 185, p. 21
\end{tabular} \\
\hline $239.376-1$ & $\begin{array}{l}\text { Apelação } \\
\text { Cível }\end{array}$ & 1996 & $\begin{array}{l}\text { Acesso à } \\
\text { educação } \\
\text { básica }\end{array}$ & $\begin{array}{l}\text { Acesso Ed } \\
\text { Profissional }\end{array}$ & $\begin{array}{l}\text { Informação } \\
\text { ausente }\end{array}$ & $\begin{array}{l}\text { Informação } \\
\text { ausente }\end{array}$ & $\begin{array}{l}\text { Informação } \\
\text { ausente }\end{array}$ & $\begin{array}{l}9^{\text {a }} \text { Câmara } \\
\text { de Direito } \\
\text { Público }\end{array}$ & Unânime & $\begin{array}{l}\text { Recurso não } \\
\text { provido }\end{array}$ & \begin{tabular}{|l|} 
Yoshiaki \\
Ichihara
\end{tabular} & $\begin{array}{l}\text { Sítio eletrônico } \\
\text { biblioteca TJ- } \\
\text { SP }\end{array}$ \\
\hline $247.131-1$ & $\begin{array}{l}\text { Apelação } \\
\text { Cível }\end{array}$ & 1996 & \begin{tabular}{|l|} 
Poder de \\
regulação \\
estatal
\end{tabular} & $\begin{array}{l}\text { Mensalidade } \\
\text { escolar }\end{array}$ & São Paulo & $\begin{array}{l}\text { Criança ou } \\
\text { adolescente }\end{array}$ & $\begin{array}{l}\text { Escola Dioce- } \\
\text { sana Virgem } \\
\text { de Pilar }\end{array}$ & $\begin{array}{l}\text { Primeira } \\
\text { Câmara de } \\
\text { Direito } \\
\text { Privado }\end{array}$ & Unânime & $\begin{array}{l}\text { Recurso não } \\
\text { provido }\end{array}$ & $\begin{array}{l}\text { Gildo dos } \\
\text { Santos }\end{array}$ & $\begin{array}{l}\text { JTJ } \\
\text { v. } 195, \text { p.56 }\end{array}$ \\
\hline $250.089-1$ & $\begin{array}{l}\text { Apelação } \\
\text { Cível }\end{array}$ & 1996 & $\begin{array}{l}\text { Poder de } \\
\text { regulação } \\
\text { estatal }\end{array}$ & $\begin{array}{l}\text { Autorização/ } \\
\text { credencia- } \\
\text { mento }\end{array}$ & São Paulo & $\begin{array}{l}\text { Informação } \\
\text { ausente }\end{array}$ & $\begin{array}{l}\text { Informação } \\
\text { ausente }\end{array}$ & $\begin{array}{l}4^{\mathrm{a}} \text { Câmara } \\
\text { de Direito } \\
\text { Público }\end{array}$ & $\begin{array}{l}\text { Informação } \\
\text { ausente }\end{array}$ & $\begin{array}{l}\text { Recurso não } \\
\text { provido }\end{array}$ & $\begin{array}{l}\text { Aldemar } \\
\text { Silva }\end{array}$ & $\begin{array}{l}\text { Sítio eletrônico } \\
\text { biblioteca TJ- } \\
\text { SP }\end{array}$ \\
\hline $250.225-1$ & $\begin{array}{l}\text { Apelação } \\
\text { Cível }\end{array}$ & 1996 & \begin{tabular}{|l|} 
Poder de \\
regulação \\
estatal
\end{tabular} & $\begin{array}{l}\text { Mensalidade } \\
\text { escolar }\end{array}$ & $\begin{array}{l}\text { Santo An- } \\
\text { dré }\end{array}$ & $\begin{array}{l}\text { R.M.R Criança } \\
\text { ou adolescente } \\
\text { e outros }\end{array}$ & $\begin{array}{l}\text { Colégio Sin- } \\
\text { gular }\end{array}$ & $\begin{array}{l}\text { Primeira } \\
\text { Câmara de } \\
\text { Direito } \\
\text { Privado }\end{array}$ & $\begin{array}{l}\text { Maioria dos } \\
\text { votos }\end{array}$ & $\begin{array}{l}\text { Rejeitada a } \\
\text { preliminar no } \\
\text { mérito e } \\
\text { recurso ne- } \\
\text { gado }\end{array}$ & \begin{tabular}{|l|} 
Erbetta \\
Filho
\end{tabular} & \begin{tabular}{|l|} 
JTJ \\
v.188, p.34
\end{tabular} \\
\hline
\end{tabular}




\begin{tabular}{|c|c|c|c|c|c|c|c|c|c|c|c|c|}
\hline $\begin{array}{l}\text { Número } \\
\text { decisão }\end{array}$ & Natureza & Ano & Categorias & Tema & Origem & $\begin{array}{l}\text { Apelante } \\
\text { recorrente }\end{array}$ & $\begin{array}{l}\text { Apelados } \\
\text { recorridos }\end{array}$ & Câmara & Votação & Resultado & Relator & $\begin{array}{l}\text { Localização } \\
\text { da ementa / } \\
\text { acórdão }\end{array}$ \\
\hline $254.839-1$ & $\begin{array}{l}\text { Apelação } \\
\text { Cível }\end{array}$ & 1996 & $\begin{array}{l}\text { Poder de } \\
\text { regulação } \\
\text { estatal }\end{array}$ & $\begin{array}{l}\text { Mensalidade } \\
\text { escolar }\end{array}$ & São Paulo & $\begin{array}{l}\text { Criança ou } \\
\text { adolescente }\end{array}$ & $\begin{array}{l}\text { Sociedade } \\
\text { Brasileira de } \\
\text { Educação, } \\
\text { entidade } \\
\text { mantenedora } \\
\text { do Colégio } \\
\text { São Francisco } \\
\text { Xavier. } \\
\end{array}$ & $\begin{array}{l}\text { Décima } \\
\text { Câmara de } \\
\text { Direito } \\
\text { Privado }\end{array}$ & Unânime & $\begin{array}{l}\text { Recurso não } \\
\text { provido }\end{array}$ & Rui Camilo & $\begin{array}{l}\text { JTJ } \\
\text { v.190, p.55 }\end{array}$ \\
\hline $255.398-1$ & $\begin{array}{l}\text { Apelação } \\
\text { Cível }\end{array}$ & 1996 & $\begin{array}{l}\text { Poder de } \\
\text { regulação } \\
\text { estatal }\end{array}$ & $\begin{array}{l}\text { Mensalidade } \\
\text { escolar }\end{array}$ & São Paulo & $\begin{array}{l}\text { Criança ou } \\
\text { adolescente }\end{array}$ & $\begin{array}{l}\text { Escola Dioce- } \\
\text { sana Virgem } \\
\text { de Pilar }\end{array}$ & $\begin{array}{l}\text { Segunda } \\
\text { Câmara de } \\
\text { Direito } \\
\text { Privado } \\
\end{array}$ & Unânime & $\begin{array}{l}\text { Recurso } \\
\text { provido para } \\
\text { extinção do } \\
\text { processo. }\end{array}$ & $\begin{array}{l}\text { Cezar Pe- } \\
\text { luso }\end{array}$ & $\begin{array}{l}\text { JTJ } \\
\text { v. } 192, \text { p.55 }\end{array}$ \\
\hline $265.465-1$ & $\begin{array}{l}\text { Apelação } \\
\text { Cível }\end{array}$ & 1996 & $\begin{array}{l}\text { Acesso à } \\
\text { educaçãoo } \\
\text { básica }\end{array}$ & Acesso EF & $\begin{array}{l}\text { Monte } \\
\text { Aprazível }\end{array}$ & $\begin{array}{l}\text { Juízo Ex } \\
\text { Offício; } \\
\text { Fazenda do } \\
\text { Estado }\end{array}$ & $\begin{array}{l}\text { Criança ou } \\
\text { adolescente }\end{array}$ & $\begin{array}{l}\text { Oitava } \\
\text { Câmara de } \\
\text { Direito } \\
\text { Público } \\
\end{array}$ & Unânime & $\begin{array}{l}\text { Recurso não } \\
\text { provido }\end{array}$ & $\begin{array}{l}\text { Pinheiro } \\
\text { Franco }\end{array}$ & $\begin{array}{l}\text { JTJ } \\
\text { v.260, p.211 }\end{array}$ \\
\hline $268.004-1$ & $\begin{array}{l}\text { Apelação } \\
\text { Cível }\end{array}$ & 1996 & $\begin{array}{l}\text { Poder de } \\
\text { regulação } \\
\text { estatal }\end{array}$ & $\begin{array}{l}\text { Mensalidade } \\
\text { escolar }\end{array}$ & São Paulo & $\begin{array}{l}\text { Criança ou } \\
\text { adolescente }\end{array}$ & $\begin{array}{l}\text { Centro de } \\
\text { Habilitação, } \\
\text { Filosofia e } \\
\text { Cultura }\end{array}$ & $\begin{array}{l}\text { Primeira } \\
\text { Câmara de } \\
\text { Férias B de } \\
\text { Direito } \\
\text { Privado } \\
\end{array}$ & Unânime & $\begin{array}{l}\text { Recurso } \\
\text { provido }\end{array}$ & $\begin{array}{l}\text { Guimarães e } \\
\text { Souza }\end{array}$ & $\begin{array}{l}\text { JTJ } \\
\text { v. } 188, \text { p.41 }\end{array}$ \\
\hline $273.837-2$ & $\begin{array}{l}\text { Apelação } \\
\text { Cível }\end{array}$ & 1996 & $\begin{array}{l}\text { Poder de } \\
\text { regulação } \\
\text { estatal }\end{array}$ & $\begin{array}{l}\text { Mensalidade } \\
\text { escolar }\end{array}$ & Araraquara & $\begin{array}{l}\text { Décima } \\
\text { Câmara Civil } \\
\text { do TJ }\end{array}$ & $\begin{array}{l}\text { Sexta Câmara } \\
\text { Civil do TJ }\end{array}$ & $\begin{array}{l}\text { Grupo } \\
\text { Especial de } \\
\text { Câmaras } \\
\text { Civis do TJ }\end{array}$ & Unânime & $\begin{array}{l}\text { Dúvida } \\
\text { procedente e } \\
\text { competente à } \\
\text { Primeira } \\
\text { Seção Civil }\end{array}$ & $\begin{array}{l}\text { Borelli } \\
\text { Machado }\end{array}$ & $\begin{array}{l}\text { JTJ } \\
\text { v.179, p.243 }\end{array}$ \\
\hline \multicolumn{13}{|l|}{1997} \\
\hline $2.421-5$ & $\begin{array}{l}\text { Apelação } \\
\text { Cível }\end{array}$ & 1997 & $\begin{array}{l}\text { Responsabili } \\
\text { dade estatal }\end{array}$ & $\begin{array}{l}\text { Ação de } \\
\text { reparaçãao de } \\
\text { danos }\end{array}$ & São Paulo & $\begin{array}{l}9^{\text {a }} \text { Câmara } \\
\text { "Julho 1997" } \\
\text { de Direito } \\
\text { Público }\end{array}$ & $\begin{array}{l}\text { Juízo Ex } \\
\text { Officio; } \\
\text { Prefeitura } \\
\text { Municipal }\end{array}$ & $\begin{array}{l}\text { Ministério } \\
\text { Público }\end{array}$ & Unânime & $\begin{array}{l}\text { Apelação não } \\
\text { provida à } \\
\text { Municipalida } \\
\text { de e ao } \\
\text { reexame } \\
\text { necessário. } \\
\text { Provimento } \\
\text { parcial à } \\
\text { apelação do } \\
\text { MP }\end{array}$ & $\begin{array}{l}\text { Sidnei } \\
\text { Beneti }\end{array}$ & $\begin{array}{l}\text { JTJ } \\
\text { v.203, p.101 }\end{array}$ \\
\hline
\end{tabular}




\begin{tabular}{|c|c|c|c|c|c|c|c|c|c|c|c|c|}
\hline $\begin{array}{l}\text { Número } \\
\text { decisão }\end{array}$ & Natureza & Ano & Categorias & Tema & Origem & $\begin{array}{l}\text { Apelante } \\
\text { recorrente }\end{array}$ & $\begin{array}{l}\text { Apelados } \\
\text { recorridos }\end{array}$ & Câmara & Votação & Resultado & Relator & $\begin{array}{l}\text { Localização } \\
\text { da ementa / } \\
\text { acórdão }\end{array}$ \\
\hline $002.645-4 / 2$ & $\begin{array}{l}\text { Apelação } \\
\text { Cível }\end{array}$ & 1997 & $\begin{array}{l}\text { Poder de } \\
\text { regulação } \\
\text { estatal }\end{array}$ & $\begin{array}{l}\text { Mensalidade } \\
\text { escolar }\end{array}$ & Barueri & $\begin{array}{l}\text { Escola de } \\
\text { Educação } \\
\text { Katatau S/C } \\
\text { Ltda. }\end{array}$ & $\begin{array}{l}\text { Criança ou } \\
\text { adolescente }\end{array}$ & $\begin{array}{l}3^{\text {a }} \text { Câmara } \\
\text { de Direito } \\
\text { Privado }\end{array}$ & $\begin{array}{l}\text { Maioria dos } \\
\text { votos. Consta } \\
\text { voto } \\
\text { vencedor e } \\
\text { vencido }\end{array}$ & $\begin{array}{l}\text { Recurso } \\
\text { provido }\end{array}$ & $\begin{array}{l}\text { Toledo } \\
\text { Cesar }\end{array}$ & $\begin{array}{l}\text { Sítio eletrônico } \\
\text { biblioteca TJ- } \\
\text { SP }\end{array}$ \\
\hline $26.588-4$ & $\begin{array}{l}\text { Agravo de } \\
\text { Instrumento }\end{array}$ & 1997 & $\begin{array}{l}\text { Poder de } \\
\text { regulação } \\
\text { estatal }\end{array}$ & $\begin{array}{l}\text { Mensalidade } \\
\text { escolar }\end{array}$ & $\begin{array}{l}\text { Ribeirão } \\
\text { Preto }\end{array}$ & $\begin{array}{l}\text { Ministério } \\
\text { Público }\end{array}$ & $\begin{array}{l}\text { Sistema COC } \\
\text { de Educação } \\
\text { e } \\
\text { Comunicação } \\
\text { S.C. Ltda. }\end{array}$ & $\begin{array}{l}\text { Primeira } \\
\text { Câmara de } \\
\text { Direito } \\
\text { Privado }\end{array}$ & Unânime & $\begin{array}{l}\text { Extinto o } \\
\text { processo, } \\
\text { sem } \\
\text { julgamento } \\
\text { de mérito e } \\
\text { prejudicado o } \\
\text { recurso }\end{array}$ & \begin{tabular}{|l|} 
Álvaro \\
Lazzarini
\end{tabular} & $\begin{array}{l}\text { JTJ } \\
\text { v.197, p.172 }\end{array}$ \\
\hline $36.139-0$ & $\begin{array}{l}\text { Agravo de } \\
\text { instrumento }\end{array}$ & 1997 & $\begin{array}{l}\text { Decisões } \\
\text { administrativ } \\
\text { as e políticas }\end{array}$ & $\begin{array}{l}\text { Programa de } \\
\text { reorganizaçã } \\
\text { o das escolas } \\
\text { estaduais }\end{array}$ & $\begin{array}{l}\text { São Miguel } \\
\text { Paulista }\end{array}$ & $\begin{array}{l}\text { Promotor de } \\
\text { Justiça da Vara } \\
\text { Central da } \\
\text { Infância e } \\
\text { Juventude do } \\
\text { Foro Regional } \\
\text { de São Miguel } \\
\text { Paulista }\end{array}$ & $\begin{array}{l}\text { Fazenda do } \\
\text { Estado de São } \\
\text { Paulo }\end{array}$ & \begin{tabular}{|l|} 
Câmara \\
Especial
\end{tabular} & Unânime & $\begin{array}{l}\text { Recurso } \\
\text { provido para } \\
\text { a } \\
\text { competência } \\
\text { da Vara da } \\
\text { Infância e } \\
\text { Juventude do } \\
\text { Foro } \\
\text { Regional de } \\
\text { São Miguel } \\
\text { Paulista. } \\
\text { Declaração } \\
\text { de voto } \\
\text { vencido. }\end{array}$ & Carlos Ortiz & $\begin{array}{l}\text { JTJ } \\
\text { v. } 228, \text { p. } 170\end{array}$ \\
\hline $36.351-5$ & $\begin{array}{l}\text { Mandado de } \\
\text { Segurança }\end{array}$ & 1997 & $\begin{array}{l}\text { Acesso à } \\
\text { educação } \\
\text { básica }\end{array}$ & Acesso EF & Santos & & & $\begin{array}{l}1^{\text {a }} \text { Câmara } \\
\text { de Direito } \\
\text { Público }\end{array}$ & Unânime & $\begin{array}{l}\text { Recurso não } \\
\text { provido }\end{array}$ & $\begin{array}{l}\text { Demóstenes } \\
\text { Braga }\end{array}$ & $\begin{array}{l}\text { Sítio eletrônico } \\
\text { biblioteca TJ- } \\
\text { SP }\end{array}$ \\
\hline $38.049-0$ & $\begin{array}{l}\text { Apelação } \\
\text { Cível }\end{array}$ & 1997 & Permanência & $\begin{array}{l}\text { Violação às } \\
\text { normas } \\
\text { escolares }\end{array}$ & Ausente & $\begin{array}{l}\text { Diretor do } \\
\text { Colégio de } \\
\text { Aplicação }\end{array}$ & $\begin{array}{l}\text { Criança ou } \\
\text { adolescente }\end{array}$ & $\begin{array}{l}\text { Câmara } \\
\text { Especial }\end{array}$ & Unânime & $\begin{array}{l}\text { Recurso não } \\
\text { provido }\end{array}$ & $\begin{array}{l}\text { Cunha } \\
\text { Bueno }\end{array}$ & $\begin{array}{l}\text { JTJ } \\
\text { v.204, p.29 }\end{array}$ \\
\hline $39.375-0$ & $\begin{array}{l}\text { Apelação } \\
\text { Cível }\end{array}$ & 1997 & $\begin{array}{l}\text { Responsabili } \\
\text { dade estatal }\end{array}$ & $\begin{array}{l}\text { Condições de } \\
\text { funcionament } \\
\text { o das escolas }\end{array}$ & Guarulhos & $\begin{array}{l}\text { Fazenda do } \\
\text { Estado }\end{array}$ & $\begin{array}{l}\text { Ministério } \\
\text { Público }\end{array}$ & $\begin{array}{l}\text { Câmara } \\
\text { Especial do } \\
\text { TJ }\end{array}$ & Unânime & $\begin{array}{l}\text { Recurso não } \\
\text { provido }\end{array}$ & $\begin{array}{l}\text { Luís de } \\
\text { Macedo }\end{array}$ & $\begin{array}{l}\text { JTJ } \\
\text { v.197, p.18 }\end{array}$ \\
\hline
\end{tabular}




\begin{tabular}{|c|c|c|c|c|c|c|c|c|c|c|c|c|}
\hline $\begin{array}{l}\text { Número } \\
\text { decisão }\end{array}$ & Natureza & Ano & Categorias & Tema & Origem & $\begin{array}{l}\text { Apelante } \\
\text { recorrente }\end{array}$ & $\begin{array}{l}\text { Apelados } \\
\text { recorridos }\end{array}$ & Câmara & Votação & Resultado & Relator & $\begin{array}{l}\text { Localização } \\
\text { da ementa / } \\
\text { acórdão }\end{array}$ \\
\hline $39.392-0$ & $\begin{array}{l}\text { Agravo de } \\
\text { instrumento }\end{array}$ & 1997 & $\begin{array}{l}\text { Acesso à } \\
\text { educação } \\
\text { básica }\end{array}$ & Acesso EF & São Paulo & $\begin{array}{l}\text { Informação } \\
\text { ausente }\end{array}$ & $\begin{array}{l}\text { Informação } \\
\text { ausente }\end{array}$ & $\begin{array}{l}\text { Câmara } \\
\text { Especial do } \\
\text { TJ }\end{array}$ & Unânime & $\begin{array}{l}\text { Informação } \\
\text { ausente }\end{array}$ & $\begin{array}{l}\text { Luís de } \\
\text { Macedo }\end{array}$ & $\begin{array}{l}\text { Sítio eletrônico } \\
\text { biblioteca TJ- } \\
\text { SP }\end{array}$ \\
\hline $40.865-0$ & $\begin{array}{l}\text { Agravo de } \\
\text { instrumento }\end{array}$ & 1997 & $\begin{array}{l}\text { Gestão dos } \\
\text { recursos } \\
\text { públicos }\end{array}$ & $\begin{array}{l}\text { Aplicação } \\
\text { dos recursos }\end{array}$ & São Paulo & $\begin{array}{l}\text { Ministério } \\
\text { Público }\end{array}$ & $\begin{array}{l}\text { Prefeitura } \\
\text { Municipal }\end{array}$ & $\begin{array}{l}\text { Câmara } \\
\text { Especial }\end{array}$ & Unânime & $\begin{array}{l}\text { Recurso não } \\
\text { provido }\end{array}$ & $\begin{array}{l}\text { Dirceu de } \\
\text { Mello }\end{array}$ & $\begin{array}{l}\text { JTJ } \\
\text { v.205, p.206 }\end{array}$ \\
\hline $40.893-0$ & $\begin{array}{l}\text { Apelação } \\
\text { Cível }\end{array}$ & 1997 & $\begin{array}{l}\text { Acesso à } \\
\text { educação } \\
\text { básica }\end{array}$ & Acesso EF & Marília & $\begin{array}{l}\text { Informação } \\
\text { ausente }\end{array}$ & $\begin{array}{l}\text { Informação } \\
\text { ausente }\end{array}$ & $\begin{array}{l}\text { Câmara } \\
\text { Especial }\end{array}$ & $\begin{array}{l}\text { Mairoria dos } \\
\text { votos }\end{array}$ & $\begin{array}{l}\text { Recursos não } \\
\text { providos }\end{array}$ & $\begin{array}{l}\text { Luís de } \\
\text { Macedo }\end{array}$ & $\begin{array}{l}\text { Sítio eletrônico } \\
\text { biblioteca TJ- } \\
\text { SP }\end{array}$ \\
\hline $40.992-0$ & $\begin{array}{l}\text { Apelação } \\
\text { Cível }\end{array}$ & 1997 & $\begin{array}{l}\text { Acesso à } \\
\text { educação } \\
\text { básica }\end{array}$ & Acesso EF & Marília & & & $\begin{array}{l}\text { Câmara } \\
\text { Especial }\end{array}$ & Unânime & $\begin{array}{l}\text { Recurso não } \\
\text { provido }\end{array}$ & $\begin{array}{l}\text { Luís de } \\
\text { Macedo }\end{array}$ & $\begin{array}{l}\text { Sítio eletrônico } \\
\text { biblioteca TJ- } \\
\text { SP }\end{array}$ \\
\hline $40.994-0$ & $\begin{array}{l}\text { Apelação } \\
\text { Cível }\end{array}$ & 1997 & $\begin{array}{l}\text { Acesso à } \\
\text { educação } \\
\text { básica }\end{array}$ & Acesso EF & Marília & $\begin{array}{l}\text { Informação } \\
\text { ausente }\end{array}$ & $\begin{array}{l}\text { Informação } \\
\text { ausente }\end{array}$ & $\begin{array}{l}\text { Câmara } \\
\text { Especial }\end{array}$ & $\begin{array}{l}\text { Mairoria dos } \\
\text { votos }\end{array}$ & $\begin{array}{l}\text { Recurso não } \\
\text { provido }\end{array}$ & $\begin{array}{l}\text { Luís de } \\
\text { Macedo }\end{array}$ & $\begin{array}{l}\text { Sítio eletrônico } \\
\text { biblioteca TJ- } \\
\text { SP }\end{array}$ \\
\hline $41.019-0$ & $\begin{array}{l}\text { Apelação } \\
\text { Cível }\end{array}$ & 1997 & $\begin{array}{l}\text { Acesso à } \\
\text { educação } \\
\text { básica }\end{array}$ & Acesso EF & Marília & $\begin{array}{l}\text { Informação } \\
\text { ausente }\end{array}$ & $\begin{array}{l}\text { Informação } \\
\text { ausente }\end{array}$ & $\begin{array}{l}\text { Câmara } \\
\text { Especial }\end{array}$ & Unânime & $\begin{array}{l}\text { Recurso não } \\
\text { provido }\end{array}$ & $\begin{array}{l}\text { Luís de } \\
\text { Macedo }\end{array}$ & $\begin{array}{l}\text { Sítio eletrônico } \\
\text { biblioteca TJ- } \\
\text { SP }\end{array}$ \\
\hline $41.033-0$ & $\begin{array}{l}\text { Apelação } \\
\text { Cível }\end{array}$ & 1997 & $\begin{array}{l}\text { Acesso à } \\
\text { educação } \\
\text { básica }\end{array}$ & Acesso EF & Marília & $\begin{array}{l}\text { Informação } \\
\text { ausente }\end{array}$ & $\begin{array}{l}\text { Informação } \\
\text { ausente }\end{array}$ & $\begin{array}{l}\text { Câmara } \\
\text { Especial }\end{array}$ & Unânime & $\begin{array}{l}\text { Recurso não } \\
\text { provido }\end{array}$ & $\begin{array}{l}\text { Luís de } \\
\text { Macedo }\end{array}$ & $\begin{array}{l}\text { Sítio eletrônico } \\
\text { biblioteca TJ- } \\
\text { SP }\end{array}$ \\
\hline $41.375-0$ & $\begin{array}{l}\text { Apelação } \\
\text { Cível }\end{array}$ & 1997 & $\begin{array}{l}\text { Acesso à } \\
\text { educação } \\
\text { básica }\end{array}$ & Acesso EF & Mairiporã & $\begin{array}{l}\text { Informação } \\
\text { ausente }\end{array}$ & $\begin{array}{l}\text { Informação } \\
\text { ausente }\end{array}$ & $\begin{array}{l}\text { Câmara } \\
\text { Especial }\end{array}$ & Unânime & $\begin{array}{l}\text { Recurso não } \\
\text { provido }\end{array}$ & $\begin{array}{l}\text { Luís de } \\
\text { Macedo }\end{array}$ & $\begin{array}{l}\text { Sítio eletrônico } \\
\text { biblioteca TJ- } \\
\text { SP }\end{array}$ \\
\hline $\begin{array}{l}64.896-5 / 4- \\
00\end{array}$ & $\begin{array}{l}\text { Agravo de } \\
\text { Instrumento }\end{array}$ & 1997 & $\begin{array}{l}\text { Poder de } \\
\text { regulação } \\
\text { estatal }\end{array}$ & $\begin{array}{l}\text { Autorização/ } \\
\text { credenciame } \\
\text { nto }\end{array}$ & São Paulo & $\begin{array}{l}\text { Flamingo } 2001 \\
\text { Curso } \\
\text { Fundamental }\end{array}$ & $\begin{array}{l}\text { Fazenda do } \\
\text { Estado de SP }\end{array}$ & $\begin{array}{l}5^{\text {a }} \text { Câmara } \\
\text { de Direito } \\
\text { Público }\end{array}$ & Unânime & $\begin{array}{l}\text { Recurso não } \\
\text { provido }\end{array}$ & $\begin{array}{l}\text { William } \\
\text { Marinho }\end{array}$ & $\begin{array}{l}\text { Sítio eletrônico } \\
\text { biblioteca TJ- } \\
\text { SP }\end{array}$ \\
\hline $273.473-1$ & $\begin{array}{l}\text { Apelação } \\
\text { Cível }\end{array}$ & 1997 & $\begin{array}{l}\text { Poder de } \\
\text { regulação } \\
\text { estatal }\end{array}$ & $\begin{array}{l}\text { Mensalidade } \\
\text { escolar }\end{array}$ & Santos & $\begin{array}{l}\text { Cidadania } \\
\text { Associação de } \\
\text { Defesa dos } \\
\text { Direitos do } \\
\text { Cidadão e } \\
\text { outros }\end{array}$ & $\begin{array}{l}\text { Cidadania } \\
\text { Associação } \\
\text { de Defesa dos } \\
\text { Direitos do } \\
\text { Cidadão e } \\
\text { Associação } \\
\text { Prudentina de } \\
\text { Educação e } \\
\text { Cultura }\end{array}$ & $\begin{array}{l}\text { Quinta } \\
\text { Câmara de } \\
\text { Direito } \\
\text { Privado }\end{array}$ & Unânime & $\begin{array}{l}\text { Recurso } \\
\text { provido em } \\
\text { parte }\end{array}$ & $\begin{array}{l}\text { Jorge } \\
\text { Tannus }\end{array}$ & $\begin{array}{l}\text { JTJ } \\
\text { v.196, p.42 }\end{array}$ \\
\hline
\end{tabular}




\begin{tabular}{|c|c|c|c|c|c|c|c|c|c|c|c|c|}
\hline $\begin{array}{l}\text { Número } \\
\text { decisão }\end{array}$ & Natureza & Ano & Categorias & Tema & Origem & $\begin{array}{l}\text { Apelante } \\
\text { recorrente }\end{array}$ & $\begin{array}{l}\text { Apelados } \\
\text { recorridos }\end{array}$ & Câmara & Votação & Resultado & Relator & $\begin{array}{l}\text { Localização } \\
\text { da ementa / } \\
\text { acórdão }\end{array}$ \\
\hline $258.714-1$ & $\begin{array}{l}\text { Apelação } \\
\text { Cível }\end{array}$ & 1997 & $\begin{array}{l}\text { Poder de } \\
\text { regulação } \\
\text { estatal }\end{array}$ & $\begin{array}{l}\text { Mensalidade } \\
\text { escolar }\end{array}$ & São Paulo & $\begin{array}{l}\text { IDEC; } \\
\text { Sociedade } \\
\text { Educacional e } \\
\text { Assistência } \\
\text { Social Irmãs } \\
\text { Franciscanas } \\
\text { Providência } \\
\text { Divina e } \\
\text { mantenedoras } \\
\text { dos colégios } \\
\text { Pio XII e } \\
\text { Colégio } \\
\text { Aquarius Ltda. }\end{array}$ & $\begin{array}{l}\text { IDEC; } \\
\text { Sociedade } \\
\text { Educacional e } \\
\text { Assistência } \\
\text { Social Irmãs } \\
\text { Franciscanas } \\
\text { Providência } \\
\text { Divina e } \\
\text { mantenedoras } \\
\text { dos colégios } \\
\text { Pio XII e } \\
\text { Colégio } \\
\text { Aquarius } \\
\text { Ltda. } \\
\end{array}$ & \begin{tabular}{|l} 
Primeira \\
Câmara de \\
Direito \\
Privado
\end{tabular} & Unânime & $\begin{array}{l}\text { Recurso } \\
\text { provido. } \\
\text { Extinção do } \\
\text { processo sem } \\
\text { exame do } \\
\text { mérito. }\end{array}$ & $\begin{array}{l}\text { Erbetta } \\
\text { Filho }\end{array}$ & $\begin{array}{l}\text { JTJ } \\
\text { v.198, p.142 }\end{array}$ \\
\hline $265.694-1$ & $\begin{array}{l}\text { Apelação } \\
\text { Cível }\end{array}$ & 1997 & $\begin{array}{l}\text { Poder de } \\
\text { regulação } \\
\text { estatal }\end{array}$ & $\begin{array}{l}\text { Mensalidade } \\
\text { escolar }\end{array}$ & Piracicaba & $\begin{array}{l}\text { Ministério } \\
\text { Público }\end{array}$ & $\begin{array}{l}\text { Colégio } \\
\text { Salesiano } \\
\text { Dom Bosco }\end{array}$ & $\begin{array}{l}\text { Informação } \\
\text { ausente }\end{array}$ & $\begin{array}{l}\text { Informação } \\
\text { ausente }\end{array}$ & $\begin{array}{l}\text { Recurso } \\
\text { provido }\end{array}$ & $\begin{array}{l}\text { Informação } \\
\text { ausente }\end{array}$ & $\begin{array}{l}\text { JTJ } \\
\text { v.205, p.9 }\end{array}$ \\
\hline \multicolumn{13}{|l|}{1998} \\
\hline $24.150-4$ & $\begin{array}{l}\text { Apelação } \\
\text { Cível }\end{array}$ & 1998 & $\begin{array}{l}\text { Responsabili } \\
\text { dade estatal }\end{array}$ & $\begin{array}{l}\text { Ação de } \\
\text { reparação de } \\
\text { danos }\end{array}$ & São Paulo & $\begin{array}{l}\text { Colégio Stella } \\
\text { Maris }\end{array}$ & $\begin{array}{l}\text { D.W.H. } \\
\text { menor } \\
\text { representado } \\
\text { pelos pais }\end{array}$ & $\begin{array}{l}7^{\text {a }} \text { Câmara } \\
\text { de Direito } \\
\text { Privado }\end{array}$ & Unânime & $\begin{array}{l}\text { Recurso não } \\
\text { provido }\end{array}$ & $\begin{array}{l}\text { Benini } \\
\text { Cabral }\end{array}$ & $\begin{array}{l}\text { JTJ } \\
\text { v.207, p.112 }\end{array}$ \\
\hline $27.984-5$ & $\begin{array}{l}\text { Apelação } \\
\text { Cível }\end{array}$ & 1998 & Permanência & $\begin{array}{l}\text { Violação às } \\
\text { normas } \\
\text { escolares }\end{array}$ & São Paulo & $\begin{array}{l}\text { Criança ou } \\
\text { adolescente } \\
\text { representado } \\
\text { pelo pai }\end{array}$ & $\begin{array}{l}\text { Diretoria da } \\
\text { Sociedade } \\
\text { Educacional } \\
\text { Doze de } \\
\text { Outubro Ltda. }\end{array}$ & $\begin{array}{l}4^{\text {a }} \text { Câmara } \\
\text { de Direito } \\
\text { Público }\end{array}$ & Unânime & $\begin{array}{l}\text { Recurso não } \\
\text { provido }\end{array}$ & $\begin{array}{l}\text { Nelson } \\
\text { Schiesari }\end{array}$ & $\begin{array}{l}\text { JTJ } \\
\text { v. } 219, \text { p.51 }\end{array}$ \\
\hline $31.149-5$ & $\begin{array}{l}\text { Apelação } \\
\text { Cível }\end{array}$ & 1998 & $\begin{array}{l}\text { Acesso à } \\
\text { educação } \\
\text { básica }\end{array}$ & Acesso EF & $\begin{array}{l}\text { Informação } \\
\text { ausente }\end{array}$ & $\begin{array}{l}\text { Informação } \\
\text { ausente }\end{array}$ & $\begin{array}{l}\text { Informação } \\
\text { ausente }\end{array}$ & $\begin{array}{l}4^{\mathrm{a}} \text { Câmara } \\
\text { de Direito } \\
\text { Público }\end{array}$ & Unânime & $\begin{array}{l}\text { Recurso não } \\
\text { provido }\end{array}$ & $\begin{array}{l}\text { Eduardo } \\
\text { Braga }\end{array}$ & $\begin{array}{l}\text { Sítio eletrônico } \\
\text { biblioteca TJ- } \\
\text { SP }\end{array}$ \\
\hline $35.389-5$ & $\begin{array}{l}\text { Apelação } \\
\text { Cível }\end{array}$ & 1998 & $\begin{array}{l}\text { Acesso à } \\
\text { educação } \\
\text { básica }\end{array}$ & $\begin{array}{l}\text { Acesso Ed } \\
\text { Profissional }\end{array}$ & Jaú & $\begin{array}{l}\text { Juízo Ex } \\
\text { Officio / } \\
\text { Fazenda do } \\
\text { Estado de São } \\
\text { Paulo }\end{array}$ & P.A.M. & $\begin{array}{l}\text { 9a Câmara } \\
\text { de Direito } \\
\text { Público }\end{array}$ & Unânime & $\begin{array}{l}\text { Recurso não } \\
\text { provido }\end{array}$ & $\begin{array}{l}\text { Santi } \\
\text { Ribeiro }\end{array}$ & $\begin{array}{l}\text { JTJ } \\
\text { v.224, p.54 }\end{array}$ \\
\hline $40.896-0 / 0$ & $\begin{array}{l}\text { Apelação } \\
\text { Cível }\end{array}$ & 1998 & $\begin{array}{l}\text { Acesso à } \\
\text { educação } \\
\text { básica }\end{array}$ & Acesso EF & Marília & $\begin{array}{l}\text { Informação } \\
\text { ausente }\end{array}$ & $\begin{array}{l}\text { Informação } \\
\text { ausente }\end{array}$ & $\begin{array}{l}\text { Informação } \\
\text { ausente }\end{array}$ & $\begin{array}{l}\text { Informação } \\
\text { ausente }\end{array}$ & $\begin{array}{l}\text { Recurso não } \\
\text { provido }\end{array}$ & $\begin{array}{l}\text { Luís de } \\
\text { Macedo }\end{array}$ & Publicação MP \\
\hline
\end{tabular}




\begin{tabular}{|c|c|c|c|c|c|c|c|c|c|c|c|c|}
\hline $\begin{array}{l}\text { Número } \\
\text { decisão }\end{array}$ & Natureza & Ano & Categorias & Tema & Origem & $\begin{array}{l}\text { Apelante } \\
\text { recorrente }\end{array}$ & $\begin{array}{l}\text { Apelados } \\
\text { recorridos }\end{array}$ & Câmara & Votação & Resultado & Relator & $\begin{array}{l}\text { Localização } \\
\text { da ementa / } \\
\text { acórdão }\end{array}$ \\
\hline $41.518-0$ & $\begin{array}{l}\text { Apelação } \\
\text { Cível }\end{array}$ & 1998 & $\begin{array}{l}\text { Acesso à } \\
\text { educação } \\
\text { básica }\end{array}$ & Acesso EF & Osasco & $\begin{array}{l}\text { Juízo Ex } \\
\text { Officio / } \\
\text { Fazenda do } \\
\text { Estado de São } \\
\text { Paulo }\end{array}$ & & \begin{tabular}{|l} 
Câmara \\
Especial
\end{tabular} & Unânime & $\begin{array}{l}\text { Recurso não } \\
\text { provido }\end{array}$ & $\begin{array}{l}\text { Luís de } \\
\text { Macedo }\end{array}$ & $\begin{array}{l}\text { Sítio eletrônico } \\
\text { biblioteca TJ- } \\
\text { SP }\end{array}$ \\
\hline $41.630 .0 / 5$ & $\begin{array}{l}\text { Apelação } \\
\text { Cível }\end{array}$ & 1998 & $\begin{array}{l}\text { Acesso à } \\
\text { educação } \\
\text { básica }\end{array}$ & Acesso EF & São Paulo & $\begin{array}{l}\text { Fazenda do } \\
\text { Estado }\end{array}$ & \begin{tabular}{|l|} 
Promotor de \\
Justiça da \\
Vara da \\
Infância e \\
Juventude do \\
Foro \\
Regional de \\
Pinheiros \\
\end{tabular} & \begin{tabular}{|l|} 
Câmara \\
Especial
\end{tabular} & $\begin{array}{l}\text { Provimento } \\
\text { parcial ao } \\
\text { apelo, } \\
\text { rejeitando a } \\
\text { preliminar }\end{array}$ & Unânime & $\begin{array}{l}\text { Cunha } \\
\text { Bueno }\end{array}$ & $\begin{array}{l}\text { Publicação } \\
\text { MP; Sítio } \\
\text { eletrônico TJ- } \\
\text { SP }\end{array}$ \\
\hline $42.228-0$ & $\begin{array}{l}\text { Apelação } \\
\text { Cível }\end{array}$ & 1998 & $\begin{array}{l}\text { Acesso à } \\
\text { educação } \\
\text { básica }\end{array}$ & Acesso EF & Mauá & $\begin{array}{l}\text { Informação } \\
\text { ausente }\end{array}$ & \begin{tabular}{|l|}
$\begin{array}{l}\text { Informação } \\
\text { ausente }\end{array}$ \\
\end{tabular} & \begin{tabular}{|l|} 
Câmara \\
Especial
\end{tabular} & Unânime & $\begin{array}{l}\text { Recurso não } \\
\text { provido }\end{array}$ & $\begin{array}{l}\text { Luís de } \\
\text { Macedo }\end{array}$ & $\begin{array}{l}\text { Sítio eletrônico } \\
\text { biblioteca TJ- } \\
\text { SP }\end{array}$ \\
\hline $42.264-0$ & $\begin{array}{l}\text { Apelação } \\
\text { Cível }\end{array}$ & 1998 & $\begin{array}{l}\text { Acesso à } \\
\text { educação } \\
\text { básica }\end{array}$ & Acesso EF & Mauá & $\begin{array}{l}\text { Informação } \\
\text { ausente }\end{array}$ & $\begin{array}{l}\text { Informação } \\
\text { ausente }\end{array}$ & \begin{tabular}{|l|} 
Câmara \\
Especial
\end{tabular} & Unânime & $\begin{array}{l}\text { Recurso não } \\
\text { provido }\end{array}$ & \begin{tabular}{|l|} 
Luís de \\
Macedo
\end{tabular} & $\begin{array}{l}\text { Sítio eletrônico } \\
\text { biblioteca TJ- } \\
\text { SP }\end{array}$ \\
\hline $43.245-5 / 0$ & $\begin{array}{l}\text { Apelação } \\
\text { Cível }\end{array}$ & 1998 & $\begin{array}{l}\text { Acesso à } \\
\text { educação } \\
\text { básica }\end{array}$ & Acesso EF & Valparaíso & \begin{tabular}{|l} 
Juízo Ex \\
Officio
\end{tabular} & Criança & $\begin{array}{l}5^{\text {a Câmara }} \\
\text { "Julho/98" } \\
\text { de Direito } \\
\text { Público }\end{array}$ & Unânime & $\begin{array}{l}\text { Recurso não } \\
\text { provido }\end{array}$ & $\begin{array}{l}\text { Paulo } \\
\text { Franco }\end{array}$ & $\begin{array}{l}\text { Sítio eletrônico } \\
\text { TJ-SP }\end{array}$ \\
\hline $44.389-0 / 6$ & $\begin{array}{l}\text { Apelação } \\
\text { Cível }\end{array}$ & 1998 & $\begin{array}{l}\text { Responsabili } \\
\text { dade estatal }\end{array}$ & $\begin{array}{l}\text { Condições de } \\
\text { funcionament } \\
\text { o das escolas }\end{array}$ & São Paulo & $\begin{array}{l}\text { Informação } \\
\text { ausente }\end{array}$ & $\begin{array}{l}\text { Informação } \\
\text { ausente }\end{array}$ & $\begin{array}{l}\text { Informação } \\
\text { ausente }\end{array}$ & $\begin{array}{l}\text { Informação } \\
\text { ausente }\end{array}$ & $\begin{array}{l}\text { Recurso não } \\
\text { provido }\end{array}$ & $\begin{array}{l}\text { Oetterer } \\
\text { Guedes }\end{array}$ & Publicação MP \\
\hline $44.586-0 / 5$ & $\begin{array}{l}\text { Apelação } \\
\text { Cível }\end{array}$ & 1998 & $\begin{array}{l}\text { Acesso à } \\
\text { educação } \\
\text { básica }\end{array}$ & Acesso EF & São Paulo & \begin{tabular}{|l|} 
Fazenda do \\
Estado de SP
\end{tabular} & $\begin{array}{l}\text { Ministério } \\
\text { Público }\end{array}$ & \begin{tabular}{|l|} 
Câmara \\
Especial
\end{tabular} & Unânime & $\begin{array}{l}\text { Recurso } \\
\text { negado }\end{array}$ & \begin{tabular}{|l} 
Oetterer \\
Guedes
\end{tabular} & $\begin{array}{l}\text { Publicação } \\
\text { MP; Sítio } \\
\text { eletrônico } \\
\text { biblioteca TJ- } \\
\text { SP }\end{array}$ \\
\hline $45.068-5 / 7$ & $\begin{array}{l}\text { Apelação } \\
\text { Cível }\end{array}$ & 1998 & $\begin{array}{l}\text { Acesso à } \\
\text { educação } \\
\text { básica }\end{array}$ & Acesso EF & Valparaíso & \begin{tabular}{|l} 
Juízo Ex \\
Offício
\end{tabular} & Criança & $\begin{array}{l}5^{\text {a }} \text { Câmara } \\
\text { de Direito } \\
\text { Público, } \\
\text { julho } 98\end{array}$ & Unânime & $\begin{array}{l}\text { Recurso não } \\
\text { provido }\end{array}$ & \begin{tabular}{|l|} 
Paulo \\
Franco
\end{tabular} & $\begin{array}{l}\text { Sítio eletrônico } \\
\text { TJ-SP }\end{array}$ \\
\hline
\end{tabular}




\begin{tabular}{|c|c|c|c|c|c|c|c|c|c|c|c|c|}
\hline $\begin{array}{l}\text { Número } \\
\text { decisão }\end{array}$ & Natureza & Ano & Categorias & Tema & Origem & $\begin{array}{l}\text { Apelante } \\
\text { recorrente }\end{array}$ & \begin{tabular}{|l|} 
Apelados \\
recorridos
\end{tabular} & Câmara & Votação & Resultado & Relator & $\begin{array}{l}\text { Localização } \\
\text { da ementa / } \\
\text { acórdão }\end{array}$ \\
\hline $45.244-5 / 0$ & \begin{tabular}{|l|} 
Apelação \\
Cível
\end{tabular} & 1998 & $\begin{array}{l}\text { Acesso à } \\
\text { educação } \\
\text { básica }\end{array}$ & Acesso EF & Valparaíso & \begin{tabular}{|l} 
Juízo Ex \\
Officio
\end{tabular} & \begin{tabular}{|l} 
Menor \\
representado \\
pela mãe
\end{tabular} & $\begin{array}{l}5^{\text {a }} \text { Câmara } \\
\text { de Direito } \\
\text { Público, } \\
\text { julho } 98\end{array}$ & Unânime & $\begin{array}{l}\text { Recurso não } \\
\text { provido }\end{array}$ & \begin{tabular}{|l|} 
Borelli \\
Machado
\end{tabular} & $\begin{array}{l}\text { Sítio eletrônico } \\
\text { TJ-SP }\end{array}$ \\
\hline $45.274-5 / 7$ & \begin{tabular}{|l} 
Apelação \\
Cível
\end{tabular} & 1998 & $\begin{array}{l}\text { Acesso à } \\
\text { educação } \\
\text { básica }\end{array}$ & Acesso EF & $\begin{array}{l}\text { Cajamar/Ju } \\
\text { ndiaí }\end{array}$ & \begin{tabular}{|l} 
Juízo Ex \\
Officio
\end{tabular} & $\begin{array}{l}\text { Ministério } \\
\text { Público }\end{array}$ & \begin{tabular}{|l|}
$5^{\text {a }}$ Câmara \\
de Direito \\
Público
\end{tabular} & Unânime & $\begin{array}{l}\text { Recurso não } \\
\text { provido }\end{array}$ & \begin{tabular}{|l|} 
Borelli \\
Machado
\end{tabular} & $\begin{array}{l}\text { Sítio eletrônico } \\
\text { TJ-SP }\end{array}$ \\
\hline $45.733-5 / 2$ & \begin{tabular}{|l|} 
Apelação \\
Cível
\end{tabular} & 1998 & $\begin{array}{l}\text { Acesso à } \\
\text { educação } \\
\text { básica }\end{array}$ & Acesso EF & \begin{tabular}{|l|} 
São \\
Caetano do \\
Sul
\end{tabular} & \begin{tabular}{|l} 
Juízo Ex \\
Officio
\end{tabular} & Criança & $\begin{array}{l}5^{\text {a }} \text { Câmara } \\
\text { de Direito } \\
\text { Público, } \\
\text { julho } 98\end{array}$ & Unânime & $\begin{array}{l}\text { Recurso não } \\
\text { provido }\end{array}$ & \begin{tabular}{|l|} 
Paulo \\
Franco
\end{tabular} & $\begin{array}{l}\text { Sítio eletrônico } \\
\text { TJ-SP }\end{array}$ \\
\hline $45.925-0 / 0$ & $\begin{array}{l}\text { Apelação } \\
\text { Cível }\end{array}$ & 1998 & $\begin{array}{l}\text { Acesso à } \\
\text { educação } \\
\text { básica }\end{array}$ & Acesso EF & Guarulhos & \begin{tabular}{|c|} 
Informação \\
indisponível
\end{tabular} & \begin{tabular}{|l|} 
Informação \\
indisponível
\end{tabular} & \begin{tabular}{|} 
Informação \\
indisponível
\end{tabular} & $\begin{array}{l}\text { Informação } \\
\text { ausente }\end{array}$ & $\begin{array}{l}\text { Recurso não } \\
\text { provido }\end{array}$ & \begin{tabular}{|l} 
Oetterer \\
Guedes
\end{tabular} & Publicação MP \\
\hline $45.937-5$ & \begin{tabular}{|l|} 
Apelação \\
Cível
\end{tabular} & 1998 & $\begin{array}{l}\text { Poder de } \\
\text { regulação } \\
\text { estatal }\end{array}$ & \begin{tabular}{|l|} 
Mensalidade \\
escolar
\end{tabular} & \begin{tabular}{|l} 
Vargem \\
Grande do \\
Sul
\end{tabular} & $\begin{array}{l}\text { Juízo Ex } \\
\text { Officio }\end{array}$ & \begin{tabular}{|l|} 
Criança ou \\
adolescente \\
representado \\
pelos pais
\end{tabular} & $\begin{array}{l}7^{\mathrm{a}} \text { Câmara } \\
\text { de Direito } \\
\text { Público }\end{array}$ & $\begin{array}{l}\text { Recurso não } \\
\text { provido }\end{array}$ & Unânime & \begin{tabular}{|l|} 
Barreto \\
Fonseca
\end{tabular} & \begin{tabular}{|l|} 
JTJ \\
v. 209, p.111
\end{tabular} \\
\hline $45.942-5 / 6$ & $\begin{array}{l}\text { Apelação } \\
\text { Cível }\end{array}$ & 1998 & $\begin{array}{l}\text { Acesso à } \\
\text { educação } \\
\text { básica }\end{array}$ & Acesso EF & Promissão & \begin{tabular}{|l} 
Juízo Ex \\
Officio
\end{tabular} & $\begin{array}{l}\text { Criança ou } \\
\text { adolescente } \\
\text { representado } \\
\text { pelos pais }\end{array}$ & $\begin{array}{l}5^{\text {a }} \text { Câmara } \\
\text { de Direito } \\
\text { Público, } \\
\text { julho } 98\end{array}$ & Unânime & $\begin{array}{l}\text { Recurso não } \\
\text { provido }\end{array}$ & \begin{tabular}{|l|} 
Paulo \\
Franco
\end{tabular} & $\begin{array}{l}\text { Sítio eletrônico } \\
\text { TJ-SP }\end{array}$ \\
\hline $45.948-5 / 3$ & $\begin{array}{l}\text { Apelação } \\
\text { Cível }\end{array}$ & 1998 & $\begin{array}{l}\text { Acesso à } \\
\text { educação } \\
\text { básica }\end{array}$ & Acesso EF & Valparaíso & \begin{tabular}{|l} 
Juízo Ex \\
Officio
\end{tabular} & \begin{tabular}{|l|} 
Criança ou \\
adolescente \\
representado \\
pelos pais \\
\end{tabular} & $\begin{array}{l}5^{\text {a }} \text { Câmara } \\
\text { de Direito } \\
\text { Público, } \\
\text { julho/98 }\end{array}$ & Unânime & $\begin{array}{l}\text { Recurso não } \\
\text { provido }\end{array}$ & \begin{tabular}{|l|} 
Borelli \\
Machado
\end{tabular} & $\begin{array}{l}\text { Sítio eletrônico } \\
\text { TJ-SP }\end{array}$ \\
\hline $46.493-5 / 3$ & $\begin{array}{l}\text { Apelação } \\
\text { Cível }\end{array}$ & 1998 & $\begin{array}{l}\text { Acesso à } \\
\text { educação } \\
\text { básica }\end{array}$ & Acesso EF & Araçatuba & \begin{tabular}{|l|} 
Juízo Ex \\
Officio
\end{tabular} & \begin{tabular}{|l} 
Criança ou \\
adolescente \\
representado \\
pelos pais \\
\end{tabular} & $\begin{array}{l}\text { 5 Câmara } \\
\text { de Direito } \\
\text { Público, } \\
\text { julho/98 }\end{array}$ & Unânime & $\begin{array}{l}\text { Recurso não } \\
\text { provido }\end{array}$ & \begin{tabular}{|l} 
Borelli \\
Machado
\end{tabular} & $\begin{array}{l}\text { Sítio eletrônico } \\
\text { TJ-SP }\end{array}$ \\
\hline $46.521-0 / 4$ & \begin{tabular}{|l} 
Apelação \\
Cível
\end{tabular} & 1998 & $\begin{array}{l}\text { Acesso à } \\
\text { educação } \\
\text { básica }\end{array}$ & Acesso EF & Guarulhos & $\begin{array}{l}\text { Informação } \\
\text { indisponível }\end{array}$ & $\begin{array}{l}\text { Informação } \\
\text { indisponível }\end{array}$ & $\begin{array}{l}\text { Informação } \\
\text { indisponível }\end{array}$ & $\begin{array}{l}\text { Informação } \\
\text { ausente }\end{array}$ & $\begin{array}{l}\text { Informação } \\
\text { indisponível }\end{array}$ & \begin{tabular}{|l|} 
Álvaro \\
Lazzarini
\end{tabular} & Publicação MP \\
\hline $46.716-5 / 2$ & \begin{tabular}{|l} 
Apelação \\
Cível
\end{tabular} & 1998 & $\begin{array}{l}\text { Acesso à } \\
\text { educação } \\
\text { básica }\end{array}$ & Acesso EF & Valparaíso & \begin{tabular}{|l} 
Juízo Ex \\
Officio
\end{tabular} & Criança & $\begin{array}{l}5^{\text {a }} \text { Câmara } \\
\text { de Direito } \\
\text { Público, } \\
\text { julho } 98\end{array}$ & Unânime & $\begin{array}{l}\text { Recurso não } \\
\text { provido }\end{array}$ & \begin{tabular}{|l|} 
Paulo \\
Franco
\end{tabular} & $\begin{array}{l}\text { Sítio eletrônico } \\
\text { TJ-SP }\end{array}$ \\
\hline
\end{tabular}




\begin{tabular}{|c|c|c|c|c|c|c|c|c|c|c|c|c|}
\hline $\begin{array}{l}\text { Número } \\
\text { decisão }\end{array}$ & Natureza & Ano & Categorias & Tema & Origem & $\begin{array}{l}\text { Apelante } \\
\text { recorrente }\end{array}$ & $\begin{array}{l}\text { Apelados } \\
\text { recorridos }\end{array}$ & Câmara & Votação & Resultado & Relator & $\begin{array}{l}\text { Localização } \\
\text { da ementa / } \\
\text { acórdão }\end{array}$ \\
\hline $46.784-5 / 1$ & $\begin{array}{l}\text { Apelação } \\
\text { Cível }\end{array}$ & 1998 & $\begin{array}{l}\text { Acesso à } \\
\text { educaçãoo } \\
\text { básica }\end{array}$ & Acesso EF & Araçatuba & $\begin{array}{l}\text { Juízo Ex } \\
\text { Officio }\end{array}$ & $\begin{array}{l}\text { menor } \\
\text { representado } \\
\text { pelo pai }\end{array}$ & $\begin{array}{l}8^{\text {a Câmara }} \\
\text { "Julho/98" } \\
\text { de Direito } \\
\text { Público }\end{array}$ & Unânime & $\begin{array}{l}\text { Recurso não } \\
\text { provido }\end{array}$ & $\begin{array}{l}\text { Todelo } \\
\text { Silva }\end{array}$ & $\begin{array}{l}\text { Sítio biblioteca } \\
\text { TJ-SP; Sítio } \\
\text { TJ-SP }\end{array}$ \\
\hline $47.081-0$ & $\begin{array}{l}\text { Agravo de } \\
\text { Instrumento }\end{array}$ & 1998 & $\begin{array}{l}\text { Gestão dos } \\
\text { recursos } \\
\text { públicos }\end{array}$ & $\begin{array}{l}\text { Aplicação } \\
\text { dos recursos }\end{array}$ & São Paulo & $\begin{array}{l}\text { Município de } \\
\text { São Paulo }\end{array}$ & $\begin{array}{l}\text { Ministério } \\
\text { Público/ Foro } \\
\text { Regional de } \\
\text { Pinheiros }\end{array}$ & $\begin{array}{l}\text { Câmara } \\
\text { Especial }\end{array}$ & Unânime & $\begin{array}{l}\text { Anular o } \\
\text { processo por } \\
\text { incompetênci } \\
\text { a do Juízo e } \\
\text { determinar a } \\
\text { distribuição } \\
\text { dos autos } \\
\text { para a Vara } \\
\text { da Fazenda } \\
\text { Pública }\end{array}$ & Alves Braga & $\begin{array}{l}\text { JTJ } \\
\text { v. } 222, \text { p.200 }\end{array}$ \\
\hline $47.498-015$ & $\begin{array}{l}\text { Apelação } \\
\text { Cível }\end{array}$ & 1998 & $\begin{array}{l}\text { Acesso à } \\
\text { educação } \\
\text { básica }\end{array}$ & Acesso EF & São Paulo & $\begin{array}{l}\text { Promotor de } \\
\text { Justiça da Vara } \\
\text { Central da } \\
\text { Infância e } \\
\text { Juventude da } \\
\text { Capital }\end{array}$ & $\begin{array}{l}\text { Delegado } \\
\text { Estadual de } \\
\text { Ensino da } 5^{\text {a }} \\
\text { Delegacia de } \\
\text { Ensino da } \\
\text { Capital }\end{array}$ & $\begin{array}{l}\text { Câmara } \\
\text { Especial }\end{array}$ & Unânime & $\begin{array}{l}\text { Provimento } \\
\text { ao recurso } \\
\text { para } \\
\text { determinar o } \\
\text { prosseguime } \\
\text { nto do } \\
\text { processo no } \\
\text { Juízo de } \\
\text { origem }\end{array}$ & $\begin{array}{l}\text { Álvaro } \\
\text { Lazzarini }\end{array}$ & $\begin{array}{l}\text { Publicação } \\
\text { MP; Sítio } \\
\text { eletrônico TJ- } \\
\text { SP }\end{array}$ \\
\hline $47.503-0 / 0$ & $\begin{array}{l}\text { Apelação } \\
\text { Cível }\end{array}$ & 1998 & $\begin{array}{l}\text { Acesso à } \\
\text { educação } \\
\text { básica }\end{array}$ & Acesso EF & São Paulo & $\begin{array}{l}\text { Promotoria de } \\
\text { Justiça da Vara } \\
\text { da Infância e } \\
\text { Juventude da } \\
\text { Capital }\end{array}$ & $\begin{array}{l}\text { Delegado } \\
\text { Estadual de } \\
\text { Ensino da } \\
\text { Quinta } \\
\text { Delegacia de } \\
\text { Ensino da } \\
\text { Capital }\end{array}$ & $\begin{array}{l}\text { Câmara } \\
\text { Especial }\end{array}$ & Unânime & $\begin{array}{l}\text { Recurso } \\
\text { provido }\end{array}$ & $\begin{array}{l}\text { Djalma } \\
\text { Lofrano }\end{array}$ & $\begin{array}{l}\text { Publicação } \\
\text { MP; Sítio } \\
\text { eletrônico TJ- } \\
\text { SP }\end{array}$ \\
\hline $47.540-5 / 6$ & $\begin{array}{l}\text { Apelação } \\
\text { Cível }\end{array}$ & 1998 & $\begin{array}{l}\text { Acesso à } \\
\text { educação } \\
\text { básica }\end{array}$ & Acesso EF & Araçatuba & $\begin{array}{l}\text { Fazenda do } \\
\text { Estado de SP }\end{array}$ & $\begin{array}{l}\text { Criança } \\
\text { representada } \\
\text { pelo pai }\end{array}$ & $\begin{array}{l}5^{\text {a }} \text { Câmara } \\
\text { de Direito } \\
\text { Público, } \\
\text { julho } 98\end{array}$ & Unânime & $\begin{array}{l}\text { Recurso não } \\
\text { provido }\end{array}$ & $\begin{array}{l}\text { Borelli } \\
\text { Machado }\end{array}$ & $\begin{array}{l}\text { Sítio eletrônico } \\
\text { TJ-SP }\end{array}$ \\
\hline
\end{tabular}




\begin{tabular}{|c|c|c|c|c|c|c|c|c|c|c|c|c|}
\hline $\begin{array}{l}\text { Número } \\
\text { decisão }\end{array}$ & Natureza & Ano & Categorias & Tema & Origem & $\begin{array}{l}\text { Apelante } \\
\text { recorrente }\end{array}$ & $\begin{array}{l}\text { Apelados } \\
\text { recorridos }\end{array}$ & Câmara & Votação & Resultado & Relator & $\begin{array}{l}\text { Localização } \\
\text { da ementa / } \\
\text { acórdão }\end{array}$ \\
\hline $\begin{array}{l}47.551 .0 / 8- \\
00\end{array}$ & $\begin{array}{l}\text { Apelação } \\
\text { Cível }\end{array}$ & 1998 & $\begin{array}{l}\text { Acesso à } \\
\text { educação } \\
\text { básica }\end{array}$ & Acesso EF & São Paulo & $\begin{array}{l}\text { Ministério } \\
\text { Público }\end{array}$ & $\begin{array}{l}\text { Delegado } \\
\text { Estadual de } \\
\text { Ensino da } 13^{\text {a }} \\
\text { Delegacia de } \\
\text { Ensino da } \\
\text { Capital }\end{array}$ & $\begin{array}{l}\text { Câmara } \\
\text { Especial }\end{array}$ & Unânime & $\begin{array}{l}\text { Provimento } \\
\text { ao recurso } \\
\text { para anular a } \\
\text { decisão que } \\
\text { decretou a } \\
\text { extinção do } \\
\text { feito. }\end{array}$ & Alves Braga & $\begin{array}{l}\text { Publicação } \\
\text { MP; Sítio } \\
\text { eletrônico TJ- } \\
\text { SP }\end{array}$ \\
\hline $48.446-0 / 6$ & $\begin{array}{l}\text { Agravo de } \\
\text { Instrumento }\end{array}$ & 1998 & $\begin{array}{l}\text { Decisões } \\
\text { administrativ } \\
\text { as e políticas }\end{array}$ & Outros & Jardinópolis & $\begin{array}{l}\text { Informação } \\
\text { ausente }\end{array}$ & $\begin{array}{l}\text { Informação } \\
\text { ausente }\end{array}$ & $\begin{array}{l}\text { Informação } \\
\text { ausente }\end{array}$ & $\begin{array}{l}\text { Informação } \\
\text { ausente }\end{array}$ & $\begin{array}{l}\text { Recurso não } \\
\text { provido }\end{array}$ & $\begin{array}{l}\text { Yussef } \\
\text { Cahali }\end{array}$ & Publicação MP \\
\hline $48.888-0$ & $\begin{array}{l}\text { Apelação } \\
\text { Cível }\end{array}$ & 1998 & $\begin{array}{l}\text { Acesso à } \\
\text { educação } \\
\text { básica }\end{array}$ & Acesso EF & Sorocaba & Indisponível & Indisponível & $\begin{array}{l}\text { Câmara } \\
\text { Especial }\end{array}$ & Unânime & $\begin{array}{l}\text { Recurso não } \\
\text { provido }\end{array}$ & $\begin{array}{l}\text { Alvaro } \\
\text { Lazzarini }\end{array}$ & $\begin{array}{l}\text { Sítio eletrônico } \\
\text { biblioteca TJ- } \\
\text { SP }\end{array}$ \\
\hline $49.187-0 / 0$ & $\begin{array}{l}\text { Apelação } \\
\text { Cível }\end{array}$ & 1998 & $\begin{array}{l}\text { Acesso à } \\
\text { educação } \\
\text { básica }\end{array}$ & Acesso EF & Serra Negra & Indisponível & Indisponível & Indisponível & $\begin{array}{l}\text { Informação } \\
\text { ausente }\end{array}$ & $\begin{array}{l}\text { Recurso não } \\
\text { provido }\end{array}$ & $\begin{array}{l}\text { Oetterer } \\
\text { Guedes }\end{array}$ & Publicação MP \\
\hline $49.207-0$ & $\begin{array}{l}\text { Apelação } \\
\text { Cível }\end{array}$ & 1998 & $\begin{array}{l}\text { Acesso à } \\
\text { educação } \\
\text { básica }\end{array}$ & Acesso EF & Americana & Indisponível & Indisponível & $\begin{array}{l}\text { Câmara } \\
\text { Especial }\end{array}$ & Unânime & $\begin{array}{l}\text { Recurso não } \\
\text { provido }\end{array}$ & $\begin{array}{l}\text { Djalma } \\
\text { Lofrano }\end{array}$ & $\begin{array}{l}\text { Sítio eletrônico } \\
\text { biblioteca TJ- } \\
\text { SP }\end{array}$ \\
\hline $49.324-5 / 5$ & $\begin{array}{l}\text { Apelação } \\
\text { Cível }\end{array}$ & 1998 & $\begin{array}{l}\text { Acesso à } \\
\text { educação } \\
\text { básica }\end{array}$ & Acesso EF & $\begin{array}{l}\text { Palmeira } \\
\text { D'Oeste }\end{array}$ & $\begin{array}{l}\text { Fazenda do } \\
\text { Estado de SP }\end{array}$ & $\begin{array}{l}\text { Criança ou } \\
\text { adolescente } \\
\text { representado } \\
\text { pelos pais }\end{array}$ & $\begin{array}{l}5^{\text {a }} \text { Câmara } \\
\text { de Direito } \\
\text { Público }\end{array}$ & Unânime & $\begin{array}{l}\text { Recurso não } \\
\text { provido }\end{array}$ & $\begin{array}{l}\text { Borelli } \\
\text { Machado }\end{array}$ & $\begin{array}{l}\text { Sítio eletrônico } \\
\text { TJ-SP }\end{array}$ \\
\hline $49.626-5 / 3$ & $\begin{array}{l}\text { Apelação } \\
\text { Cível }\end{array}$ & 1998 & $\begin{array}{l}\text { Acesso à } \\
\text { educaçãao } \\
\text { básica }\end{array}$ & Acesso EF & Araçatuba & $\begin{array}{l}\text { Fazenda do } \\
\text { Estado de SP }\end{array}$ & $\begin{array}{l}\text { Criança ou } \\
\text { adolescente } \\
\text { representado } \\
\text { pelos pais } \\
\end{array}$ & $\begin{array}{l}4^{\text {a }} \text { Câmara } \\
\text { de Direito } \\
\text { Público }\end{array}$ & Unânime & $\begin{array}{l}\text { Recurso não } \\
\text { provido }\end{array}$ & $\begin{array}{l}\text { Vianna } \\
\text { Santos }\end{array}$ & $\begin{array}{l}\text { Sítio eletrônico } \\
\text { biblioteca TJ- } \\
\text { SP }\end{array}$ \\
\hline $49.732-0$ & $\begin{array}{l}\text { Recurso Ex } \\
\text { Officio }\end{array}$ & 1998 & $\begin{array}{l}\text { Acesso à } \\
\text { educação } \\
\text { básica }\end{array}$ & Acesso EF & Ausente & Ausente & Ausente & $\begin{array}{l}\text { Câmara } \\
\text { Especial }\end{array}$ & Unânime & $\begin{array}{l}\text { Recurso não } \\
\text { provido }\end{array}$ & Alves Braga & $\begin{array}{l}\text { JTJ } \\
\text { v. } 211, \text { p. } 140\end{array}$ \\
\hline $49.804-5 / 6$ & $\begin{array}{l}\text { Apelação } \\
\text { Cível }\end{array}$ & 1998 & $\begin{array}{l}\text { Acesso à } \\
\text { educação } \\
\text { básica }\end{array}$ & Acesso EF & Guararapes & $\begin{array}{l}\text { Fazenda do } \\
\text { Estado de SP }\end{array}$ & $\begin{array}{l}\text { Criança ou } \\
\text { adolescente }\end{array}$ & $\begin{array}{l}5^{\text {a }} \text { Câmara } \\
\text { de Direito } \\
\text { Público }\end{array}$ & Unânime & $\begin{array}{l}\text { Recurso não } \\
\text { provido }\end{array}$ & $\begin{array}{l}\text { Borelli } \\
\text { Machado }\end{array}$ & $\begin{array}{l}\text { Sítio eletrônico } \\
\text { TJ-SP }\end{array}$ \\
\hline
\end{tabular}




\begin{tabular}{|c|c|c|c|c|c|c|c|c|c|c|c|c|}
\hline $\begin{array}{l}\text { Número } \\
\text { decisão }\end{array}$ & Natureza & Ano & Categorias & Tema & Origem & $\begin{array}{l}\text { Apelante } \\
\text { recorrente }\end{array}$ & $\begin{array}{l}\text { Apelados } \\
\text { recorridos }\end{array}$ & Câmara & Votação & Resultado & Relator & $\begin{array}{l}\text { Localização } \\
\text { da ementa / } \\
\text { acórdão }\end{array}$ \\
\hline $50.205-0 / 7$ & $\begin{array}{l}\text { Apelação } \\
\text { Cível }\end{array}$ & 1998 & $\begin{array}{l}\text { Acesso à } \\
\text { educação } \\
\text { básica }\end{array}$ & Acesso EF & $\begin{array}{l}\text { Indisponíve } \\
1\end{array}$ & Indisponível & Indisponível & Indisponível & $\begin{array}{l}\text { Informação } \\
\text { ausente }\end{array}$ & $\begin{array}{l}\text { Recurso não } \\
\text { provido }\end{array}$ & $\begin{array}{l}\text { Márcio } \\
\text { Bonilha }\end{array}$ & Publicação MP \\
\hline $50.271-0 / 7$ & $\begin{array}{l}\text { Recurso Ex } \\
\text { Officio }\end{array}$ & 1998 & $\begin{array}{l}\text { Acesso à } \\
\text { educação } \\
\text { básica }\end{array}$ & Acesso EF & São Paulo & Indisponível & Indisponível & Indisponível & $\begin{array}{l}\text { Informação } \\
\text { ausente }\end{array}$ & & $\begin{array}{l}\text { Cunha } \\
\text { Bueno }\end{array}$ & Publicação MP \\
\hline $50.376-0 / 6$ & $\begin{array}{l}\text { Apelação } \\
\text { Cível }\end{array}$ & 1998 & $\begin{array}{l}\text { Acesso à } \\
\text { educação } \\
\text { básica }\end{array}$ & Acesso EF & $\begin{array}{l}\text { Mogi } \\
\text { Guaçu }\end{array}$ & Indisponível & Indisponível & Indisponível & $\begin{array}{l}\text { Informação } \\
\text { ausente }\end{array}$ & $\begin{array}{l}\text { Recurso não } \\
\text { provido }\end{array}$ & $\begin{array}{l}\text { Álvaro } \\
\text { Lazzarini }\end{array}$ & Publicação MP \\
\hline $50.392-0 / 9$ & $\begin{array}{l}\text { Recurso Ex } \\
\text { Officio }\end{array}$ & 1998 & $\begin{array}{l}\text { Acesso à } \\
\text { educação } \\
\text { básica }\end{array}$ & Acesso EF & São Paulo & Indisponível & Indisponível & Indisponível & $\begin{array}{l}\text { Informação } \\
\text { ausente }\end{array}$ & & $\begin{array}{l}\text { Álvaro } \\
\text { Lazzarini }\end{array}$ & $\begin{array}{l}\text { Sítio eletrônico } \\
\text { ABMP; } \\
\text { Publicação MP }\end{array}$ \\
\hline $50.566-0 / 3$ & $\begin{array}{l}\text { Apelação } \\
\text { Cível }\end{array}$ & 1998 & $\begin{array}{l}\text { Acesso à } \\
\text { educação } \\
\text { básica }\end{array}$ & Acesso EF & São Paulo & Indisponível & Indisponível & Indisponível & $\begin{array}{l}\text { Informação } \\
\text { ausente }\end{array}$ & & $\begin{array}{l}\text { Álvaro } \\
\text { Lazzarini }\end{array}$ & Publicação MP \\
\hline $50.613-0 / 9$ & $\begin{array}{l}\text { Apelação } \\
\text { Cível }\end{array}$ & 1998 & $\begin{array}{l}\text { Acesso à } \\
\text { educação } \\
\text { básica }\end{array}$ & Acesso EF & Marília & Indisponível & Indisponível & Indisponível & $\begin{array}{l}\text { Informação } \\
\text { ausente }\end{array}$ & & $\begin{array}{l}\text { Cunha } \\
\text { Bueno }\end{array}$ & Publicação MP \\
\hline $50.678-0$ & $\begin{array}{l}\text { Apelação } \\
\text { Cível }\end{array}$ & 1998 & $\begin{array}{l}\text { Acesso à } \\
\text { educação } \\
\text { básica }\end{array}$ & Acesso EF & Piracicaba & Indisponível & Indisponível & $\begin{array}{l}\text { Câmara } \\
\text { Especial }\end{array}$ & Unânime & $\begin{array}{l}\text { Recurso não } \\
\text { provido }\end{array}$ & $\begin{array}{l}\text { Djalma } \\
\text { Lofrano }\end{array}$ & $\begin{array}{l}\text { Sítio eletrônico } \\
\text { biblioteca TJ- } \\
\text { SP }\end{array}$ \\
\hline $50.862-0 / 4$ & $\begin{array}{l}\text { Recurso Ex } \\
\text { Officio }\end{array}$ & 1998 & $\begin{array}{l}\text { Acesso à } \\
\text { educação } \\
\text { básica }\end{array}$ & Acesso EF & São Paulo & $\begin{array}{l}\text { Juízo Ex } \\
\text { Officio }\end{array}$ & $\begin{array}{l}\text { Promotor de } \\
\text { Justiça da } \\
\text { Infância e } \\
\text { Juventude do } \\
\text { Foro } \\
\text { Regional de } \\
\text { Tatuapé }\end{array}$ & $\begin{array}{l}\text { Câmara } \\
\text { Especial }\end{array}$ & Unânime & $\begin{array}{l}\text { Recurso não } \\
\text { provido }\end{array}$ & $\begin{array}{l}\text { Cunha } \\
\text { Bueno }\end{array}$ & $\begin{array}{l}\text { Sítio eletrônico } \\
\text { TJ-SP }\end{array}$ \\
\hline $52.093-0 / 9$ & $\begin{array}{l}\text { Mandado de } \\
\text { segurança }\end{array}$ & 1998 & $\begin{array}{l}\text { Acesso à } \\
\text { educação } \\
\text { básica }\end{array}$ & Acesso EF & $\begin{array}{l}\text { Franco da } \\
\text { Rocha }\end{array}$ & Indisponível & Indisponível & Indisponível & $\begin{array}{l}\text { Informação } \\
\text { ausente }\end{array}$ & $\begin{array}{l}\text { Recurso não } \\
\text { provido }\end{array}$ & Alves Braga & Publicação MP \\
\hline $281.613-1$ & $\begin{array}{l}\text { Embargos } \\
\text { Infringentes }\end{array}$ & 1998 & $\begin{array}{l}\text { Poder de } \\
\text { regulação } \\
\text { estatal }\end{array}$ & $\begin{array}{l}\text { Mensalidade } \\
\text { escolar }\end{array}$ & $\begin{array}{l}\text { Guaratingu } \\
\text { etá }\end{array}$ & $\begin{array}{l}\text { Organização } \\
\text { Guará de } \\
\text { Ensino }\end{array}$ & $\begin{array}{l}\text { Ministério } \\
\text { Público }\end{array}$ & $\begin{array}{l}1^{\text {a }} \text { Câmara } \\
\text { de Direito } \\
\text { Privado }\end{array}$ & $\begin{array}{l}\text { Maioria dos } \\
\text { votos. }\end{array}$ & $\begin{array}{l}\text { Embargos } \\
\text { aceitos }\end{array}$ & $\begin{array}{l}\text { Luís de } \\
\text { Macedo }\end{array}$ & $\begin{array}{l}\text { JTJ v. } 210, \\
\text { p. } 226\end{array}$ \\
\hline
\end{tabular}




\begin{tabular}{|c|c|c|c|c|c|c|c|c|c|c|c|c|}
\hline $\begin{array}{l}\text { Número } \\
\text { decisão }\end{array}$ & Natureza & Ano & Categorias & Tema & Origem & $\begin{array}{l}\text { Apelante } \\
\text { recorrente }\end{array}$ & $\begin{array}{l}\text { Apelados } \\
\text { recorridos }\end{array}$ & Câmara & Votação & Resultado & Relator & $\begin{array}{l}\text { Localização } \\
\text { da ementa / } \\
\text { acórdão }\end{array}$ \\
\hline \multicolumn{13}{|l|}{1999} \\
\hline $39.019-5$ & $\begin{array}{l}\text { Apelação } \\
\text { Cível }\end{array}$ & 1999 & \begin{tabular}{|l|} 
Decisões \\
administrativ \\
as e políticas
\end{tabular} & \begin{tabular}{|l|} 
Programa de \\
reorganizaçã \\
o das escolas \\
estaduais
\end{tabular} & Cerquilho & $\begin{array}{l}\text { Juízo Ex } \\
\text { Officio / } \\
\text { Fazenda do } \\
\text { Estado de São } \\
\text { Paulo }\end{array}$ & \begin{tabular}{|l} 
Ministério \\
Público
\end{tabular} & \begin{tabular}{|l}
$1^{\mathrm{a}}$ Câmara \\
de Direito \\
Público
\end{tabular} & Unânime & \begin{tabular}{|l} 
Recurso \\
provido
\end{tabular} & $\begin{array}{l}\text { Indisponíve } \\
1\end{array}$ & \begin{tabular}{|l|} 
JTJ \\
v.229, p.68
\end{tabular} \\
\hline $46.606-0 / 2$ & \begin{tabular}{|l} 
Apelação \\
Cível
\end{tabular} & 1999 & $\begin{array}{l}\text { Acesso à } \\
\text { educação } \\
\text { básica }\end{array}$ & Acesso EF & São Paulo & Indisponível & Indisponível & Indisponível & Indisponível & $\begin{array}{l}\text { Provimento } \\
\text { parcial ao } \\
\text { recurso }\end{array}$ & \begin{tabular}{|l} 
Álvaro \\
Lazzarini
\end{tabular} & Publicação MP \\
\hline $47.136-0 / 4$ & \begin{tabular}{|l} 
Agravo de \\
Instrumento
\end{tabular} & 1999 & $\begin{array}{l}\text { Acesso à } \\
\text { educação } \\
\text { básica }\end{array}$ & Acesso EF & São Paulo & \begin{tabular}{|l} 
Fazenda do \\
Estado de SP
\end{tabular} & \begin{tabular}{|l} 
Ministério \\
Público
\end{tabular} & $\begin{array}{l}\text { Câmara } \\
\text { Especial }\end{array}$ & Unânime & $\begin{array}{l}\text { Provimento } \\
\text { parcial ao } \\
\text { recurso }\end{array}$ & \begin{tabular}{|l} 
Oetterer \\
Guedes
\end{tabular} & $\begin{array}{l}\text { Publicação MP } \\
\text { Sítio eletrônico } \\
\text { TJ-SP }\end{array}$ \\
\hline $47.543-0 / 1$ & $\begin{array}{l}\text { Apelação } \\
\text { Cível }\end{array}$ & 1999 & $\begin{array}{l}\text { Responsabili } \\
\text { dade estatal }\end{array}$ & $\begin{array}{l}\text { Ação de } \\
\text { reparação de } \\
\text { danos }\end{array}$ & Campinas & $\begin{array}{l}\text { Informação } \\
\text { ausente }\end{array}$ & $\begin{array}{l}\text { Informação } \\
\text { ausente }\end{array}$ & $\begin{array}{l}\text { Informação } \\
\text { ausente }\end{array}$ & $\begin{array}{l}\text { Informação } \\
\text { ausente }\end{array}$ & $\begin{array}{l}\text { Recurso não } \\
\text { provido }\end{array}$ & $\begin{array}{l}\text { Cunha } \\
\text { Bueno }\end{array}$ & Publicação MP \\
\hline $48.676-5$ & $\begin{array}{l}\text { Apelação } \\
\text { Cível }\end{array}$ & 1999 & $\begin{array}{l}\text { Acesso à } \\
\text { educação } \\
\text { básica }\end{array}$ & Acesso EF & São Paulo & $\begin{array}{l}\text { Ministério } \\
\text { Público }\end{array}$ & $\begin{array}{l}\text { Diretor da } \\
\text { Escola } \\
\text { Estadual }\end{array}$ & $\begin{array}{l}7^{\text {a }} \text { Câmara } \\
\text { de Direito } \\
\text { Público }\end{array}$ & Unânime & $\begin{array}{l}\text { Recurso } \\
\text { provido para } \\
\text { prosseguime } \\
\text { nto da } \\
\text { demanda, } \\
\text { com decisão } \\
\text { sobre o } \\
\text { mérito }\end{array}$ & \begin{tabular}{|l} 
Jovino de \\
Sylos
\end{tabular} & \begin{tabular}{|l|} 
JTJ \\
v.228, p.92
\end{tabular} \\
\hline $49.463-0 / 0$ & $\begin{array}{l}\text { Apelação } \\
\text { Cível }\end{array}$ & 1999 & Permanência & Outros & Campinas & Indisponível & Indisponível & Indisponível & Indisponível & $\begin{array}{l}\text { Recurso não } \\
\text { provido }\end{array}$ & $\begin{array}{l}\text { Oetterer } \\
\text { Guedes }\end{array}$ & Publicação MP \\
\hline $50.447-0 / 0$ & $\begin{array}{l}\text { Apelação } \\
\text { Cível }\end{array}$ & 1999 & $\begin{array}{l}\text { Acesso à } \\
\text { educação } \\
\text { básica }\end{array}$ & Acesso EM & São Paulo & \begin{tabular}{|l|} 
Juízo Ex \\
Officio / \\
Fazenda do \\
Estado de SP
\end{tabular} & $\begin{array}{l}\text { Promotor de } \\
\text { Justiça da } \\
\text { Vara da } \\
\text { Infância e da } \\
\text { Juventude da } \\
\text { Comarca de } \\
\text { Pacaembu }\end{array}$ & $\begin{array}{l}\text { Câmara } \\
\text { Especial }\end{array}$ & Unânime & \begin{tabular}{|l} 
Recurso \\
negado
\end{tabular} & \begin{tabular}{|l|} 
Djalma \\
Lofrano
\end{tabular} & $\begin{array}{l}\text { Publicação } \\
\text { MP; Sítio } \\
\text { eletrônico } \\
\text { ABMP; } \\
\text { Acórdão Sítio } \\
\text { eletrônico MP }\end{array}$ \\
\hline
\end{tabular}




\begin{tabular}{|c|c|c|c|c|c|c|c|c|c|c|c|c|}
\hline $\begin{array}{l}\text { Número } \\
\text { decisão }\end{array}$ & Natureza & Ano & Categorias & Tema & Origem & $\begin{array}{l}\text { Apelante } \\
\text { recorrente }\end{array}$ & $\begin{array}{l}\text { Apelados } \\
\text { recorridos }\end{array}$ & Câmara & Votação & Resultado & Relator & $\begin{array}{l}\text { Localização } \\
\text { da ementa / } \\
\text { acórdão }\end{array}$ \\
\hline $55.367-0 / 1$ & $\begin{array}{l}\text { Agravo de } \\
\text { Instrumento }\end{array}$ & 1999 & $\begin{array}{l}\text { Responsabili } \\
\text { dade estatal }\end{array}$ & $\begin{array}{l}\text { Transporte } \\
\text { escolar }\end{array}$ & São Carlos & $\begin{array}{l}\text { Município de } \\
\text { São Carlos }\end{array}$ & $\begin{array}{l}\text { Promotor de } \\
\text { Justiça da } \\
\text { Vara da } \\
\text { Infância e } \\
\text { Juventude da } \\
\text { Comarca de } \\
\text { São Carlos }\end{array}$ & $\begin{array}{l}\text { Câmara } \\
\text { Especial }\end{array}$ & Unânime & $\begin{array}{l}\text { Recurso } \\
\text { provido }\end{array}$ & $\begin{array}{l}\text { Álvaro } \\
\text { Lazzarini }\end{array}$ & $\begin{array}{l}\text { Sítio biblioteca } \\
\text { TJ-SP / Sítio } \\
\text { eletrônicoTJ- } \\
\text { SP }\end{array}$ \\
\hline $57.199-5$ & $\begin{array}{l}\text { Apelação } \\
\text { Cível }\end{array}$ & 1999 & Permanência & $\begin{array}{l}\text { Violação às } \\
\text { normas } \\
\text { escolares }\end{array}$ & $\begin{array}{l}\text { Ribeirão } \\
\text { Preto }\end{array}$ & $\begin{array}{l}\text { Criança ou } \\
\text { adolescente }\end{array}$ & $\begin{array}{l}\text { Diretor da } \\
\text { Escola } \\
\text { Municipal }\end{array}$ & $\begin{array}{l}7^{\text {a Câmara }} \\
\text { "Janeiro/99" } \\
\text { de Direito } \\
\text { Público } \\
\end{array}$ & Unânime & $\begin{array}{l}\text { Recurso } \\
\text { provido } \\
\text { parcialmente }\end{array}$ & $\begin{array}{l}\text { Prado } \\
\text { Pereira }\end{array}$ & $\begin{array}{l}\text { JTJ } \\
\text { v. } 229, \text { p.66 }\end{array}$ \\
\hline $56.048-5$ & $\begin{array}{l}\text { Apelação } \\
\text { Cível }\end{array}$ & 1999 & $\begin{array}{l}\text { Acesso à } \\
\text { educação } \\
\text { básica }\end{array}$ & $\begin{array}{l}\text { Educação } \\
\text { Especial }\end{array}$ & Assis & $\begin{array}{l}\text { Juízo Ex } \\
\text { Officio }\end{array}$ & $\begin{array}{l}\text { Ministério } \\
\text { Público / } \\
\text { Fazenda do } \\
\text { Estado de SP }\end{array}$ & $\begin{array}{l}1^{a} \text { Câmara } \\
\text { de Direito } \\
\text { Público }\end{array}$ & Unânime & $\begin{array}{l}\text { Recurso não } \\
\text { provido }\end{array}$ & $\begin{array}{l}\text { José Raul } \\
\text { Gavião de } \\
\text { Almeida }\end{array}$ & $\begin{array}{l}\text { JTJ } \\
\text { v. } 240, \text { p.38 }\end{array}$ \\
\hline $56.259-5 / 4$ & $\begin{array}{l}\text { Apelação } \\
\text { Cível }\end{array}$ & 1999 & $\begin{array}{l}\text { Acesso à } \\
\text { educação } \\
\text { básica }\end{array}$ & Acesso EI & Rinópolis & $\begin{array}{l}\text { Juízo Ex } \\
\text { Officio / } \\
\text { Diretor da } \\
\text { EMEI }\end{array}$ & $\begin{array}{l}\text { Duas crianças } \\
\text { representadas } \\
\text { pelos pais }\end{array}$ & $\begin{array}{l}7^{\text {a Câmara }} \\
\text { "Janeiro/99" } \\
\text { de Direito } \\
\text { Público } \\
\end{array}$ & Unânime & $\begin{array}{l}\text { Recurso não } \\
\text { provido }\end{array}$ & $\begin{array}{l}\text { Jovino de } \\
\text { Sylos }\end{array}$ & $\begin{array}{l}\text { Sítio eletrônico } \\
\text { TJ-SP }\end{array}$ \\
\hline $58.270-0$ & $\begin{array}{l}\text { Agravo } \\
\text { Regimental }\end{array}$ & 1999 & $\begin{array}{l}\text { Acesso à } \\
\text { educação } \\
\text { básica }\end{array}$ & Acesso EF & $\begin{array}{l}\text { S. José dos } \\
\text { Campos }\end{array}$ & $\begin{array}{l}\text { Recurso Ex } \\
\text { Offício }\end{array}$ & Indisponível & $\begin{array}{l}\text { Câmara } \\
\text { Especial }\end{array}$ & Unânime & $\begin{array}{l}\text { Agravo não } \\
\text { provido }\end{array}$ & $\begin{array}{l}\text { Cunha } \\
\text { Bueno }\end{array}$ & $\begin{array}{l}\text { JTJ } \\
\text { v. } 224, \text { p. } 282\end{array}$ \\
\hline $60.258-0$ & $\begin{array}{l}\text { Apelação } \\
\text { Cível }\end{array}$ & 1999 & $\begin{array}{l}\text { Acesso à } \\
\text { educação } \\
\text { básica }\end{array}$ & Acesso EF & São Paulo & $\begin{array}{l}\text { Juízo Ex } \\
\text { Officio }\end{array}$ & $\begin{array}{l}\text { Promotor de } \\
\text { Justiça da } \\
\text { Vara da } \\
\text { Infância e da } \\
\text { Juventude de } \\
\text { Pinheiros e a } \\
\text { Fazenda } \\
\text { Pública do } \\
\text { Estado }\end{array}$ & $\begin{array}{l}\text { Câmara } \\
\text { Especial }\end{array}$ & Unânime & $\begin{array}{l}\text { Recurso não } \\
\text { provido }\end{array}$ & $\begin{array}{l}\text { Cunha } \\
\text { Bueno }\end{array}$ & $\begin{array}{l}\text { JTJ } \\
\text { v. } 227, \text { p. } 288\end{array}$ \\
\hline 65.373-0/7 & $\begin{array}{l}\text { Agravo de } \\
\text { Instrumento }\end{array}$ & 1999 & $\begin{array}{l}\text { Acesso à } \\
\text { educação } \\
\text { básica }\end{array}$ & Acesso EI & $\begin{array}{l}\text { Santo } \\
\text { André }\end{array}$ & $\begin{array}{l}\text { Município de } \\
\text { Santo André }\end{array}$ & $\begin{array}{l}\text { Informação } \\
\text { ausente }\end{array}$ & $\begin{array}{l}\text { Informação } \\
\text { ausente }\end{array}$ & $\begin{array}{l}\text { Informação } \\
\text { ausente }\end{array}$ & $\begin{array}{l}\text { Recurso não } \\
\text { provido }\end{array}$ & $\begin{array}{l}\text { Oetterer } \\
\text { Guedes }\end{array}$ & Publicação MP \\
\hline
\end{tabular}




\begin{tabular}{|c|c|c|c|c|c|c|c|c|c|c|c|c|}
\hline $\begin{array}{l}\text { Número } \\
\text { decisão }\end{array}$ & Natureza & Ano & Categorias & Tema & Origem & $\begin{array}{l}\text { Apelante } \\
\text { recorrente }\end{array}$ & $\begin{array}{l}\text { Apelados } \\
\text { recorridos }\end{array}$ & Câmara & Votação & Resultado & Relator & $\begin{array}{l}\text { Localização } \\
\text { da ementa / } \\
\text { acórdão }\end{array}$ \\
\hline $68.654-5 / 0$ & $\begin{array}{l}\text { Apelação } \\
\text { Cível }\end{array}$ & 1999 & $\begin{array}{l}\text { Acesso à } \\
\text { educação } \\
\text { básica }\end{array}$ & Acesso EF & $\begin{array}{l}\text { Martinópo- } \\
\text { lis }\end{array}$ & $\begin{array}{l}\text { Juízo Ex } \\
\text { Officio; } \\
\text { Fazenda do } \\
\text { Estado de SP }\end{array}$ & $\begin{array}{l}\text { Criança ou } \\
\text { adolescente }\end{array}$ & $\begin{array}{l}8^{a} \text { Câmara } \\
\text { de Direito } \\
\text { Público }\end{array}$ & Unânime & $\begin{array}{l}\text { Recurso não } \\
\text { provido }\end{array}$ & $\begin{array}{l}\text { Teresa } \\
\text { Ramos } \\
\text { Marques }\end{array}$ & $\begin{array}{l}\text { Sítio eletrônico } \\
\text { ABMP / Sítio } \\
\text { eletrônico } \\
\text { biblioteca TJ- } \\
\text { SP }\end{array}$ \\
\hline $72.885-5$ & $\begin{array}{l}\text { Apelação } \\
\text { Cível }\end{array}$ & 1999 & $\begin{array}{l}\text { Acesso à } \\
\text { educação } \\
\text { básica }\end{array}$ & Acesso EJA & São Paulo & $\begin{array}{l}\text { Juizo Ex } \\
\text { Officio }\end{array}$ & $\begin{array}{l}\text { Antonio } \\
\text { Carlos Azem }\end{array}$ & $\begin{array}{l}9^{\text {a }} \text { Câmara } \\
\text { de Direito } \\
\text { Público }\end{array}$ & Unânime & $\begin{array}{l}\text { Recurso não } \\
\text { provido }\end{array}$ & $\begin{array}{l}\text { Gonzaga } \\
\text { Franceschin } \\
\text { i }\end{array}$ & $\begin{array}{l}\text { Sítio eletrônico } \\
\text { biblioteca TJ- } \\
\text { SP }\end{array}$ \\
\hline $77.819-5 / 4$ & $\begin{array}{l}\text { Apelação } \\
\text { Cível }\end{array}$ & 1999 & $\begin{array}{l}\text { Acesso à } \\
\text { educação } \\
\text { básica }\end{array}$ & $\begin{array}{l}\text { Acesso Ed } \\
\text { Profissional }\end{array}$ & São Paulo & $\begin{array}{l}\text { Sindicato dos } \\
\text { Trabalhadores } \\
\text { do CEETPS do } \\
\text { Ensino Público } \\
\text { Estadual, } \\
\text { Técnico, } \\
\text { Tecnológico e } \\
\text { Profissional do } \\
\text { Estado de São } \\
\text { Paulo } \\
\end{array}$ & $\begin{array}{l}\text { Governo do } \\
\text { Estado de São } \\
\text { Paulo e outros }\end{array}$ & $\begin{array}{l}6^{\text {a }} \text { Câmara } \\
\text { de Direito } \\
\text { Público }\end{array}$ & Unânime & $\begin{array}{l}\text { Recurso não } \\
\text { provido }\end{array}$ & Afonso Faro & $\begin{array}{l}\text { Sítio eletrônico } \\
\text { biblioteca TJ- } \\
\text { SP }\end{array}$ \\
\hline $77.912-5 / 9$ & $\begin{array}{l}\text { Apelação } \\
\text { Cível }\end{array}$ & 1999 & $\begin{array}{l}\text { Acesso à } \\
\text { educação } \\
\text { básica }\end{array}$ & Acesso EJA & São Paulo & $\begin{array}{l}\text { Ministério } \\
\text { Público }\end{array}$ & $\begin{array}{l}\text { Fazenda do } \\
\text { Estado de São } \\
\text { Paulo e outros }\end{array}$ & $\begin{array}{l}8^{\text {a }} \text { Câmara } \\
\text { de Direito } \\
\text { Público }\end{array}$ & Unânime & $\begin{array}{l}\text { Recurso } \\
\text { provido }\end{array}$ & $\begin{array}{l}\text { Todelo } \\
\text { Silva }\end{array}$ & $\begin{array}{l}\text { Publicação } \\
\text { MP; Sítio } \\
\text { eletrônico TJ- } \\
\text { SP }\end{array}$ \\
\hline $82.692-4$ & $\begin{array}{l}\text { Apelação } \\
\text { Cível }\end{array}$ & 1999 & $\begin{array}{l}\text { Responsabili } \\
\text { dade estatal }\end{array}$ & $\begin{array}{l}\text { Ação de } \\
\text { reparação de } \\
\text { danos }\end{array}$ & Ituverava & $\begin{array}{l}\text { Menor } \\
\text { representado } \\
\text { pelos pais }\end{array}$ & $\begin{array}{l}\text { Criança ou } \\
\text { adolescente }\end{array}$ & $\begin{array}{l}6^{\text {a }} \text { Câmara } \\
\text { de Direito } \\
\text { Privado }\end{array}$ & Unânime & $\begin{array}{l}\text { Recurso } \\
\text { provido ao } \\
\text { reú e em } \\
\text { parte ao do } \\
\text { autor } \\
\end{array}$ & $\begin{array}{l}\text { Testa } \\
\text { Marchi }\end{array}$ & $\begin{array}{l}\text { JTJ } \\
\text { v. } 230, \text { p. } 101\end{array}$ \\
\hline $83.093-5$ & $\begin{array}{l}\text { Apelação } \\
\text { Cível }\end{array}$ & 1999 & Permanência & $\begin{array}{l}\text { Violação às } \\
\text { normas } \\
\text { escolares }\end{array}$ & $\begin{array}{l}\text { Santa Cruz } \\
\text { do Rio } \\
\text { Pardo }\end{array}$ & $\begin{array}{l}\text { Criança ou } \\
\text { adolescente }\end{array}$ & $\begin{array}{l}\text { Diretora da } \\
\text { EEPSG }\end{array}$ & $\begin{array}{l}1^{\text {a }} \text { Câmara } \\
\text { de Direito } \\
\text { Público }\end{array}$ & Unânime & $\begin{array}{l}\text { Recurso não } \\
\text { provido }\end{array}$ & $\begin{array}{l}\text { José Raul } \\
\text { Gavião de } \\
\text { Almeida }\end{array}$ & $\begin{array}{l}\text { JTJ v. } 222, \\
\text { p.144 }\end{array}$ \\
\hline $87.482-5$ & $\begin{array}{l}\text { Apelação } \\
\text { Cível }\end{array}$ & 1999 & $\begin{array}{l}\text { Acesso à } \\
\text { educação } \\
\text { básica }\end{array}$ & Acesso EF & Assis & $\begin{array}{l}\text { Juízo Ex } \\
\text { Officio }\end{array}$ & $\begin{array}{l}\text { Menor } \\
\text { representado } \\
\text { pela mãe }\end{array}$ & $\begin{array}{l}4^{\text {a }} \text { Câmara } \\
\text { de Direito } \\
\text { Público }\end{array}$ & Unânime & $\begin{array}{l}\text { Recurso } \\
\text { provido }\end{array}$ & $\begin{array}{l}\text { Vianna } \\
\text { Santos }\end{array}$ & $\begin{array}{l}\text { JTJ } \\
\text { v.221, p.43 }\end{array}$ \\
\hline $93.208-5 / 3$ & $\begin{array}{l}\text { Apelação } \\
\text { Cível }\end{array}$ & 1999 & $\begin{array}{l}\text { Acesso à } \\
\text { educação } \\
\text { básica }\end{array}$ & Acesso EF & $\begin{array}{l}\text { Palmeira } \\
\text { D'Oeste }\end{array}$ & $\begin{array}{l}\text { Juizo Ex } \\
\text { Officio }\end{array}$ & $\begin{array}{l}\text { Fazenda do } \\
\text { Estado de SP }\end{array}$ & $\begin{array}{l}\text { Criança ou } \\
\text { adolescente }\end{array}$ & Unânime & $\begin{array}{l}\text { Recurso não } \\
\text { provido }\end{array}$ & $\begin{array}{l}\text { William } \\
\text { Marinho }\end{array}$ & $\begin{array}{l}\text { Sítio eletrônico } \\
\text { biblioteca TJ- } \\
\text { SP }\end{array}$ \\
\hline
\end{tabular}




\begin{tabular}{|c|c|c|c|c|c|c|c|c|c|c|c|c|}
\hline $\begin{array}{l}\text { Número } \\
\text { decisão }\end{array}$ & Natureza & Ano & Categorias & Tema & Origem & $\begin{array}{l}\text { Apelante } \\
\text { recorrente }\end{array}$ & $\begin{array}{l}\text { Apelados } \\
\text { recorridos }\end{array}$ & Câmara & Votação & Resultado & Relator & $\begin{array}{l}\text { Localização } \\
\text { da ementa / } \\
\text { acórdão }\end{array}$ \\
\hline $96.450-5$ & $\begin{array}{l}\text { Apelação } \\
\text { Cível }\end{array}$ & 1999 & \begin{tabular}{|l} 
Poder de \\
regulação \\
estatal
\end{tabular} & $\begin{array}{l}\text { Autorização/ } \\
\text { credenciame } \\
\text { nto }\end{array}$ & Guarulhos & $\begin{array}{l}\text { Criança ou } \\
\text { adolescente }\end{array}$ & $\begin{array}{l}\text { Delegado de } \\
\text { Ensino da } 1^{\text {a }} \\
\text { Delegacia de } \\
\text { Guarulhos }\end{array}$ & $\begin{array}{l}1^{a} \text { Câmara } \\
\text { de Direito } \\
\text { Público }\end{array}$ & Unânime & $\begin{array}{l}\text { Recurso não } \\
\text { provido }\end{array}$ & $\begin{array}{l}\text { Octaviano } \\
\text { Lobo }\end{array}$ & $\begin{array}{l}\text { Sítio eletrônico } \\
\text { biblioteca TJ- } \\
\text { SP; Sítio } \\
\text { eletrônico TJ- } \\
\text { SP } \\
\end{array}$ \\
\hline $97.419-5$ & $\begin{array}{l}\text { Apelação } \\
\text { Cível }\end{array}$ & 1999 & $\begin{array}{l}\text { Poder de } \\
\text { regulação } \\
\text { estatal }\end{array}$ & $\begin{array}{l}\text { Autorização/ } \\
\text { credenciame } \\
\text { nto }\end{array}$ & Guarulhos & $\begin{array}{l}\text { Criança ou } \\
\text { adolescente }\end{array}$ & $\begin{array}{l}\text { Delegacia de } \\
\text { Ensino da } 1^{\text {a }} \\
\text { Delegacia }\end{array}$ & $\begin{array}{l}2^{\text {a }} \text { Câmara } \\
\text { de Direito } \\
\text { Público }\end{array}$ & Unânime & $\begin{array}{l}\text { Recurso não } \\
\text { provido }\end{array}$ & $\begin{array}{l}\text { Aloísio de } \\
\text { Toledo }\end{array}$ & \begin{tabular}{|l|} 
JTJ \\
v. 229, p.64
\end{tabular} \\
\hline $103.071-5 / 2$ & $\begin{array}{l}\text { Apelação } \\
\text { Cível }\end{array}$ & 1999 & $\begin{array}{l}\text { Responsabili } \\
\text { dade estatal }\end{array}$ & \begin{tabular}{|l|} 
Transporte \\
escolar
\end{tabular} & Guará & $\begin{array}{l}\text { Recurso Ex } \\
\text { Officio }\end{array}$ & $\begin{array}{l}\text { Ministério } \\
\text { Público }\end{array}$ & \begin{tabular}{|l|}
$6^{a}$ Câmara \\
de Direito \\
Público \\
\end{tabular} & Unânime & $\begin{array}{l}\text { Recurso não } \\
\text { provido }\end{array}$ & $\begin{array}{l}\text { Christiano } \\
\text { Nuntz }\end{array}$ & $\begin{array}{l}\text { Sítio eletrônico } \\
\text { TJ-SP }\end{array}$ \\
\hline \multicolumn{13}{|l|}{2000} \\
\hline $54.438-0$ & $\begin{array}{l}\text { Apelação } \\
\text { Cível }\end{array}$ & 2000 & $\begin{array}{l}\text { Acesso à } \\
\text { educação } \\
\text { básica }\end{array}$ & Acesso EF & \begin{tabular}{|l} 
São \\
Caetano do \\
Sul
\end{tabular} & Indisponível & Indisponível & Indisponível & Unânime & $\begin{array}{l}\text { Recurso não } \\
\text { provido }\end{array}$ & \begin{tabular}{|l|} 
Nigro \\
Conceição
\end{tabular} & $\begin{array}{l}\text { Sítio eletrônico } \\
\text { biblioteca TJ- } \\
\text { SP }\end{array}$ \\
\hline $58.179-0 / 5$ & $\begin{array}{l}\text { Apelação } \\
\text { Cível }\end{array}$ & 2000 & $\begin{array}{l}\text { Acesso à } \\
\text { educação } \\
\text { básica }\end{array}$ & Acesso EF & $\begin{array}{l}\text { Santo } \\
\text { André }\end{array}$ & $\begin{array}{l}\text { Recurso } E x \\
\text { Officio }\end{array}$ & Indisponível & Indisponível & $\begin{array}{l}\text { Informação } \\
\text { ausente }\end{array}$ & Não provido & $\begin{array}{l}\text { Hermes } \\
\text { Pinotti }\end{array}$ & Publicação MP \\
\hline $58.495-5$ & $\begin{array}{l}\text { Apelação } \\
\text { Cível }\end{array}$ & 2000 & $\begin{array}{l}\text { Responsabili } \\
\text { dade estatal }\end{array}$ & $\begin{array}{l}\text { Ação de } \\
\text { reparação de } \\
\text { danos }\end{array}$ & São Paulo & \begin{tabular}{|l|} 
Juízo Ex \\
Officio / \\
Fazenda do \\
Estado de São \\
Paulo \\
\end{tabular} & $\begin{array}{l}\text { Criança ou } \\
\text { adolescente }\end{array}$ & $\begin{array}{l}5^{\text {a }} \text { Câmara } \\
\text { de Direito } \\
\text { Público }\end{array}$ & Unânime & $\begin{array}{l}\text { Recurso não } \\
\text { provido }\end{array}$ & $\begin{array}{l}\text { Xavier de } \\
\text { Aquino }\end{array}$ & $\begin{array}{l}\text { JTJ v. 230, } \\
\text { p.83 }\end{array}$ \\
\hline $\begin{array}{l}58.859-0 / 9- \\
00\end{array}$ & ADIN & 2000 & $\begin{array}{l}\text { Decisões } \\
\text { administrativ } \\
\text { as e políticas }\end{array}$ & \begin{tabular}{|l|} 
Competência \\
para legislar
\end{tabular} & São Paulo & $\begin{array}{l}\text { Prefeito do } \\
\text { Município de } \\
\text { São Paulo }\end{array}$ & $\begin{array}{l}\text { Câmara } \\
\text { Municipal de } \\
\text { São Paulo }\end{array}$ & \begin{tabular}{|l} 
Órgão \\
Especial do \\
TJ
\end{tabular} & Unânime & $\begin{array}{l}\text { Rejeitada a } \\
\text { matéria } \\
\text { preliminar e } \\
\text { julgada } \\
\text { procedente a } \\
\text { ação } \\
\end{array}$ & $\begin{array}{l}\text { Mohamed } \\
\text { Amaro }\end{array}$ & $\begin{array}{l}\text { Sítio eletrônico } \\
\text { biblioteca TJ- } \\
\text { SP }\end{array}$ \\
\hline $59.092-0$ & $\begin{array}{l}\text { Apelação } \\
\text { Cível }\end{array}$ & 2000 & $\begin{array}{l}\text { Acesso à } \\
\text { educação } \\
\text { básica }\end{array}$ & Acesso EF & Batatais & Indisponível & Indisponível & $\begin{array}{l}\text { Câmara } \\
\text { Especial }\end{array}$ & Unânime & $\begin{array}{l}\text { Recurso não } \\
\text { provido }\end{array}$ & \begin{tabular}{|l|} 
Alvaro \\
Lazzarini
\end{tabular} & $\begin{array}{l}\text { Sítio eletrônico } \\
\text { biblioteca TJ- } \\
\text { SP }\end{array}$ \\
\hline $59.903-0 / 8$ & $\begin{array}{l}\text { Apelação } \\
\text { Cível }\end{array}$ & 2000 & $\begin{array}{l}\text { Acesso à } \\
\text { educação } \\
\text { básica }\end{array}$ & Acesso EF & $\begin{array}{l}\text { Itapecerica } \\
\text { da Serra }\end{array}$ & Indisponível & Indisponível & & $\begin{array}{l}\text { Informação } \\
\text { ausente }\end{array}$ & $\begin{array}{l}\text { Recurso não } \\
\text { provido }\end{array}$ & Gentil Leite & Publicação MP \\
\hline
\end{tabular}




\begin{tabular}{|c|c|c|c|c|c|c|c|c|c|c|c|c|}
\hline $\begin{array}{l}\text { Número } \\
\text { decisão }\end{array}$ & Natureza & Ano & Categorias & Tema & Origem & $\begin{array}{l}\text { Apelante } \\
\text { recorrente }\end{array}$ & $\begin{array}{l}\text { Apelados } \\
\text { recorridos }\end{array}$ & Câmara & Votação & Resultado & Relator & $\begin{array}{l}\text { Localização } \\
\text { da ementa / } \\
\text { acórdão }\end{array}$ \\
\hline $60.066-0$ & $\begin{array}{l}\text { Recurso } E x \\
\text { Officio }\end{array}$ & 2000 & Permanência & $\begin{array}{l}\text { Violação às } \\
\text { normas } \\
\text { escolares }\end{array}$ & $\begin{array}{l}\text { Indisponíve } \\
1\end{array}$ & $\begin{array}{l}\text { Criança ou } \\
\text { adolescente }\end{array}$ & $\begin{array}{l}\text { Diretora da } \\
\text { escolar }\end{array}$ & $\begin{array}{l}\text { Câmara } \\
\text { Especial }\end{array}$ & Unânime & $\begin{array}{l}\text { Concessão da } \\
\text { segurança } \\
\text { mantida }\end{array}$ & $\begin{array}{l}\text { Hermes } \\
\text { Pinotti }\end{array}$ & \begin{tabular}{|l|} 
JTJ \\
v. 236, p.286
\end{tabular} \\
\hline $60.384-0$ & \begin{tabular}{|l} 
Apelação \\
Cível
\end{tabular} & 2000 & Permanência & $\begin{array}{l}\text { Violação às } \\
\text { normas } \\
\text { escolares }\end{array}$ & $\begin{array}{l}\text { Indisponíve } \\
1\end{array}$ & Ex Officio & $\begin{array}{l}\text { Criança ou } \\
\text { adolescente }\end{array}$ & \begin{tabular}{|l|} 
Câmara \\
Especial
\end{tabular} & Unânime & $\begin{array}{l}\text { Processo } \\
\text { extinto, sem } \\
\text { apreciação } \\
\text { do mérito } \\
\end{array}$ & \begin{tabular}{|l} 
Hermes \\
Pinotti
\end{tabular} & \begin{tabular}{|l|} 
JTJ \\
v. 236, p.144
\end{tabular} \\
\hline $60.561-0$ & $\begin{array}{l}\text { Apelação } \\
\text { Cível }\end{array}$ & 2000 & $\begin{array}{l}\text { Acesso à } \\
\text { educação } \\
\text { básica }\end{array}$ & Acesso EF & $\begin{array}{l}\text { Monte } \\
\text { Mor/Capiva } \\
\text { ri }\end{array}$ & Indisponível & Indisponível & \begin{tabular}{|l|} 
Câmara \\
Especial
\end{tabular} & Unânime & $\begin{array}{l}\text { Recurso não } \\
\text { provido }\end{array}$ & \begin{tabular}{|l} 
Fonseca \\
Tavares
\end{tabular} & $\begin{array}{l}\text { Sítio eletrônico } \\
\text { biblioteca TJ- } \\
\text { SP }\end{array}$ \\
\hline $62.113-0 / 0$ & $\begin{array}{l}\text { Apelação } \\
\text { Cível }\end{array}$ & 2000 & $\begin{array}{l}\text { Acesso à } \\
\text { educação } \\
\text { básica }\end{array}$ & Acesso EF & São Paulo & Indisponível & Indisponível & & $\begin{array}{l}\text { Informação } \\
\text { ausente }\end{array}$ & $\begin{array}{l}\text { Recurso não } \\
\text { provido }\end{array}$ & \begin{tabular}{|l|} 
Nigro \\
Conceição
\end{tabular} & Publicação MP \\
\hline $62.335-0$ & $\begin{array}{l}\text { Apelação } \\
\text { Cível }\end{array}$ & 2000 & $\begin{array}{l}\text { Acesso à } \\
\text { educação } \\
\text { básica }\end{array}$ & Acesso EF & Mococa & Indisponível & Indisponível & \begin{tabular}{|l|} 
Câmara \\
Especial
\end{tabular} & $\begin{array}{l}\text { Informação } \\
\text { ausente }\end{array}$ & $\begin{array}{l}\text { Recurso não } \\
\text { provido }\end{array}$ & \begin{tabular}{|l} 
Fonseca \\
Tavares
\end{tabular} & $\begin{array}{l}\text { Sítio eletrônico } \\
\text { biblioteca TJ- } \\
\text { SP }\end{array}$ \\
\hline $\begin{array}{l}62.543 .0 / 3- \\
00\end{array}$ & \begin{tabular}{|l} 
Apelação \\
Cível
\end{tabular} & 2000 & $\begin{array}{l}\text { Acesso à } \\
\text { educação } \\
\text { básica }\end{array}$ & Acesso EI & $\begin{array}{l}\text { Santo } \\
\text { André }\end{array}$ & $\begin{array}{l}\text { Município de } \\
\text { Santo André }\end{array}$ & $\begin{array}{l}\text { Presidente do } \\
\text { TJ-SP }\end{array}$ & \begin{tabular}{|l} 
Sessão \\
Plenária
\end{tabular} & Unânime & $\begin{array}{l}\text { Agravo } \\
\text { provido }\end{array}$ & \begin{tabular}{|l|} 
Márcio \\
Bonilha
\end{tabular} & $\begin{array}{l}\text { Sítio biblioteca } \\
\text { TJ-SP; Sítio } \\
\text { TJ-SP }\end{array}$ \\
\hline $62.624-0$ & $\begin{array}{l}\text { Apelação } \\
\text { Cível }\end{array}$ & 2000 & $\begin{array}{l}\text { Acesso à } \\
\text { educação } \\
\text { básica }\end{array}$ & Acesso EF & \begin{tabular}{|l} 
Ribeirão \\
Preto
\end{tabular} & Indisponível & Indisponível & \begin{tabular}{|l|} 
Câmara \\
Especial
\end{tabular} & $\begin{array}{l}\text { Informação } \\
\text { ausente }\end{array}$ & $\begin{array}{l}\text { Recurso não } \\
\text { provido }\end{array}$ & \begin{tabular}{|l} 
Fonseca \\
Tavares
\end{tabular} & $\begin{array}{l}\text { Sítio eletrônico } \\
\text { biblioteca TJ- } \\
\text { SP }\end{array}$ \\
\hline $\begin{array}{l}62.937-0 / 0- \\
00\end{array}$ & $\begin{array}{l}\text { Recurso } E x \\
\text { Officio }\end{array}$ & 2000 & $\begin{array}{l}\text { Responsabili } \\
\text { dade estatal }\end{array}$ & $\begin{array}{l}\text { Transporte } \\
\text { escolar }\end{array}$ & \begin{tabular}{|l|} 
Gavião \\
Peixoto
\end{tabular} & $\begin{array}{l}\text { Recurso } E x \\
\text { Officio }\end{array}$ & $\begin{array}{l}\text { Promotor de } \\
\text { Justiça da } \\
\text { Vara da } \\
\text { Infância e } \\
\text { Juventude de } \\
\text { Araraquara }\end{array}$ & \begin{tabular}{|l|} 
Câmara \\
Especial
\end{tabular} & $\begin{array}{l}\text { Maioria dos } \\
\text { votos }\end{array}$ & $\begin{array}{l}\text { Recurso não } \\
\text { provido }\end{array}$ & \begin{tabular}{|l} 
Fonseca \\
Tavares
\end{tabular} & $\begin{array}{l}\text { Sítio eletrônico } \\
\text { TJ-SP }\end{array}$ \\
\hline $62.956-0 / 6$ & $\begin{array}{l}\text { Apelação } \\
\text { Cível }\end{array}$ & 2000 & Permanência & \begin{tabular}{|l|} 
Evasão \\
escolar
\end{tabular} & $\begin{array}{l}\text { Presidente } \\
\text { Prudente }\end{array}$ & Indisponível & Indisponível & Indisponível & Indisponível & $\begin{array}{l}\text { Recurso não } \\
\text { provido }\end{array}$ & \begin{tabular}{|l|} 
Nuevo \\
Campos
\end{tabular} & Publicação MP \\
\hline $63.069-0 / 5$ & $\begin{array}{l}\text { Apelação } \\
\text { Cível }\end{array}$ & 2000 & Permanência & \begin{tabular}{|l|} 
Evasão \\
escolar
\end{tabular} & $\begin{array}{l}\text { Presidente } \\
\text { Prudente }\end{array}$ & $\begin{array}{l}\text { Informação } \\
\text { ausente }\end{array}$ & $\begin{array}{l}\text { Informação } \\
\text { ausente }\end{array}$ & $\begin{array}{l}\text { Informação } \\
\text { ausente }\end{array}$ & $\begin{array}{l}\text { Informação } \\
\text { ausente }\end{array}$ & $\begin{array}{l}\text { Recurso não } \\
\text { provido }\end{array}$ & \begin{tabular}{|l|} 
Jesus \\
Lofrano
\end{tabular} & $\begin{array}{l}\text { Sítio eletrônico } \\
\text { ABMP; } \\
\text { Publicação MP }\end{array}$ \\
\hline
\end{tabular}




\begin{tabular}{|c|c|c|c|c|c|c|c|c|c|c|c|c|}
\hline $\begin{array}{l}\text { Número } \\
\text { decisão }\end{array}$ & Natureza & Ano & Categorias & Tema & Origem & $\begin{array}{l}\text { Apelante } \\
\text { recorrente }\end{array}$ & $\begin{array}{l}\text { Apelados } \\
\text { recorridos }\end{array}$ & Câmara & Votação & Resultado & Relator & $\begin{array}{l}\text { Localização } \\
\text { da ementa / } \\
\text { acórdão }\end{array}$ \\
\hline $\begin{array}{l}64.579-0 / 0- \\
00\end{array}$ & $\begin{array}{l}\text { Apelação } \\
\text { Cível }\end{array}$ & 2000 & Permanência & $\begin{array}{l}\text { Evasão } \\
\text { escolar }\end{array}$ & Sumaré & $\begin{array}{l}\text { Promotor de } \\
\text { Justiça da } \\
\text { Infância e } \\
\text { Juventude de } \\
\text { Sumaré }\end{array}$ & $\begin{array}{l}\text { Juiz de } \\
\text { Direito da } 3^{\text {a }} \\
\text { Vara } \\
\text { Criminal da } \\
\text { Infância e } \\
\text { Juventude de } \\
\text { Sumaré }\end{array}$ & $\begin{array}{l}\text { Câmara } \\
\text { Especial }\end{array}$ & $\begin{array}{l}\text { Maioria dos } \\
\text { votos }\end{array}$ & $\begin{array}{l}\text { Recurso não } \\
\text { provido }\end{array}$ & $\begin{array}{l}\text { Hermes } \\
\text { Pinotti }\end{array}$ & $\begin{array}{l}\text { Sítio eletrônico } \\
\text { TJ-SP }\end{array}$ \\
\hline $71.061-0$ & $\begin{array}{l}\text { Agravo de } \\
\text { Instrumento }\end{array}$ & 2000 & $\begin{array}{l}\text { Responsabili } \\
\text { dade estatal }\end{array}$ & $\begin{array}{l}\text { Transporte } \\
\text { escolar }\end{array}$ & $\begin{array}{l}\text { Indisponíve } \\
1\end{array}$ & Município & Adolescente & $\begin{array}{l}\text { Câmara } \\
\text { Especial }\end{array}$ & Unânime & $\begin{array}{l}\text { Recurso } \\
\text { provido }\end{array}$ & $\begin{array}{l}\text { Hermes } \\
\text { Pinotti }\end{array}$ & $\begin{array}{l}\text { JTJ } \\
\text { v. } 231, \text { p.235 }\end{array}$ \\
\hline $72.324-0 / 0$ & $\begin{array}{l}\text { Agravo de } \\
\text { Instrumento }\end{array}$ & 2000 & $\begin{array}{l}\text { Responsabili } \\
\text { dade estatal }\end{array}$ & $\begin{array}{l}\text { Transporte } \\
\text { escolar }\end{array}$ & São Paulo & $\begin{array}{l}\text { Fazenda } \\
\text { Pública do } \\
\text { Estado de SP }\end{array}$ & $\begin{array}{l}\text { Promotor de } \\
\text { Justiça da } \\
\text { Defesa dos } \\
\text { Interesses } \\
\text { Difusos e } \\
\text { Coletivos da } \\
\text { Infância e } \\
\text { Juventude da } \\
\text { Capital }\end{array}$ & $\begin{array}{l}\text { Câmara } \\
\text { Especial }\end{array}$ & Unânime & $\begin{array}{l}\text { Recurso } \\
\text { negado }\end{array}$ & $\begin{array}{l}\text { Nigro } \\
\text { Conceição }\end{array}$ & $\begin{array}{l}\text { Sítio eletrônico } \\
\text { ABMP; } \\
\text { Publicação } \\
\text { MP; Sítio } \\
\text { eletrônico TJ- } \\
\text { SP }\end{array}$ \\
\hline $72.584-0$ & $\begin{array}{l}\text { Agravo de } \\
\text { Instrumento }\end{array}$ & 2000 & $\begin{array}{l}\text { Acesso à } \\
\text { educação } \\
\text { básica }\end{array}$ & Acesso EI & $\begin{array}{l}\text { São } \\
\text { Bernardo } \\
\text { do Campo }\end{array}$ & $\begin{array}{l}\text { Informação } \\
\text { ausente }\end{array}$ & $\begin{array}{l}\text { Informação } \\
\text { ausente }\end{array}$ & $\begin{array}{l}\text { Câmara } \\
\text { Especial }\end{array}$ & Unânime & $\begin{array}{l}\text { Agravo } \\
\text { provido }\end{array}$ & $\begin{array}{l}\text { Álvaro } \\
\text { Lazzarini }\end{array}$ & $\begin{array}{l}\text { Sítio biblioteca } \\
\text { TJ-SP }\end{array}$ \\
\hline $73.118-0 / 8$ & $\begin{array}{l}\text { Agravo de } \\
\text { Instrumento }\end{array}$ & 2000 & $\begin{array}{l}\text { Acesso à } \\
\text { educação } \\
\text { básica }\end{array}$ & Acesso EI & $\begin{array}{l}\text { Santo } \\
\text { André }\end{array}$ & Município & $\begin{array}{l}\text { Informação } \\
\text { ausente }\end{array}$ & $\begin{array}{l}\text { Informação } \\
\text { ausente }\end{array}$ & $\begin{array}{l}\text { Informação } \\
\text { ausente }\end{array}$ & $\begin{array}{l}\text { Recurso não } \\
\text { provido }\end{array}$ & Gentil Leite & Publicação MP \\
\hline $74.654-0 / 0$ & $\begin{array}{l}\text { Agravo de } \\
\text { Instrumento }\end{array}$ & 2000 & $\begin{array}{l}\text { Acesso à } \\
\text { educação } \\
\text { básica }\end{array}$ & Acesso EI & $\begin{array}{l}\text { São } \\
\text { Bernardo }\end{array}$ & $\begin{array}{l}\text { Prefeitura } \\
\text { Municipal }\end{array}$ & Criança & $\begin{array}{l}\text { Câmara } \\
\text { Especial }\end{array}$ & Unânime & $\begin{array}{l}\text { Provimento } \\
\text { parcial ao } \\
\text { recurso }\end{array}$ & Gentil Leite & $\begin{array}{l}\text { Sítio eletrônico } \\
\text { ABMP; } \\
\text { Publicação } \\
\text { MP; JTJ v. } \\
238, \text { p.190 }\end{array}$ \\
\hline $96.766-5 / 0$ & $\begin{array}{l}\text { Apelação } \\
\text { Cível }\end{array}$ & 2000 & $\begin{array}{l}\text { Poder de } \\
\text { regulação } \\
\text { estatal }\end{array}$ & $\begin{array}{l}\text { Autorização/ } \\
\text { credenciame } \\
\text { nto }\end{array}$ & Guarulhos & E.B.R. & $\begin{array}{l}\text { Delegado de } \\
\text { Ensino da } 1^{\text {a }} \\
\text { Delegacia de } \\
\text { Guarulhos }\end{array}$ & $\begin{array}{l}8^{a} \text { Câmara } \\
\text { de Direito } \\
\text { Público }\end{array}$ & Unânime & Não provido & $\begin{array}{l}\text { Teresa } \\
\text { Ramos } \\
\text { Marques }\end{array}$ & $\begin{array}{l}\text { Sítio eletrônico } \\
\text { TJ-SP }\end{array}$ \\
\hline
\end{tabular}




\begin{tabular}{|c|c|c|c|c|c|c|c|c|c|c|c|c|}
\hline $\begin{array}{l}\text { Número } \\
\text { decisão }\end{array}$ & Natureza & Ano & Categorias & Tema & Origem & $\begin{array}{l}\text { Apelante } \\
\text { recorrente }\end{array}$ & $\begin{array}{l}\text { Apelados } \\
\text { recorridos }\end{array}$ & Câmara & Votação & Resultado & Relator & $\begin{array}{l}\text { Localização } \\
\text { da ementa / } \\
\text { acórdão }\end{array}$ \\
\hline $102.764-5$ & $\begin{array}{l}\text { Apelação } \\
\text { Cível }\end{array}$ & 2000 & $\begin{array}{l}\text { Poder de } \\
\text { regulação } \\
\text { estatal }\end{array}$ & $\begin{array}{l}\text { Autorização/ } \\
\text { credenciame } \\
\text { nto }\end{array}$ & Campinas & $\begin{array}{l}\text { Juízo Ex } \\
\text { Officio; } \\
\text { Fazenda do } \\
\text { Estado de São } \\
\text { Paulo }\end{array}$ & $\begin{array}{l}\text { Saber } \\
\text { Sociedade } \\
\text { Acadêmica } \\
\text { Brasileira de } \\
\text { Ensino } \\
\text { Renovado } \\
\text { Ltda. } \\
\end{array}$ & $\begin{array}{l}9^{a} \text { Câmara } \\
\text { "Janeiro/200 } \\
\text { 0" de Direito } \\
\text { Público }\end{array}$ & Unânime & $\begin{array}{l}\text { Recurso não } \\
\text { provido }\end{array}$ & $\begin{array}{l}\text { Rui } \\
\text { Cascaldi }\end{array}$ & $\begin{array}{l}\text { JTJ } \\
\text { v. } 228, \text { p. } 37\end{array}$ \\
\hline $105.026-5$ & $\begin{array}{l}\text { Apelação } \\
\text { Cível }\end{array}$ & 2000 & $\begin{array}{l}\text { Poder de } \\
\text { regulação } \\
\text { estatal }\end{array}$ & $\begin{array}{l}\text { Autorização/ } \\
\text { credenciame } \\
\text { nto }\end{array}$ & Guarulhos & M.H.L.S. & $\begin{array}{l}\text { Delegado de } \\
\text { Ensino da } 1^{\text {a }} \\
\text { Delegacia de } \\
\text { Guarulhos }\end{array}$ & $\begin{array}{l}7^{\text {a }} \text { Câmara } \\
\text { "Janeiro/200 } \\
\text { 0"de Direito } \\
\text { Público }\end{array}$ & Unânime & $\begin{array}{l}\text { Recurso não } \\
\text { provido }\end{array}$ & $\begin{array}{l}\text { Jovino de } \\
\text { Sylos }\end{array}$ & $\begin{array}{l}\text { Sítio eletrônico } \\
\text { biblioteca TJ- } \\
\text { SP / Sítio } \\
\text { eletrônico TJ- } \\
\text { SP }\end{array}$ \\
\hline $\begin{array}{l}105.448- \\
5 / 8-00\end{array}$ & $\begin{array}{l}\text { Apelação } \\
\text { Cível }\end{array}$ & 2000 & $\begin{array}{l}\text { Responsabili } \\
\text { dade estatal }\end{array}$ & $\begin{array}{l}\text { Transporte } \\
\text { escolar }\end{array}$ & Avaré & $\begin{array}{l}\text { Juízo Ex } \\
\text { Officio }\end{array}$ & $\begin{array}{l}\text { Ministério } \\
\text { Público }\end{array}$ & $\begin{array}{l}8^{\mathrm{a}} \text { Câmara } \\
\text { de Direito } \\
\text { Público } \\
\end{array}$ & Unânime & $\begin{array}{l}\text { Recurso não } \\
\text { provido }\end{array}$ & $\begin{array}{l}\text { Paulo } \\
\text { Travain }\end{array}$ & $\begin{array}{l}\text { Sítio eletrônico } \\
\text { TJ-SP }\end{array}$ \\
\hline $106.357-5 / 0$ & $\begin{array}{l}\text { Apelação } \\
\text { Cível }\end{array}$ & 2000 & $\begin{array}{l}\text { Acesso à } \\
\text { educação } \\
\text { básica }\end{array}$ & Acesso EF & Taubaté & $\begin{array}{l}\text { Juízo Ex } \\
\text { Officio }\end{array}$ & $\begin{array}{l}\text { Criança ou } \\
\text { adolescente } \\
\text { representado } \\
\text { pelos pais }\end{array}$ & $\begin{array}{l}6^{\text {a Câmara }} \\
\text { de } \\
\text { Janeiro/2000 } \\
\text { de Direito } \\
\text { Público }\end{array}$ & Unânime & $\begin{array}{l}\text { Recurso não } \\
\text { provido }\end{array}$ & $\begin{array}{l}\text { Christiano } \\
\text { Kuntz }\end{array}$ & $\begin{array}{l}\text { Sítio eletrônico } \\
\text { biblioteca TJ- } \\
\text { SP }\end{array}$ \\
\hline $107.687-5$ & $\begin{array}{l}\text { Apelação } \\
\text { Cível }\end{array}$ & 2000 & Permanência & $\begin{array}{l}\text { Violação às } \\
\text { normas } \\
\text { escolares }\end{array}$ & São Paulo & $\begin{array}{l}\text { Fundação } \\
\text { Armando } \\
\text { Álvares } \\
\text { Penteado }\end{array}$ & $\begin{array}{l}\text { Criança ou } \\
\text { adolescente } \\
\text { representado } \\
\text { pelos pais } \\
\end{array}$ & $\begin{array}{l}7^{\mathrm{a}} \text { Câmara } \\
\text { de Direito } \\
\text { Público }\end{array}$ & Unânime & $\begin{array}{l}\text { Recurso não } \\
\text { provido }\end{array}$ & $\begin{array}{l}\text { Guerrieri } \\
\text { Rezende }\end{array}$ & $\begin{array}{l}\text { JTJ } \\
\text { v. } 232, \text { p.68 }\end{array}$ \\
\hline $117.680-5$ & $\begin{array}{l}\text { Apelação } \\
\text { Cível }\end{array}$ & 2000 & $\begin{array}{l}\text { Decisões } \\
\text { administrativ } \\
\text { as e políticas }\end{array}$ & Outros & Rinópolis & $\begin{array}{l}\text { Juízo Ex } \\
\text { Officio / } \\
\text { Prefeito } \\
\text { Municipal }\end{array}$ & $\begin{array}{l}\text { Câmara } \\
\text { Municipal de } \\
\text { Rinópolis }\end{array}$ & $\begin{array}{l}9^{\text {a }} \text { Câmara } \\
\text { de Direito } \\
\text { Público }\end{array}$ & Unânime & $\begin{array}{l}\text { Recurso não } \\
\text { provido }\end{array}$ & $\begin{array}{l}\text { Ricardo } \\
\text { Lewandows } \\
\text { ki }\end{array}$ & $\begin{array}{l}\text { JTJ } \\
\text { v.228, p.39 }\end{array}$ \\
\hline $156.812-5$ & $\begin{array}{l}\text { Apelação } \\
\text { Cível }\end{array}$ & 2000 & $\begin{array}{l}\text { Acesso à } \\
\text { educação } \\
\text { básica }\end{array}$ & $\begin{array}{l}\text { Acesso Ed } \\
\text { Profissional }\end{array}$ & São Paulo & $\begin{array}{l}\text { Fazenda do } \\
\text { Estado de SP }\end{array}$ & P.A.C. & $\begin{array}{l}1^{\text {a }} \text { Câmara } \\
\text { de Direito } \\
\text { Público }\end{array}$ & Unânime & $\begin{array}{l}\text { Recurso não } \\
\text { provido }\end{array}$ & $\begin{array}{l}\text { Demóstenes } \\
\text { Braga }\end{array}$ & $\begin{array}{l}\text { JTJ } \\
\text { v. } 239, \text { p.220 }\end{array}$ \\
\hline \multicolumn{13}{|l|}{2001} \\
\hline $60.084-0$ & $\begin{array}{l}\text { Apelação } \\
\text { Cível }\end{array}$ & 2001 & $\begin{array}{l}\text { Acesso à } \\
\text { educação } \\
\text { básica }\end{array}$ & Acesso EF & São Paulo & $\begin{array}{l}\text { Fazenda do } \\
\text { Estado de SP }\end{array}$ & $\begin{array}{l}\text { Promotor de } \\
\text { Justiça da } \\
\text { Vara da } \\
\text { Infância e } \\
\text { Juventude de } \\
\text { Pinheiros } \\
\end{array}$ & $\begin{array}{l}\text { Câmara } \\
\text { Especial }\end{array}$ & Unânime & $\begin{array}{l}\text { Recurso } \\
\text { provido }\end{array}$ & $\begin{array}{l}\text { Mohamed } \\
\text { Amaro }\end{array}$ & $\begin{array}{l}\text { JTJ } \\
\text { v. } 245, \text { p. } 9\end{array}$ \\
\hline
\end{tabular}




\begin{tabular}{|c|c|c|c|c|c|c|c|c|c|c|c|c|}
\hline $\begin{array}{l}\text { Número } \\
\text { decisão }\end{array}$ & Natureza & Ano & Categorias & Tema & Origem & $\begin{array}{l}\text { Apelante } \\
\text { recorrente }\end{array}$ & $\begin{array}{l}\text { Apelados } \\
\text { recorridos }\end{array}$ & Câmara & Votação & Resultado & Relator & $\begin{array}{l}\text { Localização } \\
\text { da ementa / } \\
\text { acórdão }\end{array}$ \\
\hline $\begin{array}{l}62.937-0 / 1- \\
01\end{array}$ & $\begin{array}{l}\text { Embargos } \\
\text { Infringentes }\end{array}$ & 2001 & $\begin{array}{l}\text { Responsabili } \\
\text { dade estatal }\end{array}$ & $\begin{array}{l}\text { Transporte } \\
\text { escolar }\end{array}$ & Araraquara & $\begin{array}{l}\text { Fazenda } \\
\text { Pública do } \\
\text { Estado de São } \\
\text { Paulo }\end{array}$ & $\begin{array}{l}\text { Promotor de } \\
\text { Justiça da } \\
\text { Vara da } \\
\text { Infância e } \\
\text { Juventude de } \\
\text { Araraquara }\end{array}$ & $\begin{array}{l}\text { Câmara } \\
\text { Especial }\end{array}$ & Unânime & $\begin{array}{l}\text { Recurso não } \\
\text { provido }\end{array}$ & $\begin{array}{l}\text { Álvaro } \\
\text { Lazzarini }\end{array}$ & $\begin{array}{l}\text { Sítio eletrônico } \\
\text { TJ-SP }\end{array}$ \\
\hline $63.951-0 / 0$ & $\begin{array}{l}\text { Apelação } \\
\text { Cível }\end{array}$ & 2001 & $\begin{array}{l}\text { Acesso à } \\
\text { educação } \\
\text { básica }\end{array}$ & Acesso EI & Campinas & $\begin{array}{l}\text { Juízo Ex } \\
\text { Officio / } \\
\text { Prefeitura } \\
\text { Municipal de } \\
\text { Campinas }\end{array}$ & $\begin{array}{l}\text { Promtor de } \\
\text { Justiça da } \\
\text { Infância e } \\
\text { Juventude de } \\
\text { Campinas }\end{array}$ & $\begin{array}{l}\text { Câmara } \\
\text { Especial }\end{array}$ & Unânime & $\begin{array}{l}\text { Recurso não } \\
\text { provido }\end{array}$ & $\begin{array}{l}\text { Nigro } \\
\text { Conceição }\end{array}$ & Publicação MP \\
\hline $\begin{array}{l}\text { 64.281-0/0- } \\
00\end{array}$ & $\begin{array}{l}\text { Apelação } \\
\text { Cível }\end{array}$ & 2001 & $\begin{array}{l}\text { Acesso à } \\
\text { educação } \\
\text { básica }\end{array}$ & Acesso EF & São Paulo & $\begin{array}{l}\text { Juízo Ex } \\
\text { Officio / } \\
\text { Fazenda do } \\
\text { Estado de São } \\
\text { Paulo }\end{array}$ & $\begin{array}{l}\text { Promotor de } \\
\text { Justiça da } \\
\text { Vara da } \\
\text { Infância e } \\
\text { Juventude do } \\
\text { Foro } \\
\text { Regional de } \\
\text { Pinheiros }\end{array}$ & $\begin{array}{l}\text { Câmara } \\
\text { Especial }\end{array}$ & $\begin{array}{l}\text { Em voto } \\
\text { unânime } \\
\text { rejeitaram a } \\
\text { matéria } \\
\text { preliminar e, } \\
\text { por maioria } \\
\text { dos votos, } \\
\text { deram parcial } \\
\text { recurso }\end{array}$ & $\begin{array}{l}\text { Recurso } \\
\text { parcial ao } \\
\text { recurso }\end{array}$ & Gentil Leite & $\begin{array}{l}\text { Sítio eletrônico } \\
\text { TJ-SP }\end{array}$ \\
\hline $65.199-0$ & $\begin{array}{l}\text { Apelação } \\
\text { Cível }\end{array}$ & 2001 & $\begin{array}{l}\text { Deveres dos } \\
\text { pais }\end{array}$ & $\begin{array}{l}\text { Negligência } \\
\text { dos pais/ } \\
\text { responsáveis }\end{array}$ & Bananal & $\begin{array}{l}\text { Informação } \\
\text { ausente }\end{array}$ & $\begin{array}{l}\text { Informação } \\
\text { ausente }\end{array}$ & $\begin{array}{l}\text { Câmara } \\
\text { Especial }\end{array}$ & Unânime & $\begin{array}{l}\text { Recurso } \\
\text { provido }\end{array}$ & $\begin{array}{l}\text { Jesus } \\
\text { Lofrano }\end{array}$ & $\begin{array}{l}\text { Sítio biblioteca } \\
\text { TJ-SP }\end{array}$ \\
\hline $67.758 .0-9$ & $\begin{array}{l}\text { Apelação } \\
\text { Cível }\end{array}$ & 2001 & $\begin{array}{l}\text { Acesso à } \\
\text { educação } \\
\text { básica }\end{array}$ & Acesso EJA & São Paulo & $\begin{array}{l}\text { Fazenda } \\
\text { Pública do } \\
\text { Estado de São } \\
\text { Paulo }\end{array}$ & $\begin{array}{l}\text { Promotor de } \\
\text { Justiça da } \\
\text { Vara da } \\
\text { Infância e } \\
\text { Juventude do } \\
\text { Foro } \\
\text { Regional de } \\
\text { Pinheiros }\end{array}$ & $\begin{array}{l}\text { Câmara } \\
\text { Especial }\end{array}$ & Unânime & $\begin{array}{l}\text { Recurso } \\
\text { provido }\end{array}$ & Gentil Leite & $\begin{array}{l}\text { Sítio eletrônico } \\
\text { TJ-SP }\end{array}$ \\
\hline $68.831-0$ & $\begin{array}{l}\text { Apelação } \\
\text { Cível }\end{array}$ & 2001 & $\begin{array}{l}\text { Deveres dos } \\
\text { pais }\end{array}$ & $\begin{array}{l}\text { Negligência } \\
\text { dos pais/ } \\
\text { responsáveis }\end{array}$ & $\begin{array}{l}\text { Taquariting } \\
\text { a }\end{array}$ & $\begin{array}{l}\text { Criança ou } \\
\text { adolescente }\end{array}$ & $\begin{array}{l}\text { Promotor de } \\
\text { Justiça da } \\
\text { Vara da } \\
\text { Infância de } \\
\text { Taquaritinga } \\
\end{array}$ & $\begin{array}{l}\text { Câmara } \\
\text { Especial }\end{array}$ & Unânime & $\begin{array}{l}\text { Recurso } \\
\text { provido, com } \\
\text { recomendaçã } \\
\text { o }\end{array}$ & Gentil Leite & $\begin{array}{l}\text { JTJ } \\
\text { v. } 246, \text { p. } 117\end{array}$ \\
\hline
\end{tabular}




\begin{tabular}{|c|c|c|c|c|c|c|c|c|c|c|c|c|}
\hline $\begin{array}{l}\text { Número } \\
\text { decisão }\end{array}$ & Natureza & Ano & Categorias & Tema & Origem & $\begin{array}{l}\text { Apelante } \\
\text { recorrente }\end{array}$ & $\begin{array}{l}\text { Apelados } \\
\text { recorridos }\end{array}$ & Câmara & Votação & Resultado & Relator & $\begin{array}{l}\text { Localização } \\
\text { da ementa / } \\
\text { acórdão }\end{array}$ \\
\hline $68.863-0 / 5$ & $\begin{array}{l}\text { Apelação } \\
\text { Cível }\end{array}$ & 2001 & $\begin{array}{l}\text { Acesso à } \\
\text { educação } \\
\text { básica }\end{array}$ & Acesso EI & São Paulo & $\begin{array}{l}\text { Promotor de } \\
\text { Justiça da } \\
\text { Infância e } \\
\text { Juventude do } \\
\text { Foro Regional } \\
\text { do Ipiranga }\end{array}$ & $\begin{array}{l}\text { Municipalida } \\
\text { de de São } \\
\text { Paulo }\end{array}$ & $\begin{array}{l}\text { Câmara } \\
\text { Especial }\end{array}$ & Unânime & $\begin{array}{l}\text { Recurso não } \\
\text { provido }\end{array}$ & $\begin{array}{l}\text { Álvaro } \\
\text { Lazzarini }\end{array}$ & $\begin{array}{l}\text { Publicação } \\
\text { MP; Sítio } \\
\text { eletrônico TJ- } \\
\text { SP }\end{array}$ \\
\hline $69.069-0 / 9$ & $\begin{array}{l}\text { Apelação } \\
\text { Cível }\end{array}$ & 2001 & $\begin{array}{l}\text { Acesso à } \\
\text { educação } \\
\text { básica }\end{array}$ & Acesso EF & Barueri & & & & $\begin{array}{l}\text { Informação } \\
\text { ausente }\end{array}$ & $\begin{array}{l}\text { Recurso não } \\
\text { provido }\end{array}$ & Gentil Leite & Publicação MP \\
\hline $70.178-0 / 9$ & $\begin{array}{l}\text { Apelação } \\
\text { Cível }\end{array}$ & 2001 & $\begin{array}{l}\text { Responsabili } \\
\text { dade estatal }\end{array}$ & $\begin{array}{l}\text { Condições de } \\
\text { funcionament } \\
\text { o das escolas }\end{array}$ & São Paulo & $\begin{array}{l}\text { Fazenda do } \\
\text { Estado de SP }\end{array}$ & $\begin{array}{l}\text { Promotor de } \\
\text { Justiça da } \\
\text { Vara da } \\
\text { Infância e } \\
\text { Juventude do } \\
\text { Foro } \\
\text { Regional de } \\
\text { Penha de } \\
\text { França }\end{array}$ & $\begin{array}{l}\text { Câmara } \\
\text { Especial }\end{array}$ & Unânime & $\begin{array}{l}\text { Extinto o } \\
\text { processo, } \\
\text { sem } \\
\text { apreciação } \\
\text { do mérito }\end{array}$ & $\begin{array}{l}\text { Hermes } \\
\text { Pinotti }\end{array}$ & $\begin{array}{l}\text { Publicação } \\
\text { MP; Sítio } \\
\text { eletrônico TJ- } \\
\text { SP }\end{array}$ \\
\hline $70.606-0$ & $\begin{array}{l}\text { Apelação } \\
\text { Cível }\end{array}$ & 2001 & $\begin{array}{l}\text { Acesso à } \\
\text { educação } \\
\text { básica }\end{array}$ & Acesso EI & $\begin{array}{l}\text { Indisponíve } \\
1\end{array}$ & $\begin{array}{l}\text { Município não } \\
\text { divulgado }\end{array}$ & $\begin{array}{l}\text { Ministério } \\
\text { Público }\end{array}$ & $\begin{array}{l}\text { Câmara } \\
\text { Especial }\end{array}$ & Unânime & $\begin{array}{l}\text { Provimento } \\
\text { parcial ao } \\
\text { recurso } \\
\text { apenas para } \\
\text { cancelar a } \\
\text { condenação } \\
\text { em } \\
\text { honorários } \\
\text { advocatícios. }\end{array}$ & $\begin{array}{l}\text { Álvaro } \\
\text { Lazzarini }\end{array}$ & $\begin{array}{l}\text { JTJ } \\
\text { v. } 253, \text { p. } 11\end{array}$ \\
\hline $\begin{array}{l}70.869-0 / 2- \\
00\end{array}$ & $\begin{array}{l}\text { Apelação } \\
\text { Cível }\end{array}$ & 2001 & $\begin{array}{l}\text { Acesso à } \\
\text { educação } \\
\text { básica }\end{array}$ & Acesso EI & São Paulo & $\begin{array}{l}\text { Promotor de } \\
\text { Justiça da Vara } \\
\text { da Infância e } \\
\text { Juventude do } \\
\text { Foro Central } \\
\text { da Capital }\end{array}$ & $\begin{array}{l}\text { Municipalida } \\
\text { de de São } \\
\text { Paulo }\end{array}$ & $\begin{array}{l}\text { Câmara } \\
\text { Especial }\end{array}$ & Unânime & $\begin{array}{l}\text { Recurso não } \\
\text { provido }\end{array}$ & $\begin{array}{l}\text { Álvaro } \\
\text { Lazzarini }\end{array}$ & $\begin{array}{l}\text { Publicação } \\
\text { MP; Sítio } \\
\text { eletrônico TJ- } \\
\text { SP }\end{array}$ \\
\hline $71.734-0$ & $\begin{array}{l}\text { Apelação } \\
\text { Cível }\end{array}$ & 2001 & $\begin{array}{l}\text { Deveres dos } \\
\text { pais }\end{array}$ & $\begin{array}{l}\text { Negligência } \\
\text { dos pais/ } \\
\text { responsáveis }\end{array}$ & $\begin{array}{l}\text { Indisponíve } \\
1\end{array}$ & $\begin{array}{l}\text { Pais do } \\
\text { adolescente }\end{array}$ & Indisponível & $\begin{array}{l}\text { Câmara } \\
\text { Especial }\end{array}$ & Unânime & $\begin{array}{l}\text { Recurso } \\
\text { provido }\end{array}$ & $\begin{array}{l}\text { Hermes } \\
\text { Pinotti }\end{array}$ & $\begin{array}{l}\text { JTJ } \\
\text { v. } 242, \text { p. } 135\end{array}$ \\
\hline
\end{tabular}




\begin{tabular}{|c|c|c|c|c|c|c|c|c|c|c|c|c|}
\hline $\begin{array}{l}\text { Número } \\
\text { decisão }\end{array}$ & Natureza & Ano & Categorias & Tema & Origem & $\begin{array}{l}\text { Apelante } \\
\text { recorrente }\end{array}$ & $\begin{array}{l}\text { Apelados } \\
\text { recorridos }\end{array}$ & Câmara & Votação & Resultado & Relator & $\begin{array}{l}\text { Localização } \\
\text { da ementa / } \\
\text { acórdão }\end{array}$ \\
\hline $\begin{array}{l}72.407 .0 / 0- \\
00\end{array}$ & $\begin{array}{l}\text { Apelação } \\
\text { Cível }\end{array}$ & 2001 & Permanência & $\begin{array}{l}\text { Evasão } \\
\text { escolar }\end{array}$ & Sumaré & $\begin{array}{l}\text { Promotor de } \\
\text { Justiça da Vara } \\
\text { da Infância e } \\
\text { Juventude de } \\
\text { Sumaré }\end{array}$ & $\begin{array}{l}\text { Juiz de } \\
\text { Direito Vara } \\
\text { da Infância e } \\
\text { Juventude de } \\
\text { Sumaré }\end{array}$ & $\begin{array}{l}\text { Câmara } \\
\text { Especial }\end{array}$ & Unânime & $\begin{array}{l}\text { Recurso não } \\
\text { provido }\end{array}$ & $\begin{array}{l}\text { Álvaro } \\
\text { Lazzarini }\end{array}$ & $\begin{array}{l}\text { Sítio eletrônico } \\
\text { TJ-SP }\end{array}$ \\
\hline $76.209-0 / 5$ & $\begin{array}{l}\text { Apelação } \\
\text { Cível }\end{array}$ & 2001 & $\begin{array}{l}\text { Acesso à } \\
\text { educação } \\
\text { básica }\end{array}$ & Acesso EI & $\begin{array}{l}\text { São } \\
\text { Bernardo } \\
\text { do Campo }\end{array}$ & Município & $\begin{array}{l}\text { Informação } \\
\text { ausente }\end{array}$ & $\begin{array}{l}\text { Câmara } \\
\text { Especial }\end{array}$ & Unânime & $\begin{array}{l}\text { Recurso não } \\
\text { provido }\end{array}$ & $\begin{array}{l}\text { Álvaro } \\
\text { Lazzarini }\end{array}$ & $\begin{array}{l}\text { Sítio eletrônico } \\
\text { TJ-SP }\end{array}$ \\
\hline $76.640-0$ & $\begin{array}{l}\text { Apelação } \\
\text { Cível }\end{array}$ & 2001 & $\begin{array}{l}\text { Acesso à } \\
\text { educação } \\
\text { básica }\end{array}$ & Acesso EJA & São Paulo & $\begin{array}{l}\text { Promotor de } \\
\text { Justiça da } \\
\text { Defesa dos } \\
\text { Interesses } \\
\text { Difusos e } \\
\text { Coletivos da } \\
\text { Infância e } \\
\text { Juventude da } \\
\text { Capital }\end{array}$ & $\begin{array}{l}\text { Fazenda } \\
\text { Pública do } \\
\text { Estado de SP }\end{array}$ & $\begin{array}{l}\text { Câmara } \\
\text { Especial }\end{array}$ & Unânime & $\begin{array}{l}\text { Recurso } \\
\text { provido }\end{array}$ & $\begin{array}{l}\text { Álvaro } \\
\text { Lazzarini }\end{array}$ & $\begin{array}{l}\text { Sítio eletrônico } \\
\text { TJ-SP } \\
\text { v. } 246, \text { p.59 }\end{array}$ \\
\hline $\begin{array}{l}81.514-0 / 9- \\
00\end{array}$ & $\begin{array}{l}\text { Apelação } \\
\text { Cível }\end{array}$ & 2001 & $\begin{array}{l}\text { Acesso à } \\
\text { educação } \\
\text { básica }\end{array}$ & Acesso EI & São Paulo & $\begin{array}{l}\text { Municipalidad } \\
\text { e de São Paulo }\end{array}$ & $\begin{array}{l}\text { Promotor de } \\
\text { Justiça dos } \\
\text { Interesses } \\
\text { Difusos e } \\
\text { Coletivos da } \\
\text { Infância e } \\
\text { Juventude da } \\
\text { Capital }\end{array}$ & $\begin{array}{l}\text { Câmara } \\
\text { Especial }\end{array}$ & $\begin{array}{l}\text { Maioria dos } \\
\text { votos / } \\
\text { Consta a } \\
\text { declaração de } \\
\text { voto vencido } \\
\text { do Des. } \\
\text { Gentil Leite }\end{array}$ & $\begin{array}{l}\text { Recurso } \\
\text { provido }\end{array}$ & $\begin{array}{l}\text { Luiz } \\
\text { Tâmbara }\end{array}$ & $\begin{array}{l}\text { Sítio eletrônico } \\
\text { TJ-SP }\end{array}$ \\
\hline $\begin{array}{l}\text { 118.947- } \\
5 / 8-00\end{array}$ & $\begin{array}{l}\text { Apelação } \\
\text { Cível }\end{array}$ & 2001 & $\begin{array}{l}\text { Acesso à } \\
\text { educação } \\
\text { básica }\end{array}$ & Acesso EI & $\begin{array}{l}\text { Pindamonh } \\
\text { angaba }\end{array}$ & $\begin{array}{l}\text { Juízo Ex } \\
\text { Officio }\end{array}$ & $\begin{array}{l}\text { Menor } \\
\text { representada } \\
\text { pelo pai }\end{array}$ & $\begin{array}{l}5^{\text {a }} \text { Câmara } \\
\text { de Direito } \\
\text { Público }\end{array}$ & Unânime & $\begin{array}{l}\text { Recurso não } \\
\text { provido }\end{array}$ & $\begin{array}{l}\text { William } \\
\text { Marinho }\end{array}$ & $\begin{array}{l}\text { Sítio eletrônico } \\
\text { TJ-SP }\end{array}$ \\
\hline $120.952-0$ & $\begin{array}{l}\text { Apelação } \\
\text { Cível }\end{array}$ & 2001 & $\begin{array}{l}\text { Acesso à } \\
\text { educação } \\
\text { básica }\end{array}$ & Acesso EJA & São Paulo & $\begin{array}{l}\text { Juízo Ex } \\
\text { Officio / } \\
\text { Centro } \\
\text { Educacional } \\
\text { Santa Inês S/C } \\
\text { Ltda. }\end{array}$ & $\begin{array}{l}\text { Adolescente } \\
\text { representada } \\
\text { pelo pai }\end{array}$ & $\begin{array}{l}7^{\text {a }} \text { Câmara } \\
\text { de Direito } \\
\text { Público }\end{array}$ & Unânime & $\begin{array}{l}\text { Recurso não } \\
\text { provido }\end{array}$ & $\begin{array}{l}\text { Lourenço } \\
\text { Abbá Filho }\end{array}$ & $\begin{array}{l}\text { JTJ } \\
\text { v. } 250, \text { p.74 }\end{array}$ \\
\hline
\end{tabular}




\begin{tabular}{|c|c|c|c|c|c|c|c|c|c|c|c|c|}
\hline $\begin{array}{l}\text { Número } \\
\text { decisão }\end{array}$ & Natureza & Ano & Categorias & Tema & Origem & $\begin{array}{l}\text { Apelante } \\
\text { recorrente }\end{array}$ & $\begin{array}{l}\text { Apelados } \\
\text { recorridos }\end{array}$ & Câmara & Votação & Resultado & Relator & $\begin{array}{l}\text { Localização } \\
\text { da ementa / } \\
\text { acórdão }\end{array}$ \\
\hline $128.541-5$ & $\begin{array}{l}\text { Apelação } \\
\text { Cível }\end{array}$ & 2001 & $\begin{array}{l}\text { Acesso à } \\
\text { educação } \\
\text { básica }\end{array}$ & Acesso EF & Assis & $\begin{array}{l}\text { Juízo Ex } \\
\text { Officio }\end{array}$ & Criança & $\begin{array}{l}1^{\mathrm{a}} \text { Câmara } \\
\text { de Direito } \\
\text { Público }\end{array}$ & Unânime & $\begin{array}{l}\text { Provido o } \\
\text { reexame } \\
\text { necessário e } \\
\text { denegado a } \\
\text { segurança }\end{array}$ & $\begin{array}{l}\text { José Raul } \\
\text { Gavião de } \\
\text { Almeida }\end{array}$ & $\begin{array}{l}\text { JTJ } \\
\text { v. } 253, \text { p.73 }\end{array}$ \\
\hline $133.685-5$ & $\begin{array}{l}\text { Apelação } \\
\text { Cível }\end{array}$ & 2001 & $\begin{array}{l}\text { Acesso à } \\
\text { educação } \\
\text { básica }\end{array}$ & $\begin{array}{l}\text { Acesso Ed } \\
\text { Profissional }\end{array}$ & Marília & $\begin{array}{l}\text { Juízo Ex } \\
\text { Officio }\end{array}$ & $\begin{array}{l}\text { Adolescente } \\
\text { menor } \\
\text { representada } \\
\text { pelo pai }\end{array}$ & $\begin{array}{l}6^{\text {a }} \text { Câmara } \\
\text { de Direito } \\
\text { Público }\end{array}$ & Unânime & $\begin{array}{l}\text { Recurso não } \\
\text { provido }\end{array}$ & $\begin{array}{l}\text { Coimbra } \\
\text { Schmidt }\end{array}$ & $\begin{array}{l}\text { JTJ v.249, } \\
\text { p.123 }\end{array}$ \\
\hline $182.122-5$ & $\begin{array}{l}\text { Apelação } \\
\text { Cível }\end{array}$ & 2001 & $\begin{array}{l}\text { Poder de } \\
\text { regulação } \\
\text { estatal }\end{array}$ & $\begin{array}{l}\text { Autorização/ } \\
\text { credenciame } \\
\text { nto }\end{array}$ & São Paulo & $\begin{array}{l}\text { Colégio Nossa } \\
\text { Senhora da } \\
\text { Lapa }\end{array}$ & $\begin{array}{l}\text { Presidente do } \\
\text { Conselho } \\
\text { Estadual de } \\
\text { Educação do } \\
\text { Estado de SP }\end{array}$ & $\begin{array}{l}8^{a} \text { Câmara } \\
\text { de Direito } \\
\text { Público }\end{array}$ & Unânime & $\begin{array}{l}\text { Recurso não } \\
\text { provido }\end{array}$ & $\begin{array}{l}\text { Antonio } \\
\text { Villen }\end{array}$ & JTJ v.248, p.63 \\
\hline $197.185-5$ & $\begin{array}{l}\text { Apelação } \\
\text { Cível }\end{array}$ & 2001 & $\begin{array}{l}\text { Poder de } \\
\text { regulação } \\
\text { estatal }\end{array}$ & $\begin{array}{l}\text { Autorização/ } \\
\text { credenciame } \\
\text { nto }\end{array}$ & São Paulo & $\begin{array}{l}\text { Rumo } \\
\text { Valeparaibano } \\
\text { Sistema de } \\
\text { Ensino S/C } \\
\text { Ltda. }\end{array}$ & $\begin{array}{l}\text { Presidente do } \\
\text { Conselho } \\
\text { Estadual de } \\
\text { Educação do } \\
\text { Estado de SP }\end{array}$ & $\begin{array}{l}9^{\text {a }} \text { Câmara } \\
\text { de Direito } \\
\text { Público }\end{array}$ & Unânime & $\begin{array}{l}\text { Recurso não } \\
\text { provido }\end{array}$ & $\begin{array}{l}\text { Yoshiaki } \\
\text { Ichihara }\end{array}$ & JTJ v.241, p.42 \\
\hline $249.569-5$ & $\begin{array}{l}\text { Agravo de } \\
\text { instrumento }\end{array}$ & 2001 & $\begin{array}{l}\text { Poder de } \\
\text { regulação } \\
\text { estatal }\end{array}$ & $\begin{array}{l}\text { Autorização/ } \\
\text { credenciame } \\
\text { nto }\end{array}$ & São Paulo & $\begin{array}{l}\text { Instituto } \\
\text { Universal } \\
\text { Brasileiro } \\
\text { Ltda. }\end{array}$ & $\begin{array}{l}\text { Fazenda do } \\
\text { Estado de São } \\
\text { Paulo }\end{array}$ & $\begin{array}{l}9^{\text {a }} \text { Câmara } \\
\text { de Direito } \\
\text { Público }\end{array}$ & Unânime & $\begin{array}{l}\text { Recurso não } \\
\text { provido }\end{array}$ & $\begin{array}{l}\text { Rui } \\
\text { Cascaldi }\end{array}$ & $\begin{array}{l}\text { JTJ v.252, } \\
\text { p.266 }\end{array}$ \\
\hline \multicolumn{13}{|l|}{2002} \\
\hline $\begin{array}{l}43.739-0 / 7- \\
00\end{array}$ & $\begin{array}{l}\text { Apelação } \\
\text { Cível }\end{array}$ & 2002 & $\begin{array}{l}\text { Acesso à } \\
\text { educação } \\
\text { básica }\end{array}$ & Acesso EI & São Paulo & $\begin{array}{l}\text { Ministério } \\
\text { Público }\end{array}$ & Indisponível & $\begin{array}{l}2^{\text {a }} \text { Câmara } \\
\text { de Direito } \\
\text { Público }\end{array}$ & Unânime & $\begin{array}{l}\text { Recurso não } \\
\text { provido, } \\
\text { mantendo a } \\
\text { sentença que } \\
\text { julgou } \\
\text { extinto o } \\
\text { processo, } \\
\text { sem } \\
\text { conheciment } \\
\text { o do mérito. }\end{array}$ & $\begin{array}{l}\text { Alvaro } \\
\text { Lazzarini }\end{array}$ & JTJ v.254, p.9 \\
\hline $\begin{array}{l}70.903-0 / 2- \\
02\end{array}$ & $\begin{array}{l}\text { Embargos } \\
\text { Infringentes }\end{array}$ & 2002 & $\begin{array}{l}\text { Acesso à } \\
\text { educação } \\
\text { básica }\end{array}$ & Acesso EI & $\begin{array}{l}\text { Santo } \\
\text { André }\end{array}$ & $\begin{array}{l}\text { Município de } \\
\text { Santo André }\end{array}$ & $\begin{array}{l}\text { Ministério } \\
\text { Público }\end{array}$ & $\begin{array}{l}\text { Câmara } \\
\text { Especial }\end{array}$ & $\begin{array}{l}\text { Maioria dos } \\
\text { votos }\end{array}$ & $\begin{array}{l}\text { Embargos } \\
\text { rejeitados. } \\
\text { Consta } \\
\text { declaração de } \\
\text { voto vencido. }\end{array}$ & $\begin{array}{l}\text { Borelli } \\
\text { Machado }\end{array}$ & $\begin{array}{l}\text { Sítio eletrônico } \\
\text { TJ-SP }\end{array}$ \\
\hline
\end{tabular}




\begin{tabular}{|c|c|c|c|c|c|c|c|c|c|c|c|c|}
\hline $\begin{array}{l}\text { Número } \\
\text { decisão }\end{array}$ & Natureza & Ano & Categorias & Tema & Origem & $\begin{array}{l}\text { Apelante } \\
\text { recorrente }\end{array}$ & $\begin{array}{l}\text { Apelados } \\
\text { recorridos }\end{array}$ & Câmara & Votação & Resultado & Relator & $\begin{array}{l}\text { Localização } \\
\text { da ementa / } \\
\text { acórdão }\end{array}$ \\
\hline $\begin{array}{l}74.317-0 / 9- \\
03\end{array}$ & $\begin{array}{l}\text { Embargos de } \\
\text { Declaração }\end{array}$ & 2002 & $\begin{array}{l}\text { Acesso à } \\
\text { educação } \\
\text { básica }\end{array}$ & Acesso EI & $\begin{array}{l}\text { Santo } \\
\text { André }\end{array}$ & $\begin{array}{l}\text { Ministério } \\
\text { Público }\end{array}$ & $\begin{array}{l}\text { Município de } \\
\text { Santo André }\end{array}$ & $\begin{array}{l}\text { Câmara } \\
\text { Especial }\end{array}$ & Unânime & $\begin{array}{l}\text { Embargos } \\
\text { rejeitados }\end{array}$ & $\begin{array}{l}\text { Mohamed } \\
\text { Amaro }\end{array}$ & $\begin{array}{l}\text { Sítio eletrônico } \\
\text { TJ-SP }\end{array}$ \\
\hline $\begin{array}{l}75.064-0 / 0- \\
03\end{array}$ & $\begin{array}{l}\text { Embargos de } \\
\text { Declaração }\end{array}$ & 2002 & $\begin{array}{l}\text { Acesso à } \\
\text { educação } \\
\text { básica }\end{array}$ & Acesso EI & $\begin{array}{l}\text { Santo } \\
\text { André }\end{array}$ & $\begin{array}{l}\text { Ministério } \\
\text { Público }\end{array}$ & $\begin{array}{l}\text { Município de } \\
\text { Santo André }\end{array}$ & $\begin{array}{l}\text { Câmara } \\
\text { Especial }\end{array}$ & Unânime & $\begin{array}{l}\text { Embargos } \\
\text { rejeitados }\end{array}$ & $\begin{array}{l}\text { Mohamed } \\
\text { Amaro }\end{array}$ & $\begin{array}{l}\text { Sítio eletrônico } \\
\text { TJ-SP }\end{array}$ \\
\hline $\begin{array}{l}75.180-0 / 6- \\
01\end{array}$ & $\begin{array}{l}\text { Embargos de } \\
\text { Declaração }\end{array}$ & 2002 & $\begin{array}{l}\text { Acesso à } \\
\text { educação } \\
\text { básica }\end{array}$ & Acesso EI & $\begin{array}{l}\text { Santo } \\
\text { André }\end{array}$ & $\begin{array}{l}\text { Município de } \\
\text { Santo André }\end{array}$ & $\begin{array}{l}\text { Ministério } \\
\text { Público }\end{array}$ & $\begin{array}{l}\text { Câmara } \\
\text { Especial }\end{array}$ & Unânime & $\begin{array}{l}\text { Embargos } \\
\text { rejeitados }\end{array}$ & $\begin{array}{l}\text { Nigro } \\
\text { Conceição }\end{array}$ & $\begin{array}{l}\text { Sítio eletrônico } \\
\text { TJ-SP }\end{array}$ \\
\hline $\begin{array}{l}76.080-0 / 7- \\
01\end{array}$ & $\begin{array}{l}\text { Embargos de } \\
\text { Declaração }\end{array}$ & 2002 & $\begin{array}{l}\text { Acesso à } \\
\text { educação } \\
\text { básica }\end{array}$ & Acesso EI & $\begin{array}{l}\text { Santo } \\
\text { André }\end{array}$ & $\begin{array}{l}\text { Município de } \\
\text { Santo André }\end{array}$ & $\begin{array}{l}\text { Ministério } \\
\text { Público }\end{array}$ & $\begin{array}{l}\text { Câmara } \\
\text { Especial }\end{array}$ & Unânime & $\begin{array}{l}\text { Embargos } \\
\text { rejeitados }\end{array}$ & $\begin{array}{l}\text { Nigro } \\
\text { Conceição }\end{array}$ & $\begin{array}{l}\text { Sítio eletrônico } \\
\text { TJ-SP }\end{array}$ \\
\hline $\begin{array}{l}76.203-0 / 0- \\
01\end{array}$ & $\begin{array}{l}\text { Embargos } \\
\text { Infringentes }\end{array}$ & 2002 & $\begin{array}{l}\text { Acesso à } \\
\text { educação } \\
\text { básica }\end{array}$ & Acesso EI & $\begin{array}{l}\text { São } \\
\text { Bernardo } \\
\text { do Campo }\end{array}$ & $\begin{array}{l}\text { Município de } \\
\text { São Bernardo } \\
\text { do Campo }\end{array}$ & $\begin{array}{l}\text { Promotor de } \\
\text { Justiça da } \\
\text { Infância e } \\
\text { Juventude de } \\
\text { São Bernardo } \\
\text { do Campo }\end{array}$ & $\begin{array}{l}\text { Câmara } \\
\text { Especial }\end{array}$ & $\begin{array}{l}\text { Maioria dos } \\
\text { votos }\end{array}$ & $\begin{array}{l}\text { Embargos } \\
\text { recebidos }\end{array}$ & $\begin{array}{l}\text { Roberto } \\
\text { Vallim } \\
\text { Bellocchi }\end{array}$ & $\begin{array}{l}\text { Sítio eletrônico } \\
\text { TJ-SP }\end{array}$ \\
\hline $\begin{array}{l}\text { 78.313-0/6- } \\
01\end{array}$ & $\begin{array}{l}\text { Embargos } \\
\text { Infringentes }\end{array}$ & 2002 & $\begin{array}{l}\text { Acesso à } \\
\text { educação } \\
\text { básica }\end{array}$ & Acesso EI & $\begin{array}{l}\text { São José } \\
\text { dos } \\
\text { Campos }\end{array}$ & $\begin{array}{l}\text { Ministério } \\
\text { Público }\end{array}$ & $\begin{array}{l}\text { Prefeitura } \\
\text { Municipal de } \\
\text { São José dos } \\
\text { Campos } \\
\end{array}$ & $\begin{array}{l}\text { Câmara } \\
\text { Especial }\end{array}$ & Unânime & $\begin{array}{l}\text { Embargos } \\
\text { rejeitados }\end{array}$ & $\begin{array}{l}\text { Theodoro } \\
\text { Guimarães }\end{array}$ & $\begin{array}{l}\text { Sítio eletrônico } \\
\text { TJ-SP }\end{array}$ \\
\hline $\begin{array}{l}79.392-0 / 6- \\
03\end{array}$ & $\begin{array}{l}\text { Embargos de } \\
\text { Declaração }\end{array}$ & 2002 & $\begin{array}{l}\text { Acesso à } \\
\text { educação } \\
\text { básica }\end{array}$ & Acesso EI & $\begin{array}{l}\text { Santo } \\
\text { André }\end{array}$ & $\begin{array}{l}\text { Ministério } \\
\text { Público de São } \\
\text { Paulo }\end{array}$ & $\begin{array}{l}\text { Município de } \\
\text { Santo André }\end{array}$ & $\begin{array}{l}\text { Câmara } \\
\text { Especial }\end{array}$ & Unânime & $\begin{array}{l}\text { Embargos } \\
\text { rejeitados }\end{array}$ & $\begin{array}{l}\text { Mohamed } \\
\text { Amaro }\end{array}$ & $\begin{array}{l}\text { Sítio eletrônico } \\
\text { TJ-SP }\end{array}$ \\
\hline $\begin{array}{l}79.696-0 / 1- \\
02\end{array}$ & $\begin{array}{l}\text { Embargos de } \\
\text { Declaração }\end{array}$ & 2002 & $\begin{array}{l}\text { Acesso à } \\
\text { educaçãao } \\
\text { básica }\end{array}$ & Acesso EI & $\begin{array}{l}\text { Santo } \\
\text { André }\end{array}$ & $\begin{array}{l}\text { Ministério } \\
\text { Público de São } \\
\text { Paulo }\end{array}$ & $\begin{array}{l}\text { Município de } \\
\text { Santo André }\end{array}$ & $\begin{array}{l}\text { Câmara } \\
\text { Especial }\end{array}$ & Unânime & $\begin{array}{l}\text { Embargos } \\
\text { rejeitados }\end{array}$ & $\begin{array}{l}\text { Mohamed } \\
\text { Amaro }\end{array}$ & $\begin{array}{l}\text { Sítio eletrônico } \\
\text { TJ-SP }\end{array}$ \\
\hline $\begin{array}{l}080.260- \\
0 / 5-02\end{array}$ & $\begin{array}{l}\text { Embargos de } \\
\text { Declaração }\end{array}$ & 2002 & $\begin{array}{l}\text { Acesso à } \\
\text { educação } \\
\text { básica }\end{array}$ & Acesso EI & $\begin{array}{l}\text { Santo } \\
\text { André }\end{array}$ & $\begin{array}{l}\text { Ministério } \\
\text { Público }\end{array}$ & $\begin{array}{l}\text { Município de } \\
\text { Santo André }\end{array}$ & $\begin{array}{l}\text { Câmara } \\
\text { Especial }\end{array}$ & Unânime & $\begin{array}{l}\text { Embargos } \\
\text { rejeitados }\end{array}$ & $\begin{array}{l}\text { Mohamed } \\
\text { Amaro }\end{array}$ & $\begin{array}{l}\text { Sítio eletrônico } \\
\text { TJ-SP }\end{array}$ \\
\hline
\end{tabular}




\begin{tabular}{|c|c|c|c|c|c|c|c|c|c|c|c|c|}
\hline $\begin{array}{l}\text { Número } \\
\text { decisão }\end{array}$ & Natureza & Ano & Categorias & Tema & Origem & $\begin{array}{l}\text { Apelante } \\
\text { recorrente }\end{array}$ & $\begin{array}{l}\text { Apelados } \\
\text { recorridos }\end{array}$ & Câmara & Votação & Resultado & Relator & $\begin{array}{l}\text { Localização } \\
\text { da ementa / } \\
\text { acórdão }\end{array}$ \\
\hline $\begin{array}{l}80.262-0 / 4- \\
02\end{array}$ & $\begin{array}{l}\text { Embargos de } \\
\text { Declaração }\end{array}$ & 2002 & $\begin{array}{l}\text { Acesso à } \\
\text { educação } \\
\text { básica }\end{array}$ & Acesso EI & $\begin{array}{l}\text { Santo } \\
\text { André }\end{array}$ & $\begin{array}{l}\text { Ministério } \\
\text { Público }\end{array}$ & $\begin{array}{l}\text { Município de } \\
\text { Santo André }\end{array}$ & $\begin{array}{l}\text { Câmara } \\
\text { Especial }\end{array}$ & Unânime & $\begin{array}{l}\text { Embargos } \\
\text { rejeitados }\end{array}$ & $\begin{array}{l}\text { Mohamed } \\
\text { Amaro }\end{array}$ & $\begin{array}{l}\text { Sítio eletrônico } \\
\text { TJ-SP }\end{array}$ \\
\hline $\begin{array}{l}80.293-0 / 3- \\
01\end{array}$ & $\begin{array}{l}\text { Embargos } \\
\text { Infringentes }\end{array}$ & 2002 & $\begin{array}{l}\text { Acesso à } \\
\text { educação } \\
\text { básica }\end{array}$ & Acesso EI & $\begin{array}{l}\text { Santo } \\
\text { André }\end{array}$ & $\begin{array}{l}\text { Ministério } \\
\text { Público }\end{array}$ & $\begin{array}{l}\text { Município de } \\
\text { Santo André }\end{array}$ & $\begin{array}{l}\text { Câmara } \\
\text { Especial }\end{array}$ & $\begin{array}{l}\text { Maioria dos } \\
\text { votos }\end{array}$ & $\begin{array}{l}\text { Embargos } \\
\text { recebidos }\end{array}$ & $\begin{array}{l}\text { Denser de } \\
\text { Sá }\end{array}$ & $\begin{array}{l}\text { Sítio eletrônico } \\
\text { TJ-SP }\end{array}$ \\
\hline $\begin{array}{l}80.380-0 / 0- \\
01\end{array}$ & $\begin{array}{l}\text { Embargos } \\
\text { Infringentes }\end{array}$ & 2002 & $\begin{array}{l}\text { Acesso à } \\
\text { educação } \\
\text { básica }\end{array}$ & Acesso EI & $\begin{array}{l}\text { Santo } \\
\text { André }\end{array}$ & $\begin{array}{l}\text { Ministério } \\
\text { Público }\end{array}$ & $\begin{array}{l}\text { Municipalida } \\
\text { de de Santo } \\
\text { André }\end{array}$ & $\begin{array}{l}\text { Câmara } \\
\text { Especial }\end{array}$ & $\begin{array}{l}\text { Maioria dos } \\
\text { votos }\end{array}$ & $\begin{array}{l}\text { Acolhe-se os } \\
\text { embargos } \\
\text { para } \\
\text { restabelecer a } \\
\text { decisão de } \\
\text { primeiro } \\
\text { grau. }\end{array}$ & \begin{tabular}{|l|} 
Denser de \\
Sá
\end{tabular} & $\begin{array}{l}\text { Sítio eletrônico } \\
\text { TJ-SP }\end{array}$ \\
\hline $82.006-0$ & $\begin{array}{l}\text { Apelação } \\
\text { Cível }\end{array}$ & 2002 & $\begin{array}{l}\text { Acesso à } \\
\text { educação } \\
\text { básica }\end{array}$ & Acesso EI & $\begin{array}{l}\text { Santo } \\
\text { André }\end{array}$ & Município & $\begin{array}{l}\text { Ministério } \\
\text { Público }\end{array}$ & $\begin{array}{l}\text { Câmara } \\
\text { Especial }\end{array}$ & $\begin{array}{l}\text { Maioria dos } \\
\text { votos. Consta } \\
\text { a declaração } \\
\text { de voto } \\
\text { vencido do } \\
\text { Des. } \\
\text { Mohamed } \\
\text { Amaro }\end{array}$ & $\begin{array}{l}\text { Recurso não } \\
\text { provido }\end{array}$ & $\begin{array}{l}\text { Alvaro } \\
\text { Lazzarini }\end{array}$ & $\begin{array}{l}\text { JTJ v. } 252, \\
\text { p. } 174\end{array}$ \\
\hline $\begin{array}{l}82.040-0 / 6- \\
02\end{array}$ & $\begin{array}{l}\text { Embargos de } \\
\text { Declaração }\end{array}$ & 2002 & $\begin{array}{l}\text { Acesso à } \\
\text { educação } \\
\text { básica }\end{array}$ & Acesso EI & $\begin{array}{l}\text { Santo } \\
\text { André }\end{array}$ & $\begin{array}{l}\text { Ministério } \\
\text { Público }\end{array}$ & $\begin{array}{l}\text { Município de } \\
\text { Santo André }\end{array}$ & $\begin{array}{l}\text { Câmara } \\
\text { Especial }\end{array}$ & Unânime & $\begin{array}{l}\text { Embargos } \\
\text { rejeitados }\end{array}$ & $\begin{array}{l}\text { Mohamed } \\
\text { Amaro }\end{array}$ & $\begin{array}{l}\text { Sítio eletrônico } \\
\text { TJ-SP }\end{array}$ \\
\hline $\begin{array}{l}82.055-0 / 2- \\
01\end{array}$ & $\begin{array}{l}\text { Embargos } \\
\text { Infringentes }\end{array}$ & 2002 & $\begin{array}{l}\text { Acesso à } \\
\text { educação } \\
\text { básica }\end{array}$ & Acesso EI & $\begin{array}{l}\text { Santo } \\
\text { André }\end{array}$ & $\begin{array}{l}\text { Ministério } \\
\text { Público }\end{array}$ & $\begin{array}{l}\text { Município de } \\
\text { Santo André }\end{array}$ & $\begin{array}{l}\text { Câmara } \\
\text { Especial }\end{array}$ & $\begin{array}{l}\text { Maioria dos } \\
\text { votos }\end{array}$ & $\begin{array}{l}\text { Embargos } \\
\text { rejeitados }\end{array}$ & $\begin{array}{l}\text { Luís de } \\
\text { Macedo }\end{array}$ & $\begin{array}{l}\text { Sítio eletrônico } \\
\text { TJ-SP }\end{array}$ \\
\hline $\begin{array}{l}82.467-0 / 2- \\
01\end{array}$ & $\begin{array}{l}\text { Embargos } \\
\text { Infringentes }\end{array}$ & 2002 & $\begin{array}{l}\text { Acesso à } \\
\text { educação } \\
\text { básica }\end{array}$ & Acesso EI & $\begin{array}{l}\text { Santo } \\
\text { André }\end{array}$ & $\begin{array}{l}\text { Município de } \\
\text { Santo André }\end{array}$ & $\begin{array}{l}\text { Criança ou } \\
\text { adolescente }\end{array}$ & $\begin{array}{l}\text { Câmara } \\
\text { Especial }\end{array}$ & $\begin{array}{l}\text { Maioria dos } \\
\text { votos }\end{array}$ & $\begin{array}{l}\text { Embargos } \\
\text { rejeitados }\end{array}$ & $\begin{array}{l}\text { Borelli } \\
\text { Machado }\end{array}$ & $\begin{array}{l}\text { Sítio eletrônico } \\
\text { TJ-SP }\end{array}$ \\
\hline $\begin{array}{l}82.648-0 / 9- \\
01\end{array}$ & $\begin{array}{l}\text { Embargos } \\
\text { Infringentes }\end{array}$ & 2002 & $\begin{array}{l}\text { Acesso à } \\
\text { educação } \\
\text { básica }\end{array}$ & Acesso EI & $\begin{array}{l}\text { Santo } \\
\text { André }\end{array}$ & $\begin{array}{l}\text { Ministério } \\
\text { Público }\end{array}$ & $\begin{array}{l}\text { Município de } \\
\text { Santo André }\end{array}$ & $\begin{array}{l}\text { Câmara } \\
\text { Especial }\end{array}$ & $\begin{array}{l}\text { Maioria dos } \\
\text { votos }\end{array}$ & $\begin{array}{l}\text { Embargos } \\
\text { rejeitados }\end{array}$ & $\begin{array}{l}\text { Mohamed } \\
\text { Amaro }\end{array}$ & $\begin{array}{l}\text { Sítio eletrônico } \\
\text { TJ-SP }\end{array}$ \\
\hline
\end{tabular}




\begin{tabular}{|c|c|c|c|c|c|c|c|c|c|c|c|c|}
\hline $\begin{array}{l}\text { Número } \\
\text { decisão }\end{array}$ & Natureza & Ano & Categorias & Tema & Origem & $\begin{array}{l}\text { Apelante } \\
\text { recorrente }\end{array}$ & $\begin{array}{l}\text { Apelados } \\
\text { recorridos }\end{array}$ & Câmara & Votação & Resultado & Relator & $\begin{array}{l}\text { Localização } \\
\text { da ementa / } \\
\text { acórdão }\end{array}$ \\
\hline $\begin{array}{l}82.654-0 / 8- \\
02\end{array}$ & $\begin{array}{l}\text { Embargos de } \\
\text { Declaração }\end{array}$ & 2002 & $\begin{array}{l}\text { Acesso à } \\
\text { educação } \\
\text { básica }\end{array}$ & Acesso EI & $\begin{array}{l}\text { Santo } \\
\text { André }\end{array}$ & $\begin{array}{l}\text { Ministério } \\
\text { Público }\end{array}$ & $\begin{array}{l}\text { Município de } \\
\text { Santo André }\end{array}$ & $\begin{array}{l}\text { Câmara } \\
\text { Especial }\end{array}$ & Unânime & $\begin{array}{l}\text { Embargos } \\
\text { rejeitados }\end{array}$ & $\begin{array}{l}\text { Mohamed } \\
\text { Amaro }\end{array}$ & $\begin{array}{l}\text { Sítio eletrônico } \\
\text { TJ-SP }\end{array}$ \\
\hline $\begin{array}{l}83.794-0 / 1- \\
01\end{array}$ & $\begin{array}{l}\text { Embargos } \\
\text { Infringentes }\end{array}$ & 2002 & $\begin{array}{l}\text { Acesso à } \\
\text { educação } \\
\text { básica }\end{array}$ & Acesso EI & $\begin{array}{l}\text { Santo } \\
\text { André }\end{array}$ & $\begin{array}{l}\text { Município de } \\
\text { Santo André }\end{array}$ & $\begin{array}{l}\text { Ministério } \\
\text { Público }\end{array}$ & $\begin{array}{l}\text { Câmara } \\
\text { Especial }\end{array}$ & Unânime & $\begin{array}{l}\text { Embargos } \\
\text { rejeitados }\end{array}$ & $\begin{array}{l}\text { Mohamed } \\
\text { Amaro }\end{array}$ & $\begin{array}{l}\text { Sítio eletrônico } \\
\text { TJ-SP }\end{array}$ \\
\hline $\begin{array}{l}83.844-0 / 0- \\
01\end{array}$ & $\begin{array}{l}\text { Embargos } \\
\text { Infringentes }\end{array}$ & 2002 & $\begin{array}{l}\text { Acesso à } \\
\text { educação } \\
\text { básica }\end{array}$ & Acesso EI & $\begin{array}{l}\text { Santo } \\
\text { André }\end{array}$ & $\begin{array}{l}\text { Município de } \\
\text { Santo André }\end{array}$ & $\begin{array}{l}\text { Ministério } \\
\text { Público }\end{array}$ & $\begin{array}{l}\text { Câmara } \\
\text { Especial }\end{array}$ & $\begin{array}{l}\text { Maioria dos } \\
\text { votos }\end{array}$ & $\begin{array}{l}\text { Embargos } \\
\text { recebidos }\end{array}$ & $\begin{array}{l}\text { Borelli } \\
\text { Machado }\end{array}$ & $\begin{array}{l}\text { Sítio eletrônico } \\
\text { TJ-SP }\end{array}$ \\
\hline $\begin{array}{l}88.941-0 / 8- \\
00\end{array}$ & $\begin{array}{l}\text { Agravo de } \\
\text { instrumento }\end{array}$ & 2002 & $\begin{array}{l}\text { Acesso à } \\
\text { educação } \\
\text { básica }\end{array}$ & Acesso EI & $\begin{array}{l}\text { Presidente } \\
\text { Prudente }\end{array}$ & $\begin{array}{l}\text { Promotor de } \\
\text { Justiça da Vara } \\
\text { da Infância e } \\
\text { Juventude de } \\
\text { Presidente } \\
\text { Prudente }\end{array}$ & $\begin{array}{l}\text { Fazenda } \\
\text { Pública } \\
\text { Municipal de } \\
\text { Presidente } \\
\text { Prudente }\end{array}$ & $\begin{array}{l}\text { Câmara } \\
\text { Especial }\end{array}$ & $\begin{array}{l}\text { Maioria dos } \\
\text { votos }\end{array}$ & $\begin{array}{l}\text { Provimento } \\
\text { ao recurso }\end{array}$ & $\begin{array}{l}\text { Denser de } \\
\text { Sá }\end{array}$ & $\begin{array}{l}\text { Publicação } \\
\text { MP; Sítio } \\
\text { eletrônico TJ- } \\
\text { SP }\end{array}$ \\
\hline $\begin{array}{l}89.934-0 / 5- \\
01\end{array}$ & $\begin{array}{l}\text { Embargos } \\
\text { Infringentes }\end{array}$ & 2002 & $\begin{array}{l}\text { Acesso à } \\
\text { educaçãao } \\
\text { básica }\end{array}$ & Acesso EI & $\begin{array}{l}\text { Santo } \\
\text { André }\end{array}$ & $\begin{array}{l}\text { Ministério } \\
\text { Público }\end{array}$ & $\begin{array}{l}\text { Município de } \\
\text { Santo André }\end{array}$ & $\begin{array}{l}\text { Câmara } \\
\text { Especial }\end{array}$ & $\begin{array}{l}\text { Maioria dos } \\
\text { votos }\end{array}$ & $\begin{array}{l}\text { Embargos } \\
\text { recebidos }\end{array}$ & $\begin{array}{l}\text { Denser de } \\
\text { Sá }\end{array}$ & $\begin{array}{l}\text { Sítio eletrônico } \\
\text { TJ-SP }\end{array}$ \\
\hline $\begin{array}{l}91.380-0 / 4- \\
00\end{array}$ & $\begin{array}{l}\text { Recurso Ex } \\
\text { Officio }\end{array}$ & 2002 & $\begin{array}{l}\text { Acesso à } \\
\text { educaçãao } \\
\text { básica }\end{array}$ & Acesso EI & São Paulo & $\begin{array}{l}\text { Juízo Ex } \\
\text { Officio }\end{array}$ & $\begin{array}{l}\text { Promotor de } \\
\text { Justiça da } \\
\text { Vara da } \\
\text { Infância e } \\
\text { Juventude do } \\
\text { Foro } \\
\text { Regional de } \\
\text { Santana }\end{array}$ & $\begin{array}{l}\text { Câmara } \\
\text { Especial }\end{array}$ & Unânime & $\begin{array}{l}\text { Recurso não } \\
\text { provido }\end{array}$ & $\begin{array}{l}\text { Borelli } \\
\text { Machado }\end{array}$ & $\begin{array}{l}\text { Sítio eletrônico } \\
\text { TJ-SP }\end{array}$ \\
\hline $\begin{array}{l}92.828-0 / 7- \\
00\end{array}$ & $\begin{array}{l}\text { Agravo de } \\
\text { instrumento }\end{array}$ & 2002 & $\begin{array}{l}\text { Acesso à } \\
\text { educação } \\
\text { básica }\end{array}$ & Acesso EI & São Paulo & $\begin{array}{l}\text { Municipalida- } \\
\text { de de São } \\
\text { Paulo }\end{array}$ & $\begin{array}{l}\text { Promotor de } \\
\text { Justiça da } \\
\text { Vara da } \\
\text { Infância e } \\
\text { Juventude de } \\
\text { Pinheiros } \\
\end{array}$ & $\begin{array}{l}\text { Câmara } \\
\text { Especial }\end{array}$ & Unânime & $\begin{array}{l}\text { Recurso não } \\
\text { provido }\end{array}$ & $\begin{array}{l}\text { Theodoro } \\
\text { Guimarães }\end{array}$ & $\begin{array}{l}\text { Sítio eletrônico } \\
\text { TJ-SP }\end{array}$ \\
\hline
\end{tabular}




\begin{tabular}{|c|c|c|c|c|c|c|c|c|c|c|c|c|}
\hline $\begin{array}{l}\text { Número } \\
\text { decisão }\end{array}$ & Natureza & Ano & Categorias & Tema & Origem & $\begin{array}{l}\text { Apelante } \\
\text { recorrente }\end{array}$ & $\begin{array}{l}\text { Apelados } \\
\text { recorridos }\end{array}$ & Câmara & Votação & Resultado & Relator & $\begin{array}{l}\text { Localização } \\
\text { da ementa / } \\
\text { acórdão }\end{array}$ \\
\hline $\begin{array}{l}92.928-0 / 3- \\
00\end{array}$ & $\begin{array}{l}\text { Apelação } \\
\text { Cível }\end{array}$ & 2002 & $\begin{array}{l}\text { Acesso à } \\
\text { educação } \\
\text { básica }\end{array}$ & Acesso EI & São Paulo & $\begin{array}{l}\text { Municipalida- } \\
\text { de de São } \\
\text { Paulo e Juízo } \\
\text { Ex Officio }\end{array}$ & $\begin{array}{l}\text { Promotor de } \\
\text { Justiça da } \\
\text { Defesa dos } \\
\text { Interesses } \\
\text { Difusos e } \\
\text { Coletivos da } \\
\text { Infância e } \\
\text { Juventude da } \\
\text { Capital }\end{array}$ & $\begin{array}{l}\text { Câmara } \\
\text { Especial }\end{array}$ & Unânime & $\begin{array}{l}\text { Recurso } \\
\text { provido }\end{array}$ & $\begin{array}{l}\text { Moura } \\
\text { Ribeiro }\end{array}$ & $\begin{array}{l}\text { Sítio eletrônico } \\
\text { TJ-SP }\end{array}$ \\
\hline $\begin{array}{l}94.660-0 / 6- \\
01\end{array}$ & $\begin{array}{l}\text { Embargos de } \\
\text { Declaração }\end{array}$ & 2002 & $\begin{array}{l}\text { Acesso à } \\
\text { educação } \\
\text { básica }\end{array}$ & Acesso EI & $\begin{array}{l}\text { Santo } \\
\text { André }\end{array}$ & $\begin{array}{l}\text { Município de } \\
\text { Santo André }\end{array}$ & $\begin{array}{l}\text { Promotor de } \\
\text { Justiça da } \\
\text { Infância e } \\
\text { Juventude de } \\
\text { Santo André }\end{array}$ & $\begin{array}{l}\text { Câmara } \\
\text { Especial }\end{array}$ & Unânime & $\begin{array}{l}\text { Embargos } \\
\text { rejeitados }\end{array}$ & $\begin{array}{l}\text { Moura } \\
\text { Ribeiro }\end{array}$ & $\begin{array}{l}\text { Sítio eletrônico } \\
\text { TJ-SP }\end{array}$ \\
\hline $\begin{array}{l}95.924-0 / 7- \\
00\end{array}$ & $\begin{array}{l}\text { Apelação } \\
\text { Cível }\end{array}$ & 2002 & $\begin{array}{l}\text { Acesso à } \\
\text { educação } \\
\text { básica }\end{array}$ & Acesso EI & $\begin{array}{l}\text { Santo } \\
\text { André }\end{array}$ & $\begin{array}{l}\text { Juízo Ex } \\
\text { Officio / } \\
\text { Município de } \\
\text { Santo André }\end{array}$ & $\begin{array}{l}\text { Criança ou } \\
\text { adolescente }\end{array}$ & $\begin{array}{l}\text { Câmara } \\
\text { Especial }\end{array}$ & $\begin{array}{l}\text { Maioria dos } \\
\text { votos. Consta } \\
\text { a declaração } \\
\text { de voto } \\
\text { vencido do } \\
\text { Des. Luís de } \\
\text { Macedo }\end{array}$ & $\begin{array}{l}\text { Recurso não } \\
\text { provido }\end{array}$ & Gentil Leite & $\begin{array}{l}\text { Sítio eletrônico } \\
\text { TJ-SP }\end{array}$ \\
\hline $\begin{array}{l}95.975-0 / 9- \\
00\end{array}$ & $\begin{array}{l}\text { Apelação } \\
\text { Cível }\end{array}$ & 2002 & $\begin{array}{l}\text { Deveres dos } \\
\text { pais }\end{array}$ & $\begin{array}{l}\text { Negligência } \\
\text { dos pais/ } \\
\text { responsáveis }\end{array}$ & $\begin{array}{l}\text { Indisponíve } \\
1\end{array}$ & $\begin{array}{l}\text { Pais de duas } \\
\text { crianças ou } \\
\text { adolescentes }\end{array}$ & $\begin{array}{l}\text { Ministério } \\
\text { Público }\end{array}$ & $\begin{array}{l}\text { Câmara } \\
\text { Especial }\end{array}$ & Unânime & $\begin{array}{l}\text { Recurso não } \\
\text { provido, mas } \\
\text { com } \\
\text { substituição } \\
\text { da pena } \\
\text { pecuniária } \\
\text { pela de } \\
\text { advertência. }\end{array}$ & $\begin{array}{l}\text { Moura } \\
\text { Ribeiro }\end{array}$ & $\begin{array}{l}\text { JTJ v.260, } \\
\text { p.211 }\end{array}$ \\
\hline $\begin{array}{l}96.256-0 / 5- \\
00\end{array}$ & $\begin{array}{l}\text { Apelação } \\
\text { Cível }\end{array}$ & 2002 & $\begin{array}{l}\text { Acesso à } \\
\text { educação } \\
\text { básica }\end{array}$ & Acesso EI & Adamantina & $\begin{array}{l}\text { Promotor de } \\
\text { Justiça da Vara } \\
\text { da Infância e } \\
\text { Juventude de } \\
\text { Adamantina }\end{array}$ & $\begin{array}{l}\text { Prefeitura do } \\
\text { Município de } \\
\text { Adamantina }\end{array}$ & $\begin{array}{l}\text { Câmara } \\
\text { Especial }\end{array}$ & Unânime & $\begin{array}{l}\text { Recurso não } \\
\text { provido }\end{array}$ & $\begin{array}{l}\text { Theodoro } \\
\text { Guimarães }\end{array}$ & $\begin{array}{l}\text { Sítio eletrônico } \\
\text { TJ-SP }\end{array}$ \\
\hline $\begin{array}{l}96.423 .0 / 0- \\
01\end{array}$ & $\begin{array}{l}\text { Agravo } \\
\text { Regimental }\end{array}$ & 2002 & $\begin{array}{l}\text { Acesso à } \\
\text { educação } \\
\text { básica }\end{array}$ & Acesso EI & $\begin{array}{l}\text { Santo } \\
\text { André }\end{array}$ & $\begin{array}{l}\text { Criança ou } \\
\text { adolescente }\end{array}$ & $\begin{array}{l}\text { Município de } \\
\text { Santo André }\end{array}$ & $\begin{array}{l}\text { Sessão } \\
\text { Plenária }\end{array}$ & Unânime & $\begin{array}{l}\text { Agravo não } \\
\text { provido }\end{array}$ & $\begin{array}{l}\text { Sérgio } \\
\text { Augusto } \\
\text { Nigro } \\
\text { Conceição }\end{array}$ & $\begin{array}{l}\text { Sítio eletrônico } \\
\text { TJ-SP }\end{array}$ \\
\hline
\end{tabular}




\begin{tabular}{|c|c|c|c|c|c|c|c|c|c|c|c|c|}
\hline $\begin{array}{l}\text { Número } \\
\text { decisão }\end{array}$ & Natureza & Ano & Categorias & Tema & Origem & $\begin{array}{l}\text { Apelante } \\
\text { recorrente }\end{array}$ & $\begin{array}{l}\text { Apelados } \\
\text { recorridos }\end{array}$ & Câmara & Votação & Resultado & Relator & $\begin{array}{l}\text { Localização } \\
\text { da ementa / } \\
\text { acórdão }\end{array}$ \\
\hline $\begin{array}{l}96.819-0 / 5- \\
00\end{array}$ & $\begin{array}{l}\text { Apelação } \\
\text { Cível }\end{array}$ & 2002 & $\begin{array}{l}\text { Acesso à } \\
\text { educação } \\
\text { básica }\end{array}$ & Acesso EF & $\begin{array}{l}\text { Indisponíve } \\
1\end{array}$ & $\begin{array}{l}\text { Municipalidad } \\
\text { e }\end{array}$ & $\begin{array}{l}\text { Criança ou } \\
\text { adolescente } \\
\text { não } \\
\text { identificado }\end{array}$ & \begin{tabular}{|l|} 
Câmara \\
Especial
\end{tabular} & Unânime & $\begin{array}{l}\text { Recurso } \\
\text { provido para } \\
\text { denegar a } \\
\text { ordem } \\
\end{array}$ & \begin{tabular}{|l|} 
Moura \\
Ribeiro
\end{tabular} & $\begin{array}{l}\text { JTJ v.262, } \\
\text { p.168 }\end{array}$ \\
\hline $\begin{array}{l}98.920 .0 / 2- \\
01\end{array}$ & \begin{tabular}{|l|} 
Agravo \\
Regimental
\end{tabular} & 2002 & $\begin{array}{l}\text { Acesso à } \\
\text { educação } \\
\text { básica }\end{array}$ & Acesso EI & São Paulo & Criança & $\begin{array}{l}\text { Município de } \\
\text { Santo André }\end{array}$ & \begin{tabular}{|l|} 
Sessão \\
Plenária
\end{tabular} & Unânime & $\begin{array}{l}\text { Agravo não } \\
\text { provido }\end{array}$ & \begin{tabular}{|l} 
Sérgio \\
Augusto \\
Nigro \\
Conceição \\
\end{tabular} & $\begin{array}{l}\text { Sítio eletrônico } \\
\text { TJ-SP }\end{array}$ \\
\hline $\begin{array}{l}142.993- \\
5 / 5-00\end{array}$ & $\begin{array}{l}\text { Apelação } \\
\text { Cível }\end{array}$ & 2002 & \begin{tabular}{|l|} 
Decisões \\
administrativ \\
as e políticas
\end{tabular} & Outros & \begin{tabular}{|l|} 
Novo \\
Horizonte
\end{tabular} & \begin{tabular}{|l} 
Juízo Ex \\
Officio
\end{tabular} & $\begin{array}{l}\text { Criança ou } \\
\text { adolescente } \\
\text { representado } \\
\text { pelo pai }\end{array}$ & $\begin{array}{l}9^{\text {a }} \text { Câmara } \\
\text { de Direito } \\
\text { Público }\end{array}$ & Unânime & \begin{tabular}{|l} 
Recurso \\
negado
\end{tabular} & $\begin{array}{l}\text { Ricardo } \\
\text { Lewandows } \\
\text { ki }\end{array}$ & JTJ v.264, p.90 \\
\hline $\begin{array}{l}145.721- \\
5 / 7-00\end{array}$ & $\begin{array}{l}\text { Apelação } \\
\text { Cível }\end{array}$ & 2002 & Permanência & Outros & \begin{tabular}{|l} 
São José \\
dos \\
Campos
\end{tabular} & \begin{tabular}{|l} 
Juízo Ex \\
Officio
\end{tabular} & $\begin{array}{l}\text { Criança ou } \\
\text { adolescente } \\
\text { representado } \\
\text { pela mãe }\end{array}$ & $\begin{array}{l}9^{\text {a }} \text { Câmara } \\
\text { de Direito } \\
\text { Público }\end{array}$ & Unânime & $\begin{array}{l}\text { Recurso não } \\
\text { provido }\end{array}$ & \begin{tabular}{|l} 
Geraldo \\
Lucena
\end{tabular} & $\begin{array}{l}\text { JTJ v. 256, } \\
\text { p.160 }\end{array}$ \\
\hline $\begin{array}{l}150.600- \\
5 / 7-00\end{array}$ & $\begin{array}{l}\text { Apelação } \\
\text { Cível }\end{array}$ & 2002 & $\begin{array}{l}\text { Acesso à } \\
\text { educação } \\
\text { básica }\end{array}$ & Acesso EF & Capivari & \begin{tabular}{|l|} 
Juízo Ex \\
Officio / \\
Fazenda do \\
Estado de SP \\
\end{tabular} & $\begin{array}{l}\text { Criança ou } \\
\text { adolescente } \\
\text { representado } \\
\text { pelos pais } \\
\end{array}$ & $\begin{array}{l}2^{\mathrm{a}} \text { Câmara } \\
\text { de Direito } \\
\text { Público }\end{array}$ & $\begin{array}{l}\text { Informação } \\
\text { ausente }\end{array}$ & $\begin{array}{l}\text { Recurso não } \\
\text { provido }\end{array}$ & \begin{tabular}{|l} 
Alves \\
Bevilácqua
\end{tabular} & $\begin{array}{l}\text { JTJ } \\
\text { v. } 257, \text { p.51 }\end{array}$ \\
\hline $\begin{array}{l}151.402- \\
5 / 0-00\end{array}$ & $\begin{array}{l}\text { Apelação } \\
\text { Cível }\end{array}$ & 2002 & Permanência & $\begin{array}{l}\text { Violação às } \\
\text { normas } \\
\text { escolares }\end{array}$ & \begin{tabular}{|l} 
São José \\
dos \\
Campos
\end{tabular} & $\begin{array}{l}\text { Juízo Ex } \\
\text { Offício / } \\
\text { Fazenda do } \\
\text { Estado de São } \\
\text { Paulo }\end{array}$ & $\begin{array}{l}\text { Criança ou } \\
\text { adolescente }\end{array}$ & $\begin{array}{l}9^{\text {a }} \text { Câmara } \\
\text { de Direito } \\
\text { Público }\end{array}$ & Unânime & $\begin{array}{l}\text { Recurso não } \\
\text { provido }\end{array}$ & \begin{tabular}{|l|} 
Rui \\
Cascaldi
\end{tabular} & $\begin{array}{l}\text { JTJ } \\
\text { v.260, p.198 }\end{array}$ \\
\hline $\begin{array}{l}155.017 .5 / 2 \\
-00\end{array}$ & $\begin{array}{l}\text { Apelação } \\
\text { Cível }\end{array}$ & 2002 & $\begin{array}{l}\text { Decisões } \\
\text { administrativ } \\
\text { as e políticas }\end{array}$ & Outros & $\begin{array}{l}\text { Presidente } \\
\text { Epitácio }\end{array}$ & $\begin{array}{l}\text { Centro de } \\
\text { Ensino } \\
\text { Superior } \\
\text { Presidente } \\
\text { Epitácio e Ex } \\
\text { prefeito }\end{array}$ & $\begin{array}{l}\text { Ministério } \\
\text { Público / } \\
\text { Prefeitura } \\
\text { Municipal de } \\
\text { Presidente } \\
\text { Epitácio }\end{array}$ & $\begin{array}{l}9^{\text {a }} \text { Câmara } \\
\text { de Direito } \\
\text { Público }\end{array}$ & Unânime & $\begin{array}{l}\text { Extinto o } \\
\text { processo }\end{array}$ & $\begin{array}{l}\text { Sidnei } \\
\text { Beneti }\end{array}$ & $\begin{array}{l}\text { Sítio eletrônico } \\
\text { TJ-SP }\end{array}$ \\
\hline $\begin{array}{l}269.384- \\
5 / 2-00\end{array}$ & $\begin{array}{l}\text { Apelação } \\
\text { Cível }\end{array}$ & 2002 & $\begin{array}{l}\text { Responsabili } \\
\text { dade estatal }\end{array}$ & $\begin{array}{l}\text { Ação de } \\
\text { reparação de } \\
\text { danos }\end{array}$ & Guapiaçu & $\begin{array}{l}\text { A.F. / } \\
\text { Prefeitura } \\
\text { Municipal de } \\
\text { Guapiaçu }\end{array}$ & $\begin{array}{l}\text { Criança ou } \\
\text { adolescente } \\
\text { Prefeitura } \\
\text { Municipal de } \\
\text { Guapiaçu }\end{array}$ & $\begin{array}{l}3^{\circ} \text { Câmara } \\
\text { de Direito } \\
\text { Público }\end{array}$ & Unânime & \begin{tabular}{|l} 
Não \\
conheceram \\
do recurso \\
adesivo e \\
negaram \\
provimento à \\
apelação
\end{tabular} & $\begin{array}{l}\text { Peiretti de } \\
\text { Godoy }\end{array}$ & $\begin{array}{l}\text { Sítio eletrônico } \\
\text { TJ-SP }\end{array}$ \\
\hline
\end{tabular}




\begin{tabular}{|c|c|c|c|c|c|c|c|c|c|c|c|c|}
\hline $\begin{array}{l}\text { Número } \\
\text { decisão }\end{array}$ & Natureza & Ano & Categorias & Tema & Origem & $\begin{array}{l}\text { Apelante } \\
\text { recorrente }\end{array}$ & $\begin{array}{l}\text { Apelados } \\
\text { recorridos }\end{array}$ & Câmara & Votação & Resultado & Relator & $\begin{array}{l}\text { Localização } \\
\text { da ementa / } \\
\text { acórdão }\end{array}$ \\
\hline \multicolumn{13}{|l|}{2003} \\
\hline $\begin{array}{l}075.130- \\
0 / 7-00\end{array}$ & ADIN & 2003 & $\begin{array}{l}\text { Decisões } \\
\text { administrativ } \\
\text { as e políticas }\end{array}$ & \begin{tabular}{|l|} 
Competência \\
para legislar
\end{tabular} & Araçatuba & $\begin{array}{l}\text { Prefeita } \\
\text { Municipal de } \\
\text { Araçatuba }\end{array}$ & $\begin{array}{l}\text { Presidente da } \\
\text { Câmara } \\
\text { Municipal de } \\
\text { Araçatuba }\end{array}$ & \begin{tabular}{|l|} 
Órgão \\
Especial
\end{tabular} & Unânime & $\begin{array}{l}\text { Procedente a } \\
\text { ação }\end{array}$ & \begin{tabular}{|l|} 
Sinésio de \\
Souza
\end{tabular} & $\begin{array}{l}\text { JTJ v. } 287, \\
\text { p.463 }\end{array}$ \\
\hline $\begin{array}{l}\text { 78.699-0/6- } \\
01\end{array}$ & $\begin{array}{l}\text { Embargos } \\
\text { infringentes }\end{array}$ & 2003 & $\begin{array}{l}\text { Acesso à } \\
\text { educação } \\
\text { básica }\end{array}$ & Acesso EI & São Paulo & $\begin{array}{l}\text { Municipalidad } \\
\text { e de São Paulo }\end{array}$ & $\begin{array}{l}\text { Promotor de } \\
\text { Justiça da } \\
\text { Defesa dos } \\
\text { Interesses } \\
\text { Difusos e } \\
\text { Coletivos da } \\
\text { Infância e } \\
\text { Juventude da } \\
\text { Capital }\end{array}$ & \begin{tabular}{|l} 
Câmara \\
Especial
\end{tabular} & Unânime & $\begin{array}{l}\text { Embargos } \\
\text { não aceitos }\end{array}$ & \begin{tabular}{|l|} 
Theodoro \\
Guimarães
\end{tabular} & $\begin{array}{l}\text { Sítio eletrônico } \\
\text { TJ-SP }\end{array}$ \\
\hline $94.101 .0 / 4$ & ADIN & 2003 & $\begin{array}{l}\text { Decisões } \\
\text { administrativ } \\
\text { as e políticas }\end{array}$ & \begin{tabular}{|l|} 
Competência \\
para legislar
\end{tabular} & Americana & \begin{tabular}{|l} 
Prefeito \\
Municipal de \\
Americana
\end{tabular} & $\begin{array}{l}\text { Presidente da } \\
\text { Câmara } \\
\text { Municipal de } \\
\text { Americana }\end{array}$ & \begin{tabular}{|l|} 
Órgão \\
Especial
\end{tabular} & Unânime & $\begin{array}{l}\text { Procedente a } \\
\text { ação }\end{array}$ & \begin{tabular}{|l|} 
Paulo \\
Franco
\end{tabular} & \begin{tabular}{|l|} 
JTJ \\
v. 267, p. 523
\end{tabular} \\
\hline $\begin{array}{l}\text { 95.819-0/0- } \\
01\end{array}$ & $\begin{array}{l}\text { Embargos } \\
\text { Infringentes }\end{array}$ & 2003 & $\begin{array}{l}\text { Acesso à } \\
\text { educação } \\
\text { básica }\end{array}$ & Acesso EI & $\begin{array}{l}\text { Santo } \\
\text { André }\end{array}$ & $\begin{array}{l}\text { Ministério } \\
\text { Público }\end{array}$ & $\begin{array}{l}\text { Município de } \\
\text { Santo André }\end{array}$ & \begin{tabular}{|l|} 
Câmara \\
Especial
\end{tabular} & $\begin{array}{l}\text { Maioria dos } \\
\text { votos }\end{array}$ & $\begin{array}{l}\text { Embargos } \\
\text { não aceitos }\end{array}$ & \begin{tabular}{|l|} 
Luís de \\
Macedo
\end{tabular} & $\begin{array}{l}\text { Sítio eletrônico } \\
\text { TJ-SP }\end{array}$ \\
\hline $\begin{array}{l}097.769- \\
0 / 3-00\end{array}$ & ADIN & 2003 & $\begin{array}{l}\text { Decisões } \\
\text { administrativ } \\
\text { as e políticas }\end{array}$ & \begin{tabular}{|l|} 
Competência \\
para legislar
\end{tabular} & Mauá & \begin{tabular}{|l} 
Prefeito do \\
Município de \\
Mauá
\end{tabular} & $\begin{array}{l}\text { Presidente da } \\
\text { Câmara } \\
\text { Municipal de } \\
\text { Mauá }\end{array}$ & \begin{tabular}{|l|} 
Órgão \\
Especial
\end{tabular} & Unânime & $\begin{array}{l}\text { Procedente a } \\
\text { ação }\end{array}$ & \begin{tabular}{|l} 
Gildo dos \\
Santos
\end{tabular} & $\begin{array}{l}\text { JTJ } \\
\text { v.274, p.463 }\end{array}$ \\
\hline $\begin{array}{l}\text { 98.458-0/3- } \\
01\end{array}$ & $\begin{array}{l}\text { Embargos } \\
\text { Infringentes }\end{array}$ & 2003 & $\begin{array}{l}\text { Acesso à } \\
\text { educação } \\
\text { básica }\end{array}$ & Acesso EI & $\begin{array}{l}\text { Santo } \\
\text { André }\end{array}$ & $\begin{array}{l}\text { Ministério } \\
\text { Público }\end{array}$ & $\begin{array}{l}\text { Município de } \\
\text { Santo André }\end{array}$ & \begin{tabular}{|l|} 
Câmara \\
Especial
\end{tabular} & $\begin{array}{l}\text { Maioria dos } \\
\text { votos }\end{array}$ & $\begin{array}{l}\text { Embargos } \\
\text { não aceitos }\end{array}$ & \begin{tabular}{|l|} 
Luís de \\
Macedo
\end{tabular} & $\begin{array}{l}\text { Sítio eletrônico } \\
\text { TJ-SP }\end{array}$ \\
\hline $\begin{array}{l}\text { 99.259-0/2- } \\
01\end{array}$ & $\begin{array}{l}\text { Embargos } \\
\text { Infringentes }\end{array}$ & 2003 & $\begin{array}{l}\text { Acesso à } \\
\text { educação } \\
\text { básica }\end{array}$ & Acesso EI & $\begin{array}{l}\text { Santo } \\
\text { André }\end{array}$ & $\begin{array}{l}\text { Ministério } \\
\text { Público }\end{array}$ & $\begin{array}{l}\text { Município de } \\
\text { Santo André }\end{array}$ & \begin{tabular}{|l|} 
Câmara \\
Especial
\end{tabular} & $\begin{array}{l}\text { Maioria dos } \\
\text { votos }\end{array}$ & $\begin{array}{l}\text { Embargos } \\
\text { não aceitos }\end{array}$ & \begin{tabular}{|l|} 
Roberto \\
Vallim \\
Bellocchi
\end{tabular} & $\begin{array}{l}\text { Sítio eletrônico } \\
\text { TJ-SP }\end{array}$ \\
\hline $\begin{array}{l}99.293-0 / 7- \\
01\end{array}$ & $\begin{array}{l}\text { Agravo } \\
\text { Regimental }\end{array}$ & 2003 & $\begin{array}{l}\text { Acesso à } \\
\text { educação } \\
\text { básica }\end{array}$ & Acesso EI & São Paulo & $\begin{array}{l}\text { Municipalidad } \\
\text { e de São Paulo }\end{array}$ & $\begin{array}{l}\text { Promotor de } \\
\text { Justiça da } \\
\text { Vara da } \\
\text { Infância e } \\
\text { Juventude do } \\
\text { Foro } \\
\text { Regional da } \\
\text { Lapa }\end{array}$ & \begin{tabular}{|l|} 
Câmara \\
Especial
\end{tabular} & Unânime & $\begin{array}{l}\text { Agravo } \\
\text { provido }\end{array}$ & $\begin{array}{l}\text { Luís de } \\
\text { Macedo }\end{array}$ & $\begin{array}{l}\text { Sítio eletrônico } \\
\text { TJ-SP }\end{array}$ \\
\hline
\end{tabular}




\begin{tabular}{|c|c|c|c|c|c|c|c|c|c|c|c|c|}
\hline $\begin{array}{l}\text { Número } \\
\text { decisão }\end{array}$ & Natureza & Ano & Categorias & Tema & Origem & $\begin{array}{l}\text { Apelante } \\
\text { recorrente }\end{array}$ & $\begin{array}{l}\text { Apelados } \\
\text { recorridos }\end{array}$ & Câmara & Votação & Resultado & Relator & $\begin{array}{l}\text { Localização } \\
\text { da ementa / } \\
\text { acórdão }\end{array}$ \\
\hline 101.446.0/1 & ADIN & 2003 & $\begin{array}{l}\text { Decisões } \\
\text { administrativ } \\
\text { as e políticas }\end{array}$ & \begin{tabular}{|l} 
Competência \\
para legislar
\end{tabular} & $\begin{array}{l}\text { Ribeirão } \\
\text { Preto }\end{array}$ & $\begin{array}{l}\text { Prefeito } \\
\text { Municipal de } \\
\text { Ribeirão Preto }\end{array}$ & $\begin{array}{l}\text { Presidente da } \\
\text { Câmara } \\
\text { Municipal de } \\
\text { Ribeirão } \\
\text { Preto }\end{array}$ & $\begin{array}{l}\text { Órgão } \\
\text { Especial }\end{array}$ & Unânime & $\begin{array}{l}\text { Procedente a } \\
\text { ação }\end{array}$ & $\begin{array}{l}\text { Marco } \\
\text { César }\end{array}$ & $\begin{array}{l}\text { JTJ v.272, } \\
\text { p.480 }\end{array}$ \\
\hline $\begin{array}{l}101.568- \\
0 / 8-00\end{array}$ & ADIN & 2003 & $\begin{array}{l}\text { Decisões } \\
\text { administrativ } \\
\text { as e políticas }\end{array}$ & $\begin{array}{l}\text { Competência } \\
\text { para legislar }\end{array}$ & $\begin{array}{l}\text { Ribeirão } \\
\text { Preto }\end{array}$ & $\begin{array}{l}\text { Prefeito } \\
\text { Municipal de } \\
\text { Ribeirão Preto }\end{array}$ & $\begin{array}{l}\text { Presidente da } \\
\text { Câmara } \\
\text { Municipal de } \\
\text { Ribeirão } \\
\text { Preto }\end{array}$ & $\begin{array}{l}\text { Órgão } \\
\text { Especial }\end{array}$ & Unânime & $\begin{array}{l}\text { Procedente a } \\
\text { ação }\end{array}$ & $\begin{array}{l}\text { Flávio } \\
\text { Pinheiro }\end{array}$ & $\begin{array}{l}\text { JTJ v.269, } \\
\text { p.488 }\end{array}$ \\
\hline $\begin{array}{l}101.652- \\
0 / 1-00\end{array}$ & ADIN & 2003 & $\begin{array}{l}\text { Decisões } \\
\text { administrativ } \\
\text { as e políticas }\end{array}$ & \begin{tabular}{|l|} 
Competência \\
para legislar
\end{tabular} & Tapiraí & $\begin{array}{l}\text { Prefeito } \\
\text { Municipal de } \\
\text { Tapiraí }\end{array}$ & $\begin{array}{l}\text { Presidente da } \\
\text { Câmara } \\
\text { Municipal de } \\
\text { Tapiraí }\end{array}$ & $\begin{array}{l}\text { Órgão } \\
\text { Especial }\end{array}$ & Unânime & $\begin{array}{l}\text { Procedente a } \\
\text { ação }\end{array}$ & $\begin{array}{l}\text { Vallim } \\
\text { Bellocchi }\end{array}$ & $\begin{array}{l}\text { JTJ v. } 277, \\
\text { p.465 }\end{array}$ \\
\hline $102.112-0 / 5$ & $\begin{array}{l}\text { Apelação } \\
\text { Cível }\end{array}$ & 2003 & $\begin{array}{l}\text { Acesso à } \\
\text { educação } \\
\text { básica }\end{array}$ & Acesso EI & $\begin{array}{l}\text { Presidente } \\
\text { Prudente }\end{array}$ & $\begin{array}{l}\text { Promotor de } \\
\text { Justiça da Vara } \\
\text { da Infância e } \\
\text { Juventude de } \\
\text { Presidente } \\
\text { Prudente }\end{array}$ & $\begin{array}{l}\text { Município de } \\
\text { Presidente } \\
\text { Prudente }\end{array}$ & $\begin{array}{l}\text { Câmara } \\
\text { Especial }\end{array}$ & $\begin{array}{l}\text { Maioria dos } \\
\text { votos. } \\
\text { Declaração } \\
\text { de voto } \\
\text { vencido de } \\
\text { Denser Sá }\end{array}$ & $\begin{array}{l}\text { Recurso } \\
\text { negado }\end{array}$ & $\begin{array}{l}\text { Mohamed } \\
\text { Amaro }\end{array}$ & $\begin{array}{l}\text { Sítio eletrônico } \\
\text { TJ-SP }\end{array}$ \\
\hline $103.681-0 / 8$ & $\begin{array}{l}\text { Apelação } \\
\text { Cível }\end{array}$ & 2003 & $\begin{array}{l}\text { Acesso à } \\
\text { educação } \\
\text { básica }\end{array}$ & Acesso EI & $\begin{array}{l}\text { Ribeirão } \\
\text { Preto }\end{array}$ & $\begin{array}{l}\text { Prefeitura } \\
\text { Municipal de } \\
\text { Ribeirão Preto }\end{array}$ & $\begin{array}{l}\text { Promotor de } \\
\text { Justiça da } \\
\text { Vara da } \\
\text { Infância e } \\
\text { Juventude de } \\
\text { Ribeirão } \\
\text { Preto }\end{array}$ & $\begin{array}{l}\text { Câmara } \\
\text { Especial }\end{array}$ & $\begin{array}{l}\text { Maioria dos } \\
\text { votos. } \\
\text { Declaração } \\
\text { de voto } \\
\text { vencido de } \\
\text { Jesus } \\
\text { Lofrano }\end{array}$ & $\begin{array}{l}\text { Recurso } \\
\text { provido }\end{array}$ & $\begin{array}{l}\text { Mohamed } \\
\text { Amaro }\end{array}$ & $\begin{array}{l}\text { Sítio eletrônico } \\
\text { TJ-SP }\end{array}$ \\
\hline $\begin{array}{l}103.950- \\
0 / 6-00\end{array}$ & $\begin{array}{l}\text { Recurso Ex } \\
\text { Officio }\end{array}$ & 2003 & $\begin{array}{l}\text { Acesso à } \\
\text { educaçãoo } \\
\text { básica }\end{array}$ & Acesso EI & $\begin{array}{l}\text { Santo } \\
\text { André }\end{array}$ & $\begin{array}{l}\text { Juízo Ex } \\
\text { Officio }\end{array}$ & $\begin{array}{l}\text { Promotor de } \\
\text { Justiça da } \\
\text { Vara da } \\
\text { Infância e } \\
\text { Juventude e } \\
\text { Município de } \\
\text { Santo André }\end{array}$ & $\begin{array}{l}\text { Câmara } \\
\text { Especial }\end{array}$ & $\begin{array}{l}\text { Maioria dos } \\
\text { votos. } \\
\text { Declaração } \\
\text { de voto } \\
\text { vencido de } \\
\text { Denser Sá }\end{array}$ & $\begin{array}{l}\text { Recurso } \\
\text { provido }\end{array}$ & $\begin{array}{l}\text { Mohamed } \\
\text { Amaro }\end{array}$ & $\begin{array}{l}\text { Sítio eletrônico } \\
\text { TJ-SP }\end{array}$ \\
\hline $104.360-0 / 0$ & $\begin{array}{l}\text { Apelação } \\
\text { Cível }\end{array}$ & 2003 & $\begin{array}{l}\text { Decisões } \\
\text { administrativ } \\
\text { as e políticas }\end{array}$ & $\begin{array}{l}\text { Fechamento } \\
\text { de creche em } \\
\text { período de } \\
\text { férias }\end{array}$ & Taituva & $\begin{array}{l}\text { Promotor de } \\
\text { Justiça da } \\
\text { Infância e } \\
\text { Juventude de } \\
\text { Jaboticabal }\end{array}$ & $\begin{array}{l}\text { Município de } \\
\text { Taituva }\end{array}$ & $\begin{array}{l}\text { Câmara } \\
\text { Especial }\end{array}$ & Unânime & $\begin{array}{l}\text { Recurso } \\
\text { negado }\end{array}$ & $\begin{array}{l}\text { Luís de } \\
\text { Macedo }\end{array}$ & $\begin{array}{l}\text { Sítio eletrônico } \\
\text { TJ-SP }\end{array}$ \\
\hline
\end{tabular}




\begin{tabular}{|c|c|c|c|c|c|c|c|c|c|c|c|c|}
\hline $\begin{array}{l}\text { Número } \\
\text { decisão }\end{array}$ & Natureza & Ano & Categorias & Tema & Origem & $\begin{array}{l}\text { Apelante } \\
\text { recorrente }\end{array}$ & \begin{tabular}{|l|} 
Apelados \\
recorridos
\end{tabular} & Câmara & Votação & Resultado & Relator & $\begin{array}{l}\text { Localização } \\
\text { da ementa / } \\
\text { acórdão }\end{array}$ \\
\hline $\begin{array}{l}\text { 105.430- } \\
0 / 8-00\end{array}$ & $\begin{array}{l}\text { Agravo de } \\
\text { Instrumento }\end{array}$ & 2003 & $\begin{array}{l}\text { Acesso à } \\
\text { educação } \\
\text { básica }\end{array}$ & Acesso EI & São Paulo & $\begin{array}{l}\text { Municipalidad } \\
\text { e de São Paulo }\end{array}$ & \begin{tabular}{|l|} 
Promotor de \\
Justiça da \\
Vara da \\
Infância e \\
Juventude do \\
Foro \\
Regional de \\
Itaquera \\
\end{tabular} & \begin{tabular}{|l} 
Câmara \\
Especial
\end{tabular} & Unânime & $\begin{array}{l}\text { Recurso não } \\
\text { provido }\end{array}$ & $\begin{array}{l}\text { Denser de } \\
\text { Sá }\end{array}$ & $\begin{array}{l}\text { Sítio eletrônico } \\
\text { TJ-SP }\end{array}$ \\
\hline $\begin{array}{l}132.714- \\
5 / 5-00\end{array}$ & $\begin{array}{l}\text { Apelação } \\
\text { Cível }\end{array}$ & 2003 & $\begin{array}{l}\text { Gestão dos } \\
\text { recursos } \\
\text { públicos }\end{array}$ & $\begin{array}{l}\text { Repasse de } \\
\text { recurso } \\
\text { público a } \\
\text { instituição } \\
\text { privada }\end{array}$ & \begin{tabular}{|l|} 
Teodoro \\
Sampaio
\end{tabular} & $\begin{array}{l}\text { Juízo Ex } \\
\text { Officio }\end{array}$ & $\begin{array}{l}\text { Centro Social } \\
\text { Nossa } \\
\text { Senhora } \\
\text { Aparecida de } \\
\text { Teodoro } \\
\text { Sampaio }\end{array}$ & $\begin{array}{l}6^{\circ} \text { Câmara } \\
\text { de Direito } \\
\text { Público de } \\
\text { Férias } \\
\text { "Julho/2003" }\end{array}$ & Unânime & $\begin{array}{l}\text { Recurso não } \\
\text { provido }\end{array}$ & Afonso Faro & $\begin{array}{l}\text { Sítio eletrônico } \\
\text { TJ-SP }\end{array}$ \\
\hline $212.177 .5 / 6$ & \begin{tabular}{|l} 
Apelação \\
Cível
\end{tabular} & 2003 & $\begin{array}{l}\text { Gestão dos } \\
\text { recursos } \\
\text { públicos }\end{array}$ & $\begin{array}{l}\text { Aplicação } \\
\text { dos recursos }\end{array}$ & $\begin{array}{l}\text { Penápolis/ } \\
\text { Município } \\
\text { de Braúna }\end{array}$ & \begin{tabular}{|l} 
J.A.S. ex \\
prefeito do \\
Município de \\
Braúna \\
\end{tabular} & \begin{tabular}{|l|} 
Ministério \\
Público
\end{tabular} & $\begin{array}{l}8^{\mathrm{a}} \text { Câmara } \\
\text { de Direito } \\
\text { Público }\end{array}$ & Unânime & $\begin{array}{l}\text { Recurso } \\
\text { provido }\end{array}$ & $\begin{array}{l}\text { Celso } \\
\text { Bonilha }\end{array}$ & $\begin{array}{l}\text { JTJ v.268, } \\
\text { p.213 }\end{array}$ \\
\hline $\begin{array}{l}231.136- \\
5 / 9-00\end{array}$ & $\begin{array}{l}\text { Apelação } \\
\text { Cível }\end{array}$ & 2003 & $\begin{array}{l}\text { Acesso à } \\
\text { educação } \\
\text { básica }\end{array}$ & \begin{tabular}{|l|} 
Educação \\
Especial
\end{tabular} & \begin{tabular}{|l} 
Ribeirão \\
Preto
\end{tabular} & \begin{tabular}{|l|} 
Ministério \\
Público
\end{tabular} & \begin{tabular}{|l|} 
Prefeitura \\
Municipal de \\
Ribeirão \\
Preto \\
\end{tabular} & $\begin{array}{l}8^{\text {a }} \text { Câmara } \\
\text { de Direito } \\
\text { Público }\end{array}$ & Unânime & $\begin{array}{l}\text { Recurso } \\
\text { provido }\end{array}$ & $\begin{array}{l}\text { Toledo } \\
\text { Silva }\end{array}$ & JTJ v. 279, p.14 \\
\hline $\begin{array}{l}326.326- \\
5 / 3-00\end{array}$ & $\begin{array}{l}\text { Agravo de } \\
\text { Instrumento }\end{array}$ & 2003 & $\begin{array}{l}\text { Acesso à } \\
\text { educação } \\
\text { básica }\end{array}$ & \begin{tabular}{|l|} 
Educação \\
Especial
\end{tabular} & São Paulo & \begin{tabular}{|l} 
Prefeitura \\
Municipal de \\
São Paulo
\end{tabular} & \begin{tabular}{|l|} 
Ministério \\
Público
\end{tabular} & $\begin{array}{l}\text { Quarta } \\
\text { Câmara de } \\
\text { Direito } \\
\text { Público }\end{array}$ & Unânime & \begin{tabular}{|l|} 
Não \\
conheceram \\
do recurso, \\
determinando \\
remessa dos \\
autos à \\
Câmara \\
Especial \\
\end{tabular} & \begin{tabular}{|l} 
Samuel \\
Júnior
\end{tabular} & $\begin{array}{l}\text { Sítio eletrônico } \\
\text { biblioteca TJ- } \\
\text { SP }\end{array}$ \\
\hline $345.172-5 / 9$ & $\begin{array}{l}\text { Agravo de } \\
\text { instrumento }\end{array}$ & 2003 & $\begin{array}{l}\text { Acesso à } \\
\text { educação } \\
\text { básica }\end{array}$ & Acesso EI & São Paulo & \begin{tabular}{|l|} 
Prefeitura \\
Municipal de \\
São Paulo \\
\end{tabular} & \begin{tabular}{|l} 
Criança \\
representada \\
pela mãe \\
\end{tabular} & \begin{tabular}{|l|}
$8^{\mathrm{a}}$ Câmara \\
de Direito \\
Público \\
\end{tabular} & Unânime & $\begin{array}{l}\text { Recurso não } \\
\text { provido }\end{array}$ & \begin{tabular}{|l|} 
Celso \\
Bonilha
\end{tabular} & $\begin{array}{l}\text { Sítio eletrônico } \\
\text { TJ-SP }\end{array}$ \\
\hline \multicolumn{13}{|l|}{2004} \\
\hline $\begin{array}{l}101.624- \\
0 / 4-00\end{array}$ & $\begin{array}{l}\text { Agravo de } \\
\text { instrumento }\end{array}$ & 2004 & $\begin{array}{l}\text { Responsabili } \\
\text { dade estatal }\end{array}$ & $\begin{array}{l}\text { Transporte } \\
\text { escolar }\end{array}$ & Bauru & \begin{tabular}{|l} 
Fazenda \\
Pública do \\
Estado de São \\
Paulo
\end{tabular} & $\begin{array}{l}\text { Promotor de } \\
\text { Justiça da } \\
\text { Infância e } \\
\text { Juventude de } \\
\text { Bauru } \\
\end{array}$ & \begin{tabular}{|l|} 
Câmara \\
Especial
\end{tabular} & $\begin{array}{l}\text { Maioria dos } \\
\text { votos }\end{array}$ & $\begin{array}{l}\text { Provimento } \\
\text { parcial ao } \\
\text { recurso }\end{array}$ & \begin{tabular}{|l|} 
Roberto \\
Vallim \\
Bellocchi
\end{tabular} & $\begin{array}{l}\text { Sítio eletrônico } \\
\text { TJ-SP }\end{array}$ \\
\hline
\end{tabular}




\begin{tabular}{|c|c|c|c|c|c|c|c|c|c|c|c|c|}
\hline $\begin{array}{l}\text { Número } \\
\text { decisão }\end{array}$ & Natureza & Ano & Categorias & Tema & Origem & $\begin{array}{l}\text { Apelante } \\
\text { recorrente }\end{array}$ & $\begin{array}{l}\text { Apelados } \\
\text { recorridos }\end{array}$ & Câmara & Votação & Resultado & Relator & $\begin{array}{l}\text { Localização } \\
\text { da ementa / } \\
\text { acórdão }\end{array}$ \\
\hline $\begin{array}{l}101.751 .0 / 3 \\
-00\end{array}$ & ADIN & 2004 & $\begin{array}{l}\text { Decisões } \\
\text { administrativ } \\
\text { as e políticas }\end{array}$ & $\begin{array}{l}\text { Competência } \\
\text { para legislar }\end{array}$ & Bauru & $\begin{array}{l}\text { Prefeito do } \\
\text { Município de } \\
\text { Bauru }\end{array}$ & $\begin{array}{l}\text { Presidente da } \\
\text { Câmara } \\
\text { Municipal de } \\
\text { Bauru }\end{array}$ & $\begin{array}{l}\text { Órgão } \\
\text { Especial }\end{array}$ & Unânime & $\begin{array}{l}\text { Procente a } \\
\text { ação }\end{array}$ & $\begin{array}{l}\text { Luiz } \\
\text { Tâmbara }\end{array}$ & $\begin{array}{l}\text { Sítio eletrônico } \\
\text { TJ-SP }\end{array}$ \\
\hline $\begin{array}{l}102.806- \\
0 / 2-00\end{array}$ & ADIN & 2004 & $\begin{array}{l}\text { Decisões } \\
\text { administrativ } \\
\text { as e políticas }\end{array}$ & $\begin{array}{l}\text { Competência } \\
\text { para legislar }\end{array}$ & $\begin{array}{l}\text { São José do } \\
\text { Rio Preto }\end{array}$ & $\begin{array}{l}\text { Sindicato dos } \\
\text { Condutores } \\
\text { Autônomos de } \\
\text { Veículos } \\
\text { Rodoviários de } \\
\text { S.J.do Rio } \\
\text { Preto }\end{array}$ & $\begin{array}{l}\text { Presidente da } \\
\text { Câmara } \\
\text { Municipal de } \\
\text { S.J. do Rio } \\
\text { Preto }\end{array}$ & $\begin{array}{l}\text { Órgão } \\
\text { Especial }\end{array}$ & Unânime & $\begin{array}{l}\text { Procedente a } \\
\text { ação }\end{array}$ & $\begin{array}{l}\text { Álvaro } \\
\text { Lazzarini }\end{array}$ & $\begin{array}{l}\text { JTJ v.286, } \\
\text { p.471 }\end{array}$ \\
\hline $103.182-0 / 0$ & ADIN & 2004 & $\begin{array}{l}\text { Decisões } \\
\text { administrativ } \\
\text { as e políticas }\end{array}$ & \begin{tabular}{|l|} 
Competência \\
para legislar
\end{tabular} & $\begin{array}{l}\text { Ribeirão } \\
\text { Preto }\end{array}$ & $\begin{array}{l}\text { Prefeito do } \\
\text { Município de } \\
\text { Ribeirão Preto }\end{array}$ & \begin{tabular}{|l|} 
Presidente da \\
Câmara \\
Municipal de \\
Ribeirão \\
Preto \\
\end{tabular} & $\begin{array}{l}\text { Órgão } \\
\text { Especial }\end{array}$ & Unânime & $\begin{array}{l}\text { Procedente a } \\
\text { ação }\end{array}$ & $\begin{array}{l}\text { Denser de } \\
\text { Sá }\end{array}$ & $\begin{array}{l}\text { JTJ v.293, } \\
\text { p.491 }\end{array}$ \\
\hline $\begin{array}{l}104.182- \\
0 / 8-00\end{array}$ & $\begin{array}{l}\text { Apelação } \\
\text { Cível }\end{array}$ & 2004 & $\begin{array}{l}\text { Deveres dos } \\
\text { pais }\end{array}$ & $\begin{array}{l}\text { Negligência } \\
\text { dos pais/ } \\
\text { responsáveis }\end{array}$ & Piracaia & $\begin{array}{l}\text { Mãe da criança } \\
\text { ou adolescente }\end{array}$ & $\begin{array}{l}\text { Promotor de } \\
\text { Justiça da } \\
\text { Infância e } \\
\text { Juventude de } \\
\text { Piracaia }\end{array}$ & $\begin{array}{l}\text { Câmara } \\
\text { Especial }\end{array}$ & Unânime & $\begin{array}{l}\text { Rejeitaram a } \\
\text { matéria } \\
\text { preliminar e } \\
\text { no mérito } \\
\text { deram } \\
\text { provimento } \\
\text { ao recurso } \\
\end{array}$ & Gentil Leite & $\begin{array}{l}\text { Sítio eletrônico } \\
\text { TJ-SP }\end{array}$ \\
\hline 105.297.0/0 & ADIN & 2004 & $\begin{array}{l}\text { Decisões } \\
\text { administrativ } \\
\text { as e políticas }\end{array}$ & $\begin{array}{l}\text { Competência } \\
\text { para legislar }\end{array}$ & Guarulhos & $\begin{array}{l}\text { Prefeito do } \\
\text { Município de } \\
\text { Guarulhos }\end{array}$ & $\begin{array}{l}\text { Presidente da } \\
\text { Câmara } \\
\text { Municipal de } \\
\text { Guarulhos }\end{array}$ & $\begin{array}{l}\text { Órgão } \\
\text { Especial }\end{array}$ & Unânime & $\begin{array}{l}\text { Procedente a } \\
\text { ação }\end{array}$ & Gentil Leite & $\begin{array}{l}\text { JTJ } \\
\text { v. } 290, \text { p.59 }\end{array}$ \\
\hline $106.965-0 / 6$ & $\begin{array}{l}\text { Apelação } \\
\text { Cível }\end{array}$ & 2004 & $\begin{array}{l}\text { Deveres dos } \\
\text { pais }\end{array}$ & $\begin{array}{l}\text { Negligência } \\
\text { dos pais/ } \\
\text { responsáveis }\end{array}$ & Matão & $\begin{array}{l}\text { L.F.O e L.N.O } \\
\text { (pais do } \\
\text { menor) }\end{array}$ & $\begin{array}{l}\text { Promotor de } \\
\text { Justiça da } \\
\text { Infância e } \\
\text { Juventude de } \\
\text { Matão }\end{array}$ & $\begin{array}{l}\text { Câmara } \\
\text { Especial }\end{array}$ & Unânime & $\begin{array}{l}\text { Recurso } \\
\text { provido }\end{array}$ & $\begin{array}{l}\text { Jarbas } \\
\text { Mazzoni }\end{array}$ & $\begin{array}{l}\text { Sítio eletrônico } \\
\text { TJ-SP }\end{array}$ \\
\hline $\begin{array}{l}108.474 .0 / 0 \\
-00\end{array}$ & ADIN & 2004 & $\begin{array}{l}\text { Decisões } \\
\text { administrativ } \\
\text { as e políticas }\end{array}$ & \begin{tabular}{|l|} 
Competência \\
para legislar
\end{tabular} & Guarulhos & $\begin{array}{l}\text { Prefeito do } \\
\text { Município de } \\
\text { Guarulhos }\end{array}$ & $\begin{array}{l}\text { Presidente da } \\
\text { Câmara } \\
\text { Municipal de } \\
\text { Guarulhos } \\
\end{array}$ & $\begin{array}{l}\text { Órgão } \\
\text { Especial }\end{array}$ & Unânime & $\begin{array}{l}\text { Procedente a } \\
\text { ação }\end{array}$ & $\begin{array}{l}\text { Luiz } \\
\text { Tâmbara }\end{array}$ & $\begin{array}{l}\text { Sítio eletrônico } \\
\text { TJ-SP }\end{array}$ \\
\hline
\end{tabular}




\begin{tabular}{|c|c|c|c|c|c|c|c|c|c|c|c|c|}
\hline $\begin{array}{l}\text { Número } \\
\text { decisão }\end{array}$ & Natureza & Ano & Categorias & Tema & Origem & $\begin{array}{l}\text { Apelante } \\
\text { recorrente }\end{array}$ & $\begin{array}{l}\text { Apelados } \\
\text { recorridos }\end{array}$ & Câmara & Votação & Resultado & Relator & $\begin{array}{l}\text { Localização } \\
\text { da ementa / } \\
\text { acórdão }\end{array}$ \\
\hline $\begin{array}{l}108.688- \\
0 / 6-00\end{array}$ & ADIN & 2004 & $\begin{array}{l}\text { Decisões } \\
\text { administrativ } \\
\text { as e políticas }\end{array}$ & $\begin{array}{l}\text { Competência } \\
\text { para legislar }\end{array}$ & $\begin{array}{l}\text { Ribeirão } \\
\text { Preto }\end{array}$ & $\begin{array}{l}\text { Prefeito do } \\
\text { Município de } \\
\text { Ribeirão Preto }\end{array}$ & $\begin{array}{l}\text { Presidente da } \\
\text { Câmara } \\
\text { Municipal de } \\
\text { Ribeirão } \\
\text { Preto } \\
\end{array}$ & $\begin{array}{l}\text { Órgão } \\
\text { Especial }\end{array}$ & Unânime & $\begin{array}{l}\text { Procedente a } \\
\text { ação }\end{array}$ & $\begin{array}{l}\text { Luiz } \\
\text { Tâmbara }\end{array}$ & $\begin{array}{l}\text { Sítio eletrônico } \\
\text { TJ-SP }\end{array}$ \\
\hline $\begin{array}{l}110.231- \\
0 / 1-00\end{array}$ & $\begin{array}{l}\text { Apelação } \\
\text { Cível }\end{array}$ & 2004 & $\begin{array}{l}\text { Deveres dos } \\
\text { pais }\end{array}$ & $\begin{array}{l}\text { Negligência } \\
\text { dos pais/ } \\
\text { responsáveis }\end{array}$ & $\begin{array}{l}\text { Rio das } \\
\text { Pedras }\end{array}$ & $\begin{array}{l}\text { P. R. e M. P. } \\
\text { R. (pais do } \\
\text { menor) }\end{array}$ & $\begin{array}{l}\text { Promotor de } \\
\text { Justiça da } \\
\text { Vara da } \\
\text { Infância e } \\
\text { Juventude de } \\
\text { Rio das } \\
\text { Pedras }\end{array}$ & $\begin{array}{l}\text { Câmara } \\
\text { Especial }\end{array}$ & Unânime & $\begin{array}{l}\text { Recurso } \\
\text { provido }\end{array}$ & Gentil Leite & $\begin{array}{l}\text { Sítio eletrônico } \\
\text { TJ-SP }\end{array}$ \\
\hline $\begin{array}{l}110.690- \\
0 / 5-00\end{array}$ & $\begin{array}{l}\text { Apelação } \\
\text { Cível }\end{array}$ & 2004 & $\begin{array}{l}\text { Acesso à } \\
\text { educação } \\
\text { básica }\end{array}$ & $\begin{array}{l}\text { Educação } \\
\text { Especial }\end{array}$ & São Paulo & $\begin{array}{l}\text { Município de } \\
\text { São Paulo }\end{array}$ & $\begin{array}{l}\text { Promotor de } \\
\text { Justiça da } \\
\text { Vara da } \\
\text { Infância e } \\
\text { Juventude do } \\
\text { Foro } \\
\text { Regional de } \\
\text { Santana }\end{array}$ & $\begin{array}{l}\text { Câmara } \\
\text { Especial }\end{array}$ & Unânime & $\begin{array}{l}\text { Recurso não } \\
\text { provido }\end{array}$ & Gentil Leite & $\begin{array}{l}\text { JTJ v.286, } \\
\text { p.162 }\end{array}$ \\
\hline $\begin{array}{l}\text { 175.902- } \\
5 / 8-00\end{array}$ & $\begin{array}{l}\text { Apelação } \\
\text { Cível }\end{array}$ & 2004 & $\begin{array}{l}\text { Poder de } \\
\text { regulação } \\
\text { estatal }\end{array}$ & $\begin{array}{l}\text { Autorização/ } \\
\text { credenciame } \\
\text { nto }\end{array}$ & São Paulo & $\begin{array}{l}\text { Centro de } \\
\text { Ensino } \\
\text { Supletivo } \\
\text { Nova } \\
\text { Esperança }\end{array}$ & $\begin{array}{l}\text { Presidente do } \\
\text { Conselho } \\
\text { Estadual de } \\
\text { Educação do } \\
\text { Estado de SP }\end{array}$ & $\begin{array}{l}4^{\text {a }} \text { Câmara } \\
\text { de Direito } \\
\text { Público }\end{array}$ & Unânime & $\begin{array}{l}\text { Recurso não } \\
\text { provido }\end{array}$ & $\begin{array}{l}\text { Ferreira } \\
\text { Rodrigues }\end{array}$ & $\begin{array}{l}\text { Sítio eletrônico } \\
\text { TJ-SP }\end{array}$ \\
\hline $\begin{array}{l}241.185- \\
5 / 0-00\end{array}$ & $\begin{array}{l}\text { Apelação } \\
\text { Cível }\end{array}$ & 2004 & $\begin{array}{l}\text { Responsabili } \\
\text { dade estatal }\end{array}$ & $\begin{array}{l}\text { Transporte } \\
\text { escolar }\end{array}$ & $\begin{array}{l}\text { Teodoro } \\
\text { Sampaio }\end{array}$ & $\begin{array}{l}\text { Juízo Ex } \\
\text { Officio / } \\
\text { Prefeitura } \\
\text { Municipal de } \\
\text { Teodoro } \\
\text { Sampaio / } \\
\text { Fazenda do } \\
\text { Estado de SP }\end{array}$ & $\begin{array}{l}\text { Ministério } \\
\text { Público }\end{array}$ & $\begin{array}{l}3^{\text {a }} \text { Câmara } \\
\text { de Direito } \\
\text { Público }\end{array}$ & Unânime & $\begin{array}{l}\text { Recurso não } \\
\text { provido }\end{array}$ & $\begin{array}{l}\text { Laerte } \\
\text { Sampaio }\end{array}$ & $\begin{array}{l}\text { JTJ v. } 278, \\
\text { p.22 }\end{array}$ \\
\hline $\begin{array}{l}244.253- \\
5 / 2-00\end{array}$ & $\begin{array}{l}\text { Apelação } \\
\text { Cível }\end{array}$ & 2004 & $\begin{array}{l}\text { Acesso à } \\
\text { educação } \\
\text { básica }\end{array}$ & \begin{tabular}{|l|} 
Educação \\
Especial
\end{tabular} & $\begin{array}{l}\text { Ribeirão } \\
\text { Preto }\end{array}$ & $\begin{array}{l}\text { Ministério } \\
\text { Público }\end{array}$ & $\begin{array}{l}\text { Fazenda do } \\
\text { Estado de São } \\
\text { Paulo }\end{array}$ & $\begin{array}{l}3^{\text {a }} \text { Câmara } \\
\text { de Direito } \\
\text { Público }\end{array}$ & $\begin{array}{l}\text { Declaração } \\
\text { de voto } \\
\text { vencido de } \\
\text { Laerte } \\
\text { Sampaio } \\
\end{array}$ & $\begin{array}{l}\text { Recurso } \\
\text { provido }\end{array}$ & $\begin{array}{l}\text { Gama } \\
\text { Pellegrini }\end{array}$ & $\begin{array}{l}\text { JTJ v. } 281, \\
\text { p.12 }\end{array}$ \\
\hline
\end{tabular}




\begin{tabular}{|c|c|c|c|c|c|c|c|c|c|c|c|c|}
\hline $\begin{array}{l}\text { Número } \\
\text { decisão }\end{array}$ & Natureza & Ano & Categorias & Tema & Origem & $\begin{array}{l}\text { Apelante } \\
\text { recorrente }\end{array}$ & $\begin{array}{l}\text { Apelados } \\
\text { recorridos }\end{array}$ & Câmara & Votação & Resultado & Relator & $\begin{array}{l}\text { Localização } \\
\text { da ementa / } \\
\text { acórdão }\end{array}$ \\
\hline $354.816 .5 / 0$ & $\begin{array}{l}\text { Apelação } \\
\text { Cível }\end{array}$ & 2004 & $\begin{array}{l}\text { Acesso à } \\
\text { educação } \\
\text { básica }\end{array}$ & Acesso EI & Paulínia & $\begin{array}{l}\text { Ministério } \\
\text { Público }\end{array}$ & $\begin{array}{l}\text { Prefeitura } \\
\text { Municipal de } \\
\text { Paulínia }\end{array}$ & $\begin{array}{l}8^{\circ} \text { Câmara } \\
\text { de Direito } \\
\text { Público }\end{array}$ & Unânime & $\begin{array}{l}\text { Recurso } \\
\text { provido }\end{array}$ & $\begin{array}{l}\text { Celso } \\
\text { Bonilha }\end{array}$ & $\begin{array}{l}\text { Sítio eletrônico } \\
\text { TJ-SP }\end{array}$ \\
\hline \multicolumn{13}{|l|}{2005} \\
\hline $\begin{array}{l}\text { 111.613- } \\
0 / 2-00\end{array}$ & $\begin{array}{l}\text { Agravo de } \\
\text { instrumento }\end{array}$ & 2005 & $\begin{array}{l}\text { Acesso à } \\
\text { educação } \\
\text { básica }\end{array}$ & Acesso EI & $\begin{array}{l}\text { Indisponíve } \\
1\end{array}$ & $\begin{array}{l}\text { Prefeito } \\
\text { Municipal }\end{array}$ & Indisponível & $\begin{array}{l}\text { Câmara } \\
\text { Especial }\end{array}$ & $\begin{array}{l}\text { Maioria dos } \\
\text { votos }\end{array}$ & $\begin{array}{l}\text { Recurso } \\
\text { provido }\end{array}$ & Ruy Camilo & $\begin{array}{l}\text { JTJ } \\
\text { v.292, p.486 }\end{array}$ \\
\hline $\begin{array}{l}112.830- \\
0 / 1-01\end{array}$ & $\begin{array}{l}\text { Embargos } \\
\text { infringentes }\end{array}$ & 2005 & $\begin{array}{l}\text { Acesso à } \\
\text { educação } \\
\text { básica }\end{array}$ & Acesso EI & São Paulo & $\begin{array}{l}\text { Ministério } \\
\text { Público }\end{array}$ & $\begin{array}{l}\text { Municipalida } \\
\text { de de São } \\
\text { Paulo }\end{array}$ & $\begin{array}{l}\text { Câmara } \\
\text { Especial }\end{array}$ & $\begin{array}{l}\text { Maioria dos } \\
\text { votos }\end{array}$ & $\begin{array}{l}\text { Rejeitado os } \\
\text { embargos } \\
\text { infringentes }\end{array}$ & $\begin{array}{l}\text { Roberto } \\
\text { Solimene }\end{array}$ & $\begin{array}{l}\text { Sítio eletrônico } \\
\text { TJ-SP }\end{array}$ \\
\hline $\begin{array}{l}113.542- \\
0 / 2-00\end{array}$ & $\begin{array}{l}\text { Agravo de } \\
\text { instrumento }\end{array}$ & 2005 & $\begin{array}{l}\text { Acesso à } \\
\text { educação } \\
\text { básica }\end{array}$ & Acesso EI & $\begin{array}{l}\text { Presidente } \\
\text { Prudente }\end{array}$ & $\begin{array}{l}\text { Promotor de } \\
\text { Justiça da } \\
\text { Infância e } \\
\text { Juventude de } \\
\text { Presidente } \\
\text { Prudente }\end{array}$ & $\begin{array}{l}\text { Municipalida } \\
\text { de de } \\
\text { Presidente } \\
\text { Prudente }\end{array}$ & $\begin{array}{l}\text { Câmara } \\
\text { Especial }\end{array}$ & Unânime & $\begin{array}{l}\text { Recurso } \\
\text { provido }\end{array}$ & Gentil Leite & $\begin{array}{l}\text { Sítio eletrônico } \\
\text { TJ-SP }\end{array}$ \\
\hline $\begin{array}{l}114.148- \\
0 / 1-00\end{array}$ & ADIN & 2005 & $\begin{array}{l}\text { Decisões } \\
\text { administrativ } \\
\text { as e políticas }\end{array}$ & \begin{tabular}{|l|} 
Competência \\
para legislar
\end{tabular} & Itu & $\begin{array}{l}\text { Procurador } \\
\text { Geral de } \\
\text { Justiça }\end{array}$ & $\begin{array}{l}\text { Prefeito } \\
\text { Municipal de } \\
\text { Itu e } \\
\text { Presidência } \\
\text { da Câmara } \\
\text { Municipal de } \\
\text { Itu }\end{array}$ & $\begin{array}{l}\text { Órgão } \\
\text { Especial }\end{array}$ & Unânime & $\begin{array}{l}\text { Procedente a } \\
\text { ação }\end{array}$ & $\begin{array}{l}\text { Canguçu de } \\
\text { Almeida }\end{array}$ & $\begin{array}{l}\text { JTJ } \\
\text { v.293, p.491 }\end{array}$ \\
\hline $\begin{array}{l}115.045 .0 / 0 \\
-01\end{array}$ & $\begin{array}{l}\text { Agravo } \\
\text { Regimental }\end{array}$ & 2005 & $\begin{array}{l}\text { Acesso à } \\
\text { educação } \\
\text { básica }\end{array}$ & Acesso EI & $\begin{array}{l}\text { Santo } \\
\text { André }\end{array}$ & Criança & $\begin{array}{l}\text { Município de } \\
\text { Santo André }\end{array}$ & $\begin{array}{l}\text { Sessão } \\
\text { Plenária }\end{array}$ & Unânime & $\begin{array}{l}\text { Agravo } \\
\text { negado }\end{array}$ & $\begin{array}{l}\text { Luiz } \\
\text { Tâmbara }\end{array}$ & $\begin{array}{l}\text { Sítio eletrônico } \\
\text { TJ-SP }\end{array}$ \\
\hline $\begin{array}{l}117.872- \\
0 / 7-00\end{array}$ & $\begin{array}{l}\text { Recurso Ex } \\
\text { Officio }\end{array}$ & 2005 & $\begin{array}{l}\text { Acesso à } \\
\text { educação } \\
\text { básica }\end{array}$ & Acesso EI & Campinas & $\begin{array}{l}\text { Juízo Ex } \\
\text { Officio }\end{array}$ & $\begin{array}{l}\text { Criança e } \\
\text { Município de } \\
\text { Campinas }\end{array}$ & $\begin{array}{l}\text { Câmara } \\
\text { Especial }\end{array}$ & Unânime & $\begin{array}{l}\text { Recurso } \\
\text { provido }\end{array}$ & $\begin{array}{l}\text { Roberto } \\
\text { Solimene }\end{array}$ & $\begin{array}{l}\text { Sítio eletrônico } \\
\text { TJ-SP }\end{array}$ \\
\hline $\begin{array}{l}119.168- \\
0 / 9-00\end{array}$ & $\begin{array}{l}\text { Apelação } \\
\text { Cível }\end{array}$ & 2005 & $\begin{array}{l}\text { Acesso à } \\
\text { educação } \\
\text { básica }\end{array}$ & Acesso EI & $\begin{array}{l}\text { Indisponíve } \\
1\end{array}$ & Ex Officio & Indisponível & $\begin{array}{l}\text { Câmara } \\
\text { Especial }\end{array}$ & $\begin{array}{l}\text { Maioria dos } \\
\text { votos / } \\
\text { Consta a } \\
\text { declaração de } \\
\text { voto vencido } \\
\text { do Des. } \\
\text { Eduardo } \\
\text { Gouvêa }\end{array}$ & $\begin{array}{l}\text { Recurso } \\
\text { provido }\end{array}$ & $\begin{array}{l}\text { Paulo } \\
\text { Alcides }\end{array}$ & $\begin{array}{l}\text { JTJ } \\
\text { v. } 295, \text { p. } 196\end{array}$ \\
\hline
\end{tabular}




\begin{tabular}{|c|c|c|c|c|c|c|c|c|c|c|c|c|}
\hline $\begin{array}{l}\text { Número } \\
\text { decisão }\end{array}$ & Natureza & Ano & Categorias & Tema & Origem & $\begin{array}{l}\text { Apelante } \\
\text { recorrente }\end{array}$ & \begin{tabular}{|l|} 
Apelados \\
recorridos
\end{tabular} & Câmara & Votação & Resultado & Relator & $\begin{array}{l}\text { Localização } \\
\text { da ementa / } \\
\text { acórdão }\end{array}$ \\
\hline $\begin{array}{l}124.826- \\
0 / 4-00\end{array}$ & \begin{tabular}{|l|} 
Apelação \\
Cível
\end{tabular} & 2005 & $\begin{array}{l}\text { Acesso à } \\
\text { educação } \\
\text { básica }\end{array}$ & Acesso EI & São Paulo & $\begin{array}{l}\text { Município de } \\
\text { São Paulo }\end{array}$ & \begin{tabular}{|l|} 
Promotor de \\
Justiça Vara \\
Infância e \\
Juventude do \\
Foro \\
Regional \\
Santana \\
\end{tabular} & \begin{tabular}{|l|} 
Câmara \\
Especial
\end{tabular} & Unânime & $\begin{array}{l}\text { Recurso } \\
\text { prejudicado }\end{array}$ & $\begin{array}{l}\text { Mario A. } \\
\text { Silveira }\end{array}$ & $\begin{array}{l}\text { Sítio eletrônico } \\
\text { TJ-SP }\end{array}$ \\
\hline $\begin{array}{l}275.964- \\
5 / 9-00\end{array}$ & \begin{tabular}{|l|} 
Apelação \\
Cível
\end{tabular} & 2005 & $\begin{array}{l}\text { Acesso à } \\
\text { educação } \\
\text { básica }\end{array}$ & \begin{tabular}{|l|} 
Educação \\
Especial
\end{tabular} & \begin{tabular}{|l|} 
Ribeirão \\
Preto
\end{tabular} & $\begin{array}{l}\text { Juízo Ex } \\
\text { Officio / } \\
\text { Fazenda do } \\
\text { Estado de São } \\
\text { Paulo }\end{array}$ & \begin{tabular}{|l|} 
Ministério \\
Público
\end{tabular} & $\begin{array}{l}7^{\mathrm{a}} \text { Câmara } \\
\text { de Direito } \\
\text { Público }\end{array}$ & Unânime & $\begin{array}{l}\text { Recurso não } \\
\text { provido }\end{array}$ & $\begin{array}{l}\text { Milton } \\
\text { Gordo }\end{array}$ & \begin{tabular}{|l|} 
JTJ \\
v.290, p.21
\end{tabular} \\
\hline $\begin{array}{l}268.924- \\
5 / 0-00\end{array}$ & $\begin{array}{l}\text { Apelação } \\
\text { Cível com } \\
\text { revisão }\end{array}$ & 2005 & $\begin{array}{l}\text { Responsabili } \\
\text { dade estatal }\end{array}$ & \begin{tabular}{|l} 
Ação de \\
reparação de \\
danos
\end{tabular} & \begin{tabular}{|l|} 
Alfredo \\
Marcondes
\end{tabular} & $\begin{array}{l}\text { Juízo Ex } \\
\text { Officio }\end{array}$ & \begin{tabular}{|l|} 
Prefeitura \\
Municipal de \\
Alfredo \\
Marcondes \\
\end{tabular} & $\begin{array}{l}5^{\circ} \text { Câmara } \\
\text { de Direito } \\
\text { Público }\end{array}$ & Unânime & \begin{tabular}{|l} 
Recurso \\
negado
\end{tabular} & \begin{tabular}{|l} 
Alberto \\
Zvirblis
\end{tabular} & $\begin{array}{l}\text { Sítio eletrônico } \\
\text { TJ-SP }\end{array}$ \\
\hline $\begin{array}{l}\text { 301.167- } \\
5 / 4-00\end{array}$ & $\begin{array}{l}\text { Apelação } \\
\text { Cível com } \\
\text { revisão }\end{array}$ & 2005 & $\begin{array}{l}\text { Responsabili } \\
\text { dade estatal }\end{array}$ & \begin{tabular}{|l} 
Ação de \\
reparação de \\
danos
\end{tabular} & $\begin{array}{l}\text { Sud } \\
\text { Mennucci }\end{array}$ & \begin{tabular}{|l|} 
Prefeitura \\
Municipal de \\
Sud Mennucci
\end{tabular} & \begin{tabular}{|l|} 
Criança ou \\
adolescente
\end{tabular} & $\begin{array}{l}7^{\mathrm{a}} \text { Câmara } \\
\text { de Direito } \\
\text { Público }\end{array}$ & Unânime & \begin{tabular}{|l} 
Provimento \\
parcial ao \\
recurso da \\
autora, \\
provimento \\
negado ao \\
reexame \\
necessário e \\
ao recurso \\
voluntário da \\
municipalida \\
de.
\end{tabular} & $\begin{array}{l}\text { Guerrieri } \\
\text { Rezende }\end{array}$ & $\begin{array}{l}\text { Sítio eletrônico } \\
\text { TJ-SP }\end{array}$ \\
\hline $\begin{array}{l}375.810- \\
5 / 6-00\end{array}$ & \begin{tabular}{|l|} 
Apelação \\
Cível com \\
revisão \\
\end{tabular} & 2005 & $\begin{array}{l}\text { Acesso à } \\
\text { educação } \\
\text { básica }\end{array}$ & Acesso EI & Paulínia & $\begin{array}{l}\text { Ministério } \\
\text { Público }\end{array}$ & \begin{tabular}{|l|} 
Prefeitura \\
Municipal de \\
Paulínia \\
\end{tabular} & $\begin{array}{l}\text { 4 Câmara }^{\text {a Câm }} \\
\text { de Direito } \\
\text { Público } \\
\end{array}$ & Unânime & $\begin{array}{l}\text { Recurso } \\
\text { provido }\end{array}$ & \begin{tabular}{|l|} 
Ferreira \\
Rodrigues
\end{tabular} & $\begin{array}{l}\text { Sítio eletrônico } \\
\text { TJ-SP }\end{array}$ \\
\hline $\begin{array}{l}359.325- \\
5 / 7-01\end{array}$ & $\begin{array}{l}\text { Embargos de } \\
\text { Declaração }\end{array}$ & 2005 & $\begin{array}{l}\text { Acesso à } \\
\text { educação } \\
\text { básica }\end{array}$ & Acesso EI & Ipuã & $\begin{array}{l}\text { Ministério } \\
\text { Público }\end{array}$ & \begin{tabular}{|l|} 
Prefeitura \\
Municipal de \\
Ipuã \\
\end{tabular} & $\begin{array}{l}4^{\text {a }} \text { Câmara } \\
\text { de Direito } \\
\text { Público } \\
\end{array}$ & Unânime & $\begin{array}{l}\text { Embargos } \\
\text { rejeitados }\end{array}$ & \begin{tabular}{|l} 
Jo Tatsumi \\
\end{tabular} & $\begin{array}{l}\text { Sítio eletrônico } \\
\text { TJ-SP }\end{array}$ \\
\hline $409.603 .5 / 2$ & $\begin{array}{l}\text { Agravo de } \\
\text { instrumento }\end{array}$ & 2005 & \begin{tabular}{|l|} 
Poder de \\
regulação \\
estatal
\end{tabular} & $\begin{array}{l}\text { Mensalidade } \\
\text { escolar }\end{array}$ & Campinas & $\begin{array}{l}\text { Criança ou } \\
\text { adolescente }\end{array}$ & $\begin{array}{l}\text { Diretor do } \\
\text { Colégio } \\
\text { Politécnico } \\
\text { Bento } \\
\text { Quirino }\end{array}$ & $\begin{array}{l}10^{\text {a }} \text { Câmara } \\
\text { de Direito } \\
\text { Público }\end{array}$ & Unânime & $\begin{array}{l}\text { Recurso } \\
\text { provido }\end{array}$ & $\begin{array}{l}\text { Antonio } \\
\text { Carlos } \\
\text { Villen }\end{array}$ & $\begin{array}{l}\text { JTJ v.292, } \\
\text { p.487 }\end{array}$ \\
\hline
\end{tabular}




\begin{tabular}{|c|c|c|c|c|c|c|c|c|c|c|c|c|}
\hline $\begin{array}{l}\text { Número } \\
\text { decisão }\end{array}$ & Natureza & Ano & Categorias & Tema & Origem & $\begin{array}{l}\text { Apelante } \\
\text { recorrente }\end{array}$ & $\begin{array}{l}\text { Apelados } \\
\text { recorridos }\end{array}$ & Câmara & Votação & Resultado & Relator & $\begin{array}{l}\text { Localização } \\
\text { da ementa / } \\
\text { acórdão }\end{array}$ \\
\hline \multicolumn{13}{|l|}{2006} \\
\hline $\begin{array}{l}122.618- \\
0 / 0-00\end{array}$ & $\begin{array}{l}\text { Apelação } \\
\text { Cível }\end{array}$ & 2006 & $\begin{array}{l}\text { Acesso à } \\
\text { educação } \\
\text { básica }\end{array}$ & Acesso EI & São Paulo & $\begin{array}{l}\text { Recurso Ex } \\
\text { Offício / } \\
\text { Município de } \\
\text { São Paulo }\end{array}$ & $\begin{array}{l}\text { Associação } \\
\text { de Apoio a } \\
\text { meninos e } \\
\text { meninas da } \\
\text { região da Sé }\end{array}$ & $\begin{array}{l}\text { Câmara } \\
\text { Especial }\end{array}$ & Unânime & $\begin{array}{l}\text { Recurso } \\
\text { provido }\end{array}$ & $\begin{array}{l}\text { Sidney } \\
\text { Romano }\end{array}$ & $\begin{array}{l}\text { Sítio eletrônico } \\
\text { TJ-SP }\end{array}$ \\
\hline $\begin{array}{l}124.741- \\
0 / 6-00\end{array}$ & $\begin{array}{l}\text { Apelação } \\
\text { Cível }\end{array}$ & 2006 & $\begin{array}{l}\text { Acesso à } \\
\text { educação } \\
\text { básica }\end{array}$ & Acesso EI & Birigui & $\begin{array}{l}\text { Criança e Juízo } \\
\text { Ex Officio }\end{array}$ & $\begin{array}{l}\text { Prefeitura } \\
\text { Municipal de } \\
\text { Birigui }\end{array}$ & $\begin{array}{l}\text { Câmara } \\
\text { Especial }\end{array}$ & Unânime & $\begin{array}{l}\text { Apelação } \\
\text { provida e ao } \\
\text { recurso ex } \\
\text { officio }\end{array}$ & $\begin{array}{l}\text { Mario A. } \\
\text { Silveira }\end{array}$ & $\begin{array}{l}\text { Sítio eletrônico } \\
\text { TJ-SP }\end{array}$ \\
\hline $\begin{array}{l}127.659- \\
0 / 3-00\end{array}$ & $\begin{array}{l}\text { Apelação } \\
\text { Cível }\end{array}$ & 2006 & $\begin{array}{l}\text { Acesso à } \\
\text { educação } \\
\text { básica }\end{array}$ & Acesso EI & Peruíbe & $\begin{array}{l}\text { Prefeitura do } \\
\text { Município de } \\
\text { Peruíbe }\end{array}$ & $\begin{array}{l}\text { Ministério } \\
\text { Público }\end{array}$ & $\begin{array}{l}\text { Câmara } \\
\text { Especial }\end{array}$ & Unânime & $\begin{array}{l}\text { Provimento } \\
\text { parcial ao } \\
\text { recurso }\end{array}$ & $\begin{array}{l}\text { Maria } \\
\text { Olivia } \\
\text { Alves }\end{array}$ & $\begin{array}{l}\text { Sítio eletrônico } \\
\text { TJ-SP }\end{array}$ \\
\hline $\begin{array}{l}127.747- \\
0 / 5-00\end{array}$ & $\begin{array}{l}\text { Apelação } \\
\text { Cível }\end{array}$ & 2006 & $\begin{array}{l}\text { Acesso à } \\
\text { educação } \\
\text { básica }\end{array}$ & Acesso EI & $\begin{array}{l}\text { Presidente } \\
\text { Prudente }\end{array}$ & $\begin{array}{l}\text { Promotor de } \\
\text { Justiça de } \\
\text { Presidente } \\
\text { Prudente / } \\
\text { Município de } \\
\text { Presidente } \\
\text { Prudente }\end{array}$ & $\begin{array}{l}\text { Município de } \\
\text { Presidente } \\
\text { Prudente / } \\
\text { Ministério } \\
\text { Público de } \\
\text { Presidente } \\
\text { Prudente }\end{array}$ & $\begin{array}{l}\text { Câmara } \\
\text { Especial }\end{array}$ & Unânime & $\begin{array}{l}\text { Não } \\
\text { conheceram } \\
\text { do recurso } \\
\text { interposto } \\
\text { pela } \\
\text { Municipalida } \\
\text { de, negaram } \\
\text { provimento } \\
\text { ao recurso de } \\
\text { ofício e } \\
\text { rejeitada a } \\
\text { preliminar no } \\
\text { recurso } \\
\text { ministerial a } \\
\text { ele deram } \\
\text { provimento }\end{array}$ & $\begin{array}{l}\text { Paulo } \\
\text { Alcides }\end{array}$ & $\begin{array}{l}\text { Sítio eletrônico } \\
\text { TJ-SP }\end{array}$ \\
\hline $\begin{array}{l}127.951- \\
0 / 6-00\end{array}$ & $\begin{array}{l}\text { Apelação } \\
\text { Cível }\end{array}$ & 2006 & $\begin{array}{l}\text { Acesso à } \\
\text { educação } \\
\text { básica }\end{array}$ & Acesso EI & Santos & $\begin{array}{l}\text { Juízo Ex } \\
\text { Officio e } \\
\text { Prefeitura } \\
\text { Municipal de } \\
\text { Santos }\end{array}$ & $\begin{array}{l}\text { Promotor de } \\
\text { Justiça da } \\
\text { Vara da } \\
\text { Infância e } \\
\text { Juventude de } \\
\text { Santos }\end{array}$ & $\begin{array}{l}\text { Câmara } \\
\text { Especial }\end{array}$ & Unânime & $\begin{array}{l}\text { Provimento } \\
\text { parcial ao } \\
\text { recurso }\end{array}$ & $\begin{array}{l}\text { Fábio } \\
\text { Quadros }\end{array}$ & $\begin{array}{l}\text { Sítio eletrônico } \\
\text { TJ-SP }\end{array}$ \\
\hline $\begin{array}{l}127.996- \\
0 / 2-01\end{array}$ & $\begin{array}{l}\text { Embargos de } \\
\text { declaração }\end{array}$ & 2006 & $\begin{array}{l}\text { Acesso à } \\
\text { educação } \\
\text { básica }\end{array}$ & Acesso EI & Santos & $\begin{array}{l}\text { Município de } \\
\text { Santos }\end{array}$ & $\begin{array}{l}\text { Promotor de } \\
\text { Justiça de } \\
\text { Santos }\end{array}$ & $\begin{array}{l}\text { Câmara } \\
\text { Especial }\end{array}$ & Unânime & $\begin{array}{l}\text { Rejeitaram } \\
\text { os embargos }\end{array}$ & $\begin{array}{l}\text { Fábio } \\
\text { Quadros }\end{array}$ & $\begin{array}{l}\text { Sítio eletrônico } \\
\text { TJ-SP }\end{array}$ \\
\hline
\end{tabular}




\begin{tabular}{|c|c|c|c|c|c|c|c|c|c|c|c|c|}
\hline $\begin{array}{l}\text { Número } \\
\text { decisão }\end{array}$ & Natureza & Ano & Categorias & Tema & Origem & $\begin{array}{l}\text { Apelante } \\
\text { recorrente }\end{array}$ & $\begin{array}{l}\text { Apelados } \\
\text { recorridos }\end{array}$ & Câmara & Votação & Resultado & Relator & $\begin{array}{l}\text { Localização } \\
\text { da ementa / } \\
\text { acórdão }\end{array}$ \\
\hline $\begin{array}{l}128.228 .0 / 4 \\
-00\end{array}$ & ADIN & 2006 & $\begin{array}{l}\text { Decisões } \\
\text { administrativ } \\
\text { as e políticas }\end{array}$ & \begin{tabular}{|l} 
Competência \\
para legislar
\end{tabular} & São Paulo & \begin{tabular}{|l} 
Prefeito \\
Municipal de \\
Tietê
\end{tabular} & $\begin{array}{l}\text { Presidente da } \\
\text { Câmara } \\
\text { Municipal de } \\
\text { Tietê }\end{array}$ & \begin{tabular}{|l|} 
Órgão \\
Especial
\end{tabular} & Unânime & $\begin{array}{l}\text { Ação } \\
\text { procedente }\end{array}$ & $\begin{array}{l}\text { Passos de } \\
\text { Freitas }\end{array}$ & $\begin{array}{l}\text { Sítio eletrônico } \\
\text { TJ-SP }\end{array}$ \\
\hline $\begin{array}{l}129.675- \\
0 / 0-00\end{array}$ & $\begin{array}{l}\text { Apelação } \\
\text { Cível }\end{array}$ & 2006 & $\begin{array}{l}\text { Deveres dos } \\
\text { pais }\end{array}$ & $\begin{array}{l}\text { Negligência } \\
\text { dos pais/ } \\
\text { responsáveis }\end{array}$ & $\begin{array}{l}\text { Rio das } \\
\text { Pedras }\end{array}$ & Mãe & \begin{tabular}{|l|} 
Promotor de \\
Justiça da \\
Vara da \\
Infância e \\
Juventude do \\
Foro Distrital \\
de Rio das \\
Pedras \\
\end{tabular} & \begin{tabular}{|l|} 
Câmara \\
Especial
\end{tabular} & Unânime & \begin{tabular}{|l} 
Recurso \\
provido com \\
recomendaçã \\
o
\end{tabular} & $\begin{array}{l}\text { Ribeiro dos } \\
\text { Santos }\end{array}$ & $\begin{array}{l}\text { Sítio eletrônico } \\
\text { TJ-SP }\end{array}$ \\
\hline $\begin{array}{l}133.103- \\
0 / 6-00\end{array}$ & $\begin{array}{l}\text { Apelação } \\
\text { Cível }\end{array}$ & 2006 & $\begin{array}{l}\text { Acesso à } \\
\text { educação } \\
\text { básica }\end{array}$ & Acesso EI & São Paulo & $\begin{array}{l}\text { Municipalidad } \\
\text { e de São Paulo } \\
\text { / Juízo Ex } \\
\text { Officio }\end{array}$ & \begin{tabular}{|l|} 
Promotor de \\
Justiça da \\
Vara da \\
Infância e \\
Juventude do \\
Foro \\
Regional da \\
Lapa \\
\end{tabular} & $\begin{array}{l}\text { Câmara } \\
\text { Especial }\end{array}$ & Unânime & \begin{tabular}{|l|} 
Recurso \\
negado
\end{tabular} & \begin{tabular}{|l|} 
Fábio \\
Quadros
\end{tabular} & $\begin{array}{l}\text { Sítio eletrônico } \\
\text { TJ-SP }\end{array}$ \\
\hline $\begin{array}{l}134.489- \\
0 / 3-00\end{array}$ & $\begin{array}{l}\text { Apelação } \\
\text { Cível }\end{array}$ & 2006 & $\begin{array}{l}\text { Acesso à } \\
\text { educação } \\
\text { básica }\end{array}$ & Acesso EI & Santos & $\begin{array}{l}\text { Prefeitura } \\
\text { Municipal de } \\
\text { Santos }\end{array}$ & \begin{tabular}{|l} 
Promotor de \\
Justiça da \\
Infância e \\
Juventude de \\
Santos \\
\end{tabular} & \begin{tabular}{|l|} 
Câmara \\
Especial
\end{tabular} & Unânime & \begin{tabular}{|l} 
Recurso \\
negado
\end{tabular} & \begin{tabular}{|l} 
Ademir \\
Benedito
\end{tabular} & $\begin{array}{l}\text { Sítio eletrônico } \\
\text { TJ-SP }\end{array}$ \\
\hline $\begin{array}{l}134.506- \\
0 / 2-00\end{array}$ & $\begin{array}{l}\text { Apelação } \\
\text { Cível }\end{array}$ & 2006 & $\begin{array}{l}\text { Acesso à } \\
\text { educação } \\
\text { básica }\end{array}$ & Acesso EI & São Paulo & $\begin{array}{l}\text { Município de } \\
\text { São Paulo / } \\
\text { Juízo Ex } \\
\text { Officio }\end{array}$ & \begin{tabular}{|l|} 
Promotor de \\
Justiça da \\
Vara da \\
Infância e \\
Juventude do \\
Foro \\
Regional da \\
Lapa \\
\end{tabular} & \begin{tabular}{|l|} 
Câmara \\
Especial
\end{tabular} & Unânime & $\begin{array}{l}\text { Recurso } \\
\text { negado }\end{array}$ & \begin{tabular}{|l|} 
Fábio \\
Quadros
\end{tabular} & $\begin{array}{l}\text { Sítio eletrônico } \\
\text { TJ-SP }\end{array}$ \\
\hline $\begin{array}{l}134.742- \\
0 / 9-00\end{array}$ & $\begin{array}{l}\text { Apelação } \\
\text { Cível }\end{array}$ & 2006 & $\begin{array}{l}\text { Acesso à } \\
\text { educação } \\
\text { básica }\end{array}$ & Acesso EI & São Paulo & $\begin{array}{l}\text { Municipalidad } \\
\text { e de São Paulo } \\
\text { / Juízo Ex } \\
\text { Officio }\end{array}$ & \begin{tabular}{|l|} 
Promotor de \\
Justiça da \\
Vara Central \\
da Infância e \\
Juventude da \\
Capital \\
\end{tabular} & \begin{tabular}{|l|} 
Câmara \\
Especial
\end{tabular} & Unânime & $\begin{array}{l}\text { Recurso } \\
\text { negado }\end{array}$ & $\begin{array}{l}\text { Fábio } \\
\text { Quadros }\end{array}$ & $\begin{array}{l}\text { Sítio eletrônico } \\
\text { TJ-SP }\end{array}$ \\
\hline
\end{tabular}




\begin{tabular}{|c|c|c|c|c|c|c|c|c|c|c|c|c|}
\hline $\begin{array}{l}\text { Número } \\
\text { decisão }\end{array}$ & Natureza & Ano & Categorias & Tema & Origem & $\begin{array}{l}\text { Apelante } \\
\text { recorrente }\end{array}$ & $\begin{array}{l}\text { Apelados } \\
\text { recorridos }\end{array}$ & Câmara & Votação & Resultado & Relator & $\begin{array}{l}\text { Localização } \\
\text { da ementa / } \\
\text { acórdão }\end{array}$ \\
\hline $\begin{array}{l}134.918- \\
0 / 2-00\end{array}$ & $\begin{array}{l}\text { Apelação } \\
\text { Cível }\end{array}$ & 2006 & $\begin{array}{l}\text { Acesso à } \\
\text { educação } \\
\text { básica }\end{array}$ & Acesso EI & São Paulo & $\begin{array}{l}\text { Municipalidad } \\
\text { e de São Paulo } \\
\text { / Juízo Ex } \\
\text { Officio }\end{array}$ & $\begin{array}{l}\text { Promotor de } \\
\text { Justiça da } \\
\text { Vara da } \\
\text { Infância e } \\
\text { Juventude do } \\
\text { Foro } \\
\text { Regional de } \\
\text { Santo Amaro }\end{array}$ & $\begin{array}{l}\text { Câmara } \\
\text { Especial }\end{array}$ & Unânime & $\begin{array}{l}\text { Recurso } \\
\text { negado }\end{array}$ & $\begin{array}{l}\text { Fábio } \\
\text { Quadros }\end{array}$ & $\begin{array}{l}\text { Sítio eletrônico } \\
\text { TJ-SP }\end{array}$ \\
\hline $\begin{array}{l}135.603 .0- \\
01\end{array}$ & $\begin{array}{l}\text { Agravo } \\
\text { Regimental }\end{array}$ & 2006 & $\begin{array}{l}\text { Acesso à } \\
\text { educação } \\
\text { básica }\end{array}$ & Acesso EI & $\begin{array}{l}\text { Santo } \\
\text { André }\end{array}$ & $\begin{array}{l}\text { Municipalidad } \\
\text { e de Santo } \\
\text { André }\end{array}$ & Criança & $\begin{array}{l}\text { Sessão } \\
\text { Plenária }\end{array}$ & Unânime & $\begin{array}{l}\text { Provimento } \\
\text { negado ao } \\
\text { agravo } \\
\text { regimental }\end{array}$ & $\begin{array}{l}\text { Celso } \\
\text { Limongi }\end{array}$ & $\begin{array}{l}\text { Sítio eletrônico } \\
\text { TJ-SP }\end{array}$ \\
\hline $\begin{array}{l}135.606 .0 / 8 \\
-01\end{array}$ & $\begin{array}{l}\text { Agravo } \\
\text { Regimental }\end{array}$ & 2006 & $\begin{array}{l}\text { Acesso à } \\
\text { educação } \\
\text { básica }\end{array}$ & Acesso EI & $\begin{array}{l}\text { Santo } \\
\text { André }\end{array}$ & $\begin{array}{l}\text { Município de } \\
\text { Santo André }\end{array}$ & Criança & $\begin{array}{l}\text { Sessão } \\
\text { Plenária }\end{array}$ & Unânime & $\begin{array}{l}\text { Provimento } \\
\text { negado ao } \\
\text { agravo } \\
\text { regimental }\end{array}$ & $\begin{array}{l}\text { Celso } \\
\text { Limongi }\end{array}$ & $\begin{array}{l}\text { Sítio eletrônico } \\
\text { TJ-SP }\end{array}$ \\
\hline $\begin{array}{l}135.646 .0 / 0 \\
-01\end{array}$ & $\begin{array}{l}\text { Agravo } \\
\text { Regimental }\end{array}$ & 2006 & $\begin{array}{l}\text { Acesso à } \\
\text { educação } \\
\text { básica }\end{array}$ & Acesso EI & $\begin{array}{l}\text { Santo } \\
\text { André }\end{array}$ & $\begin{array}{l}\text { Município de } \\
\text { Santo André }\end{array}$ & Criança & $\begin{array}{l}\text { Sessão } \\
\text { Plenária }\end{array}$ & Unânime & $\begin{array}{l}\text { Provimento } \\
\text { negado ao } \\
\text { agravo } \\
\text { regimental }\end{array}$ & $\begin{array}{l}\text { Celso } \\
\text { Limongi }\end{array}$ & $\begin{array}{l}\text { Sítio eletrônico } \\
\text { TJ-SP }\end{array}$ \\
\hline $\begin{array}{l}135.650 .0 / 8 \\
-01\end{array}$ & $\begin{array}{l}\text { Agravo } \\
\text { Regimental }\end{array}$ & 2006 & $\begin{array}{l}\text { Acesso à } \\
\text { educação } \\
\text { básica }\end{array}$ & Acesso EI & $\begin{array}{l}\text { Santo } \\
\text { André }\end{array}$ & $\begin{array}{l}\text { Município de } \\
\text { Santo André }\end{array}$ & Criança & $\begin{array}{l}\text { Sessão } \\
\text { Plenária }\end{array}$ & Unânime & $\begin{array}{l}\text { Provimento } \\
\text { negado ao } \\
\text { agravo } \\
\text { regimental }\end{array}$ & $\begin{array}{l}\text { Celso } \\
\text { Limongi }\end{array}$ & $\begin{array}{l}\text { Sítio eletrônico } \\
\text { TJ-SP }\end{array}$ \\
\hline $\begin{array}{l}136.354 .0 / 4 \\
-01\end{array}$ & $\begin{array}{l}\text { Agravo } \\
\text { Regimental }\end{array}$ & 2006 & $\begin{array}{l}\text { Acesso à } \\
\text { educação } \\
\text { básica }\end{array}$ & Acesso EI & $\begin{array}{l}\text { Santo } \\
\text { André }\end{array}$ & $\begin{array}{l}\text { Município de } \\
\text { Santo André }\end{array}$ & Criança & $\begin{array}{l}\text { Sessão } \\
\text { Plenária }\end{array}$ & Unânime & $\begin{array}{l}\text { Provimento } \\
\text { negado ao } \\
\text { agravo } \\
\text { regimental }\end{array}$ & $\begin{array}{l}\text { Celso } \\
\text { Limongi }\end{array}$ & $\begin{array}{l}\text { Sítio eletrônico } \\
\text { TJ-SP }\end{array}$ \\
\hline $\begin{array}{l}136.356 .0 / 3 \\
-01\end{array}$ & $\begin{array}{l}\text { Agravo } \\
\text { Regimental }\end{array}$ & 2006 & $\begin{array}{l}\text { Acesso à } \\
\text { educação } \\
\text { básica }\end{array}$ & Acesso EI & $\begin{array}{l}\text { Santo } \\
\text { André }\end{array}$ & $\begin{array}{l}\text { Município de } \\
\text { Santo André }\end{array}$ & Criança & $\begin{array}{l}\text { Sessão } \\
\text { Plenária }\end{array}$ & Unânime & $\begin{array}{l}\text { Provimento } \\
\text { negado ao } \\
\text { agravo } \\
\text { regimental }\end{array}$ & $\begin{array}{l}\text { Celso } \\
\text { Limongi }\end{array}$ & $\begin{array}{l}\text { Sítio eletrônico } \\
\text { TJ-SP }\end{array}$ \\
\hline $\begin{array}{l}136.365 .0 / 4 \\
-01\end{array}$ & $\begin{array}{l}\text { Agravo } \\
\text { Regimental }\end{array}$ & 2006 & $\begin{array}{l}\text { Acesso à } \\
\text { educação } \\
\text { básica }\end{array}$ & Acesso EI & $\begin{array}{l}\text { Santo } \\
\text { André }\end{array}$ & $\begin{array}{l}\text { Município de } \\
\text { Santo André }\end{array}$ & Criança & $\begin{array}{l}\text { Sessão } \\
\text { Plenária }\end{array}$ & Unânime & $\begin{array}{l}\text { Provimento } \\
\text { negado ao } \\
\text { agravo } \\
\text { regimental }\end{array}$ & $\begin{array}{l}\text { Celso } \\
\text { Limongi }\end{array}$ & $\begin{array}{l}\text { Sítio eletrônico } \\
\text { TJ-SP }\end{array}$ \\
\hline
\end{tabular}




\begin{tabular}{|c|c|c|c|c|c|c|c|c|c|c|c|c|}
\hline $\begin{array}{l}\text { Número } \\
\text { decisão }\end{array}$ & Natureza & Ano & Categorias & Tema & Origem & $\begin{array}{l}\text { Apelante } \\
\text { recorrente }\end{array}$ & $\begin{array}{l}\text { Apelados } \\
\text { recorridos }\end{array}$ & Câmara & Votação & Resultado & Relator & $\begin{array}{l}\text { Localização } \\
\text { da ementa / } \\
\text { acórdão }\end{array}$ \\
\hline $\begin{array}{l}136.366 .0 / 9 \\
-01\end{array}$ & $\begin{array}{l}\text { Agravo } \\
\text { Regimental }\end{array}$ & 2006 & $\begin{array}{l}\text { Acesso à } \\
\text { educação } \\
\text { básica }\end{array}$ & Acesso EI & $\begin{array}{l}\text { Santo } \\
\text { André }\end{array}$ & $\begin{array}{l}\text { Município de } \\
\text { Santo André }\end{array}$ & Criança & $\begin{array}{l}\text { Sessão } \\
\text { Plenária }\end{array}$ & Unânime & $\begin{array}{l}\text { Provimento } \\
\text { negado ao } \\
\text { agravo } \\
\text { regimental }\end{array}$ & $\begin{array}{l}\text { Celso } \\
\text { Limongi }\end{array}$ & $\begin{array}{l}\text { Sítio eletrônico } \\
\text { TJ-SP }\end{array}$ \\
\hline $\begin{array}{l}136.391 .0 / 2 \\
-01\end{array}$ & $\begin{array}{l}\text { Agravo } \\
\text { Regimental }\end{array}$ & 2006 & $\begin{array}{l}\text { Acesso à } \\
\text { educação } \\
\text { básica }\end{array}$ & Acesso EI & $\begin{array}{l}\text { Santo } \\
\text { André }\end{array}$ & $\begin{array}{l}\text { Município de } \\
\text { Santo André }\end{array}$ & Criança & $\begin{array}{l}\text { Sessão } \\
\text { Plenária }\end{array}$ & Unânime & $\begin{array}{l}\text { Provimento } \\
\text { negado ao } \\
\text { agravo } \\
\text { regimental }\end{array}$ & $\begin{array}{l}\text { Celso } \\
\text { Limongi }\end{array}$ & $\begin{array}{l}\text { Sítio eletrônico } \\
\text { TJ-SP }\end{array}$ \\
\hline $\begin{array}{l}136.392 .0 / 7 \\
-01\end{array}$ & $\begin{array}{l}\text { Agravo } \\
\text { Regimental }\end{array}$ & 2006 & $\begin{array}{l}\text { Acesso à } \\
\text { educação } \\
\text { básica }\end{array}$ & Acesso EI & $\begin{array}{l}\text { Santo } \\
\text { André }\end{array}$ & $\begin{array}{l}\text { Municipalidad } \\
\text { e de Santo } \\
\text { André }\end{array}$ & Criança & $\begin{array}{l}\text { Sessão } \\
\text { Plenária }\end{array}$ & Unânime & $\begin{array}{l}\text { Provimento } \\
\text { negado ao } \\
\text { agravo } \\
\text { regimental }\end{array}$ & $\begin{array}{l}\text { Celso } \\
\text { Limongi }\end{array}$ & $\begin{array}{l}\text { Sítio eletrônico } \\
\text { TJ-SP }\end{array}$ \\
\hline $\begin{array}{l}136.393 .0 / 1 \\
-01\end{array}$ & $\begin{array}{l}\text { Agravo } \\
\text { Regimental }\end{array}$ & 2006 & $\begin{array}{l}\text { Acesso à } \\
\text { educação } \\
\text { básica }\end{array}$ & Acesso EI & $\begin{array}{l}\text { Santo } \\
\text { André }\end{array}$ & $\begin{array}{l}\text { Município de } \\
\text { Santo André }\end{array}$ & Criança & $\begin{array}{l}\text { Sessão } \\
\text { Plenária }\end{array}$ & Unânime & $\begin{array}{l}\text { Provimento } \\
\text { negado ao } \\
\text { agravo } \\
\text { regimental }\end{array}$ & $\begin{array}{l}\text { Celso } \\
\text { Limongi }\end{array}$ & $\begin{array}{l}\text { Sítio eletrônico } \\
\text { TJ-SP }\end{array}$ \\
\hline $\begin{array}{l}136.395 .0 / 0 \\
-01\end{array}$ & $\begin{array}{l}\text { Agravo } \\
\text { Regimental }\end{array}$ & 2006 & $\begin{array}{l}\text { Acesso à } \\
\text { educação } \\
\text { básica }\end{array}$ & Acesso EI & $\begin{array}{l}\text { Santo } \\
\text { André }\end{array}$ & $\begin{array}{l}\text { Município de } \\
\text { Santo André }\end{array}$ & Criança & $\begin{array}{l}\text { Sessão } \\
\text { Plenária }\end{array}$ & Unânime & $\begin{array}{l}\text { Provimento } \\
\text { negado ao } \\
\text { agravo } \\
\text { regimental }\end{array}$ & $\begin{array}{l}\text { Celso } \\
\text { Limongi }\end{array}$ & $\begin{array}{l}\text { Sítio eletrônico } \\
\text { TJ-SP }\end{array}$ \\
\hline $\begin{array}{l}137.139 .0 / 0 \\
-01\end{array}$ & $\begin{array}{l}\text { Agravo } \\
\text { Regimental }\end{array}$ & 2006 & $\begin{array}{l}\text { Acesso à } \\
\text { educação } \\
\text { básica }\end{array}$ & Acesso EI & $\begin{array}{l}\text { Santo } \\
\text { André }\end{array}$ & $\begin{array}{l}\text { Município de } \\
\text { Santo André }\end{array}$ & Criança & $\begin{array}{l}\text { Sessão } \\
\text { Plenária }\end{array}$ & Unânime & $\begin{array}{l}\text { Provimento } \\
\text { negado ao } \\
\text { agravo } \\
\text { regimental }\end{array}$ & $\begin{array}{l}\text { Celso } \\
\text { Limongi }\end{array}$ & $\begin{array}{l}\text { Sítio eletrônico } \\
\text { TJ-SP }\end{array}$ \\
\hline $\begin{array}{l}137.140 . / 5- \\
01\end{array}$ & $\begin{array}{l}\text { Agravo } \\
\text { Regimental }\end{array}$ & 2006 & $\begin{array}{l}\text { Acesso à } \\
\text { educação } \\
\text { básica }\end{array}$ & Acesso EI & $\begin{array}{l}\text { Santo } \\
\text { André }\end{array}$ & $\begin{array}{l}\text { Município de } \\
\text { Santo André }\end{array}$ & Criança & $\begin{array}{l}\text { Sessão } \\
\text { Plenária }\end{array}$ & Unânime & $\begin{array}{l}\text { Provimento } \\
\text { negado }\end{array}$ & $\begin{array}{l}\text { Celso } \\
\text { Limongi }\end{array}$ & $\begin{array}{l}\text { Sítio eletrônico } \\
\text { TJ-SP }\end{array}$ \\
\hline $\begin{array}{l}137.141 .0 / 0 \\
-01\end{array}$ & $\begin{array}{l}\text { Agravo } \\
\text { Regimental }\end{array}$ & 2006 & $\begin{array}{l}\text { Acesso à } \\
\text { educação } \\
\text { básica }\end{array}$ & Acesso EI & $\begin{array}{l}\text { Santo } \\
\text { André }\end{array}$ & $\begin{array}{l}\text { Município de } \\
\text { Santo André }\end{array}$ & Criança & $\begin{array}{l}\text { Sessão } \\
\text { Plenária }\end{array}$ & Unânime & $\begin{array}{l}\text { Provimento } \\
\text { negado ao } \\
\text { agravo } \\
\text { regimental }\end{array}$ & $\begin{array}{l}\text { Celso } \\
\text { Limongi }\end{array}$ & $\begin{array}{l}\text { Sítio eletrônico } \\
\text { TJ-SP }\end{array}$ \\
\hline $\begin{array}{l}137.145 .0 / 8 \\
-01\end{array}$ & $\begin{array}{l}\text { Agravo } \\
\text { Regimental }\end{array}$ & 2006 & $\begin{array}{l}\text { Acesso à } \\
\text { educação } \\
\text { básica }\end{array}$ & Acesso EI & $\begin{array}{l}\text { Santo } \\
\text { André }\end{array}$ & $\begin{array}{l}\text { Município de } \\
\text { Santo André }\end{array}$ & Criança & $\begin{array}{l}\text { Sessão } \\
\text { Plenária }\end{array}$ & Unânime & $\begin{array}{l}\text { Provimento } \\
\text { negado ao } \\
\text { agravo } \\
\text { regimental }\end{array}$ & $\begin{array}{l}\text { Celso } \\
\text { Limongi }\end{array}$ & $\begin{array}{l}\text { Sítio eletrônico } \\
\text { TJ-SP }\end{array}$ \\
\hline $\begin{array}{l}137.197 .0 / 4 \\
-01\end{array}$ & $\begin{array}{l}\text { Agravo } \\
\text { Regimental }\end{array}$ & 2006 & $\begin{array}{l}\text { Acesso à } \\
\text { educação } \\
\text { básica }\end{array}$ & Acesso EI & $\begin{array}{l}\text { Santo } \\
\text { André }\end{array}$ & $\begin{array}{l}\text { Município de } \\
\text { Santo André }\end{array}$ & Criança & $\begin{array}{l}\text { Sessão } \\
\text { Plenária }\end{array}$ & Unânime & $\begin{array}{l}\text { Provimento } \\
\text { negado }\end{array}$ & $\begin{array}{l}\text { Celso } \\
\text { Limongi }\end{array}$ & $\begin{array}{l}\text { Sítio eletrônico } \\
\text { TJ-SP }\end{array}$ \\
\hline
\end{tabular}




\begin{tabular}{|c|c|c|c|c|c|c|c|c|c|c|c|c|}
\hline $\begin{array}{l}\text { Número } \\
\text { decisão }\end{array}$ & Natureza & Ano & Categorias & Tema & Origem & $\begin{array}{l}\text { Apelante } \\
\text { recorrente }\end{array}$ & $\begin{array}{l}\text { Apelados } \\
\text { recorridos }\end{array}$ & Câmara & Votação & Resultado & Relator & $\begin{array}{l}\text { Localização } \\
\text { da ementa / } \\
\text { acórdão }\end{array}$ \\
\hline $\begin{array}{l}137.198 .0 / 9 \\
-01\end{array}$ & $\begin{array}{l}\text { Agravo } \\
\text { Regimental }\end{array}$ & 2006 & $\begin{array}{l}\text { Acesso à } \\
\text { educação } \\
\text { básica }\end{array}$ & Acesso EI & $\begin{array}{l}\text { Santo } \\
\text { André }\end{array}$ & $\begin{array}{l}\text { Município de } \\
\text { Santo André }\end{array}$ & Criança & $\begin{array}{l}\text { Sessão } \\
\text { Plenária }\end{array}$ & Unânime & $\begin{array}{l}\text { Provimento } \\
\text { negado ao } \\
\text { agravo } \\
\text { regimental }\end{array}$ & $\begin{array}{l}\text { Celso } \\
\text { Limongi }\end{array}$ & $\begin{array}{l}\text { Sítio eletrônico } \\
\text { TJ-SP }\end{array}$ \\
\hline $\begin{array}{l}137.199 .0 / 3 \\
-01\end{array}$ & $\begin{array}{l}\text { Agravo } \\
\text { Regimental }\end{array}$ & 2006 & $\begin{array}{l}\text { Acesso à } \\
\text { educação } \\
\text { básica }\end{array}$ & Acesso EI & $\begin{array}{l}\text { Santo } \\
\text { André }\end{array}$ & $\begin{array}{l}\text { Municipalidad } \\
\text { e de Santo } \\
\text { André }\end{array}$ & Criança & $\begin{array}{l}\text { Sessão } \\
\text { Plenária }\end{array}$ & Unânime & $\begin{array}{l}\text { Provimento } \\
\text { negado ao } \\
\text { agravo } \\
\text { regimental }\end{array}$ & $\begin{array}{l}\text { Celso } \\
\text { Limongi }\end{array}$ & $\begin{array}{l}\text { Sítio eletrônico } \\
\text { TJ-SP }\end{array}$ \\
\hline $\begin{array}{l}137.202 .0 / 9 \\
-01\end{array}$ & $\begin{array}{l}\text { Agravo } \\
\text { Regimental }\end{array}$ & 2006 & $\begin{array}{l}\text { Acesso à } \\
\text { educação } \\
\text { básica }\end{array}$ & Acesso EI & $\begin{array}{l}\text { Santo } \\
\text { André }\end{array}$ & $\begin{array}{l}\text { Municipalidad } \\
\text { e de Santo } \\
\text { André }\end{array}$ & Criança & $\begin{array}{l}\text { Sessão } \\
\text { Plenária }\end{array}$ & Unânime & $\begin{array}{l}\text { Provimento } \\
\text { negado ao } \\
\text { agravo } \\
\text { regimental }\end{array}$ & $\begin{array}{l}\text { Celso } \\
\text { Limongi }\end{array}$ & $\begin{array}{l}\text { Sítio eletrônico } \\
\text { TJ-SP }\end{array}$ \\
\hline $\begin{array}{l}137.548 .0 / 7 \\
-01\end{array}$ & $\begin{array}{l}\text { Agravo } \\
\text { Regimental }\end{array}$ & 2006 & $\begin{array}{l}\text { Acesso à } \\
\text { educação } \\
\text { básica }\end{array}$ & Acesso EI & $\begin{array}{l}\text { Santo } \\
\text { André }\end{array}$ & $\begin{array}{l}\text { Municipalidad } \\
\text { e de Santo } \\
\text { André }\end{array}$ & Criança & $\begin{array}{l}\text { Sessão } \\
\text { Plenária }\end{array}$ & Unânime & $\begin{array}{l}\text { Provimento } \\
\text { negado ao } \\
\text { agravo } \\
\text { regimental }\end{array}$ & $\begin{array}{l}\text { Celso } \\
\text { Limongi }\end{array}$ & $\begin{array}{l}\text { Sítio eletrônico } \\
\text { TJ-SP }\end{array}$ \\
\hline $\begin{array}{l}137.853- \\
0 / 9-01\end{array}$ & $\begin{array}{l}\text { Agravo } \\
\text { Regimental }\end{array}$ & 2006 & $\begin{array}{l}\text { Acesso à } \\
\text { educação } \\
\text { básica }\end{array}$ & Acesso EI & $\begin{array}{l}\text { Santo } \\
\text { André }\end{array}$ & $\begin{array}{l}\text { Município de } \\
\text { Santo André }\end{array}$ & Criança & \begin{tabular}{|l} 
Sessão \\
Plenária
\end{tabular} & Unânime & $\begin{array}{l}\text { Provimento } \\
\text { negado ao } \\
\text { agravo } \\
\text { regimental }\end{array}$ & $\begin{array}{l}\text { Celso } \\
\text { Limongi }\end{array}$ & $\begin{array}{l}\text { Sítio eletrônico } \\
\text { TJ-SP }\end{array}$ \\
\hline $\begin{array}{l}138.002- \\
0 / 1-00\end{array}$ & $\begin{array}{l}\text { Apelação } \\
\text { Cível }\end{array}$ & 2006 & $\begin{array}{l}\text { Acesso à } \\
\text { educação } \\
\text { básica }\end{array}$ & \begin{tabular}{|l|} 
Educação \\
Especial
\end{tabular} & Santos & $\begin{array}{l}\text { Município de } \\
\text { Santos }\end{array}$ & Criança e MP & $\begin{array}{l}\text { Câmara } \\
\text { Especial }\end{array}$ & Unânime & $\begin{array}{l}\text { Provimento } \\
\text { negado }\end{array}$ & $\begin{array}{l}\text { Sidnei } \\
\text { Beneti }\end{array}$ & $\begin{array}{l}\text { JTJ } \\
\text { v. } 316, p .21\end{array}$ \\
\hline $\begin{array}{l}138.071 .0- \\
01\end{array}$ & $\begin{array}{l}\text { Agravo } \\
\text { Regimental }\end{array}$ & 2006 & $\begin{array}{l}\text { Acesso à } \\
\text { educação } \\
\text { básica }\end{array}$ & Acesso EI & $\begin{array}{l}\text { Santo } \\
\text { André }\end{array}$ & $\begin{array}{l}\text { Municipalidad } \\
\text { e de Santo } \\
\text { André }\end{array}$ & Criança & $\begin{array}{l}\text { Sessão } \\
\text { Plenária }\end{array}$ & Unânime & $\begin{array}{l}\text { Provimento } \\
\text { negado ao } \\
\text { agravo } \\
\text { regimental }\end{array}$ & $\begin{array}{l}\text { Celso } \\
\text { Limongi }\end{array}$ & $\begin{array}{l}\text { Sítio eletrônico } \\
\text { TJ-SP }\end{array}$ \\
\hline $\begin{array}{l}138.069 .0 / 8 \\
-01\end{array}$ & $\begin{array}{l}\text { Agravo } \\
\text { Regimental }\end{array}$ & 2006 & $\begin{array}{l}\text { Acesso à } \\
\text { educação } \\
\text { básica }\end{array}$ & Acesso EI & $\begin{array}{l}\text { Santo } \\
\text { André }\end{array}$ & $\begin{array}{l}\text { Municipalidad } \\
\text { e de Santo } \\
\text { André }\end{array}$ & Criança & $\begin{array}{l}\text { Sessão } \\
\text { Plenária }\end{array}$ & Unânime & $\begin{array}{l}\text { Provimento } \\
\text { negado ao } \\
\text { agravo } \\
\text { regimental }\end{array}$ & $\begin{array}{l}\text { Celso } \\
\text { Limongi }\end{array}$ & $\begin{array}{l}\text { Sítio eletrônico } \\
\text { TJ-SP }\end{array}$ \\
\hline $\begin{array}{l}138.434 .0 / 4 \\
-01\end{array}$ & $\begin{array}{l}\text { Agravo } \\
\text { Regimental }\end{array}$ & 2006 & $\begin{array}{l}\text { Acesso à } \\
\text { educação } \\
\text { básica }\end{array}$ & Acesso EI & $\begin{array}{l}\text { Santo } \\
\text { André }\end{array}$ & $\begin{array}{l}\text { Município de } \\
\text { Santo André }\end{array}$ & Criança & \begin{tabular}{|l} 
Sessão \\
Plenária
\end{tabular} & Unânime & $\begin{array}{l}\text { Provimento } \\
\text { negado ao } \\
\text { agravo } \\
\text { regimental }\end{array}$ & $\begin{array}{l}\text { Celso } \\
\text { Limongi }\end{array}$ & $\begin{array}{l}\text { Sítio eletrônico } \\
\text { TJ-SP }\end{array}$ \\
\hline $\begin{array}{l}138.435 .0 / 9 \\
-01\end{array}$ & $\begin{array}{l}\text { Agravo } \\
\text { Regimental }\end{array}$ & 2006 & $\begin{array}{l}\text { Acesso à } \\
\text { educação } \\
\text { básica }\end{array}$ & Acesso EI & $\begin{array}{l}\text { Santo } \\
\text { André }\end{array}$ & $\begin{array}{l}\text { Município de } \\
\text { Santo André }\end{array}$ & Criança & $\begin{array}{l}\text { Sessão } \\
\text { Plenária }\end{array}$ & Unânime & $\begin{array}{l}\text { Provimento } \\
\text { negado ao } \\
\text { agravo }\end{array}$ & $\begin{array}{l}\text { Celso } \\
\text { Limongi }\end{array}$ & $\begin{array}{l}\text { Sítio eletrônico } \\
\text { TJ-SP }\end{array}$ \\
\hline
\end{tabular}




\begin{tabular}{|c|c|c|c|c|c|c|c|c|c|c|c|c|}
\hline $\begin{array}{l}\text { Número } \\
\text { decisão }\end{array}$ & Natureza & Ano & Categorias & Tema & Origem & $\begin{array}{l}\text { Apelante } \\
\text { recorrente }\end{array}$ & $\begin{array}{l}\text { Apelados } \\
\text { recorridos }\end{array}$ & Câmara & Votação & Resultado & Relator & $\begin{array}{l}\text { Localização } \\
\text { da ementa / } \\
\text { acórdão }\end{array}$ \\
\hline $\begin{array}{l}139.169 .0 / 1 \\
-01\end{array}$ & $\begin{array}{l}\text { Agravo } \\
\text { Regimental }\end{array}$ & 2006 & $\begin{array}{l}\text { Acesso à } \\
\text { educaçãoo } \\
\text { básica }\end{array}$ & Acesso EI & $\begin{array}{l}\text { Santo } \\
\text { André }\end{array}$ & $\begin{array}{l}\text { Município de } \\
\text { Santo André }\end{array}$ & Criança & $\begin{array}{l}\text { Sessão } \\
\text { Plenária }\end{array}$ & Unânime & $\begin{array}{l}\text { Provimento } \\
\text { negado ao } \\
\text { agravo } \\
\text { regimental }\end{array}$ & $\begin{array}{l}\text { Celso } \\
\text { Limongi }\end{array}$ & $\begin{array}{l}\text { Sítio eletrônico } \\
\text { TJ-SP }\end{array}$ \\
\hline $\begin{array}{l}139.929 .0 / 0 \\
-01\end{array}$ & $\begin{array}{l}\text { Agravo } \\
\text { Regimental }\end{array}$ & 2006 & $\begin{array}{l}\text { Acesso à } \\
\text { educação } \\
\text { básica }\end{array}$ & Acesso EI & $\begin{array}{l}\text { Santo } \\
\text { André }\end{array}$ & $\begin{array}{l}\text { Município de } \\
\text { Santo André }\end{array}$ & Criança & $\begin{array}{l}\text { Sessão } \\
\text { Plenária }\end{array}$ & Unânime & $\begin{array}{l}\text { Provimento } \\
\text { negado ao } \\
\text { agravo } \\
\text { regimental }\end{array}$ & $\begin{array}{l}\text { Celso } \\
\text { Limongi }\end{array}$ & $\begin{array}{l}\text { Sítio eletrônico } \\
\text { TJ-SP }\end{array}$ \\
\hline $\begin{array}{l}140.306 .0 / 0 \\
-01\end{array}$ & $\begin{array}{l}\text { Agravo } \\
\text { Regimental }\end{array}$ & 2006 & $\begin{array}{l}\text { Acesso à } \\
\text { educação } \\
\text { básica }\end{array}$ & Acesso EI & $\begin{array}{l}\text { Santo } \\
\text { André }\end{array}$ & $\begin{array}{l}\text { Município de } \\
\text { Santo André }\end{array}$ & Criança & $\begin{array}{l}\text { Sessão } \\
\text { Plenária }\end{array}$ & Unânime & $\begin{array}{l}\text { Provimento } \\
\text { negado ao } \\
\text { agravo } \\
\text { regimental }\end{array}$ & $\begin{array}{l}\text { Celso } \\
\text { Limongi }\end{array}$ & $\begin{array}{l}\text { Sítio eletrônico } \\
\text { TJ-SP }\end{array}$ \\
\hline $\begin{array}{l}140.653 .0 / 3 \\
-01\end{array}$ & $\begin{array}{l}\text { Agravo } \\
\text { Regimental }\end{array}$ & 2006 & $\begin{array}{l}\text { Acesso à } \\
\text { educação } \\
\text { básica }\end{array}$ & Acesso EI & $\begin{array}{l}\text { Santo } \\
\text { André }\end{array}$ & $\begin{array}{l}\text { Município de } \\
\text { Santo André }\end{array}$ & Criança & $\begin{array}{l}\text { Sessão } \\
\text { Plenária }\end{array}$ & Unânime & $\begin{array}{l}\text { Provimento } \\
\text { negado ao } \\
\text { agravo } \\
\text { regimental }\end{array}$ & $\begin{array}{l}\text { Celso } \\
\text { Limongi }\end{array}$ & $\begin{array}{l}\text { Sítio eletrônico } \\
\text { TJ-SP }\end{array}$ \\
\hline $\begin{array}{l}140.799 .0 / 9 \\
-01\end{array}$ & $\begin{array}{l}\text { Agravo } \\
\text { Regimental }\end{array}$ & 2006 & $\begin{array}{l}\text { Acesso à } \\
\text { educação } \\
\text { básica }\end{array}$ & Acesso EI & $\begin{array}{l}\text { Santo } \\
\text { André }\end{array}$ & $\begin{array}{l}\text { Município de } \\
\text { Santo André }\end{array}$ & Criança & \begin{tabular}{|l} 
Sessão \\
Plenária
\end{tabular} & Unânime & $\begin{array}{l}\text { Provimento } \\
\text { negado ao } \\
\text { agravo } \\
\text { regimental }\end{array}$ & $\begin{array}{l}\text { Celso } \\
\text { Limongi }\end{array}$ & $\begin{array}{l}\text { Sítio eletrônico } \\
\text { TJ-SP }\end{array}$ \\
\hline $\begin{array}{l}244.253- \\
5 / 4-01\end{array}$ & $\begin{array}{l}\text { Embargos } \\
\text { infringentes }\end{array}$ & 2006 & $\begin{array}{l}\text { Acesso à } \\
\text { educação } \\
\text { básica }\end{array}$ & $\begin{array}{l}\text { Educação } \\
\text { Especial }\end{array}$ & $\begin{array}{l}\text { Ribeirão } \\
\text { Preto }\end{array}$ & $\begin{array}{l}\text { Fazenda do } \\
\text { Estado de SP }\end{array}$ & $\begin{array}{l}\text { Ministério } \\
\text { Público }\end{array}$ & $\begin{array}{l}3^{\text {a }} \text { Câmara } \\
\text { de Direito } \\
\text { Público }\end{array}$ & $\begin{array}{l}\text { Maioria dos } \\
\text { votos }\end{array}$ & $\begin{array}{l}\text { Rejeitaram } \\
\text { os embargos, } \\
\text { vencido o } 5^{\circ} \\
\text { Juíz }\end{array}$ & $\begin{array}{l}\text { Antonio C. } \\
\text { Malheiros }\end{array}$ & $\begin{array}{l}\text { JTJ v.301, } \\
\text { p. } 476\end{array}$ \\
\hline $\begin{array}{l}253.606- \\
5 / 5-00\end{array}$ & $\begin{array}{l}\text { Apelação } \\
\text { Cível com } \\
\text { revisão }\end{array}$ & 2006 & Permanência & $\begin{array}{l}\text { Violação às } \\
\text { normas } \\
\text { escolares }\end{array}$ & Mococa & $\begin{array}{l}\text { Juízo Ex } \\
\text { Offício / } \\
\text { Fazenda do } \\
\text { Estado de SP }\end{array}$ & Criança & $\begin{array}{l}7^{\mathrm{a}} \text { Câmara } \\
\text { de Direito } \\
\text { Público }\end{array}$ & Unânime & $\begin{array}{l}\text { Recurso não } \\
\text { provido }\end{array}$ & $\begin{array}{l}\text { Constança } \\
\text { Gonzaga }\end{array}$ & $\begin{array}{l}\text { JTJ } \\
\text { v. } 310, \text { p. } 110\end{array}$ \\
\hline $\begin{array}{l}265.433- \\
5 / 8-00\end{array}$ & $\begin{array}{l}\text { Apelação } \\
\text { Cível com } \\
\text { revisão }\end{array}$ & 2006 & Permanência & $\begin{array}{l}\text { Cancelament } \\
\text { o de } \\
\text { matrícula em } \\
\text { curso de } \\
\text { língua } \\
\text { estrangeira }\end{array}$ & $\begin{array}{l}\text { Presidente } \\
\text { Prudente }\end{array}$ & $\begin{array}{l}\text { Juízo Ex } \\
\text { Officio / } \\
\text { Fazenda do } \\
\text { Estado de SP }\end{array}$ & $\begin{array}{l}\text { Criança } \\
\text { representada } \\
\text { pela mãe }\end{array}$ & $\begin{array}{l}6^{\mathrm{a}} \text { Câmara } \\
\text { de Direito } \\
\text { Público }\end{array}$ & Unânime & $\begin{array}{l}\text { Recurso não } \\
\text { provido }\end{array}$ & $\begin{array}{l}\text { Oliveira } \\
\text { Santos }\end{array}$ & $\begin{array}{l}\text { JTJ v.301, } \\
\text { p.131 }\end{array}$ \\
\hline
\end{tabular}




\begin{tabular}{|c|c|c|c|c|c|c|c|c|c|c|c|c|}
\hline $\begin{array}{l}\text { Número } \\
\text { decisão }\end{array}$ & Natureza & Ano & Categorias & Tema & Origem & $\begin{array}{l}\text { Apelante } \\
\text { recorrente }\end{array}$ & $\begin{array}{l}\text { Apelados } \\
\text { recorridos }\end{array}$ & Câmara & Votação & Resultado & Relator & $\begin{array}{l}\text { Localização } \\
\text { da ementa / } \\
\text { acórdão }\end{array}$ \\
\hline $\begin{array}{l}265.222- \\
5 / 5-00\end{array}$ & $\begin{array}{l}\text { Apelação } \\
\text { Cível com } \\
\text { revisão }\end{array}$ & 2006 & $\begin{array}{l}\text { Responsabili } \\
\text { dade estatal }\end{array}$ & $\begin{array}{l}\text { Ação de } \\
\text { reparação de } \\
\text { danos }\end{array}$ & $\begin{array}{l}\text { Santa Cruz } \\
\text { do Rio } \\
\text { Pardo }\end{array}$ & $\begin{array}{l}\text { Criança ou } \\
\text { adolescente } \\
\text { (Assistência } \\
\text { Judiciária)/ } \\
\text { Prefeitura } \\
\text { Municipal de } \\
\text { Santa Cruz do } \\
\text { Rio Pardo }\end{array}$ & 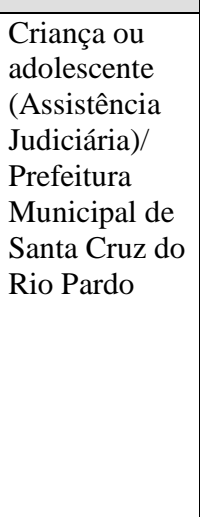 & $\begin{array}{l}2^{\circ} \text { Câmara } \\
\text { de Direito } \\
\text { Público }\end{array}$ & Unânime & $\begin{array}{l}\text { Negaram } \\
\text { provimento } \\
\text { ao agravo } \\
\text { retido, ao } \\
\text { recurso } \\
\text { voluntário da } \\
\text { municipalida } \\
\text { de e ao } \\
\text { reexame } \\
\text { necessário e } \\
\text { proveram } \\
\text { parcialmente } \\
\text { o recurso da } \\
\text { autora. }\end{array}$ & $\begin{array}{l}\text { Lineu } \\
\text { Peinado }\end{array}$ & $\begin{array}{l}\text { Sítio eletrônico } \\
\text { TJ-SP }\end{array}$ \\
\hline $\begin{array}{l}269.681- \\
5 / 8-00\end{array}$ & $\begin{array}{l}\text { Apelação } \\
\text { Cível com } \\
\text { revisão }\end{array}$ & 2006 & Permanência & \begin{tabular}{|l|} 
Cancelament \\
o de \\
matrícula em \\
curso de \\
língua \\
estrangeira
\end{tabular} & Araçatuba & $\begin{array}{l}\text { Juízo Ex } \\
\text { Officio / } \\
\text { Fazenda do } \\
\text { Estado de SP }\end{array}$ & $\begin{array}{l}\text { Adolescente } \\
\text { representado } \\
\text { pela mãe }\end{array}$ & $\begin{array}{l}12^{\mathrm{a}} \text { Câmara } \\
\text { de Direito } \\
\text { Público }\end{array}$ & Unânime & $\begin{array}{l}\text { Recurso não } \\
\text { provido }\end{array}$ & $\begin{array}{l}\text { Rebello } \\
\text { Pinho }\end{array}$ & $\begin{array}{l}\text { JTJ v. } 308, \\
\text { p. } 277\end{array}$ \\
\hline $\begin{array}{l}285.632- \\
5 / 2-00\end{array}$ & $\begin{array}{l}\text { Apelação } \\
\text { Cível com } \\
\text { revisão }\end{array}$ & 2006 & Permanência & $\begin{array}{l}\text { Cancelament } \\
\text { o de } \\
\text { matrícula em } \\
\text { curso de } \\
\text { língua } \\
\text { estrangeira }\end{array}$ & $\begin{array}{l}\text { José } \\
\text { Bonifácio }\end{array}$ & $\begin{array}{l}\text { Juízo Ex } \\
\text { Officio / } \\
\text { Fazenda do } \\
\text { Estado de SP }\end{array}$ & Adolescente & $\begin{array}{l}12^{\mathrm{a}} \text { Câmara } \\
\text { de Direito } \\
\text { Público }\end{array}$ & Unânime & $\begin{array}{l}\text { Recurso não } \\
\text { provido }\end{array}$ & $\begin{array}{l}\text { Rebello } \\
\text { Pinho }\end{array}$ & $\begin{array}{l}\text { JTJ } \\
\text { v. } 10, \text { p.112 }\end{array}$ \\
\hline $\begin{array}{l}290.440- \\
5 / 8-00\end{array}$ & $\begin{array}{l}\text { Apelação } \\
\text { Cível com } \\
\text { revisão }\end{array}$ & 2006 & $\begin{array}{l}\text { Responsabili } \\
\text { dade estatal }\end{array}$ & $\begin{array}{l}\text { Ação de } \\
\text { reparação de } \\
\text { danos }\end{array}$ & São Paulo & $\begin{array}{l}\text { Juízo Ex } \\
\text { Officio / } \\
\text { Prefeitura } \\
\text { Municipal de } \\
\text { São Paulo }\end{array}$ & $\begin{array}{l}\text { Criança ou } \\
\text { adolescente }\end{array}$ & $\begin{array}{l}2^{\circ} \text { Câmara } \\
\text { de Direito } \\
\text { Público }\end{array}$ & Unânime & $\begin{array}{l}\text { Recurso } \\
\text { negado }\end{array}$ & $\begin{array}{l}\text { Nelson } \\
\text { Calandra }\end{array}$ & $\begin{array}{l}\text { Sítio eletrônico } \\
\text { TJ-SP }\end{array}$ \\
\hline $\begin{array}{l}\text { 309.688- } \\
5 / 9-00\end{array}$ & $\begin{array}{l}\text { Apelação } \\
\text { Cível com } \\
\text { revisão }\end{array}$ & 2006 & $\begin{array}{l}\text { Acesso à } \\
\text { educação } \\
\text { básica }\end{array}$ & $\begin{array}{l}\text { Acesso Ed } \\
\text { Profissional }\end{array}$ & Jaú & $\begin{array}{l}\text { Juízo Ex } \\
\text { Officio / } \\
\text { Fazenda do } \\
\text { Estado de SP }\end{array}$ & A. C. B. & $\begin{array}{l}11^{\mathrm{a}} \text { Câmara } \\
\text { de Direito } \\
\text { Público }\end{array}$ & Unânime & $\begin{array}{l}\text { Recurso } \\
\text { negado }\end{array}$ & $\begin{array}{l}\text { Francisco } \\
\text { Vicente } \\
\text { Rossi }\end{array}$ & $\begin{array}{l}\text { Sítio eletrônico } \\
\text { TJ-SP }\end{array}$ \\
\hline
\end{tabular}




\begin{tabular}{|c|c|c|c|c|c|c|c|c|c|c|c|c|}
\hline $\begin{array}{l}\text { Número } \\
\text { decisão }\end{array}$ & Natureza & Ano & Categorias & Tema & Origem & $\begin{array}{l}\text { Apelante } \\
\text { recorrente }\end{array}$ & $\begin{array}{l}\text { Apelados } \\
\text { recorridos }\end{array}$ & Câmara & Votação & Resultado & Relator & $\begin{array}{l}\text { Localização } \\
\text { da ementa / } \\
\text { acórdão }\end{array}$ \\
\hline $\begin{array}{l}320.962- \\
5 / 1-00\end{array}$ & $\begin{array}{l}\text { Apelação } \\
\text { Cível com } \\
\text { revisão }\end{array}$ & 2006 & $\begin{array}{l}\text { Responsabili } \\
\text { dade estatal }\end{array}$ & $\begin{array}{l}\text { Transporte } \\
\text { escolar }\end{array}$ & Bauru & $\begin{array}{l}\text { Várias crianças } \\
\text { e adolescentes }\end{array}$ & $\begin{array}{l}\text { Prefeito } \\
\text { Municipal de } \\
\text { Bauru, } \\
\text { Dirigente } \\
\text { Regional de } \\
\text { Ensino de } \\
\text { Bauru }\end{array}$ & $\begin{array}{l}9^{a} \text { Câmara } \\
\text { de Direito } \\
\text { Público }\end{array}$ & $\begin{array}{l}\text { Maioria dos } \\
\text { votos }\end{array}$ & $\begin{array}{l}\text { Por maioria, } \\
\text { vencido o } \\
\text { revisor, } \\
\text { afastaram a } \\
\text { carência da } \\
\text { ação, } \\
\text { rejeitaram a } \\
\text { matéria } \\
\text { preliminar e } \\
\text { deram } \\
\text { provimento } \\
\text { ao recurso. }\end{array}$ & $\begin{array}{l}\text { Antonio } \\
\text { Rulli }\end{array}$ & $\begin{array}{l}\text { JTJ; Sítio } \\
\text { eletrônico TJ- } \\
\text { SP v.313, } \\
\text { p.231 }\end{array}$ \\
\hline $\begin{array}{l}\text { 335.871- } \\
5 / 0-00\end{array}$ & $\begin{array}{l}\text { Apelação } \\
\text { Cível com } \\
\text { revisão }\end{array}$ & 2006 & $\begin{array}{l}\text { Poder de } \\
\text { regulação } \\
\text { estatal }\end{array}$ & $\begin{array}{l}\text { Autorização/ } \\
\text { credenciame } \\
\text { nto }\end{array}$ & São Paulo & $\begin{array}{l}\text { Fazenda do } \\
\text { Estado de SP }\end{array}$ & $\begin{array}{l}\text { Borba Gato } \\
\text { Ltda. }\end{array}$ & $\begin{array}{l}1^{\text {a }} \text { Câmara } \\
\text { de Direito } \\
\text { Público }\end{array}$ & Unânime & $\begin{array}{l}\text { Recurso } \\
\text { provido }\end{array}$ & $\begin{array}{l}\text { Regina } \\
\text { Capistrano }\end{array}$ & $\begin{array}{l}\text { JTJ v.314, } \\
\text { p.264 }\end{array}$ \\
\hline $\begin{array}{l}348.364- \\
5 / 9-00\end{array}$ & $\begin{array}{l}\text { Apelação } \\
\text { Cível com } \\
\text { revisão }\end{array}$ & 2006 & $\begin{array}{l}\text { Acesso à } \\
\text { educação } \\
\text { básica }\end{array}$ & Acesso EI & $\begin{array}{l}\text { São } \\
\text { Caetano do } \\
\text { Sul }\end{array}$ & $\begin{array}{l}\text { Prefeitura } \\
\text { Municipal de } \\
\text { São Caetano } \\
\text { do Sul }\end{array}$ & $\begin{array}{l}\text { Criança } \\
\text { representada } \\
\text { pela mãe }\end{array}$ & $\begin{array}{l}10^{\mathrm{a}} \text { Câmara } \\
\text { de Direito } \\
\text { Público }\end{array}$ & Unânime & $\begin{array}{l}\text { Recurso não } \\
\text { provido }\end{array}$ & $\begin{array}{l}\text { Urbano } \\
\text { Ruiz }\end{array}$ & $\begin{array}{l}\text { Sítio eletrônico } \\
\text { TJ-SP }\end{array}$ \\
\hline $\begin{array}{l}\text { 375.635- } \\
5 / 7-00\end{array}$ & $\begin{array}{l}\text { Apelação } \\
\text { Cível com } \\
\text { revisão }\end{array}$ & 2006 & $\begin{array}{l}\text { Responsabili } \\
\text { dade estatal }\end{array}$ & $\begin{array}{l}\text { Transporte } \\
\text { escolar }\end{array}$ & Promissão & $\begin{array}{l}\text { Prefeitura } \\
\text { Municipal de } \\
\text { Promissão }\end{array}$ & $\begin{array}{l}\text { Criança ou } \\
\text { adolescente }\end{array}$ & $\begin{array}{l}10^{\circ} \text { Câmara } \\
\text { de Direito } \\
\text { Público }\end{array}$ & Unânime & $\begin{array}{l}\text { Deram } \\
\text { provimento } \\
\text { aos recursos } \\
\text { oficial e } \\
\text { voluntário } \\
\text { para cassar a } \\
\text { segurança } \\
\end{array}$ & $\begin{array}{l}\text { Antonio } \\
\text { Carlos } \\
\text { Villen }\end{array}$ & $\begin{array}{l}\text { Sítio eletrônico } \\
\text { TJ-SP }\end{array}$ \\
\hline $\begin{array}{l}409.465- \\
5 / 1-00\end{array}$ & $\begin{array}{l}\text { Agravo de } \\
\text { Instrumento }\end{array}$ & 2006 & $\begin{array}{l}\text { Gestão dos } \\
\text { recursos } \\
\text { públicos }\end{array}$ & $\begin{array}{l}\text { Repasse de } \\
\text { recurso } \\
\text { público a } \\
\text { instituição } \\
\text { privada }\end{array}$ & Florinea & $\begin{array}{l}\text { Prefeitura } \\
\text { Municipal de } \\
\text { Florinea }\end{array}$ & $\begin{array}{l}\text { Ministério } \\
\text { Público }\end{array}$ & $\begin{array}{l}10^{\mathrm{a}} \text { Câmara } \\
\text { de Direito } \\
\text { Público }\end{array}$ & Unânime & $\begin{array}{l}\text { Recurso não } \\
\text { provido }\end{array}$ & $\begin{array}{l}\text { Reinaldo } \\
\text { Miluzzi }\end{array}$ & $\begin{array}{l}\text { Sítio eletrônico } \\
\text { TJ-SP }\end{array}$ \\
\hline $\begin{array}{l}416.740- \\
5 / 3-00\end{array}$ & $\begin{array}{l}\text { Apelação } \\
\text { Cível com } \\
\text { revisão }\end{array}$ & 2006 & $\begin{array}{l}\text { Gestão dos } \\
\text { recursos } \\
\text { públicos }\end{array}$ & $\begin{array}{l}\text { Aplicação } \\
\text { dos recursos }\end{array}$ & Palestina & $\begin{array}{l}\text { Prefeitura } \\
\text { Municipal de } \\
\text { Palestina }\end{array}$ & $\begin{array}{l}\text { Prefeito } \\
\text { municipal }\end{array}$ & $\begin{array}{l}7^{\text {a }} \text { Câmara } \\
\text { de Direito } \\
\text { Público }\end{array}$ & Unânime & $\begin{array}{l}\text { Recurso não } \\
\text { provido }\end{array}$ & $\begin{array}{l}\text { Guerrieri } \\
\text { Rezende }\end{array}$ & $\begin{array}{l}\text { Sítio eletrônico } \\
\text { TJS-P }\end{array}$ \\
\hline $\begin{array}{l}\text { 423.994- } \\
5 / 8-00\end{array}$ & $\begin{array}{l}\text { Apelação } \\
\text { Cível com } \\
\text { revisão }\end{array}$ & 2006 & $\begin{array}{l}\text { Decisões } \\
\text { administrativ } \\
\text { as e políticas }\end{array}$ & Outros & $\begin{array}{l}\text { Presidente } \\
\text { Prudente }\end{array}$ & $\begin{array}{l}\text { Ministério } \\
\text { Público }\end{array}$ & $\begin{array}{l}\text { Prefeitura } \\
\text { Municipal de } \\
\text { Presidente } \\
\text { Prudente }\end{array}$ & $\begin{array}{l}2^{\mathrm{a}} \text { Câmara } \\
\text { de Direito } \\
\text { Público }\end{array}$ & Unânime & $\begin{array}{l}\text { Recurso não } \\
\text { provido }\end{array}$ & $\begin{array}{l}\text { Nelson } \\
\text { Calandra }\end{array}$ & $\begin{array}{l}\text { Sítio eletrônico } \\
\text { TJ-SP }\end{array}$ \\
\hline
\end{tabular}




\begin{tabular}{|c|c|c|c|c|c|c|c|c|c|c|c|c|}
\hline $\begin{array}{l}\text { Número } \\
\text { decisão }\end{array}$ & Natureza & Ano & Categorias & Tema & Origem & $\begin{array}{l}\text { Apelante } \\
\text { recorrente }\end{array}$ & $\begin{array}{l}\text { Apelados } \\
\text { recorridos }\end{array}$ & Câmara & Votação & Resultado & Relator & $\begin{array}{l}\text { Localização } \\
\text { da ementa / } \\
\text { acórdão }\end{array}$ \\
\hline $\begin{array}{l}463.265- \\
5 / 4-00\end{array}$ & $\begin{array}{l}\text { Apelação } \\
\text { Cível com } \\
\text { revisão }\end{array}$ & 2006 & $\begin{array}{l}\text { Responsabili } \\
\text { dade estatal }\end{array}$ & $\begin{array}{l}\text { Ação de } \\
\text { reparação de } \\
\text { danos }\end{array}$ & Parisi & $\begin{array}{l}\text { Prefeitura } \\
\text { Municipal de } \\
\text { Parisi }\end{array}$ & $\begin{array}{l}\text { Criança ou } \\
\text { adolescente }\end{array}$ & $\begin{array}{l}\text { Juízo Ex } \\
\text { Officio / } \\
\text { Prefeitura } \\
\text { Municipal } \\
\text { de Parisi }\end{array}$ & Unânime & $\begin{array}{l}\text { Recurso não } \\
\text { provido }\end{array}$ & $\begin{array}{l}\text { Magalhães } \\
\text { Coelho }\end{array}$ & $\begin{array}{l}\text { Sítio eletrônico } \\
\text { TJ-SP }\end{array}$ \\
\hline $\begin{array}{l}530.756- \\
5 / 8-00\end{array}$ & $\begin{array}{l}\text { Agravo de } \\
\text { Instrumento }\end{array}$ & 2006 & Permanência & $\begin{array}{l}\text { Violação às } \\
\text { normas } \\
\text { escolares }\end{array}$ & Sorocaba & $\begin{array}{l}\text { Criança ou } \\
\text { adolescente }\end{array}$ & \begin{tabular}{|l|} 
Diretor da \\
Escola \\
Estadual \\
Antonio \\
Padilha \\
\end{tabular} & $\begin{array}{l}8^{\text {a }} \text { Câmara } \\
\text { de Direito } \\
\text { Público }\end{array}$ & Unânime & $\begin{array}{l}\text { Recurso } \\
\text { provido }\end{array}$ & \begin{tabular}{|l|} 
Paulo \\
Dimas \\
Mascaretti
\end{tabular} & $\begin{array}{l}\text { JTJ v. 311, } \\
\text { p.334 }\end{array}$ \\
\hline $\begin{array}{l}1.014 .531- \\
0 / 7\end{array}$ & $\begin{array}{l}\text { Agravo de } \\
\text { Instrumento }\end{array}$ & 2006 & $\begin{array}{l}\text { Poder de } \\
\text { regulação } \\
\text { estatal }\end{array}$ & $\begin{array}{l}\text { Mensalidade } \\
\text { escolar }\end{array}$ & Poá & $\begin{array}{l}\text { Ministério } \\
\text { Público }\end{array}$ & \begin{tabular}{|l|} 
Sociedade \\
Civil de \\
Educação do \\
Colégio \\
Técnico \\
Batuíra Ltda. \\
\end{tabular} & $\begin{array}{l}32^{\mathrm{a}} \text { Seção de } \\
\text { Direito } \\
\text { Privado }\end{array}$ & Unânime & $\begin{array}{l}\text { Provimento } \\
\text { parcial ao } \\
\text { recurso }\end{array}$ & \begin{tabular}{|l|} 
Kioitsi \\
Chicuta
\end{tabular} & $\begin{array}{l}\text { JTJ } \\
\text { v.303, p.332 }\end{array}$ \\
\hline \multicolumn{13}{|l|}{2007} \\
\hline $\begin{array}{l}138.147 .0 / 4 \\
-01\end{array}$ & \begin{tabular}{|l} 
Agravo \\
Regimental
\end{tabular} & 2007 & $\begin{array}{l}\text { Acesso à } \\
\text { educação } \\
\text { básica }\end{array}$ & Acesso EI & $\begin{array}{l}\text { Santo } \\
\text { André }\end{array}$ & $\begin{array}{l}\text { Município de } \\
\text { Santo André }\end{array}$ & Crianças & $\begin{array}{l}\text { Sessão } \\
\text { Plenária }\end{array}$ & Unânime & $\begin{array}{l}\text { Provimento } \\
\text { negado }\end{array}$ & \begin{tabular}{|l|} 
Celso \\
Limongi
\end{tabular} & $\begin{array}{l}\text { Sítio eletrônico } \\
\text { TJ-SP }\end{array}$ \\
\hline $\begin{array}{l}139.606 .0 / 7 \\
-01\end{array}$ & \begin{tabular}{|l|} 
Agravo \\
Regimental
\end{tabular} & 2007 & $\begin{array}{l}\text { Acesso à } \\
\text { educação } \\
\text { básica }\end{array}$ & Acesso EI & $\begin{array}{l}\text { Santo } \\
\text { André }\end{array}$ & $\begin{array}{l}\text { Município de } \\
\text { Santo André }\end{array}$ & Crianças & $\begin{array}{l}\text { Sessão } \\
\text { Plenária }\end{array}$ & Unânime & $\begin{array}{l}\text { Provimento } \\
\text { negado }\end{array}$ & \begin{tabular}{|l|} 
Celso \\
Limongi
\end{tabular} & $\begin{array}{l}\text { Sítio eletrônico } \\
\text { TJ-SP }\end{array}$ \\
\hline $\begin{array}{l}140.408 .0 / 6 \\
-01\end{array}$ & $\begin{array}{l}\text { Agravo } \\
\text { Regimental }\end{array}$ & 2007 & $\begin{array}{l}\text { Acesso à } \\
\text { educação } \\
\text { básica }\end{array}$ & Acesso EI & $\begin{array}{l}\text { Santo } \\
\text { André }\end{array}$ & $\begin{array}{l}\text { Município de } \\
\text { Santo André }\end{array}$ & Criança & $\begin{array}{l}\text { Sessão } \\
\text { Plenária }\end{array}$ & Unânime & $\begin{array}{l}\text { Agravo não } \\
\text { provido }\end{array}$ & \begin{tabular}{|l} 
Celso \\
Limongi
\end{tabular} & $\begin{array}{l}\text { Sítio eletrônico } \\
\text { TJ-SP }\end{array}$ \\
\hline $\begin{array}{l}\text { 140.739- } \\
0 / 4-00\end{array}$ & \begin{tabular}{|l|} 
Apelação \\
Cível
\end{tabular} & 2007 & $\begin{array}{l}\text { Deveres dos } \\
\text { pais }\end{array}$ & $\begin{array}{l}\text { Negligência } \\
\text { dos pais/ } \\
\text { responsáveis }\end{array}$ & Itapira & $\begin{array}{l}\text { Duas crianças } \\
\text { ou } \\
\text { adolescentes }\end{array}$ & \begin{tabular}{|l|} 
Promotor de \\
Justiça da \\
Vara da \\
Infância e \\
Juventude de \\
Itapira \\
\end{tabular} & $\begin{array}{l}\text { Câmara } \\
\text { Especial }\end{array}$ & Unânime & $\begin{array}{l}\text { Recurso } \\
\text { provido }\end{array}$ & \begin{tabular}{|l|} 
Luiz \\
Tâmbara
\end{tabular} & $\begin{array}{l}\text { Sítio eletrônico } \\
\text { TJ-SP }\end{array}$ \\
\hline $\begin{array}{l}141.296 .0 / 0 \\
-01\end{array}$ & \begin{tabular}{|l|} 
Agravo \\
Regimental
\end{tabular} & 2007 & $\begin{array}{l}\text { Acesso à } \\
\text { educação } \\
\text { básica }\end{array}$ & Acesso EI & $\begin{array}{l}\text { Santo } \\
\text { André }\end{array}$ & $\begin{array}{l}\text { Município de } \\
\text { Santo André }\end{array}$ & Criança & $\begin{array}{l}\text { Sessão } \\
\text { Plenária }\end{array}$ & $\begin{array}{l}\text { Maioria dos } \\
\text { votos }\end{array}$ & $\begin{array}{l}\text { Agravo não } \\
\text { provido }\end{array}$ & \begin{tabular}{|l|} 
Celso \\
Limongi
\end{tabular} & $\begin{array}{l}\text { Sítio eletrônico } \\
\text { TJ-SP }\end{array}$ \\
\hline $\begin{array}{l}141.456- \\
0 / 1-01\end{array}$ & \begin{tabular}{|l} 
Agravo \\
Regimental
\end{tabular} & 2007 & $\begin{array}{l}\text { Acesso à } \\
\text { educação } \\
\text { básica }\end{array}$ & Acesso EI & $\begin{array}{l}\text { Presidente } \\
\text { Prudente }\end{array}$ & $\begin{array}{l}\text { Município de } \\
\text { Presidente } \\
\text { Prudente }\end{array}$ & $\begin{array}{l}\text { Promotor de } \\
\text { Justiça da } \\
\text { Infância }\end{array}$ & $\begin{array}{l}\text { Câmara } \\
\text { Especial }\end{array}$ & Unânime & $\begin{array}{l}\text { Agravo não } \\
\text { provido }\end{array}$ & $\begin{array}{l}\text { Canguçu de } \\
\text { Almeida }\end{array}$ & $\begin{array}{l}\text { Sítio eletrônico } \\
\text { TJ-SP }\end{array}$ \\
\hline
\end{tabular}




\begin{tabular}{|c|c|c|c|c|c|c|c|c|c|c|c|c|}
\hline $\begin{array}{l}\text { Número } \\
\text { decisão }\end{array}$ & Natureza & Ano & Categorias & Tema & Origem & $\begin{array}{l}\text { Apelante } \\
\text { recorrente }\end{array}$ & $\begin{array}{l}\text { Apelados } \\
\text { recorridos }\end{array}$ & Câmara & Votação & Resultado & Relator & $\begin{array}{l}\text { Localização } \\
\text { da ementa / } \\
\text { acórdão }\end{array}$ \\
\hline $\begin{array}{l}\text { 141.610- } \\
0 / 3-00\end{array}$ & $\begin{array}{l}\text { Apelação } \\
\text { Cível }\end{array}$ & 2007 & $\begin{array}{l}\text { Acesso à } \\
\text { educação } \\
\text { básica }\end{array}$ & Acesso EI & Paulínia & $\begin{array}{l}\text { Juízo Ex } \\
\text { Officio / } \\
\text { Município de } \\
\text { Paulínia } \\
\end{array}$ & Criança & $\begin{array}{l}\text { Câmara } \\
\text { Especial }\end{array}$ & Unânime & $\begin{array}{l}\text { Recurso não } \\
\text { provido }\end{array}$ & $\begin{array}{l}\text { Ademir } \\
\text { Benedito }\end{array}$ & $\begin{array}{l}\text { Sítio eletrônico } \\
\text { TJ-SP }\end{array}$ \\
\hline $\begin{array}{l}142.040- \\
0 / 9-00\end{array}$ & $\begin{array}{l}\text { Apelação } \\
\text { Cível }\end{array}$ & 2007 & $\begin{array}{l}\text { Acesso à } \\
\text { educação } \\
\text { básica }\end{array}$ & Acesso EI & $\begin{array}{l}\text { Santo } \\
\text { André }\end{array}$ & $\begin{array}{l}\text { Município de } \\
\text { Santo André }\end{array}$ & $\begin{array}{l}\text { Várias } \\
\text { crianças }\end{array}$ & $\begin{array}{l}\text { Câmara } \\
\text { Especial }\end{array}$ & Unânime & $\begin{array}{l}\text { Recurso não } \\
\text { provido }\end{array}$ & $\begin{array}{l}\text { Sidnei } \\
\text { Beneti }\end{array}$ & $\begin{array}{l}\text { Sítio eletrônico } \\
\text { TJ-SP }\end{array}$ \\
\hline $\begin{array}{l}142.443 .0 / 8 \\
-00\end{array}$ & $\begin{array}{l}\text { Apelação } \\
\text { Cível }\end{array}$ & 2007 & $\begin{array}{l}\text { Poder de } \\
\text { regulação } \\
\text { estatal }\end{array}$ & $\begin{array}{l}\text { Autorização/ } \\
\text { credenciame } \\
\text { nto }\end{array}$ & $\begin{array}{l}\text { Ribeirão } \\
\text { Preto }\end{array}$ & P.A.O. & $\begin{array}{l}\text { Promotor de } \\
\text { Justiça da } \\
\text { Vara da } \\
\text { Infância e } \\
\text { Juventude de } \\
\text { Ribeirão } \\
\text { Preto }\end{array}$ & $\begin{array}{l}\text { Câmara } \\
\text { Especial }\end{array}$ & Unânime & $\begin{array}{l}\text { Recurso não } \\
\text { provido }\end{array}$ & $\begin{array}{l}\text { Ademir } \\
\text { Benedito }\end{array}$ & $\begin{array}{l}\text { Sítio eletrônico } \\
\text { TJ-SP }\end{array}$ \\
\hline $\begin{array}{l}142.416- \\
0 / 5-00\end{array}$ & $\begin{array}{l}\text { Agravo de } \\
\text { instrumento }\end{array}$ & 2007 & $\begin{array}{l}\text { Acesso à } \\
\text { educação } \\
\text { básica }\end{array}$ & Acesso EI & Avaré & $\begin{array}{l}\text { Município de } \\
\text { Avaré }\end{array}$ & $\begin{array}{l}\text { Promotor de } \\
\text { Justiça da } \\
\text { Vara da } \\
\text { Infância e } \\
\text { Juventude de } \\
\text { Avaré }\end{array}$ & $\begin{array}{l}\text { Câmara } \\
\text { Especial }\end{array}$ & Unânime & $\begin{array}{l}\text { Recurso não } \\
\text { provido }\end{array}$ & $\begin{array}{l}\text { Sidnei } \\
\text { Beneti }\end{array}$ & $\begin{array}{l}\text { Sítio eletrônico } \\
\text { TJ-SP }\end{array}$ \\
\hline $\begin{array}{l}142.623 .0 / 1 \\
-01\end{array}$ & $\begin{array}{l}\text { Agravo } \\
\text { Regimental }\end{array}$ & 2007 & $\begin{array}{l}\text { Acesso à } \\
\text { educação } \\
\text { básica }\end{array}$ & Acesso EI & $\begin{array}{l}\text { Santo } \\
\text { André }\end{array}$ & $\begin{array}{l}\text { Município de } \\
\text { Santo André }\end{array}$ & Criança & $\begin{array}{l}\text { Sessão } \\
\text { Plenária }\end{array}$ & Unânime & $\begin{array}{l}\text { Provimento } \\
\text { negado ao } \\
\text { agravo } \\
\text { regimental }\end{array}$ & $\begin{array}{l}\text { Celso } \\
\text { Limongi }\end{array}$ & $\begin{array}{l}\text { Sítio eletrônico } \\
\text { TJ-SP }\end{array}$ \\
\hline $\begin{array}{l}143.225 .0 / 2 \\
-01\end{array}$ & $\begin{array}{l}\text { Agravo } \\
\text { Regimental }\end{array}$ & 2007 & $\begin{array}{l}\text { Acesso à } \\
\text { educação } \\
\text { básica }\end{array}$ & Acesso EI & $\begin{array}{l}\text { Santo } \\
\text { André }\end{array}$ & $\begin{array}{l}\text { Município de } \\
\text { Santo André }\end{array}$ & $\begin{array}{l}\text { Juiz de } \\
\text { Direito da } \\
\text { Vara da } \\
\text { Infância e } \\
\text { Juventude de } \\
\text { Santo André }\end{array}$ & $\begin{array}{l}\text { Sessão } \\
\text { Plenária }\end{array}$ & Unânime & $\begin{array}{l}\text { Provimento } \\
\text { negado ao } \\
\text { agravo } \\
\text { regimental }\end{array}$ & $\begin{array}{l}\text { Celso } \\
\text { Limongi }\end{array}$ & $\begin{array}{l}\text { Sítio eletrônico } \\
\text { TJ-SP }\end{array}$ \\
\hline $\begin{array}{l}143.612- \\
0 / 7-00\end{array}$ & $\begin{array}{l}\text { Agravo de } \\
\text { instrumento }\end{array}$ & 2007 & $\begin{array}{l}\text { Poder de } \\
\text { regulação } \\
\text { estatal }\end{array}$ & $\begin{array}{l}\text { Autorização/ } \\
\text { credenciame } \\
\text { nto }\end{array}$ & São Paulo & $\begin{array}{l}\text { Escola de } \\
\text { Educação } \\
\text { Infantil } \\
\text { Castello } \\
\text { Branco S/C } \\
\text { Ltda. }\end{array}$ & $\begin{array}{l}\text { Promotor de } \\
\text { Justiça da } \\
\text { Vara da } \\
\text { Infância e } \\
\text { Juventude do } \\
\text { Foro } \\
\text { Regional de } \\
\text { Penha de } \\
\text { França }\end{array}$ & $\begin{array}{l}\text { Câmara } \\
\text { Especial }\end{array}$ & Unânime & $\begin{array}{l}\text { Recurso não } \\
\text { provido }\end{array}$ & $\begin{array}{l}\text { Sidnei } \\
\text { Beneti }\end{array}$ & $\begin{array}{l}\text { Sítio eletrônico } \\
\text { TJ-SP }\end{array}$ \\
\hline
\end{tabular}




\begin{tabular}{|c|c|c|c|c|c|c|c|c|c|c|c|c|}
\hline $\begin{array}{l}\text { Número } \\
\text { decisão }\end{array}$ & Natureza & Ano & Categorias & Tema & Origem & $\begin{array}{l}\text { Apelante } \\
\text { recorrente }\end{array}$ & $\begin{array}{l}\text { Apelados } \\
\text { recorridos }\end{array}$ & Câmara & Votação & Resultado & Relator & $\begin{array}{l}\text { Localização } \\
\text { da ementa / } \\
\text { acórdão }\end{array}$ \\
\hline $\begin{array}{l}143.734 .0 / 5 \\
-01\end{array}$ & $\begin{array}{l}\text { Agravo } \\
\text { Regimental }\end{array}$ & 2007 & $\begin{array}{l}\text { Acesso à } \\
\text { educação } \\
\text { básica }\end{array}$ & Acesso EI & $\begin{array}{l}\text { Santo } \\
\text { André }\end{array}$ & $\begin{array}{l}\text { Município de } \\
\text { Santo André }\end{array}$ & Menor & $\begin{array}{l}\text { Sessão } \\
\text { Plenária }\end{array}$ & $\begin{array}{l}\text { Maioria dos } \\
\text { votos }\end{array}$ & $\begin{array}{l}\text { Provimento } \\
\text { negado ao } \\
\text { agravo } \\
\text { regimental }\end{array}$ & $\begin{array}{l}\text { Celso } \\
\text { Limongi }\end{array}$ & $\begin{array}{l}\text { Sítio eletrônico } \\
\text { TJ-SP }\end{array}$ \\
\hline $\begin{array}{l}143.857- \\
0 / 6-01\end{array}$ & $\begin{array}{l}\text { Agravo } \\
\text { Regimental }\end{array}$ & 2007 & $\begin{array}{l}\text { Acesso à } \\
\text { educação } \\
\text { básica }\end{array}$ & Acesso EI & $\begin{array}{l}\text { Presidente } \\
\text { Prudente }\end{array}$ & $\begin{array}{l}\text { Município de } \\
\text { Presidente } \\
\text { Prudente }\end{array}$ & $\begin{array}{l}\text { Promotor de } \\
\text { Justiça da } \\
\text { Vara da } \\
\text { Infância e } \\
\text { Juventude de } \\
\text { Presidente } \\
\text { Prudente } \\
\end{array}$ & $\begin{array}{l}\text { Câmara } \\
\text { Especial }\end{array}$ & Unânime & $\begin{array}{l}\text { Provimento } \\
\text { negado ao } \\
\text { agravo } \\
\text { regimental }\end{array}$ & $\begin{array}{l}\text { Canguçu de } \\
\text { Almeida }\end{array}$ & $\begin{array}{l}\text { Sítio eletrônico } \\
\text { TJ-SP }\end{array}$ \\
\hline $\begin{array}{l}144.455 .0 / 9 \\
-01\end{array}$ & $\begin{array}{l}\text { Agravo } \\
\text { Regimental }\end{array}$ & 2007 & $\begin{array}{l}\text { Acesso à } \\
\text { educação } \\
\text { básica }\end{array}$ & Acesso EI & $\begin{array}{l}\text { Santo } \\
\text { André }\end{array}$ & $\begin{array}{l}\text { Município de } \\
\text { Santo André }\end{array}$ & Criança & $\begin{array}{l}\text { Sessão } \\
\text { Plenária }\end{array}$ & Unânime & $\begin{array}{l}\text { Provimento } \\
\text { negado ao } \\
\text { agravo } \\
\text { regimental }\end{array}$ & $\begin{array}{l}\text { Celso } \\
\text { Limongi }\end{array}$ & $\begin{array}{l}\text { Sítio eletrônico } \\
\text { TJ-SP }\end{array}$ \\
\hline $\begin{array}{l}144.457 .0 / 8 \\
-01\end{array}$ & $\begin{array}{l}\text { Agravo } \\
\text { Regimental }\end{array}$ & 2007 & $\begin{array}{l}\text { Acesso à } \\
\text { educação } \\
\text { básica }\end{array}$ & Acesso EI & $\begin{array}{l}\text { Santo } \\
\text { André }\end{array}$ & $\begin{array}{l}\text { Município de } \\
\text { Santo André }\end{array}$ & Criança & $\begin{array}{l}\text { Sessão } \\
\text { Plenária }\end{array}$ & Unânime & $\begin{array}{l}\text { Provimento } \\
\text { negado ao } \\
\text { agravo } \\
\text { regimental }\end{array}$ & $\begin{array}{l}\text { Celso } \\
\text { Limongi }\end{array}$ & $\begin{array}{l}\text { Sítio eletrônico } \\
\text { TJ-SP }\end{array}$ \\
\hline $\begin{array}{l}144.458 .0 / 2 \\
-01\end{array}$ & $\begin{array}{l}\text { Agravo } \\
\text { Regimental }\end{array}$ & 2007 & $\begin{array}{l}\text { Acesso à } \\
\text { educação } \\
\text { básica }\end{array}$ & Acesso EI & $\begin{array}{l}\text { Santo } \\
\text { André }\end{array}$ & $\begin{array}{l}\text { Município de } \\
\text { Santo André }\end{array}$ & Criança & $\begin{array}{l}\text { Sessão } \\
\text { Plenária }\end{array}$ & Unânime & $\begin{array}{l}\text { Provimento } \\
\text { negado ao } \\
\text { agravo } \\
\text { regimental }\end{array}$ & $\begin{array}{l}\text { Celso } \\
\text { Limongi }\end{array}$ & $\begin{array}{l}\text { Sítio eletrônico } \\
\text { TJ-SP }\end{array}$ \\
\hline $\begin{array}{l}145.120 .0 / 8 \\
-01\end{array}$ & $\begin{array}{l}\text { Agravo } \\
\text { Regimental }\end{array}$ & 2007 & $\begin{array}{l}\text { Acesso à } \\
\text { educação } \\
\text { básica }\end{array}$ & Acesso EI & $\begin{array}{l}\text { Santo } \\
\text { André }\end{array}$ & $\begin{array}{l}\text { Município de } \\
\text { Santo André }\end{array}$ & Criança & $\begin{array}{l}\text { Sessão } \\
\text { Plenária }\end{array}$ & Unânime & $\begin{array}{l}\text { Provimento } \\
\text { negado ao } \\
\text { agravo } \\
\text { regimental }\end{array}$ & $\begin{array}{l}\text { Celso } \\
\text { Limongi }\end{array}$ & $\begin{array}{l}\text { Sítio eletrônico } \\
\text { TJ-SP }\end{array}$ \\
\hline $\begin{array}{l}145.296 .0 / 0 \\
-01\end{array}$ & $\begin{array}{l}\text { Agravo } \\
\text { Regimental }\end{array}$ & 2007 & $\begin{array}{l}\text { Acesso à } \\
\text { educação } \\
\text { básica }\end{array}$ & Acesso EI & $\begin{array}{l}\text { Santo } \\
\text { André }\end{array}$ & $\begin{array}{l}\text { Município de } \\
\text { Santo André }\end{array}$ & Criança & $\begin{array}{l}\text { Sessão } \\
\text { Plenária }\end{array}$ & Unânime & $\begin{array}{l}\text { Provimento } \\
\text { negado ao } \\
\text { agravo } \\
\text { regimental }\end{array}$ & $\begin{array}{l}\text { Celso } \\
\text { Limongi }\end{array}$ & $\begin{array}{l}\text { Sítio eletrônico } \\
\text { TJ-SP }\end{array}$ \\
\hline $\begin{array}{l}145.279 .0 / 2 \\
-01\end{array}$ & $\begin{array}{l}\text { Agravo } \\
\text { Regimental }\end{array}$ & 2007 & $\begin{array}{l}\text { Acesso à } \\
\text { educação } \\
\text { básica }\end{array}$ & Acesso EI & $\begin{array}{l}\text { Santo } \\
\text { André }\end{array}$ & $\begin{array}{l}\text { Município de } \\
\text { Santo André }\end{array}$ & Criança & $\begin{array}{l}\text { Sessão } \\
\text { Plenária }\end{array}$ & Unânime & $\begin{array}{l}\text { Provimento } \\
\text { negado ao } \\
\text { agravo } \\
\text { regimental }\end{array}$ & $\begin{array}{l}\text { Celso } \\
\text { Limongi }\end{array}$ & $\begin{array}{l}\text { Sítio eletrônico } \\
\text { TJ-SP }\end{array}$ \\
\hline $\begin{array}{l}145.465 .0 / 1 \\
-01\end{array}$ & $\begin{array}{l}\text { Agravo } \\
\text { Regimental }\end{array}$ & 2007 & $\begin{array}{l}\text { Acesso à } \\
\text { educação } \\
\text { básica }\end{array}$ & Acesso EI & $\begin{array}{l}\text { Santo } \\
\text { André }\end{array}$ & $\begin{array}{l}\text { Município de } \\
\text { Santo André }\end{array}$ & Criança & $\begin{array}{l}\text { Sessão } \\
\text { Plenária }\end{array}$ & Unânime & $\begin{array}{l}\text { Provimento } \\
\text { negado ao } \\
\text { agravo } \\
\text { regimental }\end{array}$ & $\begin{array}{l}\text { Celso } \\
\text { Limongi }\end{array}$ & $\begin{array}{l}\text { Sítio eletrônico } \\
\text { TJ-SP }\end{array}$ \\
\hline
\end{tabular}




\begin{tabular}{|c|c|c|c|c|c|c|c|c|c|c|c|c|}
\hline $\begin{array}{l}\text { Número } \\
\text { decisão }\end{array}$ & Natureza & Ano & Categorias & Tema & Origem & $\begin{array}{l}\text { Apelante } \\
\text { recorrente }\end{array}$ & $\begin{array}{l}\text { Apelados } \\
\text { recorridos }\end{array}$ & Câmara & Votação & Resultado & Relator & $\begin{array}{l}\text { Localização } \\
\text { da ementa / } \\
\text { acórdão }\end{array}$ \\
\hline $\begin{array}{l}145.913 .0 / 7 \\
-01\end{array}$ & $\begin{array}{l}\text { Agravo } \\
\text { Regimental }\end{array}$ & 2007 & $\begin{array}{l}\text { Acesso à } \\
\text { educaçãoo } \\
\text { básica }\end{array}$ & Acesso EI & $\begin{array}{l}\text { Santo } \\
\text { André }\end{array}$ & $\begin{array}{l}\text { Município de } \\
\text { Santo André }\end{array}$ & Criança & $\begin{array}{l}\text { Sessão } \\
\text { Plenária }\end{array}$ & Unânime & $\begin{array}{l}\text { Provimento } \\
\text { negado ao } \\
\text { agravo } \\
\text { regimental }\end{array}$ & $\begin{array}{l}\text { Celso } \\
\text { Limongi }\end{array}$ & $\begin{array}{l}\text { Sítio eletrônico } \\
\text { TJ-SP }\end{array}$ \\
\hline $\begin{array}{l}145.914 .0 / 1 \\
-01\end{array}$ & $\begin{array}{l}\text { Agravo } \\
\text { Regimental }\end{array}$ & 2007 & $\begin{array}{l}\text { Acesso à } \\
\text { educação } \\
\text { básica }\end{array}$ & Acesso EI & $\begin{array}{l}\text { Santo } \\
\text { André }\end{array}$ & $\begin{array}{l}\text { Município de } \\
\text { Santo André }\end{array}$ & Criança & $\begin{array}{l}\text { Sessão } \\
\text { Plenária }\end{array}$ & Unânime & $\begin{array}{l}\text { Provimento } \\
\text { negado ao } \\
\text { agravo } \\
\text { regimental }\end{array}$ & $\begin{array}{l}\text { Celso } \\
\text { Limongi }\end{array}$ & $\begin{array}{l}\text { Sítio eletrônico } \\
\text { TJ-SP }\end{array}$ \\
\hline $\begin{array}{l}146.274 .0 / 7 \\
-01\end{array}$ & $\begin{array}{l}\text { Agravo } \\
\text { Regimental }\end{array}$ & 2007 & $\begin{array}{l}\text { Acesso à } \\
\text { educação } \\
\text { básica }\end{array}$ & Acesso EI & $\begin{array}{l}\text { Santo } \\
\text { André }\end{array}$ & $\begin{array}{l}\text { Município de } \\
\text { Santo André }\end{array}$ & Criança & $\begin{array}{l}\text { Sessão } \\
\text { Plenária }\end{array}$ & $\begin{array}{l}\text { Maioria dos } \\
\text { votos }\end{array}$ & $\begin{array}{l}\text { Provimento } \\
\text { negado ao } \\
\text { agravo } \\
\text { regimental }\end{array}$ & $\begin{array}{l}\text { Celso } \\
\text { Limongi }\end{array}$ & $\begin{array}{l}\text { Sítio eletrônico } \\
\text { TJ-SP }\end{array}$ \\
\hline $\begin{array}{l}146.315- \\
0 / 3-00\end{array}$ & $\begin{array}{l}\text { Apelação } \\
\text { Cível }\end{array}$ & 2007 & $\begin{array}{l}\text { Acesso à } \\
\text { educação } \\
\text { básica }\end{array}$ & Acesso EI & Piracicaba & $\begin{array}{l}\text { Juízo Ex } \\
\text { Officio / } \\
\text { Município de } \\
\text { Piracicaba }\end{array}$ & $\begin{array}{l}\text { Promotor de } \\
\text { Justiça da } \\
\text { Infância e } \\
\text { Juventude de } \\
\text { Piracicaba } \\
\end{array}$ & $\begin{array}{l}\text { Câmara } \\
\text { Especial }\end{array}$ & Unânime & $\begin{array}{l}\text { Recurso não } \\
\text { provido }\end{array}$ & $\begin{array}{l}\text { Roberto } \\
\text { Vallim } \\
\text { Bellocchi }\end{array}$ & $\begin{array}{l}\text { Sítio eletrônico } \\
\text { TJ-SP }\end{array}$ \\
\hline $\begin{array}{l}146.452 .0 / 0 \\
-01\end{array}$ & $\begin{array}{l}\text { Agravo } \\
\text { Regimental }\end{array}$ & 2007 & $\begin{array}{l}\text { Acesso à } \\
\text { educação } \\
\text { básica }\end{array}$ & Acesso EI & $\begin{array}{l}\text { Santo } \\
\text { André }\end{array}$ & $\begin{array}{l}\text { Município de } \\
\text { Santo André }\end{array}$ & Criança & $\begin{array}{l}\text { Sessão } \\
\text { Plenária }\end{array}$ & $\begin{array}{l}\text { Maioria dos } \\
\text { votos }\end{array}$ & $\begin{array}{l}\text { Provimento } \\
\text { negado ao } \\
\text { agravo } \\
\text { regimental } \\
\end{array}$ & $\begin{array}{l}\text { Celso } \\
\text { Limongi }\end{array}$ & $\begin{array}{l}\text { Sítio eletrônico } \\
\text { TJ-SP }\end{array}$ \\
\hline $\begin{array}{l}146.539 .0 / 5 \\
-00\end{array}$ & $\begin{array}{l}\text { Apelação } \\
\text { Cível }\end{array}$ & 2007 & $\begin{array}{l}\text { Gestão dos } \\
\text { recursos } \\
\text { públicos }\end{array}$ & $\begin{array}{l}\text { Aplicação } \\
\text { dos recursos }\end{array}$ & Guarulhos & $\begin{array}{l}\text { Município de } \\
\text { Guarulhos e } \\
\text { Juízo Ex } \\
\text { Officio }\end{array}$ & $\begin{array}{l}\text { Promotor de } \\
\text { Justiça e da } \\
\text { Juventude da } \\
\text { Comarca de } \\
\text { Guarulhos }\end{array}$ & $\begin{array}{l}\text { Câmara } \\
\text { Especial }\end{array}$ & Unânime & $\begin{array}{l}\text { Determinara } \\
\text { m a } \\
\text { redistribuição } \\
\text { do feito a } \\
\text { uma das } \\
\text { Câmaras da } \\
\text { E. Seção de } \\
\text { Direito } \\
\text { Público. }\end{array}$ & $\begin{array}{l}\text { Canguçu de } \\
\text { Almeida }\end{array}$ & $\begin{array}{l}\text { Sítio eletrônico } \\
\text { TJ-SP }\end{array}$ \\
\hline $\begin{array}{l}147.256 .0 / 0 \\
-00\end{array}$ & $\begin{array}{l}\text { Agravo } \\
\text { Regimental }\end{array}$ & 2007 & $\begin{array}{l}\text { Acesso à } \\
\text { educação } \\
\text { básica }\end{array}$ & Acesso EI & São Paulo & $\begin{array}{l}\text { Município de } \\
\text { São Paulo }\end{array}$ & $\begin{array}{l}\text { Promotor de } \\
\text { Justiça dos } \\
\text { Interesses } \\
\text { Difusos e } \\
\text { Coletivos da } \\
\text { Infância e } \\
\text { Juventude da } \\
\text { Capital }\end{array}$ & $\begin{array}{l}\text { Câmara } \\
\text { Especial }\end{array}$ & Unânime & $\begin{array}{l}\text { Recurso não } \\
\text { provido }\end{array}$ & $\begin{array}{l}\text { Luiz Carlos } \\
\text { Ribeiro dos } \\
\text { Santos }\end{array}$ & $\begin{array}{l}\text { Sítio eletrônico } \\
\text { TJ-SP }\end{array}$ \\
\hline
\end{tabular}




\begin{tabular}{|c|c|c|c|c|c|c|c|c|c|c|c|c|}
\hline $\begin{array}{l}\text { Número } \\
\text { decisão }\end{array}$ & Natureza & Ano & Categorias & Tema & Origem & $\begin{array}{l}\text { Apelante } \\
\text { recorrente }\end{array}$ & $\begin{array}{l}\text { Apelados } \\
\text { recorridos }\end{array}$ & Câmara & Votação & Resultado & Relator & $\begin{array}{l}\text { Localização } \\
\text { da ementa / } \\
\text { acórdão }\end{array}$ \\
\hline $\begin{array}{l}147.658- \\
0 / 5-00\end{array}$ & $\begin{array}{l}\text { Agravo de } \\
\text { Instrumento }\end{array}$ & 2007 & $\begin{array}{l}\text { Acesso à } \\
\text { educação } \\
\text { básica }\end{array}$ & Acesso EI & São Paulo & $\begin{array}{l}\text { Municipalidad } \\
\text { e de São Paulo }\end{array}$ & $\begin{array}{l}\text { Promotor de } \\
\text { Justiça da } \\
\text { Vara da } \\
\text { Infância e da } \\
\text { Juventude do } \\
\text { Foro } \\
\text { Regional } \\
\text { Santo Amaro }\end{array}$ & $\begin{array}{l}\text { Câmara } \\
\text { Especial }\end{array}$ & $\begin{array}{l}\text { Recurso não } \\
\text { provido }\end{array}$ & Unânime & $\begin{array}{l}\text { Sidnei } \\
\text { Beneti }\end{array}$ & $\begin{array}{l}\text { Sítio eletrônico } \\
\text { TJ-SP }\end{array}$ \\
\hline $\begin{array}{l}147.678- \\
0 / 6-00\end{array}$ & $\begin{array}{l}\text { Apelação } \\
\text { Cível }\end{array}$ & 2007 & $\begin{array}{l}\text { Acesso à } \\
\text { educação } \\
\text { básica }\end{array}$ & Acesso EI & $\begin{array}{l}\text { Ribeirão } \\
\text { Preto }\end{array}$ & $\begin{array}{l}\text { Prefeitura } \\
\text { Municipal de } \\
\text { Ribeirão Preto } \\
\text { / Juízo Ex } \\
\text { Officio }\end{array}$ & $\begin{array}{l}\text { Promotor de } \\
\text { Justiça da } \\
\text { Infância e } \\
\text { Juventude de } \\
\text { Ribeirão } \\
\text { Preto }\end{array}$ & $\begin{array}{l}\text { Câmara } \\
\text { Especial }\end{array}$ & Unânime & $\begin{array}{l}\text { Recurso não } \\
\text { provido }\end{array}$ & $\begin{array}{l}\text { Sidnei } \\
\text { Beneti }\end{array}$ & $\begin{array}{l}\text { Sítio eletrônico } \\
\text { TJ-SP }\end{array}$ \\
\hline $\begin{array}{l}149.138- \\
0 / 7-00\end{array}$ & $\begin{array}{l}\text { Apelação } \\
\text { Cível }\end{array}$ & 2007 & $\begin{array}{l}\text { Acesso à } \\
\text { educação } \\
\text { básica }\end{array}$ & Acesso EI & $\begin{array}{l}\text { Ribeirão } \\
\text { Preto }\end{array}$ & $\begin{array}{l}\text { Prefeitura } \\
\text { Municipal de } \\
\text { Ribeirão Preto } \\
\text { / Juízo Ex } \\
\text { Officio }\end{array}$ & $\begin{array}{l}\text { Promotor de } \\
\text { Justiça da } \\
\text { Infância e } \\
\text { Juventude de } \\
\text { Ribeirão } \\
\text { Preto }\end{array}$ & $\begin{array}{l}\text { Câmara } \\
\text { Especial }\end{array}$ & Unânime & $\begin{array}{l}\text { Recurso não } \\
\text { provido }\end{array}$ & $\begin{array}{l}\text { Sidnei } \\
\text { Beneti }\end{array}$ & $\begin{array}{l}\text { Sítio eletrônico } \\
\text { TJ-SP }\end{array}$ \\
\hline $\begin{array}{l}149.235- \\
0 / 00\end{array}$ & $\begin{array}{l}\text { Apelação } \\
\text { Cível }\end{array}$ & 2007 & $\begin{array}{l}\text { Acesso à } \\
\text { educação } \\
\text { básica }\end{array}$ & $\begin{array}{l}\text { Educação } \\
\text { Especial }\end{array}$ & São Paulo & $\begin{array}{l}\text { Prefeitura } \\
\text { Municipal de } \\
\text { São Paulo / } \\
\text { Juízo Ex } \\
\text { Officio }\end{array}$ & $\begin{array}{l}\text { Promotor de } \\
\text { Justiça da } \\
\text { Infância e } \\
\text { Juventude do } \\
\text { Foro } \\
\text { Regional da } \\
\text { Lapa }\end{array}$ & $\begin{array}{l}\text { Câmara } \\
\text { Especial }\end{array}$ & Unânime & $\begin{array}{l}\text { Provimento } \\
\text { parcial aos } \\
\text { recursos }\end{array}$ & $\begin{array}{l}\text { Canguçu de } \\
\text { Almeida }\end{array}$ & $\begin{array}{l}\text { Sítio eletrônico } \\
\text { TJ-SP }\end{array}$ \\
\hline $\begin{array}{l}149.237- \\
0 / 9-00\end{array}$ & $\begin{array}{l}\text { Apelação } \\
\text { Cível }\end{array}$ & 2007 & $\begin{array}{l}\text { Acesso à } \\
\text { educação } \\
\text { básica }\end{array}$ & $\begin{array}{l}\text { Educação } \\
\text { Especial }\end{array}$ & São Paulo & $\begin{array}{l}\text { Municipalidad } \\
\text { e de São Paulo } \\
\text { / Juízo Ex } \\
\text { Officio }\end{array}$ & $\begin{array}{l}\text { Promotor de } \\
\text { Justiça da } \\
\text { Vara da } \\
\text { Infância e } \\
\text { Juventude do } \\
\text { Foro } \\
\text { Regional da } \\
\text { Lapa }\end{array}$ & $\begin{array}{l}\text { Câmara } \\
\text { Especial }\end{array}$ & Unânime & $\begin{array}{l}\text { Provimento } \\
\text { parcial aos } \\
\text { recursos }\end{array}$ & $\begin{array}{l}\text { Eduardo } \\
\text { Gouvea }\end{array}$ & $\begin{array}{l}\text { Sítio eletrônico } \\
\text { TJ-SP }\end{array}$ \\
\hline
\end{tabular}




\begin{tabular}{|c|c|c|c|c|c|c|c|c|c|c|c|c|}
\hline $\begin{array}{l}\text { Número } \\
\text { decisão }\end{array}$ & Natureza & Ano & Categorias & Tema & Origem & $\begin{array}{l}\text { Apelante } \\
\text { recorrente }\end{array}$ & $\begin{array}{l}\text { Apelados } \\
\text { recorridos }\end{array}$ & Câmara & Votação & Resultado & Relator & $\begin{array}{l}\text { Localização } \\
\text { da ementa / } \\
\text { acórdão }\end{array}$ \\
\hline $\begin{array}{l}150.400 .0 / 6 \\
-00\end{array}$ & ADIN & 2007 & $\begin{array}{l}\text { Decisões } \\
\text { administrativ } \\
\text { as e políticas }\end{array}$ & $\begin{array}{l}\text { Competência } \\
\text { para legislar }\end{array}$ & Taubaté & $\begin{array}{l}\text { Prefeito do } \\
\text { Município de } \\
\text { Taubaté }\end{array}$ & $\begin{array}{l}\text { Câmara } \\
\text { Municipal de } \\
\text { Taubaté }\end{array}$ & $\begin{array}{l}\text { Órgão } \\
\text { Especial }\end{array}$ & Unânime & $\begin{array}{l}\text { Ação } \\
\text { procedente }\end{array}$ & $\begin{array}{l}\text { Canguçu de } \\
\text { Almeida }\end{array}$ & $\begin{array}{l}\text { Sítio eletrônico } \\
\text { TJ-SP }\end{array}$ \\
\hline $\begin{array}{l}152.190- \\
0 / 0-00\end{array}$ & $\begin{array}{l}\text { Apelação } \\
\text { Cível }\end{array}$ & 2007 & $\begin{array}{l}\text { Deveres dos } \\
\text { pais }\end{array}$ & \begin{tabular}{|l|} 
Negligência \\
dos pais/ \\
responsáveis
\end{tabular} & Itapeva & Criança & $\begin{array}{l}\text { Promotor de } \\
\text { Justiça da } \\
\text { Vara da } \\
\text { Infância e } \\
\text { Juventude de } \\
\text { Itapeva }\end{array}$ & $\begin{array}{l}\text { Câmara } \\
\text { Especial }\end{array}$ & Unânime & $\begin{array}{l}\text { Provimento } \\
\text { parcial ao } \\
\text { recurso }\end{array}$ & $\begin{array}{l}\text { Eduardo } \\
\text { Gouvêa }\end{array}$ & $\begin{array}{l}\text { Sítio eletrônico } \\
\text { TJ-SP }\end{array}$ \\
\hline $\begin{array}{l}152.802- \\
0 / 5-00\end{array}$ & $\begin{array}{l}\text { Apelação } \\
\text { Cível }\end{array}$ & 2007 & $\begin{array}{l}\text { Acesso à } \\
\text { educação } \\
\text { básica }\end{array}$ & Acesso EI & São Paulo & $\begin{array}{l}\text { Municipalidad } \\
\text { e de São Paulo }\end{array}$ & $\begin{array}{l}\text { Promotor de } \\
\text { Justiça dos } \\
\text { Interesses } \\
\text { Difusos e } \\
\text { Coletivos da } \\
\text { Infância e } \\
\text { Juventude do } \\
\text { Foro } \\
\text { Regional do } \\
\text { Jabaquara } \\
\end{array}$ & $\begin{array}{l}\text { Câmara } \\
\text { Especial }\end{array}$ & Unânime & $\begin{array}{l}\text { Recurso não } \\
\text { provido }\end{array}$ & $\begin{array}{l}\text { Maria } \\
\text { Olivia } \\
\text { Alves }\end{array}$ & $\begin{array}{l}\text { Sítio eletrônico } \\
\text { TJ-SP }\end{array}$ \\
\hline $\begin{array}{l}221.575- \\
5 / 3-00\end{array}$ & $\begin{array}{l}\text { Apelação } \\
\text { Cível com } \\
\text { revisão }\end{array}$ & 2007 & $\begin{array}{l}\text { Gestão dos } \\
\text { recursos } \\
\text { públicos }\end{array}$ & $\begin{array}{l}\text { Aplicação } \\
\text { dos recursos }\end{array}$ & $\begin{array}{l}\text { Ribeirão } \\
\text { Pires }\end{array}$ & V.P. & $\begin{array}{l}\text { Câmara } \\
\text { Municipal da } \\
\text { Estância de } \\
\text { Ribeirão Pires }\end{array}$ & $\begin{array}{l}12^{\circ} \text { Câmara } \\
\text { de Direito } \\
\text { Público }\end{array}$ & Unânime & $\begin{array}{l}\text { Recurso } \\
\text { negado }\end{array}$ & $\begin{array}{l}\text { Edson } \\
\text { Ferreira da } \\
\text { Silva }\end{array}$ & $\begin{array}{l}\text { Sítio eletrônico } \\
\text { TJ-SP }\end{array}$ \\
\hline $\begin{array}{l}235.770- \\
5 / 0-00\end{array}$ & $\begin{array}{l}\text { Apelação } \\
\text { Cível com } \\
\text { revisão }\end{array}$ & 2007 & Permanência & \begin{tabular}{|l|} 
Cancelament \\
o de \\
matrícula em \\
curso de \\
língua \\
estrangeira \\
\end{tabular} & Carapicuíba & $\begin{array}{l}\text { Juízo Ex } \\
\text { Offício / } \\
\text { Fazenda do } \\
\text { Estado de SP }\end{array}$ & A. A. R. G. & $\begin{array}{l}7^{\mathrm{a}} \text { Câmara } \\
\text { de Direito } \\
\text { Público }\end{array}$ & Unânime & $\begin{array}{l}\text { Recurso não } \\
\text { provido }\end{array}$ & $\begin{array}{l}\text { Sidney } \\
\text { Romano dos } \\
\text { Reis }\end{array}$ & $\begin{array}{l}\text { Sítio eletrônico } \\
\text { TJ-SP }\end{array}$ \\
\hline $\begin{array}{l}252.557- \\
5 / 3-00\end{array}$ & $\begin{array}{l}\text { Apelação } \\
\text { Cível com } \\
\text { revisão }\end{array}$ & 2007 & Permanência & \begin{tabular}{|l|} 
Violação às \\
normas \\
escolares
\end{tabular} & $\begin{array}{l}\text { Votuporang } \\
\text { a }\end{array}$ & $\begin{array}{l}\text { Criança ou } \\
\text { adolescente }\end{array}$ & $\begin{array}{l}\text { Diretor da } \\
\text { escola } \\
\text { Estadual } \\
\text { Cecília } \\
\text { Meireles }\end{array}$ & $\begin{array}{l}2^{\mathrm{a}} \text { Câmara } \\
\text { de Direito } \\
\text { Público }\end{array}$ & Unânime & $\begin{array}{l}\text { Recurso } \\
\text { provido }\end{array}$ & $\begin{array}{l}\text { Christine } \\
\text { Santini }\end{array}$ & $\begin{array}{l}\text { Sítio eletrônico } \\
\text { TJ-SP }\end{array}$ \\
\hline
\end{tabular}




\begin{tabular}{|c|c|c|c|c|c|c|c|c|c|c|c|c|}
\hline $\begin{array}{l}\text { Número } \\
\text { decisão }\end{array}$ & Natureza & Ano & Categorias & Tema & Origem & $\begin{array}{l}\text { Apelante } \\
\text { recorrente }\end{array}$ & \begin{tabular}{|l|} 
Apelados \\
recorridos
\end{tabular} & Câmara & Votação & Resultado & Relator & $\begin{array}{l}\text { Localização } \\
\text { da ementa / } \\
\text { acórdão }\end{array}$ \\
\hline $\begin{array}{l}276.057- \\
5 / 7-00\end{array}$ & $\begin{array}{l}\text { Apelação } \\
\text { Cível com } \\
\text { revisão }\end{array}$ & 2007 & Permanência & \begin{tabular}{|l|} 
Cancelament \\
o de \\
matrícula em \\
curso de \\
língua \\
estrangeira \\
\end{tabular} & São Paulo & $\begin{array}{l}\text { Criança ou } \\
\text { adolescente }\end{array}$ & \begin{tabular}{|l|} 
Secretário de \\
Estado de \\
Educação
\end{tabular} & $\begin{array}{l}2^{\mathrm{a}} \text { Câmara } \\
\text { de Direito } \\
\text { Público }\end{array}$ & Unânime & $\begin{array}{l}\text { Recurso não } \\
\text { provido }\end{array}$ & $\begin{array}{l}\text { Christine } \\
\text { Santini }\end{array}$ & $\begin{array}{l}\text { Sítio eletrônico } \\
\text { TJ-SP }\end{array}$ \\
\hline $\begin{array}{l}289.760- \\
5 / 5-00\end{array}$ & \begin{tabular}{|l|} 
Apelação \\
Cível com \\
revisão
\end{tabular} & 2007 & $\begin{array}{l}\text { Poder de } \\
\text { regulação } \\
\text { estatal }\end{array}$ & $\begin{array}{l}\text { Autorização/ } \\
\text { credenciame } \\
\text { nto }\end{array}$ & São Paulo & $\begin{array}{l}\text { Grêmio de } \\
\text { alunos do } \\
\text { Instituto } \\
\text { Universal } \\
\text { Brasileiro } \\
\end{array}$ & $\begin{array}{l}\text { Presidente do } \\
\text { Conselho } \\
\text { Estadual de } \\
\text { Educação de } \\
\text { São Paulo }\end{array}$ & $\begin{array}{l}9^{\text {a }} \text { Câmara } \\
\text { de Direito } \\
\text { Público }\end{array}$ & Unânime & $\begin{array}{l}\text { Recurso não } \\
\text { provido }\end{array}$ & $\begin{array}{l}\text { Rebouças } \\
\text { Carvalho }\end{array}$ & $\begin{array}{l}\text { Sítio eletrônico } \\
\text { TJ-SP }\end{array}$ \\
\hline $\begin{array}{l}292.581- \\
5 / 5-00\end{array}$ & $\begin{array}{l}\text { Apelação } \\
\text { Cível com } \\
\text { revisão }\end{array}$ & 2007 & Permanência & $\begin{array}{l}\text { Cancelament } \\
\text { o de } \\
\text { matrícula em } \\
\text { curso de } \\
\text { língua } \\
\text { estrangeira }\end{array}$ & $\begin{array}{l}\text { Presidente } \\
\text { Prudente }\end{array}$ & $\begin{array}{l}\text { Juízo Ex } \\
\text { Officio / } \\
\text { Fazenda do } \\
\text { Estado de SP }\end{array}$ & \begin{tabular}{|l|} 
Criança ou \\
adolescente
\end{tabular} & $\begin{array}{l}3^{\text {a }} \text { Câmara } \\
\text { de Direito } \\
\text { Público }\end{array}$ & Unânime & $\begin{array}{l}\text { Recurso não } \\
\text { provido }\end{array}$ & $\begin{array}{l}\text { Antonio C. } \\
\text { Malheiros }\end{array}$ & $\begin{array}{l}\text { Sítio eletrônico } \\
\text { TJ-SP }\end{array}$ \\
\hline $\begin{array}{l}\text { 316.194- } \\
5 / 1-00\end{array}$ & $\begin{array}{l}\text { Apelação } \\
\text { Cível com } \\
\text { revisão }\end{array}$ & 2007 & $\begin{array}{l}\text { Poder de } \\
\text { regulação } \\
\text { estatal } \\
\end{array}$ & $\begin{array}{l}\text { Autorização/ } \\
\text { credenciame } \\
\text { nto }\end{array}$ & São Paulo & \begin{tabular}{|l|} 
Fazenda do \\
Estado de SP
\end{tabular} & \begin{tabular}{|l|} 
Centro de \\
Estudos \\
Adjetivo Ltda \\
\end{tabular} & $\begin{array}{l}9^{a} \text { Câmara } \\
\text { de Direito } \\
\text { Público }\end{array}$ & Unânime & $\begin{array}{l}\text { Recurso } \\
\text { provido }\end{array}$ & $\begin{array}{l}\text { Peiretti de } \\
\text { Godoy }\end{array}$ & $\begin{array}{l}\text { Sítio eletrônico } \\
\text { TJ-SP }\end{array}$ \\
\hline $\begin{array}{l}321.928-5- \\
00\end{array}$ & $\begin{array}{l}\text { Apelação } \\
\text { Cível com } \\
\text { revisão }\end{array}$ & 2007 & Permanência & \begin{tabular}{|l|} 
Violação às \\
normas \\
escolares
\end{tabular} & Ituverava & \begin{tabular}{|l|} 
Juízo Ex \\
Officio/ \\
Fazenda do \\
Estado de São \\
Paulo \\
\end{tabular} & \begin{tabular}{|l|} 
Criança ou \\
adolescente
\end{tabular} & $\begin{array}{l}5^{\text {a }} \text { Câmara } \\
\text { de Direito } \\
\text { Público }\end{array}$ & Unânime & $\begin{array}{l}\text { Recurso não } \\
\text { provido }\end{array}$ & \begin{tabular}{|l} 
Ricardo \\
Anafe
\end{tabular} & $\begin{array}{l}\text { Sítio eletrônico } \\
\text { TJ-SP }\end{array}$ \\
\hline $\begin{array}{l}323.908- \\
5 / 8-00\end{array}$ & $\begin{array}{l}\text { Apelação } \\
\text { Cível com } \\
\text { revisão }\end{array}$ & 2007 & Permanência & \begin{tabular}{|l|} 
Cancelament \\
o de \\
matrícula em \\
curso de \\
língua \\
estrangeira
\end{tabular} & $\begin{array}{l}\text { Presidente } \\
\text { Prudente }\end{array}$ & $\begin{array}{l}\text { Criança ou } \\
\text { adolescente }\end{array}$ & \begin{tabular}{|l} 
Diretora da \\
Escola \\
Estadual \\
Monsenhor \\
Sarrion
\end{tabular} & $\begin{array}{l}5^{\text {a }} \text { Câmara } \\
\text { de Direito } \\
\text { Público }\end{array}$ & Unânime & $\begin{array}{l}\text { Anularam o } \\
\text { processo, } \\
\text { prejudicado o } \\
\text { recurso } \\
\text { interposto }\end{array}$ & \begin{tabular}{|l} 
Ricardo \\
Anafe
\end{tabular} & $\begin{array}{l}\text { Sítio eletrônico } \\
\text { TJ-SP }\end{array}$ \\
\hline $\begin{array}{l}327.881- \\
5 / 2-00\end{array}$ & $\begin{array}{l}\text { Apelação } \\
\text { Cível com } \\
\text { revisão }\end{array}$ & 2007 & $\begin{array}{l}\text { Acesso à } \\
\text { educação } \\
\text { básica }\end{array}$ & Acesso EJA & São Paulo & \begin{tabular}{|l|} 
Juízo Ex \\
Offício
\end{tabular} & \begin{tabular}{|l|} 
Fazenda do \\
Estado de São \\
Paulo
\end{tabular} & $\begin{array}{l}6^{\text {a }} \text { Câmara } \\
\text { de Direito } \\
\text { Público }\end{array}$ & Unânime & $\begin{array}{l}\text { Recurso não } \\
\text { provido }\end{array}$ & $\begin{array}{l}\text { Evaristo dos } \\
\text { Santos }\end{array}$ & $\begin{array}{l}\text { Sítio eletrônico } \\
\text { TJ-SP }\end{array}$ \\
\hline $\begin{array}{l}\text { 329.329- } \\
5 / 9-00\end{array}$ & \begin{tabular}{|l} 
Apelação \\
Cível com \\
revisão
\end{tabular} & 2007 & $\begin{array}{l}\text { Gestão dos } \\
\text { recursos } \\
\text { públicos }\end{array}$ & $\begin{array}{l}\text { Aplicação } \\
\text { dos recursos }\end{array}$ & Juquitiba & $\begin{array}{l}\text { Viação Pevatur } \\
\text { Pérola do Vale } \\
\text { Transportes } \\
\text { Urbanos e A. } \\
\text { X. C. } \\
\end{array}$ & $\begin{array}{l}\text { Prefeitura } \\
\text { Municipal de } \\
\text { Juquitiba e } \\
\text { C.D.A. }\end{array}$ & $\begin{array}{l}1^{\mathrm{a}} \text { Câmara } \\
\text { de Direito } \\
\text { Público }\end{array}$ & Unânime & $\begin{array}{l}\text { Recurso não } \\
\text { provido }\end{array}$ & \begin{tabular}{|l|} 
Castilho \\
Barbosa
\end{tabular} & \begin{tabular}{|l|} 
JTJ \\
v. 320 , p.196
\end{tabular} \\
\hline
\end{tabular}




\begin{tabular}{|c|c|c|c|c|c|c|c|c|c|c|c|c|}
\hline $\begin{array}{l}\text { Número } \\
\text { decisão }\end{array}$ & Natureza & Ano & Categorias & Tema & Origem & $\begin{array}{l}\text { Apelante } \\
\text { recorrente }\end{array}$ & $\begin{array}{l}\text { Apelados } \\
\text { recorridos }\end{array}$ & Câmara & Votação & Resultado & Relator & $\begin{array}{l}\text { Localização } \\
\text { da ementa / } \\
\text { acórdão }\end{array}$ \\
\hline $\begin{array}{l}330.684- \\
5 / 0-00\end{array}$ & $\begin{array}{l}\text { Apelação } \\
\text { Cível com } \\
\text { revisão }\end{array}$ & 2007 & $\begin{array}{l}\text { Decisões } \\
\text { administrativ } \\
\text { as e políticas }\end{array}$ & $\begin{array}{l}\text { Municipaliza } \\
\text { ção }\end{array}$ & Assis & APEOESP & $\begin{array}{l}\text { Prefeito } \\
\text { Municipal de } \\
\text { Assis }\end{array}$ & $\begin{array}{l}2^{\circ} \text { Câmara } \\
\text { de Direito } \\
\text { Público }\end{array}$ & Unânime & $\begin{array}{l}\text { Recurso } \\
\text { negado }\end{array}$ & $\begin{array}{l}\text { Samuel } \\
\text { Júnior }\end{array}$ & $\begin{array}{l}\text { Sítio eletrônico } \\
\text { TJ-SP }\end{array}$ \\
\hline $\begin{array}{l}\text { 334.194- } \\
5 / 4-00\end{array}$ & $\begin{array}{l}\text { Apelação } \\
\text { Cível com } \\
\text { revisão }\end{array}$ & 2007 & $\begin{array}{l}\text { Poder de } \\
\text { regulação } \\
\text { estatal }\end{array}$ & $\begin{array}{l}\text { Autorização/ } \\
\text { credenciame } \\
\text { nto }\end{array}$ & São Paulo & $\begin{array}{l}\text { Juízo Ex } \\
\text { Officio / } \\
\text { Fazenda do } \\
\text { Estado de SP }\end{array}$ & R.S.S. & $\begin{array}{l}9^{\text {a }} \text { Câmara } \\
\text { de Direito } \\
\text { Público }\end{array}$ & Unânime & $\begin{array}{l}\text { Recurso não } \\
\text { provido }\end{array}$ & $\begin{array}{l}\text { Antonio } \\
\text { Rulli }\end{array}$ & $\begin{array}{l}\text { Sítio eletrônico } \\
\text { TJ-SP }\end{array}$ \\
\hline $\begin{array}{l}343.637 .5 / 7 \\
-00\end{array}$ & $\begin{array}{l}\text { Apelação } \\
\text { Cível }\end{array}$ & 2007 & $\begin{array}{l}\text { Responsabili } \\
\text { dade estatal }\end{array}$ & $\begin{array}{l}\text { Ação de } \\
\text { reparação de } \\
\text { danos }\end{array}$ & $\begin{array}{l}\text { Arujá// } \\
\text { Santa Isabel }\end{array}$ & $\begin{array}{l}\text { Juízo Ex } \\
\text { Officio/ } \\
\text { Fazenda do } \\
\text { Estado de SP / } \\
\text { Criança ou } \\
\text { adolescente }\end{array}$ & $\begin{array}{l}\text { Criança ou } \\
\text { adolescente. / } \\
\text { Fazenda do } \\
\text { Estado de SP }\end{array}$ & $\begin{array}{l}11^{a} \text { Câmara } \\
\text { de Direito } \\
\text { Público }\end{array}$ & Unânime & $\begin{array}{l}\text { Provimento } \\
\text { parcial ao } \\
\text { recurso ofical } \\
\text { e da Fazenda } \\
\text { e negaram } \\
\text { provimento } \\
\text { ao recurso da } \\
\text { autora }\end{array}$ & $\begin{array}{l}\text { Oscild de } \\
\text { Lima Júnior }\end{array}$ & $\begin{array}{l}\text { Sítio eletrônico } \\
\text { TJ-SP }\end{array}$ \\
\hline $\begin{array}{l}335.747- \\
5 / 5-00\end{array}$ & $\begin{array}{l}\text { Apelação } \\
\text { Cível com } \\
\text { revisão }\end{array}$ & 2007 & Permanência & \begin{tabular}{|l|} 
Cancelament \\
o de \\
matrícula em \\
curso de \\
língua \\
estrangeira \\
\end{tabular} & $\begin{array}{l}\text { Presidente } \\
\text { Prudente }\end{array}$ & $\begin{array}{l}\text { Fazenda do } \\
\text { Estado de SP }\end{array}$ & Adolescente & $\begin{array}{l}2^{\text {a }} \text { Câmara } \\
\text { de Direito } \\
\text { Público }\end{array}$ & Unânime & $\begin{array}{l}\text { Recurso não } \\
\text { provido }\end{array}$ & $\begin{array}{l}\text { Samuel } \\
\text { Júnior }\end{array}$ & $\begin{array}{l}\text { Sítio eletrônico } \\
\text { TJ-SP }\end{array}$ \\
\hline $\begin{array}{l}357.013- \\
5 / 7-00\end{array}$ & $\begin{array}{l}\text { Apelação } \\
\text { Cível com } \\
\text { revisão }\end{array}$ & 2007 & $\begin{array}{l}\text { Gestão dos } \\
\text { recursos } \\
\text { públicos }\end{array}$ & Fundef & $\begin{array}{l}\text { Tupi } \\
\text { Paulista }\end{array}$ & R.T. & $\begin{array}{l}\text { Dracena } \\
\text { Motor Ltda, } \\
\text { Prefeitura } \\
\text { Municipal de } \\
\text { Tupi Paulista } \\
\text { e outros } \\
\end{array}$ & $\begin{array}{l}3^{\text {a }} \text { Câmara } \\
\text { de Direito } \\
\text { Público }\end{array}$ & Unânime & $\begin{array}{l}\text { Recurso não } \\
\text { provido }\end{array}$ & $\begin{array}{l}\text { Laerte } \\
\text { Sampaio }\end{array}$ & $\begin{array}{l}\text { Sítio eletrônico } \\
\text { TJ-SP }\end{array}$ \\
\hline $\begin{array}{l}\text { 390.807- } \\
5 / 2-00\end{array}$ & $\begin{array}{l}\text { Apelação } \\
\text { Cível com } \\
\text { revisão }\end{array}$ & 2007 & $\begin{array}{l}\text { Responsabili } \\
\text { dade estatal }\end{array}$ & $\begin{array}{l}\text { Ação de } \\
\text { reparação de } \\
\text { danos }\end{array}$ & Serrana & $\begin{array}{l}\text { Criança ou } \\
\text { adolescente }\end{array}$ & $\begin{array}{l}\text { Prefeitura } \\
\text { Municipal de } \\
\text { Serrana }\end{array}$ & $\begin{array}{l}6^{\circ} \text { Câmara } \\
\text { de Direito } \\
\text { Público }\end{array}$ & Unânime & $\begin{array}{l}\text { Recurso } \\
\text { negado }\end{array}$ & $\begin{array}{l}\text { Oliveira } \\
\text { Santos }\end{array}$ & $\begin{array}{l}\text { Sítio eletrônico } \\
\text { TJ-SP }\end{array}$ \\
\hline $\begin{array}{l}\text { 392.081- } \\
5 / 2-00\end{array}$ & $\begin{array}{l}\text { Apelação } \\
\text { Cível com } \\
\text { revisão }\end{array}$ & 2007 & $\begin{array}{l}\text { Acesso à } \\
\text { educação } \\
\text { básica }\end{array}$ & $\begin{array}{l}\text { Acesso (não } \\
\text { define a } \\
\text { etapa) }\end{array}$ & $\begin{array}{l}\text { Taboão da } \\
\text { Serra/ } \\
\text { Itapecerica } \\
\text { da Serra }\end{array}$ & $\begin{array}{l}\text { Criança ou } \\
\text { adolescente }\end{array}$ & $\begin{array}{l}\text { Diretor da } \\
\text { Escola } \\
\text { Estadual Prof. } \\
\text { Lúcia de } \\
\text { Castro Bueno }\end{array}$ & $\begin{array}{l}6^{\circ} \text { Câmara } \\
\text { de Direito } \\
\text { Público }\end{array}$ & Unânime & $\begin{array}{l}\text { Recurso } \\
\text { prejudicado }\end{array}$ & $\begin{array}{l}\text { Carlos } \\
\text { Eduardo } \\
\text { Pachi }\end{array}$ & $\begin{array}{l}\text { Sítio eletrônico } \\
\text { TJ-SP }\end{array}$ \\
\hline
\end{tabular}




\begin{tabular}{|c|c|c|c|c|c|c|c|c|c|c|c|c|}
\hline $\begin{array}{l}\text { Número } \\
\text { decisão }\end{array}$ & Natureza & Ano & Categorias & Tema & Origem & $\begin{array}{l}\text { Apelante } \\
\text { recorrente }\end{array}$ & $\begin{array}{l}\text { Apelados } \\
\text { recorridos }\end{array}$ & Câmara & Votação & Resultado & Relator & $\begin{array}{l}\text { Localização } \\
\text { da ementa / } \\
\text { acórdão }\end{array}$ \\
\hline $\begin{array}{l}431.258- \\
5 / 3-00\end{array}$ & $\begin{array}{l}\text { Apelação } \\
\text { Cível com } \\
\text { revisão }\end{array}$ & 2007 & $\begin{array}{l}\text { Responsabili } \\
\text { dade estatal }\end{array}$ & $\begin{array}{l}\text { Transporte } \\
\text { escolar }\end{array}$ & $\begin{array}{l}\text { Pariquera } \\
\text { Açu }\end{array}$ & $\begin{array}{l}\text { Prefeitura } \\
\text { Municipal de } \\
\text { Pariquera Açu }\end{array}$ & $\begin{array}{l}\text { Criança ou } \\
\text { adolescente } \\
\text { representado } \\
\text { pelo pai }\end{array}$ & $\begin{array}{l}12^{\mathrm{a}} \text { Câmara } \\
\text { de Direito } \\
\text { Público }\end{array}$ & Unânime & $\begin{array}{l}\text { Não } \\
\text { conheceram } \\
\text { do recurso e } \\
\text { determinara } \\
\text { m a remessa } \\
\text { dos autos } \\
\text { para a } \\
\text { Câmara } \\
\text { Especial } \\
\end{array}$ & $\begin{array}{l}\text { Sidney } \\
\text { Romano dos } \\
\text { Reis }\end{array}$ & $\begin{array}{l}\text { Sítio eletrônico } \\
\text { TJ-SP }\end{array}$ \\
\hline $\begin{array}{l}527.224- \\
5 / 3-00\end{array}$ & $\begin{array}{l}\text { Apelação } \\
\text { Cível com } \\
\text { revisão }\end{array}$ & 2007 & $\begin{array}{l}\text { Decisões } \\
\text { administrativ } \\
\text { as e políticas }\end{array}$ & $\begin{array}{l}\text { Municipaliza } \\
\text { ção }\end{array}$ & Carapicuíba & $\begin{array}{l}\text { M.A.S. e } \\
\text { outros }\end{array}$ & $\begin{array}{l}\text { Prefeito } \\
\text { Municipal de } \\
\text { Carapicuíba }\end{array}$ & $\begin{array}{l}6^{\circ} \text { Câmara } \\
\text { de Direito } \\
\text { Público }\end{array}$ & Unânime & $\begin{array}{l}\text { Recurso não } \\
\text { provido }\end{array}$ & $\begin{array}{l}\text { Oliveira } \\
\text { Santos }\end{array}$ & $\begin{array}{l}\text { Sítio eletrônico } \\
\text { TJ-SP }\end{array}$ \\
\hline $\begin{array}{l}527.920- \\
5 / 0-00\end{array}$ & $\begin{array}{l}\text { Apelação } \\
\text { Cível }\end{array}$ & 2007 & $\begin{array}{l}\text { Acesso à } \\
\text { educação } \\
\text { básica }\end{array}$ & Acesso EF & São Paulo & $\begin{array}{l}\text { Criança ou } \\
\text { adolescente }\end{array}$ & $\begin{array}{l}\text { Secretário de } \\
\text { Estado de } \\
\text { Educação / } \\
\text { Secretária } \\
\text { Municipal de } \\
\text { Educação }\end{array}$ & $\begin{array}{l}13^{a} \text { Câmara } \\
\text { de Direito } \\
\text { Público }\end{array}$ & Unânime & $\begin{array}{l}\text { Recurso não } \\
\text { provido }\end{array}$ & $\begin{array}{l}\text { Borelli } \\
\text { Thomaz }\end{array}$ & $\begin{array}{l}\text { Sítio eletrônico } \\
\text { TJ-SP }\end{array}$ \\
\hline $\begin{array}{l}537.551- \\
5 / 3-00\end{array}$ & $\begin{array}{l}\text { Apelação } \\
\text { Cível com } \\
\text { revisão }\end{array}$ & 2007 & $\begin{array}{l}\text { Responsabili } \\
\text { dade estatal }\end{array}$ & $\begin{array}{l}\text { Ação de } \\
\text { reparaçãao de } \\
\text { danos }\end{array}$ & $\begin{array}{l}\text { Palmares } \\
\text { Paulista }\end{array}$ & $\begin{array}{l}\text { Prefeitura } \\
\text { Municipal de } \\
\text { Palmares } \\
\text { Paulista / } \\
\text { J.D.S. }\end{array}$ & $\begin{array}{l}\text { J.D.S. / } \\
\text { Prefeitura } \\
\text { Municipal de } \\
\text { Palmares } \\
\text { Paulista }\end{array}$ & $\begin{array}{l}10^{\mathrm{a}} \text { Câmara } \\
\text { de Direito } \\
\text { Público }\end{array}$ & Unânime & $\begin{array}{l}\text { Julgaram } \\
\text { prejudicado o } \\
\text { apelo adesivo } \\
\text { dos autores e } \\
\text { deram } \\
\text { provimento } \\
\text { ao recurso do } \\
\text { Município e } \\
\text { do reexame } \\
\text { necessário }\end{array}$ & $\begin{array}{l}\text { Torres de } \\
\text { Carvalho }\end{array}$ & $\begin{array}{l}\text { Sítio eletrônico } \\
\text { TJ-SP }\end{array}$ \\
\hline $\begin{array}{l}\text { 544.873- } \\
5 / 9-00\end{array}$ & $\begin{array}{l}\text { Apelação } \\
\text { Cível com } \\
\text { revisão }\end{array}$ & 2007 & $\begin{array}{l}\text { Poder de } \\
\text { regulação } \\
\text { estatal }\end{array}$ & $\begin{array}{l}\text { Autorização/ } \\
\text { credenciame } \\
\text { nto }\end{array}$ & São Paulo & R. G. & $\begin{array}{l}\text { Presidente da } \\
\text { Comissão de } \\
\text { Verificação } \\
\text { Escolar do } \\
\text { Colégio São } \\
\text { José de Vila } \\
\text { Zelina }\end{array}$ & $\begin{array}{l}6^{\text {a }} \text { Câmara } \\
\text { de Direito } \\
\text { Público }\end{array}$ & Unânime & $\begin{array}{l}\text { Recurso não } \\
\text { provido }\end{array}$ & $\begin{array}{l}\text { Oliveira } \\
\text { Santos }\end{array}$ & $\begin{array}{l}\text { JTJ v.322, p. } \\
2.547\end{array}$ \\
\hline
\end{tabular}




\begin{tabular}{|c|c|c|c|c|c|c|c|c|c|c|c|c|}
\hline $\begin{array}{l}\text { Número } \\
\text { decisão }\end{array}$ & Natureza & Ano & Categorias & Tema & Origem & $\begin{array}{l}\text { Apelante } \\
\text { recorrente }\end{array}$ & $\begin{array}{l}\text { Apelados } \\
\text { recorridos }\end{array}$ & Câmara & Votação & Resultado & Relator & $\begin{array}{l}\text { Localização } \\
\text { da ementa / } \\
\text { acórdão }\end{array}$ \\
\hline $\begin{array}{l}562.498- \\
5 / 9-00\end{array}$ & $\begin{array}{l}\text { Apelação } \\
\text { Cível com } \\
\text { revisão }\end{array}$ & 2007 & Permanência & Outros & $\begin{array}{l}\text { São } \\
\text { Joaquim da } \\
\text { Barra }\end{array}$ & $\begin{array}{l}\text { Sistema COC } \\
\text { de Educação e } \\
\text { Comunicação } \\
\text { S/C Ltda / } \\
\text { A.S.P.B. }\end{array}$ & $\begin{array}{l}\text { Sistema COC } \\
\text { de Educação } \\
\mathrm{e} \\
\text { Comunicação } \\
\text { S/C Ltda / } \\
\text { A.S.P.B. }\end{array}$ & $\begin{array}{l}3^{\text {a }} \text { Câmara } \\
\text { de Direito } \\
\text { Público }\end{array}$ & Unânime & $\begin{array}{l}\text { Não } \\
\text { conheceram } \\
\text { do recurso do } \\
\text { autor e } \\
\text { negaram } \\
\text { provimento } \\
\text { ao recurso da } \\
\text { ré }\end{array}$ & $\begin{array}{l}\text { Magalhães } \\
\text { Coelho }\end{array}$ & $\begin{array}{l}\text { Sítio eletrônico } \\
\text { TJ-SP }\end{array}$ \\
\hline $\begin{array}{l}\text { 564.314- } \\
5 / 5-00\end{array}$ & $\begin{array}{l}\text { Apelação } \\
\text { Cível com } \\
\text { revisão }\end{array}$ & 2007 & $\begin{array}{l}\text { Acesso à } \\
\text { educação } \\
\text { básica }\end{array}$ & $\begin{array}{l}\text { Educação } \\
\text { Especial }\end{array}$ & São Paulo & $\begin{array}{l}\text { Juízo Ex } \\
\text { Offício }\end{array}$ & $\begin{array}{l}\text { V. M } \\
\text { representado } \\
\text { pela mãe }\end{array}$ & $\begin{array}{l}12^{\mathrm{a}} \text { Câmara } \\
\text { de Direito } \\
\text { Público }\end{array}$ & Unânime & $\begin{array}{l}\text { Recurso não } \\
\text { provido }\end{array}$ & $\begin{array}{l}\text { Magalhães } \\
\text { Coelho }\end{array}$ & $\begin{array}{l}\text { Sítio eletrônico } \\
\text { TJ-SP }\end{array}$ \\
\hline $\begin{array}{l}566.156- \\
5 / 8-00\end{array}$ & $\begin{array}{l}\text { Apelação } \\
\text { Cível com } \\
\text { revisão }\end{array}$ & 2007 & $\begin{array}{l}\text { Acesso à } \\
\text { educação } \\
\text { básica }\end{array}$ & $\begin{array}{l}\text { Acesso Ed } \\
\text { Profissional }\end{array}$ & Marília & Adolescente & $\begin{array}{l}\text { Assistente } \\
\text { Técnico de } \\
\text { direção do } \\
\text { Centro } \\
\text { Estadual de } \\
\text { Educação }\end{array}$ & $\begin{array}{l}10^{\mathrm{a}} \text { Câmara } \\
\text { de Direito } \\
\text { Público }\end{array}$ & Unânime & $\begin{array}{l}\text { Recurso não } \\
\text { provido }\end{array}$ & $\begin{array}{l}\text { Urbano } \\
\text { Ruiz }\end{array}$ & $\begin{array}{l}\text { JTJ v. } 319, \\
\text { p.126 }\end{array}$ \\
\hline $\begin{array}{l}593.734- \\
5 / 9-00\end{array}$ & $\begin{array}{l}\text { Apelação } \\
\text { Cível com } \\
\text { revisão }\end{array}$ & 2007 & $\begin{array}{l}\text { Responsabili } \\
\text { dade estatal }\end{array}$ & $\begin{array}{l}\text { Ação de } \\
\text { reparaçãa de } \\
\text { danos }\end{array}$ & $\begin{array}{l}\text { Campos do } \\
\text { Jordão }\end{array}$ & $\begin{array}{l}\text { Prefeitura } \\
\text { Municipal de } \\
\text { Campos do } \\
\text { Jordão }\end{array}$ & $\begin{array}{l}\text { Criança ou } \\
\text { adolescente }\end{array}$ & $\begin{array}{l}2^{\circ} \text { Câmara } \\
\text { de Direito } \\
\text { Público }\end{array}$ & Unânime & $\begin{array}{l}\text { Provimento } \\
\text { parcial ao } \\
\text { recurso }\end{array}$ & $\begin{array}{l}\text { Vera } \\
\text { Angrisani }\end{array}$ & $\begin{array}{l}\text { Sítio eletrônico } \\
\text { TJ-SP }\end{array}$ \\
\hline $\begin{array}{l}595.356 .5 / 8 \\
-00\end{array}$ & $\begin{array}{l}\text { Apelação } \\
\text { Cível com } \\
\text { revisão }\end{array}$ & 2007 & $\begin{array}{l}\text { Acesso à } \\
\text { educação } \\
\text { básica }\end{array}$ & Acesso EI & Paulínia & $\begin{array}{l}\text { Prefeitura } \\
\text { Municipal de } \\
\text { Paulínia }\end{array}$ & Criança & $\begin{array}{l}9^{\circ} \text { Câmara } \\
\text { de Direito } \\
\text { Público }\end{array}$ & Unânime & $\begin{array}{l}\text { Recurso } \\
\text { negado }\end{array}$ & $\begin{array}{l}\text { Rebouças } \\
\text { Carvalho }\end{array}$ & $\begin{array}{l}\text { Sítio eletrônico } \\
\text { TJ-SP }\end{array}$ \\
\hline $\begin{array}{l}\text { 609.618- } \\
5 / 9-00\end{array}$ & $\begin{array}{l}\text { Apelação } \\
\text { Cível com } \\
\text { revisão }\end{array}$ & 2007 & $\begin{array}{l}\text { Acesso à } \\
\text { educação } \\
\text { básica }\end{array}$ & $\begin{array}{l}\text { Acesso Ed } \\
\text { Profissional }\end{array}$ & São Paulo & $\begin{array}{l}\text { Centro } \\
\text { Estadual de } \\
\text { Educação } \\
\text { Tecnológica } \\
\text { Paula Souza, } \\
\text { Escola Técnica } \\
\text { Estadual Prof. } \\
\text { Horácio da } \\
\text { Silveira }\end{array}$ & Adolescente & $\begin{array}{l}5^{\text {a }} \text { Câmara } \\
\text { de Direito } \\
\text { Público }\end{array}$ & Unânime & $\begin{array}{l}\text { Recurso } \\
\text { negado }\end{array}$ & $\begin{array}{l}\text { Osvaldo } \\
\text { Magalhães }\end{array}$ & $\begin{array}{l}\text { Sítio eletrônico } \\
\text { TJ-SP; JTJ v. } \\
321 \text {, p. } 1428\end{array}$ \\
\hline $\begin{array}{l}\text { 625.397- } \\
5 / 6-00\end{array}$ & $\begin{array}{l}\text { Apelação } \\
\text { Cível com } \\
\text { revisão }\end{array}$ & 2007 & $\begin{array}{l}\text { Acesso à } \\
\text { educação } \\
\text { básica }\end{array}$ & $\begin{array}{l}\text { Acesso Ed } \\
\text { Profissional }\end{array}$ & Marília & CEETEPS & Adolescente & $\begin{array}{l}6^{\text {a }} \text { Câmara } \\
\text { de Direito } \\
\text { Público }\end{array}$ & Unânime & $\begin{array}{l}\text { Recurso não } \\
\text { provido }\end{array}$ & $\begin{array}{l}\text { Roberto } \\
\text { Vallim } \\
\text { Bellocchi }\end{array}$ & $\begin{array}{l}\text { Sítio eletrônico } \\
\text { TJ-SP }\end{array}$ \\
\hline
\end{tabular}




\begin{tabular}{|c|c|c|c|c|c|c|c|c|c|c|c|c|}
\hline $\begin{array}{l}\text { Número } \\
\text { decisão }\end{array}$ & Natureza & Ano & Categorias & Tema & Origem & $\begin{array}{l}\text { Apelante } \\
\text { recorrente }\end{array}$ & \begin{tabular}{|l|} 
Apelados \\
recorridos
\end{tabular} & Câmara & Votação & Resultado & Relator & $\begin{array}{l}\text { Localização } \\
\text { da ementa / } \\
\text { acórdão }\end{array}$ \\
\hline $\begin{array}{l}\text { 642.103- } \\
5 / 0-00\end{array}$ & $\begin{array}{l}\text { Apelação } \\
\text { Cível com } \\
\text { revisão }\end{array}$ & 2007 & $\begin{array}{l}\text { Decisões } \\
\text { administrativ } \\
\text { as e políticas }\end{array}$ & $\begin{array}{l}\text { Municipaliza } \\
\text { ção }\end{array}$ & $\begin{array}{l}\text { Votuporang } \\
\text { a }\end{array}$ & APEOESP & $\begin{array}{l}\text { Prefeitura } \\
\text { Municipal de } \\
\text { Votuporanga } \\
\text { / Fazenda do } \\
\text { Estado de SP }\end{array}$ & \begin{tabular}{|l}
$1^{\mathrm{a}}$ Câmara \\
de Direito \\
Público
\end{tabular} & Unânime & $\begin{array}{l}\text { Recurso não } \\
\text { provido }\end{array}$ & \begin{tabular}{|l|} 
Danilo \\
Panizza
\end{tabular} & $\begin{array}{l}\text { Sítio eletrônico } \\
\text { TJ-SP }\end{array}$ \\
\hline $\begin{array}{l}\text { 642.317- } \\
5 / 7-00\end{array}$ & \begin{tabular}{|l|} 
Apelação \\
Cível com \\
revisão
\end{tabular} & 2007 & $\begin{array}{l}\text { Acesso à } \\
\text { educação } \\
\text { básica }\end{array}$ & Acesso EI & Paulínia & $\begin{array}{l}\text { Recurso } E x \\
\text { Offício }\end{array}$ & \begin{tabular}{|l|} 
Criança e \\
Ministério \\
Público \\
\end{tabular} & $\begin{array}{l}5^{\circ} \text { Câmara } \\
\text { de Direito } \\
\text { Público }\end{array}$ & Unânime & $\begin{array}{l}\text { Recurso } \\
\text { negado }\end{array}$ & \begin{tabular}{|l|} 
Franco \\
Cocuzza
\end{tabular} & $\begin{array}{l}\text { Sítio eletrônico } \\
\text { TJ-SP }\end{array}$ \\
\hline $\begin{array}{l}642.628- \\
5 / 6-00\end{array}$ & \begin{tabular}{|l|} 
Apelação \\
Cível com \\
revisão
\end{tabular} & 2007 & $\begin{array}{l}\text { Acesso à } \\
\text { educação } \\
\text { básica }\end{array}$ & Acesso EI & Paulínia & \begin{tabular}{|l|} 
Prefeitura do \\
Município de \\
Paulínia
\end{tabular} & Criança & $\begin{array}{l}6^{\circ} \text { Câmara } \\
\text { de Direito } \\
\text { Público }\end{array}$ & Unânime & $\begin{array}{l}\text { Recurso } \\
\text { negado }\end{array}$ & $\begin{array}{l}\text { Evaristo dos } \\
\text { Santos }\end{array}$ & $\begin{array}{l}\text { Sítio eletrônico } \\
\text { TJ-SP }\end{array}$ \\
\hline $\begin{array}{l}643.636 .5- \\
0-00\end{array}$ & $\begin{array}{l}\text { Agravo de } \\
\text { instrumento }\end{array}$ & 2007 & $\begin{array}{l}\text { Gestão dos } \\
\text { recursos } \\
\text { públicos }\end{array}$ & Contratos & Lorena & \begin{tabular}{|l} 
Prefeitura \\
Municipal de \\
Lorena
\end{tabular} & $\begin{array}{l}\text { Ministério } \\
\text { Público }\end{array}$ & $\begin{array}{l}11^{\text {a }} \text { Câmara } \\
\text { de Direito } \\
\text { Público }\end{array}$ & Unânime & $\begin{array}{l}\text { Recurso } \\
\text { provido }\end{array}$ & $\begin{array}{l}\text { Oscild de } \\
\text { Lima Júnior }\end{array}$ & $\begin{array}{l}\text { Sítio eletrônico } \\
\text { TJ-SP }\end{array}$ \\
\hline $\begin{array}{l}\text { 644.051- } \\
5 / 7-00\end{array}$ & $\begin{array}{l}\text { Apelação } \\
\text { Cível com } \\
\text { revisão }\end{array}$ & 2007 & $\begin{array}{l}\text { Acesso à } \\
\text { educação } \\
\text { básica }\end{array}$ & \begin{tabular}{|l|} 
Educação \\
Especial
\end{tabular} & Araraquara & \begin{tabular}{|l|} 
Prefeitura do \\
Município de \\
Araraquara
\end{tabular} & \begin{tabular}{|l} 
Criança \\
representada \\
pela mãe
\end{tabular} & $\begin{array}{l}3^{\text {a } C a ̂ m a r a ~} \\
\text { de Direito } \\
\text { Público }\end{array}$ & Unânime & $\begin{array}{l}\text { Recurso não } \\
\text { provido }\end{array}$ & \begin{tabular}{|l|} 
Magalhães \\
Coelho
\end{tabular} & $\begin{array}{l}\text { Sítio eletrônico } \\
\text { TJ-SP }\end{array}$ \\
\hline $\begin{array}{l}642.317- \\
5 / 7-00\end{array}$ & \begin{tabular}{|l|} 
Apelação \\
Cível com \\
revisão \\
\end{tabular} & 2007 & $\begin{array}{l}\text { Acesso à } \\
\text { educação } \\
\text { básica }\end{array}$ & Acesso EI & Paulínia & \begin{tabular}{|l|} 
Prefeitura \\
Municipal de \\
Paulínia \\
\end{tabular} & Duas crianças & $\begin{array}{l}5^{\circ} \text { Câmara } \\
\text { de Direito } \\
\text { Público } \\
\end{array}$ & Unânime & $\begin{array}{l}\text { Recurso } \\
\text { negado }\end{array}$ & \begin{tabular}{|l|} 
Franco \\
Cocuzza
\end{tabular} & $\begin{array}{l}\text { Sítio eletrônico } \\
\text { TJ-SP }\end{array}$ \\
\hline $\begin{array}{l}647.768- \\
5 / 0-00\end{array}$ & $\begin{array}{l}\text { Agravo de } \\
\text { instrumento }\end{array}$ & 2007 & $\begin{array}{l}\text { Gestão dos } \\
\text { recursos } \\
\text { públicos }\end{array}$ & Contratos & Lorena & \begin{tabular}{|l|} 
Gráfica e \\
editora \\
Posigraf S/A
\end{tabular} & \begin{tabular}{|l|} 
Ministério \\
Público
\end{tabular} & $\begin{array}{l}11^{\mathrm{a}} \text { Câmara } \\
\text { de Direito } \\
\text { Público }\end{array}$ & Unânime & $\begin{array}{l}\text { Recurso } \\
\text { provido }\end{array}$ & $\begin{array}{l}\text { Oscild de } \\
\text { Lima Júnior }\end{array}$ & $\begin{array}{l}\text { Sítio eletrônico } \\
\text { TJ-SP }\end{array}$ \\
\hline $\begin{array}{l}668.490- \\
5 / 5-00\end{array}$ & $\begin{array}{l}\text { Agravo de } \\
\text { instrumento }\end{array}$ & 2007 & $\begin{array}{l}\text { Acesso à } \\
\text { educação } \\
\text { básica }\end{array}$ & \begin{tabular}{|l|} 
Educação \\
Especial
\end{tabular} & Itanhaém & H.S. menor & \begin{tabular}{|l|} 
Fazenda do \\
Estado de SP
\end{tabular} & $\begin{array}{l}7^{\text {a }} \text { Câmara } \\
\text { de Direito } \\
\text { Público }\end{array}$ & Unânime & $\begin{array}{l}\text { Recurso } \\
\text { provido }\end{array}$ & \begin{tabular}{|l} 
Coimbra \\
Schmidt
\end{tabular} & $\begin{array}{l}\text { Sítio eletrônico } \\
\text { TJ-SP }\end{array}$ \\
\hline $\begin{array}{l}\text { 672.111- } \\
5 / 1-00\end{array}$ & $\begin{array}{l}\text { Agravo de } \\
\text { Instrumento }\end{array}$ & 2007 & $\begin{array}{l}\text { Acesso à } \\
\text { educação } \\
\text { básica }\end{array}$ & Acesso EI & \begin{tabular}{|l|} 
São José do \\
Rio Preto
\end{tabular} & $\begin{array}{l}\text { Prefeito } \\
\text { Municipal de } \\
\text { São José do } \\
\text { Rio Preto }\end{array}$ & Criança & $\begin{array}{l}11^{\circ} \text { Câmara } \\
\text { de Direito } \\
\text { Público }\end{array}$ & Unânime & $\begin{array}{l}\text { Negaram } \\
\text { provimento } \\
\text { ao recurso }\end{array}$ & $\begin{array}{l}\text { Pires de } \\
\text { Araújo }\end{array}$ & $\begin{array}{l}\text { Sítio eletrônico } \\
\text { TJ-SP }\end{array}$ \\
\hline $\begin{array}{l}695.653- \\
5 / 2-00\end{array}$ & $\begin{array}{l}\text { Agravo de } \\
\text { Instrumento }\end{array}$ & 2007 & $\begin{array}{l}\text { Acesso à } \\
\text { educação } \\
\text { básica }\end{array}$ & Acesso EI & $\begin{array}{l}\text { São José do } \\
\text { Rio Preto }\end{array}$ & $\begin{array}{l}\text { Prefeito } \\
\text { Municipal de } \\
\text { São José do } \\
\text { Rio Preto }\end{array}$ & Criança & $\begin{array}{l}6^{\circ} \text { Câmara } \\
\text { de Direito } \\
\text { Público }\end{array}$ & Unânime & $\begin{array}{l}\text { Negaram } \\
\text { provimento } \\
\text { ao agravo }\end{array}$ & $\begin{array}{l}\text { Evaristo dos } \\
\text { Santos }\end{array}$ & $\begin{array}{l}\text { Sítio eletrônico } \\
\text { TJ-SP }\end{array}$ \\
\hline $\begin{array}{l}\text { 701.492- } \\
5 / 3-00\end{array}$ & $\begin{array}{l}\text { Agravo de } \\
\text { instrumento }\end{array}$ & 2007 & $\begin{array}{l}\text { Acesso à } \\
\text { educação } \\
\text { básica }\end{array}$ & \begin{tabular}{|l} 
Educação \\
Especial
\end{tabular} & São Paulo & \begin{tabular}{|l|} 
Fazenda do \\
Estado de SP
\end{tabular} & $\begin{array}{l}\text { Criança } \\
\text { representada } \\
\text { pela mãe }\end{array}$ & $\begin{array}{l}5^{\text {a }} \text { Câmara } \\
\text { de Direito } \\
\text { Público }\end{array}$ & Unânime & $\begin{array}{l}\text { Recurso não } \\
\text { provido }\end{array}$ & $\begin{array}{l}\text { Xavier de } \\
\text { Aquino }\end{array}$ & $\begin{array}{l}\text { Sítio eletrônico } \\
\text { TJ-SP }\end{array}$ \\
\hline
\end{tabular}




\begin{tabular}{|c|c|c|c|c|c|c|c|c|c|c|c|c|}
\hline $\begin{array}{l}\text { Número } \\
\text { decisão }\end{array}$ & Natureza & Ano & Categorias & Tema & Origem & $\begin{array}{l}\text { Apelante } \\
\text { recorrente }\end{array}$ & $\begin{array}{l}\text { Apelados } \\
\text { recorridos }\end{array}$ & Câmara & Votação & Resultado & Relator & $\begin{array}{l}\text { Localização } \\
\text { da ementa / } \\
\text { acórdão }\end{array}$ \\
\hline $\begin{array}{l}716.274- \\
5 / 3-00\end{array}$ & $\begin{array}{l}\text { Agravo de } \\
\text { instrumento }\end{array}$ & 2007 & $\begin{array}{l}\text { Acesso à } \\
\text { educação } \\
\text { básica }\end{array}$ & Acesso EI & $\begin{array}{l}\text { Santa } \\
\text { Bárbara } \\
\text { D'Oeste }\end{array}$ & $\begin{array}{l}\text { Prefeito } \\
\text { Municipal de } \\
\text { Santa Bárbara } \\
\text { D'Oeste }\end{array}$ & $\begin{array}{l}\text { J Criança } \\
\text { representada } \\
\text { pela mãe }\end{array}$ & $\begin{array}{l}8^{\mathrm{a}} \text { Câmara } \\
\text { de Direito } \\
\text { Público }\end{array}$ & Unânime & $\begin{array}{l}\text { Recurso não } \\
\text { provido }\end{array}$ & Rubens Rihl & $\begin{array}{l}\text { Sítio eletrônico } \\
\text { TJ-SP }\end{array}$ \\
\hline $\begin{array}{l}\text { 931.358- } \\
0 / 0\end{array}$ & $\begin{array}{l}\text { Apelação } \\
\text { com revisão }\end{array}$ & 2007 & $\begin{array}{l}\text { Poder de } \\
\text { regulação } \\
\text { estatal }\end{array}$ & $\begin{array}{l}\text { Mensalidade } \\
\text { escolar }\end{array}$ & São Paulo & $\begin{array}{l}\text { Organização } \\
\text { Educacional } \\
\text { Morumbi Sul } \\
\text { Ltda. }\end{array}$ & M.G.M.S.C & $\begin{array}{l}35^{\text {a }} \text { Câmara } \\
\text { de Direito } \\
\text { Privado }\end{array}$ & Unânime & $\begin{array}{l}\text { Improcedente } \\
\text { a ação, } \\
\text { extinguindo- } \\
\text { se o } \\
\text { processo, } \\
\text { com } \\
\text { resolução do } \\
\text { mérito. }\end{array}$ & \begin{tabular}{|l|} 
Clóvis \\
Castelo
\end{tabular} & $\begin{array}{l}\text { JTJ v.319, } \\
\text { p.122 }\end{array}$ \\
\hline 994.146-0/0 & $\begin{array}{l}\text { Apelação } \\
\text { com revisão }\end{array}$ & 2007 & $\begin{array}{l}\text { Poder de } \\
\text { regulação } \\
\text { estatal }\end{array}$ & $\begin{array}{l}\text { Mensalidade } \\
\text { escolar }\end{array}$ & São Paulo & H.C.F. & $\begin{array}{l}\text { Fundação } \\
\text { Rotarianos de } \\
\text { São Paulo }\end{array}$ & $\begin{array}{l}30^{\text {a }} \text { Câmara } \\
\text { de Direito } \\
\text { Privado }\end{array}$ & Unânime & $\begin{array}{l}\text { Recurso } \\
\text { negado }\end{array}$ & $\begin{array}{l}\text { Orlando } \\
\text { Pistoresi }\end{array}$ & $\begin{array}{l}\text { Sítio eletrônico } \\
\text { TJ-SP }\end{array}$ \\
\hline $940.028-0 / 1$ & $\begin{array}{l}\text { Apelação } \\
\text { Cível com } \\
\text { revisão }\end{array}$ & 2007 & $\begin{array}{l}\text { Poder de } \\
\text { regulação } \\
\text { estatal }\end{array}$ & $\begin{array}{l}\text { Mensalidade } \\
\text { escolar }\end{array}$ & São Paulo & M.G.P. & $\begin{array}{l}\text { Escola João } \\
\text { XXIII }\end{array}$ & $\begin{array}{l}35^{\text {a }} \text { Câmara } \\
\text { de Direito } \\
\text { Privado }\end{array}$ & Unânime & $\begin{array}{l}\text { Recurso não } \\
\text { provido }\end{array}$ & $\begin{array}{l}\text { Clóvis } \\
\text { Castelo }\end{array}$ & $\begin{array}{l}\text { Sítio eletrônico } \\
\text { TJ-SP }\end{array}$ \\
\hline $940.429-0 / 7$ & $\begin{array}{l}\text { Apelação } \\
\text { com revisão }\end{array}$ & 2007 & $\begin{array}{l}\text { Poder de } \\
\text { regulação } \\
\text { estatal }\end{array}$ & $\begin{array}{l}\text { Autorização/ } \\
\text { credenciame } \\
\text { nto }\end{array}$ & São Paulo & D.B.C. & $\begin{array}{l}\text { União Social } \\
\text { Camiliana }\end{array}$ & $\begin{array}{l}33^{\circ} \text { Câmara } \\
\text { de Direito } \\
\text { Privado }\end{array}$ & $\begin{array}{l}\text { Maioria dos } \\
\text { votos }\end{array}$ & $\begin{array}{l}\text { Recurso } \\
\text { negado. } \\
\text { Consta voto } \\
\text { vencido do } \\
\text { revisor. }\end{array}$ & $\begin{array}{l}\text { Cristiano } \\
\text { Ferreira } \\
\text { Leite }\end{array}$ & $\begin{array}{l}\text { Sítio eletrônico } \\
\text { TJ-SP }\end{array}$ \\
\hline $940.868-0 / 3$ & $\begin{array}{l}\text { Apelação } \\
\text { com revisão }\end{array}$ & 2007 & $\begin{array}{l}\text { Poder de } \\
\text { regulação } \\
\text { estatal }\end{array}$ & $\begin{array}{l}\text { Autorização/ } \\
\text { credenciame } \\
\text { nto }\end{array}$ & São Paulo & $\begin{array}{l}\text { CESI - Centro } \\
\text { Educacional } \\
\text { Santa Inês S/C } \\
\text { Ltda }\end{array}$ & P.D.O. & $\begin{array}{l}33^{\circ} \text { Câmara } \\
\text { de Direito } \\
\text { Privado }\end{array}$ & Unânime & $\begin{array}{l}\text { Recurso } \\
\text { negado }\end{array}$ & Eros Piceli & $\begin{array}{l}\text { Sítio eletrônico } \\
\text { TJ-SP }\end{array}$ \\
\hline $7.139 .622-0$ & $\begin{array}{l}\text { Apelação } \\
\text { com revisão }\end{array}$ & 2007 & $\begin{array}{l}\text { Poder de } \\
\text { regulação } \\
\text { estatal }\end{array}$ & $\begin{array}{l}\text { Mensalidade } \\
\text { escolar }\end{array}$ & $\begin{array}{l}\text { Praia } \\
\text { Grande }\end{array}$ & L.F. & $\begin{array}{l}\text { Centro } \\
\text { Educacional } \\
\text { de Praia } \\
\text { Grande e } \\
\text { com. de } \\
\text { artigos } \\
\text { educacionais } \\
\end{array}$ & $\begin{array}{l}16^{\mathrm{a}} \text { Câmara } \\
\text { de Direito } \\
\text { Privado }\end{array}$ & Unânime & $\begin{array}{l}\text { Recurso não } \\
\text { provido }\end{array}$ & $\begin{array}{l}\text { Maury } \\
\text { Angelo } \\
\text { Bottesini }\end{array}$ & $\begin{array}{l}\text { Sítio eletrônico } \\
\text { TJ-SP }\end{array}$ \\
\hline \multicolumn{13}{|l|}{2008} \\
\hline $\begin{array}{l}147.461- \\
0 / 6-00\end{array}$ & ADIN & 2008 & $\begin{array}{l}\text { Decisões } \\
\text { administrativ } \\
\text { as e políticas }\end{array}$ & \begin{tabular}{|l|} 
Competência \\
para legislar
\end{tabular} & Taubaté & $\begin{array}{l}\text { Prefeito } \\
\text { Municipal de } \\
\text { Taubaté }\end{array}$ & $\begin{array}{l}\text { Presidente da } \\
\text { Câmara } \\
\text { Municipal de } \\
\text { Taubaté }\end{array}$ & $\begin{array}{l}\text { Órgão } \\
\text { Especial }\end{array}$ & Unânime & $\begin{array}{l}\text { Ação } \\
\text { procedente }\end{array}$ & $\begin{array}{l}\text { Roberto } \\
\text { Vallim } \\
\text { Bellochi }\end{array}$ & $\begin{array}{l}\text { JTJ v.325, p. } \\
1157\end{array}$ \\
\hline
\end{tabular}




\begin{tabular}{|c|c|c|c|c|c|c|c|c|c|c|c|c|}
\hline $\begin{array}{l}\text { Número } \\
\text { decisão }\end{array}$ & Natureza & Ano & Categorias & Tema & Origem & $\begin{array}{l}\text { Apelante } \\
\text { recorrente }\end{array}$ & $\begin{array}{l}\text { Apelados } \\
\text { recorridos }\end{array}$ & Câmara & Votação & Resultado & Relator & $\begin{array}{l}\text { Localização } \\
\text { da ementa / } \\
\text { acórdão }\end{array}$ \\
\hline $\begin{array}{l}148.843- \\
0 / 7-00\end{array}$ & ADIN & 2008 & $\begin{array}{l}\text { Decisões } \\
\text { administrativ } \\
\text { as e políticas }\end{array}$ & \begin{tabular}{|l} 
Competência \\
para legislar
\end{tabular} & Amparo & \begin{tabular}{|l} 
Prefeito \\
Municipal de \\
Amparo
\end{tabular} & $\begin{array}{l}\text { Presidente da } \\
\text { Câmara } \\
\text { Municipal de } \\
\text { Amparo }\end{array}$ & \begin{tabular}{|l|} 
Órgão \\
Especial
\end{tabular} & Unânime & $\begin{array}{l}\text { Ação } \\
\text { procedente }\end{array}$ & \begin{tabular}{|l|} 
Roberto \\
Vallim \\
Bellochi
\end{tabular} & $\begin{array}{l}\text { Sítio biblioteca } \\
\text { TJ-SP; Sítio } \\
\text { TJ-SP }\end{array}$ \\
\hline $149.108-0 / 0$ & $\begin{array}{l}\text { Agravo de } \\
\text { instrumento }\end{array}$ & 2008 & $\begin{array}{l}\text { Acesso à } \\
\text { educação } \\
\text { básica }\end{array}$ & Acesso EI & $\begin{array}{l}\text { Santo } \\
\text { André }\end{array}$ & $\begin{array}{l}\text { Informação } \\
\text { ausente }\end{array}$ & $\begin{array}{l}\text { Informação } \\
\text { ausente }\end{array}$ & $\begin{array}{l}\text { Câmara } \\
\text { Especial }\end{array}$ & Unânime & $\begin{array}{l}\text { Recurso não } \\
\text { provido }\end{array}$ & $\begin{array}{l}\text { Eduardo } \\
\text { Gouvêa }\end{array}$ & $\begin{array}{l}\text { Sítio biblioteca } \\
\text { TJ-SP }\end{array}$ \\
\hline $\begin{array}{l}149.182- \\
0 / 7-00\end{array}$ & $\begin{array}{l}\text { Agravo de } \\
\text { Instrumento }\end{array}$ & 2008 & $\begin{array}{l}\text { Acesso à } \\
\text { educação } \\
\text { básica }\end{array}$ & Acesso EI & São Paulo & $\begin{array}{l}\text { Informação } \\
\text { ausente }\end{array}$ & $\begin{array}{l}\text { Informação } \\
\text { ausente }\end{array}$ & $\begin{array}{l}\text { Câmara } \\
\text { Especial }\end{array}$ & Unânime & $\begin{array}{l}\text { Recurso } \\
\text { municipal } \\
\text { não provido } \\
\end{array}$ & \begin{tabular}{|l|} 
Roberto \\
Vallim \\
Bellochi \\
\end{tabular} & $\begin{array}{l}\text { Sítio biblioteca } \\
\text { TJ-SP }\end{array}$ \\
\hline $\begin{array}{l}149.699- \\
0 / 6-00\end{array}$ & $\begin{array}{l}\text { Recurso Ex } \\
\text { Officio }\end{array}$ & 2008 & $\begin{array}{l}\text { Acesso à } \\
\text { educação } \\
\text { básica }\end{array}$ & Acesso EI & $\begin{array}{l}\text { Santo } \\
\text { André }\end{array}$ & \begin{tabular}{|l|} 
Juízo Ex \\
Officio
\end{tabular} & $\begin{array}{l}\text { Criança } \\
\text { representada } \\
\text { pela mãe }\end{array}$ & $\begin{array}{l}\text { Câmara } \\
\text { Especial }\end{array}$ & Unânime & $\begin{array}{l}\text { Recurso não } \\
\text { provido }\end{array}$ & \begin{tabular}{|l|} 
Luiz \\
Tâmbara
\end{tabular} & $\begin{array}{l}\text { Sítio eletrônico } \\
\text { TJ-SP }\end{array}$ \\
\hline $154.090-0 / 9$ & $\begin{array}{l}\text { Apelação } \\
\text { Cível }\end{array}$ & 2008 & $\begin{array}{l}\text { Acesso à } \\
\text { educação } \\
\text { básica }\end{array}$ & Acesso EI & Jundiaí & $\begin{array}{l}\text { Informação } \\
\text { ausente }\end{array}$ & $\begin{array}{l}\text { Informação } \\
\text { ausente }\end{array}$ & \begin{tabular}{|l|} 
Câmara \\
Especial
\end{tabular} & Unânime & \begin{tabular}{|l|} 
Recurso \\
oficial e \\
voluntário \\
parcialmente \\
provido \\
\end{tabular} & \begin{tabular}{|l} 
Eduardo \\
Pereira
\end{tabular} & $\begin{array}{l}\text { Sítio biblioteca } \\
\text { TJ-SP }\end{array}$ \\
\hline $154.126-0 / 4$ & \begin{tabular}{|l} 
Apelação \\
Cível
\end{tabular} & 2008 & $\begin{array}{l}\text { Acesso à } \\
\text { educação } \\
\text { básica }\end{array}$ & Acesso EI & Jundiaí & $\begin{array}{l}\text { Informação } \\
\text { ausente }\end{array}$ & $\begin{array}{l}\text { Informação } \\
\text { ausente }\end{array}$ & \begin{tabular}{|l|} 
Câmara \\
Especial
\end{tabular} & Unânime & $\begin{array}{l}\text { Preliminar } \\
\text { rejeitada }\end{array}$ & \begin{tabular}{|l|} 
Maria \\
Olívia \\
Alves \\
\end{tabular} & $\begin{array}{l}\text { Sítio biblioteca } \\
\text { TJ-SP }\end{array}$ \\
\hline $154.192-0 / 4$ & $\begin{array}{l}\text { Apelação } \\
\text { Cível }\end{array}$ & 2008 & $\begin{array}{l}\text { Acesso à } \\
\text { educação } \\
\text { básica }\end{array}$ & Acesso EI & Paulínia & $\begin{array}{l}\text { Informação } \\
\text { ausente }\end{array}$ & $\begin{array}{l}\text { Informação } \\
\text { ausente }\end{array}$ & $\begin{array}{l}\text { Câmara } \\
\text { Especial }\end{array}$ & Unânime & \begin{tabular}{|l} 
Recurso \\
oficial e \\
voluntário \\
improvidos \\
\end{tabular} & \begin{tabular}{|l} 
Luiz \\
Tâmbara
\end{tabular} & $\begin{array}{l}\text { Sítio biblioteca } \\
\text { TJ-SP }\end{array}$ \\
\hline $154.521-0 / 7$ & $\begin{array}{l}\text { Apelação } \\
\text { Cível }\end{array}$ & 2008 & $\begin{array}{l}\text { Acesso à } \\
\text { educação } \\
\text { básica }\end{array}$ & Acesso EI & $\begin{array}{l}\text { São José do } \\
\text { Rio Preto }\end{array}$ & $\begin{array}{l}\text { Informação } \\
\text { ausente }\end{array}$ & $\begin{array}{l}\text { Informação } \\
\text { ausente }\end{array}$ & $\begin{array}{l}\text { Câmara } \\
\text { Especial }\end{array}$ & Unânime & \begin{tabular}{|l} 
Recurso \\
parcialmente \\
provido para \\
limitar os \\
efeitos da \\
concessão da \\
segurança \\
apenas ao \\
impetrante \\
\end{tabular} & \begin{tabular}{|l|} 
Eduardo \\
Pereira
\end{tabular} & $\begin{array}{l}\text { Sítio biblioteca } \\
\text { TJ-SP }\end{array}$ \\
\hline $154.796-0 / 0$ & $\begin{array}{l}\text { Apelação } \\
\text { Cível }\end{array}$ & 2008 & $\begin{array}{l}\text { Acesso à } \\
\text { educação } \\
\text { básica }\end{array}$ & Acesso EI & Jundiaí & $\begin{array}{l}\text { Informação } \\
\text { ausente }\end{array}$ & $\begin{array}{l}\text { Informação } \\
\text { ausente }\end{array}$ & $\begin{array}{l}\text { Câmara } \\
\text { Especial }\end{array}$ & Unânime & $\begin{array}{l}\text { Recurso não } \\
\text { provido }\end{array}$ & $\begin{array}{l}\text { Maria } \\
\text { Olivia } \\
\text { Alves } \\
\end{array}$ & $\begin{array}{l}\text { Sítio biblioteca } \\
\text { TJ-SP }\end{array}$ \\
\hline
\end{tabular}




\begin{tabular}{|c|c|c|c|c|c|c|c|c|c|c|c|c|}
\hline $\begin{array}{l}\text { Número } \\
\text { decisão }\end{array}$ & Natureza & Ano & Categorias & Tema & Origem & $\begin{array}{l}\text { Apelante } \\
\text { recorrente }\end{array}$ & $\begin{array}{l}\text { Apelados } \\
\text { recorridos }\end{array}$ & Câmara & Votação & Resultado & Relator & $\begin{array}{l}\text { Localização } \\
\text { da ementa / } \\
\text { acórdão }\end{array}$ \\
\hline $\begin{array}{l}155.042- \\
0 / 8-00\end{array}$ & $\begin{array}{l}\text { Apelação } \\
\text { Cível }\end{array}$ & 2008 & $\begin{array}{l}\text { Acesso à } \\
\text { educação } \\
\text { básica }\end{array}$ & Acesso EI & Jundiaí & $\begin{array}{l}\text { Município de } \\
\text { Jundiaí }\end{array}$ & $\begin{array}{l}\text { Criança } \\
\text { representada } \\
\text { pela mãe }\end{array}$ & $\begin{array}{l}\text { Câmara } \\
\text { Especial }\end{array}$ & Unânime & $\begin{array}{l}\text { Recurso não } \\
\text { provido }\end{array}$ & $\begin{array}{l}\text { Maria } \\
\text { Olivia } \\
\text { Alves }\end{array}$ & $\begin{array}{l}\text { Sítio eletrônico } \\
\text { TJ-SP }\end{array}$ \\
\hline $155.786-0 / 5$ & $\begin{array}{l}\text { Apelação } \\
\text { Cível }\end{array}$ & 2008 & $\begin{array}{l}\text { Acesso à } \\
\text { educação } \\
\text { básica }\end{array}$ & Acesso EI & Campinas & $\begin{array}{l}\text { Informação } \\
\text { ausente }\end{array}$ & $\begin{array}{l}\text { Informação } \\
\text { ausente }\end{array}$ & $\begin{array}{l}\text { Câmara } \\
\text { Especial }\end{array}$ & Unânime & $\begin{array}{l}\text { Recurso não } \\
\text { provido }\end{array}$ & $\begin{array}{l}\text { Eduardo } \\
\text { Gouveia }\end{array}$ & $\begin{array}{l}\text { Sítio biblioteca } \\
\text { TJ-SP }\end{array}$ \\
\hline $\begin{array}{l}156.066- \\
0 / 4-00\end{array}$ & $\begin{array}{l}\text { Recurso Ex } \\
\text { Officio }\end{array}$ & 2008 & $\begin{array}{l}\text { Acesso à } \\
\text { educação } \\
\text { básica }\end{array}$ & Acesso EI & Jundiaí & $\begin{array}{l}\text { Juízo Ex } \\
\text { Officio }\end{array}$ & $\begin{array}{l}\text { Criança } \\
\text { representada } \\
\text { pela mãe }\end{array}$ & $\begin{array}{l}\text { Câmara } \\
\text { Especial }\end{array}$ & Unânime & $\begin{array}{l}\text { Recurso não } \\
\text { provido }\end{array}$ & $\begin{array}{l}\text { Viana } \\
\text { Santos }\end{array}$ & $\begin{array}{l}\text { Sítio eletrônico } \\
\text { TJ-SP }\end{array}$ \\
\hline $\begin{array}{l}157.607- \\
0 / 1-00\end{array}$ & $\begin{array}{l}\text { Apelação } \\
\text { Cível }\end{array}$ & 2008 & $\begin{array}{l}\text { Acesso à } \\
\text { educação } \\
\text { básica }\end{array}$ & Acesso EI & Paulínia & $\begin{array}{l}\text { Município de } \\
\text { Paulínia }\end{array}$ & $\begin{array}{l}\text { Criança } \\
\text { representada } \\
\text { pela mãe }\end{array}$ & $\begin{array}{l}\text { Câmara } \\
\text { Especial }\end{array}$ & Unânime & $\begin{array}{l}\text { Recurso não } \\
\text { provido }\end{array}$ & $\begin{array}{l}\text { Eduardo } \\
\text { Pereira }\end{array}$ & $\begin{array}{l}\text { Sítio eletrônico } \\
\text { TJ-SP }\end{array}$ \\
\hline $\begin{array}{l}157.637- \\
0 / 8-00\end{array}$ & $\begin{array}{l}\text { Apelação } \\
\text { Cível }\end{array}$ & 2008 & $\begin{array}{l}\text { Acesso à } \\
\text { educação } \\
\text { básica }\end{array}$ & Acesso EI & Paulínia & $\begin{array}{l}\text { Município de } \\
\text { Paulínia }\end{array}$ & $\begin{array}{l}\text { Criança } \\
\text { representada } \\
\text { pela mãe }\end{array}$ & $\begin{array}{l}\text { Câmara } \\
\text { Especial }\end{array}$ & Unânime & $\begin{array}{l}\text { Recurso não } \\
\text { provido }\end{array}$ & $\begin{array}{l}\text { Eduardo } \\
\text { Pereira }\end{array}$ & $\begin{array}{l}\text { Sítio eletrônico } \\
\text { TJ-SP }\end{array}$ \\
\hline $\begin{array}{l}158.214- \\
0 / 7-01\end{array}$ & $\begin{array}{l}\text { Agravo } \\
\text { Regimental }\end{array}$ & 2008 & $\begin{array}{l}\text { Decisões } \\
\text { administrativ } \\
\text { as e políticas }\end{array}$ & $\begin{array}{l}\text { Fechamento } \\
\text { de creche em } \\
\text { férias }\end{array}$ & São Paulo & $\begin{array}{l}\text { Defensoria } \\
\text { Pública do } \\
\text { Estado de São } \\
\text { Paulo }\end{array}$ & $\begin{array}{l}\text { Municipalida } \\
\text { de de São } \\
\text { Paulo }\end{array}$ & $\begin{array}{l}\text { Sessão } \\
\text { Plenária }\end{array}$ & $\begin{array}{l}\text { Maioria dos } \\
\text { votos / } \\
\text { Consta } \\
\text { declaração de } \\
\text { voto vencido }\end{array}$ & $\begin{array}{l}\text { Agravo não } \\
\text { provido }\end{array}$ & $\begin{array}{l}\text { Roberto } \\
\text { Vallim } \\
\text { Bellochi }\end{array}$ & $\begin{array}{l}\text { JTJ v } 331, \\
\text { p.1115 }\end{array}$ \\
\hline $158.424-0 / 3$ & $\begin{array}{l}\text { Apelação } \\
\text { Cível }\end{array}$ & 2008 & $\begin{array}{l}\text { Acesso à } \\
\text { educação } \\
\text { básica }\end{array}$ & Acesso EI & Jundiaí & $\begin{array}{l}\text { Informação } \\
\text { ausente }\end{array}$ & $\begin{array}{l}\text { Informação } \\
\text { ausente }\end{array}$ & $\begin{array}{l}\text { Câmara } \\
\text { Especial }\end{array}$ & Unânime & $\begin{array}{l}\text { Recurso não } \\
\text { provido }\end{array}$ & $\begin{array}{l}\text { Moreira } \\
\text { Carvalho }\end{array}$ & $\begin{array}{l}\text { Sítio biblioteca } \\
\text { TJ-SP }\end{array}$ \\
\hline $158.529-0 / 2$ & $\begin{array}{l}\text { Apelação } \\
\text { Cível }\end{array}$ & 2008 & $\begin{array}{l}\text { Acesso à } \\
\text { educação } \\
\text { básica }\end{array}$ & Acesso EI & Paulínia & $\begin{array}{l}\text { Informação } \\
\text { ausente }\end{array}$ & $\begin{array}{l}\text { Informação } \\
\text { ausente }\end{array}$ & $\begin{array}{l}\text { Câmara } \\
\text { Especial }\end{array}$ & Unânime & $\begin{array}{l}\text { Recurso não } \\
\text { provido }\end{array}$ & $\begin{array}{l}\text { Eduardo } \\
\text { Gouvêa }\end{array}$ & $\begin{array}{l}\text { Sítio biblioteca } \\
\text { TJ-SP }\end{array}$ \\
\hline $\begin{array}{l}159.389- \\
0 / 0-00\end{array}$ & $\begin{array}{l}\text { Recurso Ex } \\
\text { Officio }\end{array}$ & 2008 & $\begin{array}{l}\text { Acesso à } \\
\text { educação } \\
\text { básica }\end{array}$ & Acesso EI & Brodowski & $\begin{array}{l}\text { Juízo Ex } \\
\text { Officio }\end{array}$ & $\begin{array}{l}\text { Promotor de } \\
\text { Justiça da } \\
\text { Vara da } \\
\text { Infância e } \\
\text { Juventude de } \\
\text { Brodowski }\end{array}$ & $\begin{array}{l}\text { Câmara } \\
\text { Especial }\end{array}$ & Unânime & $\begin{array}{l}\text { Recurso não } \\
\text { provido }\end{array}$ & $\begin{array}{l}\text { Luiz } \\
\text { Tâmbara }\end{array}$ & $\begin{array}{l}\text { Sítio eletrônico } \\
\text { TJ-SP }\end{array}$ \\
\hline $\begin{array}{l}161.210- \\
0 / 4-00\end{array}$ & $\begin{array}{l}\text { Apelação } \\
\text { Cível }\end{array}$ & 2008 & $\begin{array}{l}\text { Acesso à } \\
\text { educação } \\
\text { básica }\end{array}$ & Acesso EI & $\begin{array}{l}\text { Santo } \\
\text { André }\end{array}$ & $\begin{array}{l}\text { Informação } \\
\text { ausente }\end{array}$ & $\begin{array}{l}\text { Informação } \\
\text { ausente }\end{array}$ & $\begin{array}{l}\text { Câmara } \\
\text { Especial }\end{array}$ & Unânime & $\begin{array}{l}\text { Recurso não } \\
\text { provido }\end{array}$ & $\begin{array}{l}\text { Moreira } \\
\text { Carvalho }\end{array}$ & $\begin{array}{l}\text { Sítio biblioteca } \\
\text { TJ-SP }\end{array}$ \\
\hline
\end{tabular}




\begin{tabular}{|c|c|c|c|c|c|c|c|c|c|c|c|c|}
\hline $\begin{array}{l}\text { Número } \\
\text { decisão }\end{array}$ & Natureza & Ano & Categorias & Tema & Origem & $\begin{array}{l}\text { Apelante } \\
\text { recorrente }\end{array}$ & $\begin{array}{l}\text { Apelados } \\
\text { recorridos }\end{array}$ & Câmara & Votação & Resultado & Relator & $\begin{array}{l}\text { Localização } \\
\text { da ementa / } \\
\text { acórdão }\end{array}$ \\
\hline $\begin{array}{l}161.717- \\
0 / 8-00\end{array}$ & $\begin{array}{l}\text { Apelação } \\
\text { Cível }\end{array}$ & 2008 & $\begin{array}{l}\text { Acesso à } \\
\text { educação } \\
\text { básica }\end{array}$ & $\begin{array}{l}\text { Acesso EI, } \\
\text { EF, EJA }\end{array}$ & São Paulo & $\begin{array}{l}\text { Município de } \\
\text { São Paulo }\end{array}$ & \begin{tabular}{|l|} 
Promotor de \\
Justiça dos \\
Interesses \\
Difusos e \\
Coletivos da \\
Infância e \\
Juventude de \\
Santo Amaro \\
\end{tabular} & \begin{tabular}{|l} 
Câmara \\
Especial
\end{tabular} & Unânime & $\begin{array}{l}\text { Preliminar } \\
\text { rejeitada }\end{array}$ & \begin{tabular}{|l|} 
Barreto \\
Fonseca
\end{tabular} & $\begin{array}{l}\text { Sítio biblioteca } \\
\text { TJ-SP }\end{array}$ \\
\hline $161.728-0 / 8$ & $\begin{array}{l}\text { Apelação } \\
\text { Cível }\end{array}$ & 2008 & $\begin{array}{l}\text { Acesso à } \\
\text { educação } \\
\text { básica }\end{array}$ & Acesso EI & Paulínia & $\begin{array}{l}\text { Informação } \\
\text { ausente }\end{array}$ & \begin{tabular}{|l|} 
Informação \\
ausente
\end{tabular} & $\begin{array}{l}\text { Câmara } \\
\text { Especial }\end{array}$ & Unânime & $\begin{array}{l}\text { Recurso não } \\
\text { provido }\end{array}$ & $\begin{array}{l}\text { Eduardo } \\
\text { Gouvêa }\end{array}$ & $\begin{array}{l}\text { Sítio biblioteca } \\
\text { TJ-SP }\end{array}$ \\
\hline $\begin{array}{l}163.737- \\
0 / 3-00\end{array}$ & $\begin{array}{l}\text { Recurso Ex } \\
\text { Officio }\end{array}$ & 2008 & $\begin{array}{l}\text { Acesso à } \\
\text { educação } \\
\text { básica }\end{array}$ & Acesso EI & Tanabi & $\begin{array}{l}\text { Juízo Ex } \\
\text { Officio }\end{array}$ & \begin{tabular}{|l|} 
Criança \\
representada \\
pela mãe
\end{tabular} & $\begin{array}{l}\text { Câmara } \\
\text { Especial }\end{array}$ & Unânime & $\begin{array}{l}\text { Recurso não } \\
\text { provido }\end{array}$ & \begin{tabular}{|l|} 
Barreto \\
Fonseca
\end{tabular} & $\begin{array}{l}\text { Sítio eletrônico } \\
\text { TJ-SP }\end{array}$ \\
\hline $\begin{array}{l}163.955- \\
0 / 8-00\end{array}$ & $\begin{array}{l}\text { Apelação } \\
\text { Cível }\end{array}$ & 2008 & $\begin{array}{l}\text { Acesso à } \\
\text { educação } \\
\text { básica }\end{array}$ & Acesso EI & Paulínia & \begin{tabular}{|l} 
Prefeitura \\
Municipal de \\
Paulínia
\end{tabular} & $\begin{array}{l}\text { menores } \\
\text { discriminados } \\
\text { na petição } \\
\text { inicial }\end{array}$ & $\begin{array}{l}\text { Câmara } \\
\text { Especial }\end{array}$ & Unânime & $\begin{array}{l}\text { Recurso não } \\
\text { provido }\end{array}$ & \begin{tabular}{|l|} 
Viana \\
Santos
\end{tabular} & $\begin{array}{l}\text { Sítio eletrônico } \\
\text { TJ-SP }\end{array}$ \\
\hline $\begin{array}{c}170.291- \\
0 / 3-00\end{array}$ & $\begin{array}{l}\text { Apelação } \\
\text { Cível }\end{array}$ & 2008 & $\begin{array}{c}\text { Acesso à } \\
\text { educação } \\
\text { básica }\end{array}$ & Acesso EI & Piracicaba & $\begin{array}{l}\text { Informação } \\
\text { ausente }\end{array}$ & $\begin{array}{l}\text { Informação } \\
\text { ausente }\end{array}$ & $\begin{array}{l}\text { Câmara } \\
\text { Especial }\end{array}$ & Unânime & $\begin{array}{l}\text { Recurso não } \\
\text { provido }\end{array}$ & $\begin{array}{l}\text { Maria } \\
\text { Olívia } \\
\text { Alves }\end{array}$ & $\begin{array}{c}\text { Sítio biblioteca } \\
\text { TJ-SP }\end{array}$ \\
\hline $\begin{array}{c}1.134 .261- \\
0 / 7\end{array}$ & $\begin{array}{l}\text { Agravo de } \\
\text { Instrumento }\end{array}$ & 2007 & Permanência & $\begin{array}{c}\text { Violação às } \\
\text { normas } \\
\text { escolares } \\
\end{array}$ & Pompéia & \begin{tabular}{|c|} 
Colégio \\
Agrícola de \\
Pompéia \\
\end{tabular} & Adolescente & $\begin{array}{c}28^{\mathrm{a}} \text { Câmara } \\
\text { de Direito } \\
\text { Privado } \\
\end{array}$ & Unânime & $\begin{array}{l}\text { Recurso não } \\
\text { provido }\end{array}$ & $\begin{array}{c}\text { Amaral } \\
\text { Vieira }\end{array}$ & \begin{tabular}{|c|} 
Sítio eletrônico \\
TJ-SP
\end{tabular} \\
\hline $\begin{array}{l}\text { 304.886- } \\
5 / 6-00\end{array}$ & $\begin{array}{l}\text { Apelação } \\
\text { Cível com } \\
\text { revisão }\end{array}$ & 2008 & Permanência & \begin{tabular}{|l|} 
Cancelament \\
o de \\
matrícula em \\
curso de \\
língua \\
estrangeira
\end{tabular} & $\begin{array}{l}\text { Presidente } \\
\text { Prudente }\end{array}$ & $\begin{array}{l}\text { Juízo Ex } \\
\text { Officio / } \\
\text { Fazenda do } \\
\text { Estado de SP }\end{array}$ & $\begin{array}{l}\text { Adolescente } \\
\text { representado } \\
\text { pela sua mãe }\end{array}$ & $\begin{array}{l}6^{a} \text { Câmara } \\
\text { de Direito } \\
\text { Público }\end{array}$ & Unânime & $\begin{array}{l}\text { Recurso não } \\
\text { provido }\end{array}$ & \begin{tabular}{|l|} 
Sidney \\
Romano dos \\
Reis
\end{tabular} & $\begin{array}{l}\text { Sítio eletrônico } \\
\text { TJ-SP }\end{array}$ \\
\hline $\begin{array}{l}356.870- \\
5 / 0-00\end{array}$ & $\begin{array}{l}\text { Apelação } \\
\text { Cível com } \\
\text { revisão }\end{array}$ & 2008 & $\begin{array}{l}\text { Decisões } \\
\text { administrativ } \\
\text { as e políticas }\end{array}$ & Outros & Guarulhos & A.M. e outros & \begin{tabular}{|l|} 
Dirigente \\
Regional de \\
Ensino da \\
Direitora da \\
Região Norte \\
de Guarulhos \\
\end{tabular} & $\begin{array}{l}2^{\text {a }} \text { Câmara } \\
\text { de Direito } \\
\text { Público }\end{array}$ & Unânime & $\begin{array}{l}\text { Recurso não } \\
\text { provido }\end{array}$ & $\begin{array}{l}\text { Henrique } \\
\text { Nelson } \\
\text { Calandra }\end{array}$ & $\begin{array}{l}\text { Sítio eletrônico } \\
\text { TJ-SP }\end{array}$ \\
\hline $\begin{array}{l}362.019- \\
5 / 6-00\end{array}$ & $\begin{array}{l}\text { Apelação } \\
\text { Cível com } \\
\text { revisão }\end{array}$ & 2008 & $\begin{array}{l}\text { Acesso à } \\
\text { educação } \\
\text { básica }\end{array}$ & Acesso EI & Paulínia & $\begin{array}{l}\text { Ministério } \\
\text { Público }\end{array}$ & \begin{tabular}{|l|} 
Prefeito \\
Municipal de \\
Paulínia \\
\end{tabular} & $\begin{array}{l}2^{\mathrm{a}} \text { Câmara } \\
\text { de Direito } \\
\text { Público }\end{array}$ & Unânime & $\begin{array}{l}\text { Recurso } \\
\text { provido }\end{array}$ & \begin{tabular}{|l|} 
Nelson \\
Calandra
\end{tabular} & $\begin{array}{l}\text { Sítio eletrônico } \\
\text { TJ-SP }\end{array}$ \\
\hline
\end{tabular}




\begin{tabular}{|c|c|c|c|c|c|c|c|c|c|c|c|c|}
\hline $\begin{array}{l}\text { Número } \\
\text { decisão }\end{array}$ & Natureza & Ano & Categorias & Tema & Origem & $\begin{array}{l}\text { Apelante } \\
\text { recorrente }\end{array}$ & $\begin{array}{l}\text { Apelados } \\
\text { recorridos }\end{array}$ & Câmara & Votação & Resultado & Relator & $\begin{array}{l}\text { Localização } \\
\text { da ementa / } \\
\text { acórdão }\end{array}$ \\
\hline $\begin{array}{l}\text { 392.631- } \\
5 / 3-00\end{array}$ & $\begin{array}{l}\text { Apelação } \\
\text { Cível com } \\
\text { revisão }\end{array}$ & 2008 & $\begin{array}{l}\text { Responsabili } \\
\text { dade estatal }\end{array}$ & \begin{tabular}{|l|} 
Ação de \\
reparação de \\
danos
\end{tabular} & Pederneiras & $\begin{array}{l}\text { Prefeitura } \\
\text { Municipal de } \\
\text { Pederneiras / } \\
\text { pais do menor }\end{array}$ & $\begin{array}{l}\text { Prefeitura } \\
\text { Municipal de } \\
\text { Pederneiras / } \\
\text { pais do menor }\end{array}$ & $\begin{array}{l}2^{\mathrm{a}} \text { Câmara } \\
\text { de Direito } \\
\text { Público }\end{array}$ & Unânime & $\begin{array}{l}\text { Recurso } \\
\text { negado às } \\
\text { famílias das } \\
\text { crianças e } \\
\text { provimento } \\
\text { parcial aos } \\
\text { recursos da } \\
\text { municipalida } \\
\text { de } \\
\end{array}$ & $\begin{array}{l}\text { Nelson } \\
\text { Calandra }\end{array}$ & $\begin{array}{l}\text { JTJ v. } 326, \\
\text { p.464 }\end{array}$ \\
\hline $\begin{array}{l}\text { 465.757- } \\
5 / 4-00\end{array}$ & $\begin{array}{l}\text { Apelação } \\
\text { Cível com } \\
\text { revisão }\end{array}$ & 2008 & Permanência & \begin{tabular}{|l|} 
Cancelament \\
o de \\
matrícula em \\
curso de \\
língua \\
estrangeira
\end{tabular} & Araçatuba & $\begin{array}{l}\text { Juízo Ex } \\
\text { Officio / } \\
\text { Fazenda do } \\
\text { Estado de SP }\end{array}$ & $\begin{array}{l}\text { Adolescente } \\
\text { menor } \\
\text { representado } \\
\text { pela mãe }\end{array}$ & $\begin{array}{l}8^{\text {a }} \text { Câmara } \\
\text { de Direito } \\
\text { Público }\end{array}$ & Unânime & $\begin{array}{l}\text { Recurso não } \\
\text { provido }\end{array}$ & Rubens Rihl & $\begin{array}{l}\text { Sítio eletrônico } \\
\text { TJ-SP }\end{array}$ \\
\hline $\begin{array}{l}538.341- \\
5 / 2-00\end{array}$ & $\begin{array}{l}\text { Apelação } \\
\text { Cível com } \\
\text { revisão }\end{array}$ & 2008 & $\begin{array}{l}\text { Responsabili } \\
\text { dade estatal }\end{array}$ & $\begin{array}{l}\text { Transporte } \\
\text { escolar }\end{array}$ & Buritizal & $\begin{array}{l}\text { Prefeitura } \\
\text { Municipal de } \\
\text { Buritizal }\end{array}$ & $\begin{array}{l}\text { Criança ou } \\
\text { adolescente } \\
\text { representado } \\
\text { pela mãe } \\
\end{array}$ & $\begin{array}{l}8^{a} \text { Câmara } \\
\text { de Direito } \\
\text { Público }\end{array}$ & Unânime & $\begin{array}{l}\text { Recurso não } \\
\text { provido }\end{array}$ & $\begin{array}{l}\text { Paulo Dias } \\
\text { Mascaretti }\end{array}$ & $\begin{array}{l}\text { Sítio eletrônico } \\
\text { TJ-SP }\end{array}$ \\
\hline $\begin{array}{l}\text { 601.392- } \\
5 / 8-00\end{array}$ & $\begin{array}{l}\text { Apelação } \\
\text { Cível com } \\
\text { revisão }\end{array}$ & 2008 & $\begin{array}{l}\text { Acesso à } \\
\text { educação } \\
\text { básica }\end{array}$ & Acesso EI & Roseira & $\begin{array}{l}\text { Prefeitura } \\
\text { Municipal de } \\
\text { Roseira }\end{array}$ & $\begin{array}{l}\text { Ministério } \\
\text { Público }\end{array}$ & $\begin{array}{l}7^{\text {a }} \text { Câmara } \\
\text { de Direito } \\
\text { Público }\end{array}$ & Unânime & $\begin{array}{l}\text { Provimento } \\
\text { parcial aos } \\
\text { recursos }\end{array}$ & $\begin{array}{l}\text { Nogueira } \\
\text { Diefenhthal } \\
\text { er }\end{array}$ & $\begin{array}{l}\text { Sítio eletrônico } \\
\text { TJ-SP / JTJ }\end{array}$ \\
\hline $\begin{array}{l}\text { 641.218- } \\
5 / 8-00\end{array}$ & $\begin{array}{l}\text { Apelação } \\
\text { Cível com } \\
\text { revisão }\end{array}$ & 2008 & $\begin{array}{l}\text { Acesso à } \\
\text { educação } \\
\text { básica }\end{array}$ & Acesso ao EF & São Paulo & $\begin{array}{l}\text { Criança } \\
\text { representada } \\
\text { pela mãe e } \\
\text { outro }\end{array}$ & $\begin{array}{l}\text { Secretário } \\
\text { estadual de } \\
\text { educação }\end{array}$ & $\begin{array}{l}12^{\mathrm{a}} \text { Câmara } \\
\text { de Direito } \\
\text { Público }\end{array}$ & Unânime & $\begin{array}{l}\text { Recurso } \\
\text { provido }\end{array}$ & $\begin{array}{l}\text { Prado } \\
\text { Pereira }\end{array}$ & $\begin{array}{l}\text { Sítio eletrônico } \\
\text { TJ-SP }\end{array}$ \\
\hline $\begin{array}{l}\text { 662.473- } \\
5 / 4-00\end{array}$ & $\begin{array}{l}\text { Apelação } \\
\text { Cível com } \\
\text { revisão }\end{array}$ & 2008 & $\begin{array}{l}\text { Responsabili } \\
\text { dade estatal }\end{array}$ & $\begin{array}{l}\text { Ação de } \\
\text { reparação de } \\
\text { danos }\end{array}$ & Marília & $\begin{array}{l}\text { Prefeitura } \\
\text { Municipal de } \\
\text { Marília }\end{array}$ & $\begin{array}{l}\text { Adolescente } \\
\text { representado } \\
\text { pelos pais }\end{array}$ & $\begin{array}{l}12^{\mathrm{a}} \text { Câmara } \\
\text { de Direito } \\
\text { Público }\end{array}$ & Unânime & $\begin{array}{l}\text { Provimento } \\
\text { parcial ao } \\
\text { recurso }\end{array}$ & $\begin{array}{l}\text { Prado } \\
\text { Pereira }\end{array}$ & $\begin{array}{l}\text { Sítio biblioteca } \\
\text { TJ-SP / Sítio } \\
\text { TJ-SP }\end{array}$ \\
\hline $\begin{array}{l}\text { 667.424- } \\
5 / 8-00\end{array}$ & $\begin{array}{l}\text { Apelação } \\
\text { Cível com } \\
\text { revisão }\end{array}$ & 2008 & $\begin{array}{l}\text { Gestão dos } \\
\text { recursos } \\
\text { públicos }\end{array}$ & $\begin{array}{l}\text { Repasse de } \\
\text { recurso } \\
\text { público a } \\
\text { instituição } \\
\text { privada }\end{array}$ & Guairá & $\begin{array}{l}\text { Juízo Ex } \\
\text { Offício }\end{array}$ & $\begin{array}{l}\text { Município de } \\
\text { Guará e S. de } \\
\text { M. }\end{array}$ & $\begin{array}{l}7^{\text {a }} \text { Câmara } \\
\text { de Direito } \\
\text { Público }\end{array}$ & Unânime & $\begin{array}{l}\text { Recurso não } \\
\text { provido }\end{array}$ & $\begin{array}{l}\text { Nogueira } \\
\text { Diefenhthal } \\
\text { er }\end{array}$ & $\begin{array}{l}\text { Sítio eletrônico } \\
\text { TJ-SP }\end{array}$ \\
\hline $\begin{array}{l}683.982- \\
5 / 0-00\end{array}$ & $\begin{array}{l}\text { Apelação } \\
\text { Cível com } \\
\text { revisão }\end{array}$ & 2008 & $\begin{array}{l}\text { Responsabili } \\
\text { dade estatal }\end{array}$ & $\begin{array}{l}\text { Transporte } \\
\text { escolar }\end{array}$ & Auriflama & $\begin{array}{l}\text { Juízo Ex } \\
\text { Offício }\end{array}$ & $\begin{array}{l}\text { Prefeitura } \\
\text { Municipal de } \\
\text { Auriflama }\end{array}$ & $\begin{array}{l}7^{\text {a }} \text { Câmara } \\
\text { de Direito } \\
\text { Público }\end{array}$ & Unânime & $\begin{array}{l}\text { Recurso não } \\
\text { provido }\end{array}$ & $\begin{array}{l}\text { Moacir } \\
\text { Peres }\end{array}$ & $\begin{array}{l}\text { Sítio eletrônico } \\
\text { TJ-SP }\end{array}$ \\
\hline
\end{tabular}




\begin{tabular}{|c|c|c|c|c|c|c|c|c|c|c|c|c|}
\hline $\begin{array}{l}\text { Número } \\
\text { decisão }\end{array}$ & Natureza & Ano & Categorias & Tema & Origem & $\begin{array}{l}\text { Apelante } \\
\text { recorrente }\end{array}$ & $\begin{array}{l}\text { Apelados } \\
\text { recorridos }\end{array}$ & Câmara & Votação & Resultado & Relator & $\begin{array}{l}\text { Localização } \\
\text { da ementa / } \\
\text { acórdão }\end{array}$ \\
\hline $\begin{array}{l}684.251- \\
5 / 2-00\end{array}$ & $\begin{array}{l}\text { Apelação } \\
\text { Cível com } \\
\text { revisão }\end{array}$ & 2008 & $\begin{array}{l}\text { Acesso à } \\
\text { educação } \\
\text { básica }\end{array}$ & Acesso EI & Paulínia & $\begin{array}{l}\text { Prefeitura } \\
\text { Municipal de } \\
\text { Paulínia }\end{array}$ & Criança & $\begin{array}{l}12^{\mathrm{a}} \text { Câmara } \\
\text { de Direito } \\
\text { Público }\end{array}$ & Unânime & $\begin{array}{l}\text { Recurso não } \\
\text { provido }\end{array}$ & $\begin{array}{l}\text { Luiz Burza } \\
\text { Neto }\end{array}$ & $\begin{array}{l}\text { Sítio eletrônico } \\
\text { TJ-SP }\end{array}$ \\
\hline $\begin{array}{l}\text { 689.118- } \\
5 / 2-00\end{array}$ & $\begin{array}{l}\text { Apelação } \\
\text { Cível com } \\
\text { revisão }\end{array}$ & 2008 & Permanência & \begin{tabular}{|l|} 
Cancelament \\
o de \\
matrícula em \\
curso de \\
língua \\
estrangeira
\end{tabular} & Araçatuba & $\begin{array}{l}\text { Juízo Ex } \\
\text { Officio / } \\
\text { Fazenda do } \\
\text { Estado de SP }\end{array}$ & $\begin{array}{l}\text { Adolescente } \\
\text { representado } \\
\text { pelo pai }\end{array}$ & $\begin{array}{l}12^{\mathrm{a}} \text { Câmara } \\
\text { de Direito } \\
\text { Público }\end{array}$ & Unânime & $\begin{array}{l}\text { Recurso não } \\
\text { provido }\end{array}$ & $\begin{array}{l}\text { Luiz Burza } \\
\text { Neto }\end{array}$ & $\begin{array}{l}\text { Sítio eletrônico } \\
\text { TJ-SP }\end{array}$ \\
\hline $\begin{array}{l}711.901- \\
5 / 0-00\end{array}$ & $\begin{array}{l}\text { Agravo de } \\
\text { Instrumento / } \\
\text { Agravo } \\
\text { Regimental }\end{array}$ & 2008 & $\begin{array}{l}\text { Acesso à } \\
\text { educação } \\
\text { básica }\end{array}$ & Acesso EI & Pontal & $\begin{array}{l}\text { Prefeitura } \\
\text { Municipal de } \\
\text { Pontal }\end{array}$ & $\begin{array}{l}\text { Ministério } \\
\text { Público }\end{array}$ & $\begin{array}{l}10^{\mathrm{a}} \text { Câmara } \\
\text { de Direito } \\
\text { Público }\end{array}$ & Unânime & $\begin{array}{l}\text { Recurso } \\
\text { parcial }\end{array}$ & $\begin{array}{l}\text { Teresa } \\
\text { Ramos } \\
\text { Marques }\end{array}$ & $\begin{array}{l}\text { Sítio biblioteca } \\
\text { TJ-SP; Sítio } \\
\text { TJ-SP }\end{array}$ \\
\hline $\begin{array}{l}718.238- \\
5 / 4-00\end{array}$ & $\begin{array}{l}\text { Apelação } \\
\text { Cível com } \\
\text { revisão }\end{array}$ & 2008 & $\begin{array}{l}\text { Acesso à } \\
\text { educação } \\
\text { básica }\end{array}$ & Acesso EI & Paulínia & \begin{tabular}{|l|} 
Prefeitura \\
Municipal de \\
Paulínia \\
\end{tabular} & $\begin{array}{l}\text { Criança } \\
\text { representada } \\
\text { pela mãe }\end{array}$ & $\begin{array}{l}7^{\text {a }} \text { Câmara } \\
\text { de Direito } \\
\text { Público }\end{array}$ & Unânime & $\begin{array}{l}\text { Recurso não } \\
\text { provido }\end{array}$ & $\begin{array}{l}\text { Guerrieri } \\
\text { Rezende }\end{array}$ & $\begin{array}{l}\text { Sítio eletrônico } \\
\text { TJ-SP }\end{array}$ \\
\hline $\begin{array}{l}735.647- \\
5 / 5-00\end{array}$ & $\begin{array}{l}\text { Apelação } \\
\text { Cível com } \\
\text { revisão }\end{array}$ & 2008 & $\begin{array}{l}\text { Acesso à } \\
\text { educação } \\
\text { básica }\end{array}$ & Acesso EI & $\begin{array}{l}\text { São José do } \\
\text { Rio Preto }\end{array}$ & \begin{tabular}{|l} 
Prefeitura \\
Municipal de \\
São José do \\
Rio Preto \\
\end{tabular} & $\begin{array}{l}\text { Criança } \\
\text { representada } \\
\text { pela mãe }\end{array}$ & $\begin{array}{l}10^{\mathrm{a}} \text { Câmara } \\
\text { de Direito } \\
\text { Público }\end{array}$ & Unânime & $\begin{array}{l}\text { Recurso não } \\
\text { provido }\end{array}$ & $\begin{array}{l}\text { Luiz Burza } \\
\text { Neto }\end{array}$ & $\begin{array}{l}\text { Sítio eletrônico } \\
\text { TJ-SP }\end{array}$ \\
\hline $\begin{array}{l}\text { 737.349- } \\
5 / 0-00\end{array}$ & $\begin{array}{l}\text { Apelação } \\
\text { Cível com } \\
\text { revisão }\end{array}$ & 2008 & $\begin{array}{l}\text { Acesso à } \\
\text { educação } \\
\text { básica }\end{array}$ & Acesso EI & Paulínia & $\begin{array}{l}\text { Prefeitura } \\
\text { Municipal de } \\
\text { Paulínia }\end{array}$ & $\begin{array}{l}\text { Criança } \\
\text { representada } \\
\text { pela mãe }\end{array}$ & $\begin{array}{l}3^{\text {a }} \text { Câmara } \\
\text { de Direito } \\
\text { Público }\end{array}$ & Unânime & $\begin{array}{l}\text { Recurso não } \\
\text { provido }\end{array}$ & $\begin{array}{l}\text { Laerte } \\
\text { Sampaio }\end{array}$ & $\begin{array}{l}\text { Sítio eletrônico } \\
\text { TJ-SP }\end{array}$ \\
\hline $\begin{array}{l}\text { 741.394- } \\
5 / 9-00\end{array}$ & $\begin{array}{l}\text { Apelação } \\
\text { Cível com } \\
\text { revisão }\end{array}$ & 2008 & $\begin{array}{l}\text { Acesso à } \\
\text { educação } \\
\text { básica }\end{array}$ & Acesso EI & Paulínia & $\begin{array}{l}\text { Prefeitura } \\
\text { Municipal de } \\
\text { Paulínia }\end{array}$ & $\begin{array}{l}\text { Criança } \\
\text { representada } \\
\text { pela mãe }\end{array}$ & $\begin{array}{l}8^{\mathrm{a}} \text { Câmara } \\
\text { de Direito } \\
\text { Público }\end{array}$ & Unânime & $\begin{array}{l}\text { Recurso não } \\
\text { provido }\end{array}$ & Rubens Rihl & $\begin{array}{l}\text { Sítio eletrônico } \\
\text { TJ-SP }\end{array}$ \\
\hline $\begin{array}{l}\text { 741.394- } \\
5 / 9-00\end{array}$ & $\begin{array}{l}\text { Apelação } \\
\text { Cível com } \\
\text { revisão }\end{array}$ & 2008 & $\begin{array}{l}\text { Acesso à } \\
\text { educação } \\
\text { básica }\end{array}$ & Acesso EI & Paulínia & $\begin{array}{l}\text { Prefeitura } \\
\text { Municipal de } \\
\text { Paulínia }\end{array}$ & $\begin{array}{l}\text { Criança } \\
\text { representada } \\
\text { pela mãe }\end{array}$ & $\begin{array}{l}8^{\text {a }} \text { Câmara } \\
\text { de Direito } \\
\text { Público }\end{array}$ & Unânime & $\begin{array}{l}\text { Recurso não } \\
\text { provido }\end{array}$ & Rubens Rihl & Sítio TJ-SP \\
\hline $\begin{array}{l}752.718- \\
5 / 4-00\end{array}$ & $\begin{array}{l}\text { Apelação } \\
\text { Cível com } \\
\text { revisão }\end{array}$ & 2008 & $\begin{array}{l}\text { Acesso à } \\
\text { educação } \\
\text { básica }\end{array}$ & \begin{tabular}{|l|} 
Educação \\
Especial
\end{tabular} & Paulínia & $\begin{array}{l}\text { Prefeitura } \\
\text { Municipal de } \\
\text { Paulínia }\end{array}$ & $\begin{array}{l}\text { Criança } \\
\text { representada } \\
\text { pela mãe }\end{array}$ & $\begin{array}{l}12^{\mathrm{a}} \text { Câmara } \\
\text { de Direito } \\
\text { Público }\end{array}$ & Unânime & $\begin{array}{l}\text { Recurso não } \\
\text { provido }\end{array}$ & $\begin{array}{l}\text { Edson } \\
\text { Pereira }\end{array}$ & Sítio TJ-SP \\
\hline $\begin{array}{l}745.735- \\
5 / 5-00\end{array}$ & $\begin{array}{l}\text { Apelação } \\
\text { Cível com } \\
\text { revisão }\end{array}$ & 2008 & $\begin{array}{l}\text { Acesso à } \\
\text { educação } \\
\text { básica }\end{array}$ & Acesso EI & São Paulo & $\begin{array}{l}\text { Prefeitura } \\
\text { Municipal de } \\
\text { São Paulo } \\
\end{array}$ & $\begin{array}{l}\text { Criança } \\
\text { representada } \\
\text { pela mãe }\end{array}$ & $\begin{array}{l}13^{\mathrm{a}} \text { Câmara } \\
\text { de Direito } \\
\text { Público }\end{array}$ & Unânime & $\begin{array}{l}\text { Recurso não } \\
\text { provido }\end{array}$ & $\begin{array}{l}\text { Peiretti de } \\
\text { Godoy }\end{array}$ & $\begin{array}{l}\text { Sítio eletrônico } \\
\text { TJ-SP }\end{array}$ \\
\hline $\begin{array}{l}\text { 786.919- } \\
5 / 5-00\end{array}$ & $\begin{array}{l}\text { Apelação } \\
\text { Cível com } \\
\text { revisão }\end{array}$ & 2008 & $\begin{array}{l}\text { Acesso à } \\
\text { educação } \\
\text { básica }\end{array}$ & \begin{tabular}{|l|} 
Educação \\
Especial
\end{tabular} & São Paulo & $\begin{array}{l}\text { Prefeitura } \\
\text { Municipal de } \\
\text { São Paulo }\end{array}$ & $\begin{array}{l}\text { Criança } \\
\text { representada } \\
\text { pela mãe }\end{array}$ & $\begin{array}{l}11^{\mathrm{a}} \text { Câmara } \\
\text { de Direito } \\
\text { Público }\end{array}$ & Unânime & $\begin{array}{l}\text { Recurso não } \\
\text { provido }\end{array}$ & Ricardo Dip & Sítio TJ-SP \\
\hline
\end{tabular}




\begin{tabular}{|c|c|c|c|c|c|c|c|c|c|c|c|c|}
\hline $\begin{array}{l}\text { Número } \\
\text { decisão }\end{array}$ & Natureza & Ano & Categorias & Tema & Origem & $\begin{array}{l}\text { Apelante } \\
\text { recorrente }\end{array}$ & $\begin{array}{l}\text { Apelados } \\
\text { recorridos }\end{array}$ & Câmara & Votação & Resultado & Relator & $\begin{array}{l}\text { Localização } \\
\text { da ementa / } \\
\text { acórdão }\end{array}$ \\
\hline $975.262-0 / 2$ & $\begin{array}{l}\text { Apelação } \\
\text { com revisão }\end{array}$ & 2008 & $\begin{array}{l}\text { Poder de } \\
\text { regulação } \\
\text { estatal }\end{array}$ & $\begin{array}{l}\text { Mensalidade } \\
\text { escolar }\end{array}$ & São Paulo & $\begin{array}{l}\text { Associação } \\
\text { Brasileira de } \\
\text { Educação e } \\
\text { Cultura } \\
\end{array}$ & $\begin{array}{l}\text { Criança ou } \\
\text { adolescente }\end{array}$ & $\begin{array}{l}26^{\mathrm{a}} \text { de } \\
\text { Direito } \\
\text { Privado }\end{array}$ & Unânime & $\begin{array}{l}\text { Recurso não } \\
\text { provido }\end{array}$ & $\begin{array}{l}\text { Vianna } \\
\text { Cotrim }\end{array}$ & \begin{tabular}{|l} 
JTJ \\
v. 324, p.390
\end{tabular} \\
\hline 961.689-0/6 & $\begin{array}{l}\text { Apelação } \\
\text { Cível }\end{array}$ & 2008 & $\begin{array}{l}\text { Poder de } \\
\text { regulação } \\
\text { estatal }\end{array}$ & $\begin{array}{l}\text { Mensalidade } \\
\text { escolar }\end{array}$ & $\begin{array}{l}\text { São Miguel } \\
\text { Paulista }\end{array}$ & $\begin{array}{l}\text { Sociedade } \\
\text { Educacional } \\
\text { Cidade de São } \\
\text { Paulo }\end{array}$ & $\begin{array}{l}\text { Criança ou } \\
\text { adolescente }\end{array}$ & $\begin{array}{l}27^{\mathrm{a}} \text { Câmara } \\
\text { de Direito } \\
\text { Privado }\end{array}$ & Unânime & $\begin{array}{l}\text { Recurso não } \\
\text { provido }\end{array}$ & $\begin{array}{l}\text { Erickson } \\
\text { Gavazza } \\
\text { Marques }\end{array}$ & $\begin{array}{l}\text { JTJ v. 331, p. } \\
303\end{array}$ \\
\hline 919.013-0/4 & $\begin{array}{l}\text { Apelação } \\
\text { Cível }\end{array}$ & 2008 & Permanência & Outros & São Paulo & $\begin{array}{l}\text { Associação } \\
\text { Escola } \\
\text { Graduada de } \\
\text { São Paulo / P. } \\
\text { C. }\end{array}$ & $\begin{array}{l}\text { Associação } \\
\text { Escola } \\
\text { Graduada de } \\
\text { São Paulo / P. } \\
\text { C. }\end{array}$ & $\begin{array}{l}32^{\mathrm{a}} \text { Câmara } \\
\text { de Direito } \\
\text { Privado }\end{array}$ & Unânime & $\begin{array}{l}\text { Não } \\
\text { conheceram } \\
\text { o recurso do } \\
\text { aluno, } \\
\text { rejeitaram a } \\
\text { matéria da } \\
\text { escola e no } \\
\text { mérito deram } \\
\text { parcial } \\
\text { provimento } \\
\text { ao aluno para } \\
\text { afastar a } \\
\text { aplicação da } \\
\text { multa }\end{array}$ & $\begin{array}{l}\text { Rocha de } \\
\text { Souza }\end{array}$ & $\begin{array}{l}\text { JTJ v.331, p. } \\
344\end{array}$ \\
\hline $7.150 .864-8$ & $\begin{array}{l}\text { Apelação } \\
\text { Cível }\end{array}$ & 2008 & Permanência & $\begin{array}{l}\text { Violação às } \\
\text { normas } \\
\text { escolares }\end{array}$ & São Paulo & $\begin{array}{l}\text { Criança ou } \\
\text { adolescente }\end{array}$ & $\begin{array}{l}\text { Centro } \\
\text { Educacional } \\
\text { Júlio Verne } \\
\text { S/C Ltda } \\
\end{array}$ & $\begin{array}{l}17^{\text {a }} \text { Câmara } \\
\text { de Direito } \\
\text { Privado }\end{array}$ & Unânime & $\begin{array}{l}\text { Recurso não } \\
\text { provido }\end{array}$ & $\begin{array}{l}\text { Elmano de } \\
\text { Oliveira }\end{array}$ & $\begin{array}{l}\text { Sítio eletrônico } \\
\text { TJ-SP }\end{array}$ \\
\hline $\begin{array}{l}160-996- \\
0 / 2-00\end{array}$ & ADIN & 2008 & $\begin{array}{l}\text { Decisões } \\
\text { administrativ } \\
\text { as e políticas }\end{array}$ & \begin{tabular}{|l} 
Competência \\
para legislar
\end{tabular} & São Paulo & $\begin{array}{l}\text { Procurador } \\
\text { Geral de } \\
\text { Justiça }\end{array}$ & $\begin{array}{l}\text { Governador } \\
\text { do Estado / } \\
\text { Fazenda do } \\
\text { Estado } \\
\end{array}$ & $\begin{array}{l}\text { Órgão } \\
\text { especial }\end{array}$ & Unânime & $\begin{array}{l}\text { Procedente a } \\
\text { ação }\end{array}$ & $\begin{array}{l}\text { Mário } \\
\text { Ferraz }\end{array}$ & $\begin{array}{l}\text { JTJ v 331, } \\
\text { p.1115 }\end{array}$ \\
\hline
\end{tabular}

